University of Louisville

ThinkIR: The University of Louisville's Institutional Repository

$5-2011$

\title{
Medieval churches on the Spanish frontier : how elite emulation in architecture contributed to the transformation of a territorial expansion into Reconquista.
}

\author{
Kelly L. Watt \\ University of Louisville
}

Follow this and additional works at: https://ir.library.louisville.edu/etd

\section{Recommended Citation}

Watt, Kelly L., "Medieval churches on the Spanish frontier : how elite emulation in architecture contributed to the transformation of a territorial expansion into Reconquista." (2011). Electronic Theses and Dissertations. Paper 1538.

https://doi.org/10.18297/etd/1538

This Doctoral Dissertation is brought to you for free and open access by ThinkIR: The University of Louisville's Institutional Repository. It has been accepted for inclusion in Electronic Theses and Dissertations by an authorized administrator of ThinkIR: The University of Louisville's Institutional Repository. This title appears here courtesy of the author, who has retained all other copyrights. For more information, please contact thinkir@louisville.edu. 
MEDIEVAL CHURCHES ON THE SPANISH FRONTIER: HOW ELITE EMULATION IN ARCHITECTURE CONTRIBUTED TO THE TRANSFORMATION OF A TERRITORIAL EXPANSION INTO RECONQUISTA

\author{
By \\ Kelly L. Watt \\ B.A., Olivet Nazarene University, 1995 \\ M.A., University of Cincinnati, 2002 \\ A Dissertation \\ Submitted to the Faculty of the \\ College of Arts and Sciences of the University of Louisville \\ In Partial Fulfillment of the requirements \\ For the Degree of \\ Doctor of Philosophy \\ Department of Fine Arts \\ University of Louisville \\ Louisville, Kentucky
}

May 2011 
Copyright 2011 by Kelly L. Watt

All rights reserved 
MEDIEVAL CHURCHES ON THE SPANISH FRONTIER: HOW ELITE EMULATION IN ARCHITECTURE CONTRIBUTED TO THE TRANSFORMATION OF A TERRITORIAL EXPANSION INTO RECONQUISTA

\author{
By
}

Kelly L. Watt

B.A., Olivet Nazarene University, 1995

M.A., University of Cincinnati, 2002

A Dissertation Approved on

April 29, 2011

by the following Dissertation Committee:

Dissertation Director 
This dissertation is dedicated to my husband

Brian Watt

And the jaunty travelers, Ian and Colin 


\section{ACKNOWLEDGEMENTS}

I would like to first thank the Lewis and Clark Fund for Exploration and Field Research from the American Philosophical Society for generously funding a portion of the research for this project. A Photographic Grant from the American Society for Hispanic Art Historical Studies was also gratefully applied toward the cost of images. Expressions of thanks are offered to the Hite Art Institute of the University of Louisville for their substantive financial support.

Significant debts of gratitude also extend to the many individuals who have supported this lengthy process. In particular, the final stages of this dissertation would have been very difficult without the unselfish support and insightful criticism of my dissertation advisor, Dr. Christopher Fulton. Special appreciation is due to Dr. Pamela Patton, who has generously served as consulting advisor for the duration of this project. Over the last five years, I have benefitted enormously from her expert mentorship, wit, and wisdom. I wish to also thank the other readers of this dissertation: Dr. Gregory Hutcheson, who provided early encouragement, critical support, and a brilliant class in Segovia and Dr. Stephanie Maloney, who not only graciously offered excellent advice but who introduced me to early medieval Iberia. This project was begun under the direction of Dr. Karen Britt, and I wish to acknowledge her contribution to the early phases of research. 
Several scholars have been kind enough to respond to my requests for information at different stages of the research and writing; in particular, Mickey Abel, Milagros Guardia, and Jose Luís Senra have all supplied important words of advice and encouragement along the way. While in Spain, I was introduced to the superb Raquel Alonso Álvarez, whose collegiality and friendship I deeply appreciate. My research in Spain was also aided by the welcome support of scholar and Soria Románica project director, Josemi Lorenzo Arribas, as well as the intrepid academic, Flora Ward.

My family and friends have sustained me with their beautiful words and deeds and I want to acknowledge their essential role. To my mother, Nancy Thor, thank you for showing me through your example that determination wins the day in graduate school and for the recent weeks spent caring for my little ones and doing mountains of laundry unasked. Much credit also goes to Walter and Janet Watt, who have driven across the Midwest to pitch in and prop up. My dear friend Jamie Ratliff has served as a scholarly sounding board and last-minute editor and I thank her for it from the bottom of my heart. Above all, I want to thank my husband, Brian Watt, for cheerfully holding down the fort, skillfully wielding the camera, and inspiring me to never give up. 


\title{
ABSTRACT \\ MEDIEVAL CHURCHES ON THE SPANISH FRONTIER: HOW ELITE EMULATION IN ARCHITECTURE CONTRIBUTED TO THE TRANSFORMATION OF A TERRITORIAL EXPANSION INTO RECONQUISTA
}

\author{
Kelly L. Watt \\ April 15, 2011
}

This dissertation examines the architectural evidence in the ongoing debate surrounding the demographical and political value of the shifting Iberian frontier of the tenth through twelfth centuries. In particular, it seeks to problematize the current generalization of rural stone churches in the central Duero River basin as "repopulation" churches. Using postcolonial theory and comparative analysis, this project argues that the construction of stone churches on sacred sites at the frontier was a useful strategy employed by those seeking to establish authority over existing indigenous and heterogeneous populations.

Convincing arguments were needed to not only justify the usurpation of power but more importantly, to persuade diverse inhabitants to submit their men and resources to the goals of the new order. Crucial to the appearance of legitimacy in a would-be ruler was the "restoration" of significant churches on holy topographies, the focus of chapters two and three. The template for a successful restoration included: the selection of a sacred landscape with a pre-conquest history, architectural forms associated with both the 
ecclesiastic hierarchy and Christian and Muslim political powers, and painting and sculpture that bolstered the patron's claims of legitimate authority.

These frontier restorations were deliberately modeled on the strategies employed by kings and abbots seeking to expand their influence over large tracts of land, for example, the holdings of San Millán de la Cogolla (Rioja) and San Juan de la Peña (Huesca). By using elite architectural elements at meaningful sites, non-royal patrons articulated their authority and the favor of God at frontier churches like San Baudelio de Berlanga (Soria) and Santa Maria de Wamba (Valladolid), the case studies for this project. While the specific ways in which patrons constructed churches varied according to place and time, the themes of "restoration" and lordship are pervasive. Over time, the symbolic dissemination of the idea that sacred centers had been "restored" to Iberian Christendom helped to transform a rationalization of territorial expansion into a heroic, Hispanic Reconquista. 
TABLE OF CONTENTS

PAGE

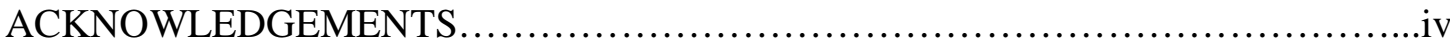

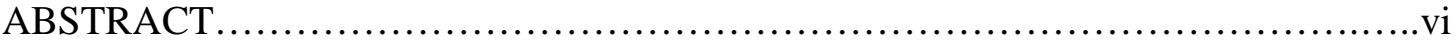

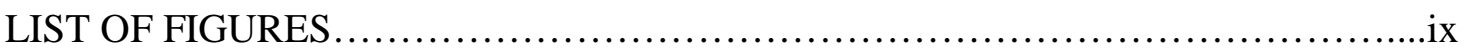

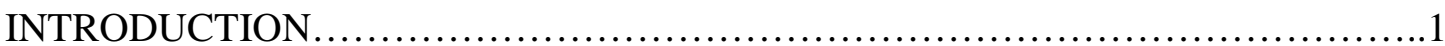

CHAPTER ONE ................................................................. 12

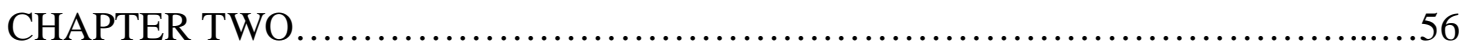

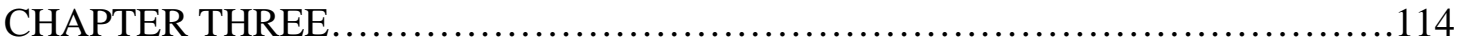

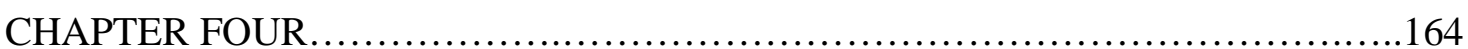

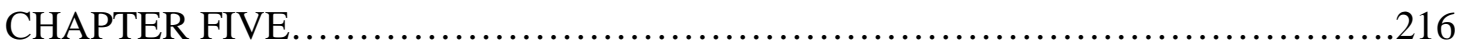

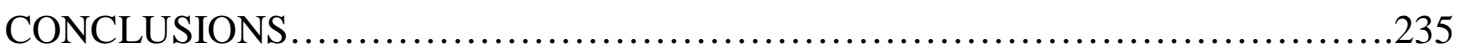

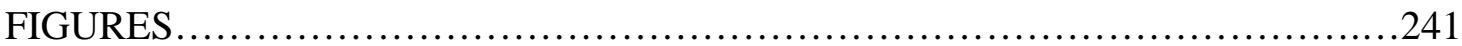

REFERENCES............................................................. 337

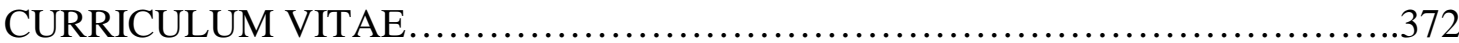

viii 


\section{LIST OF FIGURES}

FIGURE

PAGE

1. Map of tenth-century al-Andalus......................................241

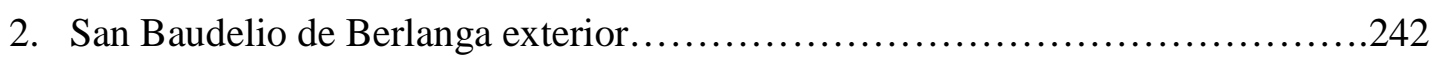

3. Floor plan of San Baudelio.................................................243

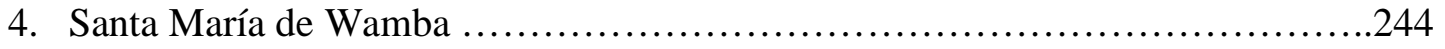

5. Floor plan of Santa María de Wamba........................................245

6. Map of multiple frontiers.............................................246

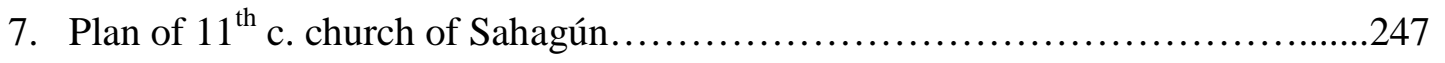

8. Surviving wall...................................................... 248

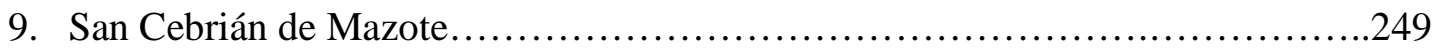

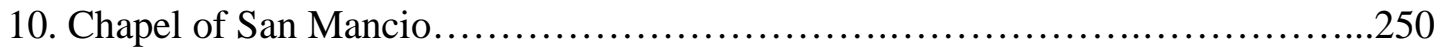

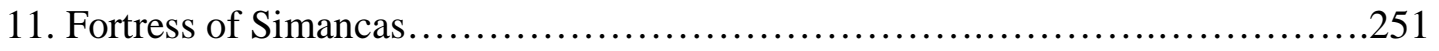

12. Fortress of Gormaz..................................................... 252

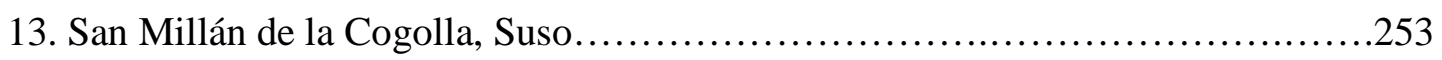

14. Plan of building phases................................................254

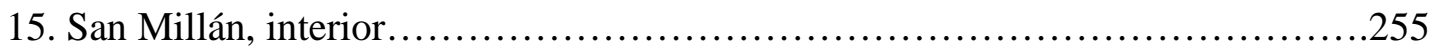

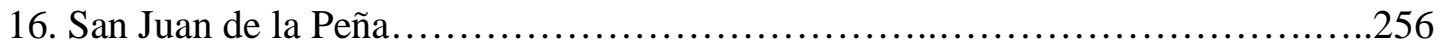

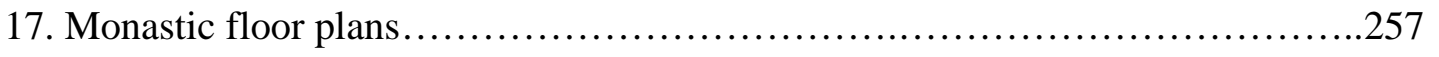

18. San Juan de la Peña, lower church....................................258

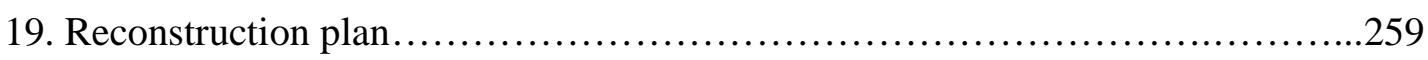

20. Altar niches............................................................... 260 
21. Cenotaph of San Millán......................................................261

22. Plan of San Millán caves................................................262

23. San Juan de la Peña, arcade............................................263

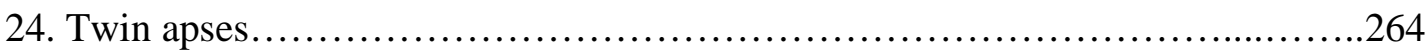

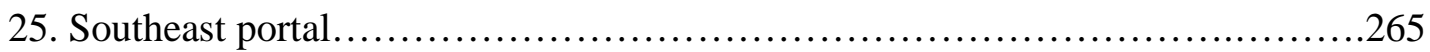

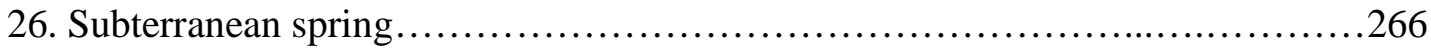

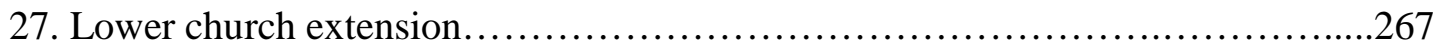

28. Sala de Concilio........................................................268

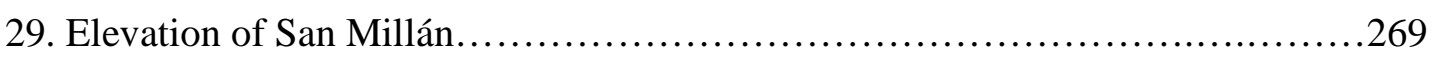

30. San Millán extension......................................................270

31. Cave entrances......................................................271

32. Panteón de los Reyes..................................................2272

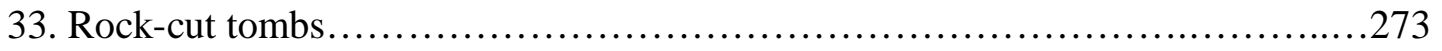

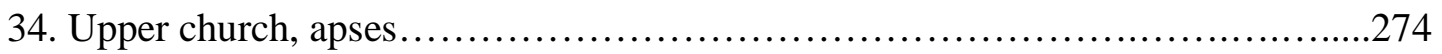

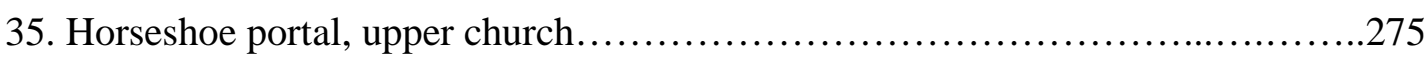

$35 \mathrm{~b} .13^{\text {th }}$ century cloister................................................276

36. Map of Wamba region.................................................277

37. Santa María de Wamba................................................278

38. Santa María de Wamba, vault............................................2 279

39. Carved capital.................................................... 280

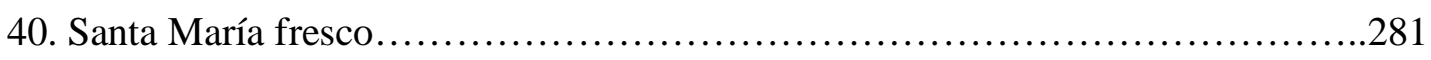

41. Transitional pier....................................................282

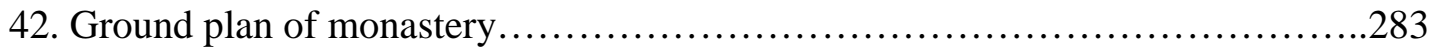

43. Tombs at Santa María de Wamba...........................................284

44. San Román de Hornija................................................28

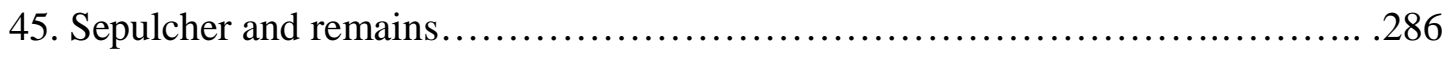


46. San Juan de Baños......................................................287

47. Diagram and tombs................................................ 288

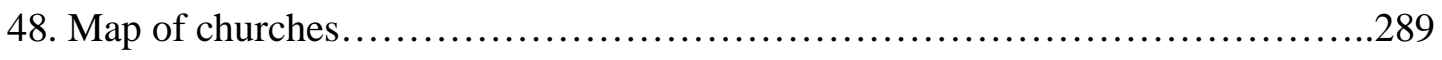

49. Reliquary of Saint Isidore............................................290

50. Silk fragment from Burgo de Osma............................................291

51. Floor plan with interior well ........................................... 292

52. Baptistery from San Miguel de Gormaz.....................................293

53. Two portals at Santa María..................................................294

54. Central column support.............................................295

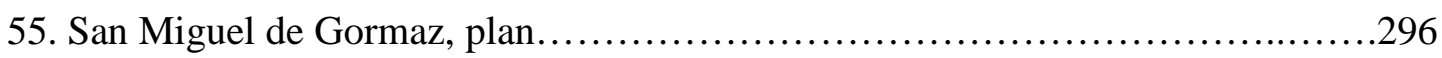

56. Ground plan with wells.................................................297

57. San Baudelio, vault...................................................298

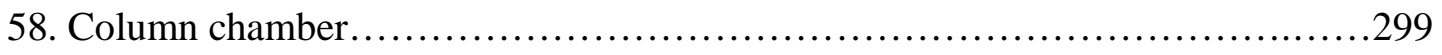

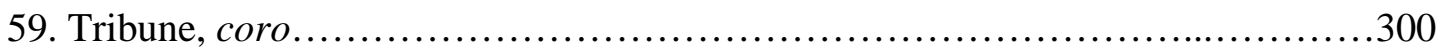

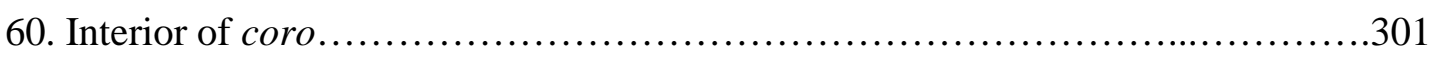

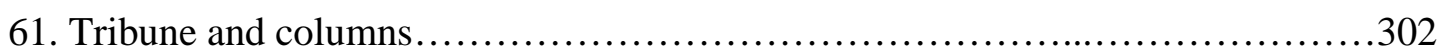

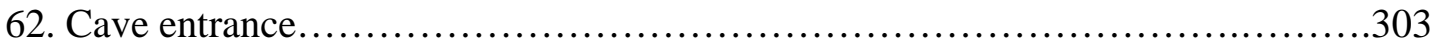

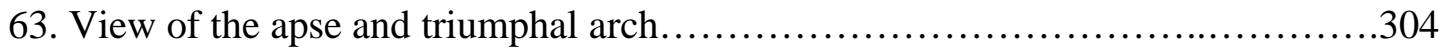

64. San Baudelio necropolis to the northeast............................... 305

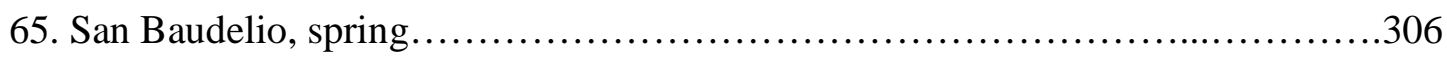

66. San Miguel de Gormaz...................................................307

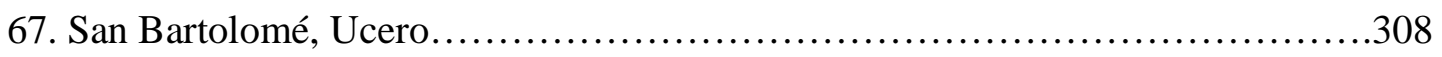

68. Preserved trees........................................................

69. Fortress of Gormaz, gate.................................................. 310

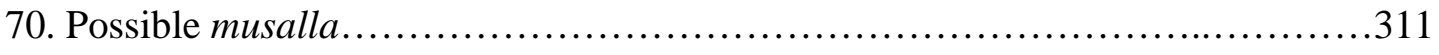

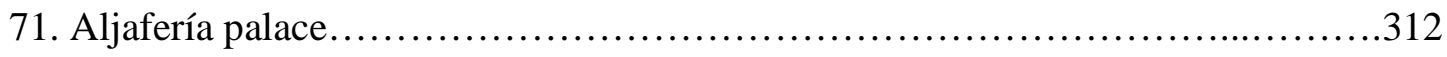


72. Troubadour Tower.

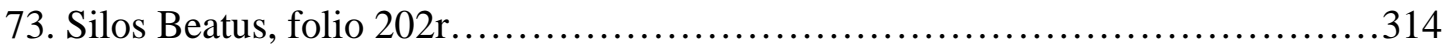

74. Tree of Life, Morgan Beatus Commentary .................................. 315

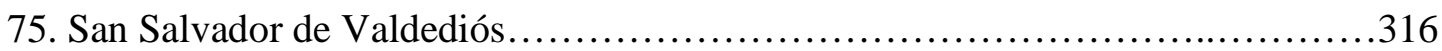

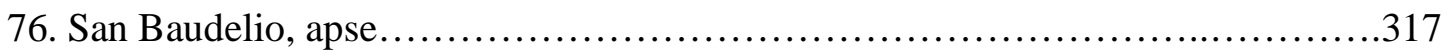

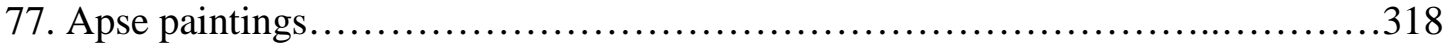

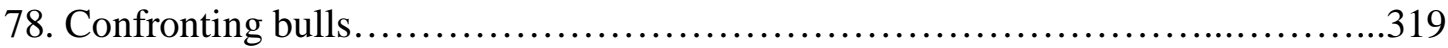

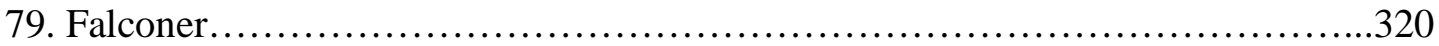

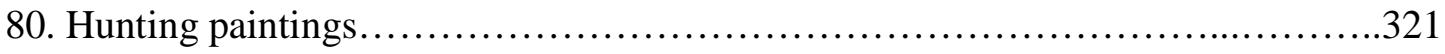

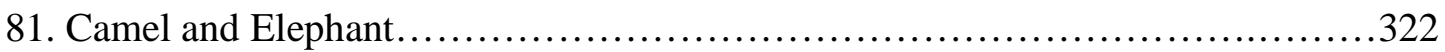

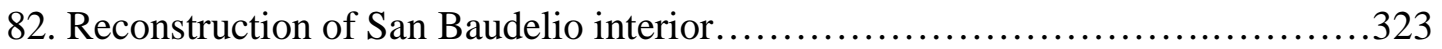

83. Last Supper and Entry into Jerusalem.....................................324

84. Temptation and Wedding Supper..........................................325

85. Resurrection and Healing of the Blind........................................ 326

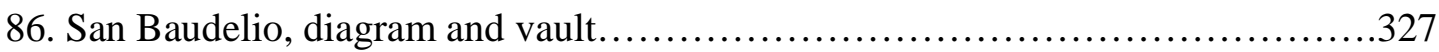

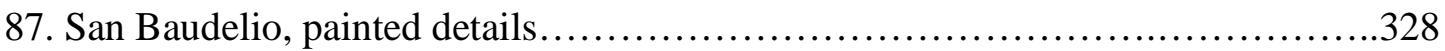

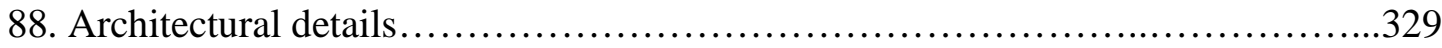

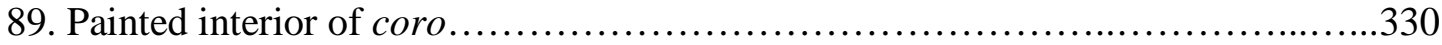

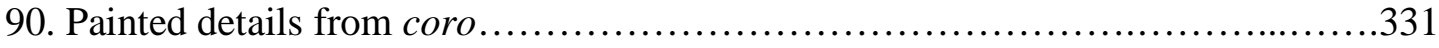

91. San Miguel de San Esteban de Gormaz......................................332

92. Carved traces from church interior...............................................

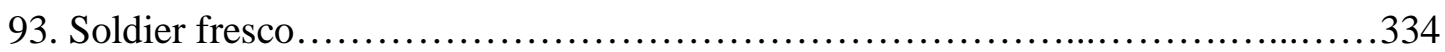

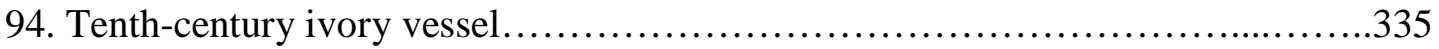

95. Painted interior of San Miguel de Gormaz.....................................336 


\section{INTRODUCTION}

The medieval Christian reconquest, or Reconquista, of Muslim al-Andalus has served as the backdrop for epic battles and scenes of cultural interaction, both collaborative and violent. ${ }^{1}$ The Christian overthrow of Muslim hegemony in the Iberian Peninsula took nearly eight centuries and is still considered an important factor in the formation of national identity for modern-day Portugal and Spain. Within that long period of Christian expansion, the period of the tenth through twelfth centuries marked an important shift in power on the Peninsula, with Christian forces posing a serious threat to al-Andalus for the first time since the Muslim invasion in 711. Taking part in the current reevaluation of the political circumstances that propelled this stage of the conflict, I will discuss how the churches along the Christian-Muslim frontier were used to advance the aims of those who sought to legitimize their right to control newly acquired territory as Christian borders expanded.

The late medieval Reconquista tradition that "many Noble Kings" reclaimed the Peninsula from foreign occupiers has created the impression that Muslims were the only opponents to these campaigns. ${ }^{2}$ Yet, after nearly three hundred years of Andalusi

\footnotetext{
${ }^{1}$ There is a substantial amount of literature on the problematic nature of the term Reconquista and Reconquest and this material will be discussed in chapter one. For the purposes of this study, the more neutral term of 'conquest' will be favored, unless relevant to the discussion.

2 Juan Gil de Zamora, Liber de preconiis Hispaniae, 232-34, quoted in Joseph F. O'Callaghan, Reconquest and Crusade in Medieval Spain (Philadelphia: University of Pennsylvania Press, 2003), 8. In recent decades, studies of historical documents from the archives of the Christian north and al-Andalus have
} 
dominance, the cultural, religious, and linguistic differences between the eleventh and twelfth-century 'liberated' Christians and their new lords were substantial. ${ }^{3}$ As James L. Boone and Nancy L. Benco explain, "In much scholarly work of the nineteenth and earlier twentieth centuries, the Islamic period was considered as a kind of foreign occupation — a historical parenthesis—without lasting cultural or demographic effects to the Hispanic cultural tradition." 4 Although this point of view is no longer accepted, the continued use of the term Reconquest/Reconquista suggests the realization of a Hispanic, Christian reclamation of the Peninsula at the expense of Muslim culture.

Unfortunately, the emphasis on Christian-Muslim categories sometimes obscures the heterogeneous reality of the Peninsula. For example, the large, nebulous frontier zone supported Christian, Muslim, and Jewish populations of Hispano-Roman, Arab, and Berber descent. ${ }^{5}$ In addition to these populations, immigrants from al-Andalus, Galicia, and Frankish territory, to name a few, further provided a diverse cultural landscape. Politically, the authority of Muslim caliphs, kings, and governors, or Christian kings, nobles, and clerics was limited to larger population centers and was regionally specific. In rural areas, systems of government appear to have been (mostly) locally-directed by supralocal elites or, at best, only indirectly subject to outside Christian or Muslim

provided a far more complicated picture of the Reconquest, prompting some scholars to adopt more neutral terms such as 'territorial expansion' to explain the southward movement of the northern kingdoms. ${ }^{3}$ I will use the term "Andalusi" to describe the people or governors of the polity of al-Andalus. Even after the dissolution of the caliphate, the inhabitants of taifa kingdoms will be described as Andalusi, in order to leave open the question of ethnic or religious identity.

4 "Islamic Settlement in North Africa and the Iberian Peninsula," Annual Review of Anthropology 28 (1999): 51-71, 60.

${ }^{5}$ The number of languages illustrates the heritage of these diverse origins. In al-Andalus, the languages spoken included Arabic, Hebrew, and Romance, and these probably had a number of dialects. However, these languages had been the norm for nearly three hundred years and so did not pose the same challenge as the number of un-related languages in the northern kingdoms. In addition to the Asturian kingdom's tongue, the languages of Gallego-Portugese, Basque, Catalan, and the development of two versions of Castilian caused confusion. Bernard Reilly, Contest of Christian and Muslim Spain 1031-1157 (Cambridge, Massachusetts: Blackwell Publishers, Inc, 1992), 32. 
authorities, such as nobles or governors. ${ }^{6}$ As a result, the Christian expansion into the Duero and Ebro river valleys of the frontier did not only challenge al-Andalus but created social and political upheaval for existing communities (figure 1). One example that may serve to illustrate the potential for indigenous groups to view Christian expansion with suspicion are the inhabitants of the Muslim frontier of Lérida. According to A $\square$ mad alRāzī’s (887-955) description of these towns, although they include groups of Christian 'natives,' pacts were in place to ensure that Muslim and Christian would support one another unreservedly. ${ }^{7}$

The consideration of how these Duero basin inhabitants might have responded to their subjugation led to key questions that inspired this project. Did conquered communities view their Christian occupiers as legitimate, and if not, how might their resistance have affected the progress of the Christian conquest? What might the location and appearance of frontier architecture reveal about the negotiation of power between conqueror and conquered $?^{8}$ In the course of investigating these questions, it became clear

\footnotetext{
${ }^{6}$ The term supralocal is often used to explain this type of local control. According to the definition provided in the Glossary in People and Space in the Middle Ages, 300-1300, ed. Wendy Davies, Guy Halsall, and Andrew Reynolds (Turnhout, Belgium: Brepols, 2006), 317: "In origin they [supralocal units] relate to the exploitation of the land, and to the organization of space, by local communities; some have central places, such as hilltop sites*. Some of them were used by Castilian rulers in the tenth century and later in order to build a structure through which to exercise political control, especially through the network of alfoces*." A deeper discussion of the sociopolitical organization of the rural Duero basin will be undertaken in chapter two.

${ }^{7}$ See Eduardo Manzano Moreno, after Lévi-Provençal, in Manzano Moreno, "Christian-Muslim Frontier in Al-Andalus; idea and reality," in The Arab Influence in Medieval Europe (Reading: Ithaca Press, 1994), 92. ${ }^{8}$ Neil Christie voices similar questions when he discusses the appearance of churches and monasteries in late antique villas, such as those located in Spain, Gaul, and Italy. See "Landscapes of Change in Late Antiquity and the Early Middle Ages: Themes, Directions and Problems," in Landscapes of Change: Rural Evolutions in Late Antiquity and the Early Middle Ages, ed. Neil Christie (London: Ashgate Publishing, Ltd., 2004), 12, 14. "Although barely perceptible in Britain, various continental monumental villas are marked also by the presence of churches or chapels (generally) in their latest phases. Is this a straightforward Christianisation of the site's owners, or does it denote the transfer in the owner's lifetime or with the owner's death to Church or monastic control? Or is this the reoccupation of an abandoned site by Church or by monks - the latter with or without local/regional/Episcopal permission? What roles did such churches or chapels have-private, estate or parish? And why these sites-location, size, materials, or local population? We might then question whether private church/chapel building was an effort by an elite
} 
that the historiographical trends of medieval Iberia marginalized the role played by this region in the Christian conquest. Approaching the frontier architecture of the Duero river basin from an interdisciplinary perspective, I will discuss how the need to persuade the frontier rural communities to support the aims of northern kings and aristocrats contributed to the later medieval concept of Reconquista.

The Duero River basin that served as the fluctuating Christian and Muslim frontier for much of the tenth through twelfth centuries encompasses approximately 98,000 square kilometers. It measures nearly 900 kilometers in length from its source near Soria to the Atlantic Ocean at Porto, Portugal. ${ }^{9}$ It is the ecclesiastical architectural spaces of the tenth through twelfth centuries in the north-central Iberian Peninsula that form the central part of this dissertation. Many of these churches were built in a territory that was long thought by scholars to be uninhabited. While there were few urban centers, recent scholarship has offered reasonable evidence that rural communities persisted after the breakdown of Visigothic power in the eighth century and the proliferation of defensive and ecclesiastical architecture thereafter would appear to support that hypothesis. ${ }^{10}$ Scholars agree that many tenth to twelfth century frontier territories other than important cities appear to have been conquered or claimed by clerics of high rank, nobles, or warriors, rather than kings.

to show conversion, to keep up with the ascetic fashion, in response to demands from others, or even another way of displaying wealth - that is, a final burst of private architectural and artistic exhibitionism and authority. The question is complex and little studied as yet. (cf. Ripoll and Arce, 2000: 107-111)." Christie goes on to say that the archaeological study of churches at villas is better accounted for in Spain and cites three late antique sites.

${ }^{9}$ Bernard Reilly, The Kingdom of León-Castilla under King Alfonso VI, 1065-1109 (Princeton, New Jersey: Princeton University Press) 1988, 5.

${ }^{10}$ Santiago Castellanos and Iñaki Martín Viso, "The Local Articulation of Central Power in the North of the Iberian Peninsula (500-1000)," in Early Medieval Europe 13, no.1 (Oxford: Blackwell Publishing, Ltd., 2005), 30. This point of view touches on seeming contradictions between medieval declarations of resettlement and archaeological (and architectural) evidence that suggests a level of continuity. 
In this dissertation, I will argue that the architecture of the frontier was deliberately designed to support a recognizable image of earthly authority in order to persuade the existing community of the conqueror's right to govern. I would offer that this was done in three ways: first, patrons chose meaningful sites with a pre-conquest sacred history; second, they used architectural forms associated with both the ecclesiastic hierarchy and the elite of al-Andalus, León-Castile, and Aragón—including sepulchral spaces; and third, frescoes and sculpture were employed to support their right to reclaim this territory from al-Andalus or a rival supralocal polity.

The precedent for this pattern of patronage may be found in the royally favored churches and monasteries in the kingdoms of the Christian north. The two examples of San Millán de la Cogolla (La Rioja) and San Juan de la Peña (Huesca) demonstrate how sacred landscape, political influence, and economic resources were appropriated by kings in order to bolster their claims of authority. ${ }^{11}$ Specifically, both monasteries are associated with pre-Christian divinity, hermit monk founders, and miraculous events. In addition, their archives record numerous property transactions testifying to their economic resources and regional influence. Both monasteries also include the prominent interment of nobles and royalty and benefitted from their building campaigns.

The strategies employed by kings at monastic centers like San Millán de la Cogolla and San Juan de la Peña were likewise incorporated into the building projects of newly conquered territories in the Duero basin. ${ }^{12}$ The two examples that will serve as the

\footnotetext{
${ }^{11}$ These particular monasteries are unusually well-documented in medieval written accounts and their multiple architectural phases not only remain largely in situ, but have been the subject of several studies. ${ }^{12}$ Although San Juan de la Peña was under the protection of the kingdom of Aragón, it (along with a number of other peninsular monasteries) nevertheless relates to other ecclesiastical centers that visually promoted royal authority, for example, San Isidoro de León. These similarities will be discussed as part of my argument for the adoption of architectural elements associated with kingship by churches and monasteries as the frontier progressed. San Isidoro has been the subject of several iconographic studies and
} 
focus of the dissertation are the churches of San Baudelio de Berlanga (Soria) and Santa María de Wamba (Valladolid). ${ }^{13}$ Although San Baudelio and Santa María de Wamba are situated in different topographical regions that were conquered at different times in the course of the Christian conquest, they represent two examples of churches that conform to the larger pattern of frontier architecture-they do not appear to be royal foundations but include topographical and architectural features that nevertheless suggest a deliberate emulation of imperial authority.

The Christian kings of the tenth through twelfth centuries continued the traditions of their Asturian predecessors and cultivated an imperial identity that connected their authority to the Visigothic past. While nobles, knights, and clerics did not claim to be kings, it appears that they saw advantages in this practice that could extend to their territorial ambitions. By appropriating pre-Islamic holy histories through the siting and construction of ecclesiastical spaces along the Duero frontier, they could imply that noble Christians had a preexisting claim to the territory. By the twelfth century, papal calls for a crusade against Muslims in Iberia further bolstered the efforts of those seeking to expand their borders to the south by sanctioning their efforts. The incorporation of elite visual elements into monasteries and churches inserted into sacred environments was one way for non-royals to evoke legitimate authority and the favor of God, enabling the conqueror or supralocal patron to effectively control the resources of existing rural communities. While the specific ways in which patrons constructed churches varied according to place and time, the theme of "restoration" was pervasive. Over time, the

excavations in the past twenty years, for example, José Luis Senra, "Aproximación a los espacios liturgicofunerarios en Castilla y León: porticos y galileas," Gesta 36, no. 2, (1997): 122-143 and Rose Walker, "The Wall Paintings in the Panteón de los Reyes at León: A Cycle of Intercession," Art Bulletin 82, no. 2, (June 2000): 200-225.

${ }^{13}$ This church is also known as Santa María de Bamba. 
symbolic dissemination of the idea that sacred centers had been "restored" to Iberian Christendom served as support for the ninth-century Asturian rhetoric that called for the territorial reclamation of the Peninsula from illegitimate and heretical Muslims. ${ }^{14}$ In the thirteenth and fourteenth centuries, the success of these strategies would prompt medieval chroniclers to develop and transform the slow Christian conquest of al-Andalus into an inevitable, heroic Reconquista.

\section{Dissertation Organization}

The history and historians of the Iberian Peninsula have profoundly affected the way we frame questions about its past. With this in mind, the first chapter will sketch a brief history for Iberia from 900 to1200 and outline important historiographical issues. Following that section, key terms will be defined and considered in relation to the goals of this dissertation. Theoretical methods, such as post-colonial and frontier studies, have informed my approach and will therefore be discussed in this chapter along with methods employed to evaluate the material evidence, such as stylistic analysis. Chapter one will conclude with the contribution that I believe this project will make to our present understanding of rural ecclesiastical spaces along the frontier: that these churches facilitated their patrons' attempts to impose political control over the inhabitants and resources of crucial frontiers.

Set against the historical background of the Christian conquest and the role of the Duero frontier, the second chapter tackles two key problems inherent in a medieval

\footnotetext{
${ }^{14}$ Joseph O'Callaghan, Reconquest and Crusade, 3-4. The author briefly describes the recent scholarship that challenges the idea of reconquest as a possible invention by modern historians. He offers instead that the reconquest was neither a modern invention nor a fully-formed idea that survived from the earliest days of the Muslim conquest, "but rather one that evolved and was shaped by the influences of successive generations."
} 
frontier architectural study-the reconstruction of the rural audience for these churches and monasteries and how these sites participated within their sociopolitical structure. Not only did the Duero basin support the raising of livestock and agricultural production but the presence of fortresses and fortified towns appear to have operated as points of defense and social organization. The presence of ecclesiastical spaces either in proximity to these fortresses or as administrative centers in their own right suggests that they, too, participated in the organization of the frontier community. This chapter is crucial to the development of my argument that the churches of Santa María de Wamba and San Baudelio de Berlanga served as points of contact between non-royal elites who claimed authority over the resources and loyalties of their rural audience in order to expand their territory.

Chapter three examines two monasteries attached to sacred landscapes located along the contested, early eleventh-century frontier: San Millán de la Cogolla (La Rioja) and San Juan de la Peña (Huesca). The noble patronage that these small, isolated foundations attracted is considered an indication of the value attributed to frontier churches by elites concerned with legitimation and the vitality of their kingdoms. San Millán and San Juan embody the visual elements that also appear in the Duero basin at small, rural ecclesiastical centers along the frontier. Royal foundations offered a readymodel for supralocal and conquering elites to appropriate . As the frontier with alAndalus progressed further southward, San Millán and San Juan experienced a decline in their influence and wealth, thus underscoring the connection between frontier proximity and political value that underpins this thesis. 
In chapters four and five I connect the sociopolitical motivations that prompted kings to patronize churches in the north to the strategic selection of Duero basin churches by non-royal patrons attempting to justify or strengthen their regional authority. The case studies selected for this group represent two different portions of the porous frontier. This was done to demonstrate that, while similarities in architectural and topographical elements appear at various points along the frontier due to their shared historical context, both churches naturally reflect the local circumstances of their production.

San Baudelio de Berlanga was located near the chain of Duero fortresses controlled by al-Andalus and later, the powerful taifa kingdom of Zaragoza (figure 2, 3). Due to the strategic value of this region, it was contested throughout the eleventh century and was likely inhabited by a religiously and culturally mixed society. Due to these circumstances, the proliferation of elements familiar to an Islamic audience, such as horseshoe arches and dome-shaped interiors, would have been the reasonable way to affect a display of elite authority. Approximately 200 kilometers to the west, Santa María de Wamba was built between the city of Zamora and the town of Valladolid (figure 4, 5). This portion of the Duero basin was a region settled by Berbers in the eighth century but subject to the raids and efforts at political restructuring made by Asturian and Leonese kings in the ninth and tenth centuries. This audience was therefore more likely to have had more contact with Christian models of power, though their proximity to al-Andalus would have put them in contact with Andalusi forms as well. Despite their distinct differences, both sites reflect the sociopolitical realities of a frontier that was experiencing a political reorganization. 
Finally, I will offer a concluding chapter in order to synthesize arguments presented in this dissertation. The ability to appropriate powerful landscapes and sovereign histories gave credence to demands made by proprietors (whether old or new) for the defense and administration of their land. Without standing armies, frontier governors relied heavily upon image and persuasion. The wide-spread adoption of these legitimizing strategies explains the architectural and topographical similarities found across the Duero frontier. Nevertheless, the motivation and methods used to justify regional governance (pre-Islamic heritage, celestial support, legitimate political authority) were eventually lost within the reductive ideology of a Christian crusade against Islam.

\section{Contribution to Scholarship}

This study seeks to open up a dialogue concerning the political strategy of legitimization through image construction encountered in the architecture between the Christian and Muslim polities of medieval Iberia. Specifically, it intends to explore the lines of power held by lay and ecclesiastical elites and the ways in which they used churches and monasteries to negotiate their position in the face of shifting political situations. By exploring the influential role of the church building within its community, this dissertation will, in turn, address the gap found in current scholarship concerning the multiple functions of frontier ecclesiastical spaces.

Any attempt to theorize architectural function must analyze potential audience reception. Unfortunately, because the debate over the so-called population and repopulation of the Duero Valley has been largely ignored by art historians, scholars have overlooked the critical ways in which patrons exploited sacred topographies and 
monumental architecture in an effort to control regional resources. This dissertation presents arguments for why the "lordly" image of this frontier architecture was more than a concession to aesthetic fashion or merely a status symbol but rather a deliberate attempt to emulate familiar elite visual programs in order to successfully rule. Because the need to present legitimate authority was common to many groups along the frontier, similar building strategies can be found within this heterogeneous collection. Finally, this dissertation will demonstrate that the acceptance or rejection of an outsider's campaign for authority affected not only the local stability of the town but contributed to the repertoire of effective rhetoric employed by those seeking to expand their influence over marginal territory. 


\section{CHAPTER 1:}

\section{THE HISTORY AND HISTORIOGRAPHY OF THE MEDIEVAL DUERO BASIN}

A Brief Political History of Central Iberia (c. 900-1200)

It is difficult to reconstruct the nature of how territory between the Cantabrian Mountains and the Tajo River was organized politically in the two hundred years that followed the Muslim conquest of 711 and the decisive end of the Visigothic Kingdom. As will be discussed in greater detail in chapter two, the only written accounts for this period date to well after the events themselves and focus on legitimizing Asturian kingship. The reactions of the existing populations to the occupation and control of their lands and resources by outside forces are unrecorded. Although the academic literature widely repeats the idea that Christian kings, nobles, and clerics occupied and laid claim to the sparsely inhabited Duero basin in the ninth and tenth centuries as the frontier with alAndalus edged southward in an irregular line, precisely how this was done, or by whom, remains unclear. ${ }^{1}$

\footnotetext{
${ }^{1}$ Neither Christian nor Muslim powers appear to have imposed a central authority in the form of taxes or military obligations upon people living along the porous frontier. The difficulty in determining who controlled what frontier territory, or even identifying the frontier is acknowledged by David Abulafia, "Introduction: Seven Types of Ambiguity, c. 1100-c.1500," in Medieval Frontiers: Concepts and Practices, ed. David Abulafia and Nora Berend (Aldershot England; Burlington, VT: Ashgate, 2002), 11. "In part this is the result of the rapid changes in ownership of land in many parts of Europe, so that a map of, say, the Spanish Reconquista must be frozen at a very precise point to bear any relation to reality, and must allow not just for great uncertainties on the part of historians at work many centuries later, but also for contemporary uncertainties about who was in control of which parts of contested territories."
} 
Progress made by Galicia, Asturias, León, Castile, and Navarre to expand their kingdoms was halted by the devastating raids of Muhammad b. Abi Amir al-Man $\square$ ūr (976-1002). Raiding deep into territory held firmly by Christian kings, Al-Mansūr's campaigns ruined many important religious and political centers north of the Duero river basin, including the holy shrine at Santiago de Compostela in $997 .^{2}$ Al-Man $\square$ ūr's military success and political savvy allowed him to pass control of al-Andalus to his son, 'Abd al-Malik al-Mu $\square$ affar (1002-1008), and by 1000 the Muslim military was the dominant power within the Peninsula. ${ }^{3}$

This situation rapidly changed, however, as discontented Umayyad factions succeeded in doing away with the 'Āmirid regime and the puppet caliph they had purported to represent. In the two decades that followed, a series of failed contests for power led to the final breakdown of the central caliphate in 1031 and the formation of independent Muslim polities known as the taifa states. The military and political superiority of al-Andalus vanished with the death of 'Abd al-Malik. Even before the final end to the caliphate in 1031, factions that would develop into the nascent taifas were jockeying for control and the continuing volatile situation progressively weakened al-

\footnotetext{
${ }^{2}$ Hugh Kennedy, "Muslim Spain and Portugal: al-Andalus and its Neighbours," in The New Cambridge Medieval History, Vol. 4, c. 1024-c.1198, ed. D. E. Luscombe and Jonathan Riley-Smith (Cambridge: Cambridge University Press, 2003), 599. Although Kennedy gives the date as 999, the date 997 for the sack of Compostela appears more frequently in the secondary literature. See: Bernard Reilly, The Medieval Spains (Cambridge: Cambridge University Press, 1993), 87, Richard Fletcher, Moorish Spain (Berkeley: University of California Press, 1993), 75, and Janice Mann, Romanesque Architecture and Its Sculptural Decoration in Christian Spain, 1000-1120; Exploring Frontiers and Defining Identities (Toronto: University of Toronto Press, 2009), 47. For a thorough account of the effective usurpation of caliphal authority by the military commander al-Man $\square$ ür and his descendents, see David Wasserstein, The Caliphate in the West (Oxford University Press, 1993), 17-27.

${ }^{3}$ Wasserstein, The Caliphate, 19.
} 
Andalus for most of the eleventh century. ${ }^{4}$ To the north, Christian kingdoms were aware of the opportunity that the new state of affairs in al-Andalus offered. ${ }^{5}$ However, they were unable to exploit the opportunity for expansion to the south because they were preoccupied with their own internal warring. ${ }^{6}$ On the other hand, for those regions with established leadership and strong armies, the conquest of neighboring kingdoms or counties through warfare or strategic marriage offered the potential for larger, stable states. $^{7}$

The foundation for future Andalusi conquests was laid by Sancho el Mayor, or King Sancho the Great of Navarre (1000-1035), who managed to greatly increase the size of his small kingdom of Navarre to include the lands between Galicia and the county of Barcelona by the time of his death. ${ }^{8}$ Although these regions were reduced and divided between his sons at his death in 1035, his youngest son Fernando I el Magno, the Great

\footnotetext{
${ }^{4}$ David Wasserstein, The Rise and Fall of the Party-Kings; Politics and Society in Islamic Spain, 10021086 (Princeton, New Jersey: Princeton University Press, 1985), 47-55, 82-115, 82. "Although some small states came into existence after this date, these were for the most part the result of rebellion against an existing taifa ruler, and they enjoyed usually but an ephemeral life. The main taifa states arose well before $422 / 1031$, and were firmly established by the time when Cordoba became a state without any territorial pretensions of its own."

${ }^{5}$ The reason that Catalonia has not been discussed in this broad picture of the early Christian expansion into al-Andalus is because Catalonia, for the most part, initially opted to develop cultural and economic contacts with the West Frankish, later French, and Andalusi municipalities, especially Córdoba, in the last half of the tenth century. Although the relationship with Córdoba was severed after Catalan counties were attacked by al-Man $\square$ ür and his son, Catalonia did not begin to join in the campaigns or alliances of its Christian Iberian neighbors until the twelfth century. For a careful description of medieval Catalonia see Adam J. Kosto, Making Agreements in Medieval Catalonia; Power, Order, and the Written Word, 10001200 (Cambridge: Cambridge University Press, 2001).

${ }^{6}$ Esther Pascua, "South of the Pyrenees: Kings, Magnates and Political Bargaining in Twelfth-Century Spain," Journal of Medieval History 27, no. 2 (2001): 101-120, 105. The author explains the fractious situation succinctly; "Twelfth-century Christian Spain could be called the period of 'Christian taifas' as a comparison with the contemporary taifas'."

${ }^{7}$ An example of the political volatility that characterized the meseta of the Duero basin is Castile. It became a county that enjoyed independence from the kingdom of León under Count Fernán Gonzalez (d. 970). It was later absorbed into the large combined kingdoms of León, Navarre and Aragón under Sancho el Mayor, or the Great (1000-1035). Parceled out as a separate kingdom to Sancho's son Fernando I (10351065 ) as an independent kingdom, Fernando went to war with his brother in León and in 1037 consolidated the two into the formidable kingdom of León-Castilla.

${ }^{8}$ Richard Fletcher, The Quest for El Cid (New York: Alfred A. Knopf, Inc., 1990), 56. He also had control over a portion of Gascony.
} 
(1035-1065), soon dominated the trans-Duero frontier with his consolidation of León-

Castile in 1037. Unfettered by neighboring Christian threats, he was able to turn his attention to al-Andalus, and intimidate the nearest large taifas into tributary status. ${ }^{9}$

Despite these successes in the center of the Peninsula, it is important to note that the east-west frontier between Christians and Muslims moved at an uneven pace, with the eastern border progressing very little in the eleventh century. The reason for this is that while many of the taifa kinglets were vulnerable due to their weak administrative and military capabilities, the taifa of Zaragoza was large and powerful. The ChristianMuslim frontier in the eastern Peninsula would yield little ground until Alfonso I of Aragón (1104-1134), also called el Batallador (the Battler), seized the city of Zaragoza in 1118. ${ }^{10}$ Located between both Christian and Islamic powers and feuding Christian kings and counts, churches and monasteries along the frontier were in a precarious position, even as the battle lines firmly moved south of the Duero River (figure 6). ${ }^{11}$

The last quarter of the eleventh century witnessed a dramatic shift south for the Christian-Muslim frontier. Despite early challenges to his crown, Alfonso VI (10691109) was able to combine the kingdoms of León-Castile and muster significant military

\footnotetext{
${ }^{9}$ Wasserstein, Rise and Fall, 137. "Now the taifa rulers began to give military help to the Christians, and also to pay them regular tribute (parias), strengthening the Christian states and encouraging them to increase their demands on the Muslims."

${ }^{10}$ Bernard Reilly, The Kingdom of León-Castilla under Queen Urraca, 1109-1126 (Princeton, New Jersey: Princeton University Press, 1982), 5-8, 40, 133.

${ }^{11}$ James Powers argues that the instability caused by raiding and war along the eleventh century Duero frontier prompted the creation of militias and the insertion of military obligations into the town charters for subsequent centuries. By the twelfth century, threats to churches and monasteries were rarely from Muslims. For example, the townspeople of Sahagún facilitated the capture of their own town by Alfonso I in order to thwart the authority of their monastery and its patron, Queen Urraca. See A Society Organized for War; The Iberian Municipal Militias in the Central Middle Ages, 1000-1284 (Berkeley; Los Angeles; London: University of California Press, 1988), 13-39, 25 in particular. That churches and monasteries could be negatively impacted by the feuding Christian powers is amply illustrated by Isabel Alfonso, "Judicial Rhetoric and Political Legitimation in Medieval León-Castile," in Building Legitimacy; Political Discourses and Forms of Legitimacy in Medieval Societies, ed. Isabel Alfonso, Hugh Kennedy and Julio Escalona (Leiden; Boston: Brill, 2004).
} 
resources. $^{12}$ Neighboring taifas confronted by León-Castile's military might paid Alfonso parias (tribute money) in order to avoid costly raids. In addition to the fabulous wealth accrued from parias, Alfonso cultivated relationships with Frankish kingdoms, Abbot Hugh of Cluny, and Pope Gregory VII, and used his position to impose the Roman rite in 1080. The king's armies provided stability for pilgrims travelling on the "Way of St. James" and expanded his territory to the south, culminating in the 1085 conquest of Toledo. ${ }^{13}$ Control of the royal capital of the Visigoths was a symbolic and strategic coup for León-Castile but the seizure of Toledo did not result in a secure occupation. The main reasons for this are two-fold: the strength of the North African armies that invaded the Peninsula in response to an invitation from nervous Muslim taifas and continued internal warring between Christian kingdoms.

Taifa kingdoms requested military assistance from the Almoravid Empire in the wake of the conquest of Toledo. ${ }^{14}$ Although the arrival of the Almoravid army in 1086 complicated the already fractured and weak taifa kingdoms of al-Andalus, the Almoravids, led by the zealous Yūsuf ibn Tāshufin, soundly defeated the LeoneseCastilian forces near Badajoz and stopped the momentum gained from the success at

\footnotetext{
${ }^{12}$ A colorful example of the sort of intimidation used to extract parias is relayed by Bernard Reilly, Contest, 84. "In the summer of 1083 Alfonso VI led a major invasion of the territories of al-Mutamid. In the course of it, the Christian army lay for three days before the city of Sevilla itself before going on to the Mediterranean at Tarifa, where the king rode his horse into the surf as a symbol of his mastery of Iberia. This great raid was intended to overawe al-Andalus and Muslim Spain generally and to prevent any interference with the subsequent campaign against Toledo."

${ }^{13}$ For a detailed account of this process, see Bernard Reilly, The Kingdom under King Alfonso VI and Santiago, Saint-Denis, and Saint Peter: The Reception of the Roman Liturgy in León-Castile in 1080, ed. Bernard Reilly (New York: Fordham University Press, 1985).

${ }^{14}$ Prior to the conquest of Toledo, Alfonso VI had carried out devastating raids into al-Andalus, like the example described in the footnote 53, to penalize Muslim kingdoms for inadequate parias and as a symbol of his power. It is uncertain who made the initial overture to the Almoravids, but the wide-ranging campaigns of Alfonso VI concerned a number of Andalusi rulers, see Hugh Kennedy, Muslim Spain and Portugal, a Political History of Al-Andalus (Harlow, England: Pearson Education Ltd., 1996), 161-162.
} 
Toledo. ${ }^{15}$ However, the Almoravids did not attempt to press further north and instead returned to Africa. From there they launched a series of campaigns against the taifa kings, whom they viewed as corrupt, until they controlled all of al-Andalus in $1110 .{ }^{16}$

Despite their successes and military strength, the taifas under Almoravid leadership were not able to create a unified al-Andalus. Nevertheless, a certain amount of security for al-Andalus was achieved under their governance. ${ }^{17}$ At the same time, the strength of their Peninsular armies and North African reserves caused grave uncertainty and concern in the northern kingdoms. ${ }^{18}$ Shaken by the Almoravid conquest, Christian kings and queens set about shoring up the defenses of frontier holdings and issuing fueros (town charters) that established the military obligations for townspeople. ${ }^{19}$

The successes of the Almoravids were short-lived, however. In the first quarter of the twelfth century, Ibn Tūmart and his followers, the Almohads, began to seriously undermine Almoravid authority in North Africa and by the middle of the twelfth century, there are reports of Andalusis assisting the Almohad armies in their conquest of Almoravid cities. ${ }^{20}$ In the decades between the Almoravid decline and the consolidation of Almohad power in al-Andalus, Christian kings were able to press forward across the breadth of the frontier and eventually assemble multi-party coalitions. ${ }^{21}$ The capture of Lisbon in the west (1147), Tortosa in the east (1148), and Almería on the southern

\footnotetext{
${ }^{15}$ Wasserstein, The Rise and Fall, 284 and Powers, A Society Organized for War, 20.

${ }^{16}$ Wasserstein, The Rise and Fall, 292.

${ }^{17}$ Wasserstein, The Rise and Fall, 288-291, 290-291. It is interesting to note that the Almoravid attacks on co-religionists were officially sanctioned by religious scholars and the 'Abbāsids in the east. See also Fletcher, Moorish Spain, 105-118.

${ }^{18}$ Lucy Pick, Conflict and Coexistence, Archbishop Rodrigo and the Muslims and Jews of Medieval Spain (Ann Arbor: University of Michigan Press, 2004), 28.

${ }^{19}$ Powers, A Society Organized for War, 22-39.

${ }^{20}$ Reilly, The Kingdom under Queen Urraca, 60-180, 180. A detailed analysis of the rise of Almoravid and Almohad power in Iberia is undertaken by Kennedy in Muslim Spain and Portugal, 154-266, see 196-209 and 187-189 in particular.

${ }^{21}$ Reilly, The Contest, 190-200. The coalition included extra-Peninsular crusaders and ships from Genoa. See also Kennedy, Muslim Spain and Portugal, 190.
} 
Peninsular coast (1147) illustrates a short period of almost unmitigated success in which

Christian forces were able to penetrate deep into al-Andalus, to the point that even

Córdoba was seriously threatened by Alfonso VII. ${ }^{22}$

In the next few years, however, the leaders of Portugal, Navarre, and Aragón-

Barcelona lost interest in expanding upon their earlier Andalusi gains in favor of political consolidation within their kingdoms and contesting the borders of their co-religionists. With Alfonso unable to campaign in 1156 due to illness, the Christian advance was stalled and the field was left open for the Almohads. For the remainder of the twelfth century, Almohad forces halted, and in many places reversed, prior Christian seizures. ${ }^{23}$ Furthermore, Almohad offensives put significant pressure on the city of Toledo and the Tajo River basin. ${ }^{24}$ Almohad success was due not only to their strength but to the return of substantial warfare among the Christian kingdoms.

Although brief truces were occasionally made to coordinate attacks against Almohad fortresses, Christian sovereigns spent the bulk of 1150-1200 fighting amongst themselves. At times, they would negotiate peace or even alliances with the Almohads in order to better concentrate their resources on their fellow Christians. ${ }^{25}$ Eventually, intense pressure from Popes Celestine III (1191-1198) and Innocent III (1198-1216), who were displeased by the situation in Iberia, succeeded in motivating most of the Christians

\footnotetext{
${ }^{22}$ Reilly, The Contest, 211-214; Kennedy, Muslim Spain and Portugal, 190-204.

${ }^{23}$ Reilly, Contest, 223-224.

${ }^{24}$ Kennedy, Muslim Spain and Portugal, 209. Almeria, Ubeda, and Baeza are examples of important Christian losses in the south.

${ }^{25}$ O'Callaghan, Reconquest and Crusade, 55-61. The author explains that after al-Man $\square$ ūr, the Victorious (1184-1199) retook recent Christian conquests in Portugal in 1190-1191 that the Christians were motivated to make peace-with the Almohads. "Thereafter the Almohads concluded a series of truces with the Christian monarchs, who resumed their quarrels. Alfonso VIII, according to Muslim sources, even offered to pay tribute and to wage war against his coreligionists. Perceiving him as domineering, the kings of León, Navarre, Aragón, and Portugal formed alliances to counterbalance Castilian power.” (ibid., 59).
} 
monarchs to return to the battle against Muslims in al-Andalus. ${ }^{26}$ In 1212, the combined forces of Castile, Portugal, León, Aragón-Barcelona, and Navarre soundly defeated Caliph Abū 'Abd Allāh al-Nā $\square$ ir (1199-1213) at Las Navas de Tolosa. ${ }^{27}$ This victory did not immediately change the appearance of Iberia in terms of Almohad hegemony or the position of the frontier but in retrospect, it symbolically signaled the beginning of Christian dominance in the Iberian Peninsula.

The brief historical sketch above demonstrates the back and forth nature of the Christian expansion into al-Andalus, particularly for the eleventh and twelfth centuries. This portrayal is somewhat at odds with the seemingly inexorable southern movement of the frontier on historical maps of the Reconquista. Yet the historical reality for medieval populations living in the Duero basin was one of uncertainty. Borders between kingdoms and counties (both Christian and Muslim) could change overnight. To modern eyes, the movement of the Christian-Muslim frontier beyond the Tajo in the eleventh century could possibly represent a period of greater security for Duero frontier communities. Instead, near-constant fighting between neighboring Christian rulers and the changing fortunes of al-Andalus did little to allay security concerns. The need to politically structure the transDuero so that military resources and supplies could be mustered in case of attack led to the imposition of authority in architectural form from a succession of patrons, lay and

\footnotetext{
${ }^{26}$ Lucy Pick persuasively argues that Archbishop of Toledo Rodrigo Jiménez de Rada (1209-1247) should be given more credit for his diplomatic and military role in the Christian victory at Las Navas de Tolosa. Conflict and Coexistence, 30-43. As evidence of the Papal displeasure over the Christian in-fighting, crusading indulgences were offered to those attacking Alfonso IX of León, who had collaborated with the Almohads against Castile in 1196 and 1197. See also O'Callaghan, Reconquest and Crusade, 62-64, 76. ${ }^{27}$ Pick, Conflict and Coexistance, 28-29; Reilly, The Medieval Spains, 135; O'Callaghan, Reconquest and Crusade, 69-74. The kings of Portugal and León did not participate in the crusade but did not hinder their subjects from doing so. In fact, the Pope was concerned that the ongoing antagonism between Alfonso IX of León and Alfonso VIII of Castile might tempt the Leonese ruler to consort with the enemy. Toward that end he issued a directive that anyone who gave support to the enemy would be excommunicated.
} 
ecclesiastical. The following section considers the state of the question for architectural production at the medieval Duero frontier.

\section{State of the Question}

Scholarly understanding of the buildings at the center of this study has been shaped by their designation as either "Mozarabic" or "Pre-Romanesque" churches, both vague terms about which little consensus exists. ${ }^{28}$ The term "Mozarabic" was initially coined to describe the work of "Mozarabs," or "Arabized Christians" who fled alAndalus in favor of the Christian north in the late ninth and early tenth centuries. "Romanesque," on the other hand, is an architectural style that is usually associated with churches built in Frankish regions north of the Pyrenees Mountains. In the past two decades, these terms, and how they are used to describe buildings in Iberia, have become problematic because of the assumptions they promote about patronage and meaning. This study elects to describe buildings as products of the tenth century, etc., whenever possible and to explain which structural elements may reflect Andalusi or Frankish influence rather than relying upon the confusing shorthand of "Mozarabic" or "Romanesque" without qualification. On the other hand, how buildings, their builders,

\footnotetext{
${ }^{28}$ Manuel Gómez Moreno first described architecture as "Mozarabic" in Iglesias Mozárabes: Arte Español de los siglos IX a XI (1919). The term Pre-Romanesque generally refers to Iberian buildings produced in the eleventh and early twelfth century. For a compelling critique of the present use of the term 'Romanesque,' see Tadhg O'Keefe, Archaeology and the Pan-European Romanesque (London: Gerald Duckworth \& Co. Ltd., 2007). O'Keefe challenges the idea that regional schools are a variant of a thematically cohesive Romanesque and instead seeks to set aside the notion of Pan-European Romanesque and reevaluate the heterogeneous nature of architecture on its own terms, rather than by how well it conforms to the conventional definition of Romanesque. In Sally Garen's description of the term, she follows those authors, such as Isidoro Bango Torviso, who dismiss the notion that the Mozarabs had their own architectural tradition in the South to draw upon, and instead uses the term Reconquest architecture. See Garen, "Santa María de Melque and Church Construction under Muslim Rule," JSAH 51 (September, 1992): 288-302 and Bango Torviso, "Arquitectura de la decimal centuria? Repoblación o mozárabe?" Goya 122 (1974): 68-75, 71.
} 
and/or audience have been traditionally characterized in the scholarly literature can reveal a great deal about underlying ideological preoccupations.

The broad visual vocabulary that medieval builders drew upon reflected the complexity of the existing culture. Along the wide border between Christian and Muslim kingdoms, one would probably have found a variety of populations. Some of the communities included Hispano-Romans who had maintained part of their Visigothic-era heritage while adopting new customs and the language of their conquerors (called "Mozarabs") alongside Hispano-Romans who had converted to Islam and embraced the dress and habits of their conquerors, possibly intermarrying or working within the Andalusi system of governance (called "Muwallads"). In addition to these groups were Muslims, most likely Berbers, who had never known an Iberia before al-Andalus but who naturally adopted some Hispano-Roman customs, and Jews, who likewise participated in cultural exchange, settling along the trade routes that bridged Muslim and Christian markets. ${ }^{29}$ Finally, there were traders and travelers from al-Andalus, Christian Iberia, Frankish kingdoms or other outside lands coming into contact with frontier populations. Any of these communities would have participated in the visual culture of Duero basin architecture. It is therefore understandable that in the past, art historians have focused on disentangling styles and exploring directions of influence. ${ }^{30}$

\footnotetext{
${ }^{29}$ Concerning the presence of Berbers alongside persisting Hispano-Romans in the Duero basin, see Iñaki Martín Viso, Fragmentos del Leviathán, la Articulación Política del Espacio Zamorano en la Alta Edad Media (Zamora: Instituto de Estudios Zamoranos, Florián de Ocampo, 2002), 39-40; for a discussion of the two-way cultural exchange between the Berber or Arab leaders of persisting Hispano-Romans in the adjacent Ebro valley, see Brian A. Catlos, The Victors and the Vanquished, Christians and Muslims of Catalonia and Aragon, 1050-1300, ed. D. E. Luscombe (Cambridge: Cambridge University Press, 2004), 24-25 and 30-31; and for the settlement of Jewish communities near trading cities, such as Tudela and Burgos, see Pick, Conflict and Coexistence, 171.

${ }^{30}$ As many scholars have pointed out, questions surrounding the meaning of words like style and influence (or appropriation) are complicated. In the past, the use of the term "influence" has been associated with one culture transmitting a style to a more passive, or subordinate, culture. This legacy will be discussed
} 
How the history of Iberian medieval scholarship has shaped the ways in which we look at Duero Valley churches will be discussed not only in this chapter overview but throughout the dissertation. Because medieval and modern authors sought to minimize the impact of Muslim culture in the Peninsula in an effort to promote their vision of an indomitable "Spanish" essence, their accounts have affected our reconstruction of frontier communities and the Christian conquest of al-Andalus. ${ }^{31}$ The construction of histories in order to serve nationalistic bias has justly received attention in the past few decades and deserves continued consideration, particularly when reevaluating entrenched art and architectural histories. $^{32}$

The 1919 publication of Iglesias Mozárabes: Arte Español de los siglos IX a XI, by Manuel Gómez-Moreno, was the first book to treat Mozarabic architecture comprehensively and to suggest the presence of both Islamic and Asturian influence in the small churches he dated approximately to the ninth and tenth centuries. In the last

\footnotetext{
later in this chapter and again in chapter three as it has certainly shaped the discourse of medieval art in Iberia. I follow ongoing scholarly efforts to avoid reifying entrenched biases by using descriptive language instead of stylistic categories and emphasizing cultural contacts over directions of influence. However, as Jas' Elsner explains in "Style," in Critical Terms for Art History, ed. Robert Nelson and Richard Shiff (Chicago: University of Chicago Press, 2003), 105: "I am not arguing here against the value or inevitability of empiricism, style art history, or the kinds of stories that we tell. But it is important to recognize that none of these fundamental building blocks of the discipline are natural, neutral, transparent, or true. They entail a particular and, in the context of art history as it exists today, an inevitable process of translation by which we understand (in a particular way) what it is we have been looking at."

${ }^{31}$ The most well known of these efforts was the influential work of Claudio Sánchez-Albornoz, España: Un Enigma Histórico, 2 vols. (Buenos Aires: Editorial Sucamericana, 1956).

${ }^{32}$ For a few Spanish scholars, the issue of national identity became wedded to the histories of medieval Spain and Portugal. For examples, see Jerrilynn Dodds' discussion of this trend in Architecture and Ideology in Early Medieval Spain (Philadelphia: Pennsylvania State University Press 1990), 2-3, fn 7 and the early observations of Richard Herr, "Review of España: Un Enigma Histórico by Claudio SánchezAlbornoz," The Hispanic American Historical Review 38, no.4 (1958): 553-554, where he identifies Américo Castro and Claudio Sánchez-Albornoz as the principle voices for this perspective in the mid $20^{\text {th }}$ century. Recently, the persistence of the trend in the second half of the twentieth century is described by Jaume Aurell, "A Secret Realm: Current Trends in Spanish Medieval Studies," Journal of English and Germanic Philology 105, no. 1 (2006): 61-86 and Rachel L. Stocking, Review Article, "Continuity, Culture and the State in Late Antique and Early Medieval Iberia," Early Medieval Europe 15, no. 3 (2007): 335 348, 335-337 in particular, in which she also describes a paradigm shift of the 1970s-1990s that was the result of the changing political landscape of Spain and Portugal that encouraged archaeologists to explore alternative theories to Spanish essentialism.
} 
century, new archaeological material and theoretical approaches have added much to this foundational study, but Iglesias Mozárabes remains an important text. It not only continues to be the most comprehensive survey of churches built after the Muslim conquest but details numerous ways in which these buildings compare to similar-looking structures found in al-Andalus, Asturias, and beyond. ${ }^{33}$ Although Gómez-Moreno rightly points out the many examples of Islamic influence in the architecture and decoration of tenth and eleventh-century churches, he does so with the perspective that it was brought to this region by Arabized Christians from al-Andalus. At the church that he considers to be one of the two most "Mozarabic" churches in Iberia, San Baudelio de Berlanga, he goes so far as to say that the only "local tradition" represented there is the round arched entrance to the tribune. ${ }^{34}$ While I consider the Islamic motifs in Christian churches to be the result of a heterogeneous community accustomed to and a product of Andalusi culture, Gómez-Moreno's careful observations of the multicultural appearance of frontier architecture nevertheless serves to support this dissertation as a resource on how post711churches compare to one another and how they bear witness to diverse populations in the Duero basin. The scope of his study furthermore complements my argument that the political needs motivating architectural patronage at the rural frontier were both tailored to the local community and part of a broader phenomenon.

\footnotetext{
${ }^{33}$ Gómez-Moreno supplied a shorter summary of Mozarabic architecture in 1951, in order to include the results of later excavations, “Arte mozárabe," Ars Hispaniae 3 (1951): 355-409. José Fernández Arenas' Mozarabic Architecture (Barcelona: Ediciones Polígrafa, 1972), 32, covers a significant number of Mozarabic churches in order to discuss what the author sees as a unique spatial treatment in Mozarabic construction, directly related to the architecture of the Visigoths. Arenas' study does not add a great deal to the work of Gómez-Moreno, except to differ with him over the extent of an Islamic influence, preferring instead to describe the power relationship in the tenth century as effecting an "Hispanicizing" of the Muslim invaders, as evidenced by the Muslim appropriation of Hispanic architectural forms.

${ }^{34}$ Gómez Moreno, Iglesias Mozarabes, 319.
} 
The scholarship of Arthur Kingsley Porter in The Romanesque Sculpture of the Pilgrimage Roads in 1923 expanded our understanding of how stylistic influences could travel and influence one another along the Camino de Santiago de Compostela, without respect to modern national borders. ${ }^{35}$ The publication of this book came on the heels of the devastations of World War I, at a time when European scholars were intent on resurrecting national pride, a preoccupation that played out in historical writing. Although Porter lived in the United States, nationalism was not absent in his work, as Janice Mann demonstrates. ${ }^{36}$ Nevertheless, Porter's efforts to suborn investigations of an architectural style's "origins" to the question of what architecture can reveal about points of cultural contact have shaped my own approach to rural churches in the Duero basin. Reconstructing the function of a frontier church relies far more on how visual elements were understood by their medieval audience than on an alleged pedigree of an arch or vault.

A student of Porter, Meyer Schapiro wrote "From Mozarabic to Romanesque in Silos," which privileged the historical context for the artistic production at the monastery of Santo Domingo de Silos over a stylistic analysis of its formal influences. Schapiro characterized the latent "Mozarabic" style in the sculpture, architecture, and manuscripts found at the monastery as evidence of resistance to the Roman rite and French monastic culture. Schapiro’s 1939 analysis continues to shape many discussions on medieval

\footnotetext{
35 (Boston: M. Jones), 1923.

${ }^{36}$ Porter saw himself as a defender of Spain and felt obliged to point out that it was not merely a copier of French models. His ideas concerning the influence of the Camino de Santiago and the dissemination of artistic style was inspired by another medievalist of Spain, Georgiana Goddard King, and possibly by the work of J. Bédier, Les legends épiques; formation des chansons de geste, 4 vols. (Paris, 1908-1913). Janice Mann describes not only the academic contributions of Porter but explored the philosophical motivations that informed his methodological point of view in "Romantic Identity, Nationalism, and the Understanding of the Advent of Romanesque art in Christian Spain," Gesta 36, no. 2 (1997): 156-164. In her 2009 discussion of Porter, she explores the ways in which his nostalgia for the American frontier shaped his approach to medieval Spain. See: Romanesque Architecture, 35-37.
} 
Spain, including the present study, because he highlighted the way the ecclesiastic community participated in the political sphere. ${ }^{37}$ Today, scholars freely admit that there was little-to-no division between the religious and secular worlds in the medieval age. From my point of view, however, this understanding has still not yet sufficiently informed the analysis of ecclesiastical architecture at the Iberian frontier. Investigations have generally begun by presuming a monastic audience for monasteries and a Christian laity for churches. This dissertation instead argues that the ecclesiastical elite wielded significant political authority in frontier towns and that their religious spaces (whether monastery or church and their environs) were designed to communicate this authority to an audience that probably included diverse faith traditions and social classes. The 'resistance' that Meyer Schapiro theorized for the clerics at Silos offers a relevant model to this study for how monasteries and churches served as platforms for regional sociopolitical negotiation and the potential for their form and decoration to reveal these power struggles in a way that documents may not.

After Gómez-Moreno, broad architectural studies of medieval Iberia largely concentrated on dating its diverse architecture (and by extension, salient architectural features) to the Visigoths, Asturians, Mozarabs, Byzantines, Arabs, or Franks, etc. How and from what sources Iberian medieval churches sprang were important to the studies of art historians like Walter Muir Whitehill for two main reasons. First, the methods that were developed around the end of the nineteenth century to categorize and serialize types

\footnotetext{
${ }^{37}$ Meyer Schapiro, "From Mozarabic to Romanesque in Silos," Art Bulletin 21 (December, 1939): 312-374. Recently, Schapiro's conclusions have met with some gentle, but justifiable criticism from scholars who feel that Schapiro may have exaggerated tensions at Silos to support his position of a 'class struggle' between the workaday monk and the aristocratically inclined abbot Domingo. See John Williams, "Meyer Schapiro in Silos: Pursuing an Iconography of Style," Art Bulletin 85, no. 3 (2003): 442-68. Porter's other students include Kenneth John Conant and Walter Muir Whitehill who also worked toward tracing the various threads that lead to the mature Romanesque.
} 
of ceramic vessels and painting were seen as a valuable, objective way to develop chronologies for undated or insecurely dated material. ${ }^{38}$ Art and architectural historians followed and expanded upon these methods, focusing on an important component of the teleological and chronological progression of an art form: the identification of its "origin." Second, as briefly mentioned above, the nationalistic preoccupations of the first half of the twentieth century shaped art historical discourse, placing exaggerated emphasis on origins and/or the dissemination of ideas and art. ${ }^{39}$ Yet the relationship of medieval Iberian buildings to their contemporaries was and continues to be an important question-directions of influence and efforts to create clear categories were sometimes prioritized at the expense of disentangling complex historical relationships or understanding the building's function. In this study, the function of the church as a religious and political space is paramount.

An example of one important break from this pattern is the work of John Williams. In 1973, he analyzed the multiple building phases of San Isidoro of León. ${ }^{40}$ In this article, Williams demonstrated that the process of dating the phases of San Isidoro

\footnotetext{
${ }^{38}$ The work of Flinders Petrie to serialize ceramics in ancient Egypt was an important development and departure from earlier attempts to create a "system" based on stylistic analysis. See Clive Orten, Paul Tyers, A. G. Vince, Pottery in Archaeology (Cambridge University Press, 1993), 5- 13 and Alex Potts, Flesh and the Ideal: Winckelmann and the Origins of Art History (Yale University Press, 1994), 33. 39 Jose Pijoan, "The Mozarabic Churches of the Ninth and Tenth Centuries in Spain," The Burlington Magazine for Conoisseurs 40, no. 230 (1922): 214-15, 217-219, 222-224, 217. The author's discussion of Mozarabic churches begins with a brief critique of the ways in which "foreign scholars" had imposed their biases on these buildings and praises the ongoing work of Spanish scholars, particularly that of GómezMoreno, to better understand the post-Muslim conquest legacy of the Visigoths: "If the Visigothic culture was strong enough to survive and permeate the Carolingian schools, we imagine it should have exercised some influence over the Barbarians of the South, the Arabs of the eighth century." The conclusions of José Fernández Arenas follow more emphatically along the essentialist theories of Claudio Sánchez-Albornoz when he concluded that Mozarabic architecture testifies to the dominance of the "Spanish spirit" which successfully "Hispanicized" first the Gothic, then the Muslim invaders, in Mozarabic Architecture (Barcelona: Ediciones Polígrafa, 1972), 30-32.

${ }^{40}$ John Williams, "San Isidoro in León: Evidence for a New History," The Art Bulletin 55, no. 2 (1973): 171-84. Walker would largely follow the conclusions of Williams in the course of her work on the meaning of the Pantheon frescoes in "The Wall Paintings in the Panteón," 200-25. She adds the compelling dimension of reading the cycles in the light of liturgical changes that marked the transition from the Mozarabic to the Latin rite, particularly as they applied to intercession for the dead.
} 
could be improved not only by the uncovering of new archaeological evidence, but also through a consideration of the political motivations of its likely patrons. The author argued that the reason disparate architectural styles appeared in successive phases within a short amount of time could be explained by the patron's desire to revive Asturian forms as a symbol of his connection to a greater Asturian, and Visigothic, past. ${ }^{41}$ The churches at the center of this dissertation were also platforms for political authority, and in some cases, the phases of construction were not necessitated by fire or decline but were undertaken solely for the legitimacy that their appearance might confer upon their patrons.

The revival of Visigothic architectural forms is likewise at the heart of Bango Torviso's “El neovisigotismo artístico de los siglos IX y X: La restauración de ciudades y templos," a phenomenon that he argued stemmed from the contact between Visigothic structures and Asturian and Leonese monks settling in newly "repopulated" frontier zones. ${ }^{42}$ Bango Torviso hesitantly participated in the controversy over the "depopulation" of the Duero basin in a limited fashion. He explains that small populations probably continued to live in the centers of castros and villas and that the church was likely a central feature of these communities-albeit in a dilapidated state. Unfortunately, the important work of Bango Torviso did not explore the potential sociopolitical motivations for the use of Visigothic forms-the historical context for which is a central concern in this dissertation. ${ }^{43}$

\footnotetext{
${ }^{41}$ Williams, "San Isidoro," 178. William suggests that Fernando I sought to take advantage of his wife Sancha's identity as the last descendant to Alfonso III of Asturias, who has claimed kinship to Visigothic kings.

${ }^{42}$ Isidoro Bango Torviso, "El neovisigotismo artistico de los siglos IX y X; la restauración de ciudades y templos," Revista de Ideas Estéticas 148 (1979): 319-38.

${ }^{43}$ Bango Torviso, "El neovisigotismo," 333-338. Bango Torviso acknowledges the contribution made to his work by J. Puig i Cadafalch, L'art wisigothique et ses survivences (Paris, 1961) but as Luis Caballero
} 
marked a significant departure from the conventional scholarship. Although a number of preceding scholars had published critical articles that revealed gaps in the traditional approaches, they were often of a limited scope, focusing on a few buildings at a time. ${ }^{44}$ The profound contribution of Architecture and Ideology was to trace the relationship of Visigothic-era structures to those built under the Asturian kings and to identify the Visigothic or Asturian features that followed in a large number of "Mozarabic" churches. Dodds characterizes the reemergence of Visigothic forms in "Mozarabic" churches as a deliberate revival, for the purpose of constructing concrete ties to a preIslamic past. Her approach to a Visigothic restoration differs from Bango Torviso's in her position that immigrant Mozarab monks were the agents of this stylistic change and that they were ideologically motivated rather than merely reacting to the styles they encountered at the frontier. For the earlier tenth century, Dodds argues that the horseshoe arch should be considered as a sign of the Visigothic past as opposed to an Islamic motif. Because she believes these builders were Christian refugees from al-Andalus, she considers the Visigothic appearance of these churches to mark their resistance to the oppressive policies of al-Andalus. On the other hand, the author contends that by the later tenth century, horseshoe arches were meant to recall Andalusi architecture in an

Zoredo explains, Puig i Cadafalch's theories, that many Visigothic churches should be re-dated to the tenth century, were largely rejected by contemporaries. See "Observations on Historiography and Change from the Sixth to Tenth Centuries in the North and West of the Iberian Peninsula," in The Archaeology of Iberia; the Dynamics of Change, ed. Margarita Díaz-Andreu and Simon Keay (London; New York: Routledge, 1997), 244-245 in particular.

${ }^{44}$ A few examples include: García de Cortázar y José Angel Ruiz de Aguirre, El dominio del monasterio de San Millán de la Cogolla (siglos X a XIII) introducción a la historia rural de Castilla altomedieval (Salamanca: Universidad de Salamanca, 1969); José María Mínguez Fernández, El dominio del monasterio de Sahagún en el siglo X, paisajes agrarios, producción y expasnión económica (Ediciones Universidad de Salamanca, 1980); Lynn H. Nelson, "The Foundation of Jaca (1076): Urban Growth in Early Aragon," Speculum 53, no. 4 (1978): 688-708; Helmut Schlunk, "La iglesia de S. Gião, cerca de Nazaré. Contribución al estudio de la influencia de la liturgia en la arquitectura de las iglesias prerrománicas de la península Ibérica," Il Congreso Nacional de Arqueología 2 (1971): 509-28. 
acknowledgment of the political power they represented. Although this dissertation argues that the pool of builders was far wider and more diverse than refugee groups of Andalusi monks, and that the horseshoe arch was a flexible sign of authorityirrespective of a so-called "Visigothic" or "Cordoban" profile-the persuasive argument made by Dodds for the strategic inclusion or exclusion of Islamic forms by indigenous and immigrant builders in order to reinforce their religious and/or political position is an essential foundation for this project. ${ }^{45}$

Since the publication of Architecture and Ideology, the volume of scholarship devoted to broad architectural developments in medieval Spain has improved steadily. ${ }^{46}$ Authors have continued Dodds' efforts to place architectural investigations within a sociopolitical context and, in so doing, to explore how buildings may reflect broader trends in beliefs and attitudes. ${ }^{47}$ However, the churches and monasteries of the frontier are often treated as byproducts of the "repopulation," isolated from regional or broader medieval trends; these studies also generally privilege ecclesiastic or stylistic connections

\footnotetext{
45 Architecture and Ideology, chapters three and four.

${ }^{46}$ The tremendous progress made by textual historians and archaeologists in the last quarter of the $20^{\text {th }}$ century has provided much of the stimulus (and data) for the new trends in art historical research. Other examples of broader architectural studies include Thomas F. Glick, From Muslim Fortress to Christian Castle: Social and Cultural Change in Medieval Spain (Manchester: Manchester University Press, 1995); Eileen P. McKiernan González, "The Persistence of the Romanesque in the Kingdom of Aragón," in Church, State, Vellum, and Stone; Essays on Medieval Spain in Honor of John Williams, ed. Therese Martin and Julie A. Harris (Leiden; Boston: Brill, 2005), 443-478; Elena Quevedo-Chigas, "Early Medieval Iberian Architecture and the Hispanic Liturgy: A Study of the Development of Church Planning from the First to the Tenth Centuries," (PhD dissertation, New York University, 1996).

${ }^{47}$ There are numerous areas of comparative studies, a good example of which are those concerned with monasticism. See: Luis Alberto Monreal Jimeno, "Arquitectura religiosa de oquedades en los siglos anteriores al románico," in VII Semana de Estudios Medievales: Nájera, 29 De Julio al 2 de Agosto de 1996, ed. José Ignacio de la Iglesia Duarte (Nájera), 1997; Tiempo de monasterios. Los monasterios de Cataluña en torno al año 1000 (Barcelona: Pòrtic, 2000); Pamela Patton, Pictorial Narrative in the Romanesque Cloister: Cloister Imagery and Religious Life in Medieval Spain (New York: Peter Lang), 2004; Monasterios y peregrinaciones en la España medieval (Palencia: Aguilar de Campo, 2004); and Monjes y Monasterios Hispanos en la Alta Edad Media (Fundación Santa María la Real, 2006).
} 
over political impact. ${ }^{48}$ Building upon the position that frontier ecclesiastical structures were more than a casual aesthetic response to available architectural styles, it would seem beneficial for scholars to consider these churches as possible visual emblems of political negotiation.

That there was ample opportunity to negotiate for the control of resources and people in the Duero and Ebro River Valleys from the ninth to the twelfth century is undisputed. Although chapter two will discuss the ongoing controversy over the number and value of the communities found along the frontier, most scholars agree that these large zones were largely without oversight from a central authority. This situation could be exploited by supralocal elites and invaders alike, with the result that it is difficult to reconstruct who controlled a particular territory at a particular point in time. ${ }^{49}$ Although royal authority is usually acknowledged in the town charters, called fueros, most scholars agree that most of the actual reorganization of rural, frontier settlements in the ninth through twelfth centuries was undertaken by ecclesiastical and lay elites, and only later brought under the control of the king. ${ }^{50}$

\footnotetext{
${ }^{48}$ Significant exceptions to this are the work by Mickey Abel, "Strategic Domain; Reconquest Romanesque along the Duero in Soria, Spain," Peregrinations, International Society for the Study of Pilgrimage Art (2007): 1-57 and Jose Luís Senra, "Aproximación a los espacios liturgico-funerarios." Other publications group architecture by region but these often seek to promote the historic sites of their province or city, for example, Luis A. Grau Lobo, Pintura Románica en Castilla y León (Junta de Castilla y León, Consejería de Educación y Cultura, 1996).

${ }^{49}$ See Julio Escalona, "Mapping Scale Change: Hierarchization and Fission in Castilian Rural Communities during the Tenth and Eleventh Centuries," in People and Space in the Middle Ages, 300-1300, ed. Wendy Davies, Guy Halsall and Andrew Reynolds (Turnhout, Belgium: Brepols, 2006) and Abulafia, "Introduction: Seven Types of Ambiguity."

${ }^{50}$ The difficulties in interpreting practical ways in which people were governed from tenth and eleventhcentury texts and identifying those documents which are corrupt are discussed by Wendy Davies in "Lordship and Community: Northern Spain on the Eve of the Year 1000," Past and Present Supplement, 2 (2007): 18-33. The relationships between elite groups and royal powers were complicated. Because the political climate was so unstable, kings, nobles, and abbots needed each other to support their claims to legitimate governance. José María Mínguez Fernández offers evidence for these negotiations by discussing the language employed in medieval charters, lawsuits, and land-grants in "Pervivencia y transformación de la concepción y práctica del poder en el reino de León (siglos X y XI)," Studia Historica. Historia Medieval 25 (2007): 15-65.
} 
Even though the extent of a king's practical power and patronage is particularly difficult to ascertain outside of strategic urban centers, Janice Mann has a provided a persuasive account of how Sancho III of Navarre, el Mayor (1004-1035) patronized significant monastic centers as part of his efforts to expand and empower the kingdom of Aragón. ${ }^{51}$ Participating in ongoing scholarly efforts to examine how architectural spaces reflect complicated historical settings, Mann investigates the reasons for Sancho's substantial building activities at San Millán de la Cogolla de Suso (Rioja) and San Juan de la Peña (Huesca). Sometime after the destructive campaigns of al-Mansur (976-1002) and his son 'Abd al-Malik (c. 1002-1008), Sancho is believed to have built or restored sections of these and other churches, monasteries, and fortresses. Mann connects Sancho's impressive transition from a Count of Navarre to that of the dominant sovereign of northern Spain to his ability to use powerful monastic sites like San Millán and San Juan to bolster his legitimacy. ${ }^{52}$

Given the large number of monasteries that functioned as sociopolitical centers, particularly in border zones, how Sancho selected which monasteries to favor raises a few questions. Was Sancho's building program a response to the campaigns of al-Mansur, an opportunity to insert his identity into a sacred landscape that also functioned as a political center, or both? Was he the only monarch or elite to take advantage of historically or

\footnotetext{
${ }^{51}$ See Janice Mann, "A New Architecture for a New Order: the Building Projects of Sancho el Mayor (1004-1035)," The White Mantle of Churches, Architecture, Liturgy, and Art around the Millennium, ed. Nigel Hiscock (Turnhout, Belgium: Brepols Publishers, 2003), 233-245. In Mann's most recent publication, she broadens this initial study to include additional examples of architecture shaped by the changing political realities of the Christian-Muslim frontier, see Romanesque Architecture.

${ }^{52}$ Mann points out that most of these conquests were Christian cities and regions, with the exception of Ribagorza. Sancho's authority king or "protector" extended to Bayonne in the north, over the Basque regions and parts of León to the west, over Castile, Aragón and Pamplona. To the south, Sancho forcefully articulated his border with al-Andalus with numerous fortresses. This action did two important things: it allowed Sancho to pursue his wars with neighboring kingdoms without leaving his lands unprotected and it permitted the safe alteration of the Pilgrimage route further south through Nájera, a substantial boon to the kingdom. Mann, Romanesque Architecture, 49-50.
} 
topographically significant sites? Textual and architectural evidence indicates that elite benefaction of important churches pre-dated Sancho and extended to other foundations in border regions. ${ }^{53}$ The same topographical features that symbolized the historical significance of San Millán and San Juan (caves, "Mozarabic" building phases, and prestigious tombs $)^{54}$ also appear at Duero basin churches. The capacity for symbols of a pre-Islamic sacred history to confer status on a church, and by extension, its patron, was understood by those who elected to build at these strategic sites. Janice Mann has made a persuasive case for the attraction that San Millán and San Juan had for Sancho el Mayor and his successor. It seems reasonable to expect that comparable, legitimating benefits could likewise be derived by non-royal patrons of Duero frontier churches. ${ }^{55}$

\footnotetext{
${ }^{53}$ In addition to the material support described above, documents, especially donations, reveal the close ties between monasteries and secular rulers. These relationships are better understood in the northern kingdoms, for which a larger body of documents survives. For an overview of the interwoven nature of royal, aristocratic, monastic, and lay powers see Davies, "Lordship and Community." Of particular interest is the substantial number of proprietary churches, or churches that belonged to aristocrats or other landed laity of means. Over time, these families appear to have been pressured into transferring control to the ecclesiastic powers (Richard Fletcher notes that this process extended well into the thirteenth century). There is less information for the frontier, leading Simon Barton to conclude that by the time of the "repopulation" (late eleventh and twelfth centuries), aristocratic ownership of churches was subordinated to ecclesiastic control. However, as Thomas Barton recently demonstrated, the proximity of a church to the border sometimes prompted Bishops to negotiate with lay lords over the question of tithes and control, see "Constructing a Diocese in a Post-Conquest Landscape: a Comparative Approach to the Lay Possession of Tithes," Journal of Medieval History 35, no. 1 (2009): 1-33. See also Simon Barton, The Aristocracy in Twelfth-Century León and Castile (Cambridge University Press, 1997); Jeffrey A. Bowman, Shifting Landmarks, Property, Proof, and Dispute in Catalonia around the Year 1000 (Cornell University Press, 2004); Richard Fletcher, The Episcopate in the Kingdom of León in the Twelfth Century (Oxford University Press, 1978), Reilly, Santiago, Saint-Denis, and Saint Peter, and O'Callaghan, Reconquest and Crusade, and for the shift from private ownership to Cluniac control: Raquel Alonso Álvarez, "El monasterio de San Salvador de Cornellana y el patrocinio nobilario: de la iglesia propia a la dependencia de Cluny," Imágenes y promotores en el arte medieval. Miscelánea en homenaje a Joaquín Yarza Luaces (Bellaterra: Universitat Autónoma de Barcelona Servei de Publicacions, 2001), 45-57.

${ }^{54}$ Mann, Romanesque Architecture, 56-57, 62.

${ }^{55}$ I would suggest that Mann's argument that the use of round arches was meant to signify a "new order," that is to say, a regime change from Muslim to Christian, does not go far enough. The monasteries of San Millán de la Cogolla and San Juan de la Peña appear to have been valuable political centers, and so at the beginning of the eleventh century it is likely that the patron's program was designed to promote his authority in a multicultural way, through elite forms familiar to both Muslims and Christians. Moreover, Sancho's round arches, suggestive of contemporary Frankish architecture, may have served to bolster his legitimacy against rival Christian kings or aristocrats. The houses of Aragón and León-Castilla had been marrying into the French aristocracy and importing Benedictine monks for well over a generation; thus,
} 
The topography, art, and architecture found at the two case studies for this project, San Baudelio de Berlanga (Soria) and Santa Maria de Wamba (Valladolid) display a close relationship between ecclesiastical and secular powers, despite the absence of royal patronage. I propose that San Baudelio and Santa Maria de Wamba, like other strategic churches or monasteries along the frontier, were the products of elite emulation. Like kings, non-royal outsiders seeking to impose control over existing populations needed to present an image of unimpeachable authority in regions of instability. The siting and preIslamic histories of these and other foundations offered a legitimate platform for those who wanted to exert influence over the nearby inhabitants and resources.

The church of Santa María de Wamba is located in the small town of Wamba in the province of Valladolid. The basilica church consists of two main parts. The tenthcentury east end consists of three squared-off apses and a tripartite choir, all of which support horseshoe-shaped barrel vaults. Fragments of a painted fresco cover a portion of the eastern wall of the central apse. In the twelfth century, new chambers were added to the north of the church and the western side of the cloister was defined by additional ashlar-vaulted chambers. The original appearance of the western section of the tenthcentury church is uncertain because it was replaced in the thirteenth century. Two arcades of pointed arches springing from compound columns continue the tripartite division of the east end but are not vaulted. Instead, the loftier space of the western includes a clerestory zone covered by a wooden roof. ${ }^{56}$

round arches may have been designed to speak more to an elite audience of monks and nobleman (particularly Castilian rivals) than to assure a lay population that the Muslim threat had been neutralized. ${ }^{56}$ José Luis de la Quintana Gordon and José Ricardo Boned Colera, "Santa María de Wamba, entre su pasado y el futuro (Valladolid)," Informes de la Construcción 43, no. 418 (1992): 35-52. According to the architects responsible for the restoration of Santa María, the southern portico and sacristy dates to around the eighteenth century and the church was built atop a Visigothic structure. 
The state of research for Santa María de Wamba is scant. Gómez-Moreno favors an early tenth-century date for the Mozarabic east end and follows the tradition that the first builders worked under the direction of a former Bishop of León, Frunimius, who retired to Wamba around $938 .^{57}$ A more recent study of the early phases of construction is the 1992 report on the church's restoration, entitled "Santa María de Wamba, entre su pasado y el futuro (Valladolid)." ${ }^{58}$ This article includes useful ground plans, one for each major stage of building at the monastery. Although the authors are architects who apparently consulted with archaeologists on the project (remains beneath one of the piers are briefly mentioned), citations are not included in the report. ${ }^{59}$ Despite the absence of additional bibliographic information that would expound upon this somewhat problematic source, I will review it alongside brief discussions of the church undertaken by Manuel Gómez Moreno, José Fernández Arenas, Karen Kingsley, and Jerrilynn Dodds.

The church of San Baudelio de Berlanga has received more attention that Santa María de Wamba because many of the spectacular frescoes that decorated its walls have been preserved either in situ or in museums around the world. ${ }^{60}$ The structure itself is

\footnotetext{
${ }^{57}$ Gómez-Moreno, Iglesias Mozárabes, 194-196. This account can be found in the Documentos de la iglesia colegial de Santa María la Mayor hoy Metropolitana de Valladolid. It should also be pointed out that Gómez-Moreno identifies a frieze along the tower and an alter support as belonging originally to the Visgothic period. Gómez-Moreno, Iglesias Moárabes, 193. The tenth century date is also accepted by Dodds in Architecture and Ideology, 75-76, n 141 and Karen Kingsley, "Visigothic Architecture in Spain and Portugal, A Study in Masonry, Documents, and Form," (PhD Dissertation, University of California, Berkeley, 1980), 172-173. This date requires further investigation given the fact that nearby Valladolid was founded by Ansúrez (d. 1117/8) and was not a secure region before the eleventh century. Reilly, The Kingdom under Queen Urraca, 15.

${ }^{58}$ de la Quintana Gordon, Boned Colera, "Santa María de Wamba,” 35-52.

${ }^{59}$ I have attempted to contact anyone who might have access to the excavator's report, if there is one. While I have not yet had successful responses, I appreciate the efforts that Raquel Alonso Álvarez has made on my behalf.

${ }^{60}$ For a recent discussion of the paintings see Elías Terés Navarro, El expolio de las pinturas murales, de la ermita Mozárabe San Baudelio (Casillas de Berlanga, Soria) (Ochoa Editores, 2008). However, the fresco paintings have long been the subject of academic study, see Philip R. Adams, "Mural Paintings from the
} 
built against the side of a hill in Soria province, a little more than seven kilometers to the southeast of the town and fortress of Baudelio. The nearly square nave of the church is covered with a high vault that is supported by ribs springing from a massive central column. The tribune-like space along the southwest half of the nave is held aloft by horseshoe arches which also shelter the entrance to a cave. Slightly raised above the rock-cut floor of the nave to the northeast is a single, nearly square apse.

The most recent scholarship concerning San Baudelio de Berlanga is the work of Milagros Guardia. Although her forthcoming volume concerns the frescoes of Baudelio more than the architecture, ${ }^{61}$ in 2002 she proposed a later date for the construction of the church, the third quarter of the eleventh century, based on recent dendrochronological

\footnotetext{
Hermitage of San Baudelio de Berlanga, Province of Soria, Spain," The Cincinnati Art Museum Bulletin 7, no. 2 (March 1963): 2-11; Manuel Anibal Álvarez and José Ramón Melida, "Un Monumento desconocido: la ermita de San Baudelio en termino de Casillas de Berlanga (Provincial De Soria)," Boletin de la Sociedad Espanola de Excursiones 15 (1907): 144-155; Antonio de Ávila Juárez, "San Baudelio de Berlanga: Fuente sellada del paraiso en el desierto del Duero," Cuadernos de Arte e Iconografía 13, no. 26 (2004): 333-396; P. Banks and J. Zozaya, "Excavacione en San Baudelio de Casillas de Berlanga (Soria)," Noticiario Arqueologico Hispanico 16 (1983): 383-440; David G. Carter, "Two Romanesque Frescoes from San Baudelio de Berlanga," Bulletin- John Herron Art Institute, Indianapolis 46, no. 1 (1959): 3-18; Walter Cook, "Romanesque Painting," Art Bulletin 11, no. 4 (1930): 327-356 and idem, "Romanesque Spanish Mural Painting (II) San Baudelio de Berlanga," Art Bulletin 12 (1930): 20-42; Jerrilynn Dodds, "Hunting for Identity," in Imágenes y Promotores en el Arte Medieval (Bellaterra: Universitat Autónoma de Barcelona Servei de Publicacions, 2001); H.G.M. Edwards, F. Rull, P. Vandenbeele, E.M. Newton, L. Moens, J. Medina, and C. García, "Mediaeval Pigments in the Monastery of San Baudelio, Spain: A Raman Spectroscopic Analysis," Applied Spectroscopy 55, no. 1, (2001): 71-76, Mojmir S. Frinta, "The Frescoes from San Baudelio de Berlanga," Gesta 1 (1964): 9-13; José Garnelo, "Descripcion de las pinturas murales que decoran la ermita de San Baudelio en Casillas de Berlanga (Soria)," Boletin de la Sociedad Espanola de Excursiones 32 (1924): 96-109; Milagros Guardia Pons, "Relire les espaces liturgiques a travers la peinture murale: le programme iconographique de San Baudelio de Berlanga, Soria," Cahiers-de-SaintMichel-de-Cuxa Liturgie, arts et architecture a l'epoque romane: actes des XXXVe Journees romanes de Cuxa: 5-12 juillet 2002 34, 79-97, ed. E. Garland (2003); April Kulp, "San Baudelio de Berlanga: New Considerations," (MA thesis, University of Washington,1984); J. M. Muñoz Jiménez, "El Tapiz de Bayeux y las pinturas de San Baudelio de Berlanga: la posible inspiración Nórdica Del Ciclo Profano. J. M. Muñoz, "Las pinturas de san Baudilio de Berlanga y el tapiz de Bayeux: la posible inspiración nórdica del ciclo profane," Goya 253/254 (July-October 1996): 12-17; Gratiniano Nieto-Gallo, "Nuevos datos sobre la iglesia de San Baudelio de Berlanga (Soria)," in Espana entre el Mediterraneo y el Atlantico, TomoII, Actas del 23 Congreso Internacional de Historia del Arte (Granada, 1973). Most of the large frescoes were removed in the early twentieth century and sold to U.S. Museums. Today they belong to the Cincinnati Art Museum, the Indianapolis Museum of Art, the Museum of Fine Arts, Boston, and the Cloisters branch of the Metropolitan Museum of Art. The majority of the frescoes owned by the Cloisters are on display at the Prado Museum, Madrid, where they are on permanent loan.

${ }^{61}$ Milagros Guardia Pons, e-mail message to author, July 16, 2006.
} 
evidence. $^{62}$ Although general consensus had placed the construction of the church in the late tenth or early eleventh century, and the painting of the church's interior to sometime in the twelfth century, Guardia also narrows the dates for the painting cycles to 1129 1134. She argues that these dates correspond to the lordship of Fortunio Aznárez, who she believes sponsored the decoration as a display of his territorial authority and participation in the Iberian Christian Crusade against al-Andalus. ${ }^{63}$

In 2001, Dodds augmented her earlier comments on the secular fresco cycles at San Baudelio in the compilation Imágenes y promotores en el arte medieval. ${ }^{64}$ She viewed San Baudelio as caught between the machinations of the Bishop of Burgo de Osma and the French Bishop of Sigüenza, Bernard of Agen, as the two bishops scrambled to claim the newly settled frontier territories for their sees (c. 1135). She described the hunting iconography, suggestive of ownership in domestic settings, as reflecting the struggle “...between a traditional, indigenous church hierarchy and one of a number of rather ravenous reforming Frenchmen, who took on an artistic vocabulary half spiritual and half lordly." 65 This interpretation is not at odds with the larger trend at work Duero basin frontier, which was a visual campaign to promote the legitimacy of one patron or possessor over another. Both Dodds and Guardia offer social historical

\footnotetext{
${ }^{62}$ In advance of Guardia's forthcoming book is the article, "Relire les espaces liturgiques," for the archaeological evidence that informs her construction date for the church, see Mattias Fernán Alonso, Luis Caballero Zoreda, and Eduardo Rodríguez Trobajo, "Cronología constructiva de la iglesia Mozárabe de S. Baudelio de Berlanga (Soria): primeros resultados de dendrocronología y carbono-14," Boletín de arqueología medieval 11 (1997): 249-64.

63 "Relire les espaces liturgiques," 84-85, 96.

${ }^{64}$ Dodds, "Hunting for Identity," 90, and idem, "Catalog Entry for Wall Paintings, the Hermitage of San Baudelio De Berlanga (Soria)," in The Art of Medieval Spain A.D. 500-1200 (New York: The Metropolitan Museum of Art), 1993, 226. In the latter work, concerning the Christological cycle for the Metropolitan Catalogue, Dodds argues that the twelfth-century narrative program makes a pointed reference to Jerusalem. She contends that this symbolism causes the tenth to eleventh-century centrally-planned church to have been recast as a copy of the Holy Sepulcher for its twelfth-century audience. The point of this transformation was to compare the crusade in Jerusalem with the ongoing "Crusade" against al-Andalus. ${ }^{65}$ Dodds, "Hunting," 97.
} 
frameworks for their iconographical interpretations of the art and architecture. My analysis benefits enormously from this work but seeks to expand upon the conclusions of Dodds and Guardia, who, despite promoting the church as a platform for propaganda between competing parties, do not investigate why this message was best suited to this site or contextualize it within what I believe is a wider pattern of frontier architecture.

The following section describes the methodologies that have benefitted my efforts to reconstruct the historical context and medieval motivations for the patrons of tenth through twelfth-century frontier architecture. A complete picture of the Duero basin is impossible at this time; however, recent scholarly efforts to complicate ethnic and religious identities in Iberia, together with the textual and material evidence suggest that rural frontier churches were not casual side-effects of "repopulation." Within the course of this discussion, I will take the opportunity to highlight those authors whose contributions may not have been specifically directed at Duero basin architecture but who nevertheless have shaped the hermeneutical approaches selected for this study.

\section{Hermeneutics and Methodology}

The attraction that medieval Iberia holds for the scholar and student can be found throughout the medieval world: cultural exchange between disparate groups, political tensions, and ideological pursuits. In an effort to simplify and clarify studies of a diverse medieval world, there has been the tendency to classify material evidence into carefully defined categories, as one element might be isolated from a compound in order to test a specific hypothesis. ${ }^{66}$ The shortcomings of this practice have been broadly

\footnotetext{
${ }^{66}$ Cynthia Robinson and Leyla Rouhi, "Editor's Introduction to Under the Influence," Under the Influence, Questioning the Comparative in Medieval Castile, ed. Cynthia Robinson and Leyla Rouhi (Leiden, Boston:
} 
acknowledged and some recent authors have chafed at the limitations imposed by categories such as Visigothic, Asturian, Mozarabic, Romanesque, and European. These and related designations continue to be common, however, albeit couched in qualifying language that reflects ongoing efforts to better reflect medieval hybridity and challenge the conventional approaches within the humanities, and in art history in particular.

Of particular concern to the present inquiry is the ontological heritage of Edward Said's Orientalism and postcolonial theory. Thoughtful scholarship continues to explore the potential of Said's two-fold construct of the West pitted against the Eastern "other," exposing articulations of power that appear to foreshadow modern expressions of postcolonialism, and instances where this relationship was reversed. ${ }^{67}$ On the other hand, the limitations of a binary model have frustrated authors who see it as simplistic and a reinforcement of polemical characterizations of East versus West. This criticism certainly applies to the study of medieval Spain and Portugal where the ongoing tendency to designate regions and towns as either Christian or Muslim has adversely affected the historical picture of medieval society, particularly along the frontier.

Neither the traditional penchant for classification nor the dichotomy of Orientalism serves the goals of this study. However, the critical way in which

Brill, 2005), 4. "Unlike literary studies, art history still relies on the notion of discrete units to be compared, and these units are usually, if not always, established on the perceived stability and separateness of 'Jewish,' 'Muslim,' and 'Christian'.' That said, there have been a number of Hispano-Medieval scholars who have utilized theoretical approaches to challenge conventional classifications in their research. The following are just a few of these: Thomas Glick, "Tribal Landscapes of Islamic Spain: History and Archaeology," in Inventing Medieval Landscapes, Senses of Place in Western Europe, ed. John Howe and Michael Wolfe (Gainesville: University Press of Florida), 2002, 113-135; Manzano Moreno, "ChristianMuslim Frontier in al-Andalus," 122-143; Escalona, "Mapping Scale Change,"; Sharon Kinoshita, Medieval Boundaries, Rethinking Difference in Old French Literature (Philadelphia: University of Pennsylvania Press, 2006).

${ }^{67}$ See Nadia R. Altschul, “The Future of Postcolonial Approaches to Medieval Iberian Studies," Journal of Medieval Iberian Studies 1, no. 1 (2009): 5-17, John M. Ganim, Medievalism and Orientalism: Three Essays on Literature, Architecture, and Cultural Identity (New York: Palgrave Macmillan, 2005) and Cecily Hilsdale, "Towards a Social History of Art: Defining 'Mozarabic'," Medieval Encounters 5, no. 3 (1999): 272-288. 
postcolonial theory treats the development of religious and national identities offers the scholar a valuable framework through which to explore the nuances of medieval society and its material production. The expectation of fluidity in sociopolitical structures and cultural identity better discloses the hybridity of medieval Iberia and facilitates a reconstruction of the viewer's experience, the key to understanding a building's purpose. $^{68}$

In general, postcolonial theory in medieval studies aims to reveal the imposition of hierarchies in order to serve the ends of a colonial system. It has been argued that the invasion of al-Andalus by Christian kingdoms is an anachronistic application of 'colonialism' to a context that precedes the concept of nationhood. ${ }^{69}$ However, there are three reasons to consider a postcolonial perspective for medieval Iberia: first, the significance of how attempts made by eleventh-century Christian kingdoms to construct legitimate reasons for territorial expansion transformed into a crusade to conquer the 'Moor' for the sake of a unified Peninsula; second, the subsequent adaptation of this history to justify late medieval and early modern colonial ambitions; and last, the mining of Visigothic and "Reconquest" histories in order to build nationalist ideologies. ${ }^{70}$

\footnotetext{
${ }^{68}$ The tendency to consider art apart from architecture or to treat distinct phases of construction as separate entities has the potential to compromise the analysis. In each of the four sites considered here, earlier phases of building informed the subsequent renovations or additions and were deliberately incorporated into the new structure. While constraints of time and evidence make discussions of some architectural phases more appropriate to the present project than others, this study will acknowledge the full context of each case history site as completely as possible.

${ }^{69}$ Jeffrey Jerome Cohen, ed. The Postcolonial Middle Ages (New York: Palgrave, 2000); Bruce W. Holsinger, "Medieval Studies, Postcolonial Studies, and the Geneaologies of Critique," Speculum 77, no. 4 (2002): 1195-1227.

${ }^{70}$ This last reason to apply postcolonial theory to medieval Iberia will be taken up again in chapter two because nationalism also contributed significantly to the historiography of the repopulation controversy.
} 
Postcolonial theory furthermore confronts the ways in which signs of transculturation can add to our understanding of socio-political negotiations for power. ${ }^{71}$ This study offers the small, rural churches of the Duero basin as valuable signs of transcultural contact. The expectation that political power was not one-sided at the frontier but a complicated exchange between indigenous populations and outside parties is reinforced by the presence of frontier churches that appear to have appreciated preservation and innovation at the same time. Significant topographies together with old and new building phases served as some of the visual cues employed by those endeavoring to legitimate their claims of authority.

In addition to challenging the dichotomies associated with the legacy of Edward Said, postcolonial theory has made important contributions to the wide-ranging scholarship devoted to frontier studies. Although it was Frederick Jackson Turner who first utilized the concept of the American frontier as a device through which to understand the development of a nation's character, the frontier as a methodological tool has been particularly relevant for historians of Iberia. ${ }^{72}$ There are two main reasons for

\footnotetext{
71 "The Future of Postcolonial Approaches," 12-13. For example, Nadia Altschul points to the subtle ways in which one group might mimic, or "mis-imitate" another's dress or language might be read as a possible sign of resistance and self-promotion.

${ }^{72}$ The suggestion to consider this thesis in light of ongoing "frontier" research was made by Dr. Karen Britt. This paper was read at the meeting of the American Historical Association in Chicago, July 12, 1893. The text of the paper may be found printed with notes at: Frederick Jackson Turner, "The Significance of the Frontier in American History," accessed March 25, 2011, http://xroads.virginia.edu/ HYPER/TURNER/home.html. In this initial installment of what would become known as the "Turner Thesis," Turner places the development of the American character and its political institutions in the western frontier. For a thorough discussion of how Turner's thesis has shaped subsequent generations of historians and been co-opted by medievalists, including Hispanists, see Robert Burns, "The Significance of the Frontier in the Middle Ages," in Medieval Frontier Societies, ed. Robert Bartlett and Angus MacKay (Oxford, 1989), 307-330. The influence of Turner's thesis on the arguments of Sánchez Albornoz is also acknowledged by Escalona, "Mapping Scale Change," and Reyna Pastor et al., Sánchez Albornoz a debate. Homenaje de la Universidad de Valladolid con motivo de su centenario (Valladolid, 1993). For additional perspectives on the general role of the frontier in medieval studies, see Robert Bartlett, The Making of Europe: Conquest, Colonization and Cultural Change 950-1350 (Princeton University Press, 1993), Kinoshita, Medieval Boundaries; and Medieval Frontiers: Concepts and Practices, ed. David Abulafia and Nora Berend (Aldershot, England; Burlington, Vermont: Ashgate), 2002. For
} 
this. First, as Lucy Pick explains, "The notion of the medieval frontier was literally invented in Spain and then exported to describe similar phenomena on other European frontiers." 73 Here she is referring to the appearance of the Latin word "frontier" in eleventh and twelfth century Aragonese royal charters. The term was specifically employed to describe how castles were built in Muslim territory and when the term appeared a century later in other parts of Europe, it continued to refer to ChristianMuslim borders. ${ }^{74}$ The second reason that the concept of the frontier is closely associated with Iberia lies in the fact that many modern historians have traced Spain's cultural and institutional development to the "Reconquest," a nearly 800 year process dominated by a fluctuating border with al-Andalus. ${ }^{75}$

discussions on the specific application of the frontier model to medieval Iberia, see Charles Bishko, Studies in Medieval Spanish Frontier History (Variorum Reprints, 1980); Peter Linehan, "At the Spanish Frontier," in The Medieval World, ed. Peter Linehan and Janet Nelson (London: Routledge, 2003); Janice Mann, Romanesque Architecture, and Manzano Moreno, "Christian-Muslim Frontier in al-Andalus: Idea and Reality."

${ }^{73}$ Pick, Conflict and Coexistence, 25 . There is some question over the authenticity of the eleventh-century passages in the Cartulario de San Juan de la Peña. Pick also points to twelfth-century royal charters by Alfonso I, but Peter Linehan resists attributing the term to a document until the thirteenth century. Regardless of its exact introduction, the words frontera or frontaria are considered to have first been used in medieval Spain, see Peter Linehan, History and the Historians of Medieval Spain (New York: Clarendon Press, Oxford University Press Inc., 1993), 263.

${ }^{74}$ Pick, Conflict and Coexistence, 25. The author emphasizes that the term frontier "....separates groups according to the religious polities of which they are members and is not used, for instance, to refer to boundaries between Christian kingdoms." Acknowledging the apparently religious nature of the frontier in eleventh and twelfth-century documents should not cancel out the study of the geo-political realities in which frontier societies might find themselves.

${ }^{75}$ Examples include the influential article by Julian Bishko, "The Castilian as Plainsman: The Medieval Ranching Frontier in La Mancha and Extremadura," in The New World Looks at its History: Proceedings of the Second International Congress of Historians of the United States and Mexico, ed. Archibald R. Lewis and Thomas F. McGann (Austin: University of Texas Press), 1963 and Angus Mackay, Spain in the Middle Ages: From Frontier to Empire, 1000-1500 (London: Palgrave), 1977. For a recent overview of the ways in which scholars have justified or criticized the use of the concept of the frontier, and to a lesser degree, Reconquest, in Medieval Spain and Portugal, see Peter Linehan, "At the Spanish Frontier," in The Medieval World, ed. Peter Linehan and Janet L. Nelson (London; New York: Routledge), 2001. The dominance of the frontier and Reconquista as essential tools in understanding the shaping of modern Spain and Portugal has been widely criticized in both ideological and methodological terms. Given the prevalence of territorial expansion and contraction that was ongoing in many part of the western world throughout the Middle Ages, there is justice in the critique that singling out the frontier in Spain is part of the larger problematic notion of 'uniqueness' sometimes found in Spanish historiography. However, given the fact that the large trans-Duero territory may have offered strategic advantages to the Christian 
The impact of the frontier upon the history of Spain and Portugal is not unique.

Historians have looked at the numerous frontiers of the western world and argued that from these spaces nations and national characteristics sprang. ${ }^{76}$ The idea that marginal regions afford greater flexibility for cultural production and political power is one facet of the broader face of frontier studies. Relying heavily upon this particular dimension of frontier studies, this dissertation takes the position that the lack of a central government in the Duero basin was an important factor for successful power negotiation among nonroyal elites-and one of the chief places in which that contest took place were the monasteries and churches of the Duero frontier.

Dating between the tenth and twelfth centuries, the churches built along the Christian frontier are usually placed beneath the wider art historical category of the preRomanesque and the Romanesque. Describing and grouping these churches with those built north of the Pyrenees for the sake of stylistic comparison downplays their local context, however. The entrenched art historical tendency to classify and the attendant problems that postcolonial proponents criticize is echoed in the analysis of Tadhg

conquerors because of its lack of centralized authority remains a valuable area of exploration within the frontier paradigm.

${ }^{76}$ A clear example of this perspective is preserved in the conference presentation that Charles Bishko made at the Annual Meeting of the American Historical Association in Washington D.C., on 29 December 1955. "Clearly, it was one frontier, a unity not in geographical contiguity but in its expression of the same deep forces of medieval dynamics and, the basic similarities of its aims, techniques and accomplishments. The frontier created for history not only new lands of European culture, but new peoples- the Portuguese, the Castilians, the Austrians, the Prussians, the Great Russians, peoples who move swiftly to dominate the modern history of their respective countries. It produced a frontier literature in historical works like Helmold's Chronicle of the Slavs or Giraldus Cambrensis' inimitable studies in Welsh and Irish frontier sociology; in heroic works like the Lay of Igor's Campaign of the Poema del Cid; the frontier ballads, romances and bylini that call for collective study. It created in abundance new types of medieval men and women - the frontier noble, whether he be called bogatyr, caballero, lord marcher or knight; it produced the Military Orders which were so prominent in frontier warfare and colonization; the pioneer woman, of whom we know nothing, the frontier churchman, the colonizing bishop or abbot, the missionary, the priest of the lonely frontier parish..." The text of this paper may be found at the stable URL:

http://libro.uca.edu/aarhms/essays/bishko.html. Bishko, like other historians, extrapolates the importance of the Reconquista frontier to the subsequent colonial ambitions of Spain and Portugal. 
O'Keefe. In Archaeology and the Pan-European Romanesque, the author challenges the simplification that he sees at the heart of the static definition of Romanesque architecture and his critique intersects with my dissertation in two ways. ${ }^{77}$ First, the author disputes the predisposition of architectural studies to privilege the meanings for the builders or patrons of medieval buildings over the "phases of reception" for the audiences of that building over time. ${ }^{78}$ Second, he offers a useful model of social constructivism called actor-network theory (ANT) as a way to justify his position that architecture is sociallyconstructed and further, that dominant actors negotiated their political position through architecture. $^{79}$

The complicated relationship among the numerous ermitas and monasteries along the Duero basin and their frontier audience requires any visual survey to include more than one approach. The façade and internal organization of space are not the only elements under evaluation. The topographical siting for each church is critical to a better understanding of how the building would have been viewed by its audiences. In medieval Iberia, landscapes could function as visual reinforcement of the site's significance, holiness, and authority. At the same time, the proximity of a church to other

\footnotetext{
${ }^{77}$ O' Keeffe, Archaeology and the Pan-European Romanesque, 66.

${ }^{78}$ O'Keeffe, Archaeology and the Pan-European Romanesque, 103. The author follows David Freedburg for this point from his book The Power of Images: Studies in the History and Theory of Response (Chigago: University of Chicago Press, 1989).

${ }^{79}$ O'Keeffe, Archaeology and the Pan-European Romanesque, 90-91. The author also explains the related model of social construction of technology (SCOT). ANT corresponds a little more closely with the approach I advocate for Iberian frontier architecture. It is made up of five phases: "Problematisation," the stage at which new actors seek to develop an 'artefact-type' that is recognizable to the audience and represents their new political construct, "Interessement" in which some actors persuade other actors to get involved with or accept the 'artefact-type,' "Enrolment," which is the process whereby new actors identify with the new 'artefact-type' a.k.a. socio-political idea, "Inscription," which describes the joining of the idea to its 'artefact-type' in a way that is broadly understood, and "Irreversibility," the point at which the sociopolitical construct and 'artefact-type' are so tightly bonded that it cannot be redefined by those within the network. However, this last stage can become the point of problematisation for actors outside of the network, or resistant actors within the network, resulting in a paradigm shift and a new cycle, 92.
} 
buildings, caves, fountains, mountain passes and roads (if known) can help to determine its strategic importance militarily and symbolically.

Concerning the symbolism of topography and architecture, a primary objective for the visual analysis is to identify features that might have symbolized legitimacy to a probable audience of the Duero basin. The pre-conquest sacred history of a church could have been signaled by the presence of a hermitage cave or a hagiographic tradition. In order to best evaluate elite architectural and ornamental forms, they will be considered individually (for example, a tribune) and in concert (the relationship between the tribune and potential liturgical processions, architectural decoration, etc.). The picture provided by this investigation is not designed to affix a single "meaning" to the spaces but to view them as multifunctional and dynamic over time. ${ }^{80}$

The question of elite emulation can only be partially addressed with the aforementioned methods of visual comparison. Yet, given the intrinsic reticence on the part of chroniclers to describe situations in which the authority of their lords was usurped, explicit references are unlikely to be found in the historical documents. ${ }^{81}$ Investigations into the question of elite emulation in architecture, when they occur, are therefore generally multifaceted—using documents, literary criticism, architectural comparanda, and historical events to construct the argument. Moreover, drawing from theoretical

\footnotetext{
${ }^{80}$ In addition to the more tangible characteristics of structure and landscape, intangible elements such as sightlines and lighting will be considered. The efforts of Byzantine art historians provide a model for approaching the question of meaning in architectural space. For example, in his essay for the collection Medieval Practices of Space, Andrzej Piotrowski sets aside an examination of ritual-based functionality in favor of how Byzantine architecture may have reflected the coexistence of the conflicting ideas of representation and the unrepresentable divine, in "Architecture and the Iconoclastic Controversy," in Medieval Practices of Space, edited by Barbara Hanawalt and Michal Kobialka (Minneapolis, MN: University of Minnesota Press, 2000).

${ }^{81}$ The amount of archival evidence for the period is substantial and available to scholars in an edited format. The painstaking efforts of textual historians have at times been underutilized by art historians, but should be additionally valued for their critical review of sources, especially in light of the fact that "histories" of monasteries of the twelfth and thirteenth centuries were often given a more "Visigothic" or "Crusader" tone by later copyists.
} 
frameworks in which the prohibition of a practice may be viewed as an indication of its existence, the power of architecture may also be inferred in the legal condemnations and concessions of medieval law.

\section{Explanation of Terminology}

Terminology is often at the center of the debate over the nature of the Christian conquest of al-Andalus and the identity of its medieval inhabitants. The friction over the use or avoidance of certain terms is often exacerbated by underlying ideological disputes. ${ }^{82}$ How an author describes the poorly understood demographic of the Duero valley is an example of this phenomenon. Words like 'depopulation' and 'repopulation' have been used by scholars to characterize the reorganization and resettlement of the Christian-Muslim frontier, particularly for the large watershed of the Duero River. The reason historians employed these terms stems from their past acceptance of the medieval record at face value. In particular, royal Asturian chronicles describe events in which their kings repopulated territory that was either left empty "ab antiquitus" or forcibly emptied in the ninth century by their predecessors. ${ }^{83}$ As will be more thoroughly discussed in chapter three, ideological concerns over national identity appear to have

\footnotetext{
${ }^{82}$ Linehan, History and the Historians, 205. The author expresses some of the frustration felt by some historians toward those who have discarded the term "Reconquest": "But 'reconquest', like 'frontier', is not a word that occurs in Spanish sources of the period, we are reminded (providentially 'Christian' does), so enlightened late twentieth-century historians dismiss the concept as a 'modern abstraction' and reject the notion that Spanish Christians were motivated by reconquering zeal as unworthy of consideration by the elect."

${ }^{83}$ The earliest Latin descriptions of this occurrence generally use the words populatur, populare, populavit. However, there is at least one instance of the word depopulauerunt (depopulation) to describe the Vikings' destruction of the population on Mallorca and Menorca. For this use of depopulauerunt and for examples of cities "ab antiquis desertas," see Crónica de Alfonso III, 49-51 (both Ovetense and Rotense versions). As other historians have pointed out, the earliest chronicles of Christians emptying or settling territory once part of al-Andalus was written around one hundred years after the events they describe and the surviving manuscripts date considerably later. For a detailed consideration of the historiography of the ninth and tenth centuries, see Linehan, History and the Historians, 77-94. The motivations that medieval authors may have had in portraying the Duero basin in this way are considered in chapter two.
} 
informed the persistent use of 'depopulation/repopulation' into the twentieth century. Although some scholars continue to use these terms, they will be avoided in this study because they imply a complete absence of local inhabitants, a problematic assertion. ${ }^{84}$ Incoming settlers and existing populations will be specifically described, where possible, in place of the more ambiguous terms 'depopulation' and 'repopulation.'

\section{Reconquest or Territorial Expansion?}

The debate over the nature of the Duero valley population takes place alongside broader questions prompted by the term 'Reconquest. ${ }^{85}$ Were medieval Christians seeking to permanently seize Andalusi lands as reclamation of their historical patrimony or were military successes an expedient way to increase their treasuries and territory?

The former point of view is usually implied with the term 'Reconquest,' or 'Reconquista,' while the latter perspective is suggested by 'territorial expansion.' While a number of scholars have made efforts to parse these terms and suggest that these concepts could overlap or exist side by side, the choice of the word 'Reconquest' still tends to foreground long-term ideological motivations for the Christian expansion into alAndalus. This dissertation views the reality of the lengthy Christian conquest as complicated and varied in its motivation while acknowledging the presence of a 'Reconquest' mentality for some.

Traditionally, the Reconquest has been understood as the deliberate reclamation of the Iberian Peninsula from the Muslims, who illegitimately seized it from the

\footnotetext{
${ }^{84}$ While sometimes these terms are employed simply out of convenience, regardless of the author's perspective on whether or not populations persisted in the Duero Valley after the Islamic conquest, at other times they signal the point of view that a devastating decline took place.

${ }^{85}$ For example, some point to those Christians content to collect tribute in lieu of settling or governing Islamic territory as illustrating a general disinterest in Reconquest.
} 
Visigoths. This nearly 800 year-long goal was once thought by historians to have originated with the northern survivors of the Islamic invasion of $711 .^{86}$ One reason for this is the depiction of the eighth-century Asturian kings as heirs to the Visigothic throne and Oviedo as the new Toledo in the ninth-century chronicles. ${ }^{87}$ Concerning the longevity of the notion that Asturians were grafted onto Visigothic royal tradition, Peter Linehan explains:

The strike took. And its success determined the future course of Spanish history. Because it succeeded it has been thought the most natural thing in the world. But it was not. Because the Visigothic trunk was dead. It had been blasted in 711. To change the metaphor (though not by much), the Asturian kings highjacked a corpse, acquired its papers, and assumed its historical identity. ${ }^{88}$

Few historians maintain that Christian survivors of the Islamic invasion invented the concept of Reconquest in the early eighth century; rather, most place the development of the idea between the ninth and thirteenth centuries, or later. ${ }^{89}$ On the other hand, many historians use the term as a convenient way to distinguish between the Islamic conquest of Visigothic Iberia and the Christian conquest of al-Andalus without clarification of its

\footnotetext{
${ }^{86}$ Marín Guzmán, "Jihad vs. Cruzada," 9-11. For more on how the perpetuation of the "myth" of the Reconquista has been utilized to justify actions during the Counter-Reformation, colonization of the Americas, and the policies of Franco, see Richard Fletcher, Moorish Spain, 6-7, Linehan, History and the Historians, 79-80.

${ }^{87}$ Linehan, History and the Historians, 101-107. The primary sources for these accounts are the Chronicle of Alfonso III and the Chronicle of Albelda. Linehan disagrees with this portrayal and presents another early document, the c. 800 Moissac Chronicle, which indicates that the Visigothic lineage had ended with the Islamic conquest.

${ }^{88}$ Linehan, History and the Historians, 82.

${ }^{89}$ A detailed discussion of the recent historiography of the Reconquest is offered by O'Callaghan, Reconquest and Crusade, 3-22. For the creation of the Reconquest ideology in the eighth century, see Derek Lomax, The Reconquest of Spain (London: Longman), 1978, 1-2; for the ninth century, see Linehan, History and the Historians, 82, 103, Manuel González Jiménez, “¿Re-Conquista? Un estado de la cuestión," in Tópicos y realidades de la Edad Media, ed. Eloy Benito Ruano (Madrid: Real Academia de la Historia, 2000), 175-176; for the eleventh century, see Roberto Marín Guzmán, "Jihad vs. cruzada en alAndalus: la reconquista Española como ideología a partir del siglo XI y sus proyecciones en la colonización de América," Revista de Historia de América 131 (July-December, 2002): 9-65, 63; and Wasserstein, Rise and Fall, 249-270; and for the thirteenth century, see Lucy Pick, Conflict and Coexistence, 46, 58.
} 
philosophical implications; it has become commonplace in the history of medieval

Spain. ${ }^{90}$ The generic usage of Reconquest can be problematic, however. It predisposes the reader to expect religious, historical, and dogmatic motivations on the part of Christian forces, which they may or may not have had. A few documentary sources before the thirteenth century do indicate a royal desire to retake the Peninsula from the Muslims. ${ }^{91}$ However, even if accurately reported, it is unlikely that this sentiment was widely held given the actions of Christian kings in the twelfth and thirteenth centuries. ${ }^{92}$ In this study, the term Christian conquest will be used except in places where the events or material evidence suggest the presence of a specific 'Reconquest' ideology. ${ }^{93}$

\section{Mozarab, Muwallad, Mudéjar and Convivencia}

Terminology is likewise at the root of the problem of how medieval inhabitants of the Iberian Peninsula and their material production are characterized by scholars. In the Duero basin, scholars agree that at some point Berbers, ${ }^{94}$ Arabs, and indigenous Hispano-

\footnotetext{
${ }^{90}$ Powers, A Society Organized for War, 7: "I use the term in this study simply to refer to that process of expansion, without any reference to the theoretical implications that some Spanish historians have attached to it regarding the continuity of Visigothic or imperial authority in the Peninsula."

${ }^{91}$ Wasserstein, The Rise and Fall, 250. The author characterizes the following statement by Ferdinand I of Castile (1035-1065) as the "first unambiguous expression" of a Reconquest feeling: "We seek only our own lands which you conquered from us in times past at the beginning of your history. Now you have dwelled in them for the time allotted to you and we have become victorious over you as a result of your own wickedness. So go to your own side of the straits (of Gibraltar) and leave our lands to us, for no good will come to you from dwelling here with us after today. For we shall not hold back from you until God decides between us."

${ }^{92}$ Pick, Conflict and Coexistence, 58. The emphasis on booty and destruction in the Crónica latina and the Chronicon mundi as opposed to the desire to acquire Andalusi land is pointed out by Pick as evidence that the desire for reconquest was not the priority, even after the success at Las Navas de Tolosa.

${ }^{93}$ I am not advocating for the abolishment of the term reconquest but for its use to be qualified and contextualized in academic writing. After surveying the development of the Reconquista and carefully explaining his position, González Jiménez likewise suggests that the term not be discontinued, but clearly defined by scholars in “¿Re-Conquista?” 176-178.

${ }^{94}$ The term Berber refers to Muslims from North Africa as opposed to the Arabian Peninsula. For information regarding the relationship between Muslim subgroups see Hugh Kennedy, Muslim Spain and Portugal, A Political History of al-Andalus (Harlow, England: Pearson Education Ltd.), 1996; Peter Scales,
} 
Romans $^{95}$ lived in the region. ${ }^{96}$ However, the religious identity of these groups is uncertain. ${ }^{97}$ Arabs and Berbers are not thought to have resided in large numbers in the meseta but this conclusion is not secure because it is related to the question of the socalled depopulation of the ninth and tenth centuries and how one defines these designations. A brief discussion follows for how these terms should be understood within the present study in an effort to outline and justify their use or omission. There are no cases in which ethnicity, religion, and social status are considered to be stable units of comparison. ${ }^{98}$ For example, not all Andalusi Christians were sympathetic to the ambitions of their co-religionists to the north any more than all Muwallads supported the political goals of their Muslim governors. ${ }^{99}$

The Fall of the Caliphate of Córdoba: Berbers and Andalusis in Conflict (Brill), 1994; Wasserstein, The Rise and Fall.

${ }^{95}$ In this study, "indigenous" will be used in a general way to characterize people living in the Iberian Peninsula before the arrival of the Muslims in 711. Current trends of scholarship tend to use indigenous interchangeably with hispano-roman and I will follow that pattern. It should be remembered that the composition of the indigenous hispano-romans would have included Visigothic elements absorbed into the Peninsular population subject to Islamic rule, see Catlos, The Victors and the Vanquished, 25.

${ }^{96}$ Bernard Reilly argues that the three religions of Christianity, Islam, and Judaism were the principal means of identifying people in Iberia. In his opinion, "All other divisions were superficial by comparison." Contest, 12. Thomas Glick also agrees that religious designations were the most important tool of classification for medieval people in Islamic and Christian Spain in the Early Middle Ages, $2^{\text {nd }}$ rev. ed. (Leiden; Boston: Brill, 2005), 185. That said, political relationships often superseded religious or ethnic affiliation, as evidenced by the variety of agreements made between different religious groups throughout the medieval period in Iberia. Political alliances will be described in conjunction with religious and ethnic identity where possible.

${ }^{97}$ The Berbers that participated in the Iberian conquest were new members of the dar al-Islam and their religious identity may have been Muslim, nominally Muslim, Jewish, Christian, or polytheist, see Richard Hitchcock, Mozarabs in Medieval and Early Modern Spain (Aldershot, England; Burlington, VT: Ashgate Publishing Ltd., 2008), xv-xvi, and Abulafia, "Introducion," 21. Likewise, it is possible that not all Hispano-Romans were Orthodox Christians, or even Christians, see E. A. Thompson, The Goths in Spain (Oxford), 1965; J. N. Hillgarth, "Popular Religion in Visigothic Spain," in Visigothic Spain, Byzantium and the Irish (London: Variorum Reprints, 1985), 10-18. For the syncretistic nature of Christianity in eighth century Zaragoza, see Catlos, The Victors and the Vanquished, 27.

${ }^{98}$ For a useful critique of the comparative in Iberian studies, particularly the art historical tendency to expect stylistic elements to maintain their meaning over time and space, see Robinson and Rouhi, "Editor's Introduction to Under the Influence.

${ }^{99}$ Wasserstein The Rise and Fall, 246. The author notes that the Christians of al-Andalus seem unconcerned with the military and political fortunes of northern Christians until the twelfth century importation of Almoravid and Almohad religious ideology hardened attitudes along religious and cultural lines. 
Because political solidarity appears to have been the most reliable indicator of social relations, this aspect of medieval life is prioritized throughout the dissertation. ${ }^{100}$ This is an area of specific concern to this project because I consider the tenth through twelfth-century rural audience for the churches at the Duero frontier to hold the key to better understanding the function of these spaces. The fact that these populations consisted of multiple ethnicities, faiths, and cultural traditions explains the need for patrons to draw upon the legitimizing power of imagery that would be accessible to a wide audience. Sacred landscapes and monumental architectural forms and decoration were constructed to persuade the community of the authority of the local political power, rather than as an unambiguous reference to a royal center with a specific ideological identity.

The word 'Mozarab' has a complicated history. According to Thomas Burnman, it is believed to relate to the Arabic musta'rab, meaning "arabicized." However, the word 'Mozarab' is not found in medieval texts until after the fall of Toledo in 1085, and then only in Christian sources characterizing the Christian population in Toledo. ${ }^{101}$ Muslims, on the other hand, generally described their Christian minorities as, "rūmi ('Roman, Byzantine'), na $\square$ àrá ('Christian,' 'Nazarene'), and mu'āhid ('keeper of the

\footnotetext{
${ }^{100}$ Concerning the alignment of Christians with Muslims, Brian Catlos explains: "In the territories of the Furthest March, the remains of rural churches also reflect Christian persistence, and there is evidence that Mozarabs fought in defense of the Thagr, participating in ghazawät against Christian neighbors and struggles between Muslim factions." in Victors and the Vanquished, 29. The Furthest March is the territory in the north-eastern portion of the Peninsula. Thagr=frontier between Islamic and non-Islamic. Ghazawa $t=$ plural for ghazw, which is a raid. Muslims also collaborated with Christians when politically expedient, leading Peter Scales to suggest that the “...concept of ' $a \square$ abiyya in the Hispano-Muslim writers is more a political one...," The Fall of the Caliphate, 162. The Arabic word ' $a \square$ abiyya=cohesion, or social solidarity.

${ }^{101}$ Thomas E. Burman, Religious Polemic and the Intellectual History of the Mozarabs, c. 1050-1200 (Leiden, NY: Brill, 1994), 1, 7-8; Richard Hitchcock, Mozarabs, 75-97.
} 
covenant,' i. e. one who has entered into a pact with the Islamic rulers)." ${ }^{102}$ It is difficult to account for the apparent contradictions. The erudite, Arabic-speaking Christians of ninth-century Córdoba described by Paul Albar in the Indiculus luminosus are not reflected in the surviving examples of 'Mozarabic' Latin works. ${ }^{103}$ The possibility, then, that there were Christian immigrants from al-Andalus that were not Arabized leads Glick, after Vicente Cantarino, to offer that 'Mozarabic' was used by Latin-speaking Christians to negatively identify co-religionists culturally sympathetic to Arabic society. ${ }^{104}$

However, as Richard Hitchcock has pointed out, it is more significant that the word "Mozarab" does not appear before the conquest of Toledo, and should therefore be avoided before $1085 .^{105}$

More important to this study than the confusion over how the appellation of 'Mozarab' was understood in Iberia are the ways in which it has been used as shorthand for the appearance of all things Islamic in Christian territory. For example, some historians have presumed that the appearance of Arabic names in Christian documents indicates the existence of 'Mozarab' immigrants and do not allow for the possibility of

\footnotetext{
${ }^{102}$ Burman, Religious Polemic, 7. See also E. Lapiedra Gutiérrez, Como los Musulmanes Llamaban a los Cristianos Hispánicos (Alicante: Instituto de Cultura Juan Gil-Albert, 1997).

${ }^{103}$ Iudiculus luminosus, n. 35, PL 121:555f. This passage reflects Paul Albar's frustration with what he sees among his co-religionists in al-Andalus as an inappropriate affinity for Andalusi culture over their Latin heritage. Given the fact that the Bible was translated into Arabic by the tenth century suggests that Arabic was nevertheless the primary language for most Christians in al-Andalus. See Carleton M. Sage, "Paul Albar of Cordoba: Studies on His Life and Writings," (PhD diss., The Catholic University of America, 1943), viii.

${ }^{104}$ Glick, Islamic and Christian Spain, 176-177, 198-199, fn 33 and Vicente Cantarino, Entre Monjes y Musulmanes, El conflicto que fue España (Madrid: Alhambra, 1978), 109.

${ }^{105}$ Hitchcock, Mozarabs, 69-75. The exception to this is the instance of its appearance in 1026 to describe the embroiderers (also called the tiraceros, after the tiraz-system) to King Alfonso V. The Mozarabs were engaged in a lawsuit and the use of the term seems in no way derogatory. In addition, the author can find no reason to assume that the tiraceros were Christians at all, thus further problematizing our present use of the word 'Mozarab.' Only one aspect of the term is straightforward, it never appeared in Muslim documents, leading Hitchcock to reject its application for Christians under Muslim rule, xviii.
} 
subject Muslim or Mudéjar populations. ${ }^{106}$ This is partly due to the reticence of medieval authors to explain the presence of Muslims in conquered territory, except in terms of execution or exile, and partly due to the historiographical perspective that all newly acquired Christian territory was 'repopulated' with Christians. ${ }^{107}$ The unqualified use of Mozarabic, then, predisposes the reader to expect a Christian of Andalusi origin, an expectation that does not reflect the more complicated reality of Medieval Iberia.

In art history, the adjective 'Mozarabic' is used to explain any material found in a Christian context that exhibits Islamic artistic influence. ${ }^{108}$ In 1919, Manuel GómezMoreno first used 'Mozarabic' to describe the mixture of Hispano-Roman and Islamic styles found in Iberian architecture of the tenth and eleventh centuries. ${ }^{109}$ The label was adopted by art and architectural historians, along with his proposal that the builders responsible for the combination of forms were immigrant populations of Andalusi Christians ('Mozarabs') who had carried Islamic influences from the south. ${ }^{110}$

\footnotetext{
${ }^{106}$ Charles Julian Bishko, "Salvus of Albelda and Frontier Monasticism in Tenth-Century Navarre," Speculum 23, no. 4 (October 1948): 559-590, particularly 561-562. For example, Bishko presumes that the Muslim names in Riojan charters were Mozarabs, while acknowledging the scarcity of information for the area.

${ }^{107}$ This question will receive further treatment in chapter two.

${ }^{108}$ For example, according to Hilsdale, "Here the problem of terminology arises: the designation Mozarabic carries a wide range of connotations depending on the context of its use. Referring to the Iberian Peninsula's Christian inhabitants living under Muslim rule or in the vicinity of Muslim-ruled territories, the term distinguishes a historically-determined terrain... Yet when this quasi-ethnographic term is employed to describe the dominant formal idiom permeating a corpus of artistic production, such clarity breaks down." in "Towards a Social History of Art," 272. Hilsdale goes on to define Mozarabic as it has been used by past historians but does not offer a solution for how the term should be employed today.

${ }^{109}$ Gómez-Moreno, Iglesias Mozárabes, 97-104. Gómez-Moreno includes an analysis of the Portuguese monastery San Pedro de Lourosa (912).

${ }^{110}$ Gómez-Moreno, Iglesias Mozárabes, ix-xxiv, particularly xiv-xv. The author maintains that Andalusi forms, like horseshoe arches, were ultimately of Visigothic origin, xix. Scholars who have accepted that Mozarabs absorbed and transported Islamic artistic forms have, in turn, attempted to reconstruct lost Islamic artistry by looking at Mozarabic art. Concerning this perspective for nearly all Beatus manuscripts, Hilsdale states, "The most fundamental problem with this assumption is that the surviving artistic record of Islamic al-Andalus does not closely resemble the Christian artistic production in the north." "Towards a Social History," 273.
} 
Gómez-Moreno's hypothesis was reasonable given the number of medieval references concerning monastic immigrants from al-Andalus. However, since the beginning of the twentieth century, it has become standard practice to automatically assume that 'Mozarab' immigrants were in some way responsible for any construction or decoration reflecting Hispano-Andalusi hybridity, regardless of the local circumstances of production. One problem with this is that it does not allow for the wider relevance that this mixture of styles had—not only for a frontier audience but for those Christians living in the north who clearly attached value to such buildings, manuscripts, textiles, etc. ${ }^{111}$

For the sake of clarity, in this dissertation care will be taken to specifically describe elements usually associated with Islamic art and architecture when they appear in a Christian context, rather than employing the term 'Mozarabic.' The fact that in most cases along the frontier the identity of patron and audience is an open question will also be discussed, so that the assumption that these constructions were connected to Andalusi immigrants might be qualified. Artistic style, patronage and audience will be treated as separate entities. For example, a monastic patron does not necessarily limit the intended viewer to the resident monks, figurative painting does not rule out an intended Muslim viewer, and so on.

The appearance and definition of the term Muwallad, or Neo-Muslim, is less problematic than 'Mozarabic.' This study accepts the prevailing use of Muwallad to

\footnotetext{
${ }^{111}$ Although María Judith Feliciano is chiefly concerned with the significance of textiles in medieval Iberian contexts, her critique has a wider application for Mozarabic art and architecture: "Traditional art historical investigations have taken a strictly formalist approach to the study of Andalusi luxury arts, treating textiles as little more than decorative objects lacking a useful social life. Such a restricted interpretive lens results from an academic practice that has established medieval Iberia as a society of extremes, either stressing the conflictive nature of its culture or overemphasizing a model of peaceful, multicultural convivencia." "Muslim Shrouds for Christian Kings? A Reassessment of Andalusi Textiles in Thirteenth-Century Castilian Life and Ritual," in Under the Influence: Questioning the Comparative in Medieval Castile, ed. Cynthia Robinson and Leyla Rouhi (Leiden, Boston: Brill, 2005), 101.
} 
describe those who converted from Christianity to Islam or those born to indigenous converts to Islam. ${ }^{112}$ Conversely, the term generally used to describe Muslims living under Christian rule is Mudéjar. ${ }^{113}$ It is likely that Muwallad/Mudéjar populations formed part of the architectural audience at the frontier; however, the more general designation of 'Muslims' is considered to better represent our developing understanding of this group's participation in the tumultuous period following Christian conquest and is therefore the preferred term. ${ }^{114}$

Finally, attempts to reconstruct the cultural and social interactions among Christians, Muslims, and Jews have received a great deal of attention lately. The term convivencia or co-existence/living together, has prompted scholars to explore the productive and destructive effects of cross-cultural contact in medieval Iberia. ${ }^{115}$ The term itself, like others explored in this chapter, has been problematized by current scholarship. Scholars agree that the degree to which different cultural and religious sects were able to peacefully coexist differed according to local circumstances. ${ }^{116}$

For this dissertation, Muslim-Christian relations are explored in greater detail than the position of Jews along the frontier because there are few references to Jews in the

\footnotetext{
${ }^{112}$ Once a Muslim is subject to Christian authority, the equally vague word Mudéjar replaces the term Muwallad.

${ }^{113}$ Robinson and Rouhi, "Editor's Introduction to Under the Influence," 5 and Kennedy, Muslim Spain and Portugal, 278. The application of the term Mudéjar encounters difficulties similar to that of Mozarab, despite the distinction in time and place. Like Mozarab, it may refer to a group of people or a style of art and architecture. .

${ }^{114}$ For example, some frontier churches, like San Miguel de Gormaz (Soria), are thought to have been designed to facilitate the conversion of Muwallads to Christianity.

115 Thomas Glick, "Convivencia: An Introductory Note," in Convivencia; Jews, Muslims, and Christians in Medieval Spain, ed. V. Mann, T. Glick, and J. Dodds (New York: George Braziller), 1. "The word, as we use it here, is loosely defined as 'coexistence,' but carries connotations of mutual interpenetration and creative influence, even as it also embraces the phenomena of mutual friction, rivalry, and suspicion." This essay also briefly relates the history of the term from its invention with Ramón Menéndez Pidal.

${ }^{116}$ Lucy Pick, after David Nirenberg, offers the possibility that violence and polemic could actually facilitate convivencia through the structuring of group identity and the defining of cultural boundaries. Conflict and Coexistence, 3.
} 
documents or architecture of the Duero valley, the geographical focus of this study. Nevertheless, they doubtless contributed to the sociopolitical interactions that drove building trends along the frontier. Encounters between coexisting groups were shaped by a changing political reality, one that prompted competitors to use architectural space in an effort to improve their bargaining position. A similar understanding of the pragmatic underpinnings of convivencia is expressed by Brian Catlos, "At bottom, these domestic conditions exercised the most influence on the mudéjar experience; complex and crisscrossing bonds of interest between Muslim and Christian parties sustained mudéjar society by virtue of its utility - a case of conveniencia, rather than convivencia." Convenience, then, appears to have informed architectural patronage at the Duero frontier as builders sought to construct impressive religious spaces that could function as authoritative political centers over diverse populations.

${ }^{117}$ Catlos, Victors and Vanquished, 407. The essay by Cynthia Robinson and Leyla Rouhi, "Editor's Introduction to Under the Influence," 5, also ascribes to the often convenient nature of convivencia, after Catlos. 
CHAPTER 2:

INVESTIGATING THE QUESTION OF AUDIENCE THROUGH THE REPOPULATION DEBATE

The term repopulation often appears in tandem with Reconquest. The reason for this is clear: many medieval Christian sources explicitly describe the repopulation of empty land as a component of territorial conquest. ${ }^{1}$ Early medieval accounts explain that the seizure of Muslim lands included the removal of Muslims by execution or exile (depopulation), followed by the mass resettlement (repopulation) of any remaining Christians to the north. These "deserted" or empty zones would subsequently become the focus of Christian repopulation by later generations. Alternatively, as Christian kingdoms expanded, large-scale settlements would be deployed to repopulate land that had been left empty from the time of antiquity. ${ }^{2}$

An example of the medieval sources that described the depopulating of the Duero basin and other frontiers is the ninth century Chronicle of Alfonso III, which portrayed the eighth century capture of numerous civitates, together with their castros, villas and

\footnotetext{
${ }^{1}$ The earliest Latin descriptions of this occurrence generally use the words populatur, populare, populavit. However, there is at least one instance of the word depopulauerunt (depopulation) to describe the Vikings' destruction of the population on Mallorca and Menorca in the Crónica de Alfonso III, 49-51 in both Ovetense and Rotense versions.

${ }^{2}$ For more on the accounts of territory left empty "ab antiquitus," see chapter two, fn. 2.
} 
villages. ${ }^{3}$ The chronicler explained that the Arabs were killed and the Christians led back to Asturias and used to populate Asturias, Castile, and Galicia among other territories. ${ }^{4}$

Seemingly concrete medieval accounts like this laid the foundation for how events were later interpreted by historians. Although initially accepted at face value, since the late twentieth century, alternative reconstructions of medieval populations along the Christian and Muslim frontier have provoked controversy. This dissertation engages in the problem of medieval settlement patterns because this debate directly affects the reconstruction of architectural audience and patronage by challenging the perspective that the Duero basin was largely unoccupied and therefore without political influence.

\footnotetext{
${ }^{3}$ A castro is a general term for a fortified hilltop. The nature of the fortification may vary considerably from earthworks to stone walls and structures.

${ }^{4}$ Crónica de Alfonso III (Rotense version), trans. Antonio Ubieto Arteta, vol. 3 Textos Medievales (Valencia: Universidad de Valencia, 1971), 36, 38: "Quo mortuo, ad uniuerso populo Adefonsus eligitur in regno, qui cum gratia diuina regni suscepit sceptra. Inimicorum ab eo simper fuit audatia comprensa. Qui cum fratre Froilane sepius exercitu mobens, multas ciuitates bellando cepit. Id est, Lucum, Tudem, Portugalem, Anegiam, Bracaram metropolitanam, Uiseo, Flauias, Letesma, Salamantica, Numantia qui nunc uocatur Zamora, Abela, Astorica, Legionem, Septemmanca, Saldania, Amaia, Secobia, Oxoma, Septempuplica, Arganza, Clunia, Mabe, Auca, Miranda, Reuendeca, Carbonarica, Abeica, Cinasaria et Alesanzo, seu castris cum uillis et uinculis suis. Omnes quoque arabes gladio interficiens, christianos autem secum ad patriam ducens. Eo tempore populantur Asturias, Primorias, Liuana, Transmera, Subporta, Carrantia, Bardulies qui nunc uocitatur Castella, et pars maritimam, et Gallecie.” This explanation of a depopulation of one area in order to settle another is continued in later periods. For a typical account of the repopulation of a formerly empty zone, consider the following in which the chronicler describes the reign of King Alfonso I of Aragón (1104-1134), also called el Batallador (the Battler): "He created the burg of Pamplona by establishing settlers in a field of his called Orunya, and conceded many privileges to them. He also populated Soria, Almazán, Berlanga, and Belorado." The Chronicle of San Juan de la Peña; a Fourteenth-Century Official History of the Crown of Aragon, trans. Lynn H. Nelson (Philadelphia: University of Pennsylvania Press, 1991), 25. The modern understanding of these primary accounts is illustrated by the twentieth-century statement of Ramón Gonzalvez, that “...there could be no reconquest without repopulation," a conclusion that reflected general scholarly consensus in "The Persistence of the Mozarabic Liturgy," 169. The reason "repopulation" is the term most frequently used to describe the medieval accounts of population, like the above account from the San Juan Chronicle is because historians are aware that many of these towns and cities, like Pamplona and Soria were previously Roman settlements. Michael Kulikowski, Late Roman Spain and its Cities (Baltimore, MD: John Hopkins Press, 2004), 103.
} 


\section{The Repopulation Debate}

In the middle of the $20^{\text {th }}$ century, scholars began to expound upon the seemingly straightforward statements concerning depopulation and repopulation made by medieval historians. For some, the idea that there were substantial zones of unoccupied territory and the total evacuation of Muslims from conquered regions dovetailed with their views of a uniquely Spanish resistance to all foreign influence, whether it was Visigothic or Muslim. ${ }^{5}$ Other historians criticized the idea of a total depopulation but, given the lack of multiple urban centers and the testimony of medieval texts, still decided that it seemed reasonable to reconstruct frontier zones as a nearly empty, and therefore powerless, territory. Over the centuries, these accounts have prompted historians such as Claudio Sánchez-Albornoz to consider one area in particular, the Duero river basin, as a strategic buffer zone between Christian and Muslim powers. ${ }^{6}$

The Duero River begins in the plains of Soria, Spain, in the center of the Iberian peninsula, and moves westward toward the border of Portugal (where it becomes the Douro), continuing until it empties into the Atlantic at Oporto. Iberian scholars call the more than 98,000 square kilometers that encompass the river and its many tributaries the

\footnotetext{
${ }^{5}$ See Claudio Sánchez-Albornoz, Despoblación y repoblación del valle del Duero (Buenos Aires, 1966).

${ }^{6}$ The standard designation of the Duero basin as a 'strategic desert' comes from Claudio SánchezAlbornoz, Despoblación, 237. This idea has been accepted and repeated in one form or another by many historians. For a few examples, see: Roger Collins, The Arab Conquest of Spain, 710-797 (Oxford UK; Cambridge, USA: Blackwell Publishers, Ltd., 1989), 154, who, albeit somewhat qualified, nevertheless describes the "remarkable foresight" of Alfonso I thus, "The removal into the north of the inhabitants of some or most of the towns of the Meseta enormously enhanced his resources of manpower, and at the same time the creation of a cordon sanitaire along the Duero valley both provided a demarcation of the zones of authority of the Arab rulers in the south and the Christian king in the north and also made the whole frontier more easily defensible."; Antonio Linaje Conde, "Frontera y desierto en la España medieval," in Actas del congresso la frontera oriental Nazari como sujeto historico (s. XIII-XVI) (Almeria, 1997), 359362; Linehan, History and the Historians, 110, where he uses a variation, "no-man's land," as do others, such as Wasserstein in The Rise and Fall, 22.
} 
Duero basin. ${ }^{7}$ Despite the large size of this region, medievalists tend to consider it merely a zone across which armies moved in the ninth through twelfth centuries, without political influence, and have consequently minimized the significance of its medieval architectural and archaeological material. ${ }^{8}$ Although fortresses are sometimes mentioned in passing, they are generally viewed by historians as military outposts, utilized by campaigning armies rather than markers of agricultural communities or local political power. As a result, the fortresses, churches, monasteries, and ermitas of the frontier sometimes appear in the secondary literature as little more than illustrations to historical arguments unrelated to the buildings themselves. ${ }^{9}$ An example is Richard Powers' use of figured capitals from churches that represent, "Soldiery on foot (tenth through twelfth centuries) with various stages of body armor and assorted weapons". ${ }^{10}$ Possible explanations for why contemporary soldiers were depicted as part of the church's visual program are not investigated. Art and architectural historians who discuss the ecclesiastic spaces and fortresses of the Duero Valley generally accept the position that some sort of depopulation/repopulation took place and therefore vaguely assign the

\footnotetext{
${ }^{7}$ The Duero/Douro played a significant role in Iberia, not only as a water source, but as a topographic element. Although not navigable by boat throughout its length, it nevertheless facilitated contact through its passes in mountainous zones. Reilly, The Medieval Spains, 3.

${ }^{8}$ The work of Bernard Reilly, O'Callaghan, and Richard Fletcher illustrate this point. The scarce textual evidence for political activity connected to royal courts drives the continued oversight. Archaeologists and historians who have adopted anthropological theories on settlement, on the other hand, have determined to fill the gaps, for example, Abel, "Strategic Domain," Castellanos and Martín Viso, "The Local Articulation," and Martín Viso, Fragmentos del Leviatán. The greatest interest in the material remains of the Duero basin focus on the late antique and early medieval ages, see J.J. García González and I. Fernández de Mata, "Antropología, arqueología e historia. La desestructuración de la cuenca del Duero en la transición de la Antigüedad a la Edad Media," Estudios sobre la transición al feudalismo en Cantabria y la cuenca del Duero (Burgos, 1999) and E. Pastor Díaz de Garayo, Castilla en el tránsito de la antigüedad al feudalismo. Poblamiento poder politico y estructura social del Arlanza al Duero (siglos VII-XI) (Valladolid, 1996).

${ }^{9}$ The word ermita means a hermitage church, but the historical function of these remote and often small churches should be evaluated on a case by case basis because a number do not appear to have been associated with hermits.

${ }^{10}$ See Powers, A Society Organized for War, page ix for the description of plates seven through ten.
} 
buildings to 'Mozarab' or 'Reconquest' settlers. There is little engagement with the specific historical events that may have prompted their construction or rehabilitation. ${ }^{11}$ Moreover, connections between churches designated as 'Mozarabic' or 'Reconquest' focus more on their stylistic relationship with others likewise categorized than with their sociopolitical function at the Christian Muslim border. ${ }^{12}$

The sociopolitical significance of architecture can only be analyzed in light of its potential audience. ${ }^{13}$ However, quantitative research concerned with the number and ethnic identity of medieval populations is not only scarce, it is subject to debate because conflicting interpretations of data collection, configuration, and methodological theory in particular, serve to complicate and render suspicious data once thought to be largely objective. ${ }^{14}$ While precise numbers for rural communities are impossible, drawing from

\footnotetext{
${ }^{11}$ For the problematic nature of the terms Mozarabic and Reconquest, see chapter one.

${ }^{12}$ This point is covered in greater depth in the literature review of Duero basin architecture of chapter one, but briefly, after the seminal publication of Gómez-Moreno's Iglesias Mozárabes, few architecturallyfocused publications about the tenth and eleventh century Duero Valley followed until the important work of Isidoro Bango Torviso and Jerrilynn Dodds who did explore questions of patronage and message in frontier architecture in "El Neovisigotismo artistico," and Architecture and Ideology, respectively. In recent years, art historians continue to follow the conclusions of Dodds with little expansion regarding the purpose of so-called Mozarabic architecture in the Duero basin, even as the terminology and dating for many of these structures receives increasing criticism. An example of this tendency is the summary of tenth-century frontier architecture provided by Sally Garen as part of her argument to attribute Santa María de Melque of Toledo to the tenth century instead of the Visigothic age: "Reconquest architecture appeared as Christians took the offensive militarily, began to repopulate the frontier between themselves and the Muslims, and established a capital at Leon. It reflected these circumstances with a reposnsiveness to many sources: masonry ateliers from the Asturias, forms of the pre-Conquest kingdom of the Visigoths, and new expertise deriving from the reconstruction of churches that had fallen in ruin. This is a familiar scenario in the history of art: sources are utilized more freely, with less bias, and are fitted together into more imaginative, new templates than could occur where established artistic presumptions held sway. These northern churches represent a coalescing of ideas in a newly developing geographical locale where there was not already an extant prevailing vision." in "Santa Maria de Melque," 288-289. On the other hand, the analysis by Mickey Abel ("Strategic Domain") concerning the cultural function of frontier churches in Soria serves an important exception to the wider art historical trend because she invests these churches with a political power to reinforce the developing Christian and military dominance at the frontier

${ }^{13}$ An example of such a study include the work of Richard W. Bulliet, Conversion to Islam in the Medieval Period (Cambridge, Mass., 1979) and José Angel García de Cortazar, "Sociedad rural y organizacion del espacio en la Castilla del año mil," in Campagnes Médiévales: L'homme et son espace; études offertes á Robert Fossier 31 (1995): 613-25.

${ }^{14}$ Josiah Cox Russell, Medieval Regions and Their Cities (Bloomington: Indiana University Press, 1972). One reason that Russell concentrates his statistical reconstructions of medieval cities to those with extant
} 
archaeological, documentary, and architectural sources, a reconstruction of Duero basin inhabitants is offered in this dissertation to provide a broad picture of the potential audience for frontier ecclesiastical spaces. ${ }^{15}$ This investigation begins with an overview of the repopulation debate and its attendant historiographical significance, which lies at the root of settlement reconstruction for the Duero valley.

In general, three approaches serve as umbrellas for repopulation discourse and will be discussed more thoroughly below. ${ }^{16}$ The traditional view, derived from a literal interpretation of medieval chronicles, maintained that Christian sovereigns either settled territory that had lain vacant since antiquity or completely replaced the inhabitants of Muslim towns with Christian colonists. This perspective fell out of favor in the second half of the twentieth century. The second approach is essentially a modification of the first and operates from the position that, although the medieval sources no doubt contain exaggerations, some level of depopulation and resettlement occurred. The third approach sets aside the debate over the extent of depopulation/repopulation in favor of the theory that medieval chroniclers were describing a political restructuring, one that required negotiation with existing social organizations, which may have included both Christians

\footnotetext{
walls is his methodology, which extrapolates population numbers based on the number of hectares within the city's walls. Nevertheless, this study overlooks populations that probably dwelled beyond walls. ${ }^{15}$ Medievalists sometimes rely on political theory to support their reconstructions of rural societies and these methods will be sporadically acknowledged and treated (though by no means comprehensively) in this and the next two chapters as warranted. For a thorough overview of current approaches, see Gerald F. Gaus and Chandran Kukathas, eds. Handbook of Political Theory (London: SAGE Publications Ltd., 2004) and for a survey of the medieval period specifically, particularly the contribution of Carolingian society, see Joseph Canning, A History of Medieval Political Thought (London; New York: Routledge, 1996).

${ }^{16}$ Although many scholars note the weaknesses of current repopulation theories, attempts to develop alternative propositions concerning the question of repopulation are viewed with skepticism, as the discussion below will show. At the least, it would be profitable for authors to be more explicit in their references to repopulation by explaining how they are using the term.
} 
and Muslims. ${ }^{17}$ The frontier architecture of the Duero valley provides an opportunity to consider the ongoing debate over how newly won territories were governed during this tumultuous time. The survival of ecclesiastic structures, fortresses and collaborative systems, such as militias, supports the third position that incoming conquerors were forced to engage with a number of independent constituencies that had continued to exist within these newly conquered territories.

The question of how diverse frontier regions were conquered, settled, and managed over the several hundred-year period of the Christian conquest of al-Andalus is complex. Further complicating this episode in Iberian history is the varied treatment of the period by the historiography of repopulation literature. While the colonization of the Rioja region in the ninth century or the settlement of the kingdom of Zaragoza in the twelfth century naturally requires different treatments in accordance with time and place, broad patterns make clear that historiography and methodology have driven the traditional repopulation conversation. For example, after surveying the disagreements between several historians, while at the same time overlooking many of the archaeological publications, Peter Linehan summarized the controversy over the frontier demographic thus:

Whatever its actual condition, however, the no man's land was long to provide a happy hunting ground in which adventurers and speculators would claim that their eighth- and ninth-century ancestors had established squatters' rights. Again, the terrain resembled what men have made of its history.... The net effect of the multi-dimensional complex of claims and counter-claims across the generations defies description. $^{18}$

\footnotetext{
${ }^{17}$ As briefly explained in chapter two, it is very difficult to reconstruct the Jewish population for the tenth through twelfth-century Duero basin and so this chapter focuses on the Christian and Muslim populations. ${ }^{18}$ Linehan, History and the Historians, 110.
} 
Although Linehan is primarily discussing how medieval documents were forged in order to justify later territorial claims, the way modern history has been constructed likewise reflects the aims of its makers and their disciplinary approaches. ${ }^{19}$

From the nineteenth to the mid-twentieth century, most scholars uncritically accepted the claims of medieval chroniclers that after a Gothic, Islamic, or Asturian depopulation, a mass colonization followed the Christian conquest. ${ }^{20}$ In addition to the aforementioned Chronicle of Alfonso III, ${ }^{21}$ the Mozarabic Chronicle of 754 provides an example of a document that seems to support the impression of large-scale depopulation in the eighth century. In it, the author described a veritable wasteland following the Islamic conquest. Combined with the knowledge that the Duero basin and high plains were a mostly rural and arid landscape in modern times, it was reasonable to accept the account of what seemed to be an eye-witness. ${ }^{22}$ However, the style of the author reveals that he was acquainted with Arabic literary devices and resigned to the legitimate conquest of the peninsula by a strong foreign army. This suggests to Kenneth Baxter

\footnotetext{
${ }^{19}$ Linehan, History and the Historians, 21. While the author notes the biases of historians, he does not embrace theoretical transparency per se: "Lucky Spaniard (supposing that was what he was) who had only to endure the heats, burdens, terrors, and dysentery of several centuries, and was spared persistent questioning regarding his motives and mentalité, and allowed to proceed towards the 'end proposed' without being constantly pestered by passing Wittgensteinian francs-tireurs anxious to explain to him the activity in which he was already engaged."

${ }^{20}$ Leonard A. Curchin, The Romanization of Central Spain: Complexity, diversity and change in a provincial hinterland, (London and New York: Routledge, Taylor and Francis Group, 2004), 16. Curchin offers the following critique of this approach, "Roman history has long been dominated by literary sources, which are often accepted literally and uncritically as if they had Biblical authority...Even archaeologists often start from the assumption that the written texts provide a factual skeleton which must be fleshed out with archaeological details." See also Ian Hodder, Theory and Practice in Archaeology, (London and New York: Routledge, 1992).

${ }^{21}$ See footnote four of this chapter.

22 "The Chronicle of 754," in Conquerors and Chroniclers of Early Medieval Spain, $2^{\text {nd }}$ ed., trans. and ed. Kenneth Wolf (Liverpool University Press, 1999), 133. "He devastated not only Hispania Ulterior, but Hispania Citerior up to and beyond the ancient and once flourishing city of Zaragoza, which was now, by the judgment of God, openly exposed to the sword, famine, and captivity." The Roman designations of Hispania Ulterior and Citerior encompass the entire Peninsula. Most historians acknowledge the presence of hyperbole in this chronicle but persist in describing the author as a witness, for example, "It is thus the only detailed peninsula witness of Christian origin to the Arab conquest and its aftermath." in Collins, The Arab Conquest of Spain, 27.
} 
Wolf that the chronicler “.... was probably a deacon or a bishop living in al-Andalus a generation after the Muslim conquest of Spain."23 There is also room for further study on how the chronicle's account reveals information pertaining to eighth and ninth century rural populations; for example, those descriptions that suggest an apparent continuity of agricultural estates and their Christian managers under Islamic rule. ${ }^{24}$

Franco-era Iberian specialists have frequently been the focus of historiographical essays directed at exposing underlying political and nationalistic biases. One reason for this is the nationalism that was endemic to medieval studies in Spain until the last few decades. ${ }^{25}$ However, historians and archaeologists outside of the Peninsula, while less explicit, were nevertheless products of their time. In general, mid-twentieth century Iberian historians accepted the idea of a literal depopulation of the Duero basin and the

\footnotetext{
${ }^{23}$ Wolf, "An Andalusian Chronicler and the Muslims," in: Conquerors and Chroniclers of Early Medieval Spain, $2^{\text {nd }}$ ed., trans. Kenneth B. Wolf (Liverpool University Press, 1999), 25-42, 42.

${ }^{24}$ See Wolf, Conquerors and Chroniclers, 133. The author broadly describes Peninsula-wide destruction but only specifically details Musa's destruction of large cities: "He ruined beautiful cities, burning them with fire; condemned lords and powerful men to the cross; and butchered youths and infants with swords. While he terrorized everyone in this way, some of the cities that remained sued for peace under duress and, after persuading and mocking them with a certain craftiness, the Saracens granted their requests without delay" (ibid., 137). Later in the account, the chronicler explains that estates that had been handed over to the Arabs were returned to Christians so that they might yield taxes for the Islamic empire. That the Muslim authorities thought the estates would yield taxes suggests that not everything was decimated in Musa's campaign.

${ }^{25}$ The last three decades in particular have witnessed an increase in critiques aimed at revealing nationalistic frameworks in Spanish scholarship. Aurell addresses the political underpinning to Iberian studies in the course of his thorough article, "A Secret Realm," 61, "Medieval studies has always been one of the most prestigious and academically famous fields of Spanish culture. The enormous weight the medieval period has had in the formation of the Spanish national identity partly explains that phenomenon." Later, he comments specifically on the essentialism that lies at the root of nationalist perspectives - the idea of the eternal Spain and how this concept was later commercialized to great effect in the tourist slogan, "Spain is Different" (ibid., 61-66). See also Philip L. Kohl and Clare Fawcett, eds. Nationalism, Politics, and the Practice of Archaeology (Cambridge University Press, 1995) and Sebastiaan Faber's examination of political impeti behind Iberian scholarship in "Economies of Prestige: the Place of Iberian Studies in the American University," Hispanic Research Journal 9, no.1 (2008): 7-32.
} 
almost simultaneous emergence of a Christian determination to reclaim the territory lost to Muslims that underpins the idea of the Reconquest, or Reconquista. ${ }^{26}$

An example of the point of view informed by the approaches outlined above is the thoughtful work of Charles Julian Bishko. In his 1948 article, "Salvus of Albelda and Frontier Monasticism in Tenth-Century Navarre," he describes how León and Castilla pushed steadily into the despoblado, ${ }^{27}$ repopulating the northern Riojan province:

By $941 \ldots$ The Muslim population, perhaps never very numerous, seems to have been largely displaced, but Riojan charter signatures suggest Mozarabic elements survived in some strength. Land cessions to pobladores seeking to settle the newly opened country must have been numerous, although little is known of this except from ecclesiastical grants. ${ }^{28}$

The footnotes provided by Bishko refer to documents written under Ordoño II of Asturias-León (914-925) and Sancho I Garcés of Navarre (905-926) that state that the Muslims had been removed from their territories. ${ }^{29}$ Bishko's interpretation cautiously qualifies the chronicler's account that the Muslims were removed by suggesting that perhaps there were not many to begin with and acknowledges the scarce information pertaining to resettlement. ${ }^{30}$ Nevertheless, he largely accepts the medieval account of the depopulation/repopulation of the Riojan territory—a position shared by his contemporaries.

\footnotetext{
${ }^{26}$ For an example, see Lomax, The Reconquest of Spain, 1-2. For more on the debate over how the term Reconquest should be understood, see chapter two.

${ }^{27}$ Bishko, "Salvus of Albelda," despoblado=deserted area and Meseta Central=central plateau.

${ }^{28}$ Bishko, "Salvus of Albelda," 561-562, pobladores=settlers.

${ }^{29}$ Bishko directs the reader to volumes five and six of Colleción de cédulas, cartas-patentes, provisiones, reales órdenes y otros documentos concernientes á las provincias Vascongadas, ed. A. Tomás González, (Madrid, 1829-1833) and L. Serrano’s edited compilation, Cartulario de San Millán de la Cogolla (Madrid, 1930) or see Gonzalo de Berceo, “Obras Completas,” ed. Carlos Clavería Laguarda and Jorge García López (Madrid: Fundación José Antonio de Castro, 2003).

${ }^{30}$ Bishko, "Salvus of Albelda," The author does not consider that the medieval account may have misrepresented the persistence of Muslims or the nature of the Christian repopulation.
} 
Bishko also explains that his assumption of a persisting Mozarabic population derives from the number of Arabic names found in regional monastic charter collections. However, his conclusions pose some difficulty for the reader. Given the number of Arabic names, Bishko dismisses too easily the possibility that Muslims may have continued to inhabit conquered areas (belying the premise that they were devoid of people in the first place), and he fails to consider the variety of political and religious identities that an Arabic name could signify beyond the loosely defined moniker 'Mozarabic.' ${ }^{31}$

In 1960, the well-known Spanish historian Ramón Menéndez Pidal suggested a critical reading of the late ninth-century chronicle of Alfonso III of Asturias-León (866910). ${ }^{32}$ Menéndez Pidal offered that it was possible that this story was recorded by Alfonso III to justify his reoccupation of these cities (they were empty, after all!). Furthermore, he argued that the accounts of depopulation more likely described the destruction of Muslim authority and that only the elites of these towns would have been removed by Alfonso I, leaving farmers, etc. behind. It was these disorganized hamlets that the later conquerors restructured and populated with a governing class. ${ }^{33}$ Menéndez Pidal particularly pressed his point in regard to the eleventh century, when he described the cities of Osma and Coimbra, retaken by al-Mansur, and declared that many were sustained by their pre-existing Christian populations and Mozarabic monastic

\footnotetext{
31 The difficulties of this and other controversial terms such as Mudéjar are discussed in chapter two.

${ }^{32}$ For the text, see footnote four of this chapter, Crónica de Alfonso III, but basically, according to the chronicler, thirty cities of the Duero, Ebro, and Miño river valleys were conquered by Alfonso I of Asturias (739-757), who after killing the Muslims brought all of the Christians back to Asturias.

${ }^{33}$ Ramón Menéndez Pidal, "Repoblación y tradicion en la cuenca del Duero; despoblación y repoblación en el primitivo reino de Asturias. La Crónica de Alfonso III,” Enciclopedia Linguísta Hispánica 1 (1960):

XXIX-LVII (the numbers change according to essay and so they do not always proceed numerically). Menéndez also supports the conviction of Orlando Ribeiro that Portugal was not the desert Alfonso described, but rather a society carrying on without an administrative structure, (ibid., 34).
} 
communities. The result of the tenacity and self-reliance of these frontier cities was a strong sense of political independence. ${ }^{34}$

Despite this more nuanced reading of the terms populatur, populare, depopulauerunt, Menéndez Pidal still credited only Christian kings with the fortification of the eleventh-century frontier without discussing the presence of construction phases that predate the eleventh and twelfth-century defensive structures. It should also be kept in mind that the author's conclusions were strongly shaped by his belief that Visigothic continuity forged a national identity among Iberian peoples. ${ }^{35}$ His inattention to the architectural evidence of Islamic and Christian strongholds and churches that predated the Christian invasion was unfortunate, but his analysis of the political dimension of medieval-era repopulation accounts contributed a great deal to the question of Duero basin population, and maintains its relevancy to the ongoing debate.

In response to the few such as Menéndez Pidal, who challenged a literal “...desierto del Duero,” Claudio Sánchez-Albornoz authored Despoblación y Repoblación del Valle Duero in $1966 .{ }^{36}$ In this book, the author expanded upon his previous position that a vast depopulation of the Duero River valley took place and that it was central to the national identities of Spain and Portugal. Sánchez-Albornoz explained that the emptying of this territory was initiated during the fighting between the Suevi and the Visigoths in the fifth century and completed by the devastations and evacuations that

\footnotetext{
${ }^{34}$ Menéndez Pidal, "Repoblación," XXXIX. An example of this independent streak is the 1057 declaration of complete sovereignty made by Aragonese noble García Áznar, who claimed that he was not subject to either Christian or Pagan kings but that his liberty derived from antiquity.

${ }^{35}$ Menéndez Pidal, "Repoblación," XXXIX-XI. An example of this is how he credits the "primitive" people who stayed on with affecting the language in some cases (I, I).

${ }^{36}$ Sánches-Albornoz, Despoblación, 237, desierto del Duero=Duero desert. Sánches-Albornoz followed the book España: Un enigma histórico, which was itself a response to the theories of convivencia (living together) espoused by Américo Castro in España en su historia: Cristianos, Moros y Judios (Buenos Aires, Argentina: Editorial Espasa, 1948).
} 
resulted from the eighth-century Islamic invasion. ${ }^{37}$ In the course of his defense of depopulation (a theory that was the basis for all of his writings concerning the social structure of Castile, and by extension, Spain), Sánchez-Albornoz rebutted the scattered challenges to his arguments that had been made by a couple of scholars. ${ }^{38}$ The author explicitly emphasized his nationalist ideology of a single Spanish identity. He saw the Spanish character as originating in Castile and preserving its purity despite ancient and medieval occupations. ${ }^{39}$

Bolstered by the copious texts put forth as evidence by the respected SánchezAlbornoz, most twentieth-century scholars accepted the position of a largely vacant Duero basin while acknowledging that it may not have been a complete depopulation. ${ }^{40}$ Unfortunately, the distinction between a desert and a lightly populated zone did little to change historiographical attitudes toward the people and material culture of the Duero

\footnotetext{
${ }^{37}$ Sánchez-Albornoz, Despoblación, 143-144, 146-149, 147-153. The author also includes the further devastations of Visigothic-era famine and plague, as described by the anonymous Mozarabic chronicler in 754 , to support his claim that even prior to the Islamic invasion, the Duero basin contained very few people.

${ }^{38}$ Sánchez-Albornoz, Despoblación, 5. "La despoblación del valle del Duero es base de todas mis tesis sobre la historia institucional y vital de Castilla y de España..." Concerning the conclusions of archaeologist Pierre David, for example, see 234-235; Sánchez-Albornoz's strong rebuttal to the doubts of R. Menendez-Pidal required a separate chapter, 155-211.

${ }^{39}$ The stridently nationalist character of Sánchez-Albornoz was criticized by some, though these concerns were largely expressed by non-Spanish historians, see Richard Herr, "Review" review of España, un enigma histórico by Claudio Sánchez-Albornoz, The Hispanic American Historical Review 38, no. 4 (1958): 553-554.

${ }^{40}$ An early example of the hesitancy to accept a literal depopulation is the work of M. A. García Guinea, J. González Echegaray, and J. L. Madariaga de la Campa, "Memoria de las excavaciones arqueológicas efectuadas en el Castellar, municipio de Villajimena (Palencia)," Publicaciones de la Institución Tello Téllez de Meneses 23 (1963): 129-58, particularly 142-144. For a later examples of scholarly consensus see Thomas Glick, Islamic and Christian Spain in the Early Middle Ages (Princeton, 1979), 86, "Indeed, the earliest phases of settlement were not dependent on conquest so much as on the occupation of such noman's land as the Duero Valley and uninhabited buffer zones in the west of the Catalan counties of Barcelona and Ausona." Later in the chapter, Glick discusses the merits of Menéndez Pidal's and SánchezAlbornoz's arguments and concludes that regardless of the extent of depopulation- the Duero was sparsely populated and therefore ripe for settlement, 87-93, 309. Glick later alters his point of view in his book From Muslim Fortress, 113-115. See also Powers, A Society Organized for War, 14, "The lightly populated zone north of the Duero made walled settlements crucial to the populating and holding of lands within Muslim raiding and conquering capabilities." None of these accounts discuss the possible local reception of the conquerors and their settlements.
} 
basin. $^{41}$ Authors were not only responding to medieval sources that emphasized the emptiness of the Duero, but were reflecting their predisposition to value political structures with which they could identify. For example, after expressing on a few occasions his amazement that "primitive" Goths ${ }^{42}$ overthrew Roman Iberia, Bernard Reilly summarized the Islamic conquest thus:

Even so the Muslim were unable to conquer the peninsula, less able than the Visigoths for that matter. The Basque country remained beyond their world. Asturias they penetrated but briefly. Galicia and northern Lusitania they occupied for perhaps forty years. The basin of the Duero they were to abandon almost as quickly. But for four centuries they were to hold its coasts and the river basins of the Guadalquivir, the Guadiana, the Tajo, and the Ebro. The Iberia that had always mattered was theirs. ${ }^{43}$ (emphasis mine)

The general lack of interest in central Iberia revealed in this passage suggests that two things were required to draw attention to the Duero basin as a worthwhile subject of study: evidence of a continuous population and changes in political theory that would recognize and empower rural, non-royal, supralocal political organization.

\section{The Argument for Political Restructuring}

Until recently, the repopulation question has largely concerned itself with how medieval sources are interpreted, with proponents taking the side of either SánchezAlbornoz or Menéndez Pidal. Scholars looking at archaeological remains, rural settlement theories, and toponymic evidence have dramatically affected the debate. These archaeologists and historians have not only found ample reason to argue for Duero

\footnotetext{
${ }^{41}$ See F. Reyes and M. L. Menéndez Robles, "Apectos ideológicos en la despoblación del Valle del Duero," in Historiografía de la Arqueología y de la Historia Antigua en España (siglos XVIII-XX) (Madrid, 1991), 203-207.

${ }^{42}$ Reilly, The Medieval Spains, "The conquest of the Roman Empire in the west by the Germanic tribes two centuries earlier is a real conundrum in that a more primitive people conquered the more advanced one and it is precisely the condition of civilization that ordinarily confers an insuperable advantage in such contests." 49.

${ }^{43}$ Reilly, The Medieval Spains, 50.
} 
basin communities but have expanded upon the reasons offered by Menéndez Pidal for why the medieval chronicles were motivated to describe the frontier as uninhabited. The benefits to later aristocratic patrons to devise a concrete provenance for the acquisition of their territories and the usefulness of marginalizing existing supralocal polities in order to undermine their influence are considered below. ${ }^{44}$

In this section, a brief overview of the methodological aspects of archaeology in Iberia will be given to explain how this discipline has dramatically impacted the repopulation debate in recent decades. The discussion will include a justification for the application of broad settlement theories, such as incastellamento, to the Iberian frontier. Concerning the possible cultural character of Duero valley communities, recent work by archaeologists and historians has shed additional light on the identity of rural populations and complicated the once discrete categories of Berber or "Mozarab." The reconstruction of potential Duero basin populations discussed here is further supported by the existence of fortresses, city walls, and churches that indicate the strategic importance of frontier communities and their resources to the Christian conquest of al-Andalus.

Medieval scholars of Iberia have grappled with the challenges posed by textual accounts of the reconquest period-their survival, ideological motivations, and historiographical interpretation. Archaeologists of medieval Spain and Portugal have faced similar obstacles. ${ }^{45}$ Constraints on where an excavation may take place and how it

\footnotetext{
${ }^{44}$ José María Mínguez Fernández is one such example of how historians continue to build upon Menéndez Pidal's scholarship, see "Pervivencia y transformación."

${ }^{45}$ See Margarita Díaz-Andreu, "Conflict and Innovation," 6-7, "The evolution of Iberian archaeology draws attention to factors which have scarcely been considered in existing histories of the discipline: the distinct dynamics which have driven archaeology's development in the different European countries; the existence of a colonial archaeology within Europe itself and not just beyond its frontiers; the influence that the dominant political ideologies in each region have had on the hypotheses put forward by archaeologists; the relation between geographical position and the consolidation of distinct theories, and between the degree of economic development and archaeology."
} 
is to be funded has historically confined archaeological investigations to areas already considered culturally significant, and as I have shown, the Duero is often not part of this group because of its historical designation as a "desert." Moreover, as Margarita DíazAndreu explains, both Portugal and Spain have experienced an increase in "rescue archaeology," resulting in greater attention being paid to urban areas at the expense of others. $^{46}$ There relative scarcity of urban areas in the Spanish Duero basin has limited the need for rescue archaeology. Archaeologists motivated to discover trends in rural settlement patterns have increasingly turned to field survey. Although field survey can be used to determine profitable zones for excavation, it can also be an end in itself and is often employed for the reconstruction of agricultural life, particularly when irrigation systems have been used. ${ }^{47}$ However, field survey has also been shown to be an imperfect solution. As Neil Christie shows in the example of a Roman villa excavated at Casalpiano near Morrone, the tombs indicating a continuing (though small) medieval farming community on the site were only discovered through excavation. ${ }^{48}$ Like the

\footnotetext{
${ }^{46}$ Díaz-Andreu, "Conflict and Innovation," 24-25. The increase in rescue archaeology in Western Europe has been noted by other authors, for example, by Patrick Périn in "The Origin of the Village in Early Medieval Gaul," in Landscapes of Change; Rural Evolutions in Late Antiquity and the Early Middle Ages, ed. Neil Christie (Aldershot and Burlington, VT: Ashgate, 2004), 256-257: "In connection with the politics of major redevelopment in France (motorways, high-speed trains, theme parks such as Disneyland Paris, etc.), the last twenty years have seen a spectacular expansion of rescue archaeology in France, and an unprecedented explosion of excavations." See also Helena Hamerow in Early Medieval Settlements, the Archaeology of Rural Communities in North-West Europe 400-900 (Oxford: Oxford University Press, 2002), 8-9.

${ }^{47}$ For the importance of aerial survey in Iberian archaeology, see R. F. J. Jones, S. J. Keay, J. M. Nolla, and J. Tarrús, "Landscape, Ancient Settlement and Survey Archaeology in Catalunya," in Papers in Iberian Archaeology, ed. T. F. C. Blagg, R. F. J. Jones, and S. J. Keay (Oxford: B. A. R., 1984), 460-464.

${ }^{48}$ Neil Christie, "Landscapes of Change in Late Antiquity and the Early Middle Ages: Themes, Directions and Problems," in Landscapes of Change: Rural Evolutions in Late Antiquity and the Early Middle Ages, ed. Neil Christie (London: Ashgate Publishing, Ltd., 2004), 10, "This community was, in effect, revealed only through the tombs, and through detailed excavation, but with precious little in the way of settlement archaeology; the same situation prevails, it seems, for sixth-century Monte Gelato and San Vincenzo (see below) and is no doubt valid elsewhere. We might argue for an early medieval rural population, but they may be elusive without excavation."
} 
survival of manuscripts, the varying opportunities for archaeological excavation present challenges for the reconstruction of medieval settlement patterns. ${ }^{49}$

Keeping this in mind, the vigorous activity of archaeologists in Portugal and Spain began to alter the stagnant situation that marked the tenure of Franco and Salazar, prompting Thomas Glick to identify a critical "archaeological revolution" for Iberia as having taken place in the 1970 s and 1980s. ${ }^{50}$ The publications that resulted from these investigations continue to stimulate debate on the demographics of medieval Spain and Portugal. These discussions are critical to the present study because they suggest that agriculturally productive and militarily strategic settlements persisted in the Duero basin. Around the same time, historian Pierre Toubert put forward his intriguing theory of incastellamento, a settlement theory that assigned supralocal power to rural communities. This theory argued that following the break-down of central power in the Roman Empire, Mediterranean populations reoccupied fortresses or castles, instead of villages, etc. ${ }^{51}$ Toubert suggested that his theory might be applied to all areas of the Mediterranean and therefore supports a continuity of population in rural Iberia after the

\footnotetext{
${ }^{49}$ See Neil Christie, ed. Landscapes of Change: Rural Evolutions in Late Antiquity and the Early Middle Ages (London: Ashgate Publishing, Ltd., 2004), 268, and for a wide-ranging discussion on the intersection of written sources, archaeology, topography, toponyms, and theory in settlement investigations see Johannes Koder, "Land Use and Settlement: Theoretical Approaches," in General Issues in the Study of Medieval Logistics, Sources, Problems and Methodologies, ed. John F. Haldon (Leiden, Boston: Brill, 2006), 159-184.

${ }^{50}$ Thomas Glick, From Muslim Fortress to Christian Castle, Social and Cultural Change in Medieval Spain (New York: Manchester University Press, 1995), xi-xviii, xiii. Glick's work seeks to redress the hurdles raised by a history of politically-motivated scholarship in Spain and an ignorance of the "historiographical and archaeological revolution" for scholars outside of the Peninsula. At the same time, he rejects the fluidity of a mentalité history in favor of the more "concrete" example provided by, for example, a study of the cultural values encoded in a medieval irrigation system, xix, xx-xxi.

${ }^{51}$ The broad category of 'late antiquity' is given because regions abandoned their lowland Roman-era villages in favor of less vulnerable hilltops at different times following the collapse of the Western Roman Empire. The pattern of incastellamento is one that appears to apply throughout the peninsula and some of the hilltops selected for reoccupation appear to date to the Iron Age, Glick, Fortress to Castle, 14, Santiago Castellanos and Iñaki Martín Viso, "The Local Articulation of Central Power in the North of the Iberian Peninsula (500-1000)," Early Medieval Europe 13, no. 1 (2005): 1-42.
} 
Islamic conquest. In Iberia, incastellamento would suggest that hill-top communities persisted despite the consolidation of the Visigothic kingdom and furthermore shaped rural settlements at the margins of Christian and Andalusi kingdoms in the wake of the Islamic invasion. ${ }^{52}$ Thomas Glick found that Toubert's general hypothesis complemented his own investigations into Iberian settlement patterns, and adjusted Toubert's definition to include the "reorganisation into castral zones." ${ }^{, 53}$ Glick, after Toubert, emphasizes not only the multifunctional nature of the fortress as managerial center, but notes that the reorganization of the countryside could also occur around villas, churches, and fortified towns, depending upon the region and the time. Incastellamento, therefore, should be understood as having a fluid definition that may include the evolution of earlier political structures into castral zones or the imposition of fortresses or strongholds upon existing systems of governance. ${ }^{54}$

\footnotetext{
${ }^{52}$ Pierre Toubert, Les structures du Latium médiéval: Le Latium méridional et la Sabine du IXe siècle à la fin du XIIe siècle, 2vols. (Rome: Bibilothèque des Écoles Françaises d'Athènes et de Rome, 1973), 310. "Ici et là, le tableau général est le même: désertion des zones basses; abandon des habitats qui s'étaient étirés à l'époque romaine le long des artères de circulation; retraction de l'occupation humaine par réoccupation ou réanimation des anciens sites de sommité, somnolents ou même abandonnés sous l'Empire, au profit des sites routiers." The broad argument put forth by Toubert has been criticized by scholars because of its sweeping generalizations and sometimes contradicting material, nevertheless, it has served to challenge the assumptions regarding the purposes of fortresses/castles, particularly in rural territory.

${ }^{53}$ Glick, Fortress to Castle, see glossary for definition. Glick emphasizes the applicability of Toubert's discussion of the fortress as an organizing center for settlements in al-Andalus to both Christian and Islamic societies, see Pierre Toubert, "Préface," in Les châteaux ruraux d'al-Andalus: histoire et archeologie des husun du sud-est de l'Espagne, ed. André Bazzana, Patrice Cressier, and Pierre Guichard (Madrid: Casa de Valásquez), 1988. Glick also qualifies his support of Toubert's thesis in regard to feudalism, "As we will have occasion to note in some detail, the $\square u \square \bar{u} n$ of Al-Andalus were not in any way 'feudal' installations nor were they part of a society which was in any way 'feudal'. Nevertheless, in a general framework of transition from late antiquity, Toubert presumes a broad chronological and functional similarity in process in the Islamic and Christian worlds." Thomas F. Glick, Fortress to Castle, 10-14, 14.

${ }^{54}$ Glick, Fortress to Castle, 105-115. The author sees the reorganization of the Andalusi and Christian countryside as adopting different forms that were specific to the region. "There were numerous castra or castellos in the Christian kingdoms of the tenth century which were wholly rural and which protected dependent villae. Both Catalonia and Castile take their names from castles, or rather from their custodians, the castlà $(>$ catala $=$ Catalan $)$ or castellano. But in Castile, to the north of the Duero at least, castles were abandoned in the eleventh century just when, in Catalonia, incastellamento entered a phase of rapid growth. The feudal reorganization there took place around fortified towns, like Burgos." 107.
} 
Duero basin churches are found both in proximity to fortresses and valley communities, so incastellamento should be considered in conjunction with the work of Pierre Guichard, who reconstructed Andalusian society in terms of the tribal and ethnic relationships that developed as a result of Berber settlement. ${ }^{55}$ Building upon Guichard's arguments for Berber settlement traditions, Glick took the model of the castle/village (or $\square i \square n / q a r y a)$ and applied to it Moroccan tribal approaches to water rights and communal customs. ${ }^{56}$ Although the agricultural nature of northern $\square u \square \bar{u} n$ is uncertain, Glick supported his adoption of Toubert's settlement theories and Guichard's tribal constructions for sites on the eastern edge of the Peninsula with additional Arabic medieval sources that described alquerías (Romance for the Arabic qarya) as forming agricultural units that usually were connected to a $\square i \square n$. The author calculates that there were an average of seven to ten alquerías for each $\square i \square n$ and maintains that they were characteristic of both Arabic and Christian settlements. The alquerías groupings were determined by water and farming rights and thus changed in appearance according to the local circumstances. Unfortunately, the footprints of medieval alquerías are difficult to discern unless traces of medieval irrigational systems are preserved-a system not usually employed in the trans-Duero. ${ }^{57}$

\footnotetext{
${ }^{55}$ Glick, Fortress to Castle, xiii. The book in question is Pierre Guichard, Al-Andalus: Estructural antropológia de una sociedad islámica en occidente (Barcelona, Barral, 1976). For responses seeking to complicate and qualify Guichard's theories concerning tribal segmentation and political organization see Patrice Cressier, Pierre Guichard, and André Bazzana, eds. Les châteaux ruraux d'al-Andalus: Histoire et archéologie des husun du sud-est de l'Espagne (Madrid: Casa de Velásquez, 1988) and James L. Boone and Nancy L. Benco, "Islamic Settlement in North Africa and the Iberian Peninsula," Annual Review of Anthropology 28 (1999): 51-71, 62-63. On the other hand, David Wasserstein prioritizes geography over ethnicity as the key determinant for political construction (despite elite appropriations of Umayyad identity), suggesting that by the late tenth and early eleventh centuries, ethnic distinctions had lost importance. See The Rise and Fall, 106-107.

${ }^{56}$ Glick, Fortress to Castle, 17.

${ }^{57}$ Glick, Fortress to Castle, 18. Not all trans-Duero communities would have been principally agricultural. At San Baudelio de Berlanga, for example, the recovered bone evidence suggests a substantial reliance on transhumant pastoralism, see chapter five. For an excellent account of the different ways alquería
} 
Like Guichard, Glick does not see the $\square i \square$ n/qarya as evidence for an Andalusi feudal system, but as a structure for the use of the tribal collective. ${ }^{58}$ Qualities specific to the Duero basin recommend considering the application of incastellamento (in its broader sense as a theory of territorial organization) to this region. First, as chapter four will demonstrate, the symbolism attached to the restoration of ancient places of power (both spiritual and political) remained meaningful to medieval populations Second, the system of organizing agricultural production into alquerías suggests Berberisation, the ethnic group most likely to have remained in settlements in the central and eastern sections of the Duero basin. ${ }^{59}$ Indigenous agricultural practices combined with the cereal cultivation and sheep and goat herding characteristic of Berber custom allows for the speculation that dry-farming communities may have benefitted from the collaborative network of alquerías. ${ }^{60}$ The appearance of fortresses, particularly in the eastern Duero basin, connected to Muslim occupation and the likely persistence of Hispano-Berber influence

arrangements might look, see Patrice Cressier, "Agua, fortificaciones y poblamiento: el aporte de la arqueología a los studios sobre el surest peninsular," Aragón en la Edad Media 9 (1991): 403-427 and Glick, "Tribal Landscapes."

${ }^{58}$ Glick, Fortress to Castle, 19-20, 26. For Glick, the irrigation system (alquerías) takes precedence over the $\square i \square n$. The nature of the agrarian community accounts for the reason that the $\square i \square n$ could continue to operate apart from larger political institutions. The connection between rural inhabitants and the land was important not only because of their dependence upon if for subsistence but because the spatial reality gave communities a sense of place and time. Concerning the need for management and arbitration of the rights and obligations of its individuals, the inherent hierarchies of kinship, prestige, etc. provided sufficient political structure to rural communities. The argument for the political power of agrarian societies is persuasively made by Victor V. Magagna in Communities of Grain; Rural Rebellion in Comparative Perspective (Ithaca; London: Cornell University Press, 1991), particularly 12-21.

${ }^{59}$ Glick, Fortress to Castle, 29, 37. Although the architectural element of the rural fortress was not characteristic of the Moroccan landscape, this apparent contradiction is mitigated by the fact that many husūn surveyed in the Upper March bear Latin names while the surrounding alquerías have Arabic or tribal designations-opening up the possibility that these settlements were the result of cross-cultural exchange between Muslims and Hispano-Romans.

${ }^{60}$ This statement is cautious because more work needs to be done to identify possible alquerías in the upper meseta. Nevertheless, José María Mínguez Fernández has demonstrated the prevalence of sheep and goat herding to the income of the large monastic holdings of Sahagún (in the Duero basin) in El dominio del monasterio de Sahagún. In addition, Boone and Benco have argued that cereal cultivation and herding were specific traits of Berber agriculture in North Africa after the Islamic conquest of that territory in "Islamic Settlement." 
in the Duero valley as a whole is a strong argument for the consideration of this synthetic settlement structure for the meseta. ${ }^{61}$

The political organization of these settlements was analyzed by Santiago Castellanos and Iñaki Martín Viso, who argue that medieval rural settlements and contracted late antique urban centers that exhibited signs of local power should be understood as a land without a lord, rather than a land without people. ${ }^{62}$ For those groups facing Muslim conquest, the authors interpreted both cooperation with and defiance against the invaders as evidence of decisions reached independently of any central government or influence. ${ }^{63}$ An alternative articulation of power governed the developing eight-century frontier, one in which the Berbers played a leading role early on but who may have been supplanted by or integrated into existing systems of authority. Arguing for continuity of settlement from the late antique period through the age of Islamic dominion in the northern peninsula, the authors claimed that the Berbers settled in the Duero region, though their influence was limited.

In the Duero valley and in Galicia, by contrast, the Berbers remained in control for some time, based on local power structures, especially the civitates. Their control was tenuous there, and life continued with little change from the way it had been in the Visigothic period. In fact, the weakness of Berber dominion and their unfamiliarity with the terrain would have meant that the former civitates and other local powers had to play a greater role in central politics. ${ }^{64}$

\footnotetext{
${ }^{61}$ San Esteban de Gormaz, Gormaz, and Burgo de Osma are a few examples of fortresses that appear to support this pattern of land-use and supralocal control.

62 See Castellanos and Martín Viso, "The Local Articulation," and Carlos Estepa Diez, Estructura social de la ciudad de León (siglos XI-XIII) (León: Centro de Estudios e Investigación San Isidoro, 1977) and idem., "Organización territorial, poder regio y tributaciones militares en la castilla plenomedieval," Cuadernos de Investigación Histórica 20 (1996): 135-76. Estepa Díez contends that the territorial control of the nobility in León and Castile was part of the feudal reality of Iberia.

${ }^{63}$ Castellanos and Martín Viso, "The Local Articulation,” 21-22. The authors identify political independence from central Visigothic powers in the eighth century landed aristocracies of the northern peninsula because their decisions to cooperate or reject Muslim authority appear to have been made individually. The basis for their political strength was probably a stable agricultural position.

Nevertheless, the authors agree that by the ninth and tenth centuries, the nobility had determined that a deliberately crafted image of Gothic continuity would benefit their territorial ambition.

${ }^{64}$ Castellanos and Martín Viso, "Local Articulation," 21-22.
} 
The authors hypothesize that the Berbers benefited from utilizing the existing local power structures of the conquered cities and towns. However, these Duero civitates should not be considered intrinsically weak, and Castellanos and Martín Viso persuasively showed that the campaigns of Asturian king Alfonso I (739-757) and his son Fruela I (757-768) against the civitates, castros, villas, and their properties, suggested that they posed a political or economical threat to the expanding authority of Asturias. ${ }^{65}$ If these population centers were worth attacking, first by Alfonso I, and later by Alfonso III, this presents a strong argument against a depopulated region—or a territory so sparsely populated as to qualify as a "no-man's land."66 Yet chronicles describe these campaigns as removing the Christians in order to "populate" territories in Galicia, northern Burgos, and Basque country. ${ }^{67}$ No matter how broadly one defines the Duero 'desert,' these territories never appear to have been emptied. Yet the language employed here (populare, populavit, etc.) is the same that appears in the later chronicles that have been understood by some scholars to be records of the population of vacant land. This inconsistency, together with material evidence of persisting populations, persuades Castellanos and Martín Viso that the repopulation should not be understood literally, but politically. $^{68}$

The past acceptance of medieval accounts of a 'Duero desert' appears seriously flawed, both methodologically and in light of recent theories of site occupation and

\footnotetext{
${ }^{65}$ Civitate $=$ city, castro=Spanish word for castrum, which is a fortified village or fortress, villa=country estate or a large, agricultural complex.

${ }^{66}$ Linehan, History and the Historians, 110. Mickey Abel also rejects the notion of an empty space and adheres to the logic that there must have been something of value to inspire such effort in "Strategic Domain," 24.

${ }^{67}$ Crónica de Alfonso III, see footnote four of this chapter.

${ }^{68}$ Castellanos and Martín Viso, "Local Articulation," 23. The authors note the earlier suggestion made by Menéndez-Pidal of the political dimension to claims of repopulation in his "Repoblación y tradicion," xxixlvii.
} 
material excavation. The approach favored here is one that anticipates a plurality of explanations, in keeping with the local socio-political circumstances of the case studies and their larger territories. The existence of monasteries, towers, fortresses, cave-shrines, and agricultural systems in the Duero basin offers evidence of some level of occupation, and more importantly, one that made raiding and state-sponsored military action worthwhile. The environmental reality of the medieval world made architectural production a valuable commodity. In reconstructing the social systems that supported or were supported by architecture, relationships between the two may be revealed.

\section{Duero Basin Society}

While it is impossible to provide a clear picture of the demographic nature of the Christian-Muslim frontier for the tenth through twelfth centuries, a brief explanation follows of the possible existing and immigrant populations that would have served as the architectural audience in the Duero valley. It is important to begin with the period immediately following the Islamic conquest of Iberia in order to outline the potential ethnic and religious groups that would have persisted until the restructuring efforts of the tenth and eleventh-century conquerors. For the eighth and ninth centuries, material evidence is the most helpful in reconstructing the likely inhabitants of the high plains of central Spain due to the dearth of written sources. ${ }^{69}$ With the tenth through twelfth centuries, the documentary situation improves but both the written and archaeological

\footnotetext{
${ }^{69}$ Collins, The Arab Conquest of Spain, 23-24.
} 
record remain complicated due to the difficulty in establishing firm fossil guides and the historiographical legacy of the Duero basin "depopulation.,"70

\section{The Eighth and Early Ninth Centuries}

With the Islamic invasion of 711 , Berbers comprised the greater part of attacking forces and are thought to have been the initial occupiers of the upper half of the Iberian Peninsula, including the Duero and Ebro valley basins. Although little about the demographic composition of the Islamic invasions is secure, the invaders were certainly in the minority in comparison to the indigenous population. It is also likely that within that preexisting population were some members of the former Visigothic regime. ${ }^{71}$

Historians largely agree that in terms of sociopolitical hierarchies, Berbers and Arabs maintained their ethnic distinctions in the first century following the eighthcentury conquest. ${ }^{72}$ Tāriq's invading forces of 711 were primarily made up of Berbers,

\footnotetext{
${ }^{70}$ For the difficulty in establishing a chronology archaeologically, see Manuel Retuerce Velasco, “Arqueología y poblamiento en la meseta Andalusí; el referente cerámico," in V Semana de Estudios Medievales (Logroño: Ediciones Instituto de Estudios Riojanos, 1995), 94-95 and for the latter point, see above discussion and Santiago Castellanos and Iñaki Martín Viso, "The Local Articulation," and Abel, "Strategic Domain,"

${ }^{71}$ Retuerce Velasco, "Arqueología y poblamiento," 95. In addition to military conquest, diplomatic agreements were reached between Visigothic officials and the invading force. In Castellar de Villajimena (Palencia) and La Flecha (Valladolid) Tomás Mañanes Pérez cautiously identifies material remains that might suggest continuity between the Visigoths and the medieval age in Arqueología del área central de la cuenca del Río Fuero: de Simancas a Coco (Valladolid: Disputación Provincial de Valladolid, 2002), 283284. Abel also favors the position that many Visigoths stayed on as peasant farmers on the central plains after the Muslim conquest in "Strategic Domain," 23.

${ }^{72}$ Glick, Islamic and Christian Spain, 200-216. Over the course of the history of al-Andalus, Muslim chroniclers, albeit writing from the Arab point of view, clearly differentiate between Berbers and Arabs, or minimize their presence by concentrating only on Arab families. Glick, after Lévi-Provençal, notes that the rising military power of the Berbers in the tenth century was viewed as particularly threatening to Andalusi Arabs and this anxiety is revealed in harsh anti-Berber sentiment. Although Muwallads were not considered to be equals of ethnic Arabs, they could participate in the Arab tribal structure as clients and were not usually subject to the same degree of social distance that separated Berber and Andalusi Arab families. Naturally, ethnic origins could be modified and disguised through clientage, marriage, and outright falsification. Despite the reality that ethnicity was a fluid concept, maintaining the appearance of an Arab origin was nevertheless important to sociopolitical status. Expanding upon the point that ethnicity was in reality very muddled by the eleventh century, Wasserstein stresses that the wars between taifas were
} 
non-Arabs, and mawāli (clients) while Mūsā's armies were dominated by Arabs in 712 and further reinforced with Arab troops in 740 with Balj. ${ }^{73}$ It is thought that a majority of Berbers settled in the northern half of Iberia because this area follows the itinerary of Tāriq. Their occupation of the central meseta has been explained by scholars as understandable in light of their familiarity with the demands of an arid environment (while the Arabs felt more at home in the more plentiful urban settings of the southern half of the Peninsula). ${ }^{74}$ Regardless of the ethnic distribution, Arab sources indicate that between 740 and 750 there was a series of Berber revolts, the results of which are difficult to piece together. ${ }^{75}$ The Berbers appear to have been joined by various factions of Muslims (and possibly Christians) who were dissatisfied with Syrian Arab demands. ${ }^{76}$ Over time, the rebellions were put down and Arab forces maintained power in most of the cities of al-Andalus. $^{77}$

rarely along ethnic or quasi-ethnic lines, they were more influenced by strategic benefit in The Rise and Fall, 132-133. Regardless, Andalusi histories widely preserve the appearance of a culture that valued ethnic identity and prioritized Arab cultural markers for the social elite.

${ }^{73}$ J. M. Viguera Molíns, "The Muslim Settlement of Spania/al-Andalus," in The Formation of al-Andalus (Ashgate, 1998), 13-38. See Pedro Chalmeta, Invasión e Islamización; la sumisión de Hispania y la formación de al-Andalus (Madrid: Editorial Mapfre, 1994), 126, 170-171. Numbers are exceedingly difficult to secure. The invading forces may have had as many as 40,000-50,000 Arabs and 350,000 Berbers or perhaps only 12,000 Berbers under the direction of Tāriq. While as many as 18,000 Arabs may have arrived with Mūsā, Richard Hitchcock speculates that as little as a few hundred representatives of the Umayyad caliphate may have comprised the contingent attempting to impose central control over alAndalus in Mozarabs, 11, fn 12, in which Hitchcock also provides a summary of the potential figures for the invasion of al-Andalus after Viguera Molíns and Chalmeta. Chalmeta also doubts that more than a few Arabs participated in the first assault under Tāriq, except as teachers of Islamic tradition and the Qur'an. Chalmeta, Invasión e Islamización, 126-127.

${ }^{74}$ Chalmeta, Invasión e Islamización, 160-168. However, as the author points out, the histories of this period were written by Arabs who tended to marginalize or obscure Berbers altogether.

${ }^{75}$ For a detailed accounting of the revolts that began in Africa and possibly inspired the Berber revolts of the 740s in al-Andalus, see Chalmeta, Invasión e Islamización, 307-344. Berbers are also associated with later revolts in the second half of the eighth and the first half of the ninth centuries. These Berbers hail from Zaragoza, Toledo and Mérida. Glick includes Neo-Muslims (muwalladūn) and Yemenī Arabs among the forces of all of the eighth and ninth-century revolts. Islamic and Christian Spain, 26-29.

${ }^{76}$ Glick, Islamic and Christian Spain, 26.

${ }^{77}$ Joseph O'Callaghan, A History of Medieval Spain (Cornell University Press, 1983), 112-113. This is not to say that the governors of Andalusi cities were ethnic Arabs. For example, in Zaragoza the family of the Banu Qasi were descended from the Visigothic Count Casius who had converted at the time of the 
The fate of the rebellious groups and the communities they left behind in the Cantabrian Mountains and northern meseta is unclear. ${ }^{78}$ North of the Duero River, historians sympathetic to the 'depopulation' model of the river basin see the Muslim wars of revolt as one of the contributors to the abandonment of the region. ${ }^{79}$ Other scholars suggest that the Berbers were simply absorbed into the communities (both Muslim and Christian) of al-Andalus. ${ }^{80}$ The terminology that appears in the second half of the eighth century to describe early Muslim settlers (baladiyyūn or ahl al-balad, meaning 'people of the country' or 'natives') supports this point of view. ${ }^{81}$ David Wasserstein's careful accounting of Berber groups instrumental in founding or leading taifa kingdoms of the eleventh century, particularly in Toledo, should restrain the tendency to dismiss the Berber influence from al-Andalus or the rural Duero basin altogether, however. ${ }^{82}$ While it appears that their roles were greatly diminished within the ascendant ninth-century Umayyad power, it is unlikely that their presence and influence in rural Duero communities were eliminated by emigration.

invasion. Despite their Muwallad status, the political allegiance of this dynasty shifted throughout the ninth century, causing substantial aggravation to the Cordoban regime.

${ }^{78}$ For the point of view that the Asturians, along with other northern tribes were never really part of the rest of Iberia under either the Romans or Visigoths, and therefore an unlikely source for the notion of Reconquest, see Manzano Moreno, "Christian-Muslim Frontier," 90.

${ }^{79}$ Mañanes Pérez, Arqueología del área central, 281-282. "Es decir la Guerra Civil entre árabes y berberes por motivos religiosos y económicos, trae como consecuencia que los noreteafricanos abandonan los asentamientos de la Meseta. A este abandono contribuye la sequía, y el hambre subsiguiente, en los años 753 y 754 d. C." Kennedy also assumes that the Berber-Muslim control of the Duero is lost and that the territory is basically emptied after the revolt and famine of around 750 in Muslim Spain and Portugal, 2829. Both authors follow Sánchez-Albornoz, Despoblación. Thomas Glick also states that the Berbers of Galicia left for North Africa during this time, suggesting that this departure contributed to its annexation by Asturias. His source for this position is not given, see Glick, Islamic and Christian Spain, 27.

${ }^{80}$ Hitchock, Mozarabs, 11-13, after Chalmeta, Invasión e Islamización, 163, 232. Again, political theory is an important contributor to these perspectives. For most historians writing about this period, the underlying assumption is that a centralized government (like the Umayyad emirate and caliphate) is stronger than the "fragile" system of independent nodes that probably characterized the rural Berber/Hispano-Roman settlements. In opposition to this point of view is Pierre Guichard, Al-Andalus, estructura antropológica, 375.

${ }^{81}$ Glick, Islamic and Christian Spain, 27.

${ }^{82}$ Wasserstein, Rise and Fall, 114. These Berbers are distinct from the "new Berbers" who were brought in by al-Mansūr as clients, 42 . 
Given the agricultural and pastoral nature of the basin it is reasonable to presume that remaining Berber and Hispano-Roman groups coexisted, or were integrated over time. ${ }^{83}$ As early evidence of the capacity for coexistence between indigenous and occupier, burials reflecting Christian and Muslim practices have been found in the same necropolis in the area of Cuenca. At the same time, supporting the persistence of Hispano-Roman settlements are the archaeological remains found at La Flecha (Valladolid) and Castellar de Villajimena (Palencia). These excavations revealed material that appears to date from the Visigothic through early medieval periods. ${ }^{84}$ In addition to these Hispano-Roman finds, the retention of Islamic place names like Almazán and Calatañzor or Berber customs, like the cyclical markets of the Leonese countryside reinforce the position that the eighth and ninth-century Duero Valley maintained some level of heterogeneous habitation. ${ }^{85}$

Manuel Retuerce Velasco evaluated the distribution of Andalusi archaeological material in order to reconstruct the likely pattern of Andalusi settlement in the Duero basin. He concluded that Andalusi ceramic can be securely found along the eastern portion of the Duero Valley in Soria, both north and south of the river. Although there is evidence for a few Andalusi settlements north of the Duero in Valladolid province, in some cases, the small amount of ceramic is more indicative of imports than of

\footnotetext{
${ }^{83}$ The use of the term Hispano-Roman is deliberately broad and should be understood to include remaining Visigothic people.

${ }^{84}$ Mañanes Pérez, Arqueología del área central, 283-284, 287. The author describes these sites as possible centers of Visigothic persistence through the medieval age (particularly La Flecha) but notes that Visigothic ceramic is limited and that medieval ceramic has been assigned to the ninth to the tenth century, or, the Castilian repopulation. Additional cemeteries with burials characteristic of Visigothic and Islamic practices have been uncovered in Simancas, which lies a little to the West of Valladolid, see Roger Collins, Spain, an Oxford Archaeological Guide (Oxford University Press, 1998), 23.

${ }^{85}$ Mañanes Pérez, Arqueología del área central, 283. Toponomy is a contentious subject but many scholars agree that place names derived from Islamic sources are more likely the result of the eighth century conquest than the influence of Christians emigrating from al-Andalus. See also, Glick, Fortress to Castle, 113-114, for Berberized markets, see Glick, Islamic and Christian Spain (1979), 119-121. This edition of the book is out of print and is available online at the site: http://libro.uca.edu/ics/emspain.htm
} 
settlement. ${ }^{86}$ Thus, the author concludes that Duero basin settlements were more likely to reflect Andalusi culture along the eastern portion of the Duero basin, along a northeastsouthwest axis. The far fewer instances of Andalusi ceramic material west of Soria province and north of the Duero River may indicate less contact with Muslim or Hispano-Andalusi culture for this region. ${ }^{87}$

\section{The Late Ninth and Tenth Centuries}

An examination of the later ninth and tenth centuries reveals that in addition to the scattered Hispano-Roman and Hispano-Andalusi populations of the Duero basin, there appear to be two main groups of immigrants. This century and a half is often described as a period of 'repopulation' because northern kings are credited with having settled the meseta with Christian emigrants from al-Andalus and colonists from their own territories

\footnotetext{
${ }^{86}$ Retuerce Velasco, “Arqueología y poblamiento,” 106-114, 120. The author notes that these identifications are those he feels securely date to the VIII-XIII century Islamic populations and that he has excluded those he suspects of being "(bajomedievales, mudéjares, modernos, etc.)" or those without a reliable fossil guide.

${ }^{87}$ Retuerce Velasco's study was conducted in the mid 1990s and in his conclusions he repeats prior calls for continued survey and excavation work in the Duero basin of the central meseta, a region he believes to be particularly underrepresented in research, "Arqueología y poblamiento," 120. It should be noted that using the ceramic record to reconstruct settlement patterns is not without problems. Retuerce Velasco explains that there are a number of sites in which architectural remains suggest Andalusi settlement, for example at Ágreda (Soria) but for which Andalusi ceramic remains have not been found. In addition, it is difficult to establish an ethnic or religious identity for these Andalusi settlements, because sometimes the evidence suggests cultural hybridity. For example, the scholarly discussion of the "technical innovation" of a glass cover for Andalusi ceramic prompts Retuerce Velasco to ask if the modification is evidence of surviving Hispano-Roman tradition or if it reflects Hispano-Andalusi cross-cultural development, see “Arqueología y poblamiento," 93-97, 99, 107-108. Finally, given the independent nature of the rural communities that would have continued into the eighth and ninth centuries, importation or production of identifiable ceramic may have been unsupportable, thus further skewing our understanding of the Duero basin demographic. This point is also made in relation to the population reduction in Iberia for the fifth and sixth centuries, during which the rural inhabitants probably moved to hilltop sites. Karen Eva Carr suggests that the unavailability of datable ceramic could indicate a demographic crisis—or merely an economic one. See Vandals to Visigoths: Rural Settlement Patterns in Early Medieval Spain (Ann Arbor, MI: University of Michigan Press, 2002), 191.
} 
or Frankish lands. ${ }^{88}$ As argued earlier in this chapter, this dissertation operates from the point of view that the Christian conquest and settlement of the Duero basin was probably not a wholesale population of vacant territory but more often the imposition of an outside power over existing populations. This process was not solely the province of kings; nobles and clerics widely took advantage of the large, politically marginal space of the frontier to establish territorial claims. Historians have long proposed that in addition to settlers from northern, Latin kingdoms, Christian immigrants from al-Andalus were feted by Asturian kings and deliberately settled at the frontier. ${ }^{89}$

How churches and lay elites came to exist at the frontier is contested, whether they were colonists in a vacant land, outside conquerors of communities, or evidence of continuous habitation. More complicated is the claim that Christians from al-Andalus (who have often been sweepingly referred to as 'Mozarabs') fled Muslim Iberia or were enticed by Asturian and Leonese kings to establish monasteries along the advancing Christian front. $^{90}$

Toponymic evidence has been cited in support of the position that Andalusi monastic immigrants participated in the population of frontier territory. The appearance of Arabic names or names claiming an Andalusi origin in northern kingdom records led scholars such as Gómez-Moreno and Bishko to argue that these signatures should be

\footnotetext{
${ }^{88}$ Christians from al-Andalus are usually called Mozarabs because they are thought to have adopted Arabic culture. As discussed in greater detail in chapter two, this term is problematic because not all immigrants to the Duero basin were securely Christian or 'Arabicized.' Moreover, as will be discussed in later chapters, the presence of Islamic culture north of the Duero appears too widely to be limited to "Mozarabic" production.

${ }^{89}$ O'Callaghan, A History of Medieval Spain, 115 and Reilly, Medieval Spains, 82-83.

${ }^{90}$ The principal enticement for settlement at the frontier in the ninth and tenth centuries was the possibility of obtaining land and seigniorial rights through the presura, a juridical custom that was likely observed since the Visigothic age. The presura will be discussed more fully below, see Wendy Davies, Acts of Giving: Individual, Community, and Church in Tenth-Century Christian Spain (Oxford: Oxford University Press, 2007), 42-45 and Glick, Islamic and Christian Spain, 86-87.
} 
understood as evidence of Christian immigration to Asturias from al-Andalus. ${ }^{91}$ However, the possible reasons for the appearance of expatriated Cordobans and Arabicized names have been the subject of debate in recent years.

Representing the traditional view that immigrants from al-Andalus were Christians, Dodds follows the general conclusions of Gómez-Moreno and perceives a strong Andalusi, Christian influence in the Asturian capital of Oviedo. For support, she points out that scholars have identified the chief author of the ninth-century sections of the Chronicle of Albelda as an Andalusi Christian working in Oviedo. ${ }^{92}$ This authorship would be significant because through it, Dodds is able to link the Chronicle's theme of Visigothic continuity with the kingdom of Oviedo and the favor accorded to southern immigrants likewise interested in the revival of Visigothic imagery and rhetoric. ${ }^{93}$

Other scholars treat the medieval testimony more skeptically in light of the vague and often contradictory medieval record. For example, Linehan points out that the earliest version of the Chronicle of Albelda, the Emilianense 39, states that the Gothic kingdom had been "exterminated" with the Muslim conquest of Iberia. To his mind, such a declaration would have thwarted the ambitions of ninth-century Asturian kings to definitively trace their heritage to the Visigothic line. It is this disparity, together with the limited evidence of ninth-century Andalusi immigration that prompts Linehan to

\footnotetext{
${ }^{91}$ See Gómez-Moreno, Iglesias Mozárabes, 107, Bishko, "Salvus of Albelda," 559-590, and Dodds, Architecture and Ideology, 77, fn 147.

92 Dodds, Architecture and Ideology, 78. It is important to remember that like the Chronicle of Alfonso III, the earliest surviving manuscripts of the ninth-century account date to the tenth century.

${ }^{93}$ The concept of Visigothic revival in Mozarabic architecture is central to Dodds' thesis. Her perspective that Andalusi Christians and Asturian kings were kindred spirits in regard to the revival of a Visigothic legacy explains for the author why large numbers of Andalusi Christians left al-Andalus for northern territory in order to build the churches denied them in al-Andalus. A second reason given is that the voluntary martyrs' movement of Córdoba in the 850s sparked a wide-spread emigration from al-Andalus. This position has fallen out of favor in recent decades due to the lack of evidence for Christian persecution in al-Andalus.
} 
dismiss collaboration between the Asturian kings and a large, pro-Visigothic, Andalusi immigrant group in the mid-ninth century. ${ }^{94}$

While Linehan and others may not concur with the idea that large numbers of immigrant Andalusi Christians allied with Asturian kings to deliberately revive a grand Visigothic legacy, the 884 translation of the bodies of Cordoban martyrs Eulogious and Leocritia to Oviedo indicates a level of political contact and potential sympathy between Asturias and a segment of the Christian community at Córdoba. ${ }^{95}$ Royal interest in Cordoban martyrs could suggest a favorable environment for late ninth and tenth-century Cordoban monks at court. On the other hand, the motivation for the translation of Andalusi martyrs to one's kingdom could also have been indicative of the spiritual and political benefits derived from acquiring martyred bodies in general, and Iberian martyrs in particular. ${ }^{96}$

\footnotetext{
${ }^{94}$ Linehan, History and the Historians, 87-89.

${ }^{95}$ Dodds, Architecture and Ideology, 79. For a thorough account of the voluntary martyrs of Córdoba, see Kenneth Baxter Wolf, Christian Martyrs in Muslim Spain, (Cambridge: Cambridge University Press), 1988. Wolf argues that the movement was limited to monks seeking individual spiritual benefits from martyrdom rather than an organized attempt to rebel against persecution or to defend their religious beliefs. To support this conclusion, he notes that many of the unsympathetic accounts of the martyrs (both Christian and Muslim) saw these sacrifices as nothing but prideful, selfish expressions, 107-119. In contrast, Dodds sees the ideological motivations of the martyrs' movement— to acquire a cultural identity distinct from that of Muslim al-Andalus as the principle motivation behind the immigration of Mozarabs and their subsequent architectural production, Architecture and Ideology, 81.

${ }^{96}$ An example of the complicated relationship between Christian kingdoms and al-Andalus may likewise be seen in the treatment of the body of Pelayo (d. 925) who was martyred under 'Abd al-Ra $\square$ mān III (912961). The body of the martyr was requested and granted to Sancho I of Asturias-León (956-966) around the time of Sancho's death. Ten years before, Sancho and 'Abd al-Ra $\square$ mān had formed a military alliance to retake Zamora in 959 and to remove Sancho's opponent, Ordoño IV of Asturias-León (958-960), from the throne. With the aid of Cordoban armies, this alliance was successful. Subsequently, Ordoño IV requested, and was given, sanctuary in Córdoba under 'Abd al-Ra $\square$ mān III. This series of events demonstrates how flexible political and military situations of the ninth and tenth century could be and should therefore check any broad assumptions of ideological religious hostility between Asturias and alAndalus. For more, see Lucy Pick, "Dominissima, prudentissima: Elvira, First Queen-Regent of León," in Religion, Text, and Society in Medieval Spain and Northern Europe: Essays in Honor of J.N. Hillgarth, ed. T. Burman, J. Hillgarth, M. Meyerson, L. Shopkow (Toronto: Pontifical Institute of Mediaeval Studies, 2002), 40, 44-46.
} 
It is difficult, therefore, to argue that 'Mozarabic' monks were members of a larger cohort sent to the frontier at the king's initiative, as has been traditionally assumed. In general, this idea springs from the brief line in the Chronicle of Albelda describing how Ordoño I (850-866) populated four cities with people from his own territory and people from "Spania," meaning al-Andalus. ${ }^{97}$ Hitchcock asserts that this text does not indicate that the settlers were either "refugees" or "Christians," and that it is therefore insupportable to assume the specific deployment of immigrant Andalusi monks as part of the king's population strategy. ${ }^{98}$ It should also be noted that because these settlers came from beyond the borders of Asturias (Spania) does not mean that they were Islamicized Christians. They could have been Romance or Arabic speakers of either faith, indigenous, non-Arab, or Berber.

Neither Linehan nor Hitchcock completely reject the idea of southern immigration to northern territory and the support for the movement of groups from al-Andalus and other parts of the Iberian Peninsula to the frontier in surviving place names is persuasive. ${ }^{99}$ Nevertheless, assumptions regarding faith and vocation should be set aside

\footnotetext{
${ }^{97}$ Hitchcock, Mozarabs, 56-57. Hitchcock cites Manuel Gómez-Moreno, "Las primeras crónica de la Reconquista: el ciclo de Alfonso III," Boletín de la Real Academia de la Historia C (1932): 526-628, 620 as his source for the Latin.

${ }^{98}$ Hitchcock, Mozarabs, 57-58, 62. The author speculates that the lack of concern for the immigrants' religious status may instead be an indicator of their value as potential soldiers. For more on the difficulty of identifying religious and ethnic affiliations among the Andalusi emigrants, even those later joined to monastic houses, Hitchcock explains, "After the 950s, there is still a plethora of Arabic names in the documentation, not all of which can be attributed to emigration. In the case of the abbots mentioned, however, I would argue that they may well not have been abbots, or even practising Christians, at their point of departure. Individuals drawn from different sectors of the population, some urban and some rural, and Arabicized to different degrees, went north for a variety of reasons. Since the opportunities offered to some of them on arrival were mainly in a monastic environment, they adopted the mantle of Christianity, and would have been appropriated for their abilities and achievements." Hitchcock's suggestion that the appearance of Arabic names in monastic records does not necessarily signal the bearer's religion explains how an early "Mozarabic" settlement could have once been called, "... Mahamut or Mahmude-$\mathrm{Mu} \square$ ammad—after an early leader," as Glick once explained in Islamic and Christian Spain, 88. ${ }^{99}$ Hitchcock, Mozarabs, 59. Toldanos, Cordobeses, Bascuenses are offered as examples, after R. Menéndez-Pidal, Orígenes del Español, $5^{\text {th }}$ ed. (Madrid, 1964), 442-444.
} 
and a wider approach taken to the appearance of Arabic names in ninth and tenth-century medieval sources. Eduardo Manzano Moreno argues that the survival of Arabized communities in the high plains could also account for the appearance of Arabic names in monastic documents. ${ }^{100}$ Following the broader approach that does not automatically attach religious or cultural definitions to ethnicity, I support the position that where Arabic place-names appear in the Duero basin, both persisting Arab or Berber communities and potential Andalusi immigration should be considered.

Archaeological and toponymic evidence allows for the perspective that in the ninth and tenth-century Duero valley, Hispano-Roman and Hispano-Andalusi populations persisted in the central meseta. The ceramic evidence suggests that Hispano-Andalusi material, and therefore cultural influence, are found in higher concentrations at the eastern end of the Duero basin than the western end; this is reasonable given the proximity of the Andalusi Upper March to the headwaters of the Duero River in modern day Soria province. Although it appears in fewer instances, Andalusi settlement and ceramic evidence of trading relationships are not absent from the Duero valley west of Valladolid, particularly in the southern reaches of the valley basin. North of the Duero, general accounts of immigration to the central meseta in the medieval chronicles together with Arabic place names confirms the existence of persisting and immigrant HispanoAndalusi groups but the religious and ethnic nature of these groups, particularly those hailing from southern regions, is difficult to secure.

In regard to how these communities were politically structured, the picture is unclear due to the scarcity of documents before the eleventh and twelfth centuries.

\footnotetext{
${ }^{100}$ Hitchcock, Mozarabs, 53-55 and Manzano Moreno, "Christian-Muslim Frontier in Al-Andalus." The Arabization of names that appear in documents is one support for Manzano Moreno's larger argument that the Duero basin sustained a persistent population and was never 'depopulated,' 93-96.
} 
Following Bonnassie's analysis that the villae of northeastern Spain were collections of peasant allods or aldea under the control of a local magnate, Glick notes that the principal incentive for the settlement of the sparsely populated frontier was the possibility of acquiring property and/or seigniorial control through the presura. ${ }^{101}$ The presura (or aprisio) was related to Germanic and Islamic laws that permitted squatters to occupy land legally if they made it productive in some way and if it was retained by the owner for at least thirty years. ${ }^{102}$ Glick notes that the arrival of outsiders may have caused conflict with the existing population and expects that town charters, or fueros, offered enticements to attract settlement to certain areas or were employed in an attempt to restrain villagers from emigrating further south in search of more favorable circumstances. ${ }^{103}$

The later ninth and tenth-century frontier supported a heterogeneous population that included persisting groups of Hispano-Andalusi and Hispano-Roman descent. The tension between existing populations and the arrival of new lords would have complicated the tenuous situation of frontier life. By the eleventh century, fueros may have assisted governors in establishing guidelines for military service but the necessary level of collaboration to defend the populace and their agricultural/pastoral assets first demanded the acceptance of a legitimate authority. Leadership could not be maintained

\footnotetext{
${ }^{101}$ Glick, From Muslim Fortress, 102-105 and Pierre Bonnassie, From Slavery to Feudalism in SouthWestern Europe, (Cambridge, Cambridge University Press, 1991), 250-251.

${ }^{102}$ Glick, Islamic and Christian Spain, 86-87.

${ }^{103}$ Glick, Islamic and Christian Spain, 90. Historians agree that surviving fueros certainly offered incentives for settlement along the frontier in the eleventh and twelfth centuries. These included exemptions from certain taxes , military service, squatter's rights over 'vacant' land or land conquered from Muslims (presura), and criminal pardons - even for murderers. Concerning the generous terms offered by fueros, see Linehan, History and the Historians, 263-267, Powers, A Society Organized for War, 18-39, and Armand Arriaza, "The Castilian Bougeoisie and the Caballeros Villanos in the Concejo before 1300: A Revisionist View," Hispanic American Historical Review 63, no. 3, (1983): 517-536. It is important to point out that the best evidence for fueros dates to the eleventh century or later. While these documents may reflect earlier practices, this is unknown, see in particular, Powers, A Society Organized for War, 15.
} 
through military superiority, since even kings did not retain standing armies. Instead, by the tenth century, stone churches and fortresses were raised by either existing supralocal or incoming claimants as part of a visual campaign to establish their sociopolitical dominance.

\section{The Eleventh and Twelfth Centuries}

The eleventh and twelfth centuries offer more in the way of written and architectural sources for investigators of frontier population than the previous centuries. Unfortunately, most of these accounts are limited to the official histories compiled by kings and therefore focus on their military exploits and imposition of royal authority. ${ }^{104}$ This period witnessed an increase in military activity in the Duero and Ebro Basins as Christians and Muslims attacked not only each other but their coreligionists in an effort to secure territory. Duero Valley populations would have been concerned and affected by the perpetual instability of this period. ${ }^{105}$

Tenth-century demands for military and agricultural resources continued into the eleventh and twelfth centuries but additional forces further disrupted everyday existence and complicated the demographic profile. ${ }^{106}$ The increasing popularity of the pilgrimage route to Santiago de Compostela and the appearance of outside military and monastic

\footnotetext{
${ }^{104}$ Barton, The Aristocracy in Twelfth-Century León and Castile, 1997, 4. "The majority of such writings, from the Asturian chronicles of the late ninth century down to the ambitious 'general histories' of Lucas of Túy and Rodrigo Jiménez de Rada in the first half of the thirteenth, were 'official' works of court historiography compiled at the behest of royal patrons and devoted almost exclusively to the deeds of the monarchs of León and Castile. By and large, the exploits of the lay nobles of the realm were virtually excluded from their gaze."

${ }^{105}$ The level of insecurity in the Peninsula varied according to region. North of the Duero River, towns and strongholds were more likely to be threatened by Christian armies, while Southern outposts, such as Ávila or Toledo, were attacked in the late twelfth century by the Almohads, see Derek W. Lomax, The Reconquest of Spain, (London; New York: Longman, 1978), 112-123, especially 120-121 and Kennedy, Muslim Spain and Portugal, 244-247.

${ }^{106}$ See Bonnassie, From Slavery to Feudalism, 246-247 for the military obligations required from peasant communities in Catalonia and Valencia by the local powers, called the boni homines by Bonassie.
} 
orders within the Peninsula have prompted scholars to describe the eleventh and twelfth centuries as a period of "Europeanization" in Spain, a designation that can be vague and problematic. ${ }^{107}$ While Christian courts and monastic houses deliberately made use of people, concepts and visual culture from north of the Pyrenees, diplomatic contact continued with Muslim kingdoms and a significant number of Muslim slaves were incorporated into the social fabric. ${ }^{108}$ Altogether, the cultural mix described for the tenth century above was certainly expanded and diversified by extra-Peninsular and former Andalusi populations, a reality that was reflected in the art and architecture of the Duero basin.

Scholars continue to designate the eleventh and twelfth-century frontier as a site of "repopulation" and to consider large numbers of settlers as critical to the success of the Christian conquest. While the higher number of settlement charters and the steady construction and reconstruction of castles, walls, and churches could support the idea of a large population influx, the problems surrounding the interpretation of these materials remains pertinent. Did the increase in building reflect a massive increase of population

\footnotetext{
${ }^{107}$ Many examples of the tendency to describe the eleventh century as having brought about a Europeanization, etc. of Iberia are easily found: Walter Muir Whitehill, Spanish Romanesque Architecture of the Eleventh Century (London, Oxford University Press), 1968, 3-10, “...this internationalization," 9; Stanley G. Payne, A History of Spain and Portugal, Vol. 1 (Madison, University of Wisconsin Press, 1973), LIBRO stable URL: http://libro.uca.edu/payne1/payne7.htm, “...a major force for Europeanization and Modernization," 132, etc. The common use of terms like "Europeanization" has received criticism because it has been used to support the argument for feudal development in Spain alongside other European regions as noted by Collins in Visigothic Spain, 4 and Linehan in History and the Historians, 192-202. This adjective continues to be employed, however. For example, when Barbara Rosenwein states, "The French connection was symptomatic of a wider process: the Europeanization of Spain," it seems to me that a such a broad term must be either thoroughly justified or omitted in favor of more specific and useful descriptions. See A Short History of the Middle Ages (University of Toronto Press), 2009, 199. For a succinct explanation of some of the difficulties with the notion of a "Europe" in the eleventh and twelfth centuries, see O'Keeffe, Archaeology and the Pan-European Romanesque, 66-68.

${ }^{108}$ François Soyer, "Muslim Freedmen in León, Castile and Portugal (1100-1300)," Al-Masāq: Islam \& the Medieval Mediterranean 18, no. 2 (September, 2006): 129-143, in particular, 133-134, 140. According to Soyer, Mozarabic and Latin charters make clear that there were a number of Muslim slaves and freedmen living in Christian kingdoms and that their relationships to their masters or patrons (if in a state of manumission) could in some cases be likened to a form of kinship. The author points out that there are instances where a substantial value was placed on highly skilled Andalusi slaves such as masons.
} 
or the imposition of control and organization of the countryside by outside parties, and in some cases, their material resistance against such a claim? There is not enough data to suggest specific numbers of immigrants; nevertheless, while acknowledging the likelihood of French influence at higher levels of political authority, it does not appear that large numbers of extra-Peninsula settlers drastically altered the general population composition. ${ }^{109}$ It seems reasonable to accept the likelihood that the eleventh and twelfth century-Duero basin supported a population that was larger than that of the tenth century due to the increased stability after the dissolution of the caliphate and the related military successes and regional consolidation. While outside settlers to the frontier region no doubt contributed to the rise in population, they did not constitute the majority but were likely part of a political reorganization.

In summary, the heterogeneous Duero society presented here supports the argument for the political restructuring of this territory rather than as a 'repopulated' Duero frontier. Interpreting medieval accounts of the depopulation of the Duero Valley as rhetorical justifications for the conquest of frontier territory, as the work of Ramón Menéndez Pidal, Eduardo Manzano Moreno, Santiago Castellanos, Iñaki Martín Viso and others suggest, opens the door to reconsidering the strategic value of this region. The military obligations imposed upon the populace at the frontier, together with the appearance of fortified towns and castles, demonstrate how this territory was truly 'a

\footnotetext{
${ }^{109}$ Bernard Reilly, "Count Raimundo of Burgundy and French Influence in León-Castilla (1087-1107)," in Church, State, Vellum, and Stone; Essays on Medieval Spain in Honor of John Williams, ed. Therese Martin and Julie A. Harris (Leiden; Boston: Brill, 2005), 108-109. "Surely eleventh- and twelfth-century Christian Iberia saw the increasing permeation of many of its cultural practices and institutions by influences from beyond the Pyrenees and in particular from that area we inevitably style 'France.' So too, there was a detectable, if small, flow of immigrants, deriving from the same regions."
} 
society organized for war. ${ }^{, 10}$ As such, frontier inhabitants held great value for kings and nobles who required men, arms, and supplies for their battles against one another and alAndalus. ${ }^{111}$ Ecclesiastical circles also benefitted from the easy appropriation of land and its appurtenances — and their presence at the rural frontier often represents an administrative center. Clerics and abbots were able to serve as independent lords who organized the defense of their community and contributed men and arms to the campaigns of their sovereign. Given the tension that probably existed in places where outside occupiers asserted their authority over existing communities, the presentation of a legitimate image through architectural production was an essential tool in securing the necessary cooperation for both the survival of the aldea and by extension, the success of the Christian conquest.

\section{Architectural Support for Political Restructuring}

Taken together, the above descriptions of Duero Basin communities argue against reconstructing the architectural audience of the frontier as a homogenous group of Christian settlers recently sent to a vacant land. Beyond the arguments of historians, archaeologists, and toponymic support, landscape systems and architecture provide reasons to reconstruct the Duero Valley as occupied by a small, rural, diverse

\footnotetext{
${ }^{110}$ Elena Lourie first used this phrase to title her essay, "A Society Organized for War: Medieval Spain," Past and Present 35 (1966): 54-76, and it has remained relevant for subsequent generations of Iberian scholars. For example, Powers, A Society Organized for War.

${ }^{111}$ This does not mean that large numbers of people were required. With the exception of the spectacular Gormaz, Juan Zozaya explains that most of these frontier fortresses would have needed to support only small garrisons or defend small populations from a raid or siege for a short amount of time in “¿Fortificaciones Tempranas?” in Actas del I Congresso de Castellogía Ibérica; 14 a 17 de septiembre de 1994, ed. Philippe Araguas, (Palencia: Diputación Provincial de Palencia, 1998), 75.
} 
populations, whose churches, monasteries, fortified centers and systems for agriculture, transhumance, and mill-production all suggest substantial social organization.

Medieval chronicles attest to how architectural construction could signal political organization or reorganization. In the Chronicle of Alfonso III architectural programs appear to symbolize a king's legitimacy and potency. "After Ramiro quieted the civil wars, he built many arched buildings of granite and marble-without using any woodon the side of Mt. Naranco two miles from Oviedo."112 The details of construction are significant; the buildings incorporated arches, were entirely built of stone, and were set against the side of a mountain. Taken together, these characteristics clearly demonstrate the visibility, cost, and therefore, status of the architectural program. Because the chronicler notes that the king's building program followed the successful conclusion of a period of civil unrest, the Mt. Naranco structures seem to have additionally served King Ramiro I (842-850) as a sign of his authority over his rivals.

The early appearance and longevity of buildings and their landscapes along the Duero frontier is better explained within a context of political restructuring than a literal repopulation. How small frontier churches were meant to function is at the center of this debate. The use of stone architecture and elite architectural forms and decoration within a significant topographical context suggests a function for these rural buildings that was more in keeping with the need to impose authority upon an existing population than to simply provide a church for Christian colonists in the wilderness. The continued use of, and modifications to, tenth-century structures by subsequent generations provides additional evidence for the propagandistic value of frontier architecture and the

\footnotetext{
112 "Chronicle of Alfonso III," in Conquerors and Chroniclers of Early Medieval Spain, $2^{\text {nd }}$ ed., trans. Kenneth Baxter Wolf (Liverpool: Liverpool University Press, 1999), 175.
} 
likelihood that audiences were not likeminded settlers but a heterogeneous group in need of persuasion.

\section{Monasteries}

The monasteries and churches of interest to this dissertation were part of different ecclesiastical groups. Most of them began as small proprietary monasteries, without ties to the larger orders. By the late eleventh century, the Benedictine Order influenced a few key churches in the Duero basin, such as the monastery of Sahagún (Palencia) and Santo Domingo de Silos (Burgos) but the majority were incorporated into reorganized Episcopal sees as these were established. ${ }^{113}$ It has been widely acknowledged that monasteries and churches were important foci of political organization for the Duero frontier, particularly in the tenth through twelfth centuries which witnessed substantial fluctuations in territorial control. ${ }^{114}$ This is not to say that fortified centers were not present and active competitors (or allies) for sociopolitical power, but that it is more difficult to establish dates and patrons before the twelfth century due to the uneven archaeological and written evidence. ${ }^{115}$ While the political role of churches and

\footnotetext{
${ }^{113}$ The Cistercian orders were also active, particularly in Cataluña, and in the twelfth century, the Hospital Order of St. John of Jerusalem acquired some monasteries, for example, Santa María de Wamba (Valladolid).

${ }^{114}$ For a general example, see Reilly, Medieval Spains, 147-149, while Isabel Alfonso provides a nuanced analysis of how monastic influence could significantly shape political power in "Judicial Rhetoric and Political Legitimation in Medieval León-Castile," in Building Legitimacy, Political Discourses and Forms of Legitimation in Medieval Societies, 51-87, ed. Isabel Alfonso, Hugh Kennedy and Julio Escalona (Leiden; Boston: Brill, 2004). It is very difficult to differentiate small churches and monasteries from one another. As Davies points out in Acts of Giving, 48, 214-221, the medieval records are imprecise when it comes to designating ecclesiae, but a large number of land transactions facilitated monastic influence, in secular as well as spiritual terms. See also Escalona, "Mapping Scale Change."

${ }^{115}$ Bernard Reilly, The Kingdom of León-Castilla Under King Alfonso VI, 1065-1109 (Princeton University Press, 1988), 5. The author describes the role of the Duero boundary for the Christian Muslim frontier, "This natural fortification was never impenetrable, of course, but from very early it was improved by a line of fortresses that made it an even more formidable obstacle. From Zamora, to Toro, to Tordesillas, to Simancas, and beyond through Peñafiel, Aranda de Duero, and Peñaranda de Duero, major fortifications guarded the river crossings at the average of one every thirty kilometers." While most of these fortresses are securely accounted for by the twelfth century, the earliest date of their establishment is contested and Reilly does not qualify his use of the phrase "very early." Manuel González Jiménez likewise loosely
} 
monasteries is imperfectly understood, in recent years, scholars have made important strides in identifying how they organized territory and exercised control over its inhabitants. The ways in which acquisitions of churches and monasteries are described in medieval texts demonstrates how building and restoration often accompanied claims for legitimate ownership of a property, even for subsequent generations. Further, material changes to ecclesiastical spaces also suggest a close relationship between shifts in power and subsequent construction.

The chronicles of medieval Spain are generally concerned with the affairs of kings and counts, including the churches and monasteries built by the sovereign and his family. ${ }^{116}$ Builders of churches and monasteries could come from a number of different stations, however, and along the frontier and outside of larger cities, this was particularly true. Medieval accounts explain how conquering patrons, usually nobles or abbots, encountered ruined structures and replaced or restored them. While the frequent repetition of phrases describing how these churches were founded may simply indicate the presence of a chronicler's formula, the impression remains that incoming powers were expected to build—especially churches.

Isidoro Bango Torviso provides numerous examples of the medieval claims of kings, bishops, priests, abbots, counts, and others who restored or founded churches upon the ruins of churches dating to antiquity. The author lists these examples to support his

situates the great fortified centers of Zamora, Toro, Simancas and a "network of castles and fortresses" sometime in the tenth and early eleventh century. See also, "Frontier and Settlement in the Kingdom of Castile (1085-1350)," in Medieval Frontier Societies, ed. Robert Bartlett and Angus MacKay (Oxford: Clarendon Press, 1989), 52.

${ }^{116}$ For typical examples, see The Chronicle of San Juan de la Peña: Fourteenth-Century Official History of the Crown of Aragon, trans. Lynn H. Nelson (Philadelphia: University of Pennsylvania Press, 1991), 20, 41 and "Historia Silense," The World of El Cid, Chronicles of the Spanish Reconquest, trans. and ed. Simon Barton and Richard Fletcher (Manchester; New York: Manchester University Press), 47, 59. See also: Alfonso, "Judicial Rhetoric," 55-56. 
contention that by rebuilding churches on sites that predated the Islamic invasion, ninth and tenth-century builders were seeking to revive their Visigothic identity. Count Gondesino Eriz's 947 foundation of the monastery of San Cristóbal and Santa Eulalia de Sanguedo, which was characterized as originating in antiquity or "ab antiquis," is typical. ${ }^{117}$ In addition to the appearance of "ab antiquis," many medieval charters describe churches as having been found in a ruinous state, "ab squalido," or restored or constructed anew from the foundations "ad fundamentis." 118 Historians have often accepted at face value descriptions of ruined churches in the Duero Valley because it was thought that they were situated in a depopulated or scarcely populated zone. However, given the perspective that incoming settlers represented a new social order (rather than the appearance of people for the first time), documenting ancient origins for rebuilt churches/monastic estates may not only have served religious or ideological motivations on the part of the builder, but may also have provided a stronger legal ground for ownership claims on these properties. ${ }^{119}$ Claims of "restoration" or rebuilding should therefore be accepted with caution.

The presura also serves as an alternative lens through which to consider why medieval contracts specified if a church had been found abandoned or in ruins. In cases of conquest, the land was additionally understood to be a grant from the supreme ruler to the occupier. For this reason, medieval records of later land transactions often list

\footnotetext{
${ }^{117}$ Bango Torviso, "Neovisigotismo," 322-327. The author provides more than two dozen references to churches renovated or replaced that medieval authors describe as dating from antiquity.

${ }^{118}$ Bango Torviso, "Neovisigotismo," 323-329. The author assumes that if a church was possessed in the frontier or "restored" that this implies a ruinous state. For descriptions of churches found in a ruined or abandoned condition and qualifications on how churches might be restored or rebuilt from their foundations.

${ }^{119}$ There were a number of advantages to designating a church as "ancient." Besides the implications for rightful ownership explained below, there was spiritual and social value in the restoration of a sacred place. For a more complete discussion of these less tangible benefits, see chapter three.
} 
properties as having originally been gifts from the king regardless of the circumstances of its initial acquisition. ${ }^{120}$ Written documentation of legitimate occupation under presura served two purposes. First, it gave the claimant written, legal ground on which to stand for any transactions pertaining to the property or its resources against possible competitors. By describing the property as ancient or in a ruinous state, the proprietor could imply that the land was uninhabited at the time of occupation, a condition that would have advanced their claim of ownership. Second, the document benefitted kings who sought to reinforce an image of supreme authority and establish their sovereignty over subjects that controlled valuable churches and properties. ${ }^{121}$ Thus, there was a broad benefit to be gained from documenting the construction or reconstruction of a church or monastery along the Duero frontier. ${ }^{122}$

Ensuring that one's role in the building or restoring of a church was in the written record could also facilitate legal attempts to prove the inheritance of a church and its revenue sources. This strategy is illustrated in the careful work of Wendy Davies, who considers the important role played by donations and other property transactions in the long-term relationship between Iberian churches and their communities. Concerning the legal contest between Brother Vimara and Count Menindo Gundisalviz over the

\footnotetext{
${ }^{120}$ Davies, Acts of Giving, 42-45 and Glick, Islamic and Christian Spain, 86-87. Glick explains that at least thirty years needed to pass in order to claim land through presura and that titles needed only to be produced in order to redistribute the property.

${ }^{121}$ Mínguez Fernández, "Pervivencia y transformación," 17-23 in particular. Contests between kings and nobles over territory were particularly heated during the Christian expansion due to the shifting political and military fortunes of each.

${ }^{122}$ I do not wish to minimize other benefits that a patron might derive from the foundations and endowment of a church or monastery, such as an increase in one's personal status or spiritual standing. Because the political function of ecclesiastical spaces along the frontier is my chief concern, I am limiting discussions of spiritual and personal elevation except where they promote a patron's right to influence the church community.
} 
ownership of San Pedro de Laroá (Orense), Davies argues that testimony of a familial connection was crucial to the success of the claim.

Eventually Vimara, together with twelve suitable witnesses, as directed by the judges of a local court, swore an oath that his ancestors had rebuilt the ruined church and that their children and grandchildren had endowed it, around 900, with 20 metres of land all round the church, for the purposes of burial, and a further 120 metres all round to generate income for the clerics resident there. ${ }^{123}$

Count Vimara's claim was recognized by the local court and subsequently recorded at the monastery at Celanova in order to demonstrate the legitimacy of their receipt of San Pedro de Laroá upon the death of Count Vimara's successor in the second half of the eleventh century. ${ }^{124}$ Davies uses this and other examples to demonstrate the prevalent nature (and importance) of family ownership in the transference and sale of ecclesiastical property. In so doing, she explains that churches in tenth and eleventh-century Iberia were generally not part of a larger parochial system but were bequeathed, donated, or sold between families. ${ }^{125}$

The author's examination of land transactions that demonstrate substantial family control of churches allows for an additional observation regarding how architecture might reflect contemporary sociopolitical transitions. While the act of building or rebuilding churches may not have legitimated ownership in and of itself, claiming a personal connection to a disputed church through its past architectural improvements could advance a legal claim on its property and appurtenances. Moreover, the frequent joint appearance of new proprietors or patrons alongside new building phases in the written

\footnotetext{
${ }^{123}$ Davies, Acts of Giving, 39. Davies states that the legal dispute occurred shortly before 1054, more than a century and a half after the initial acquisition of the church by Count Vimara's ancestors. 39-40. ${ }^{124}$ Davies, Acts of Giving, 39-40.

${ }^{125}$ Davies, Acts of Giving, 44. The author makes clear that it is impossible to disentangle lay and ecclesiastical concerns and persons because clerics and aristocrats comingled and shared material and spiritual interests.
} 
record indicates a medieval expectation that physical changes often accompanied shifts in ownership.

Further supporting the theory of a political repopulation over a literal repopulation is the material record. Like the textual accounts discussed above, the physical appearance of architectural phases often coordinate with new proprietors or patrons. The simplest way to illustrate this is to look at a monastic center that appears to have been a sociopolitical force and examine changes in its architectural fabric. ${ }^{126}$ The careful archival research carried out by José María Minguez Fernández reveals the extent of the valuable land controlled by the frontier monastery of Sahagún and the regional influence wielded by the monastery. Building on this foundation, it is possible to demonstrate how the later phases of Sahagún's monastic church corresponded to shifts in the political landscape.

The monastery of Sahagún acquired land and villas to the north and south, from the foothills of the Cantabrian Mountains to the center of the Tierra de Campos. ${ }^{127}$ These zones of expansion appear to have developed along the Cea and Pisiguera river systems that flow south to the Duero. ${ }^{128}$ The monastery itself, however, was built up around a small church dating back to at least the eighth century. Originally a cella memoriae for the relics of the martyr-saints Facundo and Primitivo, the partial ruins of the eleventh and twelfth-century structure that can be seen today were preceded by ninth and tenth-century

\footnotetext{
${ }^{126}$ Monasteries patronized by kings offer the clearest example of this process. While the fact that monasteries have served as political platforms for sovereigns is not contested, connections between how kings depicted their legitimacy and how other elites followed suit has not been explored for rural churches in the Duero basin. The following chapter offers a fuller description of the specific elements found in royally patronized monasteries that I argue are repeated in smaller spaces.

${ }^{127}$ The region of the Tierra de Campos is understood as lying mainly in Palencia and Valladolid, with a few municipalities in León and Zamora. Its southern border is the Duero River.

${ }^{128}$ Mínguez Fernández, El dominio del monasterio, 39. The Leonese zone is made up of the "Orbigo-EslaCea" rivers which parallel the system that defines the eastern boundary of the Tierra de Campos, the "Carrión-Pisuerga-Arlanzón."
} 
phases that were removed in order to build a larger church under the monastery's new patron, Alfonso VI (1065-1109) (figure 7). ${ }^{129}$ While the position of the monastery along the way of St. James and its takeover by the influential Cluniac order around 1080 would seem to explain the success of its expansion, it must be remembered that much of the monastery's territory and authority were consolidated during the tenth century. At this point, Sahagún was situated along the Christian-Muslim frontier. However, the church's accrued prestige and wealth, in addition to the increased popularity of the Camino de Santiago, attracted royal and Benedictine patronage in the eleventh century. ${ }^{130}$

A central question for Mínguez-Fernández was how the tenth-century monastery was able to acquire and profit from disconnected properties spread out over a 150 kilometer zone. ${ }^{131}$ Setting aside the unlikely account that enormous donations were made by Alfonso III to the monastery in 905, the author argues that the size of the monastery's holdings suggest the accumulation of property over time, from an earlier date. ${ }^{132}$ This point of view appears the more reasonable, particularly when looking at the way in which

\footnotetext{
${ }^{129}$ C. Cosmen Alonso, María Victoria Herráez Ortega, and Manuel Valdés Fernández, "Alfonso VI y el monasterio de Sahagún: nuevos testimonios sobre la construcción del templo monástico," De Arte: Revista de Historia del Arte 5 (2006): 29-41, 30 and José Luis Senra,

"Aproximación a los espacios." Both of these discuss the funerary aspects of the west end/galilea and political power.

${ }^{130}$ Concerning the political and financial motivations for the Cluniac presence along the way of St. James in general, see O.K. Werckmeister, "Cluny III and the Pilgrimage to Santiago de Compostela," Gesta 27, no. 1/2 (1988): 103-112, 106-108. The author provides accounts of how Cluniac attempts to commandeer the pilgrimage churches of Saint-Martial and Saint-Sernin were aided or thwarted by local support or resistance.

${ }^{131}$ Mínguez Fernández, El dominio, 23. "Sería un error, sin embargo, creer que a lo largo de esta enorme franja de $150 \mathrm{kms}$. entre Tronisco y la Lampreana, la posesiones de Sahagún se extienden sin solución de continuidad."

${ }^{132}$ For a discussion of the anachronistic imposition of tenth and eleventh-century royal donations and associations with large monasteries of frontier Iberia, see Davies, "Lordship and Community." For the acceptance of the Alfonso III purchase and donation to Andalusi monks, see Dodds, Architecture and Ideology, 77, after Gómez-Moreno, Iglesias Mozárabes, 107, and Debra Hassig, "He Will Make Alive Your Mortal Bodies: Cluniac Spirituality and the Tomb of Alfonso Ansúrez," Gesta 30, no. 2 (1991): 14053, after Historia del real monasterio de Sahagún: sacada de la que dexó escrita el padre Maestro Fr. Ioseph Perez (Madrid, 1782), 377, 905.
} 
the land was used. ${ }^{133}$ Purchases and donations described in the archive portray a diverse landscape that supported transhumance, cereal production, and viticulture-large scale cultivation projects that Mínguez-Fernández suggests should be seen as evidence of substantial social and economic organization of the large territory under the control of the monastery at Sahagún. ${ }^{134}$ Furthermore, evidence from the Sahagún archive indicates that this monastery exercised control over the population and arable land persisted from the eighth century. Later changes to the population of the Tierra de Campos, including migration and conquest, resulted in a large number of transactions for the tenth-century monastery allowing it to become a dominant political center.

The vestiges of architectural phases at Sahagún that predate the surviving structure, believed to have been built by Alfonso VI, are lost. As it stands today, only portions of the tripartite east end and the twelfth-century crossing survive in situ (figure 8). ${ }^{135}$ According to José Luis Senra Gabriel y Galán, the lost structure was approximately fifteen meters in width and thirty meters in length. These dimensions are similar to those at San Cebrián de Mazote (Valladolid) (figure 9), leading the Senra Gabriel y Galán to conclude that the nave at Sahagún was once likewise covered in wood. ${ }^{136}$ The apses at Sahagún were vaulted and around the perimeter of their interior walls a stone bench was

\footnotetext{
${ }^{133}$ Mínguez Fernández, El dominio del monasterio, 27.

${ }^{134}$ Mínguez Fernández, El dominio del monasterio, 42-43.

${ }^{135}$ Unfortunately, most of the church was destroyed by a nineteenth-century fire according to C. Cosmen Alonso, et. al., "Alfonso VI y el monasterio de Sahagún," 32.

${ }^{136}$ José Luis Senra, "Los programas constuctivos de los monasterios Benedictinos en el Camino de Santiago: arquitectura y ornamentación," in Monasterios y peregrinaciones en la España medieval, ed. José Ángel García de Cortázar and Ramón Teja (Aguilar de Campoo: Fundación Santa María la Real, 2004), 111.
} 
installed. ${ }^{137}$ A few carved Corinthian capitals survive and are characterized by broad, stylized vegetal forms, along with architectonic strips of geometric and vegetal reliefs. ${ }^{138}$

Although Cosmen Alonso, et al. base their dating of the eleventh-century apses on stylistic and structural grounds, the elevation of status resulting from the sociopolitical context for the monastery of Sahagún in the last two decades of the eleventh century was probably the motivation for the construction of a new church. ${ }^{139}$ The fractious political situation for the kingdoms of the Iberian Peninsula was particularly intense in the eleventh century. In the kingdom of León, Alfonso VI was challenged, exiled to Muslim Toledo, and restored after the death of his brother, Sancho II of Castile (1065-1072). After his return to power, Alfonso took measures to shore up his position. A crucial component was the securitization of his influence over the monastery of Sahagún. ${ }^{140}$ In order to win Rome's endorsement, Alfonso transitioned his kingdom from the Visigothic (or Mozarabic) rite to the Roman rite in 1080. Further, Alfonso appointed Bernard de Sauvetot as abbot of Sahagún (1080), replacing his previous choice, and by 1083, the monastery was placed directly beneath the authority of Rome. ${ }^{141} 1080$ was also the year that Alfonso made clear his intention to be buried at Sahagún, according to the monastery's records. ${ }^{142}$

\footnotetext{
${ }^{137}$ The northern apse, called the Chapel of the Evangelist, is nine meters in height. Around the bases of the intrados for the triumphal arch the bench wraps around the columns like a circular plinth. For more, see C. Cosmen Alonso, et. al., "Alfonso VI y el monasterio de Sahagún," 33.

${ }^{138}$ C. Cosmen Alonso, et. al., "Alfonso VI y el monasterio de Sahagún," 33.

${ }^{139}$ C. Cosmen Alonso, et. al., "Alfonso VI y el Monasterio de Sahagún," 33-36. The authors place the appearance and sculptural details of the apses as consistent with a number of Benedictine constructions dating between 1080 and 1120 and tentatively suggest a date of around 1100 for the apse of Sahagún. For the crossing, a date of the second half of the twelfth century is offered due to the sculptural stylistic evidence, masonry analysis, and a comparison of masons' marks with other twelfth-century structures. ${ }^{140}$ Bernard Reilly, The Kingdom of León-Castille under King Alfonso VI, 49-50.

${ }^{141}$ Bernard Reilly, The Kingdom of León-Castille under King Alfonso VI, 145-149. He is also called Bernard de Sedirac and Bernardo de La Sauvetat.

${ }^{142}$ C. Cosmen Alonso, et. al., “Alfonso VI y el monasterio de Sahagún,” 30, fn. 5.
} 
Recent analysis of the 1932 excavation of the monastic church of Sahagún by

José Luís Senra corroborates medieval claims that Alfonso VI was interred at the abbey

church. The excavated material supports the existence of a western façade structure, described as a portico, called the chapel of San Mancio (figure 10). ${ }^{143}$ Senra argues that the funereal function of this construction was directly tied to the local political needs of Alfonso VI, whose ambition to be buried at the monastery, together with his family, initiated the royal pantheon at the foot of the new basilica, consecrated in 1099, "with the assistance of the Archbishop Bernardo, bishops, abbots, nobles, and knights." ${ }^{144}$ After the death of Alfonso (1109), the construction of the transept and nave was delayed throughout the twelfth century and into the thirteenth century on account of the disputes between the abbot and the townspeople. ${ }^{145}$ Nevertheless, the construction of the royal pantheon, expansion of the nave and addition of a vaulted transept materially reflected the political reorganization of the Duero frontier beneath Benedictine and Leonese authority. $^{146}$

\footnotetext{
${ }^{143}$ Senra, “Aproximación a los espacios,” 122, 128.

${ }^{144}$ C. Cosmen Alonso, et. al., "Alfonso VI y el monasterio de Sahagún,” 30-31. The connection between Abbot Diego (1087-1110) and the foundation of the eleventh-century building comes from a now-lost inscription, according to authors. In addition to King Alfonso VI, his four wives, mistress and son, at least one important noble was interred at Sahagún, Alfonso Ansúrez. All of these burials occurred between the dates of 1078-1109 according to Hassig, "He Will Make Alive," 147. According to Senra in "Aproximación a los espacios," 122-124, the use of the western portico space for elite burial was a trend that appeared in multiple regions and over a long period. In the eleventh and twelfth centuries, this western space may be the structure described in Benedictine sources as the 'galilea.' Accepting this point of view, Senra explains that Benedictine stational liturgy and liturgical dramas would have viewed this space as symbolic of the transition between earth and heaven and therefore an appropriate setting for the theme of resurrection. See also Walker, "Wall Paintings in the Panteón," 207.

${ }^{145}$ C. Cosmen Alonso, et. al., "Alfonso VI y el monasterio de Sahagún," 31-32.

${ }^{146}$ Reilly, The Kingdom of León-Castilla under King Alfonso VI, 62-64. The importance of Sahagún may be seen in the large amount of time spent there by the itinerant court of Alfonso VI, as opposed to the nearby Episcopal see of Palencia or the royal city of León. As further support of the influence wielded by Sahagún, when Sancho of Castile successfully captured and exiled his brother Alfonso VI, the large, influential monastery of Sahagún was the first (and for a while, only) ecclesiastical institution to recognize Sancho's claim over the kingdom of León, “... a major first step to more general acceptance.” After his return, Alfonso VI continued his patronage of the monastery, although he did replace the abbot who had recognized the treasonous claims of his brother, (ibid., 75).
} 
The circumstances at Sahagún are not unique. Along the Duero frontier, churches and monasteries of all sizes acquired productive properties through purchase or donation. These transactions were carried out between priests, monks, lay-owners of churches, nobles, kings, and occasionally, the lay community of the church. ${ }^{147}$ The author points out that, "Rather than physically enter the monastery, the donors accept a continuing relationship with it: they become clients, accepting the abbot's patronage and support within the context of local society, as well as undertaking to make regular returns to him."148 Regardless of the precise mechanism, monasteries like Sahagún and Cardeña (Burgos) were able to organize noncontiguous properties for the purposes of agricultural and transhumant practices because the political domination of the monastery over the territory was sufficient to allow for ample communication and seasonal migration between the nuclei of possessions. ${ }^{149}$

The monastery of Sahagún clearly controlled a great deal of territory, and over time, attracted kings and the house of Cluny. Smaller churches and monasteries likewise operated as local centers of sociopolitical authority in their own right. Although written accounts of property donations and transactions only generally describe the absorption of smaller churches and monasteries by larger institutions, such as Sahagún, the ecclesiastical art and architecture in the rural Duero basin parallels the visual programs

\footnotetext{
${ }^{147}$ Davies, Acts of Giving, 52. Twenty-four untitled villagers at Villabáscones donated land to their monastic church of San Martin and later negotiated their water rights with San Martín's abbot. In some cases, the donation took the form of a person-donation formula that the author explains could express either the literal giving of their person to the monastery (often accompanied by goods and land) or the donor's acceptance of the patronage and authority of the monastery.

${ }^{148}$ Davies, Acts of Giving, 58.Obviously these self-donations could also connote the commitment of one to the monastic life. However, Davies reconsiders the traditional interpretation of self-donation in light of the many formulas that appear in the collections of masculine houses, such as Cardeña (Burgos) that connote the commitment of peasant couples and women to the monastery.

${ }^{149}$ Mínguez Fernández, El dominio del monasterio, 23. Monastic or aristocratic political domination could manifest itself in seigniorial powers that might include obligations of taxes or dues and obedience to the controlling monastery or lord. See also Davies, "Lordship and Community," 25-26.
} 
found at powerful royal foundations. The case studies of Santa María de Wamba (Valladolid) and San Baudelio de Berlanga (Soria) are prime examples of this phenomenon.

\section{Fortresses and Castles}

The formidable number of fortified structures raised or sustained between the tenth and twelfth centuries across the width of the Peninsula illustrates the military nature of the trans-Duero. The casual traveler moving across the landscape of Spain and Portugal cannot help but note their presence, in much the same way that the medieval viewer was meant to do. As visible articulations of power and authority, fortified structures were natural sites for the political reorganization of rural territory.

Despite the widespread presence of medieval fortifications in the Iberian Peninsula, there are significant lacunae in the scholarship concerning their appearance, date, and function. The towers and fortresses of the Duero basin are poorly understood and this is especially true for later medieval strongholds, like Simancas (Valladolid) that were built over early medieval and even ancient phases (figure 11). ${ }^{150}$ Some of the fortresses in the kingdom of León have received considered treatment by José Avelino Gutiérrez González. Because the author's aim was to reveal the consolidation of the Leonese kingdom against the larger historical backdrop of Iberian feudalism, many of the fortified structures of interest to this project, i.e. the walled city of Urueña and the castle

\footnotetext{
${ }^{150}$ Barton, The Aristocracy in Twelfth-Century León and Castile, 168-169. Although Barton states that a number of fortresses and castles "...have been the object of architectural or archaeological description," he offers only a few specific references. For a comparative treatment of fortifications in Aragon and Cataluña, see Phillipe Araguas, "Mozarabes et Lombards: les chateaux du premier art Roman en Aragon et Catalogne," in Actas del I Congresso de Castellogía Ibérica; 14 a 17 de septiembre de 1994 (Palencia: Diputación Provincial de Palencia, 1998).
} 
at Tiedra, are not discussed. ${ }^{151}$ Nevertheless, scholars largely agree that frontier fortresses and castles were used to organize territory and consolidate power. This point of view is in keeping with the theory that efforts to repopulate the Duero basin should be considered in terms of a political reconstruction. Difficulties arise in attempts to define the precise nature of the political authority projected by a frontier fortification. ${ }^{152}$ The following section will outline the purposes served by fortifications, broadly discuss the appearance of some of these structures, and consider how the erection of fortresses along the frontier strengthens the perspective that a political restructuring of newly conquered territory took place.

For the purposes of this study, fortified structures should be understood as places of refuge or defense, as platforms for military operations, and as governing centers. A single site could accommodate all of these functions at once or it could shift in purpose to meet changing needs. For example, the ancient site of the castle of Gormaz seems to have played a variety of roles throughout the medieval period: a garrison, a refuge for villagers and animals, a castle, a space for worship (figure 12). ${ }^{153}$ The plains to the south

\footnotetext{
${ }^{151}$ Fortificaciones y feudalismo en la origen y formación del reino Leonés (siglos IX-XIII) (Universidad de Valladolid, 1995). Likewise, the castles of the Order of Calatrava are largely situated within a broader argument on the feudal nature of medieval Iberian society. See also Carlos de Ayala Martínez, "Las fortalezas Castellanas de la Orden de Calatrava en el siglo XII," En la España Medieval 16 (1993): 9-35.

${ }^{152}$ For the most part, Spanish scholars of the last thirty years favor the model of feudalism, and see fortresses as the natural result of the evolution of lordship and vassalage, for example, de Ayala Martínez, "Las Fortalezas Castellanas," Gutiérrez González, Fortificaciones y feudalismo, and P. Martínez Sopena, La Tierra de Campos occidental. Poblamiento, poder y comunidad del siglo X al XIII (Valladolid, 1985). Outside of Spain and Portugal, the controversy appears to revolve mainly around the definition of feudalism, with most favoring the inclusion of Spain among "the association of feudal kingdoms," Linehan, History and the Historians, 233, Bonnassie, From Slavery to Feudalism, and Glick, From Muslim Fortress to Christian Castle. Glick favors a feudal framework for Iberia that to him is complementary to the reorganization of the landscape through incastellamento and alquerías.

${ }^{153}$ P. J. Banks and J. Zozoya, "Excavations in the Caliphal Fortress of Gormaz (Soria,), 1979-1981: A Summary," in Papers in Iberian Archaeology, ed. T. F. C. Blagg, R. F. J. Jones and S. J. Keay (Oxford: British Archaeological Reports, 1984), 680-682. There is ample archaeological support for the presence (at various times) of villagers, animals, soldiers and castle-types. The speculation that a chamber containing three niches along the south side of the fortress served as a musallà, or Muslim open-air oratory is reasonable, despite a lack of archaeological evidence (due to post-medieval disturbance of the excavated
} 
of Gormaz continue to be cultivated, underscoring how medieval fortified high places in proximity to arable land could additionally serve administrative and market functions. ${ }^{154}$ Fortified sites were not only used for defense but for offensive charges as well, as places from which Christian and Muslim-led raids and larger armed expeditions might be launched. ${ }^{155}$ Clearly, how the castle site was used changed over time, according to sociopolitical conditions. ${ }^{156}$

Medieval fortified sites of the Duero basin vary greatly in size, method of construction, layout, and material. ${ }^{157}$ Perhaps the only common feature to nearly all of the Peninsular castles and fortresses was the tendency to position them in high, easily defensible places, whether naturally occurring or man-made. ${ }^{158}$ Otherwise, it is difficult

area). The southeast orientation of the niches suggests that one of them may have served as a $m i \square r a \bar{b} b$. The nearby location of a circular basin also suggests a ritual quality for the space, which appears to be part of the Muslim phase of the fortress, I will return to the castle of Gormaz in chapter five.

154 "Excavations in the Caliphal Fortress," 686-687. Banks and Zozaya report that within the enclosure of Gormaz, a number of finds point to the utilization of the fortress more than military needs. Millstones, animal bones, thimbles and loom weights are among the finds that range in date from protohistorical to medieval periods.

${ }^{155}$ See "Chronica Adefonsi Imperatoris," in The World of El Cid: Chronicles of the Spanish Reconquest, trans. and ed. Simon Barton and Richard Fletcher (Manchester: New York: Manchester University Press, 2000), 166. According to the Chronica Adefonsi Imperatoris, Alfonso I of Aragon (1104-1134) seized fortified castles, "other fortifications, and many moated and walled towns in the area" in order to attack other fortified sites. Likewise, Simon Barton points out that the twelfth-century stronghold of Ávila served as a platform for militia raids in The Aristocracy in Twelfth-Century León, 169. During the time of the caliphate, Wasserstein explains that Muslims described the outlying border spaces as the thughür, which comes from the Arabic for "front teeth," The Rise and Fall, 20. Although Wasserstein does not comment further on this metaphorical term for the heavily fortified March region, taken together with the annual raids launched from al-Andalus, it does not seem unwarranted to suggest an aggressive and offensive function for fortresses. At the fortress of Gormaz, Banks and Zozoya speculate that a mercenary garrison comprised of Muslims in Christian service may have occupied the enclosure in the mid eleventh century. This may account for the continued appearance of fine, glazed wares associated with al-Andalus in the ceramic record after the Christian conquest of Gormaz, see "Excavations in the Caliphal Fortress," 682. ${ }^{156}$ Banks and Zozaya, "Excavations in the Caliphal Fortress," 687. Here the authors specifically warn against expecting "static" settlement patterns in post-Reconquest Spain. Sometimes the military function of a fortress is not readily apparent, as in the case of the castro at Fontanillas, see Gutiérrez González, Fortificaciones, 22.

${ }^{157}$ Gutiérrez González, Fortificaciones y feudalismo, 20. Although the author is discussing the diversity of fortresses in the Leonese Kingdom, with few exceptions, all fortifications found on the Christian/Andalusi frontier demonstrate heterogeneity.

${ }^{158}$ See Barton, The Aristocracy, 168, González Jiménez, "Frontier and Settlement," 55, Gutiérrez González, Fortificaciones y feudalismo, 69. 
to categorize fortresses by their appearance, or even to distinguish definitively between

Christian and Andalusi trends in building. Numerous sites, such as Zamora, Simancas,

Osma, Berlanga, San Esteban de Gormaz, and Gormaz, changed hands between Christian

and Muslim and were renovated over the course of the Christian expansion, Moving

west to east along the Duero, a few patterns emerge that permit a general description of

fortifications in this region.

Most of the fortresses appearing in the Leonese kingdom, including the Tierra de

Campos between the ninth and eleventh century could be described as castros. ${ }^{159}$ This

type of fortress was built in the mountains to the west or north of the Tierra de Campos or atop high points along the watersheds of the plains. ${ }^{160}$ Many castros of the meseta occupied sites that supported earlier habitations, for example, Castronuevo and Villamayor Campos. ${ }^{161}$ At Castronuevo, Gutiérrez González considers the lime and rock concrete walls of the castle and villa to date to the tenth century and to be in keeping with the need to refortify the Tierra de Campos in light of the repopulation of the Duero

\footnotetext{
${ }^{159}$ I am offering a broad time-span because there is little consensus on when and where early fortifications appear, with some scholars favoring a persisting population in hilltop strongholds and early Muslim use or reuse of Roman or Visigothic sites for their fortresses, called $h i \square n$. On the difficulty of identifying early fortified structures and the lack of academic writing on the subject, see Zozaya, “FFortificaciones tempranas?" particularly 72-75. There is a smaller group of fortifications, called motas, which are large earthen hills, artificially constructed. In the Tierra de Campos, local clay was the most common material for the creation of the mota, which was sometimes sited atop a preexisting castro site, as was the case at Castroponce. At the summit, a concrete, stone or tapial structure might be raised, particularly in the twelfth and thirteenth centuries, at the height of the tensions between León and Castile. See Gutiérrez González, Fortificaciones y feudalismo, 30-41.

${ }^{160}$ Gutiérrez González, Fortificaciones y feudalismo, 20-25. These structures usually feature an oval or round enclosure wall of rock or earth or a ditch. Mountain castros sometimes occupy sites that are clearly pre-Roman, as in the case of Arrabalde, and were constructed of local rock, with dry-rock walls. Along the plains, castros are situated above the surrounding landscape, but at a relatively lower height, due to the flat nature of the terrain. Sited above canyons, steep river banks, or along natural hills that have eroded more slowly than the surrounding land, the defensibility of plains castros were sometimes improved by earthen walls and ditches.

${ }^{161}$ Gutiérrez González, Fortificaciones y feudalismo, 26-29, 40, 47. I should note that the author makes clear his point of view that the ancient sites were abandoned and colonized in a feudal manner during the tenth century, under the direction of the Leonese king. The place-names suggest to Gutiérrez González that most of the magnates and settlers of the frontier were of a Mozarabic origin and that they restored the old castros into new administrative sites.
} 
valley. ${ }^{162}$ Generally speaking, the fortified hilltops of the Tierra de Campos maintained or expanded the existing perimeter enclosure and constructed (or reconstructed) castles and/or villas between the tenth and thirteenth centuries. The size, design, and construction of these structures vary considerably but favor a rectangular shape and the use of stone (with either regular or irregular courses), rough concrete, or rammed earth (tapial construction).

Like the fortifications raised in the northern part of the Peninsula, Muslim fortifications were also frequently built upon sites previously occupied. Examples of this practice include Zamora, Segovia, Sepúlveda, Osma and Gormaz. At Zamora, Muslim control was but one phase between the period of Roman dominion and Christian conquest. ${ }^{163}$ Although there is some debate over when the earliest fortifications were built, recent analysis by Juan Zozaya has lent support to those scholars who propose assigning an eighth or ninth-century date for a few Muslim fortifications previously considered to date to the tenth century. ${ }^{164}$ Muslim fortifications appear quite distinctive when compared to surviving portions of Christian fortresses and castles west of Valladolid; the stone and tapial constructions usually closely conform to their environments, following the contours of the hilltops they occupy. This method of construction causes the walls to appear as though they rise directly from the rock itself and is illustrated by the fortresses at San Esteban de Gormaz, Gormaz, and Osma.

\footnotetext{
${ }^{162}$ Gutiérrez González, Fortificaciones y feudalismo, 374-377.

${ }^{163}$ See Martín Viso, Fragmentos del Leviatán.

164 Zozaya, “FFortificaciones tempranas?” Similar to the controversy surrounding the implications of a Duero desert for Christian building at the frontier, Zozaya contends that a lack of careful textual analysis and a scarcity of Andalusi frontier excavations have contributed to a skewed understanding of the eighth and ninth centuries of Muslim dominance. The author sets aside the conventional point of view that assumes a caliphal date for the majority of fortifications. He does this because the archaeological and stylistic evidence appears to contradict the Muslim chronicle testimony.
} 
Despite differences in construction, all fortifications provided a certain amount of protection for those within and projected an image of power. Consequently, fortresses are usually viewed as manifestations of authority, either self-contained or representing the regional lord or king. Defining the nature of that authority can be complicated given the multifunctional character of fortresses and how their purpose can change over time. ${ }^{165}$ The collective nature of the society that sometimes developed around these strongholds is captures in a Catalan comital court dispute.

When both parties had in turn argued vehemently about this, the count and countess, with the group of priests and nobles and the approval of the judges, gave and imposed the following decision between the two parties: Since they were not able to disentangle in strict ownership whose right was greater, and since it was difficult for one family to exploit this place and to bring it into cultivation and to construct a fortified tower, and since no small number of neighbors gather in shelter from the approach of the yoke of the Saracens, they would make two equal portions out of these lands, and they would similarly build one tower together and one half would be given to Sant Cugat, the other half conveyed to Adalaiz. They would construct this tower together and they would possess it together happily [cum felicitate] and they would take fish together from these ponds, and those fish they would collectively divide in half. Adalaiz and her children will faithfully make a donation to the monastery of one tenth of the fish which God should provide from fishing there. ${ }^{166}$

In this case, the castrum and alod are divided between claimants who seem to be responsible for neighboring villagers as the local authorities but who ultimately answer to the count.

\footnotetext{
${ }^{165}$ For examples of how these aldeas might be arranged in relation to fortresses, ermitas, and churches, see Patrice Cressier, "Agua, fortificaciones y poblamiento: el aporte de la arqueología a los studios sobre el sureste peninsular," Aragón en la Edad Media 9 (1991): 403-27 and more generally, Glick, Islamic and Christian Spain, 180-207.

${ }^{166}$ Bowman, Shifting Landmarks, 190-191. An additional example of how fortresses could serve a multifunctional role in medieval society is portrayed in the Poem of the Cid. The Muslim fortress of Castejón was assaulted and taken by the Cid with one hundred knights while the fortress's occupants were out tending the fields. The Muslims, animals and other booty were exchanged for silver (provided by the inhabitants of Castejón, Hita and Guadaljara) so that the Cid might evacuate the fortress, which he did not wish to keep due to its lack of water and treaty with the king of Castile. The Poem of the Cid, translated by Rita Hamilton and Janet Perry, (London: Penguin Books), 1975, 45-47. Although the historical basis for this portion of the Poem is uncertain, it nevertheless represents the thirteenth-century author's understanding of the ways in which fortresses served society.
} 
It is important to acknowledge, however, that while fortresses and castles could represent a chain of authority beneath the umbrella of the king or count, castles could just as easily offer an image of rebellion against the king or, more ambiguously, symbolize the ultimate authority for a particular territory. ${ }^{167}$ Written from the royal perspective, the Historia Silense characterizes the unauthorized construction of castles as a symbol of independent rule. ${ }^{168}$

Christian fortifications were not alone in their forceful projection of authority. Both the defensive and ideological aspects of ninth-century Muslim fortress are stressed by Rafael Azuar Ruiz. He sees the similarity in construction technique between the fortresses, or $\square \bar{u} \square \bar{u} n$, of Huesca, Balaguer, Sevilla and the walls of Madrid as indicative of state patronage. These buildings, along with mosques in Córdoba and Sevilla were made with cut stone and featured reused Roman and Visigothic stone, including decorated pieces, such as capitals. ${ }^{169}$ Azuar Ruiz argues that dressed stone should be understood as a display and reinforcement of Andalusi caliphal power. ${ }^{170}$ He supports this position by pointing out that the decline of the caliphate coincided with a technical shift from stone to tapial construction. ${ }^{171}$ The appearance of tapial fortresses and walls in

\footnotetext{
${ }^{167}$ For examples of castles used in rebellion against the king, see Barton, The Aristocracy, 169-170 168 "Historia Silense," 37.

${ }^{169}$ Rafael Azuar Ruiz, "Las técnicas constructivas en al-Andalus. El origen de la sillería y del hormigón de tapial," V Semana de Estudios Medievales, Nájera, 1 al 5 de Agosto de 1994 (Logroño: Instituto de Estudios Riojanos), 1995, 125-142, 127-131. The author explains that the most important ninth century fortresses (Mérida, Sevilla and Córdoba) reflect a Syrian influence because 'Abd al-Ra $\square$ mān II wished to incorporate eastern Umayyad strategies of referencing power through building. The pattern of incorporating visible Visigothic and Roman elements is not discussed.

${ }^{170}$ Azuar Ruiz, "Las técnicas constructivas," 135. He also makes the argument that practically speaking, because stone was a more labor-intensive and costly material, only the caliphate would have had the resources to support this method of construction.

${ }^{171}$ P.A. Jaquin, C.E. Augarde, and C.M. Gerrard, "Analysis of Tapial Structures for Modern Use and Conservation," in Structural Analysis of Historical Constructions; Possibilities of Numerical and Experimental Techniques, ed. Claudio Modena, Paulo B. Lourenço, and P. Roca (London: Taylor \& Francis), 2004. Tapial is rammed earth construction, an ancient technique that was used frequently in
} 
centers of rebellion like Badajoz or Calatayud at the end of the ninth and tenth centuries leads the author to posit that the use of tapial indicates a rejection of central, caliphal authority. ${ }^{172}$ In the eleventh century, tapial construction continued to be favored by the taifa kings, who nevertheless used ashlars around windows and doors in an effort to project legitimate authority. ${ }^{173}$ While it seems reasonable to connect the use of stone to the caliphate of al-Andalus and their ambition to project Umayyad power, caution should be taken in equating caliphal authority with stone and opposition to that authority with tapial. $^{174}$

The tenth through twelfth-century architectural phases of monasteries and fortresses serve to strengthen the position that the Duero Valley witnessed the imposition of a political restructuring rather than a literal repopulation. The scholarly work of authors such as Mínguez Fernández and Glick characterize monasteries and fortresses as political centers capable of organizing the cultivation of arable land and military resources critical to the holding of the expanding frontier against al-Andalus. Building upon the authority inherent in the architectural presence of monasteries and their environments (which sometimes included castles), the next chapter will discuss the ways in which visual programs of legitimacy were presented in royal monasteries and served as models for the non-royal patrons seeking to strengthen their position along the frontier.

medieval Spain. Its durability and suitability to the climate of central Spain can be seen in its survival and continued use up to the present day.

${ }^{172}$ Azuar Ruiz, "Las técnicas constructivas," 134-136.

173 Azuar Ruiz, "Las técnicas constructivas," 135-136.

${ }^{174}$ Moreover, a discussion as to why Roman and Visigothic materials were inserted into this larger expression of authority should be undertaken and will be addressed in reference to the fortresses that are situated near frontier churches of Soria in chapter five. 


\section{CHAPTER 3:}

\section{MODELING POWER}

Throughout history, architecture has served as an efficient and powerful tool for the display of authority. Determining the patron or donor responsible for the erection of a building can, when considered alongside the functions of the building, shed light on the sociopolitical structure of the community. Such an analysis is rarely straightforward, however. In the medieval world, scholars have struggled to define the nature of the authority projected by ecclesiastical spaces, whether they should be considered 'secular,' 'sacred,' or some combination of the two. Fortunately, the difficulty in disentangling these notions of secular and spiritual authority has prompted fruitful discussions concerning how these spheres of influence intersect, complement, and compete for power. $^{1}$

In Iberia, monasteries served as particularly important stages for the interplay of secular and spiritual facets of authority. ${ }^{2}$ The monastery owned property that supported

\footnotetext{
${ }^{1}$ Thomas W. Barton, "Constructing a Diocese,"; M. Pilar Mogollón Cano-Cortés, "Manifestations of Power and Visual Culture: Some Examples in Extremaduran Mudejar Architecture," in Medieval Encounters 12, no. 3 (2006): 341-59; Heather Ecker, "How to Administer a Conquered City in al-Andalus: Mosques, Parish Churches and Parishes," in Under the Influence: Questioning the Comparative in Medieval Castile, ed. Cynthia Robinson and Leyla Rouhi (Leiden; Boston: Brill, 2005); Mínguez Fernández, "Pervivencia y transformación,"; Daniel Rico Camps, "El claustro de San Pedro el Viejo de Huesca: pascua, bautismo y Reconquista," Locus amoenus 7 (2004): 73-97.

${ }^{2}$ One of the fertile areas driving the conversation is prominent role that churches and monasteries played in the acquisition and distribution of goods and territories. Wills and administrative records shed light on how
} 
agricultural and pastoral production. It collected rents and revenues from these properties and benefitted from the donations and offerings of pious households. Frequently, the monks themselves were the sons and daughters of property holders of varying social importance, and the churches and elite burial precincts associated with monasteries made them a natural point of contact between multiple facets of society. Tenuous northern Christian kingdoms relied upon these religious and economic centers, and they in turn profited from the patronage of the court. In this study I argue that frontier settlers of the Duero Valley deliberately modeled their own attempts to construct a legitimate image after those that had been visually articulated at royally patronized monasteries such as San Millán de la Cogolla (La Rioja) and San Juan de la Peña (Huesca). This chapter seeks to discuss the ways in which their remarkable landscapes, fabled histories, and impressive architecture conferred power on their patrons.

In 2003, Janice Mann argued that King Sancho III Garcés, el Mayor (1000-1035) deliberately rebuilt the monasteries of San Millán de la Cogolla, San Juan de la Peña, and the crypt of San Antolín (Palencia) to symbolize the strength and security of his rule. ${ }^{3}$ Mann persuasively demonstrated that Sancho sought to appropriate the sanctity of these institutions and visibly insert his legacy into the fabric of the reconstructions carried out under his patronage. Legitimacy for legitimacy's sake was not Sancho's principal motivation, however. Rather, the author concluded that the volatility of the local

churches received donations, bestowed goods and properties, sometimes through hereditary agreements, and participated in existing judicial processes to protect their appurtenances. Through their investigations, scholars reveal the often ambiguous relationship between monks, priests, and the lay community. Most studies are regional in nature but the following provide an overview of current trends: Bowman, Shifting Landmarks; Davies, Acts of Giving; Teofilo F. Ruiz, From Heaven to Earth; the Reordering of Castilian Society, 1150-1350, (Princeton; Oxford: Princeton University Press), 2004, Susan Wood, The Proprietary Church in the Medieval West (Oxford University Press), 2006.

${ }^{3}$ Mann, "A New Architecture," 245. The political framework of this article strongly shaped my approach to this dissertation and Mann's recent volume, Romanesque Architecture, informs a large part of the following discussion. 
sociopolitical and religious circumstances permitted the king to expand his sovereignty over neighboring kingdoms and shape the Episcopal and monastic structure of the frontier. ${ }^{4}$ The success of his rule stemmed in part from the artful presentation of himself as a strong and secure leader through his architectural projects, which to Mann, were a deliberate break from the earlier 'Mozarabic' style.

According to the author's analysis, the architecture found at San Millán, San Juan, and San Antolín benefitted the political agenda of King Sancho, whose patronage of the complexes was well known. ${ }^{5}$ Building at prosperous monastic sites that celebrated their antiquity through the presence of anchorite caves and earlier architectural phases bolstered the image of security that the king wished to project. I propose that Mann's explanation for how components such as anchorite caves advanced Sancho's political agenda could likewise apply to patrons without court ties at churches and monasteries along the Duero frontier. Moreover, Sancho was not the first patron to exploit distinctive topographies as a means toward securing favor, rather, he was one link in a chain stretching back to antiquity that placed enormous value in sacred landscapes.

During the transitions of power that occurred in the wake of political upheaval, churches and monasteries were acquired by patrons or abbots who appear to have favored storied topographies and elite imagery. On the one hand, the status of the patron was less important than the status of the site in these outlying areas; on the other hand, the commissioning of stone architecture, donations, and elite burial precincts elevated the

\footnotetext{
${ }^{4}$ Mann, “A New Architecture," 235-237. Mann astutely points out that the apparent ambition on the part of King Sancho to nation-build has been overlooked by historians because they were distracted by outdated notions of Sancho as a great "Europeanizer."

${ }^{5}$ Mann, "A New Architecture," 235, 243. For another point of view, that the planning of monasteries in the Upper March were predominantly influenced by preexisting buildings, see Gerardo Boto Varela, "Topografía de los monasterios de la marca de Hispania (ca. 800- ca. 1030)," in Monjes y monasterios Hispanos en la Alta Edad Media, ed. José Ángel García de Cortázar and Ramón Teja (Aguilar de Campoo, 2006), 159, in particular.
} 
images of both patrons and churches. The rock formations and caves that dominate the cultic centers of San Millán and San Juan align these foundations with ancient sacred precincts that predate the monastic foundations. The earliest builders took full advantage of their spectacular settings by inserting architectural forms that represented their regional control. Subsequent patrons built at San Millán and San Juan in order to benefit by their association with the holy site. Important to the success of this strategy, however, was the maintenance of previous legitimizing structures as well as the sacred landscape because these elements illustrated the site's holy history. The visual culture at these foundations and others, like San Antolín (Palencia), offered a ready-made model for ambitious men and women of lesser rank to copy in the contested country of the Duero basin. $^{6}$

\section{San Millán de la Cogolla}

Clinging to the side of a mountain, the upper monastery of San Millán de la Cogolla, called Suso, extends from the living rock into a stone basilica (figure 13). Depending upon the season and its attendant foliage, the small, sand-colored church is visible from the road and the lower monastery of San Millán de la Cogolla, called Yuso. Today, the church consists of a double apse, double nave, ${ }^{7}$ and porticoes that are attached

\footnotetext{
${ }^{6}$ The appearance of significant donations made be women to frontier monasteries in charters suggests that an investigation of the material signs of female patronage or feminine monasticism in the Christian conquest of al-Andalus could be fruitful.

${ }^{7}$ Monreal Jimeno, "Arquitectura religiosa de oquedades," 247. Other cave or semi-cave churches feature a double nave and double apse. The reasons for this floor plan vary and Monreal Jimeno states that there is not a satisfactory answer (whether or not they are located in caves or semi-caves). Common motivations for the double church and altar include the dedication of the monastery to more than one saint, varying sepulchral functions, double houses, or the need to preserve one church for monastic use only.
} 
to the southern façade of the main structure (figure 14). ${ }^{8}$ To the east of the apses are spaces of uncertain function. ${ }^{9}$ The hillside behind the northern side of the church is made up of many caves, which are thought to have been the dwellings of anchorites. ${ }^{10}$ Entering the portico, one moves westward between stone sarcophagi in order to access the church through the horseshoe arched doorway piercing the southern wall of the double nave. To the east, the vaulted twin apses and eastern chambers appear through their horseshoe arches. Looking westward from the apses of San Millán, the axis of the basilica shifts by about fifteen degrees to the north, in keeping with the contour of the hill. This bend is rendered particularly visible by the arcade separating the naves. Halfway between the apses and the western wall, the arcade changes in appearance and direction. The three eastern arches of the arcade are horseshoe in shape and support a smaller arcade of six arches, which in turn carry a wooden roof (figure 15). ${ }^{11}$ Awkwardly joined by a rectangular pier, the western half of the arcade consists of two semicircular arches and

\footnotetext{
${ }^{8}$ The apses are actually oriented toward the northeast, with the porticoes attached to the southeast facade. The incorporation of the anchorite caves into the shrine/church was more important than an orthodox orientation. For the sake of clarity, I will describe the church as if it were oriented to the east because the eleventh century section, like the mountainside it follows, more closely conforms to the cardinal directions. A subject of controversy is the original orientation of the tenth century church, whether toward the mountain cave or toward the extant apses. For a summary of scholarly opinions, see Luis Caballero Zoreda, "La iglesia de San Millán de la Cogolla de Suso: lectura de paramentos," in arte Medieval en La Rioja: prerrománico y románico: VIII Jornadas de Arte y Patrimonio Regional, ed. Ignacio Gil-Díez Usandizaga (Logroño: Instituto de Estudios Riojanos, 2004), in particular, 15-20.

${ }^{9}$ Caballero Zoreda, "Suso," The author discusses the difficulty in assessing either the age or function of these spaces due to the confusion caused by subsequent building and restoration. Nevertheless, he theorizes that they were erected some time before the early eleventh century expansion. 54, 59-62.

${ }^{10}$ Hermits and anchorite communities have long been associated with caves on the Iberian Peninsula. For a detailed overview, see A. M. Martínez Tejera, "La realidad material de los monasterios y cenobios rupestres Hispanos (siglos V-X)," in: Monjes y monasterios Hispanos en la Alta Edad Media, ed. J. A. García de Cortázar and Ramón Teja (Aguilar de Campoo, 2006), 62-67 in particular. Martínez Tejera discusses how even the early monastic communities were probably economic centers, particularly in rural parts between the fifth and tenth century. He further explains that the financial and influential power wielded by these monks caused tensions between them and the ecclesiastical hierarchy.

${ }^{11}$ The original shape of these arches is not clear today but Gómez Moreno reconstructs them as semicircular. Gómez Moreno Iglesias Mozarabes, 299. The principle door appears to be coetaneous with the eastern half of the arcade. The door creates a straight line with the central arch (which is also slightly wider), suggesting a deliberate alignment, according to Caballero Zoreda, "Suso,"35.
} 
they serve as a support for the barrel vaults above each nave. Three caves open from the northern wall of the church and outside of the basilica, additional caves and hollows are visible in the face of the mountain. A natural spring is located approximately thirty meters west of the monastery. ${ }^{12}$

Looking at the three caves accessible from within the church, the western cave contains graves excavated into the rock, ${ }^{13}$ the central cave shields the twelfth-century cenotaph of San Millán, who was also called Aemilianus, and the purpose of the eastern cave is subject to debate. ${ }^{14}$ Although all three caves are presumed to have served the needs of the eremitic community, tradition identifies the oratorium of San Millán as his resting place before the translation of his relics to the lower monastery of Yuso in $1030 .{ }^{15}$

\section{Holy History}

According to San Millán's biographer, San Braulio, the saint began life as a simple shepherd. Around the age of twenty, he experienced the call to the hermit's life in a dream and promptly began study under a hermit named Felix. In an effort to avoid the

\footnotetext{
${ }^{12}$ Pilar Sáenz Preciado, “Arqueología en San Millán de la Cogolla: situación actual y propuestas de intervención," Berceo 133 (Logroño, 1997): 141-162, 154. A blocked well was discovered in the course of a recent excavation in the semi-subterranean space beneath the foundation of the rooms appended to the south west section of the eleventh century extension. The depth and nature of the well were not reported by the excavators, who had to stop at a depth of $286 \mathrm{~cm}$ because of the precarious location of the well.

${ }^{13}$ Martínez Tejera, "La realidad material de los monasterios," 70-77. The following Spanish terms: "monasterio," "eremita," and "cenobio" can sometimes be found almost interchangeably. Generally speaking, isolated communities of monks seem to have developed around the cells of living hermits, or after their death, their graves. The apparent contradiction in describing these communities in both eremitic and cenobitic terms can be understood in light of the fact that the anchorites sometimes pursued solitary life punctuated by limited communal interaction (the sharing of the Eucharist, for example). Martínez Tejera furthermore stresses the potential for cave churches in particular to have multiple functions, both parochial and civil, (ibid., 87). See also Ana Isabel Lapeña Paul, El Monasterio de San Juan de la Peña en la Edad Media; desde sus origenes hasta 1410 (Zaragoza: Caja de Ahorros de la Inmaculada de Aragón, 1989), 52. ${ }^{14}$ The principle question is whether or not this chamber acted as the apse for the earliest church, oriented toward the north, or as an adjacent space to a more conventionally oriented structure.

${ }^{15}$ Gómez Moreno, Iglesias Mozarabes, 299-300, fn 1. Gómez Moreno identifies the westernmost cave as the place where San Millán isolated himself during fasts and the easternmost cave as the earliest oratory for the tenth century church. See also Martínez Tejera, "La realidad material de los monasterios," 77.
} 
distraction of the multitudes that sought him out, San Millán struck out alone to the remote and secret places of Mount Dircetio, where he attracted a few followers. ${ }^{16}$ The caves behind and near the present day San Millán de Suso are said to be the cells of the founding saint and his disciples.

A. M. Martínez Tejera explains that San Millán fell into the category of "eremitas deshonestos." They were so-called because in the eyes of the Church, the large number of men and women establishing monastic hermitages without any formal training were frauds. However, the popularity of San Millán appears to have propelled church authorities to place him as the presbyter for the church of Berceo in an effort to sanction him within their hierarchy. He was soon relieved of the position, however, and at that point returned to the solitary life of the cave hermit. ${ }^{17}$

Before his death in 574, San Millán was credited with several miracles which were key in building the reputation of the site as a place with curative power. One such miracle involved a wooden beam that the saint miraculously lengthened so that it would be serviceable in the construction of his hospital. A piece of this beam was preserved as a relic and was credited with the curing of the sick. It may still be seen through the tiny window of its enclosure: a late medieval pilaster covered with blue azulejos. ${ }^{18}$ Another tradition holds that the oil lamp suspended over the grave of the saint would at times

\footnotetext{
${ }^{16}$ Martínez Tejera, "La realidad material de los monasterios," 65. San Braulio was the bishop of Zaragoza (d. 651).

${ }^{17}$ See Juan B. Olarte, Monasterio de San Millán de la Cogolla, Suso y Yuso (León: Edilesa, 1995), 13. His fellow clerics accused him of squandering church funds, a charge later qualified by popular tradition as stemming from the accusers' envy of the saint and his tendency to give everything away to the poor and needy out of love. His isolated existence appears to have nevertheless included his 'intimates or servants' and "virgenes consagradas a su servicio" (virgins consecrated to his service) according to San Braulio. Martínez Tejera reports that San Millán is not the only hermit to have enjoyed servants or other material possessions. This was one of the sources of conflict between the church hierarchy and the independent hermits or monasteries, "La realidad material de los monasterios," 65.

${ }^{18}$ Olarte, Suso y Yuso, 30. The pilaster is itself supported by a base roughly formed from the rocky floor of the site.
} 
remain lit even after the oil disappeared, or alternatively, money would miraculously appear to cover the cost of new oil. A relic of this oil was preserved by the monks and like the wooden relic, it attracted pilgrims seeking healing. ${ }^{19}$

The early history of the hermitic site is difficult to reconstruct from the texts and material evidence. The author of the Vita Sancti Aemiliani, a hagiographical account of the saint, was written by San Braulio in the early seventh century. According to Braulio, a small group of monks were already in place and the site was attracting pilgrims before San Millán's death. ${ }^{20}$ If the site was already a pilgrimage destination, some sort of structure may have been warranted. That San Braulio described one of San Millán's miracles as related to the construction of a nearby hospital may suggest that buildings were associated with San Millán by the time of the Vita Sancti Aemiliani. In addition to medieval accounts, surviving traces of a "premozárabe" construction support the position that prior to the tenth century building, some type of structure augmented the caves of San Millán and his followers. ${ }^{21}$ By the second half of the tenth century, most scholars are

\footnotetext{
${ }^{19}$ These stories are related by Ángeles García de la Borbolla, "El papel de los monasterios en las peregrinaciones medievales: cultos locales y tráfico de reliquias," in Monasterios y peregrinaciones en la España Medieval, ed. J. A. García de Cortázar and Ramón Teja (Aguilar de Campoo: Fundación Santa María la Real, 2004). Additional traditions, including the saint's combat with Satan, may be found in Olarte, Suso y Yuso, 13, 21-22.

${ }^{20}$ Mann, Romanesque Architecture and Its Sculptural Decoration, 53, Martínez Tejera, "La realidad material de los monasterios," 65. The ivory panels at the center of Julie Harris' dissertation are scenes from Braulio's Vita of San Millán, The Arca of San Millán de la Cogolla and Its Ivories (PhD dissertation, University of Pittsburgh, 1989), 1-9. In her dissertation, Harris explains that Bishop Braulio's Vita Sancti Aemiliani was written as a liturgical text in order to promote the cult of San Millán. A letter preceded the Vita, addressed to his brother Fronimiano, the Abbot of San Millán, and it requested that the abbot compose a mass to for the celebration of the saint's feast day (November 12) (ibid., 27-29, 34-35).

${ }^{21}$ Caballero Zoreda, "Suso," 24-26, Caballero Zoredo reports that the categorization of remains believed by Gómez Moreno, F. Íniguez Almech, and R. Puertas Tricas as predating those of the tenth-century structure is further supported by his stratigraphic analysis. See also the possible Visigothic church uncovered by the 1970 excavations described by J. Andrio Gonzalo, E Martín Rivas, and Philippe du Souich, "La necrópolis medieval de San Millán de la Cogolla de Suso (La Rioja)," Berceo 130 (1996): 49. 106. Archaeologists are hesitant to fix a specific date to this early material but there is little to suggest a period of abandonment at the site, see Caballero Zoreda, "Suso," 34-35. On the other hand, the limited area examined by Andrio Gonzalo, Martín Rivas, and du Souich did not include identifiable eighth-century graves but they acknowledge that this is not conclusive in "La necrópolis medieval," 106.
} 
confident that the small monastic foundation included a church. The in situ portions of this phase are: the eastern section of the arcade, the vaulted apses and horseshoe arches, and parts of the southern façade. ${ }^{22}$

Although San Millán de la Cogolla eventually became an important stop along the Way of St. James, its holy reputation predated the influx of pilgrims in the eleventh and twelfth centuries. The mystical calling of a shepherd who isolated himself in a mountain cave sanctuary, battled Satan, and miraculously provided bread, wine, and healing to pilgrims was a powerful foundation for the monastery. Despite the Islamic conquest of the Riojan region, monastic activity appears to have continued to some degree. The situation changes in the tenth century, which witnesses a time of rapid growth and prosperity for the monastery. ${ }^{23}$ In addition to donations to, and acquisitions made by the monastery, the reputation of the saint and his miracles extended beyond La Rioja and by 961, there are references to San Millán's feast day in all of the Mozarabic Calendars. ${ }^{24}$ The early tenth century also appears to have been the period for the development of a scriptorium capable of producing books at the monastery. ${ }^{25}$

\footnotetext{
${ }^{22}$ Mann, Romanesque Architecture and Its Sculptural Decoration, 53, fn. 50. The number of forged documents is considerable and the date of consecration varies from one source to another. With few exceptions, most scholars accept that most of the eastern portion of the church dates to the second half of the tenth century.

${ }^{23}$ Harris, "Ivories," 12-13. Harris, after Ubieto Arteta, suggests that in lieu of a formal monastery, only a collection of hermits survived the Islamic invasion and dominion of La Rioja and that the earliest authentic document is the donation of a house, salt, and well to the monastery from Munio Jiménez de Anan in 942. San Millán was part of a larger pattern of monastic houses that record a significant increase in transactions for the tenth century, a topic more closely examined below.

${ }^{24}$ Harris, "Ivories," 35-38.

${ }^{25}$ Most scholars agree with an early tenth-century date for a scriptorium at San Millán, see Soledad Silva y Verástegui "El monasterio de San Millán de la Cogolla: tres hitos importantes en su actividad artistica," Berceo 133 (1997): 27-50, 29-30 in particular. See also Harris, "Ivories," 15-16, and 31-32. Discussing the motifs found throughout the earliest manuscripts, the Glosario (Madrid, B.A.H., cod. 46) the Vidas de Santos (Madrid, B.A.H., cod. 13), and particularly the Exposicion de los Psalmos de Casiodoro (Madrid, B.A.H., cod. 8), the author describes stylistic influences as both Nordic and Muslim in nature. In 2004, José Angel García de Cortázar suggests that the scriptorium of San Millán, “...rivalizó con el del relativamente cercano monasterio de San Martín de Albelda en la creación de algunos de los más famosos codices hispanos altomedievales." in "La implantación monastic en el Camino de Santiago: ¿Monasterios
} 
In the late tenth or early eleventh century, the church suffered a terrible fire.

Although there is some uncertainty over the true cause of the fire, by the twelfth century, medieval authors attributed the destruction to al-Man $\square$ ūr (976-1002), who led successful raids deep into Christian kingdoms and sacked numerous churches and monasteries. ${ }^{26}$ Whether or not al-Man $\square$ ūr was actually responsible, connecting the notorious commander to the devastation at San Millán would have placed the monastery in the same circle as Santiago de Compostela (sacked 997) and thereby marked it as a survivor of persecution. Miraculous events and royal activities continued to elevate the reputation of San Millán during the eleventh century. ${ }^{27}$

Reputations of supernatural saints were plentiful in the eleventh century. What permitted San Millán de la Cogolla to stand out from its competitors were the topographical references to its ancient holy past. For both monastic authorities and lay patrons, the erection of grand arches and vaults not only constructed monumental interior spaces but provided access into the mountain. Through these portals the rock-cut tombs not only bore witness to a divine past but presented potential donors the opportunity to

del Camino o monasterios en el Camino?" in Monasterios y peregrinaciones en la España Medieval (Aguilar de Campoo: Fundación Santa María la Real, 2004), 81.

${ }^{26}$ Mann, Romanesque Architecture and Its Sculptural Decoration, 53-54; Caballero Zoreda, "Suso," 44. Most scholars, from Gómez Moreno forward, consider this event the chief reason for the church's reconstruction and expansion in the eleventh century under the patronage of Sancho el Mayor. In 1973, Antonio Ubieto Arteta threw doubt on the notion that al-Man $\square$ ür sacked the church in 1002 . Since then, a number of scholars have raised the possibility that the fire was the result of tensions between the Navarese and the Castilians or some other cause but without additional archaeological data, blame for the fire is still generally assigned to al-Man $\square$ ür.

${ }^{27}$ Harris, "Ivories," 19-20, 23-24. Three documents testify to the translation of San Millán's remains from his tomb to a precious "arca," decorated with jewels and placed at the altar. In 1030, supernatural intervention prevented an attempt to translate the remains of the saint from his cave sepulcher and this together with miracles of healing continued to attract pilgrims According to tradition, Sancho's son García III Sánchez (1035-1054), king of Navarra, attempted to move the saint's relics from their location at the altar to the Virgin to his newly founded church of Santa María of Nájera on May $28^{\text {th }}, 1053$. The vessel would not budge, prompting the king to declare that he would therefore build another church so that pilgrims would be able to venerate the relics more easily. The increasing importance of San Millán as a pilgrimage site is supported by their acquisition of the remains of San Felix, which were translated from the Bilibio Castle to the monastery at the end of the eleventh century. The monk Grimaldo describes eight miracles in association with the event, García de la Borbolla, "El papel de los monasterios," 5. 
join earthly and heavenly symbols of power and status. ${ }^{28}$ The tomb of San Millán provided yet another focal point and visual reminder of the miraculous power not merely associated with the saint but with the place. ${ }^{29}$ As the monastery acquired more territory and political influence in the eleventh century, donations and possibly internment provided avenues through which people could become associated with legitimate power, from pilgrim to king.

\section{San Juan de la Peña}

Like San Millán de la Cogolla, the San Juan de la Peña landscape also bore witness to its holy foundation and became a magnet for patrons who in turn expanded the complex, enriched its treasures, and donated their persons and properties to its service. Two hundred kilometers to the east of S. Millán, the monastic site of San Juan de la Peña can also claim hermitic saints and a devastating brush with al-Mansur. ${ }^{30}$ Located in the foothills of the Pyrenees, the position of the monastery beneath a massive, reddish stone cliff-face presents a stunning sight for the approaching traveler (figure 16). The complicated floor plan of the San Juan de la Peña monastic complex includes multiple building phases situated on two main levels (figure 17). In addition to the earliest extant building, the lower church, there is an upper church, pantheon, cloister, chapels and out buildings. The site makes the most of its rocky location: the sanctuaries of the upper and

\footnotetext{
${ }^{28}$ The interaction between the natural and man-made elements will be more thoroughly described and analyzed below.

${ }^{29}$ I have not discovered a date for the installation of the relic of the miraculously lengthened wood; it was probably displayed early on, given the early date of San Millán's hagiographical record.

${ }^{30}$ The monastery is approximately 10 kilometers southwest of Jaca, as the crow flies but its position high in the mountains requires a circuitous approach.
} 
lower churches are oriented toward the mountain, tombs are cut into the rocky floor, and the overhanging rock dominates the site.

Like San Millán, the earliest church of San Juan is wedded to the living rock and probably dates to the tenth century. ${ }^{31}$ The small, compact church was originally nearly seven meters square with twin naves ending in squared-off apses. ${ }^{32}$ Unlike San Millán, however, the apses are covered with barrel vaults and were shaped out of the cliff rock. The orientation of San Juan is to the southeast, directed toward the mountain and immediately adjacent to a subterranean spring, accessible through an arched portal in the north east wall. ${ }^{33}$ Horseshoe arches dominate in the tenth-century church, as they do at San Millán. These elements frame each apse, the niches within each apse, and the small communicating window between apses. Dividing the nave, two horseshoe arches spring from a central column and support the twin barrel vaults.

Sometime around 1027, the tenth-century church was expanded to the northwest. As Mann has pointed out, the abrupt transition between building phases is similar to San Millán due to the intervention of Sancho el Mayor (1000-1035) at both sites. Six steps and an enormous pier mark the joining of the two sections (figure 18). The height of the barrel-vaulted naves is maintained between the two different phases, despite the drop in the floor level. ${ }^{34}$ The newer, northwest arcade is formed by two semicircular arches, similar to those that support the vaulted chamber to the northeast, called the Sala del

\footnotetext{
${ }^{31}$ Gómez Moreno and others following his reasoning previously dated the church to the mid ninth century, Iglesias, 31, 39-40. The document that prompted this attribution has since been widely dismissed, leading more recent scholars, such as Lapeña Paul to assign a tenth-century date to the structure. See also Lapeña Paul, El Monasterio de San Juan, 50; Mann, Romanesque Architecture, 55, see fn. 59.

${ }^{32}$ The walls of this early church are between one and one and a half meters thick. Gómez Moreno, Iglesias, 34-35.

${ }_{33}$ Gómez Moreno, Iglesias, 33-35.

${ }^{34}$ Mann, Romanesque Architecture, 55. The northwest extension is about a meter and a half lower than the earlier church.
} 
Concilio. $^{35}$ The vaulting techniques, dimensions, and architectural style of the Sala del

Concilio suggest that it was built around the same time as the lower church expansion. ${ }^{36}$

Today, a stair ascends from the Sala del Concilio to reach the main level of the

monastic complex. An irregularly-shaped courtyard encloses the Panteón de los Reyes, an elite burial space adjacent to the upper church and closely situated to the anchorite caves associated with holy men. Located in the courtyard that precedes the northeast entrance of the upper church, the Panteón is open to rock and sky. The Panteón consists of twenty-three arches, many of them containing carved reliefs, set within a stone wall that meets the overhanging rock above. ${ }^{37}$ Funereal inscriptions range in date from 10821325 and thus indicate that the Panteón was initiated before the consecration of the upper church, which took place on December $4,1094{ }^{38}$ The extension to the lower church (and probably the addition of the Sala del Concilio) preceded the erection of the upper church

\footnotetext{
${ }^{35}$ See Pamela Patton, "The Cloister of San Juan de la Peña and Monumental Sculpture in Aragon and Navarre" (PhD diss., Boston University, 1994), 12. According to tradition, Ramiro I led a council meeting in 1057 in the Sala del Concilio; although this is not borne out by the historical record, the designation remains. Patton, after Canellas and San Vicente, Aragón (Zaragoza), 1979, favors the opinion that it served as a chapter house rather than a dormitory because of the dampness caused by the subterranean spring therein.

${ }^{36}$ Gómez Moreno, Iglesias, 33-35, 39.

${ }^{37}$ The effect is almost like that of shallow arcosolia. Some have been damaged and there is the suggestion of a twenty-fourth arched installment that is interrupted by the north eastern wall of the upper church.

${ }^{38}$ Concerning the precedence of the lower church and Sala before the construction of the upper church, see Lapeña Paul, El Monasterio de San Juan, 69. For a catalog of the inscriptions, see A. Durán Guidol, "Inscripciones medievales de la provincia de Huesca," Estudios de la Edad Media en la Corona de Aragón 8 (1967): 45-155. There are many graves at San Juan de la Peña. Funereal inscriptions located in the Panteón (and elsewhere) may refer to graves behind the wall, in the church or cloister. Evaluating these inscriptions, Lapeña Paul concludes that people of all classes were buried there. There is also a deposit of bones in the ossuary at the back of the Sala de Concilio at the base of the living rock, according to Ana Isabel Lapeña Paul, San Juan de la Peña; guía histórico-artística (Diputación General de Aragón, 1986) 9, 14. These inscriptions shed light on the numerous ways in which donors might offer their goods and bodies, and those of their heirs, to the monastery. Comparing these passages with related documents can further reveal the complicated interactions between the monastery and the faithful. For example, on the intrados of a cloister arch is a thirteenth-century inscription describing the donation of a palace in Villanueva to the monastery by the deceased, Aznar de Aruej. Lapeña Paul explains that a separate document reveals that Aznar Pérez, son of don Pedro de Aruej, became a monk in 1257 and brought his right to inherit this villa in Villanueva and other goods as a donation to the infirmary. The author also presents instances in which fraud or coercion may be suspected in Lapeña Paul, El Monasterio de San Juan, 91-101, particularly 94, 99.
} 
and the stout dimensions of the lower church's walls support the possibility that the planning of the upper church had begun during the former's construction.

The upper church was commissioned by the Aragonese ruler, Sancho Ramírez (1063-1094), and stands directly above the lower church phases. Like the lower church, it is oriented toward the cliff rock. ${ }^{39}$ From this church, a horseshoe arched portal leads to the twelfth century cloister through the southwest wall of the upper church. Scholars have long considered the doorway an artifact of the tenth century church, removed during the course of the eleventh century expansion of the lower church and inserted into the upper church. This assumption is based primarily upon the shape of the arch and the remnant of a carved impost, which suggest a stylistic relationship with the arches of the lower church. ${ }^{40}$ A Latin inscription may be read across the voussoirs of the arch; it announces that this door is a gateway to heaven for the devotee who unites faith with God's commandments. ${ }^{41}$ Beneath the rocky canopy is the last extant installment to the San Juan de la Peña complex relevant to the time period considered for this dissertation, the cloister. According to Pamela Patton, the rectangular cloister walk dates to the twelfth century and measures approximately seven by eleven meters. ${ }^{42}$ The uniquely

\footnotetext{
${ }^{39}$ Patton, Pictorial Narrative, 24, 13-14; Lapeña Paul, El Monasterio de San Juan, 69. The church was actually consecrated by Pedro I in the year of Sancho Ramírez's death.

${ }^{40}$ Gómez Moreno, Iglesias, 38. The faint trace of a second, bricked-in portal along the same wall increases the confusion surrounding the function of the door. While most scholars seem to interpret the filled-in door as fulfilling an earlier role there is a precedent for the concurrent presentation of two portals. Two portals that may have been concurrent in use, one horseshoe in shape the other semi-circular have been identified at Santa María de Wamba (Valladolid). Along the southern wall of the church of San Esteban de Gormaz, there appears a horseshoe arched portal only a couple of meters to the left of a semi-circular arched portal. Questions likewise surround this unusual organization but one of the theories is that the left-handed doorway was designed to facilitate the catechumens/converts from Islam.

${ }^{41}$ The inscription and transcription provided by Antonio Durán Guidol in "Inscripciones medievales," reads: PORTA / PER / HAC. C /AELI FI/T PVIA. CVIQ. / FIDELI / (cross) / SI S/TVDE/AD FI/DEI IV/NGE/RE IVSS/A D/EI (Porta per ha(n)c caeli fit p(er)via cuiq(ue) fideli / si studead fidei iungere iussa Dei). See also Lapeña Paul, Guía, 19, and Patton, "The Cloister of San Juan,” 11, fn. 34.

${ }^{42}$ Patton, Pictorial Narrative, 28.
} 
roofless cloister features semicircular arches springing from carved capitals that rest on single or grouped columns.

Originally, the arcades were flanked by multistoried buildings to the northwest, the upper church to the northeast, and the cliff face to the south—at the base of which flows a spring. ${ }^{43}$ This portion of the complex, like all of the others, was designed to emphasize its sacred setting. Not only does this perambulatory structure maximize its exposure to the rock by rejecting typical overhead vaults, but its close proximity to yet another natural spring is significant.

\section{Holy History}

Although San Juan de la Peña has competing foundation traditions, both incorporate the mountainous setting for the monastery in their stories. The best known account begins with young Votus of Zaragoza's deer hunt in the wilderness. Chasing his prey on horseback, Votus was only saved from pitching over a cliff after it by the intervention of Saint John, who miraculously stopped Votus' horse at the edge. After he climbed to the bottom of the rocky ledge, Votus discovered a church dedicated to Saint John and the dead but uncorrupted body of the resident hermit, named Juan de Atarés. ${ }^{44}$ Votus returned to Zaragoza and told the miraculous story to his brother Felix. Both men determined to restore the hermitage and devote their lives to the saint. Their example

\footnotetext{
${ }^{43}$ The cloister is on a different axis than that of the lower and upper churches. I will return to the significance of this shift below.

${ }^{44}$ The hermit was lying on an inscribed stone that provided his name. Lapeña Paul, El Monasterio de San Juan, 50. The story of Votus and his discovery of San Juan de la Peña is recalled in The Chronicle of San Juan de la Peña and is also described in the twelfth century Libro de San Voto.
} 
was followed by Benedict and Marcellus, who, "Because they dwelled there and because of their exemplary way of life, all Christians held that cave in great reverence."45

A second tradition designates the monastery as one of the many mountain refuges to which Christians fled in response to the Muslim invasion. The Chronicle of San Juan de la Peña explains that great fortifications were raised at San Juan de la Peña on Mount Pano (as at the other retreats) but that these were completely destroyed by Muslim forces led by "Duke" Abd al-Malik. ${ }^{46}$ Although the conflation of San Juan de la Peña with the monastery at Plano was probably an error, the notion that San Juan was a fortress at some point can be understood in light of the easy defensibility of its mountainous site and fresh water sources. A second account from The Chronicle supports the impression that medieval contemporaries viewed San Juan as a potential refuge from attack:

Because of their fear of the Moors, no one was able to resist them. On the contrary, fleeing and abandoning their homes because of fear and terror of the Moors, the Christians gathered in the cave of San Juan de la Peña as if it were an incomparable refuge. There were about six hundred Christians together with their wives, children, and all their possessions who gathered in the cave where the church of Saint John the Baptist had been built. They enlarged this and adorned it in various ways to the honor of God and Saint John."

\footnotetext{
${ }^{45}$ The Chronicle of San Juan de la Peña, xi-xv, 5-7. The italics are mine in order to bring attention to the fact that it is the natural element of the cave that receives the chronicler's attention in this account, a topic to which I will return below.

${ }^{46}$ The Chronicle of San Juan de la Peña, 5-6, fn. 21, 23. Nelson points out in her footnotes that although the Muslims identified correspond to eighth-century Cordoban emirs, the location given for the monastery, Mount Pano, is actually located in Sobrarbe, a region some fifty kilometers to the east of San Juan de la Peña. While the monastery at Pano appears to be distinct from the monastery at Peña, Lapeña Paul points out that is very difficult to establish one way or another if the monasteries were in some way connected in El Monasterio de San Juan, 56-59. Regardless of a connection with the monastery at Pano, there do not appear to be any remains that would suggest a ninth-century fortress at Peña according to Patton, "The Cloister of San Juan," 6, fn. 17.

${ }^{47}$ The Chronicle of San Juan de la Peña, 7-8, fn. 31, 37. The author then describes the translation of Juan de Atarés' body to a richly decorated tomb. This tomb, which was inscribed with the life of the hermit, was placed among three existing altars, to Saint John the Baptist, Saint Julián, and Saint Basilissa; the people then added two of their own, to Saint Michael and Saint Clement. The six hundred Christians settled there and established the monastery, consecrated by the Bishop Iñigo of Aragón. Although the events recounted would place the expansion of the earlier hermitage to approximately 920 , as mentioned above, the precise date for the foundation of San Juan de la Peña is unknown.
} 
At this point it is impossible to know if the above account relates in any way to historical events or is a later construction. The natural defensiveness of the environment has already been mentioned but two additional things may have supported the association of the monastery with supernatural protection. In this and the above earlier account from The Chronicle of San Juan de la Peña, the role of the cave received special attention. In the foundation story, the good lives of the hermits caused the cave to be revered and in this story, the cave as an "incomparable refuge" serves as a backdrop for the church and the later architectural expansions carried out by the refugees.

In addition to the above account in which San Juan successfully protects Christians from Muslim violence, tradition places San Juan (together with San Millán and others) as targets for al-Mansūr's devastating raids around $1000 .{ }^{48}$ Whether or not San Juan was specifically attacked is less important than the impression that the monastery once again survived a period of violent persecution. By the end of the eleventh century, tangible relics and elite graves augmented the significance of the venerable cave-church and contributed to its growth and prosperity. ${ }^{49}$

\footnotetext{
${ }^{48}$ Romanesque Architecture, 57, fn 65. The territory surrounding Pamplona was attacked in 998, 999, and 1006. Although medieval texts do not list San Juan as one of the victims, Mann, after Lapeña Paul, accepts that a scarcity of documents from this period indicates their misfortune.

${ }^{49}$ Lapeña Paul, El Monasterio de San Juan, 103-4. The fourteenth century collection of The Chronicle of San Juan de la Peña places the translation of the hermit Juan de Atarés to the early tenth century but this event does not appear in earlier documents and only the body of San Indalecio is recorded in medieval documents, according to Lapeña Paul. The relics of San Voto and San Felix are believed to have been the remnants found together with a pair of plates beneath the main altar in 1657 by don Pedro de Villanueva. According to José Miguel Pesqué Lecina, "En cuanto a su cronología, Alcolea las sitúa en el siglo XII, como raras pervivencias del mobiliario visigótico hispano. En cualquier caso, debieron de fabricarse en torno al año 1094, cuando se consagró el monasterio bajo de San Juan de la Peña, año a partir del cual habrían de depositarse las reliquias." "Una singular caja de reliquias de San Juan de la Peña," Bolskan: Revista de arqueología del Instituto de Estudios Altoaragoneses 10 (1993): 223-228. Antonio Durán Gudiol lists at least seventy relics for San Juan, including the bread and towel of Christ in "El traslado de las reliquias de San Indalecio a San Juan de la Peña," Argensola: Revista de Ciencias Sociales del Instituto de Estudios Altoaragoneses 109 (1995): 13-24, 22, after M. C. Díaz y Díaz, Libros y librerías de la Rioja altomedieval (Logroño, 1979), 319.
} 
In 1094, Hebrethme of Cluny chronicled ties between San Juan de la Peña and the remains of a first century bishop, San Indalecio. Hebrethme relates how two monks from San Juan, with the help of a mercenary soldier (García) in the service of a Muslim king, braved dangerous taifa wars in order to obtain and translate the remains of San Indalecio and his disciple to San Juan de la Peña from Urci. Securing the relics of San Indalecio significantly amplified the monastery's reputation because he was purportedly one of the first seven bishops of Spain, commissioned directly from Christ's apostles and a companion of the apostle Santiago. ${ }^{50}$ A number of miracles accompanied the donations to the monastery from Sancho Ramírez. ${ }^{51}$ From this point on, reports of miracles and the traffic increased along the nearby pilgrimage route toward Santiago de Compostela. ${ }^{52}$

The survival and prosperity of San Juan over the centuries was obviously due to a number of factors. The reasons that are of interest to this dissertation are how the stories

\footnotetext{
${ }^{50}$ Lapeña Paul, El Monasterio de San Juan, 104. She explains that it is more likely that San Indalecio was the first bishop of Urci, a place near Almería in the fourth or fifth century. See also Nelson, The Chronicle of San Juan de la Peña, 19-20, fn. 73.

${ }^{51}$ Lapeña Paul, El Monasterio de San Juan, 104-106. The Voto de San Indalecio claims that that shortly after San Indalecio was translated to San Juan, ceremonies and processions began to take place annually. The document insists that hundreds of representatives from neighboring regions brought substantial offerings to the monastery, and that this tradition must continue. While there are accounts of the aristocracy journeying to San Juan at Easter time to ask God to send sufficient rain, Lapeña Paul argues that the Voto de San Indalecio is probably false and that it was probably created in the fourteenth and fifteenth centuries in an effort to justify the monastery's expectations of devotion and donations in the face of local resistance. .

52 Janet Nelson credits Ramiro I of Aragón (1035-1063) with connecting Aragonese valleys with the pilgrimage route, thanks to his bridge-building activity. "The Foundation of Jaca (1076): Urban Growth in Early Aragon," Speculum 53, no. 4 (1978): 688-708, 702-703. I am principally concerned with the monastary's sacred claims and history up through the twelfth century, so there is little reason to thoroughly discuss the possible presence of the Holy Grail at San Juan. On the other hand, references pertinent to the twelfth century might include the probably falsified document of 1134 in which it claims the presence of the Grail at San Juan, the vague 1135 reference to a chalice that was exchanged with the king in return for a charter, and the more probable reference of 1399 that records the swapping of the chalice with King Martín I of Aragón for a gold cup. Richard W. Barber, The Holy Grail: imagination and belief (Cambridge, MA: Harvard University Press), 2004, 169. References to precious cups in documents from the twelfth century are also recalled by Lapeña Paul but no mention of the Holy Grail is made. She views these accounts as evidence that during hard economic times, Ramiro II had apparently taken treasures from San Juan that he later repaid. Lapeña Paul, "Aspectos materiales y espirituales en la vida Aragonesa medieval," in Arte y vida cotidiana en época medieval, ed. María del Carmen Lacarra Ducay (Institución Fernando el Católico, 2008), 251, fn 56.
} 
of divine intercession and favor were given visual substance through the setting and design of the monastic site. Although it is difficult to know when and how the legend of the hermit's miraculous revelation became popular knowledge, the survival of architectural phases that privilege subterranean spaces suggest that by at least the tenth century, patrons wished to bring attention to the cave-out of devotion for the hermit, veneration for the cave itself, or some combination of the two. Miracles attributed to San Indalecio persisted in the years following his arrival at San Juan, and this relic, together with those later acquired, no doubt proved an added attraction for pilgrims and for those who wished to be buried nearby.

San Juan de la Peña and San Millán de la Cogolla deliberately capitalized upon their environment. The topographical elements that seem to have best conferred an air of sacredness to these sites were their high locations, caves and tombs. Natural springs also appear to have been important but this is easier to argue for San Juan than at San Millán. At San Juan, natural springs are incorporated into the architectural complex in a prominent fashion, while the spring at San Millán is located in the woods, approximately a hundred feet away from the church. The sound of the water may have been audible from the caves or monastic buildings immediately outside the western enclosure of the church, but this is unclear. ${ }^{53}$ Like the subterranean chambers and use of natural rock for

\footnotetext{
${ }^{53}$ Although today one can hear faint sounds of water near the church's western enclosure wall, this is because the spring empties into a receptacle of later construction. Also, like some natural springs, it appears to flow from the mountainside in more than one place. There is a brief account in an excavation report about a filled-in well beneath the south-western corner of the stone platform beneath what later became the guard house. While it is impossible to know precisely how the water was collected or how noticeable its presence might have been to a medieval audience, the frequency with which springs and naturally fed wells appear in holy settings suggests that there may be more than a practical function assigned to their significance. That the water would have been valuable to both the monks and pilgrims who visited the site is unquestionable, however.
} 
sepulchers or vaults, the divinity of the natural water sources was tied to the intrinsic holiness of this sacred environment.

Both foundations took pride in their divine origins, their possession of hermit remains, holy relics and the miracles that accompanied these articles. Their resilience in the face of Muslim conquest and raiding helped to define each as a locus sanctus, under the protection of God. Playing a crucial role in making their holy history tangible, however, were the natural elements that invited devotees to make difficult mountains journeys and to approach the sacred landscape. These topographies not only served as witnesses to a miraculous past but they were considered powerful in and of themselves.

\section{Sacred Topography}

It is challenging to discuss the intellectual and emotional impact that the environment may have had on the monks, pilgrims, donors, and nobles who approached these basilicas because there are no textual accounts to express a contemporary's experience of the site. ${ }^{54}$ Yet, given the knowledge of pre-Christian religious traditions in Iberia and the number of other monasteries and churches that appear to have made use of their own particular topography, it is reasonable to suggest that visceral and intellectual responses to the topography of certain sites played an important part in their success. The landscapes of San Millán, San Juan, and others referenced their history through

\footnotetext{
${ }^{54}$ El Monasterio de San Juan de la Peña, 53. Lapeña Paul expressed the same challenge with supporting her ideas on the pre-Christian history of the site of SanJuan de la Peña: "Sugestivas suposiciones se me han presentado, como, por ejemplo, que, dada su peculiar situación, bajo el gran roquedal, con aguas que brotan en él mismo y oculto por la vegetación, pudiera haber sido un antiguo lugar de culto precristiano, con hondo arraigo en la zona, hasta que fue puesto bajo el signo de la Cruz. Pero la falta de cualquier indicio que pudiera server de base para una argumentación de este tipo, me ha hecho prescindir de estas conjeturas."
} 
caves, springs, and graves because these signposts had long been recognized as auspicious and sacred. ${ }^{55}$

A distant kinship with the ancient practice of worshipping divinities in sacred groves or regarding the landscape itself as a manifestation of the divine no doubt contributed to the medieval reverence toward distinctive-looking natural features. As Francisco Marco Simón explains, "The peoples of Celtic Hispania do not seem to have worshipped natural powers directly; as a matter of fact, the invisible divinities manifested themselves through visible signs like trees, springs, mountains or specific animals." The places that were frequently used for the performance of religious rituals are described by Leonard Curchin, "The sanctuary (nemeton) was an important feature of Celtic religion, though it rarely leaves a trace archaeologically. In its simplest form, the nemeton is simply a natural sacred place (a forest clearing, mountain top, rock, spring or field) rather than a man-made structure." ${ }^{, 57}$

Scholars have struggled to find a way to reconstruct ancient religious practices because the reverence accorded to specific things in nature, like bodies of water or fields, leaves scarce material evidence. ${ }^{58}$ The hazy picture of ancient Iberian beliefs obstructs the reconstruction of how related practices may have appeared in later periods. However,

\footnotetext{
${ }^{55}$ A few examples of similar foundations include the remarkable churches at "Las Gobas" de Laño, Condado de Treviño, Santos Justo y Pastor de Olleros de Pisuerga, Palencia, San Pedro de Argés, Burgos, and San Pelayo de Rebolleda in Villacibio, Palencia. All of these structures are cave or semi-cave churches that incorporate as much of the living rock as possible. At most of these sites, graves may be found excavated directly into the rock and springs are present.

${ }^{56}$ Francisco Marco Simón, "Religion and Religious practices of the Ancient Celts of the Iberian Peninsula," Journal of Interdisciplinary Celtic Studies 6 (online Date Published: March 10, 2005): $287-$ 345,296 . The author locates evidence for the worship of the main Celtic gods in the territory relevant to this dissertation - the northern-half of the Iberian Peninsula, including the Duero Basin, see 302, fig. 6. ${ }^{57}$ Leonard Curchin, The Romanization of Central Spain; Complexity, Diversity and Change in a Provincial Hinterland (London; New York: Routledge, 2004), 183. See also Marco Simón, "Religion and Religious Practices," 311-312. For how castros also appear to have performed religious functions in the Duero Basin, see 312-313. ${ }^{58}$ Marco Simón, "Religion and Religious Practices," 289. For example, scholars now believe that many indigenous religious offerings were made in the water.
} 
there are textual, toponymic and archaeological signs to support the idea that environmental elements were not only ritually significant to the peoples of ancient Iberia but to the medieval inhabitants as well.

After the Roman conquest and occupation of the Peninsula, epigraphic, textual, and archaeological evidence suggests that reverence for the nemeton continued. The syncretistic quality of Roman religious practices and their regard for nature-oriented cults complemented local rituals and the Iberian reverence for loca sancti. ${ }^{59}$ Nevertheless, some shifts in ritual practice can be detected. Stone altars erected to named deities appear, some of which bear the names of the dedicators or related iconographical representations. ${ }^{60}$ At the Sanctuary of Panóias, a number of large receptacles were carved out of the enormous rock to serve as repositories for sacrifices. The function of this place is known today because the third century epigraph details the use of the pits for the sacrifice, cremation of entrails, and gathering of blood. Panóias also has "cave structures" and inscriptions that indicate that this sanctuary supported both the indigenous gods and the Allmighty Serapis, an eastern import. ${ }^{61}$

\footnotetext{
${ }^{59}$ Marco Simón provides a detailed analysis of the literary, epigraphic, linguistic and toponymic evidence for Hispano-Roman religious practices as well as a qualified defense for these methodologies in "Religion and Religious Practices." See also Bernadette Filotas, Pagan Survivals, Superstitions and Popular Cultures in Early Medieval Pastoral Literature, Series and Texts, 151 (Toronto: Pontifical Institute of Mediaeval Studies, 2005), 31. Early Roman religion favored worship in an open, sacred place, and this tradition continued even after the Romans began to build temples.

${ }^{60}$ Marco Simón, "Religion and Religious Practices," 289, 315. The Fonte do Ídolo marks a water sanctuary in Braga and consists of a large granite block supporting figural reliefs and inscriptions. ${ }^{61}$ Marco Simón, "Religion and Religious Practices," 319. The appearance and construction of these sacrificial receptacles is similar to the later groups of rock-cut tombs favored by small, outlying monastic foundations. For example, the graves carved directly into the rock near Reccopolis and Arcávica (Cuenca), at the necropolis at Revenga (Burgos), and to the east of San Baudelio de Berlanga (Soria) were, like the receptacles at Panóias excavated from large, flat rocks and lie open to the sky. While the connection between these two precincts, separated by time and religious tradition, may seem tenuous, the persistence of nature cults allows for the speculation that the medieval practice may have been informed by the former, and presents an interesting avenue for future research. Rafael Barroso Cabrera and Jorge Morín de Pablos, "Las ciudades de Arcávaca y Recópolis y la fundación del monasterio Servitano. Organización territorial de un asentamineto monástico en la España Visigoda," in Monasteria et territoria: elites, edilicia y territorio
} 
Iberia has been designated as a place that witnessed some degree of

Christianization at an early date, perhaps as early as the late third or early fourth century, excepting that territory north of the Cantabrian Mountains. ${ }^{62}$ The extent of early conversion is unknown but historians agree that the advance of Christian doctrine was adversely affected by the disintegration of the Roman Empire and extra-Peninsular invasions. ${ }^{63}$ It seems clear that pagan beliefs were not replaced wholesale with organized, Christian practices but that religious plurality characterized Iberia, as it had for generations. ${ }^{64}$ Stefan Dix maintains, “...the division between Christianity and paganism (understood as a cultural legacy of the Romans but mainly of archaic Nordic cults) remained slender." 65 This perspective is reinforced by the apparent resilience of pre-

en el Mediterráneo medieval (siglos V-XI), ed. J. López Quiroga, A. M. Martínez Tejera and J. Morín de Pablos (Oxford: British Archaeological Reports, 2007), 235-237 in particular.

${ }^{62}$ Christopher Haas, "Mountain Constantines: the Christianization of Aksum and Iberia," Journal of Late Antiquity 1, no. 1 (2008): 101-26. Filotas describes Christianity as “...well-established in Roman Spain Gaul and Britain," Pagan Survivals, 38-39. For the persistence of paganism in the northern-most regions of the Peninsula until the end of the sixth century, see Eduardo Manzano Moreno, "Christian-Muslim Frontier," 89-90.

${ }^{63}$ Filotas, Pagan Survivals, 39.

${ }^{64}$ Simon Keay strikes a cautious tone when describing the extent of organized Christianity in fourth and early fifth century Hispania. Although he points to the increase in what appear to be Christian building projects and cemeteries, he concludes that towns and their suburbs were not clearly marked as Christian per se until the sixth-century Visigothic elites and clergy began renewing urban centers. "Recent Archaeological Work in Roman Iberia (1990-2002)," The Journal of Roman Studies, Vol. 93, (2003): 146211, 206. It is also difficult to divine how rural groups practiced Christianity in the fourth and fifth centuries. In "'Christianization' and the Rural Home," Journal of Early Christian Studies 15, no.2 (2007): 143-170, 162, Kim Bowes points out that tradition was generally privileged over the institutional church: "In short, Ausonius's easy swap of a pagan for a Christian sacrarium seems to have reflected, at least in one sense, genuine social realities: Christian estate-based cult contained many traditional elements, particularly certain spatial qualities and much of Roman religion's attendant formative sociology." Although in this article she is mostly concentrating on the framework of the dominus versus the developing episcopate, she develops the broader theme of rural, local traditions superseding orthodoxy and hierarchy in “'Une coterie espagnole pieuse': Christian Archaeology and Christian Communities in Fourth-and FifthCentury Hispania," in Hispania in Late Antiquity: Current Approaches, ed. K. Bowes and M. Kulikowski, 189-258 (Leiden: Brill), 2005.

65 "Roman Catholicism and Religious Pluralities in Portuguese (Iberian) History," Journal of Religion in Europe 1 (2008): 60-84, 64. 
Christian rituals, such as the burying of the dead with coins in their mouths or hands, well into the Middle Ages. ${ }^{66}$

Looking at late antique and medieval documents, particularly those that were issued as a result of Iberian church councils, a general state of anxiety for continued "pagan" practices is revealed on the part of sixth-century church leaders. Clergy fretted over the use of magic and divination by their fellow priests and the identification of specific locations of "pagan" activity: springs, caves, hills, groves, etc., suggest a correspondence with the ancient nemeton. ${ }^{67}$ Bernadette Filotas offers several practices that appear to have been causes of concern for the Council of Braga (572): “...lighting candles to stones, trees and wells and by crossroads, celebrating the festivals of the pagan calendar, divining, invoking Minerva and observing lucky days." 68

Church documents of the seventh through ninth centuries continued to condemn unorthodox practices, highlighting their persistence in popular culture and the likelihood that the ecclesiastical hierarchy viewed the practices as a threat to their authority. ${ }^{69}$ These practices continued to revolve around topographical markers such as tombs,

\footnotetext{
${ }^{66}$ Roberta Gilchrist, "Magic for the Dead? The Archaeology of Magic in Later Medieval Burials," Medieval Archaeology 52, no. 1 (2008): 119-59.

${ }^{67}$ For a thorough overview of non-Christian traditions in the medieval West, see: Bernadette Filotas, Pagan Survivals, Superstitions and Popular Cultures in Early Medieval Pastoral Literature, Series and Texts, vol. 151 (Toronto: Pontifical Institute of Mediaeval Studies, 2005), for the complexities of Christian practice specific to early medieval Iberia, see Hillgarth, "Popular Religion." The third Council of Toledo (589) denounced wide-spread non-Catholic practice, such as idolatry, which it claimed "...is taking root in nearly all of Spain and Gaul," according to the translation of David Nirenberg, "The Visigothic Conversion to Catholicism, the Third Council of Toldedo," in Medieval Iberia; Readings from Christian, Muslim, and Jewish Sources, ed. O. R. Constable (University of Pennsylvania Press, 1997), 17.

${ }^{68}$ Filotas, Pagan Survivals, 92. The author draws some of these from the roughly contemporaneous treatise De correctione rusticorum, which details a number of peninsular pagan practices. See also, Marco Simón, "Religion and Religious practices," 314-316.

${ }^{69}$ Filotas, Pagan Survivals, 93-94. 26. Filotas notes that although textual admonitions to masters governing their households may suggest that these practices were "mostly" limited to the lower social strata, other seventh century references to "descent and rank" point to an aristocratic sympathy or complicity in the preservation of pre-Christian rituals. The author further cautions against an uncritical acceptance of texts claiming that only the rustic and ignorant worship trees, etc., given the close relationship between the clergy and the nobility and the fact that certain forms of magic were perfectly acceptable to clerics.
} 
stones, springs, and trees according to two sermons dating to the late eighth or early ninth century. ${ }^{70}$ In light of these and an eighth-century document that prescribes harsh punishment and penance for those who would sacrifice to demons or seek the advice of witches or augurs, it would seem that the initial shockwaves of the Islamic invasion did little to curb indigenous traditions. ${ }^{71}$ Rather, the largely Berber forces that conquered and settled the Duero basin and Upper March regions were only recent converts to Islam themselves and doubtless carried with them indigenous beliefs. ${ }^{72}$

Medieval accounts of a persistent reverence for nature are supported in other ways. Marco Simón has studied numerous theonyms inscribed at fountains and caves and these, along with toponyms, persuade him that many derive from Celtiberian religious sources. ${ }^{73}$ This approach is particularly useful when trying to create a connection between ephemeral practices, like offerings made in watery environments, and Celtic beliefs in the afterlife. ${ }^{74}$ Linguistic methods combined with material evidence reveal the development and persistence of Celtiberian beliefs into the Roman and medieval ages.

\footnotetext{
${ }^{70}$ Filotas, Pagan Survivals, 22-23, fn. 77. The sermons are anonymous and preserved in the Ps. Boniface S. 6.1 and PL 89:855.

${ }^{71}$ Steffen Dix, "Roman Catholicism and Religious Pluralities in Portuguese (Iberian) History," Journal of Religion in Europe 1 (2008): 60-84, 65. Dix believes that the weak Christianization of the Peninsula, and Portugal in particular, partly explains the rapidity of the Islamic conquest and the slowness of the Christian "reconquest." 70.

${ }^{72}$ Berber culture in North Africa and al-Andalus included a strong "expectation of miracles" that was similar to some of the magical beliefs held by Peninsular Christians. See Madeline Fletcher, "Al-Andalus and North Africa in the Almohad Ideology," in The Legacy of Muslim Spain, $2^{\text {nd }}$ ed., ed. Salma Khadra Jayyusi (Leiden; New York; Köln: Brill, 1994), 251. See also Reilly, The Medieval Spains and Fletcher, Moorish Spain, 19-20. For an opposing point of view, that the Berbers were rapidly converted to Islam, see Collins, The Arab Conquest, 107.

${ }^{73}$ See Francisco Marco Simón, "Religion and Religious Practices," 292-299 in particular. The word Deva, the goddess, is inscribed in the cave of La Griega (Pedraza, Segovia) at Cabra (Cordoba), and is related to modern river names in Spain, 303. In la Griega, the theonym related to the Celtic word nemeton was also found and it is understood to signify a place where gods and people communicate. 297.

${ }^{74}$ Marco Simón, "Religion and Religious Practices," 289. The author mentions a couple of unusual exceptions to this rule, the deposits of weapons and armor recovered from the Huelva and Tajo Rivers.
} 
An example of how etymology can show the relationship between ancient and medieval religious practices is illustrated by theonyms and toponyms related to the yew tree. Marco Simón argues that the significance of the yew tree to Celtiberian groups is supported by the appearance of the deity name Eburianus (which is related to the word “yew”), and similarly derived names for places such as Eburobrittium (Évora), or people, such as the Ebura in the south of the Peninsula. ${ }^{75}$ Indigenous groups continued to revere the yew in Roman times, as was attested by the writings of Caesar and Florus who described Celtiberians committing suicide by yew poisoning rather than suffering defeat under the Romans. That the yew tree remained significant into the middle ages is amply demonstrated by the fact that more than 200 rural chapels in Asturias have a large yew nearby. ${ }^{76}$ The preservation of enormous dead trees that had clearly at ermitas of San Bartolomé at Ucero (Soria) and at de La Virgen de las Vegas, Pedraza (Segovia), which are both rural Duero basin churches, would suggest that a persistance reverence for sacred trees was a wider-spread phenomenon. Likewise, ritual saunas (generally called Pedras Formosas) have been identified in the northwestern Peninsula and the Duero basin. Some of these semi-cavernous, spring-fed structures have left evidence demonstrating their sacred uses for centuries-first for the Celtiberians, then the Hispano-Romans, and later as Christian baptisteries. ${ }^{77}$ The presence of springs at both

\footnotetext{
${ }^{75}$ See Marco Simón, "Religion and Religious Practices," 297 and Leonard Curchin, "Place-Names of the Ebro Valley: their Linguistic Origins," Palaeohispanica 8 (2008): 13-33, 21. The reference to Eburianus was found on a tombstone in Duratón (Segovia) and Marco Simón points out that the Iberian Ebura share etymological ties with the Eburones in Gaul.

${ }^{76}$ Marco Simón, "Religion and Religious Practices," 297. For a wide-ranging discussion of the significance of the yew in Ireland, see J. L. Delahunty, "Religion, War, and Changing Landscapes: an Historical and Ecological Account of the Yew Tree (Tacus baccata L.) in Ireland" (PhD diss., University of Florida, 2002).

${ }^{77}$ For categories of "pedras formosas," see Alfredo González-Ruibal, "Artistic Expression and Material Culture in Celtic Gallaecia," E-Keltoi; Journal of Interdisciplinary Celtic Studies 6 (online Date Published: December 20, 2004), 113-166, 130-133. On the use of "pedras formosas" as nympheums under the
} 
San Millán and San Juan is noteworthy but the centrality of the cave spring at San Juan particularly argues for this element to have had a significant ritual value.

Finally, both medieval hagiographies and the incorporation of sacred topographies into extant medieval churches and monasteries clearly show that medieval Christian beliefs were related to pre-Christian religions. Amy Goodrich Remensnyder emphasizes the fact that stories of rediscovered churches in medieval Western Europe are often defined by the miraculous "revelation" of the holy place and that this description distinguishes it from a consecrated space. ${ }^{78}$ The author gives the example of divine revelation with the account of the Merovingian princess Enimia. Unable to marry on account of her wedding-night leprosy, Enimia began to search for a cure. After hunting for many years, she had a vision of an angel, who sent her to the Gévaudan where she discovered a spring with curative powers. Following the miraculous healing of her leprosy, she lived by the sacred spring as a hermit and eventually established a female monastery. $^{79}$

For Goodrich Remensnyder, the twelfth-century text eliminates pagan overtones and described a holy site that was firmly Christian. While the Merovingian foundation of the monastery may have had a need to distinguish between a 'pagan' and Christian power, at least rhetorically, twelfth century Gaul did not. Thus, while medieval

Romans and as baptisteries at Santa Eulalia de Bóveda (Lugo) and Saint Mariña de Aguas Santas (Orense), see Marco Simón, "Religion and Religious practices," 328-329.

${ }^{78}$ For example, "Nonetheless, the emphasis in legend on revelation rather than on consecration is significant. In the legends, revelation most often occurs through the medium of the place itself, human beings guided by God, or animals - or some combination of them. Hinted at by each of these types of revelation is a temporality of the sacred site different from the one we have already encountered in the ritual of consecration. In the nonlegendary texts, the abbey becomes sacred space at the moment when the celestial Jerusalem descends: during the ritual of consecration. The legends, on the other hand, by using the trope of revelation, assure that the space which will become the monastery, the earthly incarnation of the celestial Jerusalem, is already, intrinsically and essentially, sacred. Through revelation, the abbey's identity is rooted in preextant sacred space and given an implicit prehistory." Remembering Kings Past: Monastic Foundation Legends in Medieval Southern France (Ithaca: Cornell University Press, 1995), 43. ${ }^{79}$ Goodrich Remensnyder, Remembering Kings Past, 44-45. 
veneration of topographical elements stemmed from Celtiberian sources, Christianity had thoroughly assimilated certain indigenous beliefs over time. ${ }^{80}$ For the purposes of this dissertation, understanding precisely how that syncretism occurred is less important than establishing the fact that natural topographies were considered special signs of the divine and were considered powerful to late antique and medieval audiences alike. Although it cannot be confirmed that the cave shrines at San Millán de la Cogolla and San Juan de la Peña were preceded by pre-Christian cults, their charged environments nevertheless projected an ancient and supernatural past. ${ }^{81}$ The combination of natural elements considered sacred by pre-Christians with what Goodrich Remensnyder terms the "implicit prehistory" of "revelatory" narratives created by the monasteries would have been a formidable pairing suggestive of supernatural power.

\section{Legitimizing architecture}

Medieval churches and monasteries maintained the widespread respect for landscapes that seemed divine. This practice was a carryover of prior beliefs and associations. But far from being merely a residual awe for nature, churches and shrines that referenced these topographical elements were actively drawing on their holy authority in order to better wield political influence. The absence of a strong

\footnotetext{
${ }^{80}$ Richard Fletcher, The Barbarian Conversion: From Paganism to Christianity, (New York: H. Holt and Co.), 1998, 49. The author relates a well-known example of how some of these rituals were redefined around the year 500. An anonymous Bishop of Javols decided to redirect the devotions of the "rustic" people who made offerings and sacrifices to a sacred lake, by building a church next to the lake and installing the relics of Hilary within it. According the chronicler, the people were duly converted and now brought the offerings they had once thrown into the lake to the church instead.

${ }^{81}$ Scholars have noted the possibility for such at both locations. At San Juan de la Peña, the caves that serve as apses are briefly described as possibly having been part of a pre-Christian, Dioscuric cult, see Patton, The Cloister, 7, fn. 20. At San Millán, the identification of two Roman inscriptions, "with the names of two indigenous divinities: Obiona and Dercetio..." suggest to the Pilar Sáenz Preciado that the area was a previously a "pagan" cult site, in "Arqueología en San Millán de la Cogolla," 144, author's italics.
} 
ecclesiastical organization after the Muslim conquest of the Duero and Ebro valleys and La Rioja created an environment in which monasteries and churches, particularly those along the rural frontier, could not only survive but assume significant independent authority. ${ }^{82}$ One of the ways they did this was to deliberately bring attention to their sacred and historied landscape through architectural programs.

\section{San Millán de la Cogolla (tenth century)}

Gómez Moreno originally oriented the two chambers that today comprise the apses of San Millán toward the altar niche in the cave. ${ }^{83}$ After the discovery of eastern chambers, Gómez Moreno altered his opinion, and in 1951, he changed the orientation of the church from the mountain to the eastern-facing double apses. ${ }^{84}$ Regardless of its original orientation, scholars agree that the northern section of the church was attached to the caverns and that the eastern-most cave was incorporated into the sanctuary, given the presence of an altar (figure 19). ${ }^{85}$ The caves have been the dominant feature of the

\footnotetext{
${ }^{82}$ Concerning the tolerance of Christian churches and monasteries, see Fletcher, The Barbarian Conversion, 305-307; on the construction of new churches in al-Andalus see Sally Garen, "Santa Maria de Melque." Garen also discusses the construction of two monasteries, Tabanos and Pinna Mellaria (Penamelaria), which were built in the mid-ninth century on the edge of Córdoba. She qualifies their existence by suggesting that they were proprietary foundations and as such, not public in nature and probably lacking a church building (basilica), 304. On the other hand, proprietary monasteries generally feature some type of sanctuary or shrine. This, together with the seemingly public profile of Tabanos, which was razed in 853 owing to its purported associations with the martyr's movement, leaves the characterization of these monasteries an open question. Partly in response to Garen's provocative re-dating of Melque, Luis Caballero Zoredo calls for a reevaluation of those churches that have heretofore been considered "Visigothic" in "Observations on Historiography."

${ }^{83}$ Gómez-Moreno, Iglesias, 296-300. Although the author notes the caves and spring at the site, features he describes as similar to those at San Pedro de Rocas and San Juan de la Peña, he assigns only practical functions to their appeal.

${ }^{84}$ Gómez-Moreno, "El arte Árabe español hasta los Almohades. Arte mozárabe," Ars Hispaniae 3 (1951): 355-409, 384, fig. 450 cited by Caballero Zoreda, "La iglesia de San Millán," 15.

${ }^{85}$ Caballero Zoredo provides a comparative anlaysis of the four floor plans of San Millán as reconstructed by the principal scholars of the twentieth century in "La iglesia de San Millán," 15-17, 20, 54, 61-62.

Trying to disentangle the numerous arguments for how the original structure looked is beyond the scope of this project. While the prospect that a second floor may have been part of a pre-tenth century, tenth century, and/or an eleventh-century structure is interesting, the data supporting these theories (primarily
} 
church's interior from the tenth century to the present. Their importance was continuously stressed through multiple architectural phases.

Although scholars have noted the appearance of structural remains which might date to the Visigothic period or earlier, there is as yet no firm evidence for a Visigothic monastery. However, given the information from the seventh century Vita Sancti Aemiliani, the long connection of San Millán to these caves, and the presence of physical material that predates the tenth century suggests that the site attracted veneration long before the tenth century. Moreover, the topographical features of the cave-dotted mountain, the fresh spring, and its high position on the mountain also permit the speculation that the place was regarded as sacred before the influence of Christianity.

Architecturally, the earliest identifiable phase is generally assigned to some time before the tenth century. ${ }^{86}$ This structure was built around three caves, the two easternmost chambers appearing to have additional emphasis due to the presence of altar-niches cut into their eastern walls (figure 20). The remaining stone walls indicate that the small building was either oriented toward eastern cave or that the subterranean sanctuary

espoused by Uranga Galdiano e Íñiguez Almech) is inconclusive, leading Caballero Zoredo to reject the likelihood of a two-storied structure.

${ }^{86}$ Caballero Zoredo has assembled the most thorough analysis of the building phases at San Millán but he acknowledges that due to the confusing arrangements of multiple phases of construction, repairs, and renovations, it is impossible to confidently date phases. For example, the author explains that the "Premozarabic" phase could eventually turn out to be Visigothic, Reconquest, or Mozarabic in "La iglesia de San Millán," 34-35. Alberto del Castillo identified tombs that he dates to the Visigothic era, according to Miguel Ibáñez Rodríguez, "La constitución del primer cenobio en San Millán," in VII Semana de Estudios Medievales: Nájera, ed. José Ignacio de la Iglesia Duarte (Logroño: Instituto de Estudios Riojanos, 1997), 390-391. 
functioned as an adjacent apse. ${ }^{87}$ It was not a hastily erected shrine but a stone building, comprised of skillfully dressed sandstone and limestone. ${ }^{88}$

The tenth-century phases and their relation to the landscape are a little easier to reconstruct. ${ }^{89}$ This church included the two extant stone chambers south of the easternmost cave. These spaces are covered with ribbed, domical vaults that measure eleven meters in height. The use of ribbed stone vaults pitched high above the floor and the dramatic horseshoe arcade that divides the westerly space of the church would have presented an impressive image to the monks, pilgrims, and patrons. As discussed in the previous chapter, stone architecture was associated with the building obligations of political powers-kings, nobles, and clerics, whether Christian or Muslim. I would suggest that the use of stone walls, carved capitals, ribbed vaults, and horseshoe arches were meant to convey a picture of noble power to a heterogeneous audience..$^{90}$ Furthermore, the antiquity and divinity of the mountain and the remains of the holy saints it protected imbued the stone architecture with additional authority. This was not only

\footnotetext{
${ }^{87}$ Caballero Zoredo identifies and describes one phase as "Premozarabic" and three phases as "Mozarabic" at San Milllán de la Cogolla. The first Mozarabic phase is sometime in the tenth century, the second is characterized by the charring made by a fire around the year 1000 and the third is loosely assigned to the first quarter of the eleventh century, "La iglesia de San Millán," 24-35.

${ }^{88}$ Tophus was also used in places.

${ }^{89}$ Caballero Zoredo admits the strong possibility that additional phases and reuse of material prohibits confident dating. For simplicity's sake, when describing any of the three "Mozarabic" phases, I will refer to a tenth-century phase because in my view, all of these interventions were intended to emphasize the setting of the monastery.

${ }^{90}$ The use of elements associated with al-Andalus is generally ascribed to the presence of Mozarabs. As explained in chapter one, I follow the arguments of Richard Hitchcock concerning the wisdom of avoiding the term before 1082 at the earliest. Moreover, decorative and architectural motifs such as Andalusi textiles and the horseshoe arch clearly had relevance for Christian and Muslim aristocratic circles and should therefore be considered as having been recognized as symbols of prestige and sociopolitical power by most frontier audiences. While I agree that horseshoe arches also resonated with those cultivating a Visigothic continuity, I do not accept that the builders of tenth or eleventh-century frontier churches were actively rejecting an arch form that, due to its profile or exaggerated springers, might be associated with Islam, contra Dodds, Architecture and ideology in Early Medieval Spain, 1990, 52-53. Examples include: São Pedro de Lourosa (Coimbra); Santa María de Melque (Toledo); San Juan de Baños (Palencia); Santa María de Lebeña (Cantabria); Santa Cristina de Lena (Asturias); Torre de Doña Urraca (Burgos); Porta Ferrada (Gerona); and of course, Santullano, Valdedios, etc.
} 
accomplished in the proximity of the structure to the subterranean chambers but in the way sightlines and atmosphere acknowledged the adjacent caves.

In places, the mountain literally supports the church. Along the north side, the rock above the eastern cave's arched opening was cut in order to install the wall of the northern apse. ${ }^{91}$ The relationship between the mountain and the structure is highlighted in other ways as well. As noted by Gómez-Moreno and others, the central arch of the triple horseshoe arched arcade is slightly larger than its fellows and aligns nearly perfectly with the tenth-century portal in the south wall. ${ }^{92}$ From that portal, it seems likely that the entrant would have been confronted with at least two caverns immediately upon entering. ${ }^{93}$ The remains of the tenth-century western enclosure wall met the hillside at an oblique angle, the direction of which would have served to further direct the participant's attention to the subterranean chambers.

The limited number of surviving tenth-century doors and windows suggests that the interior would probably have been quite dim. The southern façade is relatively wellpreserved and suggests that the only aperture was the main portal. To the east, a single, narrow, window placed high in the eastern wall of the northern apse survives. ${ }^{94}$ A clear picture is impossible due to the later phases of construction and modern renovation efforts. For example, the western enclosure does not survive, and so it is unknown if any

\footnotetext{
${ }^{91}$ Caballero Zoredo tentatively dates the construction of the rooms immediately to the east of the vaulted chambers to this period, see "La iglesia de San Millán," 35. The section of the northern wall to the west is also built into the mountain, how it was attached in the tenth and eleventh centuries has been obscured by late medieval and modern reforms, however. See plan 5 on page 83 .

${ }^{92}$ Gómez-Moreno, Iglesias, 299-300.

${ }^{93}$ Most scholars reconstruct the western enclosure as a wall that would have blocked a view of the western cave, and this is the design that seems most reasonable to me. However, if the tenth-century church consisted of an atrium to the west, as Gómez-Moreno suggested, it is possible that the cave would have been visible.

${ }^{94}$ The original rooms to the east of the apses do not survive. The late medieval restoration of their eastern façade inserted two square windows. These are not characteristic of tenth-century fenestration, however. Concerning the likelihood that the portal provided the only source of light from the south, see Caballero Zoredo, "La iglesia de San Millán," plan 9, 87
} 
windows pierced that wall. ${ }^{95}$ Although gaps in our knowledge obscure a clear reconstruction of how the space was illuminated, a comparison with contemporary churches, particularly those in proximity to caves, reinforces the argument that this church received little natural light.

The extent to which these caves may have been incorporated into the liturgy is unclear but they certainly carried a sepulchral function. The central cave, which today houses the twelfth-century cenotaph of San Millán, is supposed to have served as the resting place for his body until the eleventh century when his remains were moved to a reliquary and placed before the altar. The western cave opening leads to a series of chambers that contain anthropomorphic graves carved directly into the rock, some of which appear to be oriented toward the chamber where San Millán was interred. The impression that the tombs were orientated toward the saint is reinforced by the appearance of a communicating window between the western and central chambers (figure 21, 22). ${ }^{96}$

\footnotetext{
${ }^{95}$ The eleventh-century western wall appears to have supported only one opening, however, that of the high door which likely led to monastic living quarters to the west (now disappeared). Caballero Zoredo speculates that a similar door may have existed for similar reasons in the Mozarabic western façade, "La iglesia de San Millán," 48, 52. Little is known about how this structure might have appeared but it seems to have been erected very close to, or as an extension of, the caves associated with eremitic life.

${ }^{96}$ I could not find a reference to the age of this window in Caballero Zoredo's analysis or any of my other materials. However, the appearance of the window is not inconsistent with the tenth-century phases of the church, and its funerary function would seem to argue for a tenth-century (or earlier) date. The location of the window between the graves of the pious and the saint's cave recalls the fenestella confessionis sometimes found in martyria, for example, at the early fourth century site of San Anastasius at Marusinac, Salona, Croatia. For the fenestella confessionis, see Franz Xaver Kraus, Joseph Sauer, Geschichte der christlichen Kunst, Vol. 2, part 1, (Freiburg: Herder'sche Verlagshandlung, 1896), 304-305. For the funerary nature of rural fifth and sixth-century churches and shrines in Iberia, see Bowes, "'Une coterie espagnole pieuse'," 208-258 in particular; concerning the multiple opinions concerning the dates for the cemeteries at San Millán, see Javier García Turza, "El monasterio de San Millán de la Cogolla en la alta edad media: aproximación histórica," Berceo 133 (Logroño, 1997): 9-25, 19-20 in particular; for the explanation of why Berceo ranked hermits above martyrs in his account of Santa Oria's celestial vision, see Simina M. Farcasiu, "The Exegesis and Iconography of Vision in Gonzalo de Berceo's Vida de Santa Oria," Speculum 61, no. 2 (Apr., 1986): 305-329, 321-322 in particular. García Turza, Andrio Gonzalo, et al., and Caballero Zoredo agree that many more graves would be uncovered by additional excavations.
} 
The position of the tenth-century church on the side of the mountain, as opposed to the top or bottom, prompts additional observations. From the valley below, the dark shape of the horseshoe-arched portal against the lightly colored sandstone may have invited a comparison between it and the adjacent cave openings on the mountain side, particularly in the early tenth century. ${ }^{97}$ Taken together with the dim interior, the church's interior could be considered as an extension of the sacred caves. Moreover, for the exiting devotee, the high position of the church would have been dramatically reinforced by the extreme drop-off beyond the door and the commanding vista.

\section{San Juan de la Peña (tenth century)}

Like San Millán, it is easy to observe the architectural emphasis on the living rock throughout the monastic complex. This is particularly true for the surviving portions of the subterranean tenth-century church. The small church and its subsequent phases are all subordinated to the cliff and its springs. ${ }^{98}$ It is impossible to reconstruct precisely how this building appeared due to later interventions, but enough remains intact to form a strong impression of a church that has been carved from the living rock (figure 23).

The lower church offers the strongest supports for the argument that topography was the prime motivation for the selection and lengthy patronage of this site. The twin apses that were carved from the rock face do little to disguise their relationship to caverns; rather they appear to accentuate their earthy character. Two slightly horseshoe

\footnotetext{
${ }^{97}$ Although this portal is somewhat obscured by a stone portico today, it is a modern construction. The platform that permits access to the portal is tenth century or earlier but only a few remnants of an early eleventh-century archway to the east of the porch survive today. Although there are a few mechinales visible, these small blocks are thought to be of a modern date by Caballero Zoredo. For the discussion of possible southern façade solutions and an illustration of the south face of San Millán, see Caballero Zoredo, "La iglesia de San Millán," plan 9, 81. 38, 46-47.

${ }^{98}$ Gómez-Moreno suggested at an early date that the cave and the fountain were very important to the builders of the monastic complex in IglesiasMozárabes, 33-35.
} 
shaped niches, with notched lower ledges, are carved into back of the apse walls (figure 24). These shallow spaces are uneven and do not appear to have been covered with plaster, unlike the walls and vaults of the apses. ${ }^{99}$ There are additional reasons to describe these apses as having a subterranean appearance. In the left-hand apse there survives a substantial mineral deposit that looks like a fossilized waterfall. The manmade niche above it draws attention to the prominent position of the earth formation in the sanctuary. Also, the cave floor on which the cascade terminates is a prominent feature of this apse and a similar effect is achieved in the right hand apse, where the rocky wall of the cave is allowed to intrude into the sanctuary, heightening the sense of enclosure. The underground atmosphere of the apse structures extends into the rest of the church. The tenth-century barrel vaults for the nave are comprised of small stones of varying sizes placed in uneven courses. Sticking out and without clear organization, the privileging of natural-looking rock forms better prompts a comparison of this space with vaults hewn from rock rather than made of rock and mortar by masons.

Contrasting with the rocky vaults are finely dressed ashlars that make up the walls, horseshoe arches, and carved column in the tenth-century nave. These architectural elements are similar to those found in many surviving tenth-century stone churches. Following the point of view that these monasteries and churches were centers of economic, political, and spiritual power, their use of stone was a deliberate symbol of that authority and legitimacy (figure 23). Like at San Millán, there does not seem to be any hesitation to employ elements that may have an Andalusi source, such as the

\footnotetext{
${ }^{99}$ I have not been able to acquire archaeological reports for San Juan de la Peña, so it is quite possible that trace remains were overlooked from my position in the viewing area. The plaster and decoration that survives in the apses dates to the twelfth century; it is unknown if the tenth century was similarly covered.
} 
horseshoe arch. While it may have also conveyed the notion of Visigothic continuity, it seems to me that a more general appropriation of elite architectural motifs was the goal.

How the small church was meant to be entered and was illuminated is obscured by later phases. There is a door on the northeast wall that is original to the structure and permits access to the adjacent spring. This may have been the principal entry but the horseshoe portal preserved in the upper church may also have served as a door to the lower church (figure 25). Although a complete picture of the lower church is presently impossible, it is clear that the in situ door would have required the clergy, laity or both to pass immediately before the underground spring, thus emphasizing its close proximity to the sanctuary (figure 26). A final way in which the subterranean setting for the church was emphasized is the lack of natural light in the apses. In the Middle Ages, altar spaces were typically illuminated by fenestration and their absence would have marked the space as unusual and special.

In my opinion, at San Juan de la Peña, as at San Millán de la Cogolla, the topographical setting is the prime motivation for the foundation and survival of the tenthcentury monastic centers. That a remarkable environment can stand as testimony to a sacred history predating Christianity has been briefly discussed above. For San Juan, however, there are compelling reasons to suggest a specific pre-Christian history. In addition to the combination of caves, springs, and stories of a supernaturally preserved body, the twin nature of the tenth-century apses and naves may suggest the architectural development of a Dioscuric shrine. It is well known that a number of medieval Christian churches were built atop pagan settings or shrines, just as some Christian practices 
continued those of the pre-Christian era. ${ }^{100}$ Pamela Patton has argued that there is a connection between the monastic site and a prior Dioscuric shrine. In support of this, she describes some of the parallels between the foundation legend of Votus (one of a fraternal pair) and the attributes of the Dioscuri. ${ }^{101}$ That brother saints were venerated at the site is evident in the representation of the healing saints Cosmas and Damian in the twelfthcentury decoration of the rock-cut apses. ${ }^{102}$ I would add to these arguments that the way in which the tenth-century construction privileged the natural landscape (the source and setting for Ibero-Roman rituals) further supports the likelihood that San Juan, like San Millán, was viewed as a powerful place.

That this power was confidently assigned to the realm of Christianity by the tenth century does not mean that its ancient significance was without value to its medieval audience. Rather, for the monks and elites that sought to expand their earthly holdings and at the same time protect their eternal salvation, the antiquity of the divine landscape bolstered their proprietary claims. For the clerics controlling the shrines and churches, a powerful reputation and praiseworthy building would attract donations of lands and

\footnotetext{
${ }^{100}$ Christian shrines are also sometimes founded as the direct result of a healing spring. Naturally, the prominence of sacred springs in pre-Christian religious suggests that these springs were sacred before they served their Christian purpose (or repurposing), see Remensnyder, Remembering King's Past, 44-45. Along the same lines, the appearance of wooden, metal, or wax body parts in Spanish and Portuguese shrines are the modern heirs of similar votives offered to ancient healing shrines throughout the Mediterranean. Modern votive offerings of hair found at the shrine of Santa Casilda, Spain, also reflect a tradition that predates Christianity, according to M. L. Nolan, S. Nolan, Christian Pilgrimage in Modern Western Europe (Chapel Hill: University of North Carolina Press, 1992), 70-71.

${ }^{101}$ While the double apse and nave at San Millán could also be viewed as a development of a Dioscuric cult site, the connections are more tentative. There are miracles of healing associated with hermit San Millán but to my knowledge, saintly brothers were not venerated. Moreover, while the cave of San Millán was certainly revered, and possibly the object of an early church's orientation, it is difficult to identify a parallel prominence accorded to the adjacent cave, save for the presence of altar niches in both caves. On the other hand, fraternal-saint dedications to the Roman-era martyr-saints Facundus and Methodius at the monastery of Sahagún, a place-name that derives from Facundus, suggest that this may be a fruitful avenue of further research. See Miguel León Portilla, Bernardino de Sahagún, first anthropologist, translated by Mauricio J. Mixco (Norman: University of Oklahoma Press, 2002), 30-32.

${ }^{102}$ See Patton, "The Cloister of San Juan," 7, fn. 20. Lapeña Paul has noted the possibility that the lower church marks the site of a pre-Christian shrine but does not elaborate in El Monasterio, 39, 53.
} 
goods from all quarters. These donations and transactions not only sustained daily lives for the monks, but became an economic enterprise that compounded the value of these assets over time. ${ }^{103}$ Because these monasteries carried material and spiritual influence beyond their enclosures, they, in turn, could benefit patrons wishing to extend their secular authority in the same regions. At San Millán for example, García Sánchez of Navarre (926-970) and Fernán González of Castile (931-970) appear to have both curried favor from the monastery, which was located between their territories and whose regional influence could help or hinder their attempts to expand into the Rioja. ${ }^{104}$ San Juan de la Peña was likewise feted by aristocrats, whose donations comprise the earliest documentation for the monastery. ${ }^{105}$ It is unknown if the monks or their outside benefactors controlled the appearance of the structures attached to these holy caves. Nevertheless, costly and recognizable architectural elements were strategically built into a sacred landscape, compounding their currency as signs of power. The success of these efforts were recognized and repeated in the eleventh century by nascent kings and

\footnotetext{
${ }^{103}$ On the large numbers of transactions for north-central Spain, compared to the rest of Europe, including San Millán de la Cogolla, see Davies, Acts of Giving, 23-26. For thorough accounts of how tenth-century monasteries could dominate vast tracts of land and wield political influence as a result of these holdings, see J. A. García de Cortázar, and Ruiz de Aguirre, El Dominio del Monasterio de San Millán de la Cogolla (Siglos X a XIII) Introducción a la historia rural de Castilla Altomedieval, (Salamanca: Universidad de Salamanca), 1969 and José María Mínguez Fernández, El Dominio del Monasterio de Sahagún. ${ }^{104}$ Antonio Ubieto Arteta, "Los primeros años del monasterio de San Millán," Príncepe de Viana 34 (1973): 181-200, 197-198 in particular. Ubieto Arteta does not accept documents that link García Sánchez and Fernán González as benefactors of San Millán. He does this because some of the documents are false (particularly those authored by the famous forger Votos de San Millán) and some of them are conflicting. The acceptance of one authentic document relating to the donation of Salinas de Añana over another, particularly in light of the tendency to subdivide rights of usage among two or more parties, is problematic, however. Furthermore, Julie Harris argues that both Sánchez and González patronized San Millán due to the strategic position of the monastery in relation to the territorial ambitions of the powerful rulers, see "The Arca of San Millán," 14. Aristocratic associations are not the only records to come down to us. According to Davies, approximately twenty-three percent of all of the gifts to San Millán were donated by peasants, Acts of Giving, 209.

${ }^{105}$ See Lapeña Paul, Guía, 7-8; Davies, Acts of Giving, 209.
} 
aristocrats who likewise sought to capitalize upon the landscape and histories of San Millán de la Cogolla and San Juan de la Peña.

\section{Sancho's eleventh-century extensions}

The early eleventh-century renovations at San Millán de la Cogolla and San Juan de la Peña were carried out by Sancho el Mayor who used the sites' topographical potency to his political advantage. ${ }^{106}$ Two common elements appear to have shaped his approach to the expansions of San Juan and San Millán: architecture that complemented and directed attention toward the sacred topography and phases that were clearly distinguishable from prior building. As Janice Mann has pointed out, Sancho intended his designs to stand apart from the existing churches so that his contributions would attract attention and represent the authority and stability of his rule. ${ }^{107}$ This marks the patronage of Sancho at San Millán and San Juan as one link in a longer line of patrons utilizing the legitimizing, sacred landscape to prop up their earthly authority.

At San Juan de la Peña, Sancho’s phase maintained the height of the tenth-century vaults while lowering the floor six steps, which are the transition between sections (figure 27). Also marking this portion of the church as distinct from the former is the semicircular arched arcade, which is nearly three times longer than the tenth-century

\footnotetext{
${ }^{106}$ Caballero Zoredo uses the marks of a deliberate fire at San Millán to distinguish between the stratigraphies of the tenth-century phases and those that belong to the expansion of the church under Sancho el Mayor. As already discussed in footnote 31, the nature, author, and date of this fire is somewhat questionable, "La Iglesia de San Millán," 17-22. By 1028, the abbot of San Millán held Episcopal authority over Nájera and Pamplona and was indebted to Sancho el Mayor for their advantageous position. It was this period of benefaction that likely produced the extension and renovation at San Millán, according to Mann, Romanesque Architecture, 54. For San Juan, the 1094 consecration date of the upper church provides a terminus post quem for the lower church extension that supports its mass but the stylistic, structural, and functional similarities between San Juan de la Peña and San Millán de la Cogolla have resulted in the scholarly consensus assigning these building phases to Sancho el Mayor.

${ }^{107}$ Mann, Romanesque Architecture, 55.
} 
horseshoe arcade. While it would be reasonable to suppose that the increase in vertical space would negate the enclosed quality of the earlier church, the massive cruciform piers, broad transverse arches and applied ribs nevertheless give weight to the newer part of the church. The eleventh-century arcade is considerably thicker and instead of a decorated column, these arches have a relatively low spring and rise uninterrupted from the floor between broad, cruciform piers. The two bays of the addition also incorporate substantial applied transverse ribs that end in corbels on the outside walls of the naves and feature a single, thick, bracing arch. Although less pronounced than the stonework in the tenth century nave, the stones for the vaults are different sizes and not set in regular courses. The variety of stone shape, size, and courses for the transverse arches and ribs combines with the more organic arrangement of stones in the vault recall the excavated rock in which the lower church is situated, albeit less forcefully than in the tenth-century phases. The overall effect of Sancho's extension is an architectural space that is not only grand and imposing in its own right but that also enhances the structural and liturgical focus on the apses, which from this low vantage point appear to compress and to recede within the mountain, looking very much like the caves they are.

In order to enter the expanded lower church of San Juan, one would have approached it through the Sala del Concilio, which is also attributed to Sancho's benefaction (figure 28). ${ }^{108}$ This large space is dominated by four short semicircular arcades that are made up of two arches each. The thick arches spring from the floor and are anchored by the massive outside wall, cruciform piers and the exposed rock of the southeasterly wall. Like the lower church, the emphasis on the living rock, heavy architectural elements and rocky barrel vaults convey a subterranean quality.

${ }^{108}$ See footnotes 34-35 above. 
Although it takes a different form, the underlying interest in capitalizing upon the topographical focus in the early eleventh-century renovation and expansion of the church is as evident at San Millán de la Cogolla as it was for San Juan. It is likely that the chthonic appearance of the earlier portal was preserved and that the second portal and small windows of the western section of the south face did little to lessen its relationship to proximate cave openings. On the other hand, it is possible that this phase had a type of arcaded portico, in which case, the similarity between architectural openings and natural cave openings would be limited. ${ }^{109}$

Inside, the cave openings continued to be dominant spaces, particularly in the nave (figure 29). From the main entrance portal located in the eastern section of the nave, at least two of the caverns would have confronted the viewer through the arches of horseshoe arcade. ${ }^{110}$ As briefly mentioned above, Sancho's extension of the nave adhered to the mountain side, causing the direction of the church to shift considerably to the north (figure 30). In addition to physically clinging to the rock, this design facilitated subterranean views. A second door was added to the new section of the south wall. Due to the slanting angle of the new wall, the western cave could still be easily seen, despite the massive pier obscuring a clear view of the other two caverns (figure 31). Within, a curious 'arrow slit' window was inserted, probably to throw light upon the stone-cut tombs deeper within the chamber. ${ }^{111}$

\footnotetext{
109 "La Iglesia de San Millán,” 49. Caballero Zoredo does not speculate on when a covered porch may have appeared at San Millán.

${ }^{110}$ I have not been able to find anything concerning visibility of the caves to the congregants. It is possible that textiles or screens blocked the viewer's gaze, nevertheless, their presence would have dominated the interior of the church, shrouded or not.

${ }^{111}$ There is no longer a staircase along the southern wall, so it is difficult to recreate ways in which the tombs might have been glimpsed from a higher vantage point within the church. Likewise, due to the artificial lighting of the cave for tourists, one can see the rock walls of the cave through the slit from the
} 
Last, the prominence of graves at San Millán is significant. Naturally, the large number of tombs is related to the reputation of the saint, and from the eleventh century in particular, to the role of monks as intercessors for the souls of the elite. The most important of these graves were clustered around the cave and resting place of San Millán but there are a number of tombs on the hillside to the east of the church. ${ }^{112}$ One substantial group is situated beneath the cave of Santa Oria, an eleventh-century anchoress associated with visions and miracles, and may date from the sixth to the eleventh centuries. $^{113}$

The anthropomorphic graves excavated from the rock in the western cave are oriented in such a way that their heads are directed toward the mountain and their feet point toward the cave opening. ${ }^{114}$ This orientation suggests an interest in physically aligning the dead in the direction of San Millán and the cave itself (figure 22a). ${ }^{115}$ This impression is further supported by the insertion of a communicating archway between the western cave chambers containing the sepulchers and the central caves, which protected the body, and later the cenotaph, of the saint.

church and the stone graves from the chamber entrance but I do not know how these would appear without the lamps or with firelight only.

112 There is an important group of sepulchers located in the portico. These sarcophagi are traditionally identified as belonging to "los siete infants de Lara," their tutor, and the Navarese queens Tota, Elvira, and Jimena. It is difficult to assess the reliability of this tradition, particularly concerning the legendary seven princes. For more, see Minerva Sáenz Rodríguez, "El cenotafio de San Millán de la Cogolla en el monasterio de Suso," Berceo 133 (Logroño: 1997): 51-84, 62 in particular.

${ }^{113}$ Andrio Gonzalo, et al., "La Necrópolis medieval de San Millán," 52. For the story of Santa Oria see Gonzalo de Berceo; Anthony Lappin, Berceo's Vida de Santa Oria: Text, Translation, and Commentary (Oxford: Legenda), 2000. I have not yet encountered an analysis of how Santa Oria's presence at San Millán may have affected the reputation of the monastery but this deserves consideration. The description of the necropolis presented by Andrio Gonzalo, et al. includes references to female skeletons and small, artificial caves (covachas) in which two or three bodies are grouped.

${ }^{114}$ I have not discovered a reference to an analysis or excavation report for the stone cut graves within the anchorite caves at San Millán, only that of the necropolis to the east of the church.

${ }^{115}$ For the standing viewer looking through the communicating window from the western chambers into the central cave, the most prominent elements are the ancient altar niches. 
Graves also feature prominently in the later decades of the eleventh century at San Juan de la Peña, as indicated by the construction of the Panteón de los Reyes (figure 32). ${ }^{116}$ However, the inscriptions and relief panels that are associated with rock-cut tombs date only between1082-1325, resulting in a substantial gap in our knowledge concerning the number or nature of necropoles that may have predated those associated with the period of royal Aragonese benefaction. ${ }^{117}$ For example, Lapeña Paul notes that within the exposed rock of the Sala del Concilio an "antiguo osario" survives. ${ }^{118}$ Dates or additional information are not offered but it may be that this ossuary was assembled in anticipation of the construction of the Sala del Concilio. It was common for elite burial precincts to be located along the approach of a church portal, which may explain the need to relocate the earlier necropolis. The preservation of the remains within the cliff rock illustrates the continued reverence for the holy landscape of San Juan (figure 33).

In the last half of the eleventh century, the Panteón de los Reyes and the upper church were built. Located at the top of the stairs from the Sala del Concilio, the patron for this funerary space is unknown. Nevertheless, its construction likely coincided with the commissioning of the upper church during the period of Sancho Ramírez (10631094), who also received the important relic of San Indalecio on Easter of 1084. The earliest securely dated inscription is 1082 , which recommends linking the building of the Panteón with the royal house of Aragón. ${ }^{119}$

\footnotetext{
${ }^{116}$ For more, see J. C. Esco Sampériz and J. I. Lorenzo Lizalde, "Il campaña de excavaciones arqueológicos en el monasterio de San Juan de la Peña (Botaya-Jaca, Huesca)," Arqueología aragonés (1985): 141-44.

${ }^{117}$ See Durán Gudiol, "Inscripciones Medievales."

${ }^{118}$ Lapeña Paul, Guía, 13-14.

${ }^{119}$ According to Durán Gudiol, the earliest inscription recorded by P. Joseph de Moret (1665) and P. Ramón de Huesca (1802) is unlikely to date to 1075, which makes 1082 the earliest date recorded in stone at San Juan, see Durán Gudiol, “Inscripciones Medievales," entry number five, 78.
} 
Located below the great cliff overhang, the Panteón precedes the entrance to the eleventh century upper church (figure 34). The upper church was consecrated on December 4, 1094 by Bishop Pedro of Jaca, and with Pedro I in attendance. ${ }^{120}$ Like the lower church, it is oriented directly toward the cliff rock. Instead of twin apses, the single nave of the upper church terminates into three communicating, semicircular apses. These sanctuaries are each barrel vaulted and, through a transition provided by transverse ribs, resolve into half-domes supported by blind arcades. The openings for the apses take the shape of a triumphal arch supported by grouped columns and this triple arch is firmly wedged beneath the sloping, exposed rock that dominates the southeastern half of the nave. The smaller dimensions and darkness of the cave-like sanctuary contrasts with the nave of the church, which is covered by a single barrel vault that appears spacious by comparison, an impression enhanced by the multiple windows piercing the northwestern wall. ${ }^{121}$ Nevertheless, the liturgical focus of the shrouded apses is reinforced by the downward slope of the living rock that directs the eye toward the cave-like openings of the unfenestrated apses.

A horseshoe arched portal leads to the twelfth-century cloister through the southwest wall of the upper church (figure 35). Scholars have long considered the doorway an artifact of the tenth-century church, removed during the course of the eleventh-century expansion of the lower church and inserted into the upper church. This assumption is based primarily upon the shape of the arch and the remnant of a carved

\footnotetext{
${ }^{120}$ Lapeña Paul, Guía, 9.

${ }^{121}$ According to Lapeña Paul, the length of the upper church is 32.35 meters, El Monasterio de San Juan, 70. The barrel vault is reinforced by two substantial transverse arches. These western windows are the result of a later restoration so the level of illumination for the western portion of the chutch is uncertain.
} 
impost, which suggest a stylistic relationship with the arches of the lower church. ${ }^{122} \mathrm{~A}$ Latin inscription may be read across the voussoirs of the arch; it announces that this door is a gateway to heaven for the devotee who unites faith with God's commandments. ${ }^{123}$

Beneath the rocky canopy is the last extant installment to the San Juan de la Peña complex relevant to the time period and topographical focus of this dissertation, the cloister (figure 36). According to Patton, this rectangular cloister walk measures approximately thirteen by nine meters and features two sculptural campaigns from the late twelfth, and first half of the thirteenth centuries, respectively. ${ }^{124}$ The uniquely roofless cloister features semicircular arches springing from carved capitals that rest on single or grouped columns. Originally, the arcades were flanked by multistoried buildings to the northwest, the upper church to the northeast, and the cliff face to the south - at the base of which flows a spring. The cloister is positioned at an angle that directly confronts the cliff wall and the spring instead of a more typical alignment with the wall of the upper church. On the face of it, this orientation may have been nothing more than a concession to the site. However, taken together with its exposure to rock and

\footnotetext{
${ }^{122}$ Gómez-Moreno, Iglesias, 38. Patton points out in her dissertation that although the door is frequently described in the literature, its function remains puzzling. "The Cloister of San Juan," 11, fn. 33. The faint trace of a second, bricked-in portal along the same wall compounds the confusion surrounding the function of the door. While most scholars seem to interpret the filled-in door as functioning prior to the opening of the present-day portal, there is a precedent for the concurrent presentation of two portals. Along the southern wall of the church of San Esteban de Gormaz, for example, there appears a horseshoe-arched portal only a couple of meters to the left of a semi-circular arched portal. Questions likewise surround this unusual organization but one of the theories is that the left-handed doorway was designed to facilitate the catechumens/converts from Islam. From my point of view, this theory could be supported by the nature of the late twelfth or early thirteenth-century inscription carved over the portal of San Juan, footnote blow.

${ }^{123}$ The inscription and transcription provided by Antonio Durán Guidol reads: PORTA / PER / HAC. C/AELI FI/T PVIA. CVIQ. / FIDELI / (cross) / SI S/TVDE/AD FI/DEI IV/NGE/RE IVSS/A D/EI (Porta per ha(n)c caeli fit p(er)via cuiq(ue) fideli / si studead fidei iungere iussa Dei). Antonio Durán Gudiol, "Inscripciones medievales de la provincia de Huesca," Estudios de Edad Media de la Corona de Aragón 8 (1967): 45-155, 40, no. 17. The author notes that although Miguel Dolç assigns an approximate date of 1071 to the inscription, he favors an early thirteenth century date based on epigraphic style. For Dolç's conclusions, based largely upon historical context, see "Sobre un dístico pinatense," Argensola: Revista de Ciencias Sociales del Instituto de Estudios Altoaragoneses, 7, (1951): 267-272, 271. See also Lapeña Paul, Guía, 19, and Patton, The Cloister, 11, fn. 34.

124 Patton, "The Cloister of San Juan," 15, 18-19.
} 
fountain, the cloister seems to follow the wider architectural patterns at San Juan that prioritized the sacred history of the site as a way to illustrate the authority of the monastery and its benefactors. ${ }^{125}$

\section{Conclusions}

In the tenth through twelfth centuries, Kings and counts typically patronized churches located in the small, urban centers of their territories. The reasons for this were imminently practical. In terms of defense, most towns and cities were safely removed from unstable borders and comprised of enough people to muster a militia, if necessary. A denser population also ensured that urban foundations enjoyed potential influence over larger audiences. This was useful at a time when the lack of a strong, central government limited a sovereign's control, prompting itinerant courts to move from one center to another and to enlist the support of ecclesiastical institutions and the aristocracy. Even relatively powerful kings, such as Alfonso VI of León-Castile (1065-1109), followed this pattern and courted the support of the dominant monastic center of Sahagún (León). ${ }^{126}$

Along the nebulous borders between kingdoms, counties, and al-Andalus, rural monastic centers occupied important positions of socioeconomic power and served as points of contact for scattered landholders. In the tenth and eleventh centuries, as kingdoms expanded into the territories of co-religionists and Muslims, certain monasteries offered a superior platform upon which to present their image of legitimate ruler than others; consequently, they attracted elite patrons despite their rural setting. The

\footnotetext{
${ }^{125}$ Patton, "The Cloister of San Juan," 15. For another explanation, see Patton, who suggests that the open cloister design may have been an attempt to illuminate the walkway, which would otherwise have been over-shadowed by the cliff overhang and the multistoried outbuildings to the northwest.

${ }^{126}$ See chapter two, 54-57.
} 
ideal foundation for nascent counties and kingdoms was one that could boast a clearly visible, divine source of power. Topographies with ancient significance, i.e. caves, springs, trees, rocks, or high places, retained their significance for medieval Christians and stood as a witness to (and sometimes a participant in) the lives, miracles, and bodies of holy men and women. The preservation or revelation of these places in the time of the Christian conquest supplied a legitimating past to those who sought the support of arms, men, and supplies, and who wished to develop a dynastic image.

The various building campaigns for San Millán de la Cogolla and San Juan de la Peña from the tenth to the twelfth century display common traits in terms of function rather than form. Each phase appears to have prioritized the sacred landscape from which their shrine or church derived significance and with which it illustrated its miraculous history. At the same time, the architectural forms employed were designed to recall stone buildings associated with spiritual and secular authorities. The origins identified for masonry, arches, vaults and layouts like these range widely and have included Roman, Visigothic, Asturian, Frankish, and Andalusi sources. ${ }^{127}$ It may be, however, that the reason for the confusion on the sources for these techniques and profiles is that specific buildings were not the models for these churches. Rather, the authority and power that a stone edifice represented to these frontier patrons was paramount.

Janice Mann notes that the only known architectural patron for these monasteries, Sancho el Mayor, was not merely exposed to extra-Peninsular architecture but appears to

\footnotetext{
${ }^{127}$ The emphasis placed on stone construction in texts like the Chronicle of Albelda and the Chronicle of Alfonso III is usually considered a carryover from Visigothic, and by extension Roman, building traditions. Horseshoe arches are generally considered Visigothic and/or Andalusi while the ribbed, domical vaults can be described as Byzantine or Andalusi. For the eleventh-century phases, Romanesque forms from beyond the Pyrenees are almost always credited as the sources for semicircular arches and diverse vaults.
} 
have deliberately engaged with the buildings of Cataluña. ${ }^{128}$ More important to Mann than the stylistic influences revealed by Sancho's benefaction, however, were the reasons that Sancho built. For example, Mann explained that Sancho used the jarring transition of horseshoe arch to rounded arch at both San Millán and San Juan as a way to document the positive changes wrought by his rule. The author also emphasized the significance of these sacred environments to his image.

Their [San Millán and San Juan] presence staked a claim not just to a new political frontier but to a geography made sacred for Christians in the past by holy events in the same way early Christian churches in the Holy Land expressed the Christian possession of the loca sancta of Christ's life. The physical appearance of both San Millán and San Juan establishes their spiritual antiquity. The changes in their fabric constitute a tangible visual record of their steadfast existence through the passage of time from the caves associated with pre-Islamic Christian anchorites, through the horseshoe architecture linked with the monks who worshipped at these sites before al-Man $\square$ ür's raids around the year 1000, to the repairs and additions that expressed an age of revival under the rule of Sancho el Mayor...Built with strikingly different elements, most notably the semicircular arch, Sancho's additions were literally linked to the old while at the same time declaring the new and pointing the way toward the future. ${ }^{129}$

I follow Mann's conclusions but would like to stress that Sancho's building did more than acknowledge history—it established his possession of a sacred topography that served as an important vehicle for his legitimacy, not only as the sovereign of Pamplona, but over neighboring kingdoms, whether Christian or Muslim. Moreover, I do not see the substitution of the semicircular arch for the horseshoe arch as simply a rejection of that architectural form. ${ }^{130}$ Although Mann acknowledges the deliberate maintenance of the horseshoe arched arcades at both sites, she views this strategy as homage to monastic history. I would suggest that the horseshoe arch, like the semicircular arch, was a flexible

\footnotetext{
${ }^{128}$ Mann, Romanesque Architecture, 59.

${ }^{129}$ Mann, Romanesque Architecture, 56-57.

${ }^{130}$ Mann, Romanesque Architecture, 52.
} 
sign of authority, capable of calling to mind a Visigothic or caliphal image of legitimacy. Instead of providing a "link" to a monastic life before al-Man $\square$ ūr (a dubious historical event, particularly for San Juan) this broad architectural vocabulary allowed Sancho to project an image of sanctioned power over heterogeneous subjects, i.e. Christians and Muslims, lay and clergy.

Why did the king require the cooperation of these diverse groups? The territorial expansion that was being undertaken by the nobles of León, Castile, Navarre, Aragón and Catalonia was a haphazard affair with multiple fronts. ${ }^{131}$ These polities were not centralized governments capable of sustaining large, standing armies. Particularly around their borders, the relationship between land-holder and lord, let alone king, was tenuous and changing. ${ }^{132}$ Given the insecure loyalties of the fighting men, and the rents and agricultural resources that supplied them, occupiers needed to use whatever means available to them to promote their cause. Along the frontier, monasteries and fortresses offered the practical platform for this propaganda. By utilizing strategically-sited foundations that were inherently sacred, and therefore powerful, Sancho could benefit from the authority of existing architectures and insert himself as the legitimate heir. ${ }^{133}$

\footnotetext{
${ }^{131}$ The demands put upon the rural Pinatensian and Riojan populations of this frontier region would be similar. For an overview, see Powers, A Society Organized for War.

${ }^{132}$ See Corral Lafuente, "El proceso de centralización de los monasterios Aragoneses entre los siglos IX y XI," in Homenaje a Don Antonio Durán Gudiol (Huesca: Instituto de Estudios Altoaragoneses, Diputación de Huesca, 1995), 229-230. The author describes the challenges that Muslim conquerors of Pyrenean territory faced due to the lack of cities and structure. As a result, the he explains that the region remained under the influence of local nobles and clans who relied upon relationships of patronage and clientage, saying, "Francos o godos, godos o musulmanes, a los habitants de los valles pirenaicos quizá les diera lo mismo quién fuera su señor." (ibid., 229).

${ }^{133}$ What Sancho hoped to accomplish may have differed slightly for these and other sites patronized by the Aragonese king. While he probably benefitted from monastic influence over regional militias, at San Juan he certainly capitalized upon the opportunity to establish a legacy in the form of a dynastic burial precinct. The monasteries in turn benefitted from the goods and prestige bestowed upon them through their noble associations. For more on the intention to establish a royal pantheon, see Carlos Laliena Corbera, "La memoria real de San Juan de la Peña: poder, carisma y legitimidad en Aragón en el siglo XI," Aragón en la Edad Media19 (2006): 309-324, 314.
} 
The circumstances that prompted architectural patronage at the potent sites of San Millán and San Juan were common to those found at other Iberian frontiers; the Duero Valley was an ideal setting for expanding powers to stake territorial and political claims. On the one hand, the decentralized nature of political networks permitted substantial autonomy for towns and villages. On the other hand, this situation also facilitated the ambitions of abbots, knights and aristocrats seeking to claim new territory under the justification of the presura, as repopulators, or as representatives of monastic orders and ecclesiastical hierarchies. For the non-royal conqueror, the site-selection and building strategies of kings served as a ready model for constructing legitimacy.

In the next chapter the case studies of Santa María de Wamba and San Baudelio de Berlanga will stand as case studies for a wider trend of architectural patronage found along the Duero frontier: the representation of pre-Islamic histories and elite architectural forms in rural religious settings for the purposes of socio-political control. Although unconnected to royal patrons, similarities in site selection and the architectural forms recall characteristics found at the royal monasteries of San Millán and San Juan. These parallels suggest that the patrons of frontier ecclesiastical spaces appropriated criteria employed by sovereigns at their borders in order to achieve the same goals. Through the cultivation of flexible, elite imagery that was designed to usurp or overcome any local resistance through references to a distant, powerful past, these small, rural churches became important promoters of Christian expansion and hegemony that would eventually develop into the Reconquest. 


\section{CHAPTER 4:}

\section{ARCHITECTURE AS PROPAGANDA ALONG THE DUERO FRONTIER}

Scores of stone churches were erected along the porous borders between Christian and Muslim Iberian kingdoms in the tenth through twelfth centuries. These foundations are characterized by sophisticated masonry, vaulting, arcades, and often inhabit remarkable topographical settings. Because the majority of "Reconquest" histories focus on the southern expansion of Christian kings, such frontier churches are implicitly thought to have been religious spaces erected to serve the needs of those sent to settle the so-called "depopulated" zone. This understanding of their function appears faulty, however, in light of recent work that challenges long-standing notions of "depopulation" and "repopulation." I submit that these frontier churches should therefore be reconsidered in light of their probable sociopolitical function and offer Santa María de Wamba (Valladolid) and San Baudelio de Berlanga (Soria) as case studies for how regional political control was articulated in building campaigns.

Urban centers were uncommon in the central Peninsular region but political and administrative networks nevertheless existed. Around the monasteries and towns of the tenth through twelfth-century Duero basin were organized, agrarian communities that had ties beyond their immediate vicinities, due to the transhumant nature of their herds. It is

\footnotetext{
${ }^{1}$ See chapter two.
} 
well documented that monasteries, in particular, were able to acquire and influence large tracts of land over hundreds of kilometers. ${ }^{2}$ Given this picture of the Duero Valley, it is difficult to believe that after more than a century of largely independent and local control these groups would have accepted outside governance without any resistance. As for the occupying powers, whether they were of a predominantly clerical or militaristic nature, the potential benefits derived from conquered frontier resources would have depended upon the level of indigenous cooperation. Surplus food and animals for military campaigns, along with men and women willing and able to fight, were critical commodities.

Military power was but one approach to the control or acquisition of territory. For the largely non-royal inhabitants and outside conquerors of the Duero, Upper March, and Extremadura frontiers, the appearance of a legitimate right to govern was essential to the ambitious patron who sought to exercise authority over others absent their own, personal military force. ${ }^{3}$ Central to this 'Hearts and Minds' campaign, then, was the "restoration" of churches attached to significant landscapes and histories. ${ }^{4}$ Numerous

\footnotetext{
${ }^{2}$ See, for example, a discussion of the tenth-century holdings of San Benito de Sahagún (León) in chapter two and for a recent and general overview of the relationship between monasteries, land, and power, see de Ayala Martínez, Sacerdocio y reino en la España altomedieval; iglesia y poder político en el occidente peninsular, siglos VII-XII (Madrid: Sílex, 2008).

${ }^{3}$ For the challenges in maintaining militias and mustering men for campaign, even for kings, see Powers, $A$ Society Organized for War, 112-114.

${ }^{4}$ This phrase is frequently used to describe one of the approaches undertaken by the United States Armed Forces in their ongoing fights in Iraq and Afghanistan. According to Rob de Wijk, the phrase denotes the efforts made by an invading force to "... win the support of the populace of the opponent" in "The Role of Military Power," in: The Battle for Hearts and Minds: Using Soft Power to Undermine Terrorist Networks, ed. Alexander T. J. Lennon (Cambridge, MA: The MIT Press, 2003), 18-19. I use this well-known description to reflect the importance that political scientists have placed on the specific use of information and symbols as devices capable of altering civic and cultural identity. Michael Bruter has explored the ways in which a sense of modern European community might be fostered among disparate nationalities through information or visual symbols, explaining, “...the findings regarding the role of symbols in the development of new political identities are even more interesting. The very fact that symbols seem to affect the cultural component more than the civic component of political identities suggests that the use of symbols may help make citizens feel more clearly a part of a given system. They may also be used to enhance the acceptance of ethnic or cultural minorities in countries affected by integration problems."
} 
churches were "restored" in this way, from the Cathedral of San Antolín of Palencia to the Ermita San Bartolomé at Ucero (Soria). ${ }^{5}$ Santa María de Wamba and San Baudelio de Berlanga have long been considered to be "restored" monasteries. What is of interest to this dissertation is why patrons elected to "restore" these foundations with impressive stone structures despite their precarious frontier locations. The ways in which sacred landscapes were combined with stone architecture and sophisticated decoration at Santa María de Wamba and San Baudelio suggests that their patrons expected to benefit from the projection of an authority derived from antiquity and an image of political currency. These two foundations and their properties held strategic value.

Santa María de Wamba and San Baudelio underwent substantial transformation between the tenth and twelfth centuries. Just as this time period is marked by significant shifts in political power throughout the Peninsula, so these churches reflect the ways in which changing authorities sought to preserve or displace influence in contested territory. The critical role played by landscape was not diminished. On the contrary, subsequent patrons continued to base their benefaction on the exploitative potential of the church's environment and sacred history, particularly when these elements were highly visible and could be emphasized through architecture. The strategic use and re-use of site and structure is not only clear at Santa María and San Baudelio but is further supported by a

\footnotetext{
"Winning Hearts and Minds for Europe: the Impact of News and Symbols on Civic and Cultural European Identity," Comparative Political Studies 36, no. 10 (2003): 1148-1179, 1170. Bruter argues that disseminating positive information about a collective system of identification, in this case, Europe, strengthens the civic identification of individual nationals as Europeans. Along the same lines, symbols of Europe, like flags and currency, improve the degree to which individuals identify themselves as cultural Europeans--but to an even greater degree than the correlation between positive information and civic identity. As for the dubious and complicated characterization of architectural patronage as "restoration" see the discussion in chapter two.

${ }^{5}$ See chapter two for the reasons that claims of restoration should be accepted with caution. For recent work on the increasing number of churches discovered to have multiple late antique and medieval phases, see María de los Ángeles Utrero Agudo, "Late-Antique and Early Medieval Hispanic Churches and the Archaeology of Architecture: Revisions and Reinterpretation of Constructions, Chronologies and Contexts," Medieval Archaeology 54, no. 1 (2010): 1-33.
} 
comparison with contemporaneous churches such as San Juan de Baños, San Miguel de Gormaz, San Román de Hornija, and others situated within the Duero basin.

\section{Santa María de Wamba (Valladolid): the site and earliest structure}

Today, the church of Santa María de Wamba is located in the heart of the small town of Wamba, which occupies a gentle slope near a minor tributary running between the small Rio Sequillo and the larger Rio Pisuerga basins. Eighteen kilometers west of the city of Valladolid, Wamba is one of several towns that were in close proximity to the numerous fortified strongholds in the Duero basin (figure 36). ${ }^{6}$ The basilica style church terminates in three apses and forms part of a larger monastic complex that includes a cloister, appurtenant chambers, a southern portico, and a monumental portal on its western façade. In contrast with San Baudelio, the landscape is less prominent and the architecture less overtly Andalusi in reference. Nevertheless, the surviving portions of the tenthcentury church and the twelfth-century building campaigns appear to have been deliberately designed to call attention to two significant bodies of water and to emphasize the association of the site with a royal Visigothic past. ${ }^{7}$

\section{Tenth century structure}

As it exists today, two distinctive sections comprise the church Santa María de Wamba, due to later architectural expansions (figure 37 ). ${ }^{8}$ The tenth-century section is

\footnotetext{
${ }^{6}$ Approximately ten kilometers to the southwest is Torrelobatón, a town dominated by a fortified tower consisting of multiple phases of construction; fifteen kilometers to the southeast is Simancas, a stronghold in the middle ages and ancient Roman center; approximately twenty eight kilometers to the northwest is the castle and walled town of Urueña; a little less than fifteen kilometers to the northeast is the castle of Fuensaldaña, among others.

${ }^{7}$ The thirteenth-century nave and portal are beyond the scope of this paper.

${ }^{8}$ See de la Quintana Gordon and Boned Colera, "Santa María de Wamba."
} 
defined by the solid stone vaults of the tripartite choir and apses of the east end. The three apses are squared-off spaces covered by slightly horseshoe-shaped barrel vaults of dressed stone. ${ }^{9}$ The courses of stone that form the walls beneath the vaults are not as finely worked; they consist of smaller, rounder stones that have been roughly shaped and are less uniform (figure 38). ${ }^{10}$ The central apse is slightly longer than those that flank it and extends the central portion of the eastern façade by a little more than a meter.

Although each apse originally had a high window, a later building completely blocks the window of the northern apse today. The horseshoe arches that permit access to each apse are lower and narrower than the vaults within, creating a slightly closed-off experience. Both Gómez-Moreno and the directors of the modern restoration, José Luis de la Quintana Gordon and José Ricardo Boned Colera, reconstruct the tenth century eastern apses without communicating doorways. ${ }^{11}$

The walls and cruciform piers that form the apses and the choir are massive. The small amount of decorative carving consists of relatively low relief patterns and vegetal forms subordinated to the structure. An example of this may be found on the rectangular capitals of the south apse (figure 39). ${ }^{12}$ Slots and channels in some of the rectangular piers of the apses and choir suggest that hanging curtains or chancel screens were used at

\footnotetext{
9 "The apse vaults are composed of squared and dressed stones, which shows that in the area of Valladolid by 930, there were workshops capable of producing large stone masonry." Kingsly, "Visigothic Architecture in Spain and Portugal," 173.

${ }^{10}$ Although this disparity may reflect the fact that the lower parts of the walls were obscured by frescoes, hanging curtains, or screens, I expect that practical concerns for the success of the stone vault were paramount.

${ }^{11}$ The present day apertures are semicircular in shape and do not appear to be original due to the disruption of the masonry around their position.

${ }^{12}$ Traces of black and red paint survive and the pillars from which they were carved bear scoring marks that suggest they, too, were once painted. When the paint was applied is unknown. In addition to these friezes and capitals is an interesting carved panel. In the blocked doorway located on the northern wall of the north apse is a panel containing a cross with arms of equal length, with bifurcated ends and having the appearance of a finely wrought, bejeweled metal cross, much like the tenth-century Cross of Victory in the Cathedral of Oviedo. Although the doorway appears to have been blocked up at some point after the eighteenth century, the panel is undated, as far as I am aware.
} 
some point in Santa María's past. ${ }^{13}$ Of the small amount of decoration that has survived from this period, a section of painted fresco remains in its original place, on the eastern wall of the central apse (figure 40). ${ }^{14}$

Supported by ashlar piers, horseshoe arches not only frame the entrances to the dimly lit apses but demarcate the tripartite choir which is vaulted to different heights. Beneath the tallest vault is the central choir, which receives some light from the small window placed high above in the vault. The three barrel vaults of the choir are oriented with the longitudinal axis of the church and are also slightly horseshoe in shape. There is no consensus on how the western half of the church originally appeared. ${ }^{15}$ The pillar that provides the transition to the nave is an awkward combination of a rectangular, tenthcentury pier and the rounded compound columns that comprise the western half of the early thirteenth-century nave (figure 41 ).

The tenth-century construction of Santa María was probably motivated by the belief that King Recceswinth (d. 672) had been buried at this location. This tradition would have qualified the tenth-century church as the "restoration" of a significant Visigothic foundation and the burial site of a popular Visigothic king. Sculptural fragments consistent with the Visigothic era have been recovered from the site and may indicate the existence of an earlier church but medieval claims of proximity to the

\footnotetext{
${ }^{13}$ See also Quevedo Chigas, 205 and Gómez-Moreno, 102-103, 179, 198.

${ }^{14}$ I will discuss the fresco in detail below.

${ }^{15}$ For Gómez-Moreno the resolution was that of a cross inscribed within a square and vaulted throughout. Thus, a nine bay nave attached to three square apses, similar to Bāb al-Mardūm in Toledo, although Gómez-Moreno emphasized its Gothic and Asturian tradition. Iglesias, 196-197. Fernández Arenas, Mozarabic Architecture, after Gómez-Moreno, is convinced that the ground plan of Wamba copies that of Santa María de Lebeña, a nine-bay square 74-76. Dodds, on the other hand, prefers a basilica for the original Mozarabic nave.
} 
respected Visigothic king were probably the most important. ${ }^{16}$ According to tradition, the first builders of the present structure were "Mozarabic" monks working under the direction of a former Bishop of León, Frunimius, who retired to Wamba around $938 .{ }^{17}$ The historical significance of Wamba was well known in the Middle Ages: according to Julian of Toledo in his Story of King Wamba, the town of Gérticos was the site of the death and burial of King Recceswinth in 672 and the subsequent election of a Visigothic noble named Wamba to serve as king. The chronicler explains that the name of the town was changed from Gérticos to Wamba in honor of these events. ${ }^{18}$

In 1990, Jerrilynn Dodds used the royal, Visigothic past of Santa María de Wamba to support her position that tenth-century Leonese churches were built as part of

\footnotetext{
${ }^{16}$ For Visigothic material and the related controversy, see Gómez-Moreno, Iglesias, 200-202; Raquel Alonso Álvarez, "Hornija, Bamba, Pampliega: las elecciones funerarias de los reyes Hispanovisigodos," Territorio, sociedad, y poder 3 (2008): 13-27, 18-19. The most interesting of these materials is the altar support that is preserved at the Museo de Valladolid. It is a little more than one meter in height, square in shape with a base, shaft and Corinthian capital carved in low relief. Along the length of the pillar is an attenuated cross that is meant to represent a cross with arms of equal length, with the ends flared. At the top of the support is a small, square receptacle, perhaps for relics. The description of this altar is consistent with the typology described by as a reused Roman altar, according to Isaac Sastre de Diego, "Iconographic Influences of Roman Aras in Early Christian Altars: Prevalence of Formal and Conceptual Elements in "Hispania'," in The Reception of Antiquity in Performing and Visual Arts, ed. María Josefa Castillo Pascual, (Logroño: Universidad de La Rioja, 2008).

${ }^{17}$ Gómez-Moreno, Iglesias, 194-196. As discussed in chapter one, Mozarabs have been traditionally understood to be Christians under Muslim governance who were culturally influenced by their Andalusi rulers, or Arabicized. While it is possible that Andalusi Christians may have comprised part of the retired bishop's party and may have been involved in the design or building of Santa María, the automatic assumption that Hispano-Andalusi styles must derive from a Córdoban refugee is short sighted.

${ }^{18}$ According to Gómez Moreno, Iglesias Mozárabes, two other towns are called "Bamba." One is located in Lampreana, with the church of San Tomás (Zamora), and the other is to the south of the Duero, in Val de Xema at the monastery of San Martín (near Salamanca), 193-194. Joaquín Martínez Pizarro acknowledges that although the designation of Wamba as Gérticos is not certain, its proximity to San Juan de Baños seems favorable due to the well-known connection between San Juan de Baños and King Recceswinth. An additional argument in favor of identifying Wamba with Gérticos is the following passage in The Story of Wamba: Julian of Toledo's "Historia Wambae regis": "These events were taking place in a small estate in the region of Salamanca that from ancient times bore the name of Gérticos, distant some hundred and twenty miles from the royal city." (Washington D.C.: The Catholic University Press, 2005), 178-182, 181, fn 21. Wamba lies approximately 150 miles from Toledo. See also Alonso Álvarez, "Hornija, Bamba, Pampliega," 21. Although Alonso Álvarez agrees that the burial of King Recceswinth probably took place in Gérticos, she notes the difficulty to definitively identify the Visigothic Géritcos. Nevertheless, there appears to be support for the conclusion that by the tenth century, the present day town of Wamba (Valladolid) had successfully connected its foundation with the sepulchral precinct of the Visigothic king.
} 
a deliberate revival of Visigothic imagery. ${ }^{19}$ She argued that as Córdoban monks

repopulated the Duero basin, they discovered ruined Visigothic churches and strategically

employed their architectural forms as expressions of new-found religious freedom and

historical identity. ${ }^{20}$ Expanding upon the theories of neovisigotismo proposed by Isidoro

Bango Torviso, Dodds explains:

A Mozarab of the late ninth century must have seen such a concentration of grand sacred monuments as existed in Oviedo as testimony to the strength of Christianity in the north-as a glorious and welcome testimony-after experiencing constrictions to patronage and destruction of churches in al-Andalus. It is perhaps to this fresh, exultant interest that we can attribute so many discussions of building in the chronicles of Alfonso III's reign. Buildings and patronage were for the Mozarabs a source of demonstrative faith; their very existence and concentration in a Christian capital merited connection with the myth of Visigothic continuity, not as the faithful reproduction of a historical style but as a robust flourishing of monumental Christian building that paralleled the golden age in Toledo. ${ }^{21}$

Dodds considers the foundation story of the town and church as one that no doubt appealed to builders intent on restoring cultural and religious pride. ${ }^{22}$

\footnotetext{
${ }^{19}$ Dodds, Architecture and Ideology, 74-77 in particular.

${ }^{20}$ Dodds directs the reader to Gómez-Moreno 107 and Bango Torviso, "El neovisigotismo artistico de los siglos IX y X: la restauración de ciudades y templos,” Revista de ideas Estéticas, 148 (1979), 319-338, where one can find Bango Torviso's list of documents that explain the condition of these churches (all deserted and in ruins, of course). Dodds' explanation for the Mozarab motivation to build remains standard.

${ }^{21}$ Architecture and Ideology, 79

${ }^{22}$ Dodds, Architecture and Ideology, 81. The author argues that the reason monks from Córdoba were motivated to travel first to Asturias and later, to settle in the Duero basin, stemmed from the violent experience of the martyr's movement in al-Andalus. This point of view on the motivation for the martyrdom of Andalusi monks in Córdoba contrasts with the perspective of Kennth Baxter Wolf, who believes that the spiritual insecurity of the age, illustrated by the preoccupation with penitential rites and monasticism among lay people, combined with the possible association of Islam with the world that true penitents must renounce in order to be sure of their salvation, resulted in the extreme measure of seeking martyrdom. He notes that many of the unsympathetic accounts of the martyrs (both Christian and Muslim) see these sacrifices as nothing but prideful, selfish expressions. See Christian Martyrs in Muslim Spain, 107-119. Bonnie Effros likewise does not find evidence for a wide-spread sympathy for the ninth-century martyrs among either Northern Spanish monasteries or even Christians living in Córdoba in "Usuard's Journey to Spain and Its Influence on the Dissemination of the Cult of the Cordovan Martyrs," Comitatus: a Journal of Medieval and Renaissance Studies 21, no. 1 (1990): 21-37.
} 
Although I find it unlikely that the tenth and eleventh-century architecture of the frontier privileged Asturian architectural forms as part of a Cordoban monk-led Visigothic revival, I agree with Dodds that the regal history of Wamba was the chief reason that the church of Santa María was erected there. ${ }^{23}$ I would argue that the way water was incorporated into the stone fabric of the church symbolized an appropriation of both the power of the place and its Visigothic past to serve the territorial ambitions of Frunimius and his cohort. As briefly described above, two wells are preserved at Santa María de Wamba. While it is routine for monasteries to be built near a well and for that well to be found in the cloister, the second well's location directly beneath the nave floor in front of the present-day choir space is remarkable (figure 42). In addition to the unusual topography, patrons would have been attracted to the site of Wamba because of its association with the election of King Wamba.

Unlike most Visigothic kings, Wamba was elected by his peers at the time of King Recceswinth's death. The particular circumstances of King Wamba's transition to power-that nobles and clergy elected him, after the ancient Visigothic tradition, as opposed to inheriting the throne, no doubt provided a welcome precedent for a type of legitimate governance that could, in turn, serve the non-royal patrons of Santa María de Wamba. ${ }^{24}$ We do not have any record of who might have been living at Wamba or how

\footnotetext{
${ }^{23}$ Since the 1990 publication of Architecture and Ideology, additional information has come to light concerning the plausible demographics of the Duero basin. Scholarship in the last two decades has also complicated our present understanding of who "Mozarab" and Andalusi immigrants might have been, as explained in chapter one. From this vantage point, I expect that these churches were built by ambitious clerics and nobles of diverse origins and that elite architectural forms were selected with the local population in mind, thus a range of Andalusi, Asturian, Frankish, etc., forms appear, depending upon their likelihood to impress.

${ }^{24}$ The Story of Wamba, 178-182. Despite the long-standing legal mandate that Visigothic kings be elected, few were; most were usurpers or royal appointments. "The elective principle may therefore be understood as an aristocratic project in permanent conflict with the dynastic practice of the rulers of Spain. In so far as the councils endorse and preserve the elective formula, they speak for the nobility and represent its interests." (ibid, 13). This does not mean that Wamba represented a period in which royal power
} 
the monastery was organized or run in the tenth and eleventh centuries. Judging by comparable circumstances that arose between communities and monasteries in nearby places, however, it is reasonable to assume that the appearance of outside clerics at Wamba would have prompted some level of negotiation between the parties. ${ }^{25}$ On the one hand, the existing supralocal elites (who had maintained the town's connection to a celebrated Visigothic past) would have presumably resisted the threat to their authority posed by Frunimius and his clerical retinue. On the other hand, Frunimius planned to build a church that would elevate the status of Santa María de Wamba, positioning it to successfully compete with nearby monastic centers, such as San Cebrián de Mazote. Both the existing population and the incoming clerical authority would have benefitted from the architectural augmentation of a landscape that visibly articulated its valuable history in the form of water sources and royal tombs (figure 43).

The builders of the tenth-century church of Santa María prominently positioned the well-access in front of the central choir as a way to underscore the sanctity of the

contracted, rather, Martínez Pizarro argues that the combined reigns of Chindaswinth, Recceswinth and Wamba should be seen as a successful win for kings over the efforts of nobles, due to the dearth of church councils called during their tenure (none in Wamba's time) which is where they might have been subject to criticism. It may be significant that Wamba was likely of an advanced age without wife and children, making him more appealing to the assembled nobles and clergy, see Story of Wamba, 59, fn. 137. See also Pablo C. Diaz and M. R. Valverde, "The Theoretical Strength and Practical Weakness of the Visigothic Monarchy of Toledo," in Rituals of Power: from Late Antiquity to the Early Middle Ages, ed. Frans Theuws and Janet Nelson (Leiden; Boston; Köln: Brill, 2000), 63. Visigothic kingship was originally sanctioned only in times of war, when the "primus inter pares" or the first among equals, was given absolute authority until the crisis had passed. The tension between royal dynasties and elections illuminate some of the lingering tensions between the nobles (who were just as likely to be the next king through election, usurpation, or royal appointment) and the king in Iberia. That the clergy often sided with the nobles is all the more understandable when one considers that they often had aristocratic ties and sought security for their descendents and families as well. However, Martínez Pizarro points out that Wamba seems to have gone to great lengths to justify his election (after a thirty year period of unelected kings) and therefore his narrative addresses each traditional point, from ritual refusal to his unction and installation at the urbs regia of Toledo, 39-40.

${ }^{25}$ Wendy Davies describes the 977 agreement between the peasant community of Fuentes (outside of Sahagún) and its monastery, in which the inhabitants agree to serve only the monastery at the risk of being fined. After discussing a similar situation at the Villa Castellana, Davies acknowledges that the reasons peasant communities would have turned over control of their villas to monasteries or Bishops is not always clear, Acts of Giving, 198-199. 
meaningful landscape. ${ }^{26}$ Topographical constraints were not to blame for the siting of

Santa María over a well and the understandable hazards of building on top of water should have deterred this arrangement. That water was physically incorporated into the church of Santa María, just as a cave and spring were incorporated into multiple building phases at San Juan de la Peña, should be understood as a signal to its medieval audience that it possessed significance and power. ${ }^{27}$

A comparable example of this arrangement survives at San Román de Hornija (Valladolid), which is forty-two kilometers to the southwest of Santa María de Wamba. As at Santa María, access to a well has been preserved there under the nave floor (figure 44). It is difficult to fix the precise location of this well within the original tenth-century church of San Román because it has undergone numerous restorations over the centuries. ${ }^{28}$ However, Gómez Moreno has proposed that the present day apse occupies the space of the original apse, which is reasonable in light of medieval accounts

\footnotetext{
${ }^{26}$ To date, I have been unable to find any discussion of the wells or their source in the scholarly literature, except concerning the negative effects they have had on the preservation of the church and its frescoes: "Sin embargo, las Corrientes subterráneas del emplazamiento (existen dos pozos en los ejes de iglesia y claustro, Fig. 1) y la naturaleza de un suelo arcilloso que solo en seco alcanza buena resistencia a la compression, habían provocado la desestablilización de la cimentación..." de la Quintana Gordon and Boned Colera, "Santa María de Wamba," 26. Until more information comes to light, it seems reasonable to presume a subterranean source for the water.

${ }^{27}$ de la Quintana Gordon and Boned Colera, "Santa María de Wamba," 26. The walls of the tenth-century church have considerable thickness. This may have been done to offset the corrosive effects of building on top of a subterranean water source. Despite the quality of construction, the restorers report that in the winter of 1985, they were able to observe the spontaneous dripping "apereciendo goteos superficiales espontáneos" of some sections of the wall, where the humidity had penetrated more than four meters of material in the course of its evaporation.

${ }^{28}$ See "Hornija, Bamba, Pampliega," 16-18. The date of the original church and its connection with the Visigothic King Chindaswinth is controversial. As Raquel Alonzo Álvarez relates, some scholars have argued that an inscription and capitals indicate a Visigothic date, while the same capitals and other marble fragments have been declared to represent a Mozarabic structure of around 900. Despite the evidence for a previous occupation of Hornija, caution should be taken in firmly connecting the town to a royal tomb since the earliest textual account of this was written in the twelfth century by Bishop Pelayo of Oviedo, who is well known for producing false or interpolated texts. Regardless of the accuracy of the claim of a Visigothic foundation, the medieval patrons of San Román, like those of Santa María de Wamba, successfully connected their ecclesiastical center to material symbols of Visigothic heritage.
} 
describing its appearance in the sixteenth century. ${ }^{29}$ If this is correct, the short distance between the modern apse and the existing well access would suggest that it, too, was positioned beneath the original nave floor. ${ }^{30}$

A second connection between Santa María de Wamba and San Román de Hornija is the common medieval tradition that both of them sheltered Visigothic graves. San Román de Hornija was first described as the location for the tomb of King Chindaswinth (d. 653) by Bishop Pelayo of Oviedo in the twelfth century. Although there are reasons to suspect the accuracy of this assertion, the striking marble sepulcher in which the remains of the king and his family were purportedly placed would have served as a credible support for their claims (figure 45). ${ }^{31}$ The antiquity of the site of Hornija, together with the Visigothic tradition of burying kings at their private country villas and not in Toledo may have further supported the association of the villa of Hornija with the Visigothic monarchy. ${ }^{32}$ What is clear, however, is that physical signs of a Visigothic heritage could have been essential to the success of a foundation. Proof of this can be seen in the rapid demise of the monastery of Pampliega after King Alfonso X, el Sabio (1252-1284) translated the purported body of King Wamba (died 680) to Santa Leocadia de Toledo in $1272 .{ }^{33}$

\footnotetext{
${ }^{29}$ Iglesias Mozárabes, 186-187. Gómez-Moreno also relates a passage from the chronicler Ambrosio de Morales (d.1591) who saw the original east end of the church before its demolition in the last third of the sixteenth century and who compared the arches of San Román de Hornija to those at Santa María de Wamba.

${ }^{30}$ In the west central section of the Duero basin, cave churches are even rarer than in the eastern Duero basin or Ebro river basin. This may explain why churches are sited above wellsprings instead of excavated out of the cave-sheltered springs.

${ }^{31}$ Alonso Álvarez tentatively suggests that Hornija may indeed be the site of Chindaswinth's mausoleum but she qualifies this as little more than a suspicion in "Hornija, Bamba, Pampliega," 18.

${ }^{32}$ See "Hornija, Bamba, Pampliega," where Alonso Álvarez persuasively demonstrates that for Visigothic kings, cultural tradition would have dictated a private mausoleum, probably at the family villa, rather than a noble pantheon in the royal city.

${ }^{33}$ Raquel Alonso Álvarez, "Los enterramientos de los reyes de León y Castilla hasta Sancho IV," e-Spania 3 (2007): 1-15, 6-7. This article is available at http://e-spania.revues.org/109; consulted October 12, 2010.
} 
The architectural integration of wells and springs into medieval churches appears to have communicated to a medieval audience that the foundation inhabited sacred space. These signs may have been incorporated into churches like Santa María or San Román to support ambitious claims of an ancient, royal prestige. Conversely, the preservation or discovery of wellsprings and sarcophagi could have suggested to prospective builders that they marked a special sepulchral precinct. Regardless of the order or synchronicity of events, patrons at both sites appear to have believed that the incorporation of these wells within the church would increase the sanctity of their foundation in a visible, tangible way.

The speculation that these bodies of water were regarded as divine is strengthened by the miracles associated with the spring at San Juan de Baños (Palencia), which is approximately fifty-four kilometers to the northeast. An inscription located above the central apse in San Juan de Baños records how the church was founded by the Visigothic King Recceswinth in 661 as a thanks offering for the miraculous healing that he experienced after drinking water from the nearby springs (figure 46). ${ }^{34}$ Dates remain unclear for the multiple medieval building phases of San Juan de Baños but the physical presence of the healing springs combined with the dedicatory inscription that tied the place to Visigothic royalty and healing no doubt benefitted numerous proprietors. ${ }^{35}$ This

The legitimacy of Pampliega's claim on King Wamba's body is also suspect but as Alfonso's actions demonstrate, was not only well-accepted by the thirteenth century (if not earlier) but yielded considerable value for the monastery.

${ }^{34}$ The spring is a little less than one hundred meters away. It is a robust water source that flows not only from the channels that empty into a trough placed below but seeps out from the rock staircase and other surfaces. For an early analysis of the mineral properties of the spring, see Eugenio Muñoz Ramos, "El agua que bebió Recesvinto," Boletín de la Sociedad Castellana de Excursiones (1904-1905): 164-65.

${ }^{35}$ The nave and central apse of the present-day church is traditionally dated to 661, due to an inscription, while the north and south aisles and apses are dated to the tenth century, see Dodds, Architecture and Ideology, 126, fn. 70 and Pedro de Palol, Excavaciones en la necropolis de San Juan De Baños (Palencia) (Madrid, 1963). However, in recent years scholars have challenged the seventh century dating of the church, for example, Luis Caballero Zoreda who preferred a Mozarabic date instead in "Observations on 
elite reputation probably accounts for the large number of inhumations dating as early as the ninth century, found near the north and west church walls (figure 47). ${ }^{36}$ Similar to the topographical and historiographical distinctions claimed for San Millán de la Cogolla and San Juan de la Peña, a pre-Islamic, powerful locus attracted patrons and donors to San Juan de Baños, including Visigothic kings, and this established the site as a place of divine and terrestrial authority that subsequent proprietors would preserve and nurture.

San Juan de Baños' association with both Visigothic royalty and miraculous waters would have been known to the monks at Santa María de Wamba. ${ }^{37}$ Not only is the foundation only one day's journey away by foot but given the monks' awareness of Visigothic histories, the proximity of an established monastery with claims of both a miraculous spring and a dead Visigothic king would not likely have escaped their notice. Moreover, the monastic sites just discussed, San Román de Hornija, Santa María de Wamba, San Juan de Baños, and the monastery of Pampliega, formed a thematic group of foundations that were roughly a day away from each other along the commonly traveled conduit of the Pisuerga River (figure 48). ${ }^{38}$ Gómez Moreno follows the assertion of sixteenth-century chronicler Ambrosio de Morales that the body of King Chindaswinth at

\footnotetext{
Historiography," 239, 257, while dendrochronological analysis has revealed the reuse of timber that was felled in the mid-fifth to sixth centuries, see María de los Ángeles Utrero Agudo, "Late-Antique and Early Medieval Hispanic Churches," 10.

${ }^{36}$ For details, see Pedro de Palol, Excavaciones en la necropolis, 4-5, and 22-24.

${ }^{37}$ Giovanni Teresio Rivoira, Moslem Architecture, Its Origin and Development, trans. Gordon McNeil Rushforth (Oxford University Press, 1918). The dedication to Saint John was made not because of the miracle but because this was the site of an ancient bath, 248-249, see also Elena Quevedo-Chigas, "Early Medieval Iberian Architecture," 192. The inscription indicates that this church was on the king's land and was a proprietary church.

${ }^{38}$ The close proximity between foundations claiming royal burials would have served to mutually reinforce the claims made by each site. The convenient grouping of relics and sacred places may have furthermore served as an attraction for pilgrims, as the body of King Wamba appears to have done for the monastery of Pampliega until its thirteenth-century translation.
} 
Hornija was venerated as a saint. ${ }^{39}$ Even if the tomb was not a source of veneration, the decline witnessed at the monastery of Pampliega after the body of King Wamba was translated emphasizes the value of a royal Visigoth on the premises.

\section{Tenth century legitimacy}

The proprietors of Santa María de Wamba coordinated monumental architectural forms and the sacred landscape in order to persuade the existing community that they had religious and political authority over the region. Just as the more entrenched Islamic culture would dominate at San Baudelio in the eleventh century, the tenth-century patrons worked within the local socio-political circumstances at Wamba and brought with them their own (recent) experience of Asturian ambitions for the new capital of León. The three-part east end, barrel vaults, and exterior strip butresses of the surviving tenthcentury north wall of Santa María de Wamba recall the building projects of ninth-century Asturias, such as San Salvador de Valdediós. ${ }^{40}$

This is not to say that Islamic culture was absent at Wamba. On the contrary, the repetition of horseshoe arches and painted luxury fabrics were flexible signs of Christian and Andalusi sovereignty to an Iberian audience. The painted textile that appears on the east wall of the central apse is a sophisticated depiction of motifs typically found in Islamic textiles and it requires additional consideration (figure 40). ${ }^{41}$ The fresco is

\footnotetext{
${ }^{39}$ Gómez-Moreno, Iglesias Mozarabes, 187. The devotion accorded the Visigothic King Hermenegildo may have served as a precedent for the reverence accorded Visigothic kings. For the reasons behind Philip II's ambition to acquire pieces of all of Spain's relics, including King Hermenegildo, see Guy Lazure, "Possessing the Sacred: Monarchy and Identity in Philip II's Relic Collection at the Escorial," Renaissance Quarterly 60, no. 1 (Spring, 2007): 58-93, 78-79 in particular.

${ }^{40}$ The connection between building in stone and Asturian kingship is discussed in chapter two.

${ }^{41}$ To date, I have come across very little concerning these paintings, most of which are limited to a brief discussion of their appearance. One of the few scholars to interpret a meaning for the paintings is J.J. Martín Gonzalez, who attributes to their painter a specific Christian message: "Ahora bien, es evidente que
} 
characterized by two rows of square frames in which roundels containing heraldic animals or stylized flowers are set. Decorating the concentric rings of the roundels are chevrons, zig-zags, dots, and other designs related to Islamic woven goods, painted in colors of black, orange-red, and white. ${ }^{42}$

For the cultures of the Mediterranean world, textiles represented wealth and status and their significance to Islamic culture, in particular, has been an important area of study. ${ }^{43}$ The style and arrangement of the painted textile is similar to those sumptuous fabrics that appear in the possession of courts or cathedrals, or that line the interiors of priceless reliquaries. Looking at an eleventh-century reliquary from León and a circa 1100 silk fragment from the Cathedral of Burgo de Osma, comparisons between the painted textile at Santa María de Wamba and these fabrics are straightforward (figure 49, 50). Within the reliquary of Saint Isidore, the multi-colored silk fabric preserves rows of roundels, concentric rings, dots, circles and vegetal motifs. A similar composition appears in the fragment of an Andalusi-made silk fragment found at the Cathedral at Burgo de Osma. Here, rows of large roundels are joined to their neighbors with smaller circles inhabited by stylized rosettes. Concentric rings, decorated with circles and dots frame a larger field containing confronting harpies and lions on either side of a tree of

esta pintura no cumplió meramente una function ornamental. La cruz revela claramente la intención de ilutrar el sentido religioso." "Pintura mural del iglesia de Santa María de Wamba (Valladolid)," Boletín del Seminario de Estudios de Arte y Arquología 32 (1966): 435-436, 435. However, after the most recent restoration of the painting, the central panel of the lowest band does not appear to have featured a cross after all.

${ }^{42}$ The description of color is based on my own observations; the restoration report does not describe the original pigments that were cleaned as part of their restoration efforts, de la Quintana Gordon and Boned Colera, "Santa María de Wamba," 32.

${ }^{43}$ Lisa Golombek, "The Draped Universe of Islam," in Late Antique and Medieval Art of the

Mediterranean World, ed. Eva R. F. Hoffman (Malden, MA; Oxford, UK: Blackwell Publishing, 2007); Oleg Grabar, "The Shared Culture of Objects," in Byzantine Court Culture from 829 to 1204, ed. H.

Maguire (Cambridge, MA: Harvard University Press, 1997); Eva R. Hoffman, "Pathways of Portability: Islamic and Christian Interchange from the Tenth to the Twelfth Century," Art History 24, no. 1 (2001): 1750 . 
life. ${ }^{44}$ That said, limiting the analysis of these paintings to their stylistic properties is shortsighted. $^{45}$

As María Judith Feliciano argues in her article "Muslim Shrouds for Christian Kings," Christian and Muslim nobles sought Andalusi textiles not only for their aesthetic appeal and luxurious nature but also as a sign of their legitimate status, wealth, and divine sanction. ${ }^{46}$ She contends that these luxurious materials therefore played a highly functional role, signaling to either a Castilian or Andalusi audience that the wearer was a legitimate elite. ${ }^{47}$ The visible reference to the textile tradition of power at Santa María de Wamba, one frequently associated with Christian and Muslim nobility, within the sanctified space of the central apse should therefore be viewed as a reflection of the sociopolitical function of this church and its ability to communicate to a multicultural audience.

Finally, the incorporation of the well into the ashlar-vaulted, impressive church would have acted as a physical reminder of the ancient locus onto which it was set. Santa María was not haphazardly built over the well-access but designed so that the well was centrally positioned on the east-west axis of the central apse and western portal (figure

\footnotetext{
${ }^{44}$ For more on the reliquary of Saint Isidore and the fragment from the Cathedral of Burgo de Osma, see the catalogue entry in The Art of Medieval Spain A.D. 500-1200 (New York: The Metropolitan Museum of Art, 1993), 239-244 and 108-109, respectively. Although scholars are fairly confident that the Burgo de Osma fragment was made in al-Andalus (despite the woven inscription identifying its source as Baghdad), the origin is less certain for the reliquary fabric, which has been compared to textiles from North Africa and the Byzantine Near East.

${ }^{45}$ Feliciano offers a just critique: "Traditional art historical investigations have taken a strictly formalist approach to the study of Andalusi luxury arts, treating textiles as little more than decorative objects lacking a useful social life. Such a restricted interpretive lens results from an academic practice that has established medieval Iberia as a society of extremes, either stressing the conflictive nature of its culture or overemphasizing a model of peaceful, multicultural convivencia." "Muslim Shrouds for Christian Kings," 101.

${ }^{46}$ Although Feliciano centered her discussion around thirteenth-century textiles, the long-standing respect and adoration for Andalusi cloth and its use by nobles and kings extends at least as far back to the tenth century, as discussed by Eva Hoffman in "Pathways of Portablilty," 25-26 in particular.

${ }^{47}$ See Feliciano, "Muslim Shrouds for Christian Kings," 117-124 in particular.
} 
51). Its physical centrality to the church's structure may have been further amplified by its ritual function, if the water from the well was also used for baptism. The location of the well before the choir space is significant, since according to Visigothic and Mozarabic practices, medieval Iberian choirs served as the place where the clerical and lay segments of the population intersected, for example, during the presentation of converts or infants for baptism. ${ }^{48}$ A baptistery located at the west end of the ermita San Miguel de Gormaz (Soria) further reinforces the perception that local circumstances could shape how receptacles or fountains of water were incorporated into the topography of frontier churches (figure 52). ${ }^{49}$ At Santa María de Wamba, the landscape and architecture were designed to emphasize the close proximity to both Visigothic royalty and ancient well-springs and in so doing, prop up the regional influence of the monastery and its legitimate proprietor, Frunimius. ${ }^{50}$

\section{The twelfth century}

The most useful publication for the later phases of construction of the church and monastic complex is the restoration report published by the architects in $1992 .^{51}$

Unfortunately, the methods employed by the architects for assigning dates are not noted, so their chronology should be considered with all due caution. In this article, the restorers suggest that a hospital for pilgrims may have been established by the Order of

\footnotetext{
${ }^{48}$ Quevedo-Chigas, "Early Medieval Iberian Architecture," 96-98. For example, parents were to present their children to the bishop for baptism by entering the choir during the designated time, or honored clergy might be laid out in the choir prior to burial.

${ }^{49}$ San Miguel de Gormaz is discussed below as part of the analysis of San Baudelio and its environs.

${ }^{50}$ Death and baptism are ritually related and although beyond the scope of this project, the apparent symbolic connections between tombs, springs and baptismal fonts would benefit from additional consideration.

${ }^{51}$ I have made multiple inquiries to multiple sources in an attempt to acquire the contact information for the archaeologist listed as responsible for the excavation at Santa María de Wamba, with no success. I appreciate the efforts that Raquel Alonso Álvarez has made on my behalf. For the report of the restoration of Santa María de Wamba, see de la Quintana Gordon and Boned Colera, "Santa María de Wamba."
} 
the Hospital of St. John of Jerusalem in the twelfth century, after the conclusions of Gómez-Moreno. ${ }^{52}$ The authors indicate that the patronage of the Hospitallers probably coincided with the appearance of new rooms along the northern facade of the church and the western side of the cloister. In addition to these changes, they date the insertion of two portals into the north wall of the church nave to this century, according to their detailed plans (figure 53 for plans and figure 42 for photograph). ${ }^{53}$ The larger portal was semicircular and provided access between the choir and the cloister, while a few meters to the west, the traces of a horseshoe-arched portal are still visible today. It is also possible that the bell tower was raised over the central crossing at this time. ${ }^{54}$

It is difficult to determine the ways in which the twelfth-century additions were vaulted due to the later phases of construction, particularly for the baptistery, and to the restoration efforts to halt water damage. Nonetheless, the groin vault above the chamber immediately to the north of the choir appears to belong to the original construction, despite its unusual appearance (figure 54). Unlike the crisply dressed ashlars comprising the barrel vault in the ossuary, which appears to have been built at the same time, the vault for this small chamber is made up of small irregular stones and mortar. ${ }^{55}$ The rough stone courses are set so that the long side of narrow stones create a jagged surface, in contrast with the dressed stone that forms the walls and the four surrounding semicircular archways. The four corners of the vaults rise from a relatively low point along the wall, a little less than two meters above the floor, and the diagonal edges awkwardly come together in a shallow intersection. An organic, almost subterranean atmosphere is the

\footnotetext{
${ }^{52}$ Gómez-Moreno, Iglesias, 196.

${ }^{53}$ Although the portals are referenced briefly in the text and in the plan drawing, the chronology and function of their construction is not discussed.

${ }^{54}$ See de la Quintana Gordon and Boned Colera, "Santa María de Wamba," 22. This bell tower only survived until the beginning of the twentieth century.

55 The chamber is approximately four by four meters square.
} 
result of this low-pitched, roughly-formed chamber. Supporting this vault is a round column comprised of stone drums. Although the restorers claim that the column dates to the seventeenth century and has been damaged by dripping water, this determination is problematic in several ways. In my opinion, the thrust of the shallow vault argues that it was designed with a supporting column from its inception. The strange appearance of the vault, at odds with its contemporaneous, flanking vaults, as well as those built on the western side of the cloister at around the same time, suggests that it was meant to stand apart and that it served a different function.

The appearance of the column itself is very interesting. The lower half of the column is quite damaged while the upper half remains largely intact. The explanation of water damage offered by the restorers does not adequately explain the uneven nature of its effects. On the other hand, traditional accounts surrounding this column, still called the Árbol del Vida, or Tree of Life offer a possible explanation. ${ }^{56}$ Popular reports claim that the column was a source of miracles, derived from a tincture that the afflicted would make from scrapings of the column. This account is readily told by locals but the restorers do not discuss it and I have not been able to verify the age of this tradition, so this explanation of its potential function is offered with all due caution. Nevertheless, the damage done to the column is consistent with the oral history that it had curative power. Its position within a chthonic twelfth-century chamber further supports the tradition that this "tree" may have been revered since the Middle Ages.

The portals likewise demonstrate a desire on the part of the builders to reference and integrate the impressive architecture with its holy setting. First, if the system that La

\footnotetext{
${ }^{56}$ Later in this chapter I will return to this topic because there may be a connection between the stone trees suggested by this column and the column at San Baudelio with the reverence accorded ancient trees in Hispano-Roman and Hispano-Andalusi Iberia.
} 
Quintana Gordon and José Ricardo Boned Colera use to illustrate the position and the date of the portals is reliable, then two portals were inserted where only one was needed to give access to the twelfth-century chambers and the cloister. ${ }^{57}$ This is unusual but not unique because at the eleventh-century ermita San Miguel de Gormaz, the façade likewise contains two portals, the larger one semicircular and the smaller consisting of a horseshoe shape (figure 55). The archaeologists responsible for the report on San Miguel consider these two entrances to be contemporaneous.

Returning to Santa María de Wamba, the semicircular portal opens into the unusual, column-supported chamber to the north of the church, which in turn opens into the cloister. These doorways permit a visual alignment between the well in the cloister yard, the Tree of Life, and the tripartite choir. Given the position of the interior well along the east-west axis of the church, these two sightlines intersect beneath the high vault of the central choir space. A second alignment occurs between the well beneath the church and the horseshoe-shaped portal (figure 56). It may be that this second, horseshoe portal was meant to offer a separate entry into the nave for the laity or for catechumens, as has been theorized for the second portal at San Miguel de Gormaz. The baptistery that is preserved in the nave floor at San Miguel de Gormaz aligns with the horseshoe portal, just as the well-access aligns with the horseshoe portal at Santa María de Wamba. Even if the horseshoe portal was not intended for catechumens at Santa María, signs of holy water confronted all who entered. And from the choir, where baptismal rites were conferred, the corridor to the cloister well was marked by the Tree of Life. If, as the restorers suspect, the chambers to the north of the choir were part of a twelfth-century

\footnotetext{
${ }^{57}$ If the twelfth-century patrons were responsible for the horseshoe portal, then it would seem that men who are affiliated with the mission of crusade chose to maintain a horseshoe arch at the height of the Christian conquest of al-Andalus.
} 
hospital run by the Hospitallers, then the liturgical function of this space would have carried additional meaning for the sick or injured seeking salvation. Regardless of the precise use, it is clear that the reverence that the tenth-century builders held for the topography remained potent for the patrons of the twelfth-century monastery. ${ }^{58}$

The foundation of Santa María de Wamba demonstrates how meaning can be "written" into the landscape. ${ }^{59}$ It seems likely that the wells and the place were already revered by the Wamba inhabitants prior to the arrival of the Leonese monks.

Strategically appropriating the Visigothic past (or fabricating it), the monks literally constructed the platform from which they, as outsiders could identify with King Recceswinth and his elected successor, King Wamba. Grand, stone vaults decorated by sumptuous, royal textiles, served as an architectural framework for the sacred water beneath. The success of their legitimizing architecture is proved by the careful preservation and augmentation of their efforts in the subsequent interventions at the monastery by a second group of outside patrons, the Hospitallers. From the choir crossing, one could stand aligned with the high altar and the interior well and from there proceed north by the Tree of Life to the cloister well and the nearby royal sepulcher-all

\footnotetext{
${ }^{58}$ At some point in the thirteenth century, the tenth-century western section of the church was replaced with the present-day structure, which is a basilica plan that has extended the three naves further to the west. A thirteenth-century date is suggested for this phase and the restorers explain that the builders of this phase not only clearly understood geometry but respected the spatial concerns of the "Mozarabs," see de la Quintana Gordon and Boned Colera, "Santa María de Wamba," 22. Instead of vaults, the new nave was covered with a timber roof pitched high above the floor. The lateral naves are defined by two arcades that spring from compound piers and emphasize the longitudinal axis of the church. The columns for the arcades are embossed and support carved capitals with both figural and vegetal subjects. Although this phase of construction is beyond the scope of this project, it, too demonstrates a desire to preserve those architectural and topographical elements that were successfully utilized by previous generations. The tenth-century eastern end, the twelfth-century chamber for the Árbol del Vida, and the wells were all left intact.

59 "We may also see how the process of inventing a tradition incorporates the use of previously existing sacred spaces: rewriting tradition is also rewriting landscape." César Parcero Oubiña, Felipe Criado Boado, and Manuel Santos Estévez, "Rewriting Landscape: Incorporating Sacred Landscapes into Cultural Traditions," World Archaeology 30, no. 1 (1998): 159-176, 174. The italics belong to the authors.
} 
of these elements would have acted in concert to create a tangible reminder of the site's Visigothic past and powerful present, to the benefit of their patron.

\section{San Baudelio de Berlanga (Soria): the site and earliest structure}

Like many ermitas and rural churches, San Baudelio is set against the side of a rocky hill, not far from the summit (figure 2, 3). Built into the high rock, the church overlooks a valley that lies along the Roman road that connected Medinaceli and Osma and remained a strategic frontier pass in the medieval period. ${ }^{60}$ From below, the courses of varied beige and grey stones set in sandy mortar form a striking, bright wall against earth and sky. ${ }^{61}$ Ashlar quoins present a clear, geometric shape that forms the backdrop for the clearly articulated horseshoe-shaped portal located in the middle of the church's northwest wall. The contrast between the light stone and the horseshoe-arched portal would have been clearly visible to those travelling along the natural approach to the site.

The church itself is composed of two sections, the nave and the apse, each of which is only slightly rectangular and lies along an axis that runs from the southwest to the northeastern apse. ${ }^{62}$ The principal entrance is the double horseshoe-arched portal on the northwest façade and it leads inside where one is immediately confronted by a substantial pillar, approximately one meter in diameter and five meters in height (figure

\footnotetext{
${ }^{60}$ Fernán Alonso Matthias, Luis Caballero Zoreda, and Eduardo Rodríguez Trobajo, "Cronología constructiva de la iglesia mozárabe de San Baudelio de Berlanga (Soria): primeros resultados de dendrocronología y carbono-14," Boletín de Arqueología Medieval 11 (1997): 249-64, 250.

${ }^{61}$ Margarita González Pascual, "San Baudelio de Berlanga (Soria): la reposición de las pinturas murales de la 'palmera'," Bienes Culturales: revista del Instituto del Patrimonio Histórico Español 6 (2006): 77-97, 78. This type of construction is called mampostería, or rubble-work masonry. The stones are limestone tophus, a light and porous stone that, together with the lime powder and sand mortar, failed to prevent water damage over time.

${ }^{62}$ Agustín Escolano Benito, San Baudelio de Berlanga: guía y complementarios (Salamanca, 2003), 32. The nave measures $8.5 \times 7.3$ meters and the apse measures $4.1 \times 3.6$ meters.
} 
57). ${ }^{63}$ From the top of this pillar spring eight horseshoe ribs that support the stone vault and an unusual chamber at the top of the large pillar is located in the space created between the curves of the large arches and the nave vault above (figure 58). ${ }^{64}$

Although there is a large scholarly consensus that the structure of San Baudelio preceded its famous fresco paintings, authors generally consider the initial structure only briefly before analyzing the painting cycles and discussing their potential meaning in conjunction with the architecture. ${ }^{65}$ This oversight has resulted in an inadequate consideration of how the organization, appearance, and effect of the unpainted interior, including the cave entrance, interacted with the meaningful landscape into which the church was inserted. A better understanding of how this unique eleventh-century structure referenced its holy setting can offer insight into the potential identities of the builders, their audience and the reasons that motivated the building of a lavish stone structure at a remote shrine.

The church is organized around the central, massive pillar that dominates the nave. The vertical shaft draws the gaze upwards into a spacious monumentality that comes as a surprise after the stark simplicity of the exterior. About half-way up the pillar, a small, covered alcove extends from the column to an open tribune that occupies the southwest wall. Consisting of a small, barrel-vaulted niche in the shape of a horseshoe, the interior of this small space features a tiny horseshoe window and

\footnotetext{
${ }^{63}$ Teógenes Ortego Frías, La ermita mozarabe de San Baudelio, en Casillas de Berlanga (Caltojar), (Almazán, 1987), 17. The door measures 2.54 meters high by 1.11 meters wide.

${ }^{64}$ Gómez Moreno, Iglesias, 313.

${ }^{65}$ For a few of the scholars who argue for a later date for the painting cycles, see Peter Banks and Juan Zozaya, "Excavaciones en San Baudelio de Casillas de Berlanga (Soria)," Noticiario Arqueológico Hispánico 16 (1983): 383-440; Dodds "Catalog Entry,"; Guardia, "Relire les espaces liturgiques," and Julián Alvarez Villar, "Precisiones sobre San Baudel de Berlanga (Soria)," España entre el Mediterráneo y el Atlántico (1975): 275-79. Alvarez Villar is one of the few exceptions to this pattern but the section on the eleventh-century church is nevertheless brief.
} 
architectural details carved in relief (figure 59, 60). Despite its modest scale, the alcove, often called a coro, appears to have served a sacred function. ${ }^{66}$ The waist-high solid wall that acts as the tribune's railing is broken in order to incorporate the coro and the stair access that runs down the southeast wall from the tribune to the nave floor. The upperlevel doorway in the southwest wall provides the second means of access to the tribune and is the only semicircular arched opening at San Baudelio. ${ }^{67}$ Occupying nearly half of the nave and resting atop horseshoe arches sustained by slender columns, the tribune space is another visually dominant element that emphasizes the vertical scale of the interior.

In contrast, from the vantage point of the main portal, the multiple columns and arches and the lack of light obscure the presence of the natural cave situated in the furthest, southern corner beneath the tribune. The cave entrance is architectonically incorporated into the church (figure 61, 62). ${ }^{68}$ From the living rock at the mouth of the cave, a column and capital are carved in relief, along with a small section of the bench. The rock-cut column visually supports the horseshoe arch attached to the cliff rock above the entrance and repeats the shape and size of the installed column that stands opposite it, framing the cave entrance. These elements integrate the cavern into the system of columns, arcades, and shallow domical vaults that comprise the support for the tribune.

Turning to the northeast, a monumental horseshoe arch frames a second horseshoe opening at the top of four stairs, marking the entrance to the shadowed apse (figure 63). From the rocky floor of the nave, one can make out yet another shallow step and a half

\footnotetext{
${ }^{66}$ I will return to the potential functions of this space below.

${ }^{67}$ There is no consensus concerning the date of this door, except that it clearly preceded the twelfth-century painting program.

${ }^{68}$ Teógenes Ortego Frías, La ermita mozarabe de San Baudelio, en Casillas de Berlanga (Caltojar) (Almazán, 1987), 23. The cave opening is 1.10 meters in height and one meter in width.
} 
within the apse, leading to the place where the altar would have stood beneath a single, narrow horseshoe-arched window. Above, the stone walls transition into a tall barrel vault. Due to its elevated position above the nave floor, the apse is visible from both the nave and the tribune. ${ }^{69}$

In general, the interior of San Baudelio is fairly dim because there are very few windows and doors. In addition to the main portal and apse window, there is a small window located high on the northwest wall and the tribune doorway (though the date of the latter is uncertain). If both entry doors are wide open on a sunny day in the late afternoon, the light is modestly even in the tribune and the nave but the apse and the space beneath the tribune remain shadowed; with the doors shut, the entire church is quite dark. The muted lighting and rocky frame for the hillside church create a subterranean atmosphere for the audience.

The landscape into which the church was inserted is remarkable. The church was clearly built against the entrance to a natural cave consisting of two sizeable, chambers that were improved by human labor. ${ }^{70}$ The substantial cave also includes a small alcove that faces southeast. ${ }^{71}$ Its location to the left of the entrance suggested to Ortego Frías that it once served as a type of altar or relic depository. ${ }^{72}$ The appearance of the same alcove for which Ortego Frías offered a religious function, was instead viewed by archaeologists Philip Banks and Juan Zozaya as potential evidence of another set of

\footnotetext{
${ }^{69}$ Escolano Benito, Guía, 34.

${ }^{70}$ Julián Alvarez Villar, "Precisiones sobre San Baudel de Berlanga (Soria)," España entre el Mediterráneo y el Atlántico (1975): 275-79, 275. Alvarez Villar describes the caves as being large enough for twenty five men to sit within, along the walls. According to Ortego Frías, the length of the two caverns is 16.25 meters and the average height is 1.4 meters. For detailed description of the chambers and their passageway, see La ermita mozarabe de San Baudelio, 22-24.

${ }^{71}$ Depending upon the plan consulted, the alcove faces east or southeast; this direction is therefore provisional until I can confirm the orientation of the niche myself.

${ }^{72}$ Ortego Frías, La ermita mozarabe, 24.
} 
chambers that were begun but never fully realized. ${ }^{73}$ Although its function is not precisely understood, the cave was clearly a central feature of the site. While this fact is mentioned by scholars, the reasons for why the cave may have attracted patrons willing to erect a costly structure around it and at some distance from the town and fortress are not adequately explained.

Apart from the cave, there are a number of places around the church where the cliff-rock is emphasized. The church itself is semi-buried into the calcareous slope, with the church floor consisting of the living stone and stretches of exposed rock to either side of the edifice. In one rocky stratum stretching to the northeast of the apse, numerous groups of graves have been excavated directly out of the rock (figure 64). In addition to the cave and sections of bare cliff rock, two natural fountains spring from the hillside, a noteworthy phenomenon in the arid Duero basin. ${ }^{74}$ Although one was diverted at some point in the past, the other spring continues to flow only a few meters away from the western corner of the church (figure 65).

The unusual combination found at San Baudelio: a natural cave situated in a high place, with stretches of bare rock and fountains, corresponds to the sort of natural elements that characterize pre-Christian holy sites in Iberia. ${ }^{75}$ This and similar sacred sites, like those at San Millán de la Cogolla and San Juan de la Peña, appear to have been maintained as such through periods of Muslim domination. Although it is often difficult to identify evidence of pre-Christian and Muslim cult phases for these sites, due to the

\footnotetext{
${ }^{73}$ Philip Banks and Juan Zozaya, "Excavaciones," 387. They further speculate that the work may have been abandoned because of the Islamic invasion. The dating of the period in which these caves were inhabited is uncertain, however.

${ }^{75}$ Banks and Zozaya, "Excavaciones," 387.

${ }^{75}$ See chapter three for a discussion of Hispano-Roman holy sites and their maintenance into the Middle Ages.
} 
ephemeral character of some rituals, an important exception to this is La Cueva Santa del

Cabriel (Mira, Cuenca).

The ermita Cueva Santa is located on the side of a tall cliff. Difficult to reach, it consists of several cave chambers, natural pools and striking rock formations that fill with water when it rains. Archaeologists have persuasively demonstrated significant and continuous cultic function for La Cueva Santa from the Bronze Age through the Roman phase. For the period of Muslim control, they merely acknowledge the existence of Islamic material but from the time of the cave's conversion into an ermita in the fourteenth century, they describe the modern persistence of the belief that water from this place cures illness and promotes fecundity in both women and in crops. ${ }^{76}$ Evidence that the sacred precinct was not limited to the locus of the cave itself may be seen as late as

\footnotetext{
${ }^{76}$ A. J. Lorrio, T. Moneo, F. Moya, S. Pernas, and Ma. D. Sánchez de Prado, "La Cueva Santa del Cabriel (Mira, Cuenca): lugar de culto antiguo y ermita Cristiana," Complutum 17 (2006): 45-80, 46, 60-61. A little later on, the authors draw a connection between these sacred caves in the eastern part of the Peninsula and evidence of initiation rites performed in caves by warrior groups in the northern and western portions of Iberia (fifth-fourth century BCE). These rites would have nevertheless been compatible with the agrarian pastoral rituals also theorized for sanctuaries such as the Cueva Santa. 63. In the cave La Albufereta de Alicante, a votive representing hollowed tree trunks was found. 65. The authors explain, "Las envidiables condiciones de la Cueva Santa del Cabriel, tanto por lo que respecta a las características de la cavidad (dimensiones notables, presenciade agua, etc.) como por su emplazamiento, dominando un amplio paisaje, podrían ser la explicación de la importancia alcanzada por la Cueva Santa, en detrimento de la Cueva II del Puntal del Horno Ciego, y que justificaría, al menos en parte, la continuidad en su uso hasta nuestros días." 69. The importance of this sanctuary is related to the archaeological finds in the deepest cave chamber (which is where Islamic wares were also found, although the authors prefer to consider these not to be of cultic significance, 70), its possible use as an initiation for warriors, as part of the rejuvenation of the New Year in May - the same month in which the current festival and those of other cave-ermitas takes place, and its centrality within seven other villages. These things combine to suggest to the authors that the Cueva Sancta acted as a holy center for the surrounding territory, a quality that persisted up to the present day. 7172. Although the Cueva Sancta was probably a sepulchral space in the Bronze and Iron ages, and possibly later, it becomes increasingly difficult to establish the cultic function of the space from the Roman period on, despite ceramic remains. 72-73. However, there seems to be strong onomastic and deductive evidence that potential female deities such as Hécate or Juno served as the inspiration for the dedication of this and other cave ermitas to the Virigin Mary through the association of the Virigin with the purity, healing and fertility of the female divinities before her.73. The account of an altar set up in the center of the main chamber against the great stalagmite column formation that served as a shelter for a Bronze age polished axe head votive, is interesting, along with the description of cultic image of the "Virgen Negra" that doesn't survive today, 71 .
} 
the eighteenth and nineteenth centuries, due to documents that describe the land and the agrarian plots surrounding the cave as forming part of a protected "Tierra Santa" 77

Closer to San Baudelio de Berlanga, the stone ermitas of San Miguel de Gormaz (Soria) and San Bartolomé at Ucero (Soria) are likewise situated against spectacular environments. San Miguel de Gormaz is a hermitage of uncertain but roughly comparable date to that of San Baudelio and perches on the south side of the tall mesa that is entirely occupied by the ruined fortress of Gormaz (figure 12). Gormaz is situated approximately twenty kilometers west of San Baudelio de Berlanga and archaeologists have found traces of habitation dating as far back as the Bronze Age. ${ }^{78}$ Positioned high above the Duero below, the church has also been built directly into the hillside, with both a receptacle for baptism and graves excavated from the living rock (figure 52, 55). ${ }^{79}$ One of the most arresting features of the landscape, however, is the enormous rock that stands a few meters to the northeast of the apse (figure 66). Although there are other boulders and sections of bare rock, pocketed with hollows and small caves across the length of the mesa, by far the largest and most dramatic natural feature is the huge rock that looms toward the church of San Miguel. At the base of this rock is a hollow just large enough for one or two people to huddle within. I have been unable to find reference to this rock in the scholarly literature but would estimate its size as comparing roughly to the scale

\footnotetext{
77 A. J. Lorrio, et al., "La Cueva Santa del Cabriel," 68.

78 There may have been earlier phases of habitation, as indicated by finds such as an early Bronze Age polished axe head, but the first phase that is securely dated through excavation is that of the local later Bronze Age, the eighth to seventh centuries BCE. To date, there are comparatively few remains from the Roman and Visigothic epochs, suggesting a contraction in settlement. See Banks and Zozoya, "Excavations in the Caliphal Fortress of Gormaz," 678-680 in particular. Nevertheless, there remains a nearby strategic Duero bridge that may date to the Roman period and Roman spolia that suggest an architectural presence on the western slopes.

${ }^{79}$ Escribano Velasco and Heras Fernández, "La arqueología en San Miguel de Gormaz,” 5-6.
} 
and volume of half of the church's nave. ${ }^{80}$ This rock appears to have carried significance to builders of San Miguel and suggests a reverence for the site that dates from antiquity. ${ }^{81}$

Excavated deep into the side of a rocky ridge that runs along the base of the cañon del río Lobos is the ermita of San Bartolomé (figure 67). Not only was the twelfth to thirteenth-century church semi-buried into the hillside but the hill rock encroaches into the interior of the church. ${ }^{82}$ The high calcareous walls of the canyon have in some places been eroded into dramatic shapes and frames for the sky while lower down, water has carved dramatic subterranean chambers. Carvings and cave paintings in the canyon have been dated to the Bronze Age (2,000-900 BCE), while traces remain of Roman building projects. ${ }^{83}$ Of particular interest to this dissertation are the two dead trees of great age that have clearly been preserved for some time (figure 68). These large trees stand a little southeast of the church, somewhat starkly, in a place now devoid of mature trees. ${ }^{84}$ Like the giant rock at San Miguel de Gormaz, they are not, to my knowledge, remarked upon by scholars despite their obvious significance to the site.

The question remains for Gormaz and Ucero, as at Berlanga, as to how the significance of the topography was maintained during the period of Muslim domination.

\footnotetext{
${ }^{80}$ Carlos Martín Escorza, Geología y arqueología en torno a el Burgo de Osma (Soria), Senderos Geoarqueológicos 3 (Madrid, 2007), 5. The author remarks on this site but focuses on an unusually disruptive geological division between the upper and lower sections of the hillside. The lower section is made up of folds of limestone that date to the Upper Cretaceous while an erosive and angular section above is characterized by horizontal strata from the Upper Miocene and Pliocene.

${ }^{81}$ As discussed in greater detail in chapter three, rocks, springs, trees, etc., were some of the places that Celtiberians used as a locus sanctus for worship. See Curchin, The Romanization of Central Spain, 183. See also Marco Simón, "Religion and Religious Practices," 311-312.

${ }^{82}$ San Bartolomé is approximately fifty kilometers northwest of San Baudelio. San Bartolomé is of uncertain date, perhaps begun in the twelfth and completed in the thirteenth century.

${ }^{83}$ Martín Escorza, Geología y Arqueología, 19. There are also Visigothic hermitages and a cemetery in nearby Ucero but the author does not name them.

${ }^{84}$ See chapter three for particular significance of juniper trees to ancient and early medieval Iberia, as evidenced by the numerous churches built near large, dead trees. Although that study confines the observation to the churches in the northern part of the Peninsula, the trees at Ucero and the enormous dead tree at the Ermita de La Virgen de las Vegas (Pedraza) would suggest the likelihood of a wider-spread phenomenon that requires further attention.
} 
Generally, scholars seem to assume that only local Christian populations preserved the memory of prior sanctuaries and do not allow for a Muslim appreciation or appropriation of these sites. For example, at the La Cueva Santa del Cabriel, the authors accept the presence of ceramic pieces and votives in the deepest cave as evidence for prehistoric rites and probable support of Roman ritual but explain the presence of Islamic ceramic in the same chamber as the remnants from a period in which the cave served as a refuge. ${ }^{85}$ The fact that ceramic evidence has only been discovered in this chamber, and not in the larger, more accessible spaces, should leave open the question that a ritual significance for the cave was maintained by Christians, Muslims or both.

A second promising support for an Andalusi appreciation of revered landscape features is the placement of the great double horseshoe-arched portal, framed within an alfiz, found at the tenth century Muslim fortress at Gormaz (figure 69). In 2007, Mickey Abel argued that the portal orientation of Duero basin fortresses and attendant ermitas in Soria Province, were deliberately directed toward the vast plains as a signal of political power and refuge. ${ }^{86}$ I would offer another interpretation for the relationship between ermita and fortress at Gormaz. The ermita is not the only object in line with the double horseshoe arched gate at Gormaz, often called the "Caliphal Gate". The great rock that stands only a few meters away from the apse of the ermita is, of course, also in line with the gate. The alignment of the monumental, ceremonial entrance of the fortress with a

\footnotetext{
${ }^{85}$ A. J. Lorrio, et al., "La Cueva Santa del Cabriel," 70. The authors point out that at another cave with evidence of habitation under Andalusi rule (the "cuevo de ganado" of Tejada la Vieja), ceramic evidence did not indicate a sacred function. However, they concede that the larger chamber at La Cueva Santa, the chamber that would best serve as a place of refuge, does not preserve ceramics-although that could be due to subsequent use.

86 "Strategic Domain," 47.
} 
highly visible, revered landmark may have played a part in the positioning of this entrance. $^{87}$

A fortified bridge with Roman and Andalusi building phases crosses the Duero a little further to the east. If the only motivation for the monumental gate was the visual confrontation of an approaching threat, the strategic river crossing would seem to have been a better landmark with which to align. ${ }^{88}$ Moreover, the eleventh-century decision to build a church "...in the vulnerable position directly in front of a defensive fortress," 89 is better understood if proximity to a powerful landscape was thought to offset, or protect from, potential danger. ${ }^{90}$ While Abel makes the reasonable suggestion that the spiritual protection offered by the church was reciprocated by the protection offered by the fortress (once in Christian hands), I would argue that the common source of protection and power referenced by both structures, built at different times, was the place: the locus sanctus.

The potential for a multicultural or a Muslim audience to acknowledge sacred places revered by indigenous Peninsular groups is supported by the examples of $\mathrm{La}$

\footnotetext{
${ }^{87}$ There are several reasons that scholars tend to ascribe a "ceremonial" quality to the Caliphal Gate. In addition to its complexity and relative inaccessibility, there are its Cordoban associations: the traces of red and white polychromy on the voussoirs, the double horseshoe arches that reach nearly 9.5 meters in height, and the framing alfiz. Banks and Zozoya, "Excavations in the Caliphal Fortress of Gormaz," 676 and Antonio Almagro, "La puerta califal del castillo de Gormaz," Arqueología de la Arquitectura 5, (enerodiciembre, 2008): 55-77, 60.

${ }^{88}$ Actually, it appears that San Juan, a parochial church built in the twelfth century and located near the modern village of Gormaz, may be more closely aligned with the fortress gate of general use and the stone bridge over the Duero. For a thorough description of the three gates and the fortified bridge, see P. Banks and J. Zozoya, "Excavations in the Caliphal Fortress of Gormaz," 676.

${ }^{89}$ Abel, "Strategic Domain," 42.

${ }^{90}$ The monumental rock would not be the only example of prophylactic or potent symbolism at Gormaz. Built into the western wall of the fortress, which also overlooks a broad plain, are three stone slabs with geometric star and flower-shapes carved in relief. The central stone appears to be a Roman funerary stela and those flanking it are Islamic in style and probably date to the tenth century. Banks and Zozoya, "Excavations in the Caliphal Fortress of Gormaz," 676, after Fernando Valdés Fernández, "Precisiones cronológicas sobre los relieves profilácticos de la fortaleza de Gormaz (Soria)," Cuadernos de Prehistoria y Arqueología 5-6 (1978-1979): 177-185, see 185 in particular.
} 
Cueva Santa and Gormaz. ${ }^{91}$ Precedents for a general Muslim respect for holy landscape include: the reverence accorded the cave on Mount Hira in which Mohammad received his revelation, the grotto and sacred rock of Mount Moriah at the Dome of the Rock in Jerusalem, the cave of the Patriarchs at the Haram al-Khalil (Hebron), and the purported cave beneath the Great Mosque of Damascus. ${ }^{92}$ Furthermore, there are instances in which subterranean spaces in North Africa have continued to be venerated by Muslims as powerful places, centuries after the holy men (and political leaders) associated with them have disappeared or fallen from favor. ${ }^{93}$

Muslim devotion for Iberian cultic sites is difficult to ascertain, perhaps due in part to the relatively few Muslim worship spaces that survived the Christian conquest. Evidence for a possible Muslim open-air sanctuary, called a musalla, exists at the fortress of Gormaz but its position within the fortress does not appear to be connected with the remarkable boulder below (figure 70). ${ }^{94}$ Nevertheless, the preservation of the cave shrine

\footnotetext{
${ }^{91}$ There have been some recent explorations of the significance of sacred, natural space for the Islamic world. The Berbers in particular were likely to have continued a reverence for nature cult centers. This is due to both to the recent conversion of Berber tribes to Islam around the time of the invasion of al-Andalus and their early integration into the rural populations of Iberia, which, as I described in chapter three, likewise maintained pre-Christian rituals and beliefs. See Fletcher, "Al-Andalus and North Africa," 25 and Allen Fromherz, "The Almohad Mecca. Locating Igli and the Cave of Ibn Tumart," Al-Qantara 26, no. 1 (2005): 175-90.

${ }^{92}$ See Nuha N. N. Khoury, "The Mihrab Image: Commemorative Themes in Medieval Islamic Architecture," Muqarnas 9 (1992): 11-28, 12 and Avinoam Shalem, "Jewels and Journeys: the Case of the Medieval Gemstone Called al-Yatima," Muqarnas 14 (1997): 42-56, 48.

${ }^{93}$ See Fromherz, "The Almohad Mecca," 176-180 in particular. The author relays the accounts of Ibn Tūmart and his ribā $\square$ that he had built at the sacred cave of Igli, in which he received his revelations.

${ }^{94}$ Banks and Zozoya, "Excavations in the Caliphal Fortress of Gormaz," 681-682. Banks and Zozaya identified a room immediately to the east of the blocked gate as an open air Muslim sanctuary, or musalla. The authors explain that this theory was supported by the presence of three niches set within the south wall. One or all of these niches may have functioned as a mihrab but at the least, suggest that this is a qibla wall. In 2009, my compass indicated that this wall actually faces toward the southeast, which is an even stronger support for the identification of this space as a musalla. In addition to these things, Banks and Zozaya uncovered a small round basin within and a larger rectangular tank outside the chamber, possibly for ritual uses. The musalla was not built near the Caliphal Gate or in relation to the boulder but was constructed further to the east, near the gate more commonly used. This may suggest that the alignment of the Caliphal Gate with a sacred landmark was more in keeping with an act of appropriation than a spiritual symbol for Muslim inhabitants. On the other hand, with only three percent of the vast fortress having been excavated, it is possible that more than one religious space was part of Gormaz (ibid., 688, fn. 8).
} 
at San Baudelio despite two and a half centuries of Muslim hegemony and the unusual appearance of the eleventh-century church invites the suggestion that the cave sanctuary may have commanded respect from both Christians and Muslims. The unique columnfilled zone beneath the tribune is popularly described as a "mezquitilla" (or mosque-like) and its similarity to mosque architecture has been widely acknowledged. ${ }^{95}$ The mosquelike appearance of this space is neither incidental nor purely aesthetic, in my opinion. By designing the approach to the holy cave as a miniature mosque, the eleventh-century builders paid homage to the sanctuary in such a way that was familiar to Muslims entering the church. For Muslim members of the community, who were still essential to its defense and productivity, the integration of the holy cave into the church remained visually accessible. Milagros Guardia has suggested that the cave was preserved by the eleventh-century builders in memory of their cultural origins. Although Guardia offers this idea with a Christian history in mind, Muslim veneration may have been part of that heritage. $^{96}$

The sacred landscape at San Baudelio was a place of power that attracted people. The cave, springs and tableaus of rock compare with those features considered hallmarks of prehistoric and Hispano-Roman sacred precincts in Iberia. Its proximity to a fortress and road further casts San Baudelio as a representative example of rural churches in the Duero basin that may have served as points of sociopolitical power. Although questions remain about the precise date of today's structure, it is my opinion that current dating evidence for San Baudelio, in light of its topographical significance and historical events,

\footnotetext{
${ }^{95}$ Escolano Benito, Guía, 33. This space will be more completely discussed below.

${ }^{96}$ Guardia, "Relire les espaces liturgiques," 80 . The author explains that the monastery of the eleventh century succeeded an earlier (ancien) cave hermitage. She also acknowledges that the cave has been underestimated by the current scholarship.
} 
supports the position that it was built as a symbol of territorial authority by supralocal elites.

\section{The Construction of legitimacy}

San Baudelio appears to date from around the third quarter of the eleventh century, according to the carbon 14 and dendrochronological analysis of timbers incorporated into the original structure. ${ }^{97}$ The results of these analyses were welcomed by archaeologists and historians who had struggled with the late tenth/early eleventhcentury date proposed by Gómez-Moreno, based on his stylistic comparisons between San Baudelio and other 'Mozarabic' churches. ${ }^{98}$ Although proper qualifications must be made of this provisional date, at this time it is a useful place to begin any attempt to connect this impressive stone monument with a patron.

Investigations for an eleventh-century patron at the church of San Baudelio are assisted by surviving contemporaneous chronicles. In addition to the Islamic accounts provided by al-Maqqarī and al-Nuwayrī, Christian chronicles, such as the Historia Arabum, have served as the basis for Peter Scales' analysis of the contest for Duero fortresses in the early eleventh century. Scales demonstrates that it seems clear that the Count of Castile, Sancho García (995-1017), entered into a treaty with Sulaymān and his Berber and Zanāta troops to help them overthrow the new caliph Mu $\square$ ammad al-Mahdī

\footnotetext{
97 Alonso Matthias, et al. "Cronología constructiva," in particular, 252-253, 262. This kind of analysis is called "wiggling" or "wiggle matching" as it relies on the coordination of data between the two different methods.

${ }^{98}$ See Alonso Mattias, et al., "Cronología costructiva," 250-252 and Gómez Moreno, Iglesias, 319-320. A principal difficulty was the fact that this region was firmly in Muslim hands in the late tenth and eleventh centuries and it therefore seemed unlikely that a new Christian church would have been permitted.
} 
in $1009 .{ }^{99}$ At some point between the years 1009 and 1023, it appears that Sancho García was promised strategic Duero fortresses in return for his service. Although they are not named in the Arabic sources, Christian records identify them as the fortresses of Gormaz, Osma, Clunia, San Esteban de Gormaz, and others. ${ }^{100}$

Scales expects that Berlanga was probably among the many strongholds promised to Sancho but later events lead him to believe that the strongholds were never handed over. One reason for this doubt is the fact that shortly after the treaty between Sancho García and al-Mahdī and his vizier $\mathrm{W} \overline{\mathrm{a}} \square \mathrm{i} \square$ was drawn up, the latter two were successfully besieged in Cordoba, and eventually vanquished. ${ }^{101}$ The second event that suggests to Scales that these fortresses were never under Christian control is the 1059 Historia Silense entry describing how Fernando I of Navarre (1035-1065) captured a number of Duero basin towns, including Gormaz and Berlanga. Scales points out that the language used by the chronicler implies only a brief occupation however, and when considered alongside the lack of archaeological evidence for Christian occupation at Gormaz, he concludes that these strongholds remained under the command of Muslim forces. $^{102}$

Fernán Alonso Matthias, Luis Caballero Zoreda, and Eduardo Rodríguez Trobajo tentatively connect the construction of San Baudelio with the military campaigns of

\footnotetext{
${ }^{99}$ Peter Scales, "The Handing Over of the Duero Fortresses; 1009-1011 (399-401 A.H.)," Al-Qantara 5, no. 1-2 (1984): 109-22, 109-111.

${ }^{100}$ Scales, "The Handing Over," 116-119. Although the original agreement was between Sulaymān and Sancho, Mu $\square$ ammad al-Mahdī was reinstalled in Córdoba in 1010 and Sancho subsequently demanded the fortresses from him in an agreement (fitna) that Scales dates to 1011. Arabic sources describe claim that 200 fortresses were handed over and although Scales imagines that this is an exaggeration, it does seem likely that a number of smaller fortifications, towers, and towns were included in the treaty. It should be pointed out that despite the similarity in name, the fortress at Gormaz and the fortress at San Esteban de Gormaz are two different fortified mesas along the Duero, approximately eighteen kilometers from one another.

${ }^{101}$ Scales, "The Handing Over," 119-120.

102 Scales, "The Handing Over," 120-122. See also, Scales, The Fall of the Caliphate of Córdoba, Berbers and Andalusis in Conflict (Leiden; New York; Köln: Brill) 1994, 199-200.
} 
Fernando I based on the above historical events, dating analysis, and a comparison of San Baudelio with contemporaneous structures. At the same time, they offer the possibility that the church was built by non-royal patrons during one of the breaks in political control of the region. ${ }^{103}$ I favor the latter opinion for three reasons. First, according to Scales, the conquest of the Duero fortresses at Berlanga and Gormaz was probably shortlived, which would argue against the likelihood that he commissioned San Baudelio. Second, while comparisons are justifiably made between the churches of San Baudelio and San Miguel de Gormaz on account of the similarities of their triumphal arches, perimeter benches and vaulted apses, the most recent report of excavations at Gormaz assigns a late eleventh-century date for the church, which post-dates the reign of Fernando I (1065), thus also separating this church from royal patronage. ${ }^{104}$ Last, the site-specific appearance of the church and absence of any named royal patron in the 1136 papal bull, written less than a generation after its construction, seems more indicative of a non-royal patron than a royal commission. ${ }^{105}$

Working from the provisional date of the church, I suggest that in the absence of a territorial overlord, supralocal elites sought to firmly establish their authority by constructing an impressive church to serve as the region's sociopolitical focus. The identity of this community is unknown. Scholars widely describe the motivation for the construction of the church as stemming from the existence of the cave and assume that a Christian hermit or monastery existed during the period of Islamic control. ${ }^{106}$ These assumptions do not account for the likelihood that the inhabitants of this region, including

\footnotetext{
${ }^{103}$ Alonso Mattias, et al., "Cronología costructiva," 262.

${ }^{104}$ Escribano Velasco and Heras Fernández, "La arqueología de San Miguel de Gormaz," 5-7.

105 Gómez-Moreno, Iglesias, 318.

${ }^{106}$ See Gómez-Moreno, Iglesias, 312, J. Alvarez Villar, "Precisiones sobre San Baudel,” 386, 390. Banks and Zozaya suggest a hypothetical, late Visigothic period for the cave monastery.
} 
any potential monastic community, would have included descendents of the mostlyBerber forces that conquered and settled this region in the eighth century and went on to control the frontier fortresses of Osma, Gormaz, San Esteban de Gormaz, Berlanga, and numerous atalayas (watch towers) over the next three centuries. ${ }^{107}$ It seems clear that a culturally diverse community would have existed in and around these strongholds. This does not preclude the possibility that an outside commander seized the site of San Baudelio and made use of it but the Andalusi appearance of the architecture and evidence of a monastery with necropoli, vineyards, buildings, herds, and possibly a mill, by the first third of the twelfth century, tips the scale in favor of supralocal patronage drawing on established resources.

The 1136 papal bull that indicates a robust Christian monastic community at San Baudelio, together with archaeological evidence of a privileged burial precinct, supports the theory that the eleventh-century church could have functioned as a sociopolitical center capable of commissioning and building the sophisticated church. ${ }^{108}$ In particular, burials in the vicinity of San Baudelio offer clues as to the use of the site prior to its subordination to Christian control in the twelfth century. To date, two places with human remains have been located and excavated at San Baudelio. The first is the necropolis located to the northeast of the apse (figure 64), while a second, smaller group of graves lies to the north and northwest of the church.

Conforming to the characteristics outlined for elite burial precincts, as described by Isidoro Bango Torviso, the northeast necropolis abuts the holy apse of the church, enjoys visible prominence in relation to main portal, and at one time was marked with

\footnotetext{
${ }^{107}$ For more on the difficulty of identifying religious and ethnic affiliations among the Andalusi emigrants, even those later joined to monastic houses, see Hitchcock, Mozarabs, 57-58, and 62 in particular.

${ }^{108}$ To my knowledge, the nature of the monastic order is unknown. Gómez-Moreno, Iglesias, 318.
} 
carved stelae. ${ }^{109}$ Excavated from two broad sheets of rock open to the sky, the tombs are grouped into what J. Andrio Gonzalo and E. Loyola Perea call "panteones familiares." "110

Ranging in size, orientation, and contents, most of these are filled with bone fragments

from more than one individual, and a few are considered to be "true ossuaries," due to the numerous bones found together. ${ }^{111}$ Above and beyond its privileged location, however, the heavy reuse of the rock-cut graves demonstrates the importance assigned to this divine locus. Unfortunately, excavators have been unable to assign specific dates for the tombs and acknowledge that their conclusions on chronology rely largely on typological dating. ${ }^{112}$

Tombs uncovered in the second cemetery to the north and northwest of the church have yielded few identifiable remains and are provisionally dated in relation to the

\footnotetext{
${ }^{109}$ Isidoro Bango Torviso, "El espacio para enterramientos privilegiados en la arquitectura medieval española," Anuario del Departamento de Historia y Teoría del Arte IV (1992): 93-132, $96-97$ in particular. Concerning the missing stone stelae, see Ortego Frías, La ermita Mozarabe de San Baudelio, 15. Ortego Frías includes a drawing of the type of stela of which pieces were recovered from around the limits of the necropolis. The size and number of the pieces were not indicated, so it is difficult to ascertain the accuracy of the drawing. The stela represented by the author presents the shape and sculptural style reminiscent of funerary stones crafted and used in the Roman and Visigothic eras. These types are frequently reused in the Middle Ages, for example, in the fortress wall at Gormaz, so without an archaeological context, its appearance at San Baudelio does not shed light on the date of the necropolis.

110 "Necropolis medieval de San Baudelio," 1069-1087.

${ }^{111}$ See Andrio Gonzalo and Loyola Perea, "Necropolis medieval de San Baudelio," 1076, 1082. With the exception of a single seventeen centimeter long lance point, no grave goods were identified and the mix of bones complicates the identification of the human remains. According to excavators' analyses, the tombs contained fifty-three individuals, eighteen men, fourteen women, fourteen adolescents, and seven that were of indeterminate gender and maturation. (ibid., 1073, 1081)

${ }^{112}$ See "Necropolis medieval de San Baudelio," 1079-1080. Typological dating involves the categorization of graves according to the way the outline of the tomb opening is shaped, particularly the top, called the head. Because oval tombs were not discovered, the director of the project, Dr. Castillo, situated this cemetery closer to the eleventh century than to the tenth. The presence of rectangular shaped openings for the head of the receptacle, bi-form openings, and the beginning of anthropomorphic forms were all considered to be from the middle of the eleventh century, while the full anthropomorphic shaped tombs were dated to the twelfth century. The difficulty with this approach to dating becomes evident when a comparison is made between the almost contemporaneous descriptions of the rock-cut graves at San Millán and those of San Baudelio. Dr. Castillo directed work at both sites, and Andrio Gonzalo was involved in the presentation of the results from both of these campaigns. In contrast to the conclusion at San Baudleio, the anthropomorphic graves excavated into the rock to the east of San Millán were dated to the Visigothic age and were said to have no relationship to the Mozarabic period, see J. Andrio Gonzalo, E Martín Rivas, and Philippe du Souich, "La necrópolis medieval de San Millán de la Cogolla de Suso (La Rioja)," Berceo 130 (1996): 49-106, in particular 60-61, 81.
} 
twelfth through fourteenth-century dates assigned the painted ceramic fragments found nearby. ${ }^{113}$ Banks and Zozaya describe the excavation of additional graves to the east of the church, for which I have been unable to find reports, and observe that the surface material indicates medieval habitation in the zone above their excavation grid. ${ }^{114}$ Even without firm dates, the recovered material offers some information about the types of people associated with the site. The "panteones familiares" to the northeast of the church suggest that multiple, privileged family groups sought interment at San Baudelio; by the twelfth century at the latest, it would appear that any monastic community present was neither hermitic nor particularly isolated. ${ }^{115}$ Along the same lines, the ceramic, bone, and structural evidence in the trenches to the north and northwest of the church prompted Banks and Zozoya to suggest animal husbandry at the site and to allow for the possible presence of a twelfth-century hospital and mill. ${ }^{116}$ Those buried around the church appear to reflect a diverse community living at or near San Baudelio and the northeast necropolis in particular represents an elite burial space highly prized by local elites. At

\footnotetext{
${ }^{113}$ Banks and Zozaya. "Excavaciones en San Baudelio," 415-416, 434-437. In these tombs, three skulls were found and they were determined to belong to an infant, a child, and a mature adult. The cranium of the infant was found within an encircling ring of river rocks encircling it.

${ }^{114}$ Banks and Zozaya, "Excavaciones en San Baudelio," 435-437.

${ }^{115}$ Antonio de Avila Juárez, "San Baudelio de Berlanga: fuente sellada del paraíso en el desierto del Duero," Cuadernos de arte e iconografía 13, no. 26 (2004): 333-96. Few scholars posit specific characterizations of the monastery and its audience but in a recent article, the author proposes that San Baudelio served as an enclosed refuge against Islam, a 'paradise in the desert.' As part of his argument for how the architecture and paintings of San Baudelio demonstrate the enclosed quality of the monastic community, he cites the findings of H. G. M. Edwards, et al., "Mediaeval Pigments in the Monastery of San Baudelio," in which the authors characterize the twelfth-century community as a "closed order." However, he neither notes nor explains the rebuttal of both the evidence and conclusions of Edwards et. al. by Gregory D. Smith and Robin J. H. Clark in a "Note on Lead (II) Oxide in Mediaeval Frescoes from the Monastery of San Baudelio, Spain," Applied Spectroscopy 56 (2002): 804-06. De Avila Juárez simply reports the description of the monastery as a closed order, 335. For other characterizations of the monastery as an isolated order, see also 363, 364-365-366.

${ }^{116}$ See Banks and Zozaya, "Excavaciones en San Baudelio," 435. Given the proximity of a platform to the spring, they further suggest that the milling may even have been driven by animals. The possibility that a hospital was established here is of particular interest because, like the hospital founded at San Millán (the construction of which benefited from one of the miracles assigned to Saint Aemillianus) and at Santa María de Wamba by the Hospitallers in the twelfth century, it may reflect a more general expectation of healing at holy sites.
} 
this point in time, it is impossible to identify a monastery before the twelfth century but given the frequent connections between supralocal elites and monastic communities, the scholarly consensus for some type of eleventh-century monastery appears justified. ${ }^{117}$

The sacred landscape and privileged sepulchral precinct of San Baudelio was augmented by a structure connoting power and authority in the eleventh century. Divine and earthly power are symbolized by the stone arches, pillars, and vaults. As discussed in greater detail in chapters two and three, the impetus to physically articulate one's claim to power was not limited to the royal sphere; lesser nobles and clerics also took advantage of the legitimizing power of stone architecture. It is important to underscore the fact that while arguments over proprietary rights and spheres of control could create tension between ecclesiastical authorities and laymen, sacred and profane power were often closely intertwined. In the loosely-defined "monastic" world, it was not uncommon to find aristocrats or landowners in holy orders who maintained family ties, participated in military obligations, adjudicated disagreements, conducted trade, and governed tenants or clients. ${ }^{118}$ Connections could therefore be close between an abbot or abbess, their clerics, and regional elites or even the royal household.

\footnotetext{
${ }^{117}$ Isidoro Bango Torviso's work remains the most relevant concerning the identification of elite burial for the eleventh and twelfth centuries. Although the author typically situates such necropoli near the main portal, at San Baudelio the slope away from the façade is challenging and the evidence indicates that it was most desirable to be interred in a specific section of the calcareous stratum. See "El espacio para enterramientos privilegiados," and concerning the likelihood that the monasteries were connected to supralocal elites, see Carmen Díez Herrera, "Sociedad de frontera y monasterios familiares en la meseta del Duero en el Siglo X," in Monjes y Monesterios Hispanos (Aguilar de Campo, Palencia: Fundación Santa María la Real, Centro Estudios del Románico, 2006), in particular, 40-42 and the discussion on the variety of monastic types in chapter three above.

${ }^{118}$ For more on the multiple forms of monasticism in medieval Iberia, see Díez Herrera, "Sociedad de frontera y monasterios," 35-57; A. M. Martínez Tejera, "La realidad material de los monasterios," 61-97 (Aguilar de Campoo), 2006, also chapter three of this dissertation, 5, fn 11. For the way in which donations of properties and bodies can sometimes be considered to fall under a system of patron and client, to the point where obedience is expected, see Davies, Acts of Giving, 52, described in this dissertation on page 57 of chapter three.
} 
Although it may be argued that all ecclesiastical edifices wish to project a sense of earthly authority, the community that raised San Baudelio deliberately mimicked architectures associated with legitimate rulers, both Christian and Andalusi, in order to provide an adequate backdrop for the dispensing of law. Christian monasteries have been widely acknowledged for their function as administrator and ruler in many places across the frontier but these roles were likewise carried out by Muslim fortresses and mosques as well. ${ }^{119}$ For the multicultural communities living in the region in and around Berlanga, their relationship with a fortress, mosque, or monastery would have included the expectation that these structures served as sociopolitical centers. The deliberate references, then, to design elements common to elite mosques, churches, and palaces at San Baudelio strengthened the authority of its sponsor.

\section{Nave}

The verticality of the nave recalls the splendor of royal Andalusi audience halls, such as those built as part of the Aljafería palace complex, in Zaragoza (1046-1081). ${ }^{120}$ The cross-ribbed dome set high above the octagonal audience hall projects a sense of luxury. In place of a large column, the light of the clerestory zone draws the eye upward and although Aljafería's vault ribs do not fan out from the center in the same way that the eight supports do at San Baudelio, their arrangement nevertheless maintains the octagonal

\footnotetext{
${ }^{119}$ Glick, From Fortress to Castle, 18; Julie Harris, "Mosque to Church Conversions in the Spanish Reconquest," Medieval Encounters, Jewish, Christian, and Muslim Culture in Confluence and Dialogue 3, no. 2 (1997): 158-72, 160-162; Míkel de Epalza, "La espiritualidad militarista del Islam medieval. El ribat, los ribates, las rabitas y los Almonastires de al-Andalus," Medievalismo 3 (1993): 5-18, 16-17 in particular. De Epalza defines (among other terms) the words that designate a stronghold designed for the defense of the frontier, the ribâ $\square$, the complex where once practices the concept of rib $\bar{a} \square$, called an al-munastīr, and the $z \bar{a} w i y a$, a place for retreat that is lees militaristic in nature. He describes the social aspect of these institutions as well, which encompassed various combinations of religious, administrative, and militaristic functions.

${ }^{120}$ Bernabé Cabañero Subiza, “La Aljafería de Zaragoza,” Artigrama 22 (2007): 103-29, 104-106.
} 
emphasis of the hall below. Adjacent to the palace is the earlier, tenth-century Tower of the Troubadour that also offers visual comparison with the nave at San Baudelio (figure 72). Here the thick, horseshoe arches that define the lower, subterranean chamber of the Tower not only resemble the shape and substance of the arches that pierce the exterior and apsidal walls of San Baudelio, but they shelter the access to the spring that lies within the rock from which the chamber was excavated. Just as structures were integrated into the divine landscapes at the monastic centers of San Millán de la Cogolla, San Juan de la Peña, Santa María de la Wamba, San Baudelio de Berlanga, and others, the spring at Aljafería appears to have been considered divine and was architecturally incorporated into the structure in order to project authority and power. The visual display of ancient, supernatural power was a particularly effective strategy due to the fluid and codependent nature of spiritual and secular authority in the medieval world and its appeal could transcend religious boundaries.

Returning to the nave at San Baudelio, the construction of the vault bears further consideration. Squinches are set into the four corners of the nearly square chamber beneath the large vaulted dome but its weight appears mainly sustained by the eight ribs that emerge from the top of the column and maintain their horseshoe shape, terminating into formerets in each corner and wall. Dodds compares the construction and display of the ribbed vaulting at San Baudelio to the maq $\square \bar{u} r a$ of the Great Mosque of Cordoba and cross-ribbed, lantern-like vaults of Bāb al-Mardūm. ${ }^{121}$ This comparison is apt particularly in light of the interplay between positive and negative spaces created by the innovative joining of the eight ribs to the central column (figure 57).

\footnotetext{
${ }^{121}$ Dodds, Architecture and Ideology, 93. Dodds specifies that the relationship between squinch and hovering rib are reminiscent of the Great Mosque and the small, ribbed vault above the column is similar to those found at Bāb al-Mardūm.
} 
Grand, vertical emphasis in architecture is not limited to Andalusi architecture, and even in rural Duero basin churches, this type of vertical emphasis is found in the space above the choir or the apse, spaces of authority and privilege with strict liturgical guidelines governing their accessibility. ${ }^{122}$ Examples may be found at the earlier frontier churches of San Millán de la Cogolla (La Rioja), San Cebrián de Mazote (Valladolid), Santa María de Wamba (Valladolid), and San Miguel de Escalada (León). ${ }^{123}$ At the same time, there is little doubt that the structure of San Baudelio privileges references to the architecture of al-Andalus. It has been argued that the Islamic style of the architecture was primarily a reflection of Andalusi aesthetic conventions but I would go further and offer that the authority and power communicated by the monumental scale of this stone space was the overriding message conveyed to the eleventh-century Hispano-Andalusi audience.

An intriguing feature in the tall nave is the small but elaborate chamber that is located at the top of the pillar (figures 57, 58). The design permits an observer from the floor of the nave or the tribune to catch glimpses of the inaccessible chamber and the crisscrossed ribs of its miniature vault through attractive, horseshoe arched apertures inserted in between the spaces of the eight monumental ribs holding the roof aloft. ${ }^{124}$ Suspended beneath the center of the domical vault and visually prominent, the sculptural quality of the sizeable chamber attracts the eye of the viewer. A number of theories have

\footnotetext{
${ }^{122}$ Elena Quevedo-Chigas, "Early Medieval Iberian Architecture," 96-98. The author points out that even kings were not able to penetrate the choir space during the ritual blessings preceding battles.

${ }^{123}$ All of these examples have dramatically high vaults above their central choirs or apses.

${ }^{124}$ Guardia, "Relire les espaces liturgiques," 80 . The crossed ribs of this small vault were first compared to those found at Bāb al-Mardūm (Cristo de la Luz) by Gómez-Moreno, Iglesias Mozarabes, 314. Similar in appearance and construction is the crossing dome found in the nearby church of San Miguel (twelfth century) in Almazán. In addition to resting on squinches, it incorporates pairs of interlaced ribs, see G. G. King, "The Problem of the Duero," Art Studies 3 (1925), 8, fig. 12. The distance in time between these two churches and their otherwise differences in appearance and construction would seem to further support the idea that this method of construction was part of the regional architectural vocabulary.
} 
been offered for the function of the little room and the suggestion by Guardia that it functioned as an architectural reliquary is one of more reasonable suggestions. It is possible that items of value were kept in this room because in one drawing, a small niche appears, high on the interior wall. ${ }^{125}$ Regardless of its precise function, if it had one, the repetition of horseshoe arches paired with intricate patterns of voids and applied ribs presents an Islamic aesthetic that is closely related to mosque architecture and imbued with an importance that transcends the merely decorative. ${ }^{126}$

A great deal has been written about the meaning of the central column. ${ }^{127}$ It is widely described as a palm tree; an impression strongly supported by the twelfth-century painted texture applied to the column/trunk and is generally considered to have served as a symbol of heavenly Paradise. ${ }^{128}$ The comparison with Paradise is well supported by the numerous depictions of the Tree of Life found in illuminated manuscripts, for example, the representation of the City of God in the Silos Beatus, folio 202r (c. 1109) (figure 73)

\footnotetext{
${ }^{125}$ Earlier scholars had proposed that the chamber was designed to store valuable in case of attack but its open framework does not support that interpretation.

${ }^{126}$ Creighton Gilbert, "A Statement of the Aesthetic Attitude around 1230," Hebrew University Studies in Literature and the Arts 13, no. 2 (1985): 125-52. In this article, Gilbert dismisses the need to consider the meaning of any decoration not clearly identified as instructional in doctrine as merely decorative. This seems a short-sighted analysis given the resources and effort expended at San Baudelio.

${ }^{127}$ The way the church is organized around the column is a highly unusual architectural arrangement for Iberia. Dodds points to the ermita de Santa María de la Peñalba at Arnedillo (also called Nuestro Señora de Peñalba) as a second example of a church that was organized around a central column. In recent years, however, it has been determined that the present-day column was put in place in the eighteenth century. As Achim Arbeiter notes, however, there is the possibility that it follows a similar precedent, which seems likely to me. See "Chapas decoradas de un posible relicario altomedieval Riojano," in Arte medieval en La Rioja: prerománico y románico: VIII Jornadas de Arte y Patrimonio Regional, ed. Ignacio Gil-Díez Usandizaga (Logroño, 2004), see 97, fn. 3.

${ }^{128}$ The twelfth-century painters applied a reddish-brown stippling to the column in such a way that it strongly evokes the appearance of a tree. I am unaware of any author that contests the ubiquitous comparison between this vaulting system and a palm tree. Most recently, the identity of this structural element as a palm tree inspired an argument that interprets the entire site as an "oasis" in de Avila Juárez, "San Baudelio de Berlanga: fuente sellada," 366. He also describes the column as emblematic of the "Column of Christ," the "Tree of Life," and the axis mundi, among others, see 363-364.
} 
and the Morgan Beatus Commentary (c. 940)(figure 74) ${ }^{129}$ In Islamic art, Paradise was also commonly symbolized by the palm tree. San Baudelio was not in a desert but the powerful image of the stone palm tree on an otherwise bare hillside would nevertheless have suggested the divine and paradisiacal to both Christians and Muslims. ${ }^{130}$

Divine power could have been communicated in two different ways, architecturally, through the terrestrial and heavenly authority symbolized by monumental space and stone vaulting, and topographically, through the column's potential reference to the ancient trees revered in the Peninsula. ${ }^{131}$ The palm tree is often conflated with the Tree of Life in iconographical studies and at Santa María de Wamba (Valladolid), the unusual column that stands in the center of a chamber to the north of the apse has, for an unknown period of time, traditionally been called the "Árbol de la Vida" and believed to have curative powers (figures 54, 56). ${ }^{132}$ While it is not known if San Baudelio was considered a site of supernatural healing at some point in the past, the possibility for such

\footnotetext{
${ }^{129}$ Escolano Benito, Guía, 22-24. The author states that the palm tree that is suggested by this column would have been a motif that was recognized by the confluence of religions and an appropriate symbol of the mixed culture. See also John Williams, A Spanish Apocalypse; the Morgan Beatus Manuscript (New York: George Braziller, Inc., 1991), 184. Concerning folio 131 of the Morgan Beatus, which features a tall palm tree inhabited by birds and with six people standing at its base waving palms, John Williams states, "The reference to the palms carried by the multitude in Apoc. 7:9 prompted Beatus to insert in his explanatio a comparison made by Gregory the Great in his Moralia in Iob between the life of the Just and the palm tree. As the Just flourish in an ambience of asceticism and self-denial, the palm thrives in the desert. Moreover, alone among trees, the palm's trunk grows wider as it climbs, even as the Just draw strength from the heavenly realm and deny the earthly. Because, probably, they no longer are part of the celestial court of folios $117 \mathrm{v}-118$, the Just are no longer depicted as saints, unshod and in long robes, but are dressed as mortals. In the Beatus made in 975 at Tábera and now in the Cathedral of Girona, the Just were replaced by date harvesters, a subject found on Islamic ivories in Andalusia." (ibid., 184).

${ }^{130}$ Along the same lines, the Silos Beatus' depiction of a palm framed within the tall, horseshoe shaped portal to the City of God indicates the broad use of this motif to suggest divine authority.

${ }^{131}$ I owe the connection between the stone "trees" architecturally depicted at San Baudelio and Santa María de Wamba with the preservation of ancient trees at other hermitage churches in Iberia to an observation made by my colleague, Jamie Ratliff. For a wider discussion on the tradition of sacred trees preserved throughout the Middle Ages, see chapter three.

${ }^{132}$ The restorers of Santa María do not describe the column as a tree of life, see de la Quintana Gordon and Boned Colera, "Santa María de Wamba." As discussed above, their dating of the column to the seventeenth century appears to be an error, given the low-pitch of the original twelfth century-vault. For the popular account of the healing tradition associated with the column that is related by locals, see the following website: http://www.jdiezarnal.com/santamariadewamba.html.
} 
a history may be reflected in its early association with San Baudelio (Saint Baudelius) in the twelfth century. As Walter Cook explained, Baudelius was martyred in the second or third century at $\mathrm{N} \square$ mes for preaching to Jupiter devotees worshipping in a grove; springs arose at the site of his death and miracles were attributed to the saint, who is symbolized by the palm and the axe. ${ }^{133}$

The forest of columns and horseshoe arches that inhabit the southwestern half of the nave beneath the tribune were briefly discussed earlier because of their relationship to the cave, the cultic center of the church. In this unique space, square bays are formed by the arches springing from columns and each is covered by a domical vault that rises directly from the square base. Recalling a typical mosque, the shadowed, column-filled aisles obscure a direct view of the architecturally-incorporated cave opening from the main portal. Although the general layout of San Baudelio as a whole conforms to conventional expectations of a Christian church, with an apse, nave, and tribune, in terms of this section of the nave, the forest of columns and absence of liturgical focus affects a Muslim place of prayer. It is not unknown for Muslims and Christians to occasionally share religious spaces and cemeteries, so it bears repeating that this site may have had a latent significance for both groups. ${ }^{134}$

\footnotetext{
${ }^{133}$ Walter Cook described the column as resembling a palm tree but assigned the meaning of it to the attributes of Saint Baudelius, not paradisiacal imagery, in The Art Bulletin 12 (1930): 20-42, $22,25$. ${ }^{134}$ Collins, Spain, an Oxford Archaeological Guide, 23. As related in the previous chapter, both Christian and Islamic burial practices have been identified in a cemetery at Simancas (Valladolid). It is worth noting that although Islamic burial practices generally involve positioning the body on its side, in many instances, a Muslim inhumation is difficult to distinguish from a Jewish or Christian one. See Medieval Islamic Civilization, an Encyclopedia, ed. Josef W. Meri (New York: Routledge), Vol. 1, 2006, $270-272$.
} 


\section{Tribune}

The existence of a balcony, or tribune, is unusual in rural churches in the central Duero basin. Although tribune spaces have been identified in contemporaneous structures, they are geographically remote from Berlanga. Tribunes are generally associated with royal chapels, as privileged spaces for royalty or located within a monastic context, as a place restricted to monks. In the latter case, the function of the tribune is to facilitate the performance of the various offices or prayers for the dead without disturbing congregants attending mass below. Toward this point of view, the arguments made by Kristina Krüger to connect a walled-in western tribune (called an avant-nef) with the French Benedictine galilaea have been used by Eduardo Carrero Santamaría to support his designation of the tribune at San Baudelio as a galilaea. ${ }^{135}$

This interpretation of the tribune at San Baudelio is difficult to support for a few reasons. The fact that the tribune at San Baudelio preserves a wall and a potential altarspace aligned with the apse superficially corresponds to Krüger's characterization of a galilaea. However, in contrast to a galilaea, the wall at San Baudelio is not high enough to block the view of standing congregants and any evidence that an altar once stood within the coro is absent. A greater challenge to the reading of this tribune as a galilaea is the implausibility of a Benedictine influence over Berlanga at the time of the church's construction - the third quarter of the eleventh century. Carrero Santamaría explains his

\footnotetext{
${ }^{135}$ Edwardo Carrero Santamaría, "Centro y periferia en la ordenación de espacios litúrgicos: las estructuras corales," Hortus Artium Medievalium 14 (2008): 159-78, 167-170. In discussing the Cluniac churches of Burgundy, Kristina Krüger persuasively placed the location for multiple funereal services undertaken by the Benedictines in the galilaea, or Galilee, which she believed occupied the upper storey of double-storied narthexes. She distinguishes the galilea from the Carolingian westwork, where chapels were dedicated to saints or the Savior, and where altars did not impede the view of the nave from the gallery space, see "Architecture and Liturgical Practice: the Cluniac galilaea," in The White Mantle of Churches: Architecture, Liturgy, and Art around the Millennium, ed. Nigel Hiscock (Turnhout: Brepols), 2003, 139$160,152-153$ in particular.
} 
position by claiming that the eleventh-century church of San Baudelio would have benefitted from the “...corriente artística en la que elementos arquitectónicos del mundo francés se estarían trasladando a modos constructivos locales, como arcos de herradura y otras peculiaridades dentro de las constantes estilísticas de la arquitectura hispánica de Repoblación."136 Yet, except for the tribune, clear trans-Pyrenean architectural or decorative influences are absent at San Baudelio prior to the twelfth-century painting program.

While the survival of the tribune space in Iberia is unusual, contrary to Carrero Santamaría's claims; it does not appear to be the oldest in Iberia. ${ }^{137}$ A recent reevaluation of São Gião de Nazaré (Portugal) confirms that its tribune dates to the original construction of the church. That date has become a source of controversy in recent years, as to whether it dates to the Visigothic or Asturian period, but the latest potential date assigned it by scholars is the ninth century. ${ }^{138}$ A second surviving tribune, together with its stone staircase, is preserved at the Asturian church of San Salvador de Valdediós, which was consecrated in 893 (figure 75). ${ }^{139}$ The date of the tribune is not secure but its connection to the late ninth-century and early tenth-century Asturian court has been persuasively argued by M. $\square$ Soledad Álvarez Martínez. ${ }^{140}$ San Salvador is thought to

\footnotetext{
${ }^{136}$ Carrero Santamaría, "Centro y periferia," 169.

${ }^{137}$ Carrero Santamaría, "Centro y periferia," 169. Concerning San Baudelio, the author explains, “...un ultimo caso a tener en cuenta en este context es la tribuna más antigua conservada en territorio peninsular." ${ }^{138}$ Luis Caballero, Fernando Arce, and M. $\square$ de los Ángeles Utrero, "São Gião de Nazaré (Portugal). Un tipo original de iglesia," Arqueología de la Arquitectura 2 (2003): 75-79,79.

${ }^{139}$ Lorenzo Arias Paramo, "Geometría y proporción en la arquitectura prerrománica asturiana," in Actas del III Congresso de Arqueología Medieval Español (Oviedo: Universidad de Oviedo, 1992), 27-37, 31. M. $\square$ Soledad Álvarez Martínez, "Consideraciones en torno al templo prerrománico de San Salvador de Valdediós," LIÑO; Revista Anual de Historia del Arte 12 (2006): 9-29, 19-20. The originality of the interior staircase at San Baudelio is significant because according to Carrero Santamaría, the way that the tribune communicates with monastic appurtenances outside of the upper door on the southwest wall supports his argument that the eleventh-century tribune may have served as a Benedictine galilaea. ${ }^{140}$ See Álvarez Martínez, "Consideraciones en torno al templo prerrománico," 9, 16-17, 19-20, 25-28 in particular. Álvarez Martínez explains that although García de Castro Valdés dates the tribune phase to the
} 
have served as the place of retirement for Alfonso III (866-910) and his retinue, who would have participated in the services from the high western tribune. ${ }^{141}$

A few eleventh-century churches, such as San Zoilo de Carrión (Palencia), possessed Cluniac ties and tribunes that might justifiably be considered galilaea.

However, unlike San Baudelio, they are all located in places near the Camino de Santiago and are connected to royal houses. ${ }^{142}$ Furthermore, after noting the likely connection between the Benedictine galilaea and the western façades of Castilian and Leonese churches, José Luis Senra nevertheless insists that the Cluniac form was occasionally adopted only because it fit well within existing Peninsular traditions related to privileged sepulchral precincts. ${ }^{143}$ Senra Gabriel's perspective is the most reasonable point of view for San Baudelio. Necropoli at San Baudelio conform to characterizations of elite burial spaces and absent additional examples of tribunes in this region, the topographical focus

\footnotetext{
late tenth century, it is more likely that this phase, including the painted decoration, was added only a short time after the initial construction of the church. Part of this argument relies upon the author's observation that architectural and stylistic elements reflect the political expansion of Asturias and an Andalusi influence Functionally, the stair and tribune relate to the theocratic concept found in Asturian politics and should be understood as evidence that a palace belonging to Alfonso III was once located near Valdediós, which was built at the site of a Roman villa and cultic shrine and modeled on the palatine complex of San Miguel de Lillo (Naranco).

${ }^{141}$ John Williams proposes that it was the imperial associations of San Salvador de Valdediós that inspired the similar architectural arrangement of the western end of San Isidoro de León, particularly the tribune, that was built under the direction of Queen Urraca of León-Castile (1109-1126) toward the end of the eleventh century, see "San Isidoro in León: Evidence," 179.

${ }^{142}$ The subterranean vault that was added to the monastery of Saint-Michel-de-Cuxa in 1040 by Abbot Oliba compares with San Baudelio in part. The crypt of this western addition is organized around a massive column that organically swells outward at the top in order to form an annular vault. The dedication of this sepulchral zone to the Virgin of the Manger is intriguing for its chthonic implications but the appearance of the chamber above, dedicated to the Holy Trinity is unknown. Nevertheless, as Mann points out, Abbot Oliba sets aside the horseshoe arches used in the tenth-century church to which this phase was appended in favor of semi-circular forms in: Romanesque Architecture, 59.

${ }^{143} \mathrm{He}$ bases this conclusion on the fact that many other Benedictine architectural elements, particularly those pertaining to the east end, like transepts, were ignored. José Luis Senra "Los programas constuctivos," 109-121 in particular. Of interest is the cave that was apparently the impetus for the foundation of Santa María de Nájera (La Rioja). Senra extends his conclusions regarding the primacy of Peninsular architectural forms over those of Cluniac provenance for the eleventh-century phase of Santo Domingo de Silos (Burgos), consecrated in 1088 in "Santo Domingo de Silos: New Interpretive Suggestions for the Medieval Church (1041-1143," in Church, State, Vellum, and Stone; Essays on Medieval Spain in Honor of John Williams, ed. Therese Martin and Julie A. Harris (Leiden: Brill), 2005.
} 
and innovative design favors an indigenous form and function for the eleventh-century tribune.

I would suggest that the original function of the tribune was flexible. On the one hand, a privileged space is certainly suggested—one that would have facilitated the appearance of status and authority for community elites, who may or may not have identified as monks at that time. On the other hand, the tribune design may also have served as a pragmatic solution to the need to accommodate Muslim members of the community for civic assemblies or to make the new church accessible to catechumens. This last suggestion is partly informed by the unusual appearance of two portals at the nearby ermita San Miguel de Gormaz (figure 55). ${ }^{144}$ At this church, the semicircular portal is larger and positioned in the center of the south lateral wall while the second portal, horseshoe in shape, is located at the western end of the single nave church. Aligned with the horseshoe shaped entrance is a rectangular receptacle that was excavated out of the living rock to serve as a baptistery (figure 52). This unusual configuration may have been designed to create a space for Muslim catechumens-and as at San Baudelio, derived its persuasiveness from the sacred power of the landscape. ${ }^{145}$

\section{Functions for eleventh century structure}

Scholars have tended to explain the Islamic appearance of the columns, horseshoe arches, and (later) painted motifs as a Christian "absorption” of Andalusi imagery. ${ }^{146}$ While this appropriation is sometimes cast in terms of "Reconquest," as a display of the

\footnotetext{
${ }^{144}$ As discussed earlier, there were two portals at Santa María de Wamba and at the upper church (eleventh century) at San Juan de la Peña.

${ }_{145}^{145}$ Escribano Velasco and Heras Fernández, "La arqueología en San Miguel de Gormaz," 6-7.

${ }^{146}$ Jerrilynn Dodds, Architecture and Ideology, 92-94.
} 
booty seized by Christians from Muslims, it is most often construed as simply a reflection of stylistic preferences informed by proximity to al-Andalus. ${ }^{147}$ The dramatically Andalusi character of the eleventh-century architecture preserved at San Baudelio is neither a celebration of conquest nor an echo of the local aesthetic vocabulary, however.

The arrangement of a mosque-like architectural setting for the cultic center of the church - the cave, contradicts the idea that Islamic forms were suborned to a material representation of Christian superiority or that they were a neutral, design statement. ${ }^{148}$ Rather, the dominant Andalusi architectural space at San Baudelio should be understood as a reflection of the cultural reality for an audience that included Berber (and possibly Arab) inhabitants for more than two hundred years. ${ }^{149}$ The architectural symbols of Caliphal power in far-away Córdoba were the impressive frontier fortresses, and one assumes, mosques. This architectural vocabulary, then, was not restricted to an Islamic or even Andalusi identity but was understood as the physical manifestation of territorial power and political legitimacy. Taking advantage of the disruptions caused by the alternating seizures of the Duero fortresses, supralocal elites combined the potent landscape of San Baudelio with commanding architectural forms in order to display their legitimacy in terms designed to persuade a heterogeneous audience to submit to their authority.

\footnotetext{
${ }^{147}$ Milagros Guardia Pons offers a representational argument for viewing San Baudelio's painting cycles as communicating the Christian victory over al-Andalus; this analysis is discussed in the following chapter. ${ }^{148}$ The description of this space as being mosque-like, or a mezquitilla, stems from the organization of the small space. Like a mosque, sightlines are interrupted by the twenty-two columns and engaged columns, diffusing the idea of a ritual focus. Also, the eleven bays comprised of horseshoe arches springing from the columns are reminiscent of the vaulted bays experienced at the Great Mosque of Córdoba and Bāb alMardūm of Toledo.

${ }^{149}$ Scholars tend to date the earliest phases of occupation at the stone fortresses at Gormaz and San Esteban de Gormaz, etc. to the ninth century; it is likely, however, that Islamic forcers occupied this frontier (thagr) from the time of its eighth-century conquest.
} 


\section{CHAPTER 5:}

\section{THE PAINTED DECORATION AT SAN BAUDELIO}

The striking monumentality of the eleventh-century structure and landscape of San Baudelio was not only preserved in the twelfth century but was expanded and enriched by a complex painting program. This century appears to be the period in which: the interior was completely covered with stunning frescoes, the northeastern necropolis was heavily used and expanded by at least one additional cemetery toward the northwest, and wooden buildings were connected to the church, probably to serve the needs of the monastery. Underlying the continued focus of resources and attention on San Baudelio was, in my opinion, a persisting regard for the sacred landscape and its legitimizing potential. The strategic position of this sociopolitical center at the Duero frontier further amplified the value of San Baudelio's influence over the region's modest resources. Control over the monastery of San Baudelio was deemed vital by rival powers in the region and as we shall see, medieval records provide evidence of at least one struggle for that privilege.

Insufficient traces of the wooden buildings that once stood to the southwest of the church frustrate attempts to reconstruct a more complete picture of the twelfth-century monastery but they, the northwest necropolis, and evidence for additional cemeteries discussed in the preceding chapter should nevertheless be borne in mind as the larger 
backdrop for the sophisticated painting program. The paintings that covered the interior of San Baudelio prior to their removal in the early twentieth century have been the subject of a number of detailed and thoughtful publications. ${ }^{1}$ Although they once covered the surfaces of the vaults, nave, apse, column, cave entrance, and tribune, only a few sections are now left in situ, such as portions of the apse and nave vaults. As far as I am aware, the only large section of the church not painted was the living rock that serves as the church floor and possibly the stone bench that runs partly along the perimeter on the northwest, southwest, and southeast walls of the nave.

The paintings that once covered the northeast wall of the apse are the in situ fragments of Cain and Abel, Melchizedek, the Lamb of God, a dove, Saint Baudelius, and painted textiles (figure 76 ). ${ }^{2}$ Behind the figural panels, the negative space is generally organized into alternating bands of color and the principal saints of the apse sit within an architectural frame. On the northwest wall of the apse was a scene that has been identified as a Noli me tangere, and possibly another scene with the Three Marys. This fresco, along with panels featuring a seated saint, and an ibis, were removed and

\footnotetext{
${ }^{1}$ For a recent analysis of the events leading up to and facilitating the sale and removal of most of the frescoes (despite its declaration in 1917 as a National Monument), see Terés Navarro, El Expolio de las pinturas murals. However, the fresco paintings have long been the subject of academic study, a few of the publications include: Adams, "Mural Paintings from the Hermitage,"; de Ávila Juárez, "San Baudelio de Berlanga: fuente sellada,"; Banks and Zozaya, "Excavaciones en San Baudelio,"; Cook, "Romanesque Painting,"; idem, "Romanesque Spanish Mural Painting (II),"; Dodds, "Hunting for Identity,"; H. G. M. Edwards, et al., "Mediaevel Pigments in the Monastery,"; Garnelo, "Descripcion de las pinturas murals,"; Guardia, "Relire les espaces liturgiques,". Most of the large frescoes were removed in the early twentieth century and sold to U.S. Museums. Today they belong to the Cincinnati Art Museum, the Indianapolis Museum of Art, the Museum of Fine Arts, Boston, and the Cloisters branch of the Metropolitan Museum of Art. The majority of the frescoes owned by the Cloisters are on display at the Prado Museum, Madrid, where they are on permanent loan.

${ }^{2}$ The inscription identifying the saint on the left is partial: A V S and so the figure is generally identified as Saint Nicholas. An alternative identification, that of Saint Augustine, was made by Garnelo, "Descripción de las pinturas murals," 6-7. In my opinion, the arrangement of letters for the name of Baudelius: B A U directly over D I L I better supports the reading of the name Nicholas than Augustus. Nevertheless, in one of the most recent publications, the second saint is unnamed by the author, see Terés Navarro, El expolio de las pinturas murales, 65 . As for the identification of the bird, an ibis seems to be the best candidate due to the appearance of the bird, its Peninsular and North African habitat, and broad iconographical tradition.
} 
sold (figure 77). The barrel vault above the apse is covered with a majestic Pantocrator but it is in very poor condition.

The lowest section of the apse walls were once covered with trompe-l'oeil curtains with round disks hung before them containing heraldic animals. Surviving fragments indicate that this mode of painting is carried out around the lowest zone of the nave walls and even up the stairs to the tribune. A break in this decoration occurs in the southeast corner where today stands an altar table. Between the staircase and the wall that gives way to the apse, the curtain motif is abandoned in favor of two confronting bulls set against a dark background (figure 78).

In the middle register of the nave is a cycle of paintings that is generally considered to be profane or secular. The images that once decorated the tribune wall and the exterior surface of the coro are folded into this grouping. Moving around the nave from the northeast wall of the apse, they once included: a large horseman with a falcon to the north of the triumphal arch (figure 79); on the northwest wall was a rabbit hunt, consisting of dogs and a horseman, and a stag hunt with the bow hunter on foot (figure 80); along the tribune and coro were a bear, an elephant with a castle on its back, a walking soldier with a spear and a shield, climbing dogs, a camel, and a block of geometric patterns that resemble textiles (figures 81,82 ). The large hunt scenes from the northwest wall were economical with their details and setting, favoring a plain color field for the backdrop and stylized lines for the figures. In a similar fashion, the depictions of the soldier and the other animals prioritized the figure but the background preserved traces of a patterned border evocative of a textile. What occupied the zone where this 
cycle would have presumably continued onto the southeast wall and the eastern side of the triumphal arch is unknown.

The uppermost register of paintings on the nave walls contained scenes from the New Testament centered on the miracles and Passion of Christ. As seen with the figural panels in the apse, most of these scenes have backgrounds consisting of horizontal bands of color. Beginning again with the northern side of the northeast wall of the apse are traces of episodes from the Passion in situ, while the northwest wall once supported the removed scenes of the Last Supper and the Entry into Jerusalem (figure 83). The Temptation of Christ and the Wedding Feast at Cana were once displayed on the southwest wall at the back of the tribune (figure 84). The first scene on the southeast wall was the Resurrection of Lazarus, followed by the Curing of the Blind and the Three Marys before the Tomb (figure 85). As with the middle register, the appearance of the paintings on the eastern side of the triumphal arch wall is unknown. Even with the missing scenes, however, there does not appear to be a clear chronological sequence to their order around the nave, as noted by Dodds in $1993 .{ }^{3}$

In the spaces between the ribs of the vault are an in situ ensemble of Christological imagery related to the Birth and Infancy of Christ. Like the cycle immediately below them, these conventional narratives appear somewhat out of their typical sequence. Rotating around the vault, beginning with the panels above the portal in the northwest wall are the Annunciation and Visitation and the Flight into Egypt. Above the tribune and proceeding west to east are the Presentation at the Temple and the Murder of the Innocents. The two panels above the southeastern wall, moving toward the

\footnotetext{
${ }^{3}$ Dodds, "Catalog Entry,"; Dodds, "Hunting for Identity,"; Milagros Guardia, "Relire les espaces liturgiques,".
} 
direction of the apse, contain the Journey of the Magi and the Arrival of the Magi, while the scenes above the triumphal arch are the Annunciation to the Shepherds and the Nativity (figure 86).

The column itself is stippled with large circles of reddish paint while the vault ribs are covered with a variety of intricate vegetal motifs, interlaced ribbons, birds, and other animals and monsters. Surrounding all of the figural cycles are borders with a variety of patterns and colors, reddish-brown and light blue trompe l'oeil curtains, and heraldic animals on roundels (figures 61, 82, 87). Architectural forms such as the horseshoe arches under the tribune, squinches, and windows, are likewise masterfully decorated with colorful geometric and sinuous motifs. A particularly sophisticated arrangement of interlacing ribbons, arabesques and figures is located on the twin horseshoe arches of the triumphal archway to the apse. At the keystone for the inner arch is a roundel containing the faint imprint of the Hand of God held aloft by angels while a repetitive pattern of ibises covers the intrados of the apse opening (figure 88).

One of the sections that can appear somewhat out of step with the rest of the church is the slightly awkward painting of the interior of the coro. At the back of this alcove, the style shifts somewhat, favoring a stiffer, more iconic presentation of the Virgin with Christ on her lap, receiving the Magi (figure 89). Two kings flank her throne in a symmetrical and static scene, still set against horizontal bands of color, while a third approaches from the lateral wall on the left. He appears cramped, due to his position above the tiny window for the coro. The small space provided by the horseshoe-shaped barrel vault is encroached upon by the figures to either side, whose sketchy appearance suggests that this space did not receive the same treatment as the larger figural panels in 
the church. To the left of the uncomfortable-looking king is another figure that appears to be an angel. On the opposite lateral wall of the coro are two more angels, one of whom strikes at a dragon with a long spear (figure 90). At the zenith of the small barrel vault is the Hand of God, framed in a mandorla.

\section{Significance of the twelfth century paintings}

The principal scholars of San Baudelio, Juan Zozaya, Milagros Guardia, and Jerrilynn Dodds, generally see the twelfth-century painting cycles as reflecting the Islamicized culture of the region while at the same time promoting "Reconquest" ideals. While Zozaya focuses on how the lower paintings spring from specific works of Islamic art, Guardia and Dodds see the program as not only representing the conquest of territory formerly known as al-Andalus but as part of a larger vision of victory for Christendom over Dar al Islam.

Guardia and Dodds view the architecture, and the Christological paintings in particular, as a faint reflection of the papal call to crusade against Muslims in Jerusalem. For Guardia, this message is combined with Eucharistic symbolism and a specific reference to Iberian crusades. However, papal calls to Peninsular Christians to forego missions to Jerusalem in favor of restoring Hispania to the Church provide the broad justification cited by both Guardia and Dodds for the display of crusading themes in rural, central Iberia. ${ }^{4}$ For Dodds, the sequence in which the paintings of Christ's ministry are presented around the walls of the nave serves to locate the final scenes of the

\footnotetext{
${ }^{4}$ Dodds, "Hunting for Identity," 90. O'Callaghan points to the indulgences offered by Alexander II in 1063 and Urban II in 1089-1091 to those fighting the "Saracens" as crucial precursors for the First Crusade to the Holy Land. By the end of the century, Pope Urban II would explicitly call for would-be Crusaders to Jerusalem to concentrate their efforts on conquering the Saracens in Iberia instead. See Reconquest and Crusade, 32-33.
} 
narrative, the death and resurrection of Christ, in the apse, which she believes converted that space into an allegorical Jerusalem. ${ }^{5}$ In 2001, Dodds further supported this conclusion based on the central planning of the church. Although she acknowledges that this was clearly not a Templar foundation, she argues that the crusading backdrop of the 1140s would have nevertheless informed its reception, explaining, "It would ally Berlanga in allusive meaning with a number of Templar churches, which used the central plan and even Cordoban type ribbed vaults to create an emblematic copy of the Holy Sepulcher, calling to mind the Holy Land and yet another confrontation with a reductive Islam for the sovereignty of Christian worship."6

Although a crusading theme may have been subtly incorporated into the twelfth century appearance of San Baudelio, it isn't the dominant message. First, as Guardia thoroughly details, the lack of a chronological sequence for the Christological paintings may just as reasonably be interpreted as underscoring the importance and the mystery of the Eucharist. ${ }^{7}$ For example, in addition to the Last Supper's obvious parallels with the Eucharist, the Wedding at Cana and other narrative panels may also be interpreted as allusions to this sacrament. The second reason that Crusading motifs do not seem to have played a prominent position at San Baudelio is the weak connection that Dodds makes between round churches and the Holy Sepulcher of Jerusalem. In recent years, the assumption that centrally-planned churches are connected in some way to a Templar

\footnotetext{
${ }^{5}$ See Dodds, "Catalog Entry,".

${ }^{6}$ See Dodds, "Hunting for Identity," 90.

${ }^{7}$ Guardia also makes this observation but goes even further by pointing out a variety of Eucharistic references found in the Christological or Biblical scenes. I find this to be a fragile line of argument since any sequence of episodes from the life of Christ and his Passion are naturally going to include allegorical references to themes of the Eucharist or Resurrection.
} 
influence, and by extension to the sanctuaries of the Holy Land, has been strongly challenged for Iberian churches. ${ }^{8}$

While Dodds considers the Christological cycle as a reference to Jerusalem, Guardia constructs a multilayered argument for her reading of the painted frescoes as an homage to Crusade. Her arguments hinge upon the person that she identifies as its likely patron: Fortunio Aznárez, who she believes to have had a personal connection to the crusading ambitions of the royal court of Alfonso I, el Batallador (1104-1134). ${ }^{9}$ To reconstruct this history, Guardia pays careful attention to medieval accounts that reference San Baudelio. The twelfth century offers a few textual references to a monastery at San Baudelio that scholars, after Gómez-Moreno, have accepted as pertaining to the present-day site. The first, in which a "monasterio sancti Bauduli" is listed as belonging to Berlanga arises as the center of a dispute between the Episcopal sees of Osma and Sigüenza in 1136, and again the following year in a papal bull from Innocent II. ${ }^{10}$ Although San Baudelio was originally part of the see of Osma, it and all of its appurtenances were given over to the Bishop of Sigüenza in consolation for the loss of Soria. $^{11}$

The source of this conflict was the location of San Baudelio and other tactical centers in modern day Soria province, such as Calatañazor and Almazán. The

\footnotetext{
${ }^{8}$ See Joan Fuguet Sans, "La historiografía sobre arquitectura Templaria en la Península Ibérica," Anuario de Estudios Medievales 37, no. 1 (2007): 367-86.

${ }^{9}$ Guardia, "Relire les espaces liturgiques," 85. Bernard Reilly describes a Fortún Aznárez as the tenant of Tarazona in 1132; see, Bernard F. Reilly, The Kingdom of León-Castilla under King Alfonso VII, 11261157 (Philadelphia: University of Pennsylvania Press, 1998), 196.

${ }^{10}$ Gómez-Moreno, Iglesias, 318, fn. 2, after Juan Loperráez Corvalón, Descripción histórica del obispado de Osma, 3 vols. (Madrid, 1788).

${ }^{11}$ Gómez-Moreno, Iglesias, 318, fn.; Dodds, "Hunting for Identity," 97; Guardia, "Relire les espaces liturgiques," 84, fn. 24, after Loperráez, Descripción histórica del Obispado de Osma (Madrid, 1788), reprinted 1978, 3 vols., in particular vol. 1, 51, and T. Minguella y Arenedo, Historia de la Diócesis de Sigüenza y de sus obispos. Desde los comienzos de la diócesis hasta fines del siglo XIII (Madrid, 1910), vol. 1 50-203 and vol. 2, 246-247.
} 
communities and fortresses that occupied this strategic swath of territory south of the Duero controlled roads and passages that were critical to the success of offensive and defensive movements. From the fortresses and walled towns, raids could be launched and supplied and resources protected from attack and siege. After the conquest of Toledo in 1085, Christian expansion was halted, and in places reversed, by the military responses of first the Almoravid, and later Almohad troops. ${ }^{12}$ At the same time, the strengthening kingdoms of Aragón, León-Castile, and Portugal jockeyed with one another over newly claimed resources and land.

Against this backdrop of general warfare between co-religionists and neighboring taifas, Queen Urraca of León-Castile (1109-1126) and her husband, Alfonso I of Aragón and Navarre (1104-1134) fought over Berlanga at the beginning of the twelfth century. ${ }^{13}$ The matter was not settled until after the death of Urraca, when an agreement was struck between Alfonso of Aragón and Alfonso VII of León-Castile (1126-1157) in 1129 that assigned Berlanga to Aragonese hands. Alfonso then entrusted the territory to a Navarrese nobleman, Fortunio Aznárez, who was to act as his tenente, or lord. ${ }^{14}$ Guardia suggests that Aznárez or his family took part in a crusade to the Holy Land. ${ }^{15}$ To support this speculation, the author connects the apse portrait of Saint Nicholas at San Baudelio to the translation of this saint's relics to the court of Aragón in 1087. Because Saint Nicholas was also a patron saint of the crusade, Guardia views his prominent representation at San Baudelio as a sign that the Aragonese lord was devoted to the

\footnotetext{
${ }^{12}$ For example, see the efforts launched from Córdoba to retake Zaragoza in Powers, A Society Organized for War, 26.

${ }^{13}$ Reilly, The Kingdom of León-Castilla under Queen Urraca, 92-95; Powers, A Society Organized for War, 25 .

${ }^{14} \mathrm{I}$ am indebted to the thorough and dedicated research of Guardia for this salient, historical assemblage, Guardia, "Relire les espaces liturgiques," 84, and footnotes 18-21.

${ }^{15}$ Guardia, "Relire les espaces liturgiques," 85.
} 
Jerusalem crusade, a mission of some importance to King Alfonso I and his court.

Guardia further proposes that the chamber at the top of the column may have housed a relic from Jerusalem. If so, she argues that this would have transformed the entire church into a reliquary capable of signifying the Holy Land, pilgrimage sanctuaries, and the Eucharist. ${ }^{16}$

Guardia considers the subject matter of the lower cycle of images to be purely profane and suggestive of a general Classical tradition of land ownership and lordship, even as they were also representative of Islamic luxury arts. ${ }^{17}$ As for their appearance in a church that she considers to represent the spirit and piety of the crusade, she argues that, "...the church frames and acts as a reference to the luxury and the splendor that belongs to the culture of the other, a Muslim enemy against whom, with a spirit of a veritable crusader, Aznárez should battle, as a noble defender of the frontier. One is seeing it as a quasi-appropriation of the symbols of the vanquished." 18 The author essentially sees the paintings as a reflection of Aznárez's noble identity as a lord and to his dedication to the crusade against Islam.

While I consider Guardia's identification of patron and proposed dates for the painting phase (1129-1134) to be persuasive, I believe that her interpretation for the reception of the structure and decoration at San Baudelio is flawed. Tension is created between the probable audience for San Baudelio and the function for the church, which on the one hand, Guardia limits to the purely parochial or monastic realm, and on the

\footnotetext{
${ }^{16}$ Guardia, "Relire les espaces liturgiques," 85, 87.

${ }^{17}$ Guardia, "Relire les espaces liturgiques," 94. Dodds follows the broad outlines of this reasoning in "Hunting for Identity," 95.

${ }^{18}$ The above is my translation of the following: “...l'église peuvent aussi se comprendre comme une référence explicite au luxe et à la splendeur propres de la culture de l'autre, celle de l'ennemi musulman contre lequel, avec un esprit de véritable croisé, Aznárez se battait, lui le noble défenseur de la frontiére. Il faut y voir comme une quasi appropriation des symboles des vaincus." from Guardia, "Relire les espaces liturgiques," 96.
} 
other hand, she casts as a monument to Christian victory. The audience to whom this message was directed is never straightforwardly addressed. As I have shown, this region was probably home to a number of groups descended from or related to the administrators and defenders of the nearby fortress. Even if the majority of those who served the eleventh-century structure and the twelfth-century monastery were Christians, they were still likely to be most familiar with the visual and spoken languages of Islamic political power and sacred space, the dominant message for both of these architectural phases.

That they were probably a local community with regional influence and authority is not only supported by the appearance of the eleventh-century structure and its powerful landscape but by the twelfth-century written record. Over the course of the dispute, an 1137/1138 papal ruling transferred the monastery of San Baudelio, together with its appurtenances, from the Bishop of Osma to the oversight of the Bishop of Sigüenza. ${ }^{19}$ Dodds describes the exchange as part of a larger disagreement surrounding the assignment of Soria to Osma, in which Berlanga was offered as a "consolation" to Sigüenza. The papal assignment of Berlanga to Bernard of Agen, the French Bishop of Sigüenza, was not without resistance and Dodds suggests that the paintings were commissioned (sometime after 1143) by the new Bishop as a way to assert his lordship. She argues that his ownership was expressed in two ways: through the "secular" images of the lower cycle and the representation of the papacy's extension of authority throughout Christendom—as far as Jerusalem. ${ }^{20}$

\footnotetext{
${ }^{19}$ Banks and Zozaya, "Excavaciones en San Baudelio," 391.

${ }^{20}$ Dodds, "Hunting for Identity," 97.
} 
I consider it more likely that Fortunio Aznárez and the monastic leaders

collaborated, to one degree or another, in the decoration of San Baudelio in the second or third decade of the twelfth century. ${ }^{21}$ By that point, Aznárez would have been established as the lord of Berlanga. At the same time, documented property holdings, the necropoli, and evidence of a mill all indicate that although small, the monastery had capitalized upon its holy reputation and was an important political center in its own right with resources and influence. ${ }^{22}$

The recently recovered wall carvings from the church of San Miguel in San Esteban de Gormaz (Soria) (figure 91) serve as regional support for the sociopolitical characterization of a rural church like San Baduelio. San Miguel de San Esteban de Gormaz is located approximately forty-seven kilometers to the west of San Baudelio, along the Duero River and at the foot of a sprawling, hill-top fortress. ${ }^{23}$ The simple carvings found around the church's nave include images of falconers, knights, and crosses-ranging from the lowest to the highest portions of the nave, which is pitched very high and would have required scaffolding or ladders (figure 92). ${ }^{24}$ Figural motifs

\footnotetext{
${ }^{21}$ The monastic affiliation of the monastery-if there was one-is unknown at this time.

${ }^{22}$ Banks and Zozaya, "Excavaciones en San Baudelio," 435. It should be remembered that in the excavations that were undertaken in the 1980s remains of women, children and adolescents were found, along with a variety of animal bones, including horses.

${ }^{23}$ I was generously given access to the interior of the church by one of the project managers at SoriaRomanica, Josemi Lorenzo Arribas, while restoration was ongoing. The restorers were kind enough to point out to me the variety of material remains that they were uncovering, both on the walls and beneath the flooring of the church and the tower. For an interim account of the work, see:

http://www.soriaromanica.es/en/contenido/?idsec $=132 \& i d d o c=398$. To my knowledge, the final results have not been published. Although the church has traditionally been dated to the end of the eleventh century, the web account of the restoration cited above dates the original plaster work to the end of the twelfth century, even while the date for the edifice is listed as 1081 on another page by SoriaRomanica, see: http://www.soriaromanica.es/en/iglesias/?idsec $=152 \&$ iddoc . There is no indication as to how the date for the plaster carvings was determined, so it would seem that a great deal of caution should be exercised concerning the date of San Miguel de San Esteban de Gormaz.

${ }^{24}$ The interim restoration account suggests that an upper-level walkway once existed around the perimeter of the nave and was the means for these carvings and drawings. Again, see: http://www.soriaromanica.es/en/contenido/?idsec $=132 \&$ iddoc $=398$.
} 
are less prevalent while the majority of carvings are groups of straight lines that appear to be "counting" marks. These counting marks may reflect an accounting that was solely related to religious business, but given the intimate relationship between the sacred and profane administration of territory and the historical role that churches and monasteries have played in governing land and resources, it seems far more likely that this ecclesiastical center served as a sociopolitical hub for the region. ${ }^{25}$ Multiple depictions of falconers and knights are represented on the interior walls while detailed fortresses and soldiers survive on the carved portico capitals outside. I believe that the prevalence of militaristic imagery would have supported the legitimizing function of the church to cement its authority and successfully win the loyalty of the fighting elites of the community.

The situation between the ambitious kingdoms of León, Castile, and Aragón remained as potentially explosive as the threat of a twelfth-century Muslim reconquest of the Duero frontier. It would have been to the mutual benefit of the supralocal elites of San Baudelio and the new governor of Berlanga, Fortunio Aznárez, to negotiate with one another in order to ensure an adequate defense and administration of resources and people. The logical place for this negotiation to play out was the ancient, sacred center of the region: San Baudelio. The inherent divinity of the site continued to be acknowledged through the decorated approach to the cultic center, the cave, and the heavy reuse of graves excavated from the rock. ${ }^{26}$ In the rest of the church, frescoes emphasized lordship

\footnotetext{
${ }^{25}$ This eleventh-century church also possesses the earliest known stone portico in the "Romanesque" style. The carved capitals of this portico feature architectural representations of fortresses and soldiers, etc. ${ }^{26}$ Traces of paint remain in the space beneath the tribune but there is no evidence of figural decoration in that zone, which could support its flexible, Islamic character.
} 
and Christendom in a language accessible to Muslims and Christians more familiar with the elite architecture of the nearby taifa of Zaragoza than Pamplona or León.

The decoration that best emphasized territorial sovereignty was the repeated references to palatial riches and royalty. The ubiquitous combinations of vegetal and geometric motifs and roundels with heraldic symbols, combined the themes commonly found in sumptuous Andalusi textiles with subjects typical of noble insignia (figures 49, 50). The emphasis on exotic, luxurious fabrics recalls the earlier painted textile found in the central apse of Santa María de Wamba that likewise sought to project an aura of sovereign splendor (figure 40). At San Baudelio, the painted fabrics were "draped" around the nave and apse in the manner of hanging curtains and "suspended" from both the facing and interior walls of the tribune. I agree with Guardia and Dodds that the images of hunting scenes were employed to emphasize land ownership but find the position of Dodds, that they reflect an exercise of proprietary rights by the Bishop of Sigüenza, and that of Guardia, that they were a display of the victor's spoils, unsatisfactory.

Difficulties with Dodds' theory lie in the way the church's decoration prioritizes references to divine and royal legitimacy over imagery that might have reinforced Episcopal or papal authority. The program appears to be aimed at a diverse but strategically valuable community. While the narrative cycles may have been intended to introduce the essential doctrines of Christianity, including the sacrament of the Eucharist, they were certainly being wooed to support a new lord, particularly in regard to military obligations. ${ }^{27}$ A support for the latter point derives from the prominence of the soldier

\footnotetext{
${ }^{27}$ It is important to keep in mind that even kings were unable to maintain standing armies and relied upon an ad hoc system of rewards and penalties in order to attract soldiers for campaigns or defense. At the
} 
that greets the viewer as they enter (figure 93). The life-size figure of the soldier is turned toward the apse wall and appears to have been caught mid-stride, thus directing the movement as well as the attention of the entrant immediately ahead, toward the apse wall. Although little remains of the scenes to the east of the triumphal arch, the zone that is aligned with the orientation of the soldier, the space to the left of the triumphal arch, certainly contained a nearly life-size Falconer positioned beneath the panel devoted to the Passion of Christ, which in turn was located under the Nativity scene in the vault above. ${ }^{28}$ Upon entering the church, the viewer would have been directed toward a large-scale image of lordship designed to underscore the obligations of inhabitants to their legitimate ruler. Despite the visibility of scenes depicting essential Christian doctrine, the prominence accorded soldiers and representations of earthly authority align with the subject matter foregrounded at San Miguel de San Esteban de Gormaz.

As for the traditional view held by Guardia that the display of Islamic luxury objects refer to the subordination of Andalusi power, I believe that the sociopolitical conditions of this portion of the frontier for this period do not support that interpretation. First, in the same way that rich Islamic textiles were worn and treasured by powerful noble and ecclesiastical leaders throughout the Peninsula for generations, Andalusi motifs like the Falconer or the Elephant would have been seen first as symbols of wealth and authority before their religious or ethnic connotations were considered (figure 94). ${ }^{29}$

frontier, the question of military exemptions for the settlers of "reconquered" cities like Sepúlveda (Segovia) has received careful consideration from James Powers. Generally speaking, the role played by indigenous groups is largely unaccounted for. Powers, A Society Organized for War, 13-29. To my knowledge, a twelfth-century fuero for Berlanga does not survive.

${ }^{28}$ The very poorly conserved Passion panel is in situ, however, although some scholars have proposed that scenes of the Arrest and the Crucifixion were originally depicted, little can be securely made out except for the Ascent to Calvary, see Escolano Benito, Guía, 55.

${ }^{29}$ For an astute analysis of attitudes toward Andalusi textiles in the eleventh through thirteenth centuries, see Feliciano, "Muslim Shrouds for Christian Kings," and Hitchcock, Mozarabs. 
Second, given the delicate political situation, it would have been foolish to publicly marginalize those members in the community who more closely identified with Islamic imagery than trans-Pyrenean motifs but who were nevertheless essential to the success of the local militia.

A compelling support for the lordly emphasis found in the paintings of San Baudelio is the comparable program at the church of San Miguel de Gormaz. Both painting cycles were executed by the same workshop, as clearly demonstrated in the nearly identical treatment of the trompe l'oeil panels at the base of the nave walls at both churches. ${ }^{30}$ Despite this fact and the historical circumstances common to both ermitas, the programs emphasize fairly different themes; doubtless this is the result of different patrons.

The paintings that once decorated the eastern apse wall of San Miguel are lost due to a later replacement of the triumphal arch but most of the frescoes applied to the north and south walls of the nave and the apse are intact and in situ. All of the painted walls are organized into three registers. Two figural registers are located above the trompe l'oeil painted curtains of the lowest zone of the nave. On the north wall, the central register features a battle scene between mounted soldiers framed by fortified towers. The towers represent the eyes of the people within the walls, watching from their windows (figure 95). ${ }^{31}$ Careful attention is paid to the details of the armor and battlements,

\footnotetext{
${ }^{30}$ The painted frescoes at San Miguelde Gormaz only cover approximately two-thirds of the church and appear to have been deliberately terminated at the central, semicircular arched portal. See Carlos Tejedor Barrios, "Restauración de las pinturas murales de la iglesia de San Miguel en Gormaz," Arevacon: Revista Cultural, Asociación de Amigos del Museo Numantino 29 (2009): 22-27, 23. This is very unusual and, like the atypical insertion of two portals on the south wall, seems to indicate a segregated audience.

${ }^{31}$ The scene is introduced by an unknown, saint-like figure, see Benito Arnáiz Alonso, "En clave románica: las pinturas murals de San Miguel de Gormaz (Soria)," Arevacon: Revista Cultural, Asociación de Amigos del Museo Numantino 29 (2009): 28-48, 35. I was generously granted permission by Soria Románica
} 
permitting Benito Arnáiz Alonso to observe that one of the regiments consists of both Christian and Muslim troops. ${ }^{32}$ At the easternmost end of this section, the Three Marys are portrayed as if approaching the tomb of Christ, which was possibly located on the (now lost) eastern wall. ${ }^{33}$ On the south wall, the same middle register contains the patriarchs Abraham, Isaac, and Jacob, who shelter souls in their laps; to the right, the Archangel Michael oversees the weighing of the souls. The register ends with a Hell panel. ${ }^{34}$ The twelfth-century frescoes at both churches prioritize themes of Christian doctrine and military service, reflecting the sociopolitical function of these churches as regional centers. I would suggest that the painting programs depict the different ways in which the individual patrons of these centers sought to politically reorganize their multicultural inhabitants. ${ }^{35}$

To return to the ways in which lordly authority was emphasized at San Baudelio, the multiple and repetitive references to royalty should be more closely considered. Chief among them is the appearance of Melchizedek in the apse. This figure from the Old Testament is not only used as a forerunner to the Eucharist, as Guardia pointed out, but he is often included in programs in which the conflation of divine and earthly power is desired, for example in the mosaic panels at the Capella Palatina in Sicily. ${ }^{36}$

(Junta de Castilla y León) to take one photograph of the painted interior of the nave of San Miguel de Gormaz.

32 Arnáiz Alonso, "En clave románica," 36.

${ }^{33}$ The position and composition of this scene is similar to the same panel at San Baudelio. In the Three Marys panel at San Baudelio on the southeast wall, the Marys likewise hold their pyxis-like vessels and are behind a cohort of troops in similar costume and armor as both groups approach the angel that stood before the grave.

${ }^{34}$ Arnáiz Alonso, "En clave románica," 36-37.

${ }^{35}$ In addition to the panels depicting the weighing of the souls and the torments of hell, the apse has a decidedly apocalyptic theme. The central register consists of the twenty-four Judges of the Apocalypse.

${ }^{36}$ Guardia, "Relire les espaces liturgiques," 87; Evan F. Kuehn, "Melchizedek as Exemplar for Kingship in Twelfth-Century Political Thought," History of Political Thought 31, no. 4 (2010): 557-575, see 559-561, and the analysis provided by Mark Johnson for the appearance of Melchizedek in the mosaic panels at the 
Melchizedek's dual identity of priest and king not only symbolizes the natural overlap of power that existed in the Middle Ages between the royal and ecclesiastical realms but he represents a royal authority not descended from kings—-but ordained by God. In Melchizedek, as was also the case for the Visigothic King Wamba, a ready model for a legitimate, divinely-appointed ruler who was not related to kings was visibly prominent within the holy sanctuary. ${ }^{37}$ Non-royal patrons, such as Fortunio Aznárez, would have benefitted from the visual support of their claims to regional authority.

At San Baudelio kings appear in the painted frescoes three times; once in the small tribune coro and twice in separate vault spaces above the southeast wall. The vault scenes containing Magi are positioned over the staircase to the tribune. The panel most directly aligned with the tribune stair is the Journey of the Magi and was certainly meant to provide a visual reinforcement for processions that would have ascended and descended from the privileged space of the tribune. The subject of these panels would have been clear to those in the nave and the tribune and further supports reading the tribune as an elite space. Altogether, there are three scenes with the Magi and one scene with Melchizedek. This seems to be an unusually high number of kings with which to decorate a rural monastery.

The deliberate royal references do not indicate royal patronage but rather may allude to the fact that Aznárez was a sovereign representative who, together with the monastic representatives of the sacred site, negotiated the governance of the region. On the other hand, the inclusion of Melchizedek at San Baudelio could have served to

Capella Palatina in Sicily is very useful. "The Episcopal and Royal Views at Cefalú," Gesta 33, no. 2 (1994): 118-131, 125-126.

${ }^{37}$ See Kuehn, "Melchizedek as Exemplar," 569-571 in particular. Melchizedek is also represented in the apse at San Miguel de Gormaz and at Vera Cruz de Maderuelo, Arnáiz Alonso, "En clave románica," 45. 
elevate the status of the monks or priests at San Baudelio, as Melchizedek's portrait probably did for the clerics at San Miguel de Gormaz and Vera Cruz de Maderuelo (Segovia). It is challenging to piece together the precise dates of his tenancy but it seems as if Aznárez was either reassigned to Almazán by 1132 or governed both strongholds (and possibly more). Reilly cites six separate charters that place him in Tarazona between 1136 and 1155, however, so I am inclined to think that he was no longer associated with Berlanga after 1136 at the latest. ${ }^{38}$ The fact that San Baudelio was only ceded to the Bishop of Sigüenza by papal ruling only after the demise of Alfonso I would seem to support the proposal that the entrenched legitimacy of the monastery and the added authority of Aznárez's tenure proved a weighty deterrent the papal interference. While one could argue that the program was solely the work of the influential patron Aznárez, I view the continued resistance to the authority of Sigüenza, even to the thirteenth century, when it was finally handed over to Sigüenza, as evidence that the supralocal powers sustained their strategic value without the support of Aznárez. ${ }^{39}$ With the mounting military successes against the Almohads and an easing of the conflict between Aragón and Castile in the later thirteenth century, the importance of the transDuero fortresses and their useful cultic centers eventually faded.

${ }^{38}$ Reilly, The Kingdom of León-Castilla under King Alfonso VII, 196.

${ }^{39}$ Guardia, "Relire les espaces liturgiques," 84. 


\section{CONCLUSIONS}

One of the initial goals of this investigation was to explore the reasons why a large number of well-crafted, stone churches were built along a sparsely populated, politically unstable, rural frontier of medieval Iberia in the tenth through twelfth centuries. Scholarly literature on the subject has traditionally taken for granted that in the midst of the clashes between co-religionists as well as Christian and Muslim polities during this time period, expensive and labor-intensive churches were built simply to address the sacramental needs of the newly "settled" Christians at the frontier. This conclusion is at odds, however, with recent publications by a wide body of scholars who argue for the continuous habitation and cultivation of the Duero basin and posit the existence of political entities along the strategic frontier. Accepting this perspective, I set out to show that the misunderstanding of the demographic realities of the frontier have concealed the purposeful building strategies undertaken by patrons intent on controlling the people and resources of these small but critical communities for the purposes of territorial expansion and defense.

Material support for the theories of continuity can be found in the large number of surviving stone fortresses, churches and monasteries that were built near medieval populations that cultivated crops and herds and were largely independent from the central authorities of counts, kings or caliphs. Although the numbers of people and resources in 
towns or alquerías were never very high, in an age when raiding militias and besieging armies might comprise only fifty men, inhabitants and potential supplies were invaluable. Without the cooperation of the local sociopolitical body, generally comprised of landholding elites (also called supralocal powers), any lasting political transition would fail, either from outside military attack or the withholding of resources by locals resistant to an illegitimate imposition of authority. Until the Christian kingdoms were able to consolidate their kingdoms and secure their southernmost conquests from a Muslim reconquest in the later thirteenth century, independent frontier communities would play an important role in that process.

The second objective for this study was to consider the ways in which would-be governors would have attempted to convince the self-sufficient communities at the important trans-Duero frontier to accept their sovereignty. The most efficient way to assume control over a body of people is with their consent and so I have proposed that in many places, a persuasive campaign for the "Hearts and Minds" of the existing populace took place as supralocal elites and/or outside authorities negotiated positions of power. For later frontier communities of the eleventh and twelfth centuries, particularly large centers like Sepúlveda, the architectural record is supported by the town charters, or fueros, that present a written testimony of the sort of negotiations and concessions that took place between border populations and their Christian conquerors. For smaller communities like Santa María de Wamba and San Baudelio de Berlanga, fueros do not survive for this period but the surviving churches reveal an appropriation of meaningful topographies and elite architectural forms that indicate that these building programs were prompted by political transition. 
Visible campaigns of church or palace-building were not only traditional vehicles for the assertion of regional primacy; they served a practical function. Building programs facilitated the construction of a literal platform for the negotiation of authority between the claimant and the community. In the Duero basin, buildings were sometimes raised by indigenous elites as a way to assert their control over the wider community, as was the case for San Baudelio de Berlanga (Soria). More frequently, however, it appears that the patron was an outside conqueror or claimant, as happened at Santa María de Wamba (Valladolid) with the arrival of the retired Leonese Bishop Frunimius. Regardless of the origin or ideological affiliation of the patron, one factor was paramount in the selection of the building-site: the landscape.

As many scholars have demonstrated, the medieval inhabitants of Iberia maintained a regard for pre-Christian rituals and beliefs, including a reverence for nature cult precincts, such as rocks, trees, caves, cliffs, bodies of water, etc., that were later incorporated into Christian practice. The expectation that divine power inhabited these places offered the patron a building site that both exuded authority to a heterogeneous audience and provided visual cues of the proprietor's appropriation of the sacred landscape, and in many cases, sacred history. The reuse of prior sacred space, for churches in particular, was a standard medieval building practice that has long been acknowledged. What has not received adequate attention, however, is how the significance of natural features themselves continued to offer a route to sociopolitical legitimacy for the successive proprietors of rural holy sites and how the construction of elite, stone structures amplified their visual campaign for authority. 
The potential for an ecclesiastical foundation to render visible their holy topography and history is offered in this dissertation as an important motivation for the building or "restoration" of monasteries like San Millán de la Cogolla (La Rioja) and San Juan de la Peña (Huesca). The earliest structures at these sites were directed by the monks themselves, who wielded supralocal power over the surrounding territory. Carved ashlars, domical vaults, horseshoe arches, and columns were all employed in a manner consistent with palaces or grand churches but on a smaller scale. These architectural elements and the elite burial precincts located at both sites were inserted into the living rock in such a way as to underscore their divine setting, a pattern that was repeated by later patrons, some of whom were kings.

Further south in the Duero basin, Santa María de Wamba and San Baudelio de Berlanga, the case studies for this project, developed along similar lines with the exception that they remained outside of the royal purview, even at the zenith of their influence. The strategic building patterns remained the same: the "restoration" of churches over significant landscape features, the visual emphasis given to material signs of a sacred past, Visigothic and hermitic, respectively, and the subsequent construction phases that signaled a new proprietor but who nevertheless maintained the visual signs of the holy site and history. At these and other Duero frontier churches, multiple phases of construction or decoration appear to have been designed with both a Christian and Muslim audience in mind, underscoring efforts to be accessible to, and to convert, remaining Muslim or religiously pluralistic populations.

The medieval building strategies of patrons and proprietors at Santa María de Wamba and San Baudelio de Berlanga were not anomalies. While reconstructing the 
supernatural significance of sacred landscapes and their legitimizing potential is challenging, the large number of stone churches and monasteries built against exceptional environments offers a pattern of building with sociopolitical implications. Although these churches were built to support the influence of Christianity as well as meet the sacramental needs of frontier Christians, these sites were selected for the transcendental appeal that their revered environments held for diverse communities and for the authority that such potency could confer upon the patron.

Whether the landscape contained holy caves or the graves of royal Visigothic saints, patrons were able to showcase the antiquity of a site by rebuilding (or claiming to have rebuilt) earlier churches or eremitic sites. The emphasis that rural Duero patrons placed on the restoration of Visigothic-era shrines, churches or cemeteries as a strategy to support their right to rule later become part of the vocabulary of the Reconquest. Legendary accounts of Christian conquerors like Alfonso VI, who during the course of his capture of Toledo (1085) supposedly discovered a lamp-illuminated crucifix in a subterranean chapel beneath the Bāb al-Mardūm mosque, offers an example of the way in which "Reconquest" narratives eventually developed out of the "restoration" building strategies of the tenth to twelfth centuries.

Early modern audiences understood that the cross had been miraculously preserved during the Muslim period until such time as it would be revealed, suggesting an inevitability for the Christian conquest. However, the underlying themes of the tale, a cave-shrine, a miracle, and the revelation of all to the territorial lord clearly conform to the strategies of conquest practiced at Santa María de Wamba, San Baudelio de Berlanga, and other politically valuable centers. I would offer that the frequent repetition of 
building campaigns concerned with the construction of political legitimacy

fundamentally altered the general understanding of why Christian forces expanded south. While the builders at Santa María and San Baudelio strove to employ regionally specific, multiculturally accessible building strategies, for subsequent generations, the same visual vocabulary (a sacred place, miraculous past, stone construction) would be adapted to represent the later medieval viewpoint that a Christian Reconquista had long been the destiny for the authentic Spaniard. 


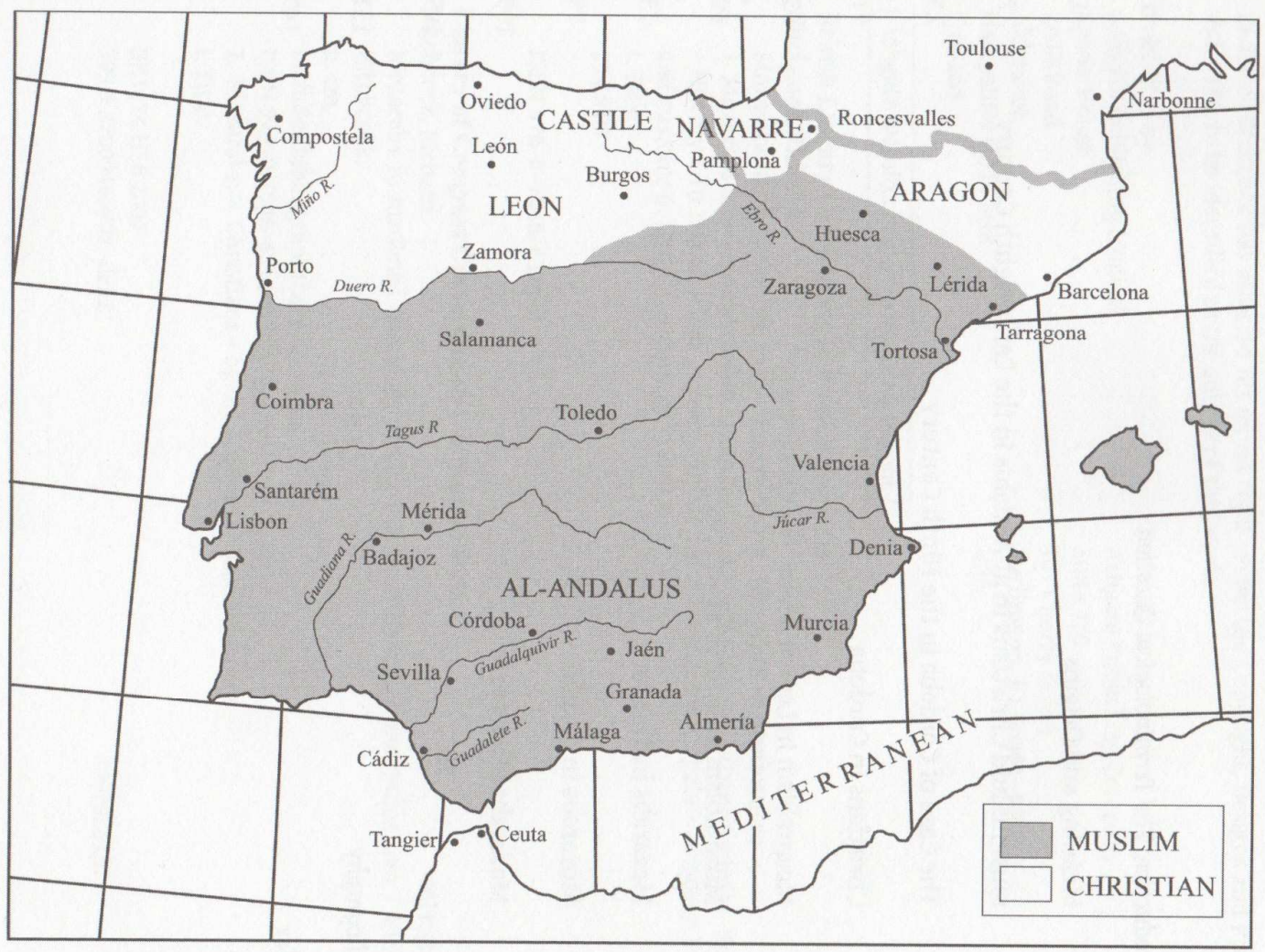

Map 1 The territory of al-Andalus in the tenth century

Figure 1: Map of al-Andalus. After R. Hitchcock, Mozarabs in Medieval and Early Modern Spain, Identities and Influences (Aldershot, 2008), Map 1. 


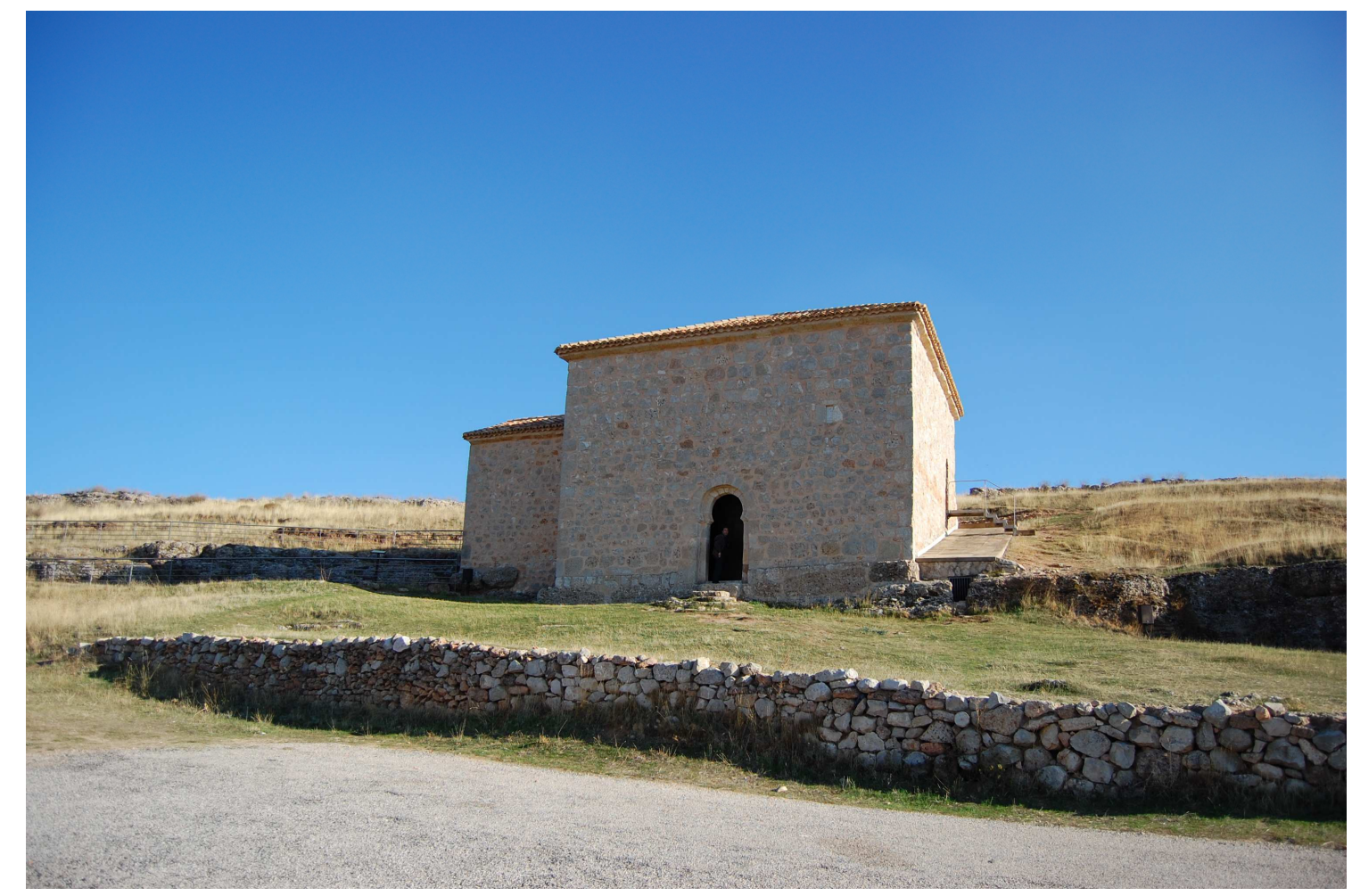

Figure 2: San Baudelio de Berlanga (Soria), view of northwest facade. Photo: author. 


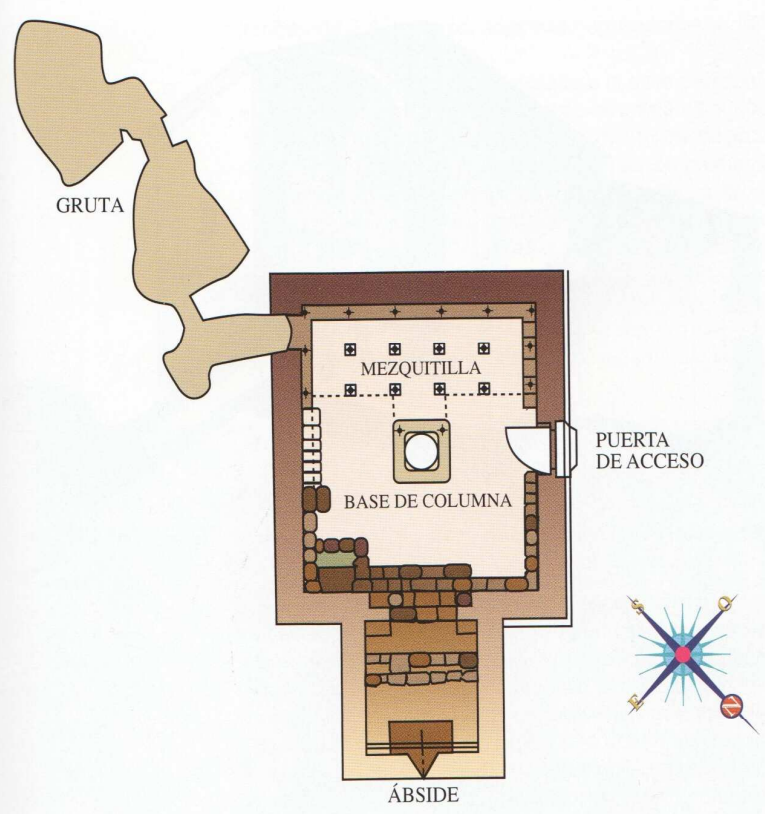

Planta de la ermita de San Baudelio (Ortego Frías)

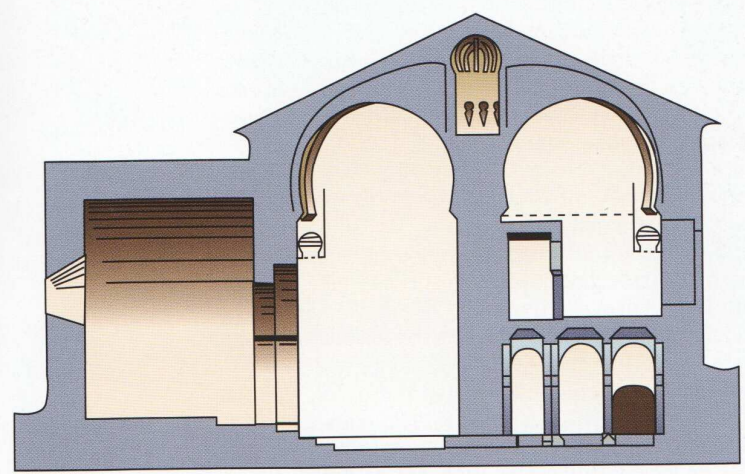

Plano y sección longitudinal de la iglesia de San Baudelio (Ortego Frías)

Figure 3: San Baudelio de Berlanga (Soria), floor plan and elevation. After T. Ortega Frías, La ermita mozarabe de San Baudelio en Casillas de Berlanga(Caltojar)(Almazán, 1987), 18, 23. 


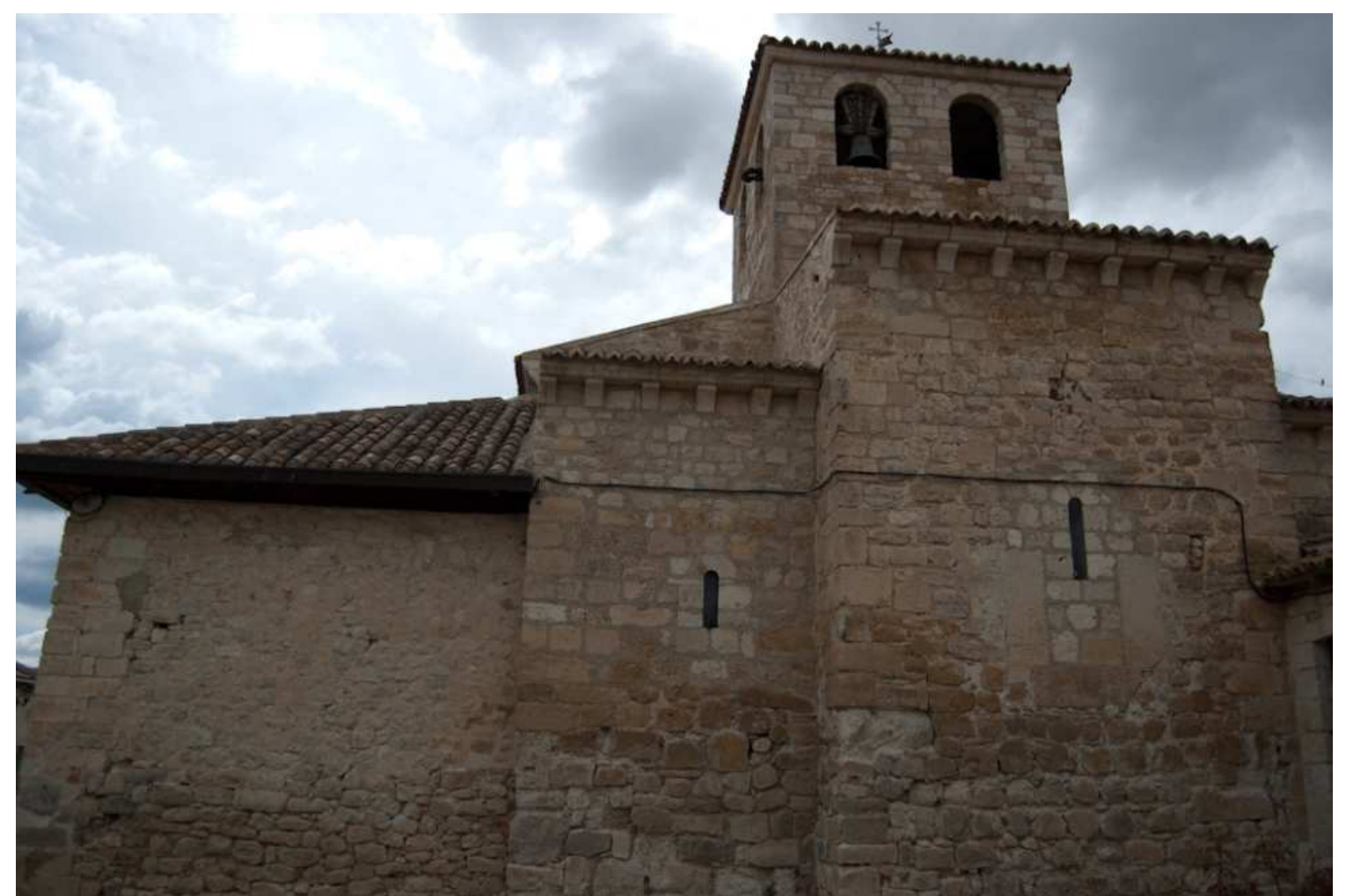

Figure 4: Santa María de Wamba (Valladolid), partial view of the original tripartite apse and later medieval sacristy. Photo: author. 


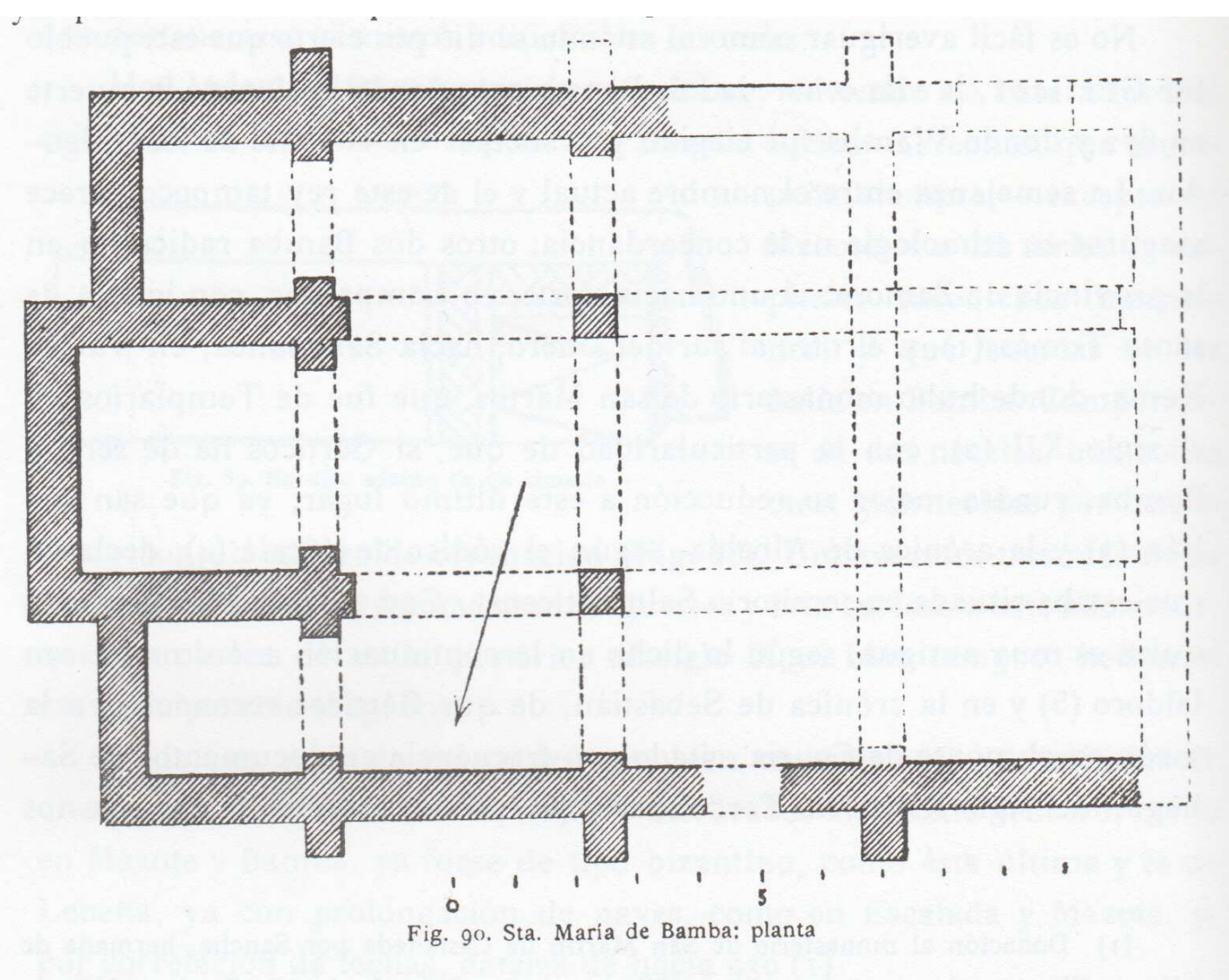

Figure 5: Santa María de Wamba (Valladolid), floor plan. After Gómez-Moreno, Iglesias Mozárabes: arte Español de los siglos IX a XI (Madrid, 1919), figure 90. 


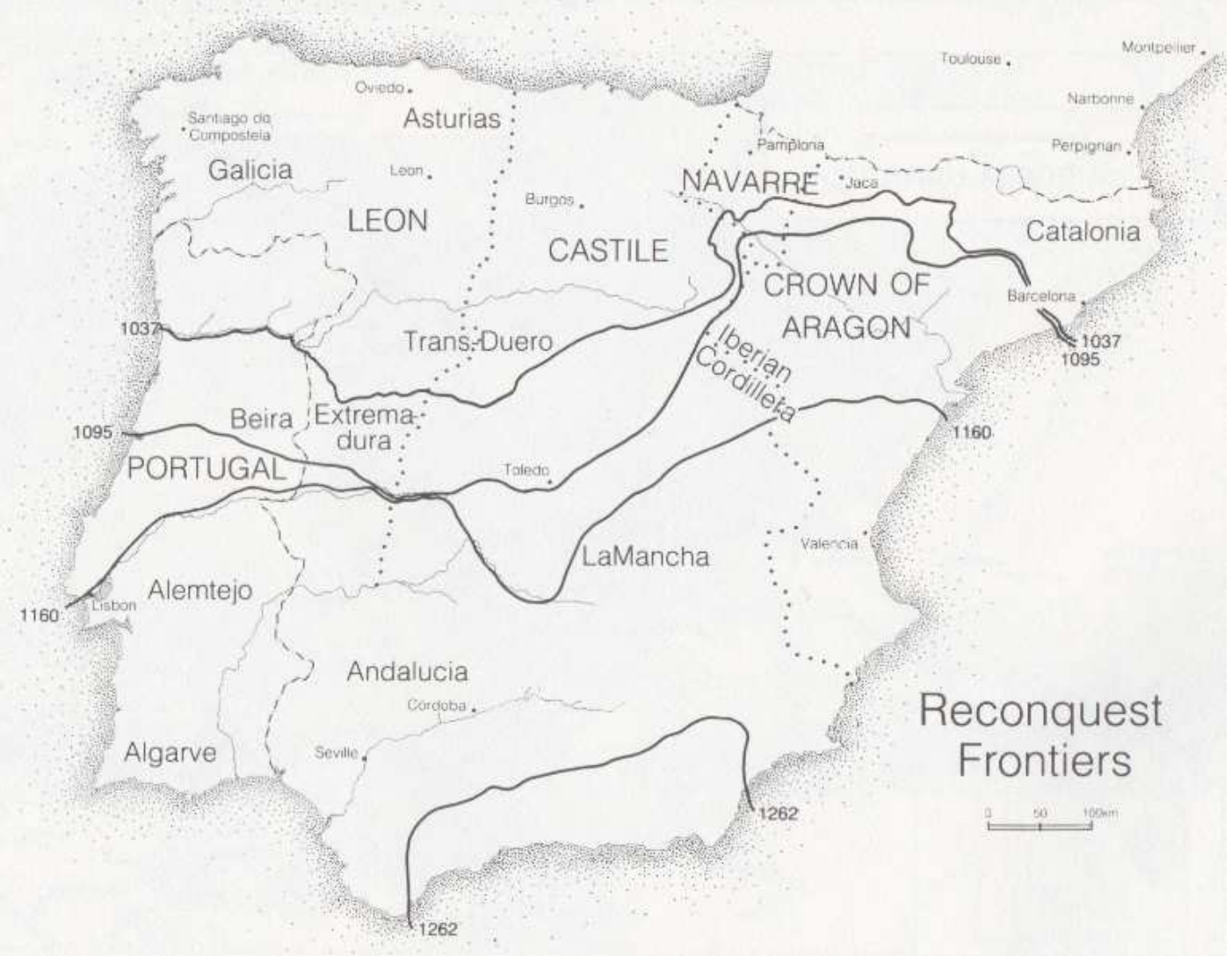

Figure 6: Map of multiple Iberian frontiers. After J.

Powers, A Society Organized for War: The Iberian

Municipal Militias in the Central Middle Ages, 1000-

1284 (Berkeley, 1998), Map I. 


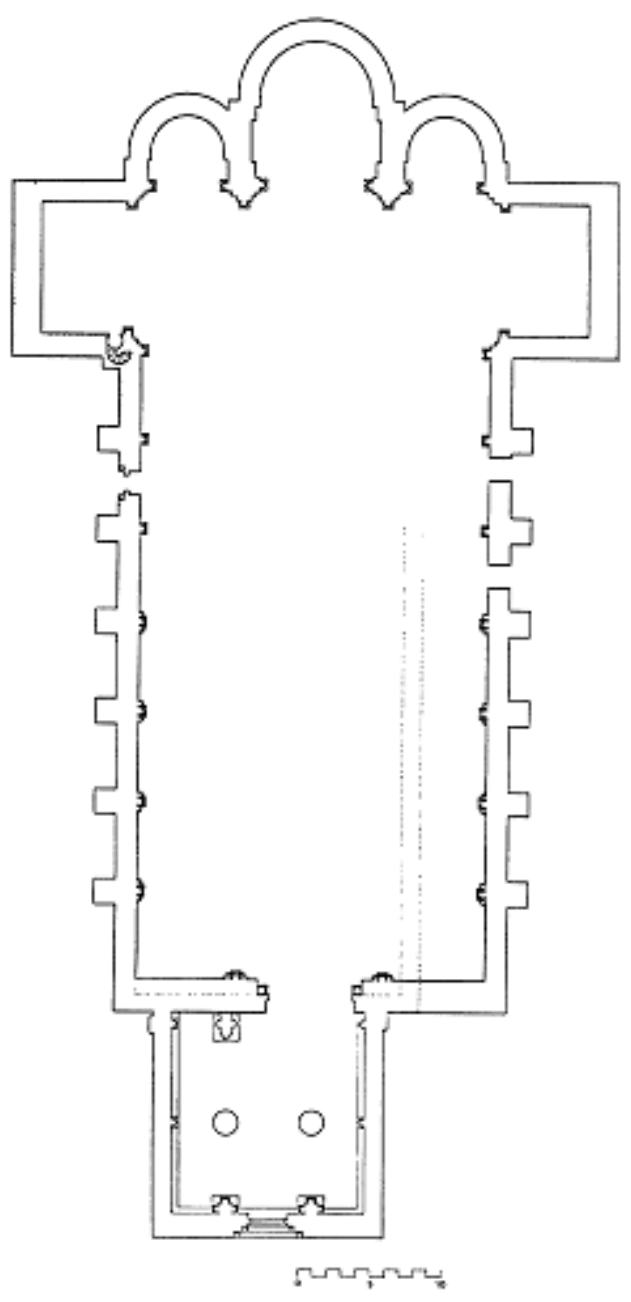

Figure 7: Plan of the eleventh-century monastery church of Sahagún. After J. L. Senra Gabriel y Galán, "Los programas constuctivos de los monasterios benedictinos en el Camino de Santiago: Arquitectura y ornamentación." In Monasterios y peregrinaciones en la España medieval, edited by José Ángel García de Cortázar and Ramón Teja, 100-27. Aguilar de Campoo: Fundación Santa María la Real, 2004, figure 10. 


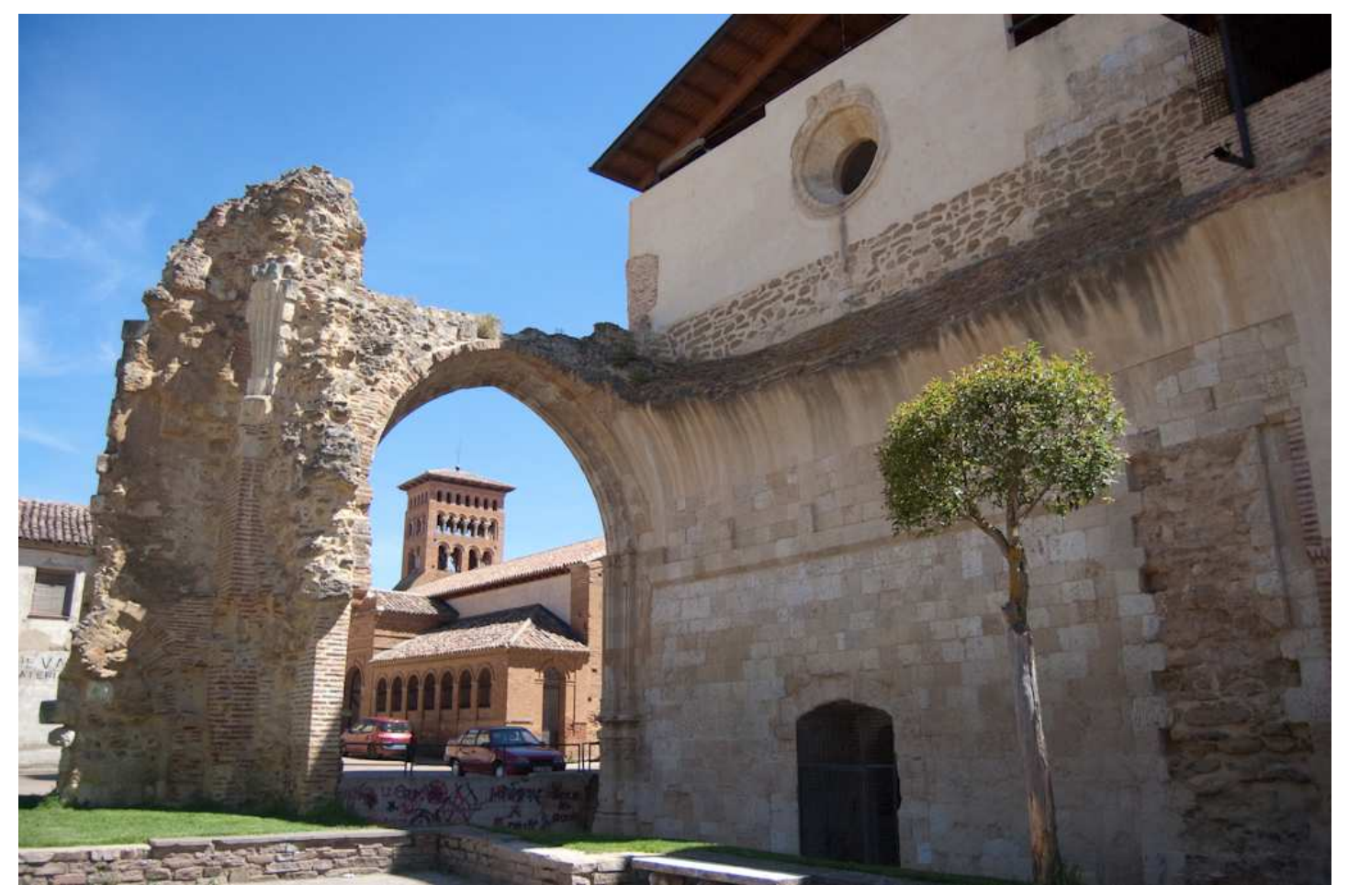

Figure 8: Surviving ashlar section of the north wall of the eleventh-century church of Sahagún. Photo: author. 


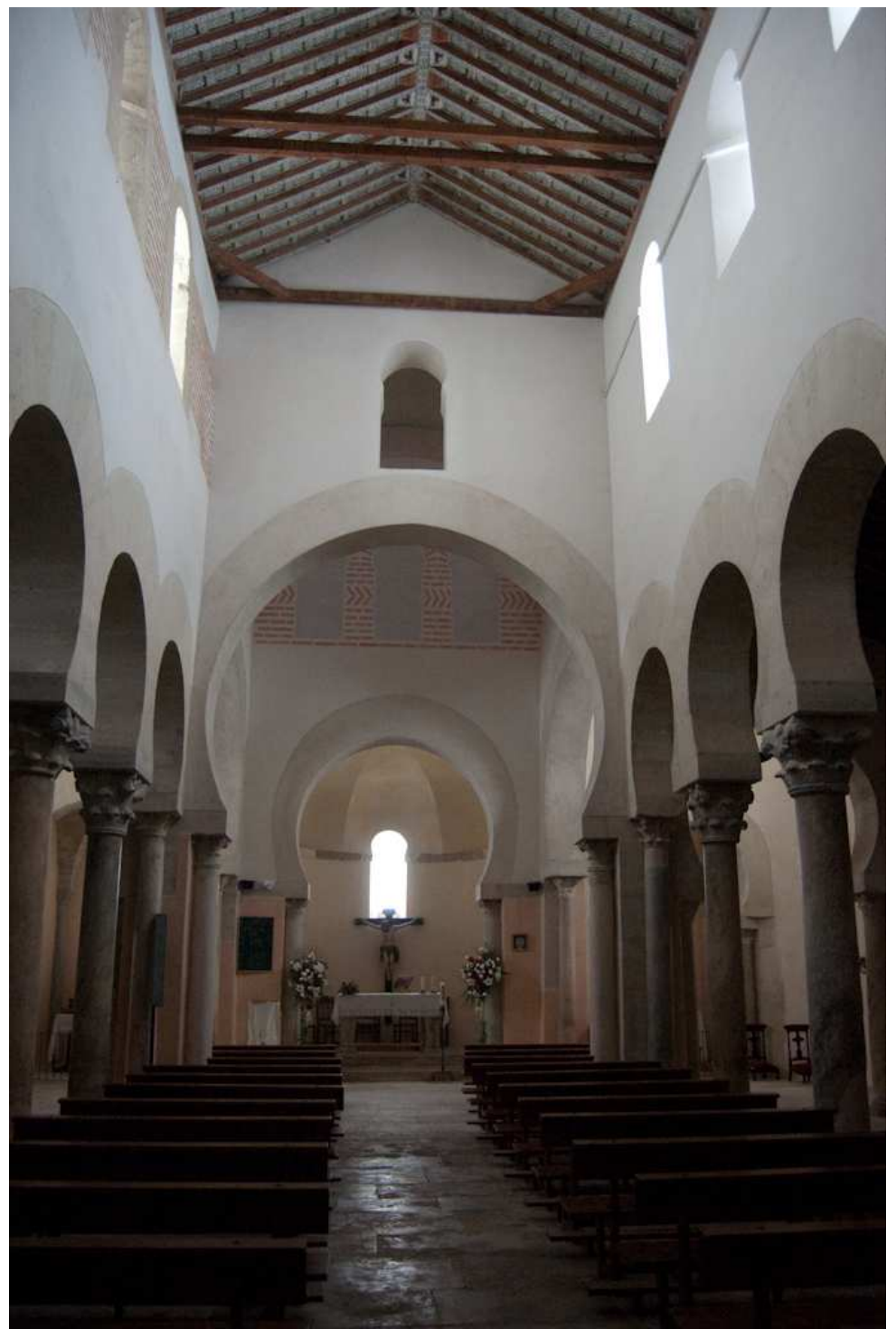

Figure 9: San Cebrián de Mazote (Valladolid). View from the nave looking toward the central, eastern apse. Photo: author. 


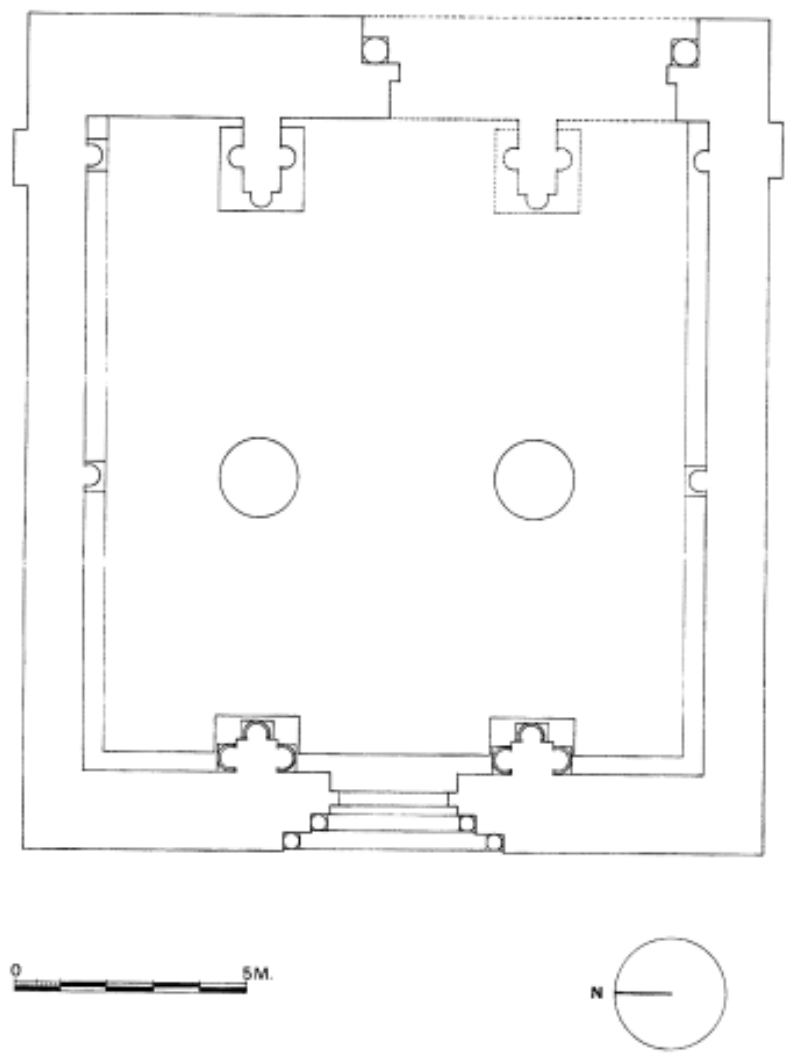

Figure 10: Reconstructed plan of the eleventh-century chapel of San Mancio, Monastery of Sahagún. After J. L. Senra, "Aproximación a los espacios liturgico-funerarios en Castilla y León: Porticos y galileas." Gesta 36, no. 2 (1997): 122-43, figure 5. 


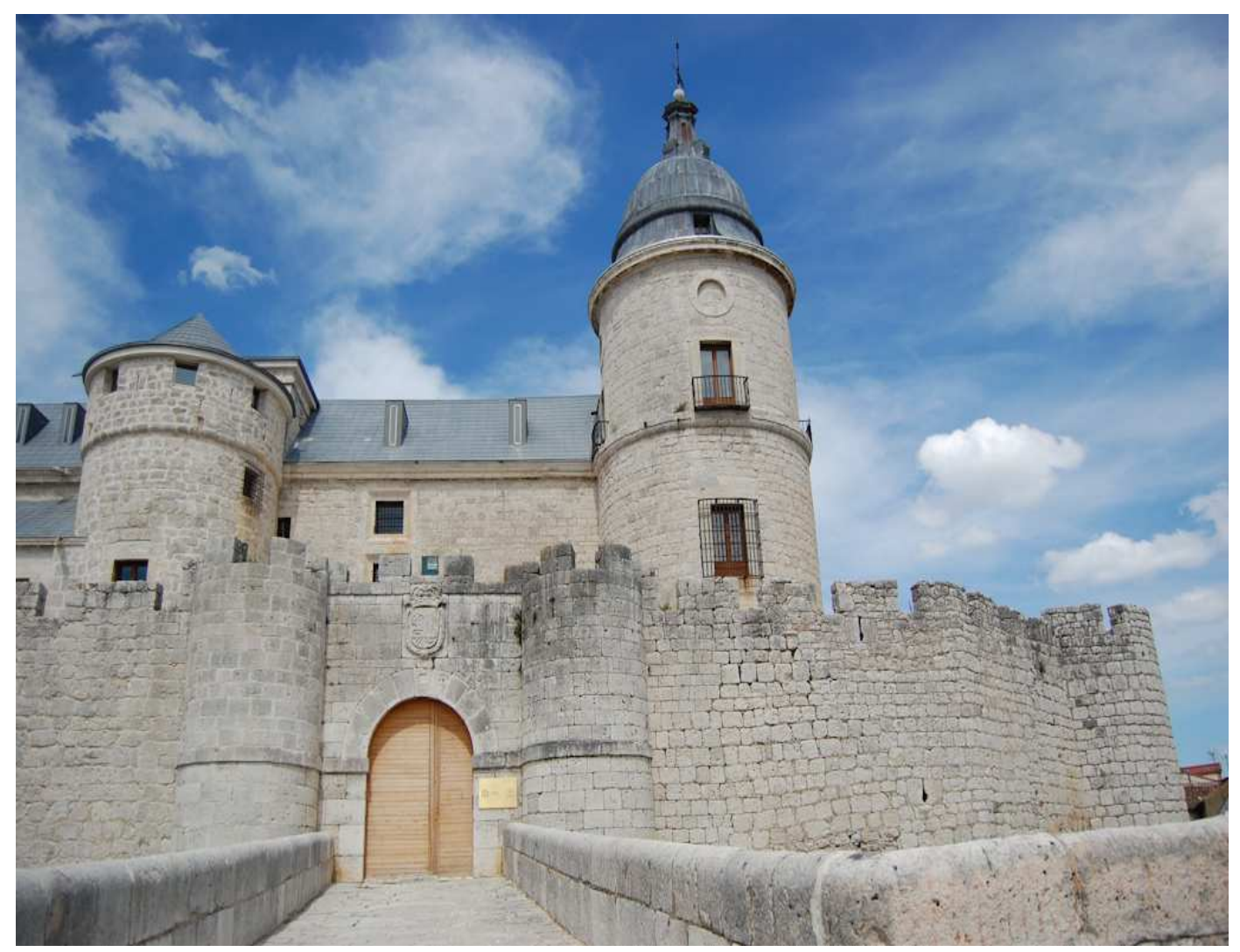

Figure 11: The fortress of Simancas (Valladolid). Photo: author. 


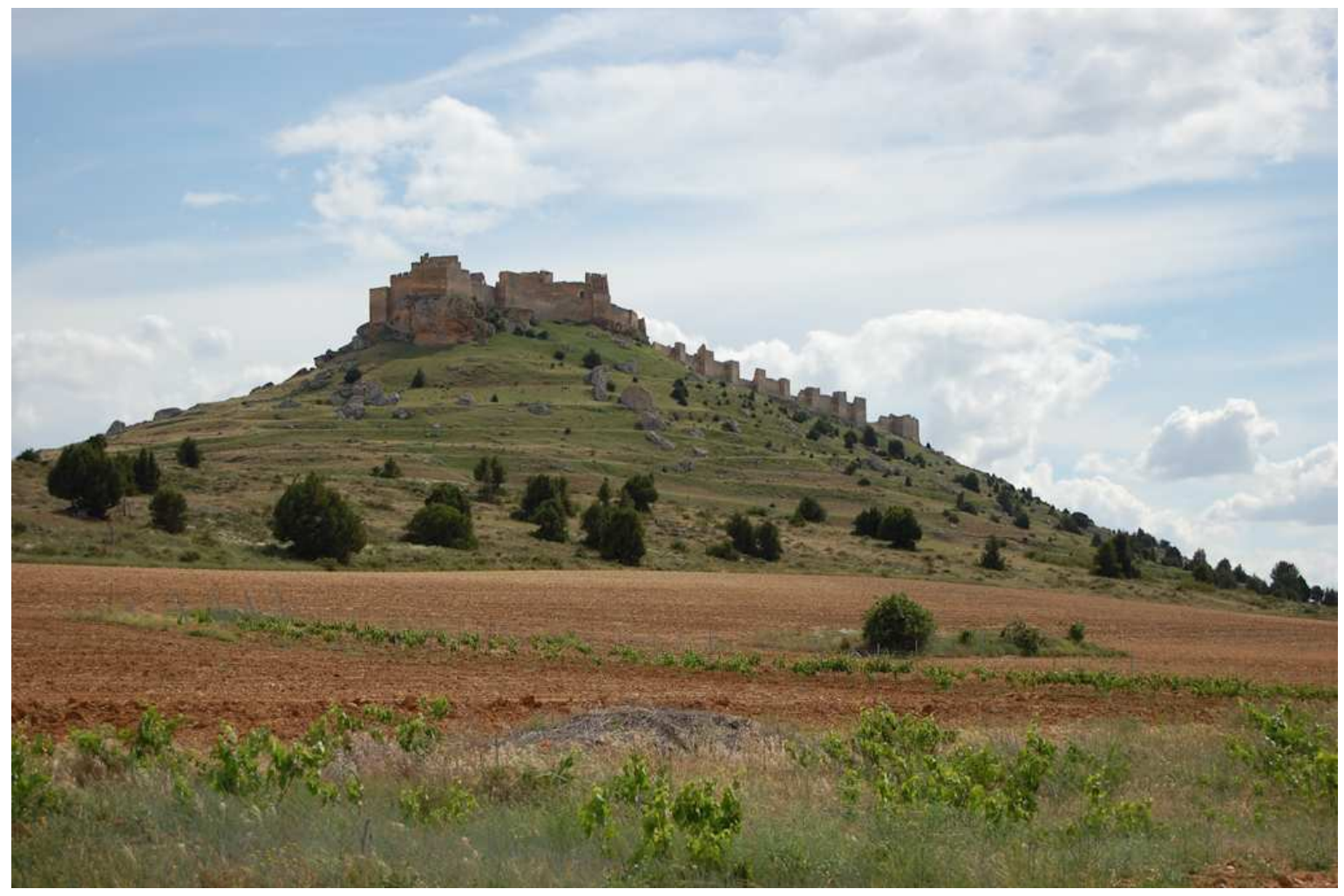

Figure 12: The fortress of Gormaz, view from the northeast. Photo: author. 


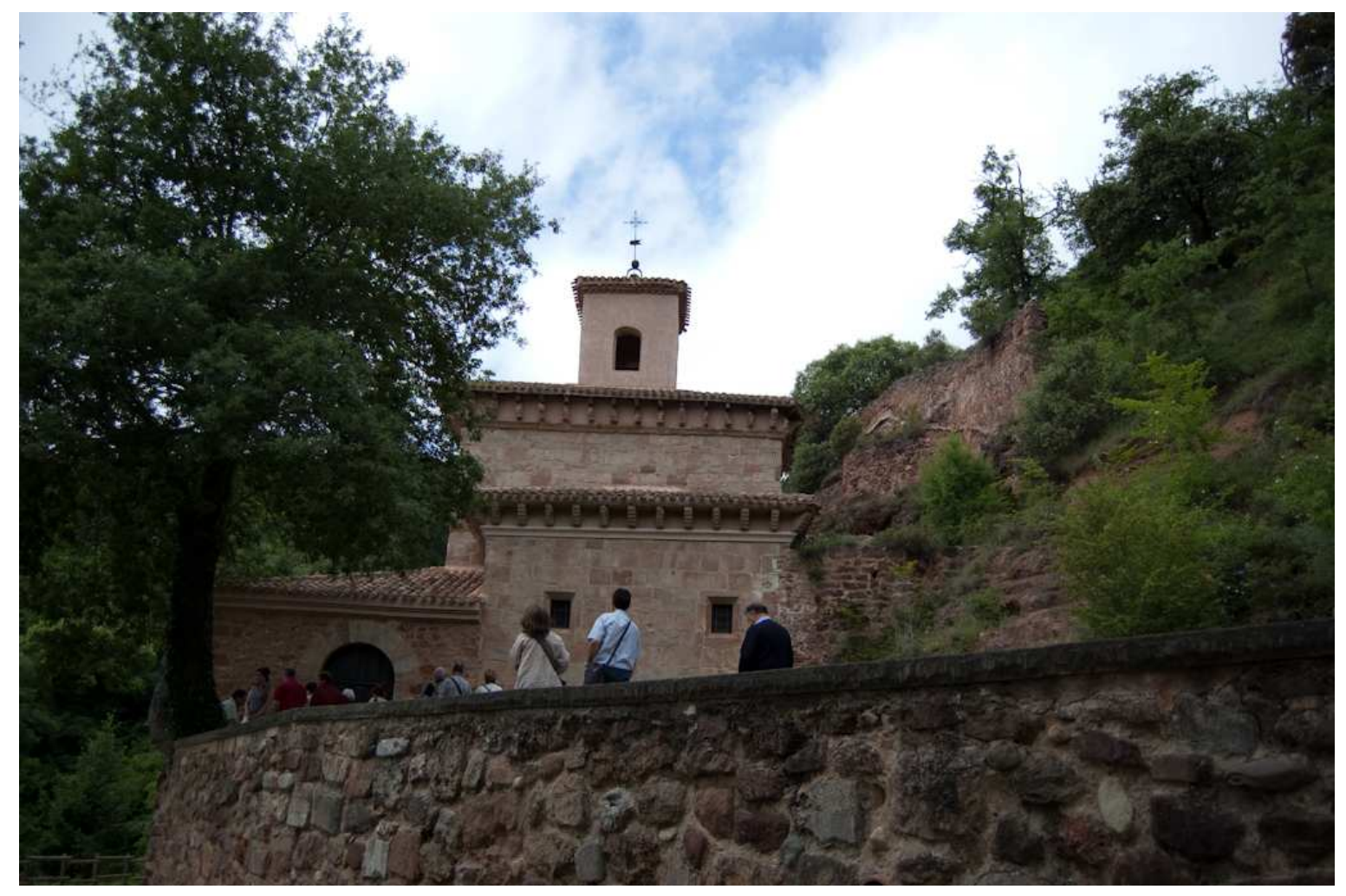

Figure 13: San Millán de la Cogolla, Suso, view from the northeast. Photo: author. 


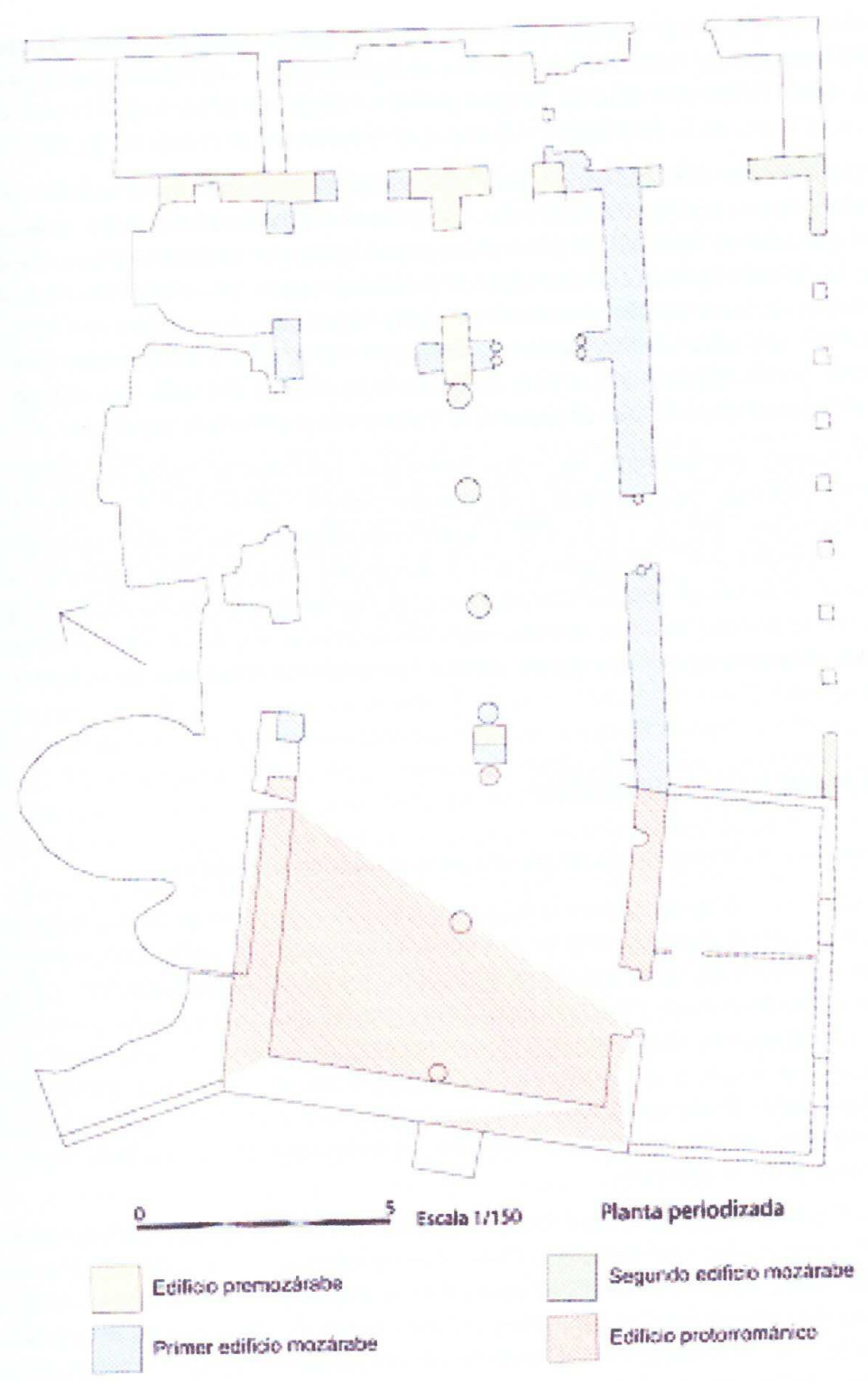

Fig. 4. Planta de S. Millán de la Cogvila.

Figure 14: Plan of the multiple phases of San Millán de la Cogolla, Suso, after Caballero Zoredo. 


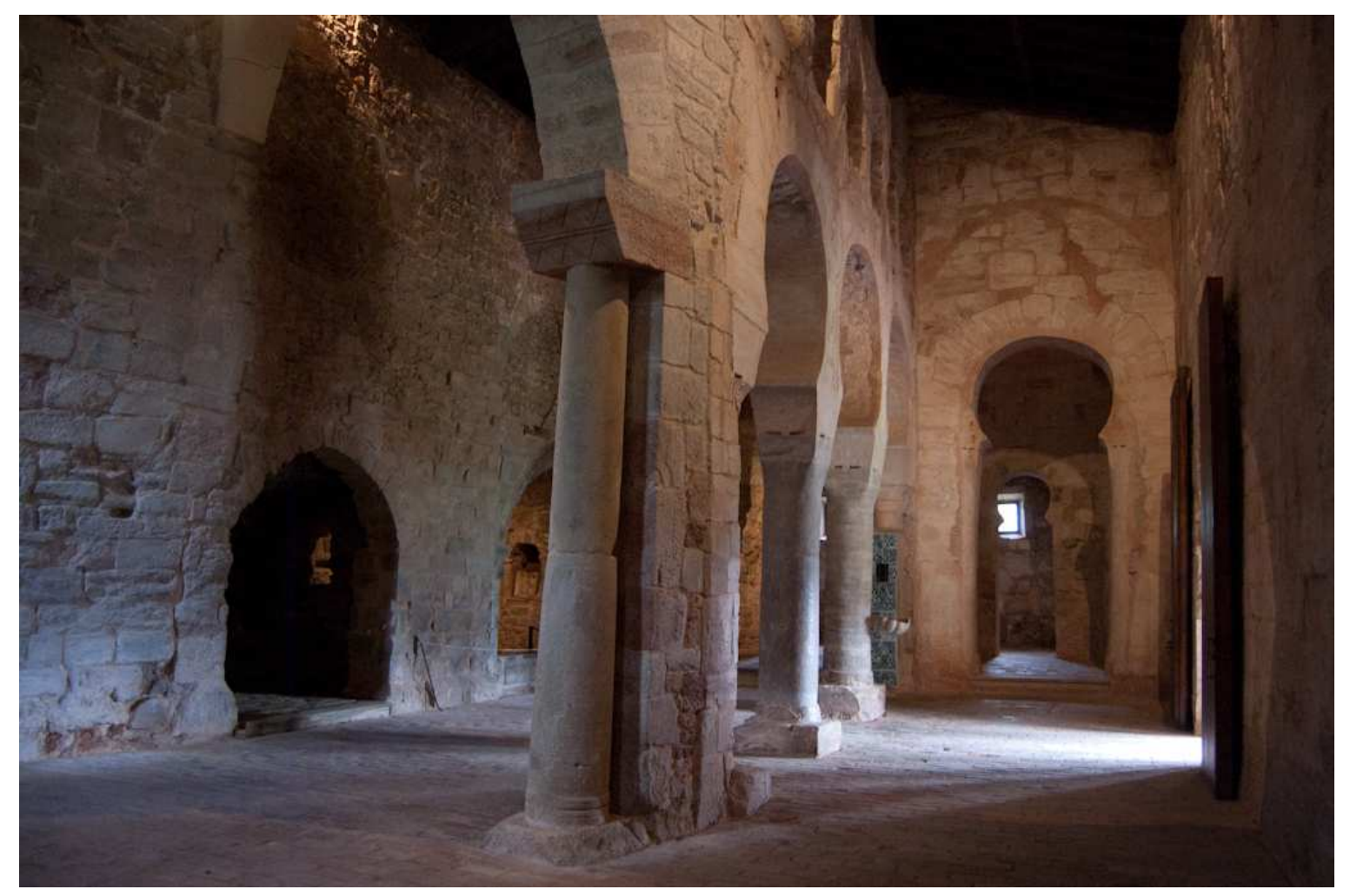

Figure 15: San Millán de la Cogolla, Suso, view of the nave looking toward the northeast. Photo: author. 


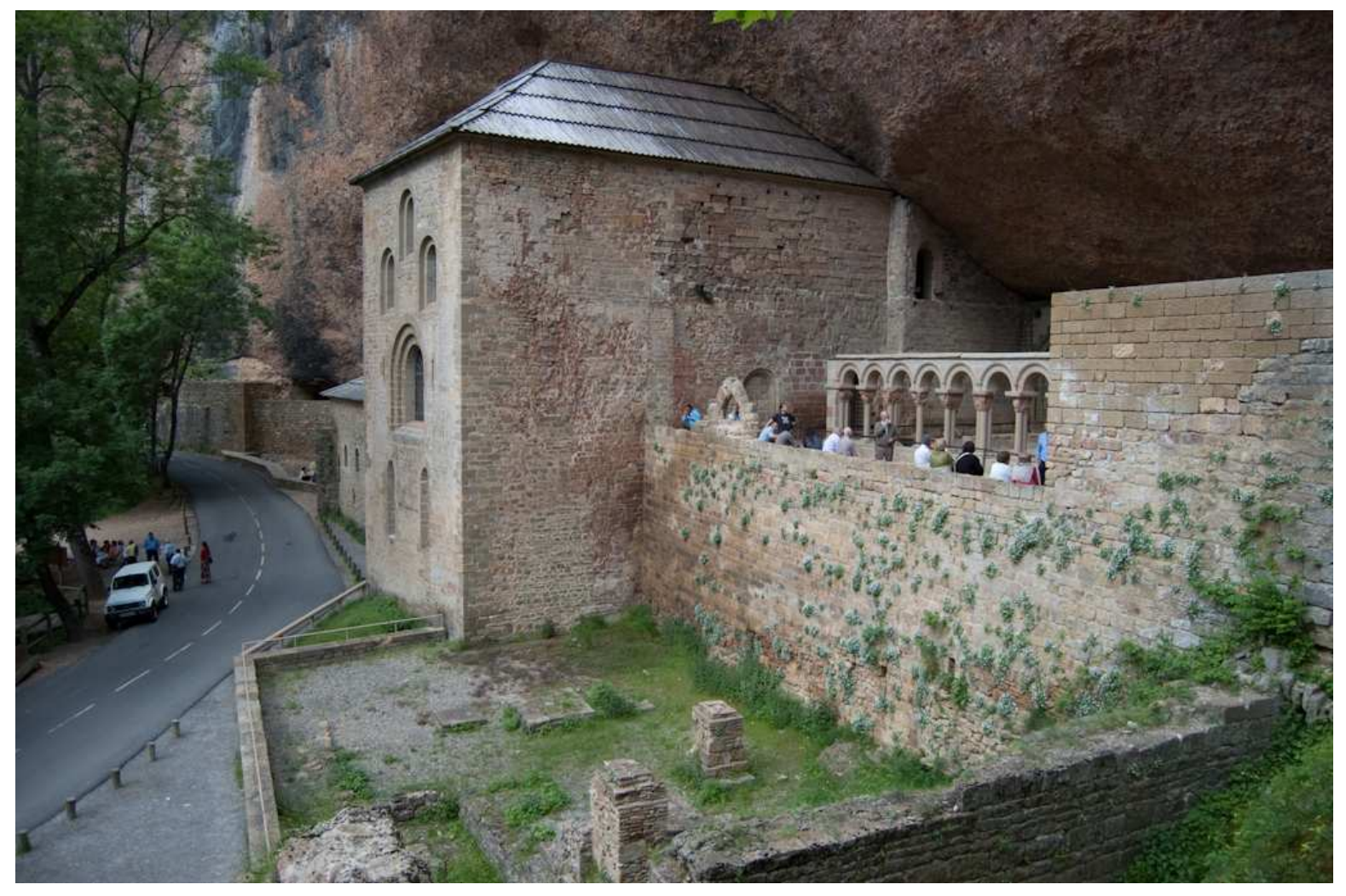

Figure 16: San Juan de la Peña, view from the West. Photo: author. 

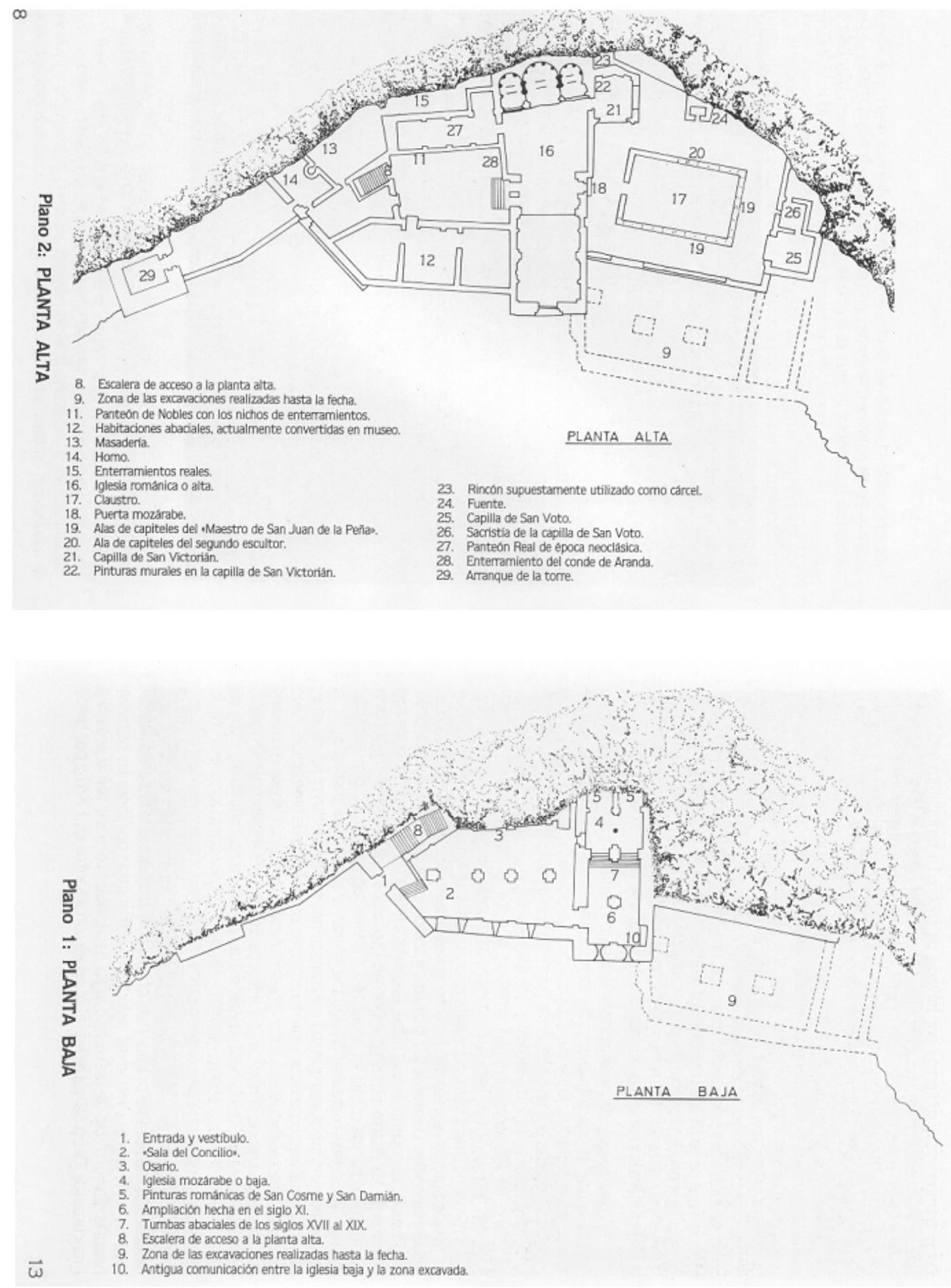

Figure 17: Floor plans of the upper level (upper image) and lower level (lower image) of the monastic site at San Juan de la Peña. After A. I. Lapeña Paul, San Juan de la Peña: Guía histórico-artística (Diputación General de Aragón, 1986), plans 1 and 2. 


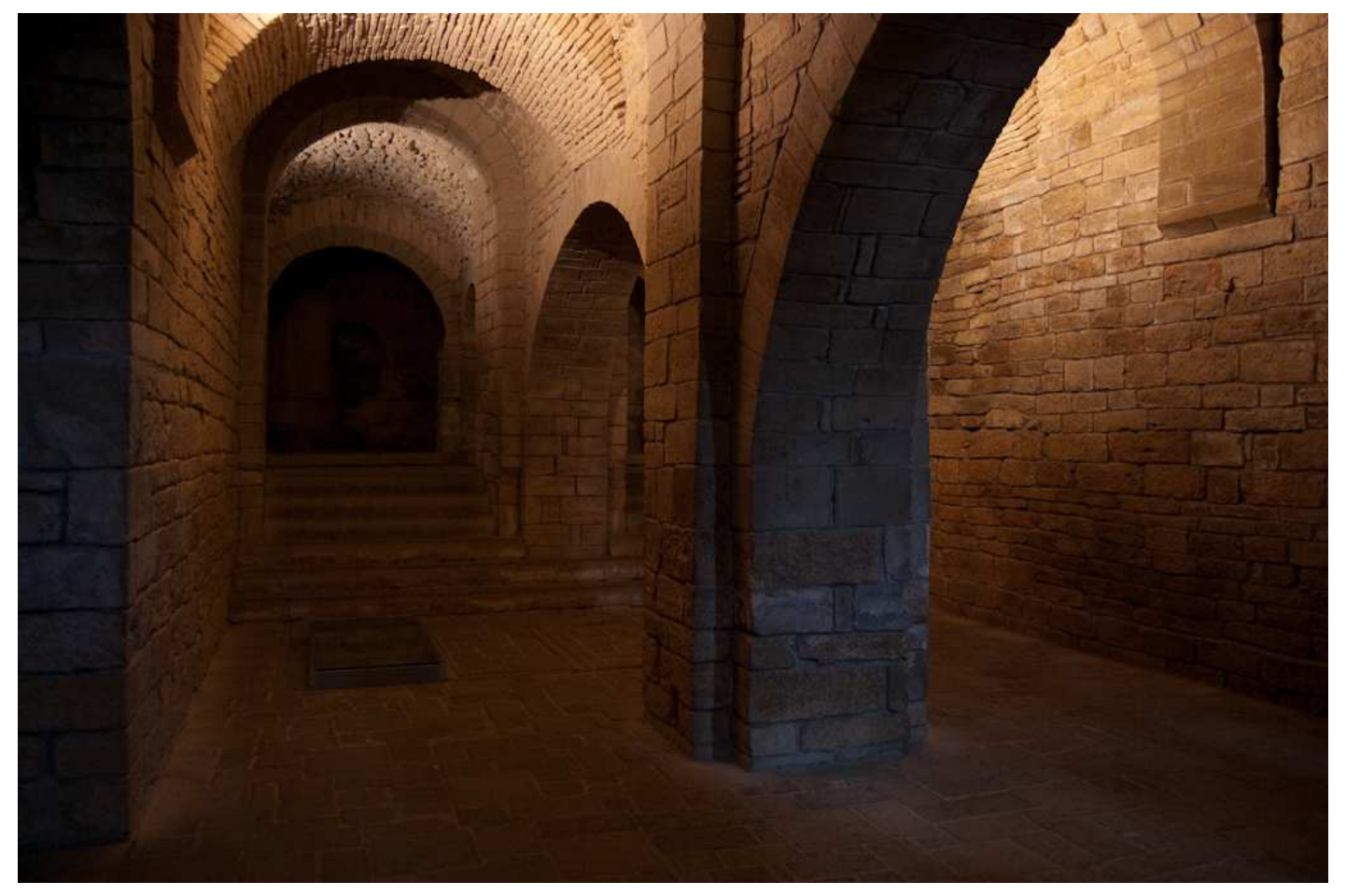

Figure 18: San Juan de la Peña, view from the extension, toward the southeastern apses. Photo: author. 

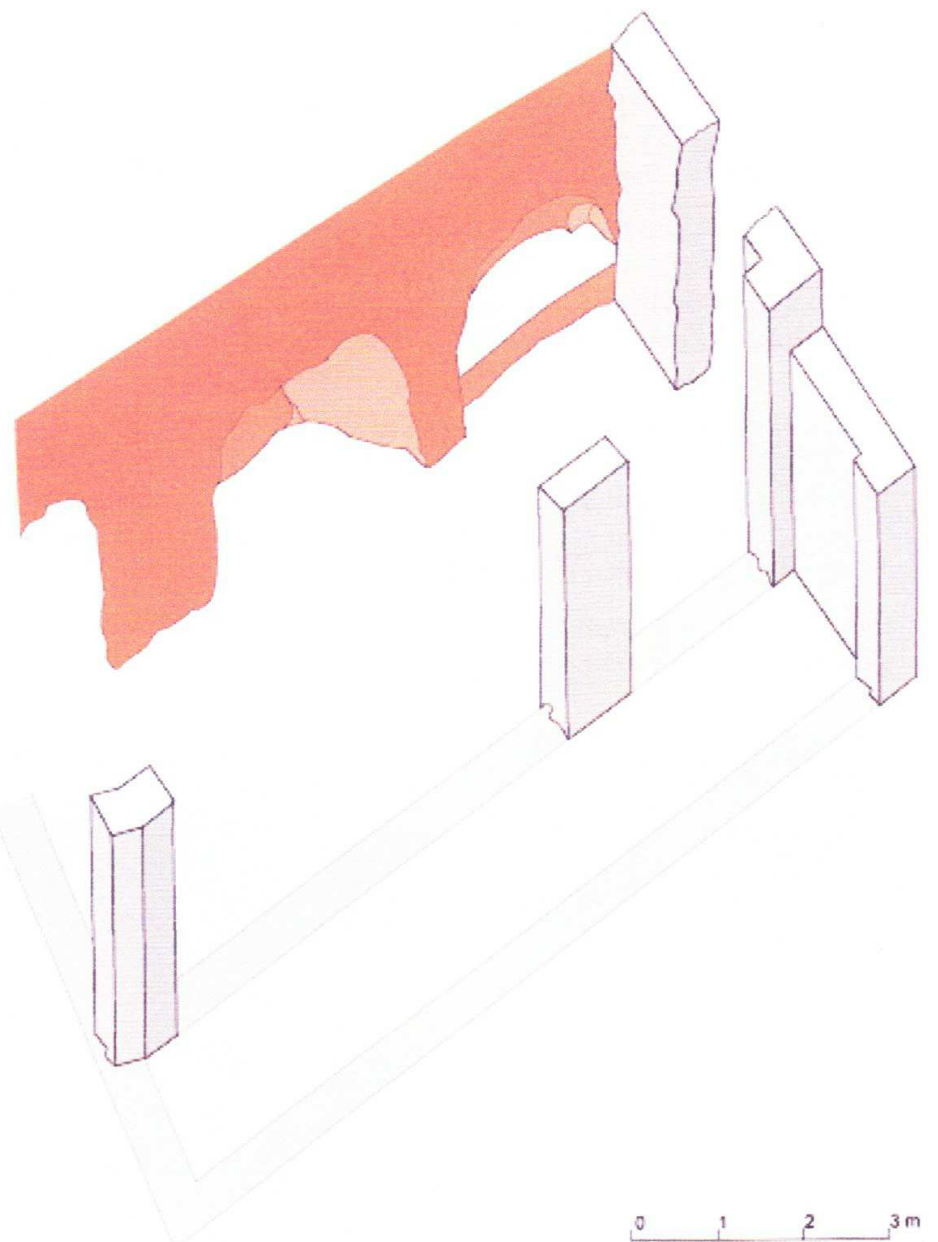

Fig. 6. Perspectiva ideal de la reconstruccion del edificio premozárabe de Suso.

Figure 19: Reconstruction plan of the ninth to tenth-century structure at San Millán de la Cogolla, Suso. After L. Caballero Zoredo, "La iglesia de San Millan de la Cogolla de Suso: Lectura de Paramentos." In Arte Medieval en la Rioja: Prerrománico y Románico: VIII Jornadas de arte y patrimonio regional, edited by Ignacio Gil-Díez Usandizaga, 13-94. Logroño: Instituto de Estudios Riojanos, 2004, figure 6. 


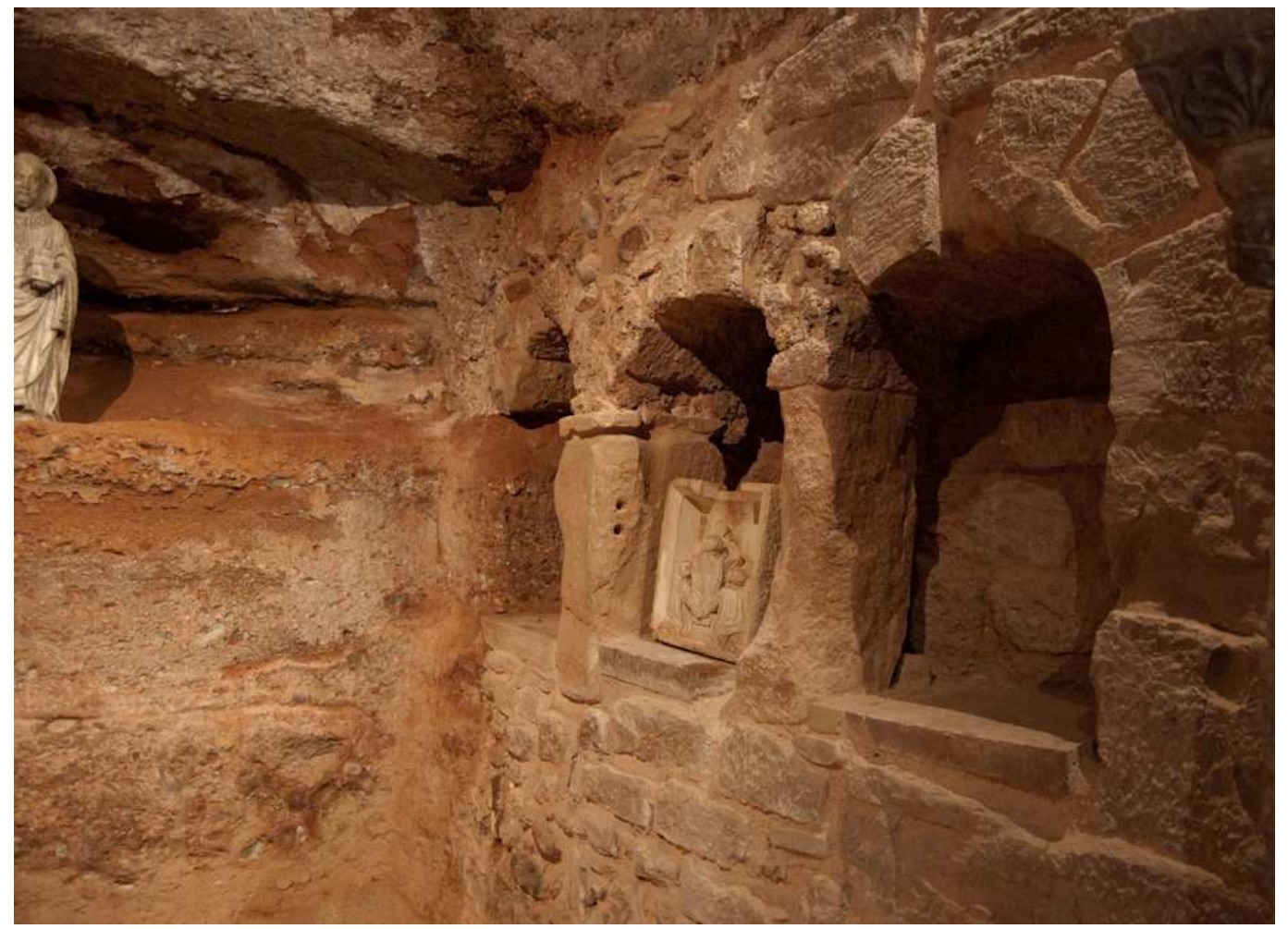

Figure 20: Altar niches in the eastern wall of the central cave of San Millán de la Cogolla, Suso. Photo: author. 


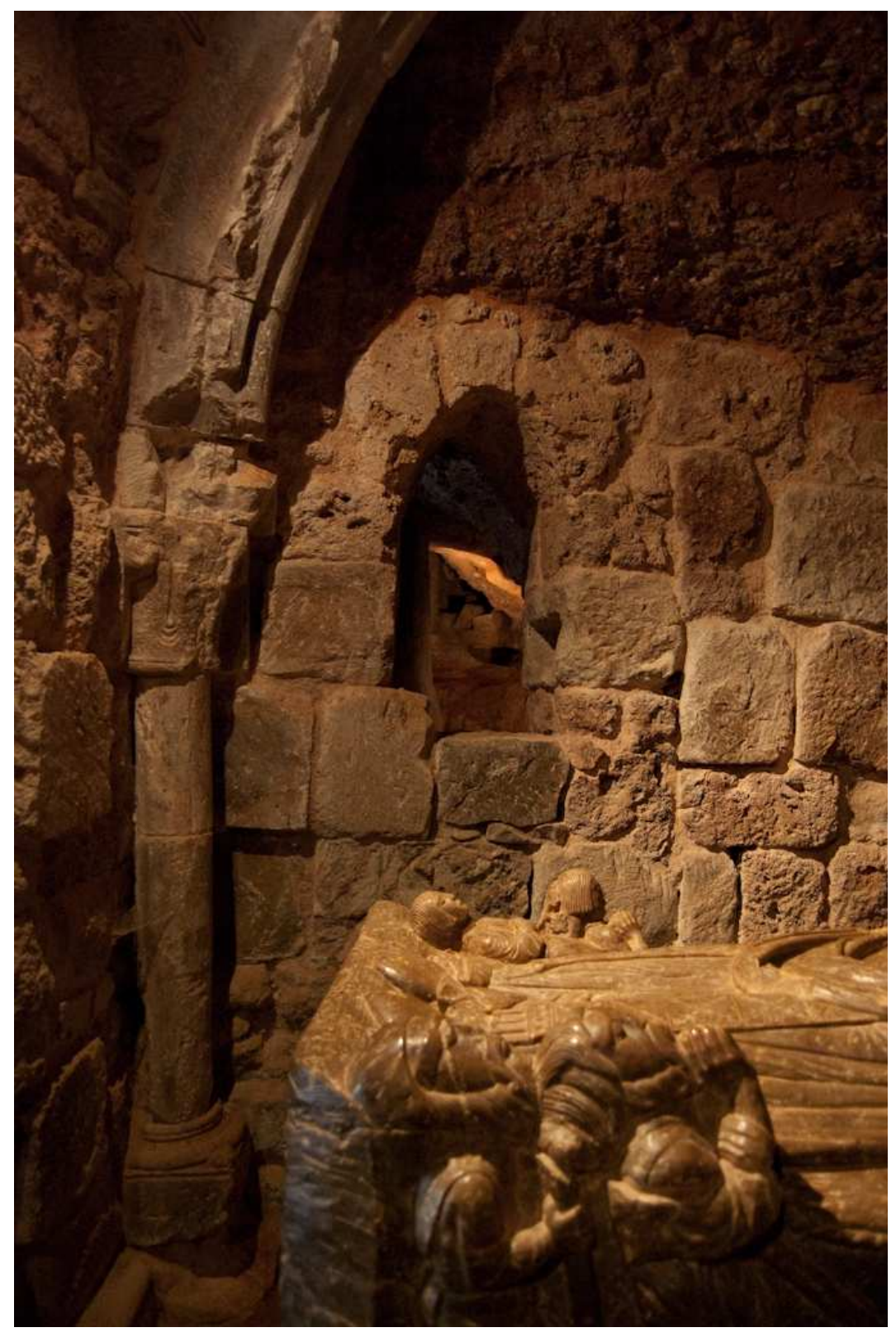

Figure 21: San Millán de la Cogolla, Suso. The foot of the cenotaph of San Millán beneath the communicating window to the westernmost caves. Photo: author. 


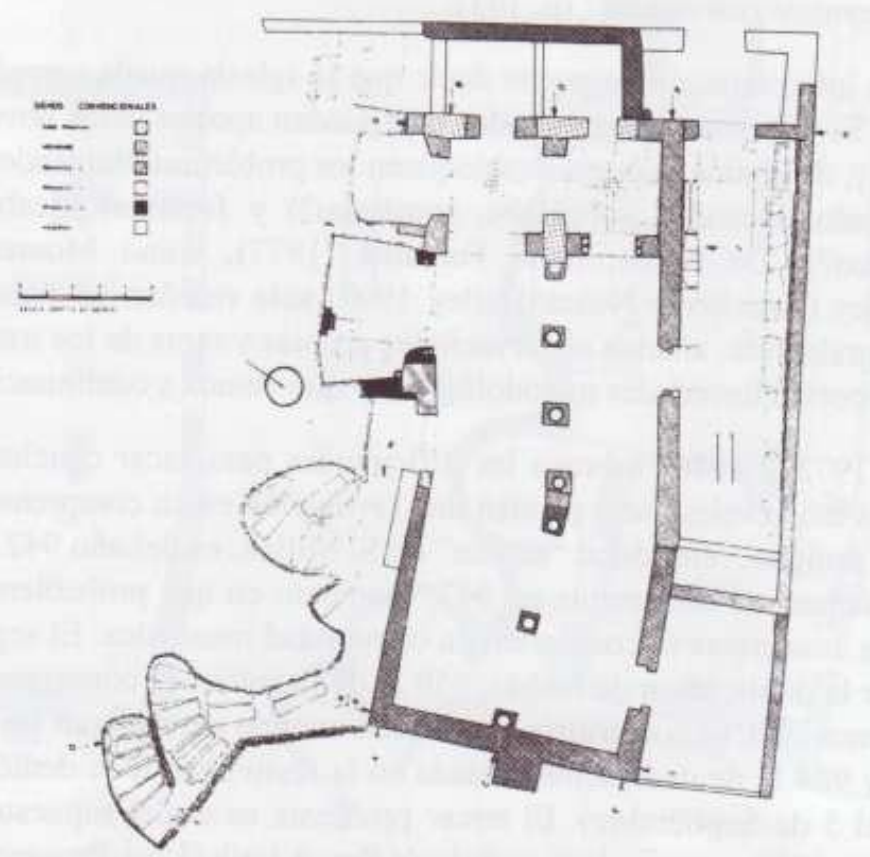

Fig. 2. Plantas de S. Millán de la Cogolla seguin Iñiguez 1971 y Puertas 1979 (escala 1/400).

a

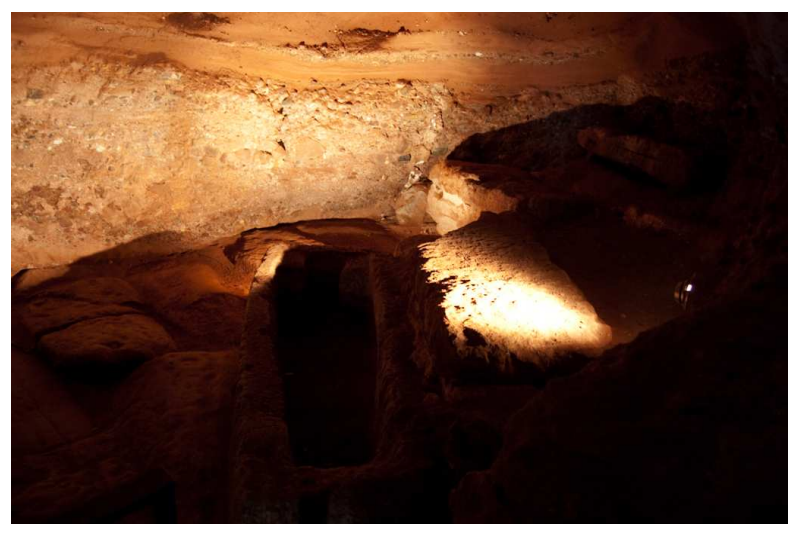

b

Figure 22a: Floor plans of San Millán de la Cogolla, Suso, after Íñiguez in 1971 and Puertas in 1979, reproduced in figure 2 of Caballero Zoredo's "La iglesia de San Millán," 2004.

Figure 22b: Rock-cut graves in the western caves. Photo: author. 


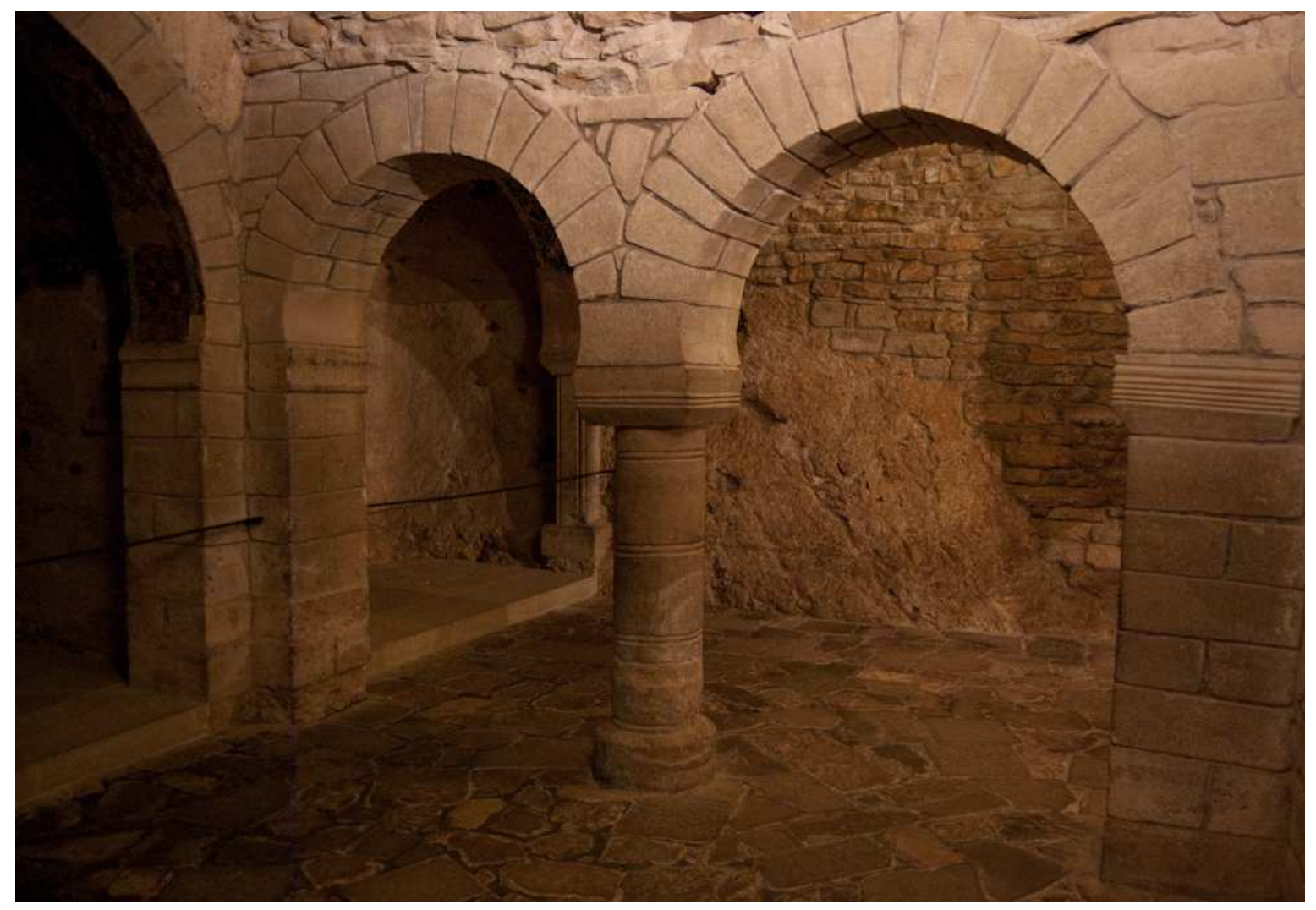

Figure 23: San Juan de la Peña, tenth-century lower church with living rock intruding from the south nave and apse walls. Photo: author. 

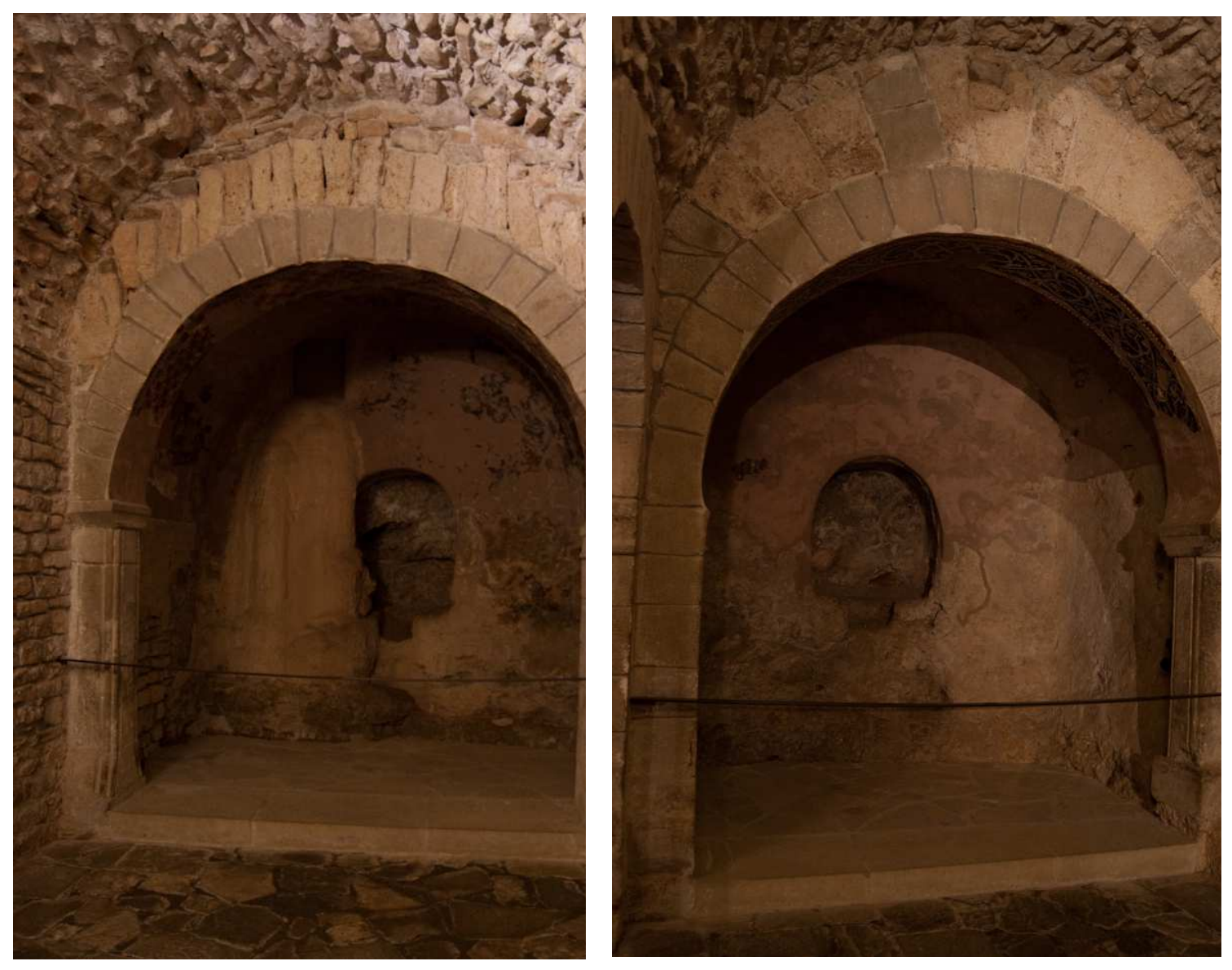

Figure 24: San Juan de la Peña, lower church, looking toward the twin apses and their niches, with rock formations around the apses. Photo: author. 


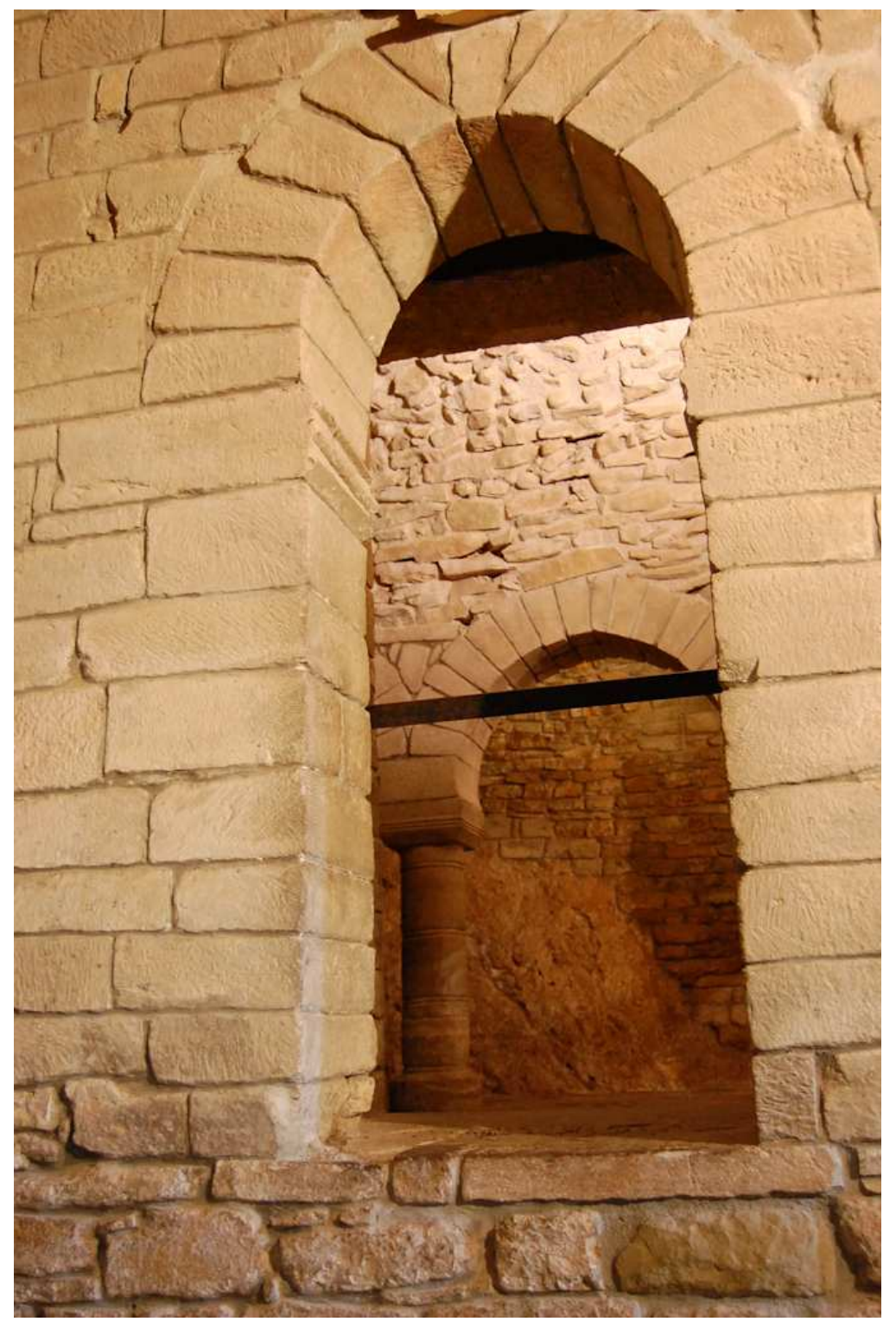

Figure 25: San Juan de la Peña, southeast portal to the lower church. Photo: author. 


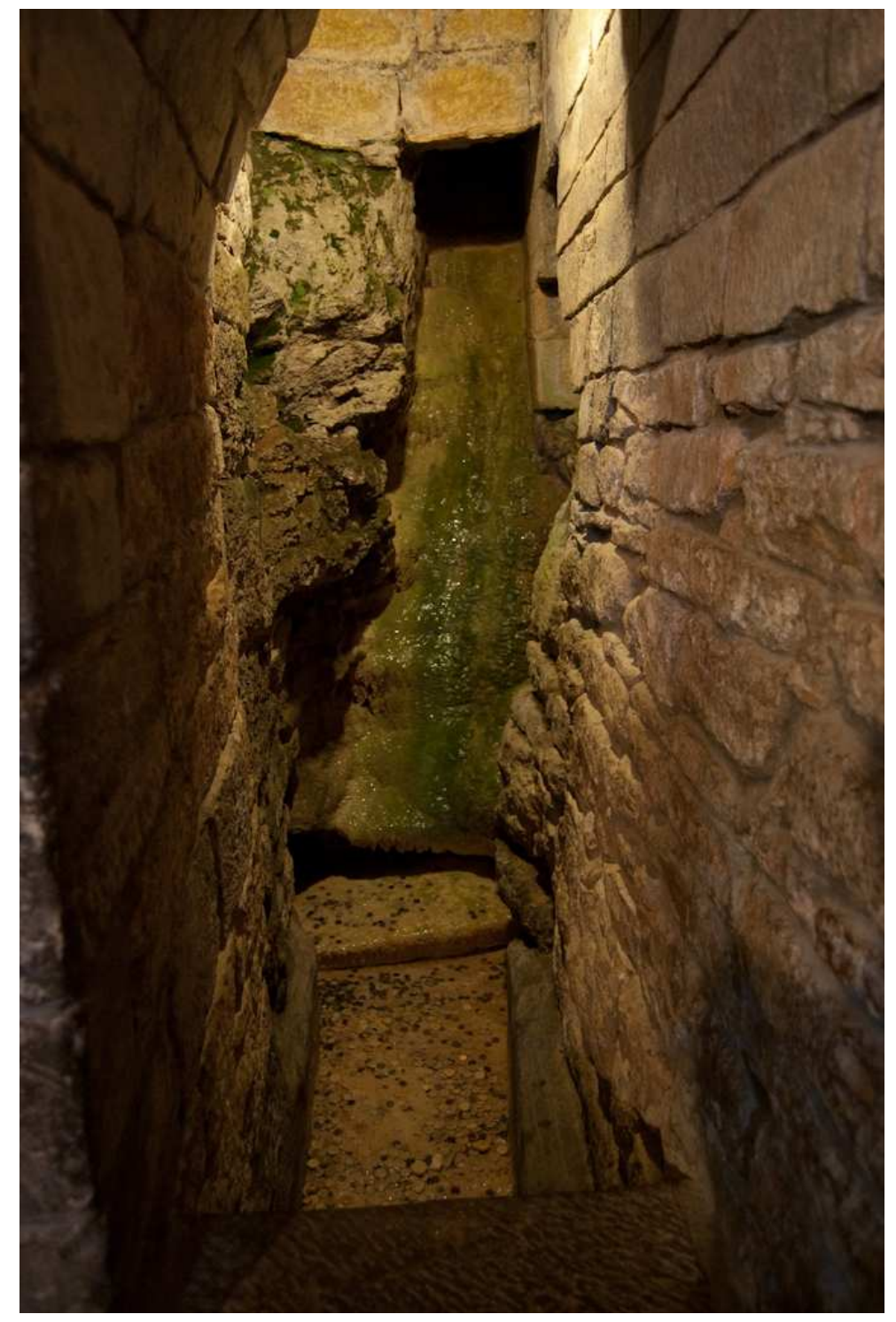

Figure 26: San Juan de la Peña, subterranean spring immediately to the east of the lower church. Photo: author. 


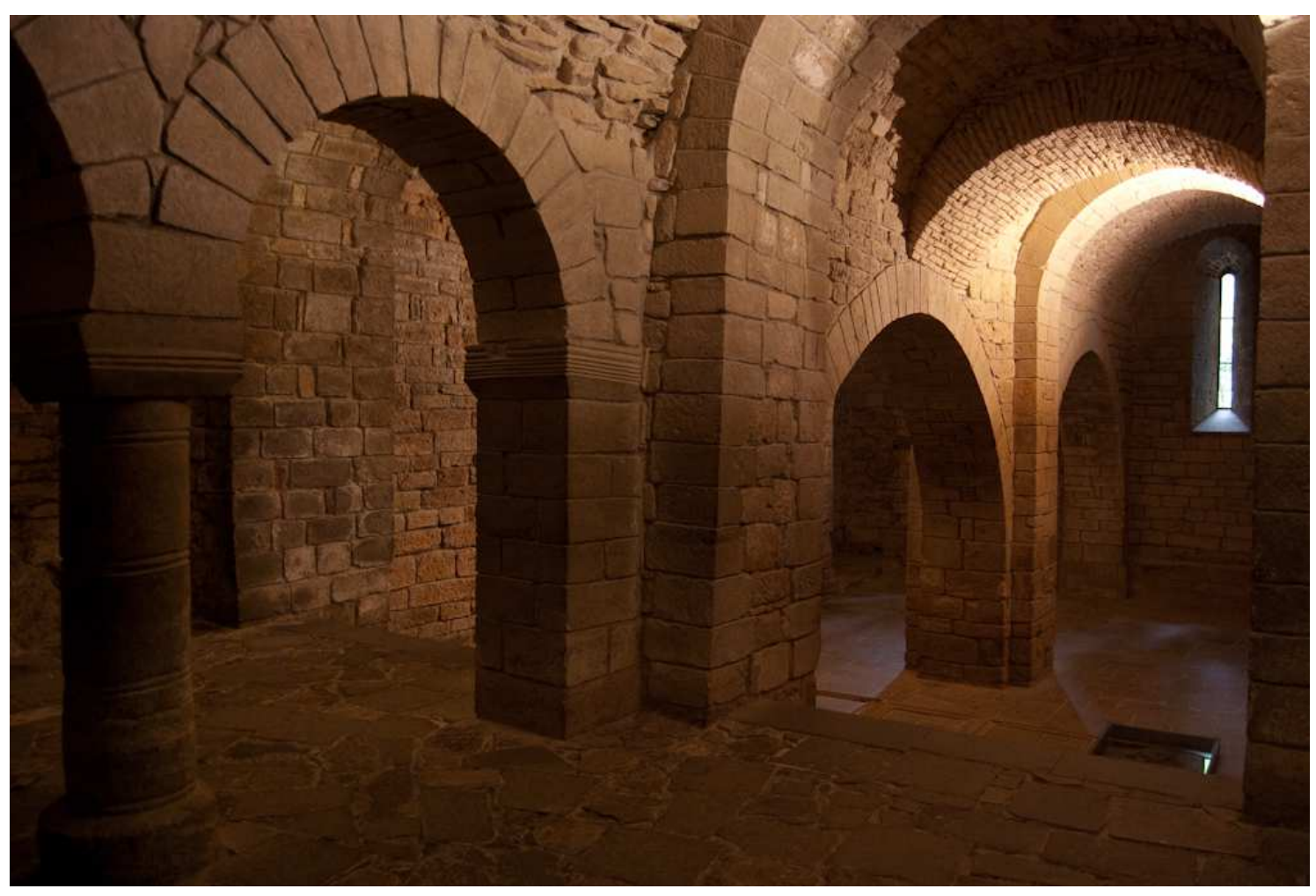

Figure 27: San Juan de la Peña, early eleventh-century extension to the northwest by Sancho el Mayor. Photo: author. 


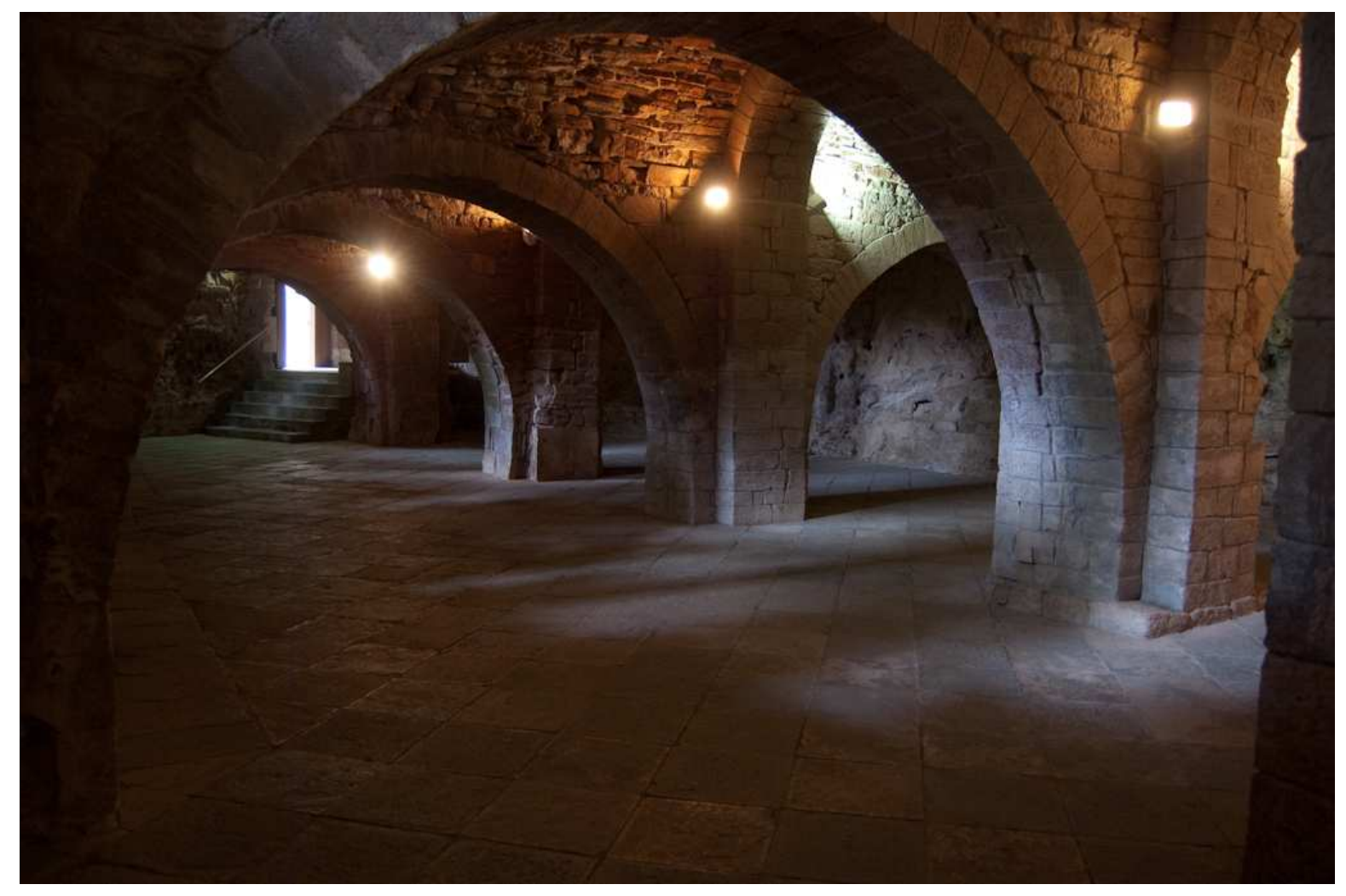

Figure 28: San Juan de la Peña, Sala de Concilio. Photo: author. 


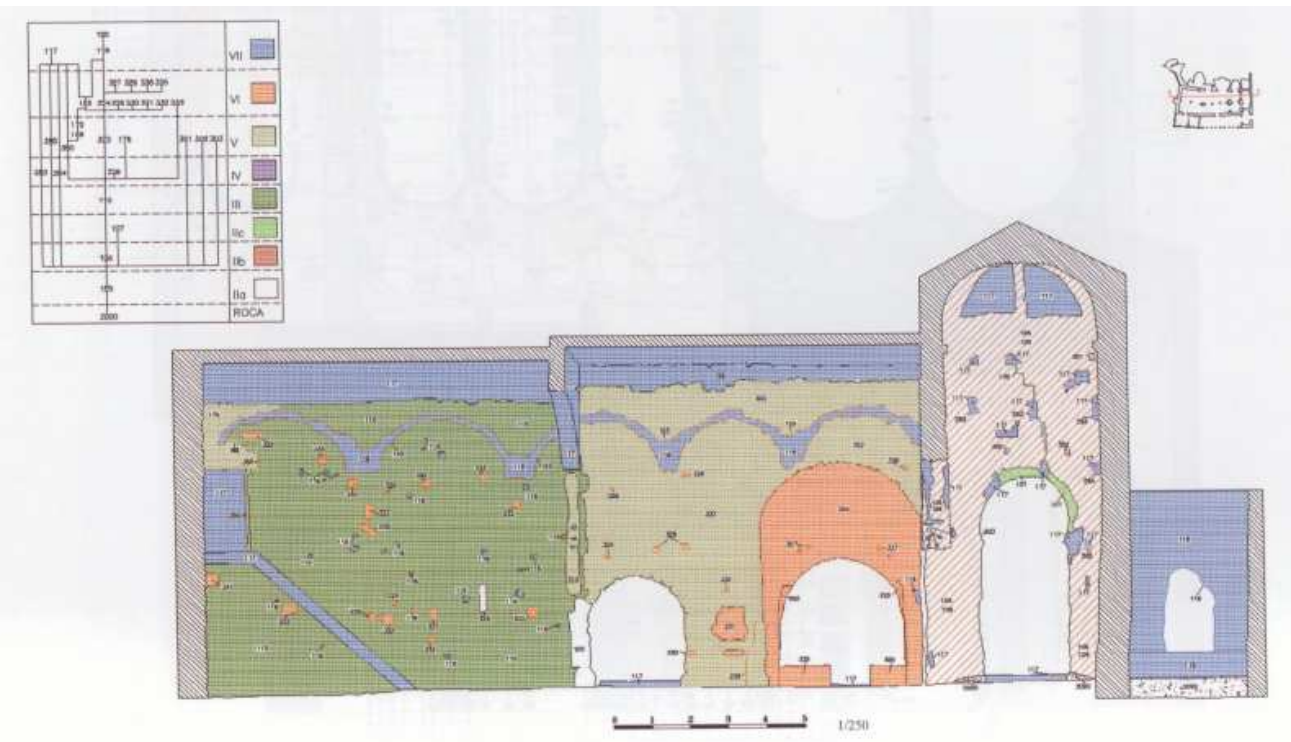

Plano 5. Sección longitudinal por las nave y cabecera norte, hacia Norte. Muro norte.

Figure 29: San Millán de la Cogolla, Suso, looking toward the north. Longitudinal elevation after L. Caballero Zoreda, "La iglesia de San Millán," 2004, plan 5. 


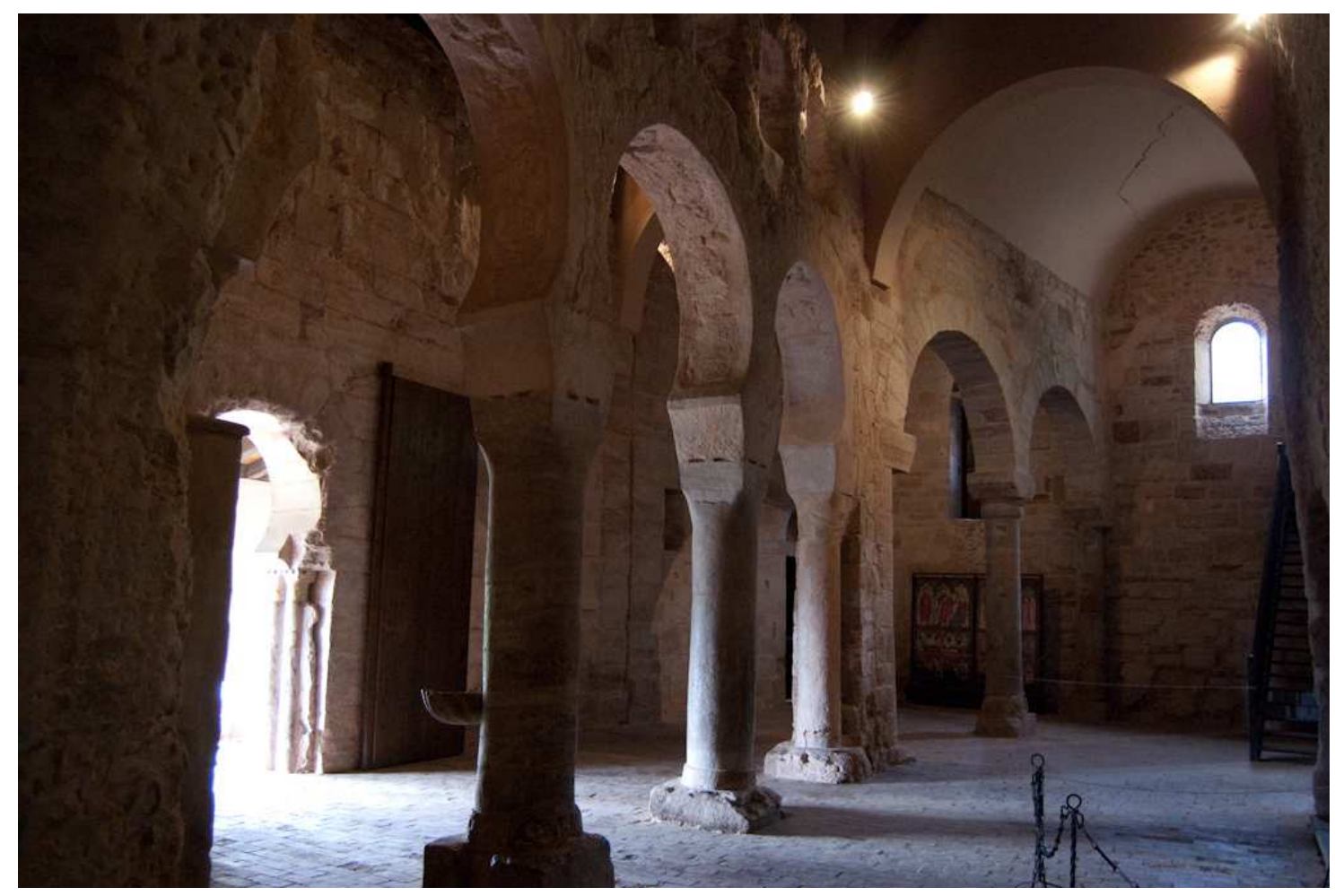

Figure 30: San Millán de la Cogolla, Suso, looking toward the early eleventhcentury western extension of Sancho El Mayor. Photo: author. 


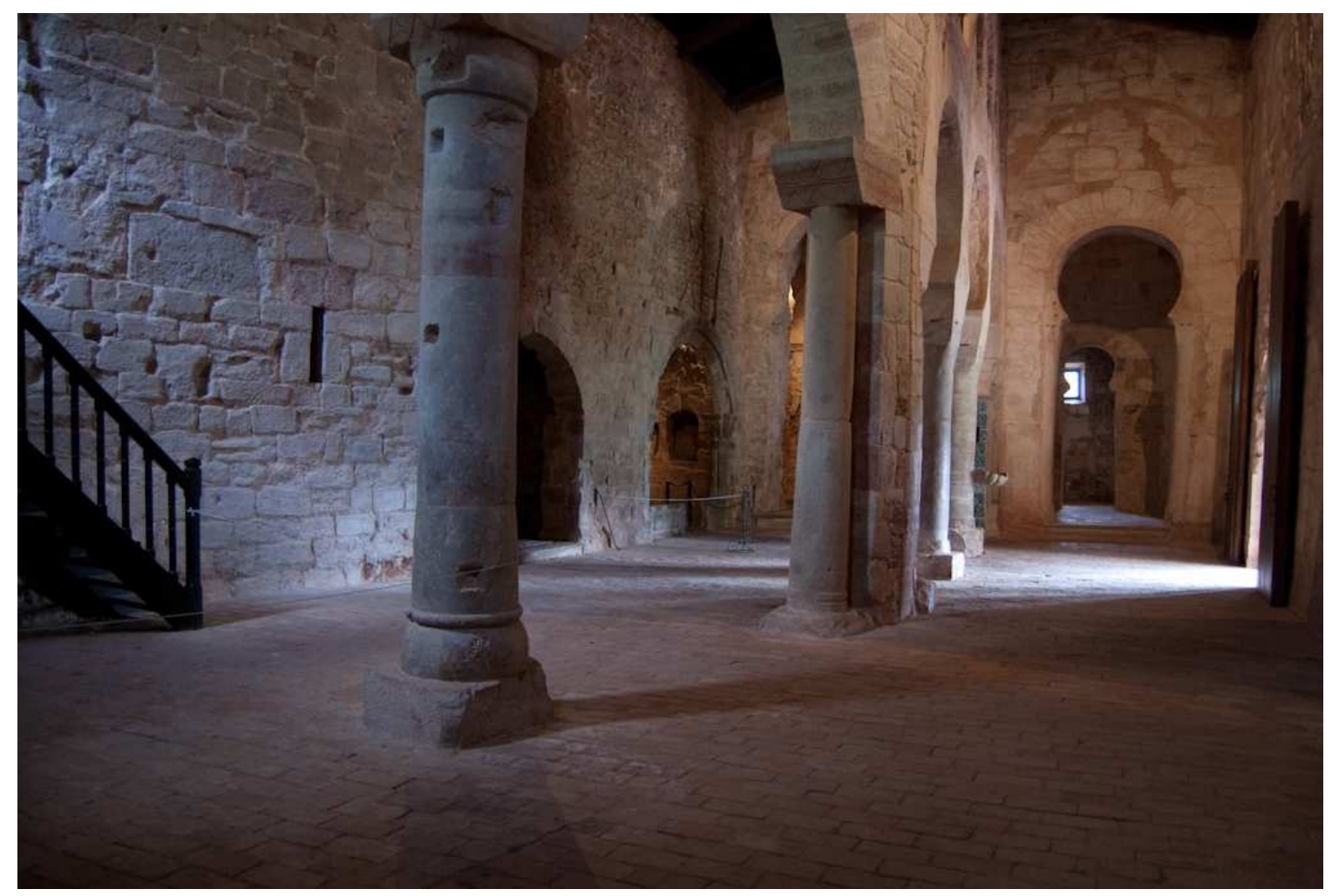

Figure 31: San Millán de la Cogolla, Suso, looking toward north and north-western cave entrances and church wall with small window. Photo: author. 


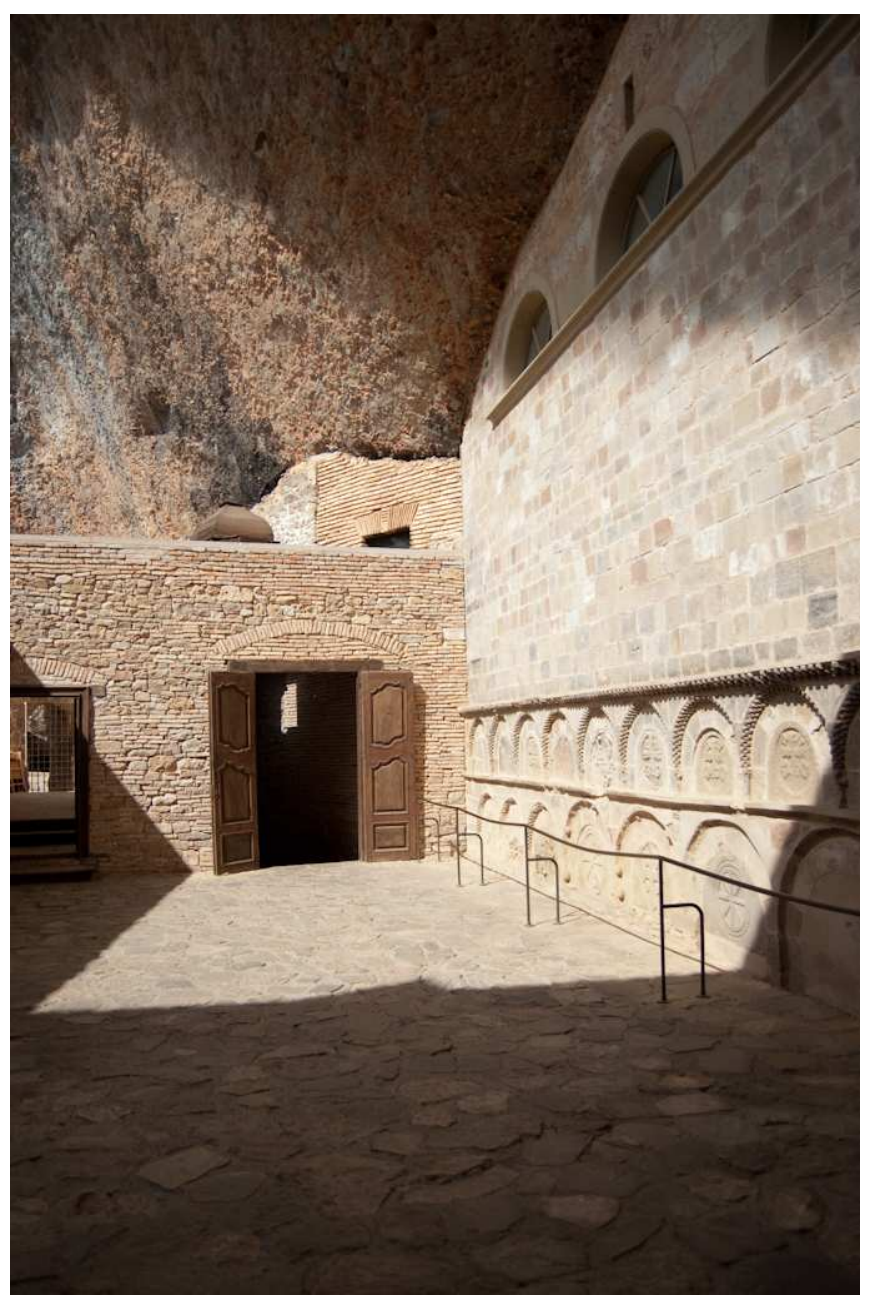

Figure 32: San Juan de la Peña, Panteón de los Reyes. Photo: author. 


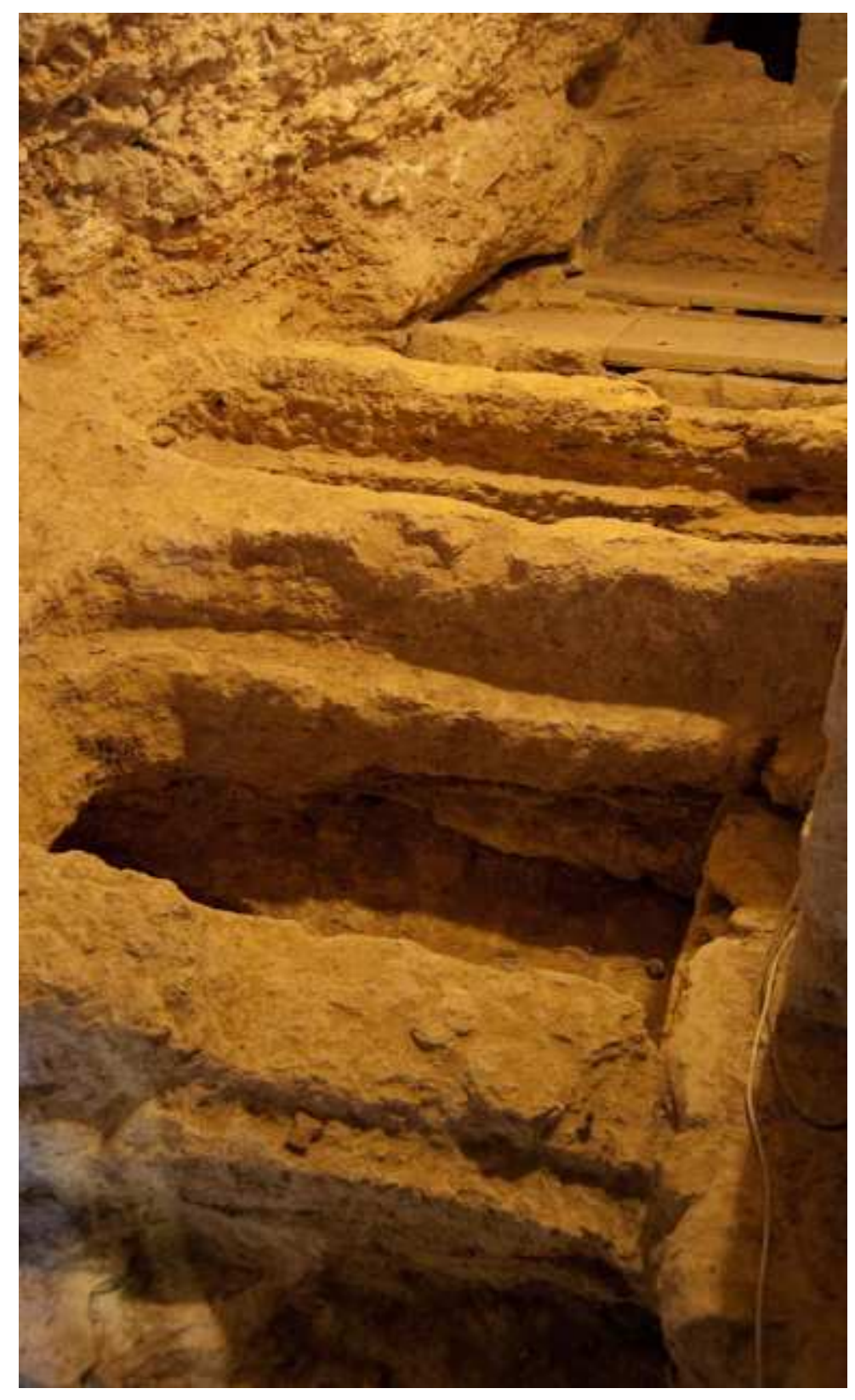

Figure 33: San Juan de la Peña, the related rock-cut tombs of the Panteón de los Reyes. Photo: author. 


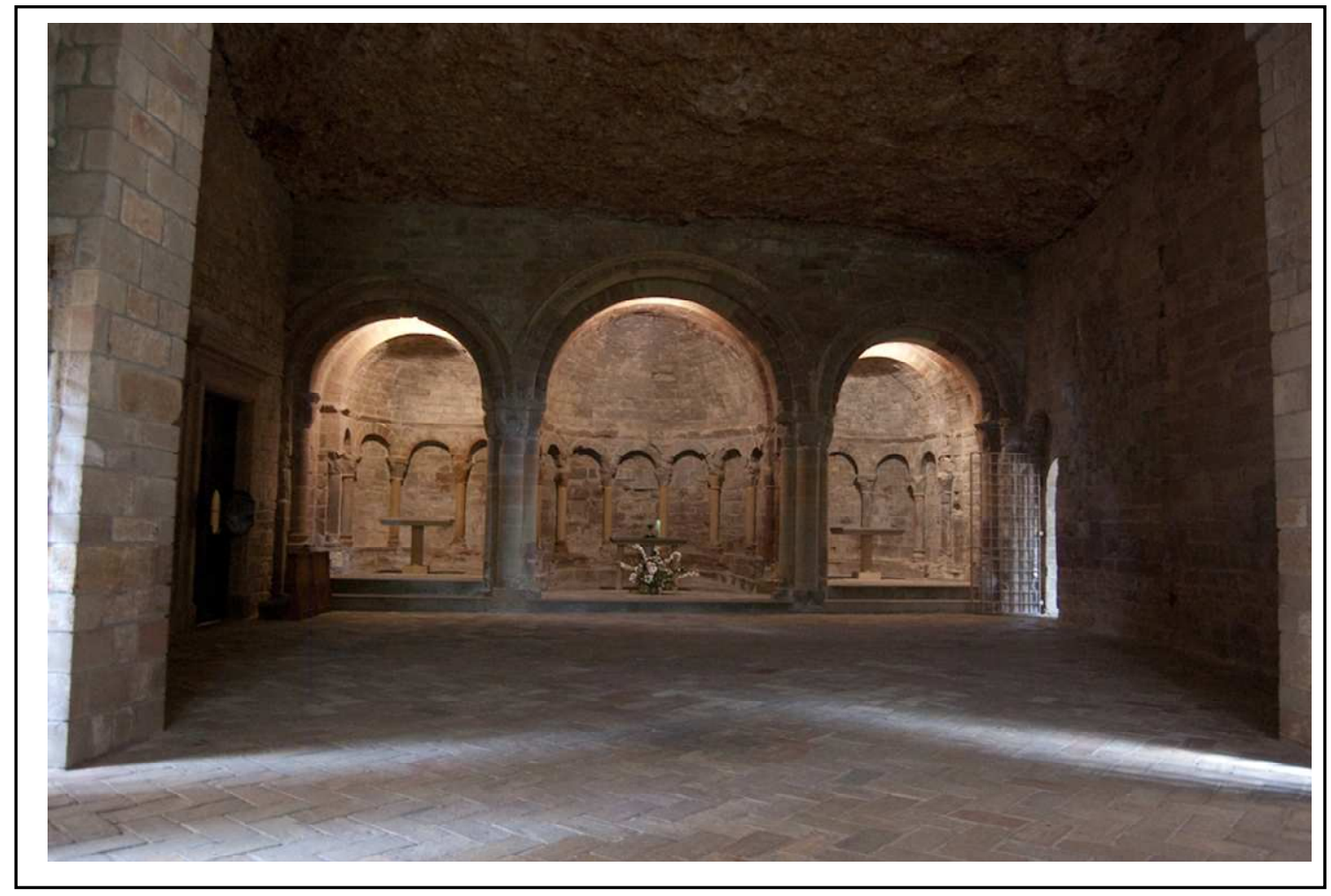

Figure 34: San Juan de la Peña, upper church, looking toward the three southeast apses, carved out of the cliff rock. Photo: author. 


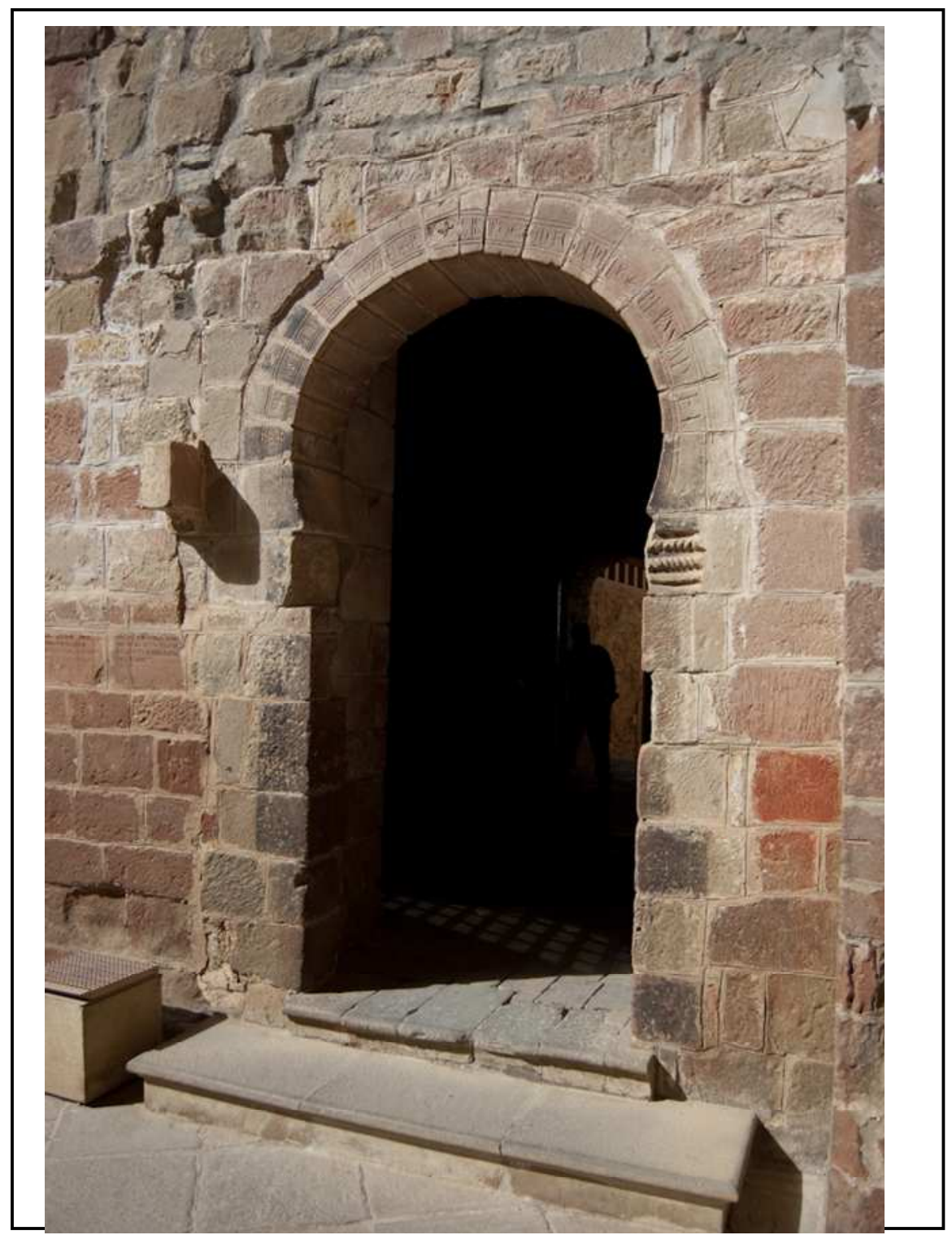

Figure 35: San Juan de la Peña, upper church. Horseshoe arched portal in the southwest wall of the upper church. Photo: author. 


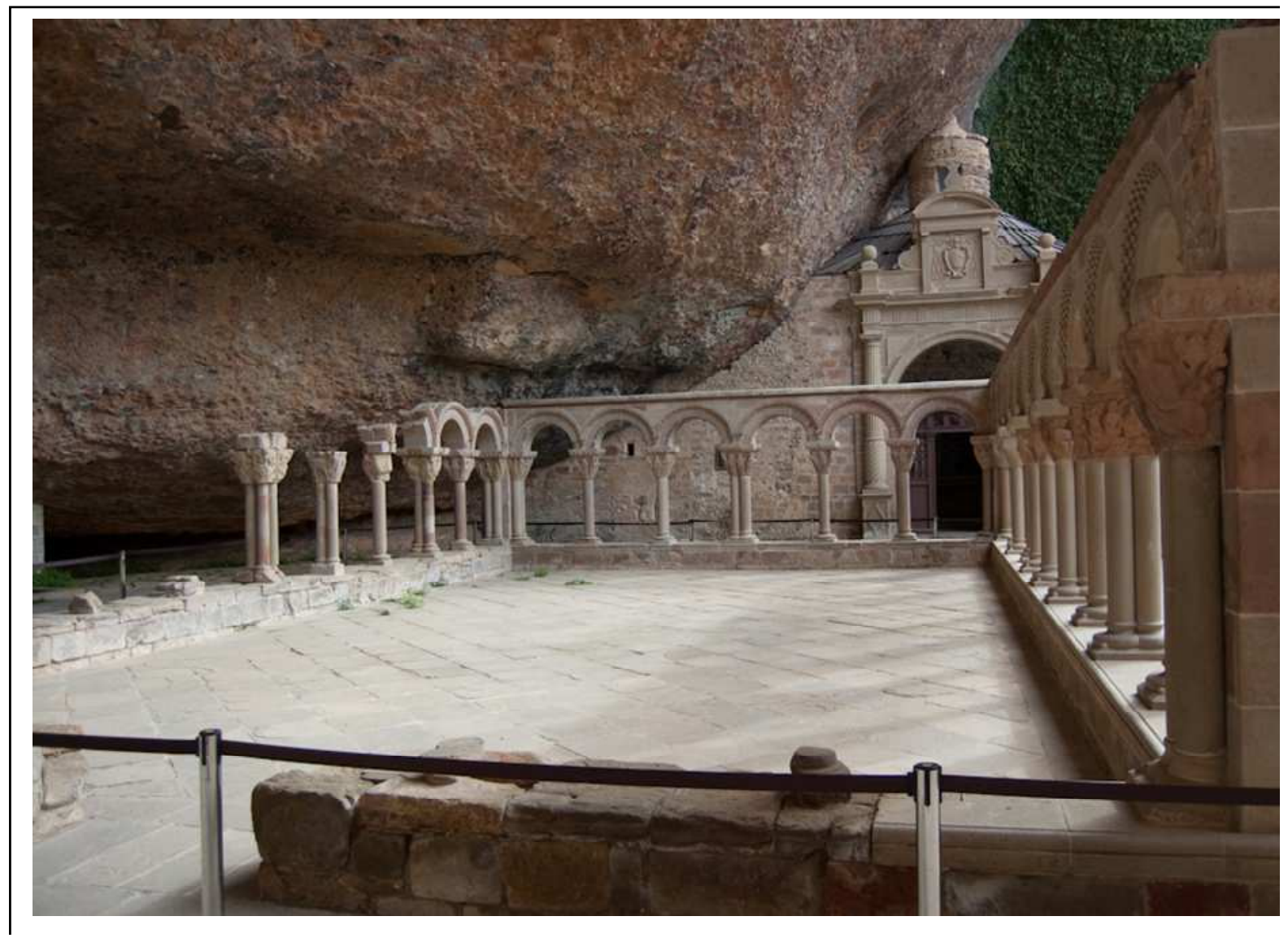

Figure 35b: San Juan de la Peña, twelfth to thirteenth-century cloister beneath cliff overhang. Photo: author. 


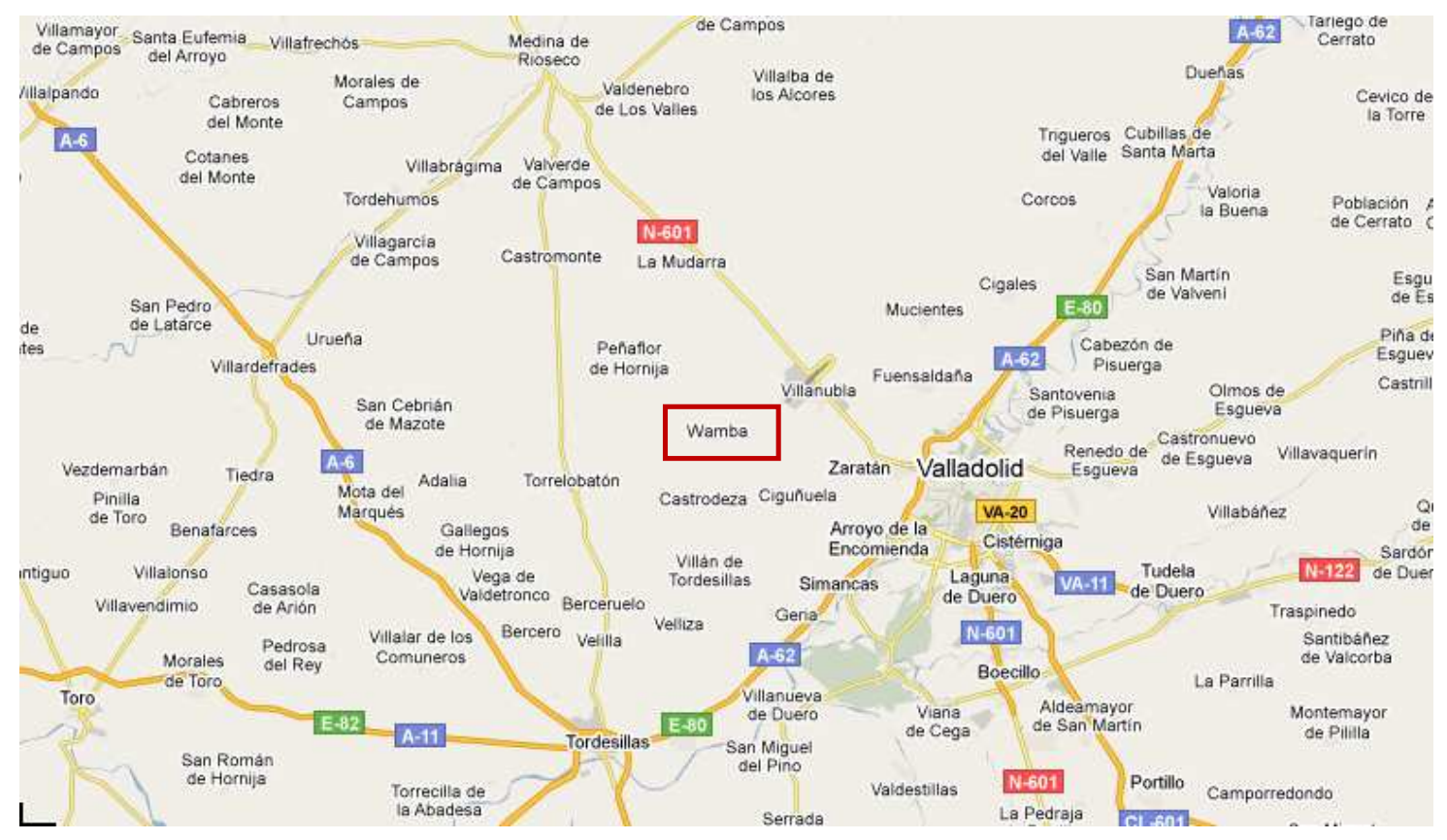

Figure 36: The location of the town of Wamba and nearby medieval strongholds. Screen shot from Google Maps. 


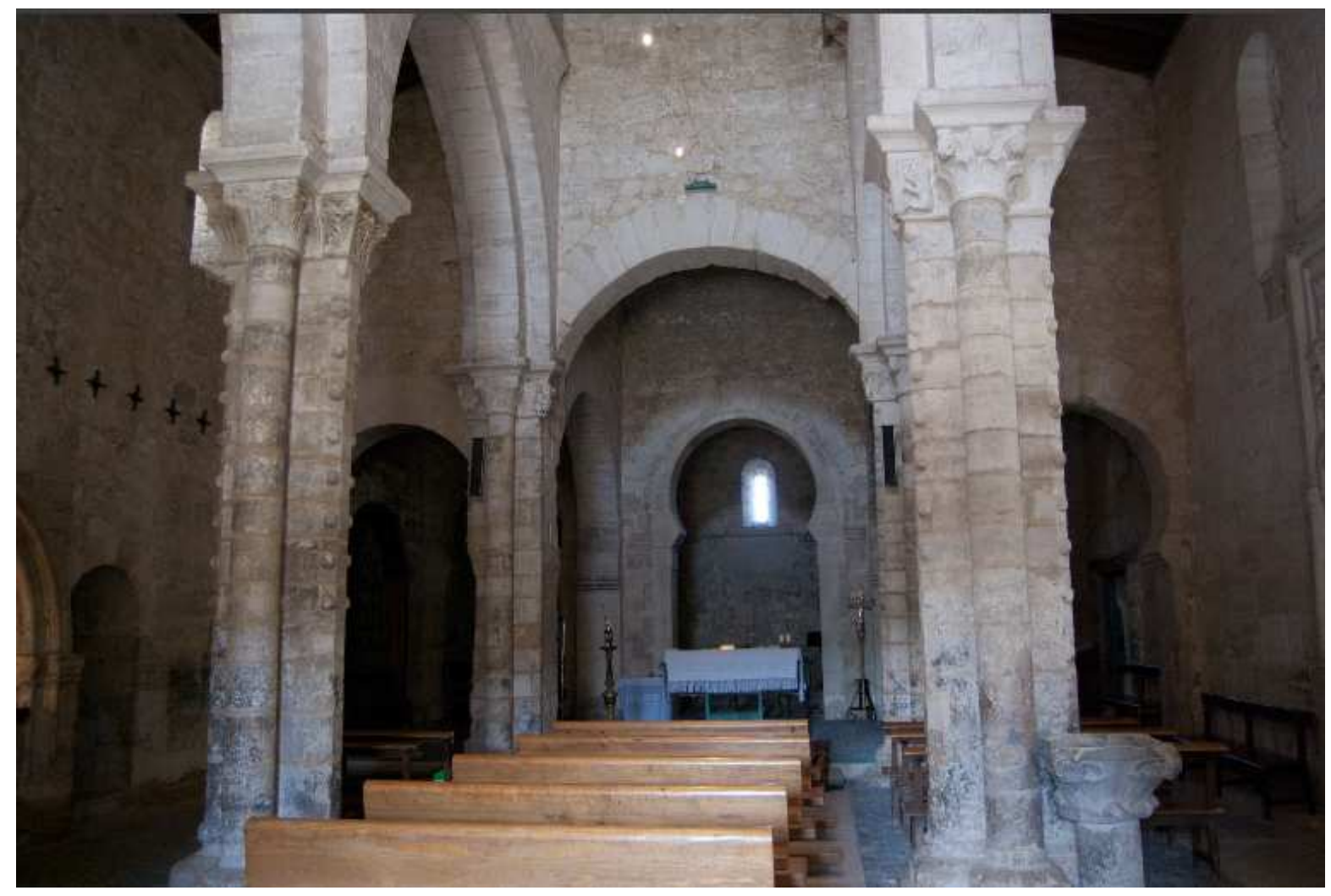

Figure 37: Santa María de Wamba, view from the nave looking toward the eastern apses. Photo: author. 


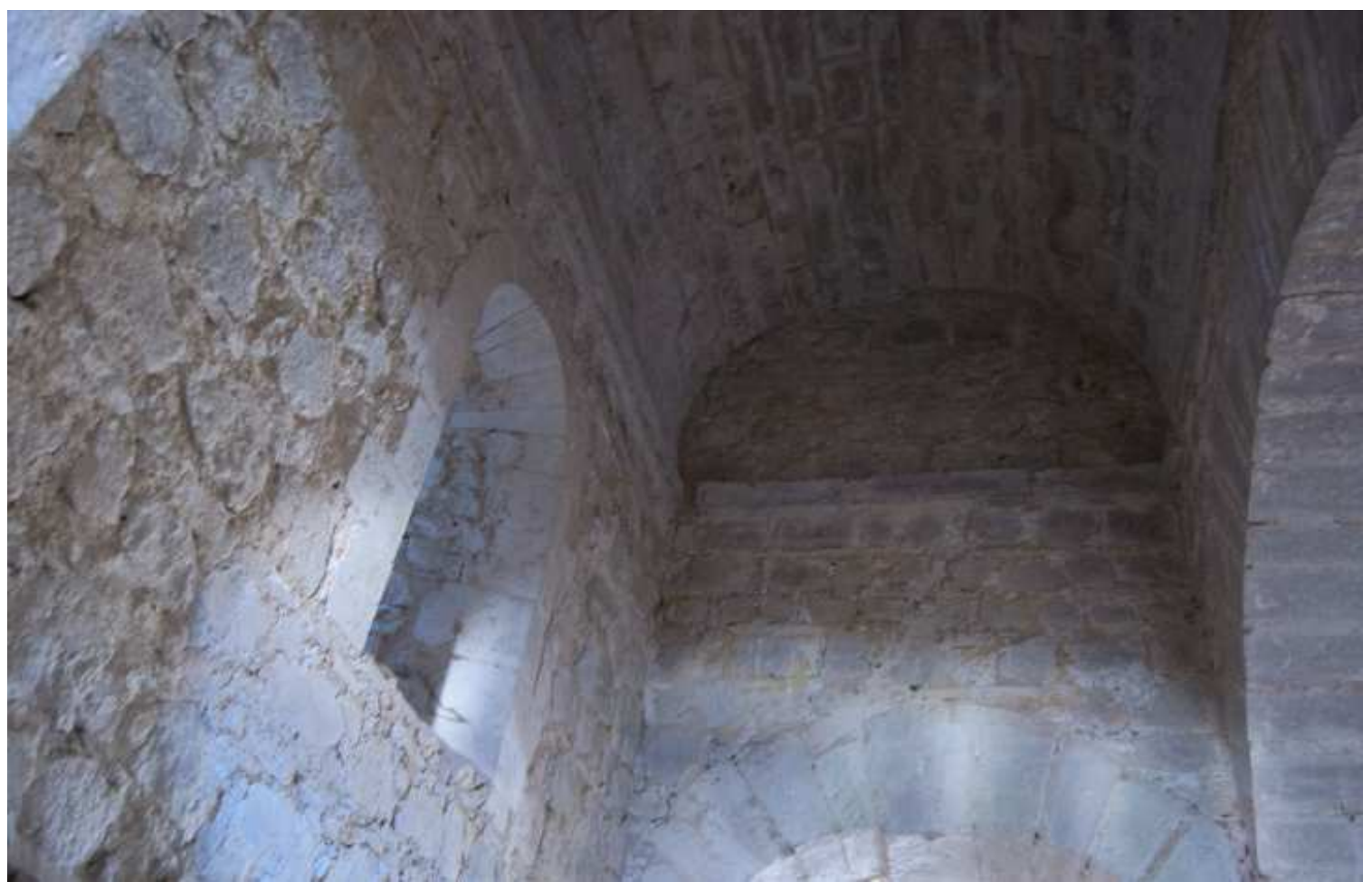

Figure 38: Santa María de Wamba, view of the stone wall and transition to the ashlar vault. Photo: author. 


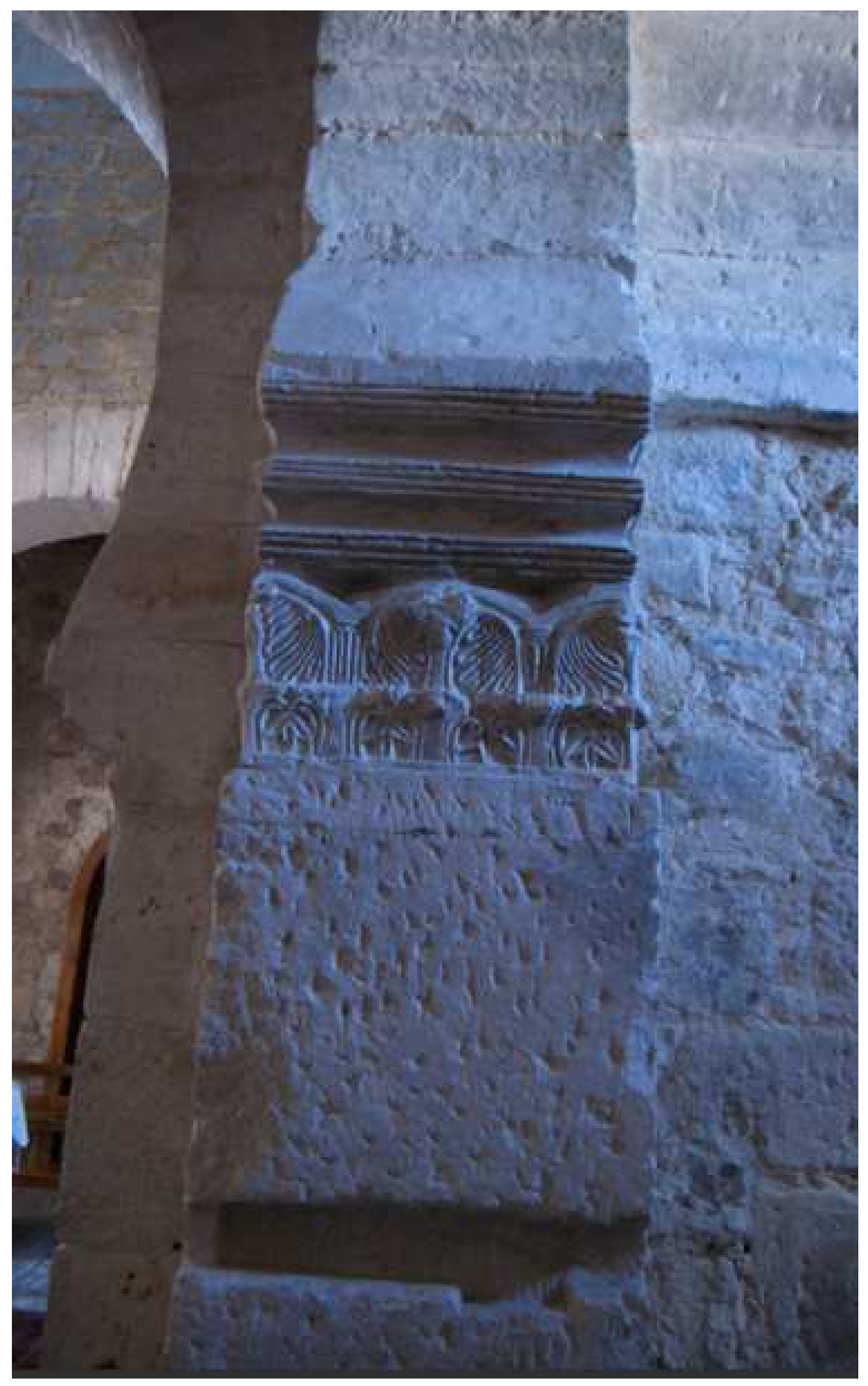

Figure 39: Santa María de Wamba, an example of a tenth-century, carved capital flanking the entrance into the southern apse of the East end. Photo: author. 

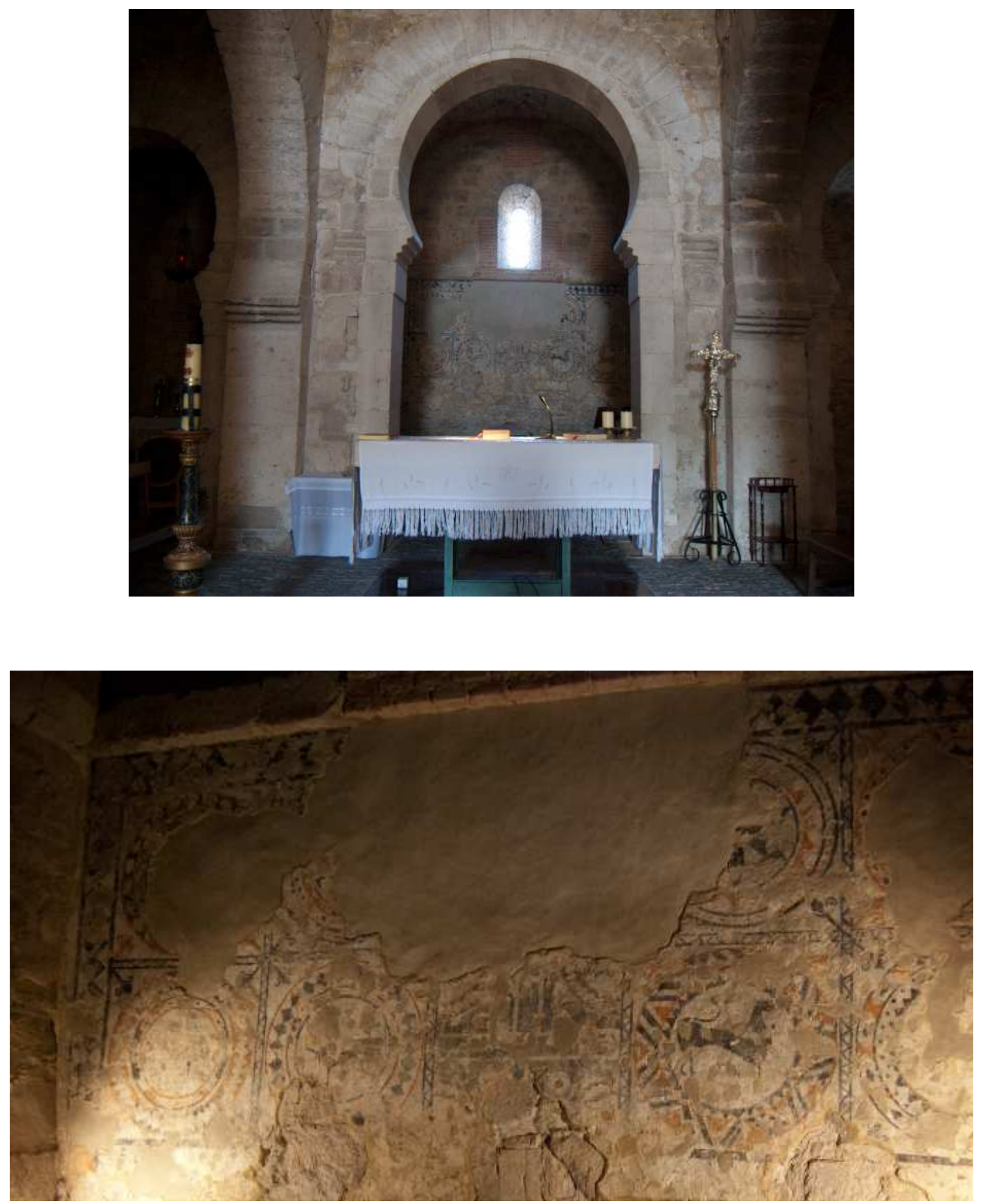

Figure 40: Santa María de Wamba, fresco in the central apse of the east end, with detail. Photo: author. 


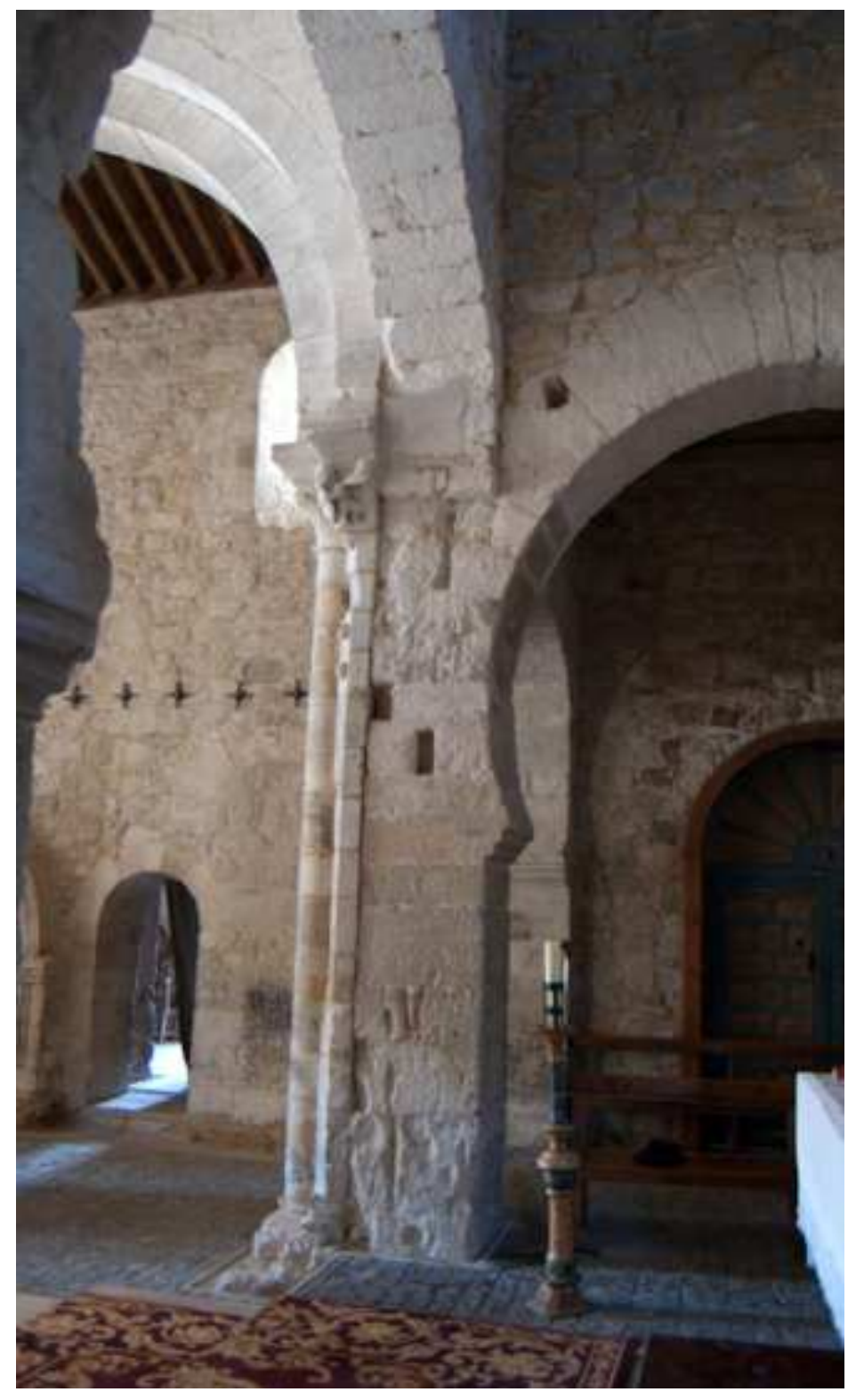

Figure 41: Santa María de Wamba, view of the transitional pier from the tenth century to the circa 1200 phase. Photo: author. 


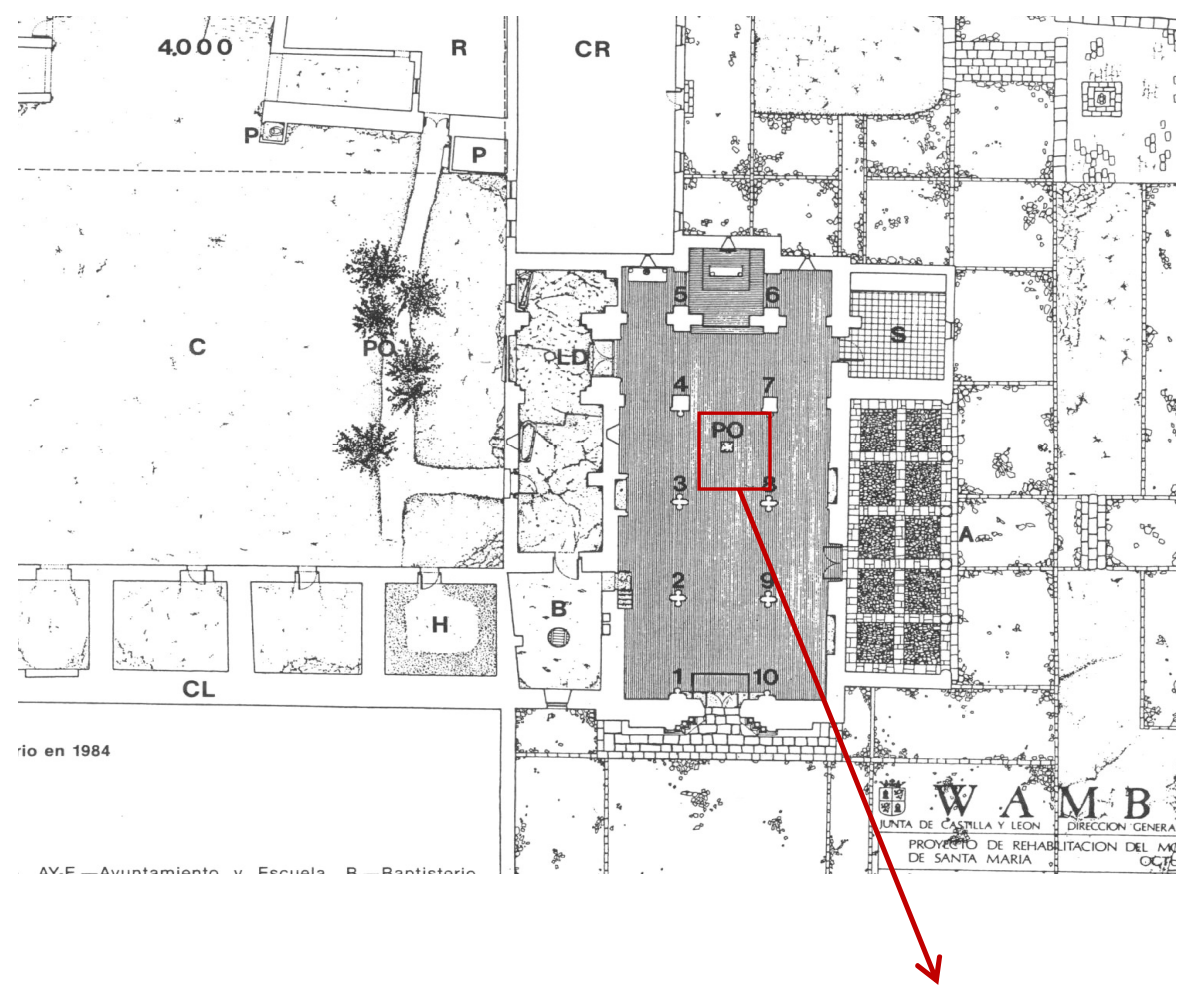

Figure 42: Ground plan of the monastery of Santa María de Wamba. After J. L. de la Quintana Gordon and J. R. Boned Colera, "Santa María de Wamba, entre su pasado y el future (Valladolid)," Informes de la construcción 43, no. 418 (1992): 35-52, figure 1.

The photo to the right is a view of the well in front of the choir, looking toward the north wall of the church.

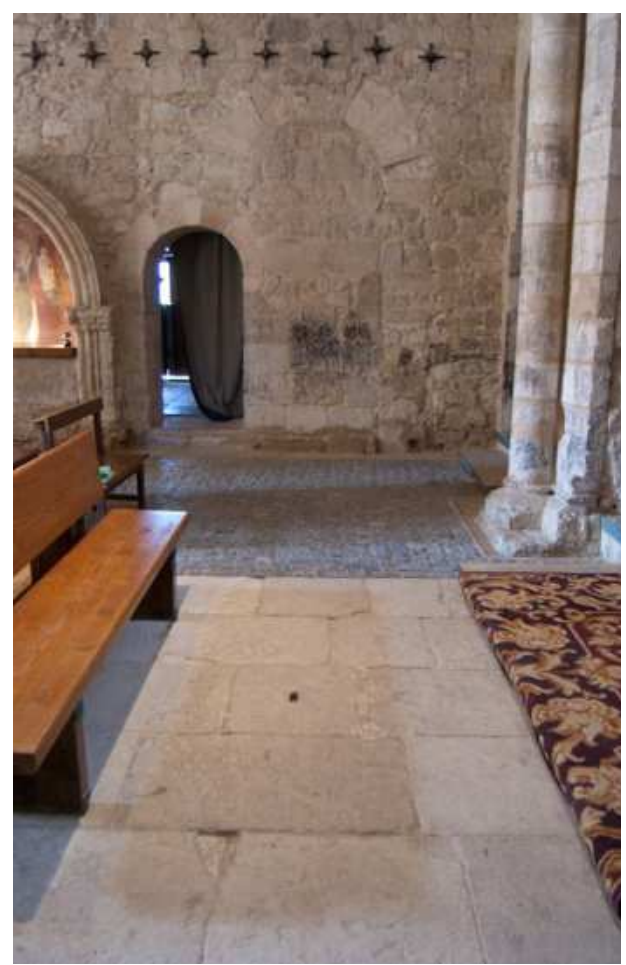




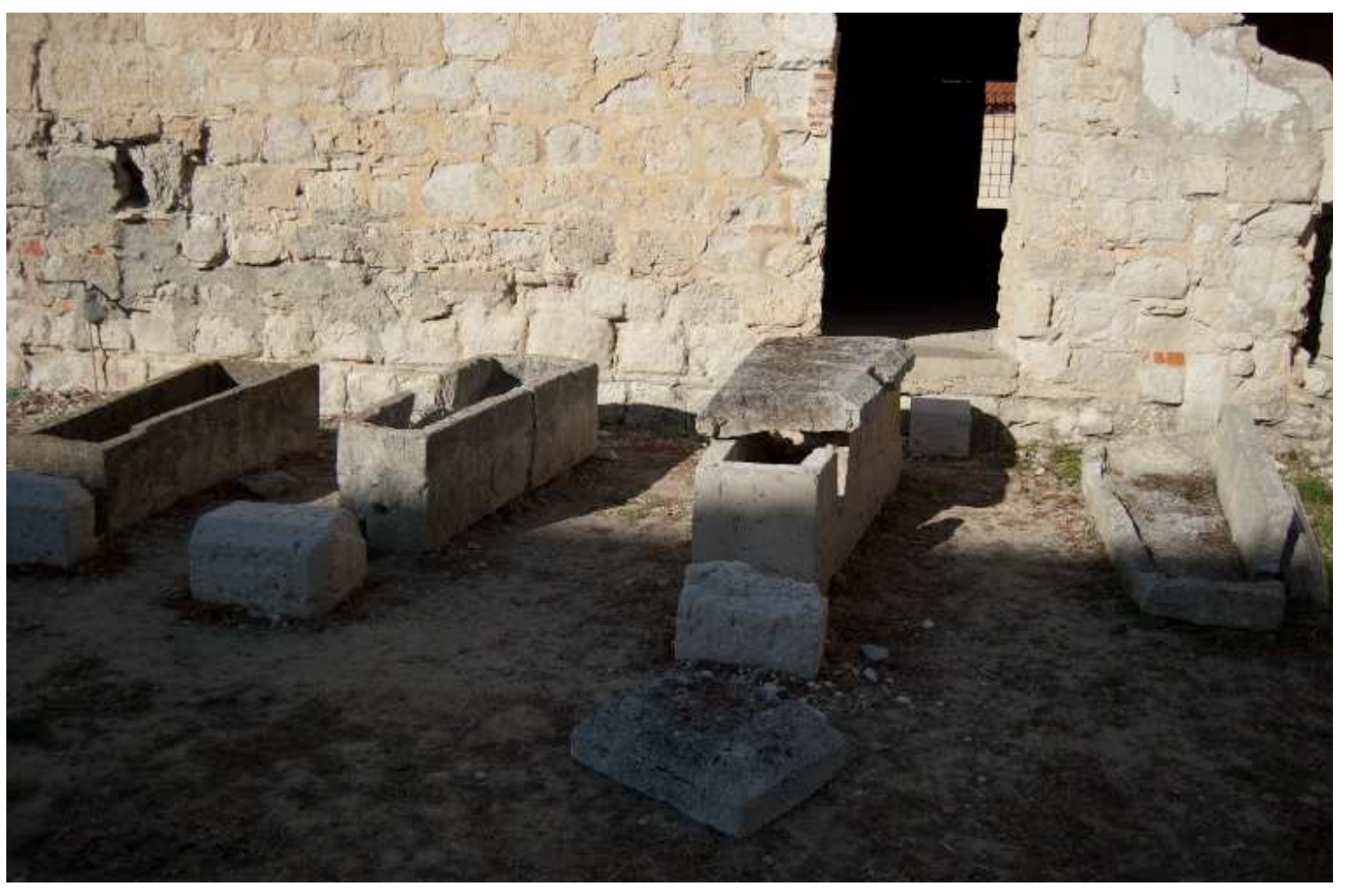

Figure 43: Santa María de Wamba. Tombs traditionally associated with the grave of King Recceswinth and other nobles in the cloister. 


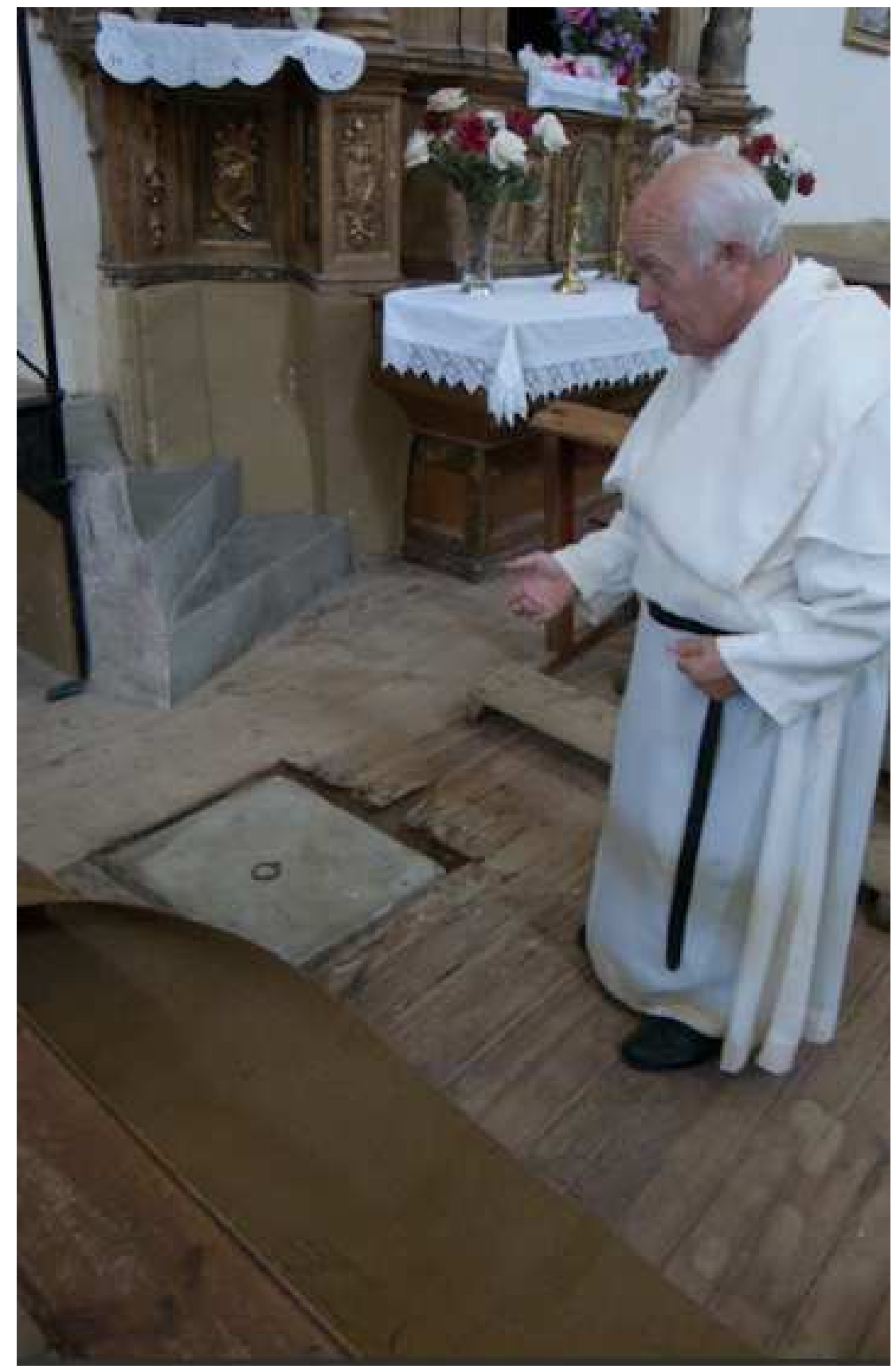

Figure 44: San Román de Hornija. View of the well beneath the nave of the present day church. Photo: author. 

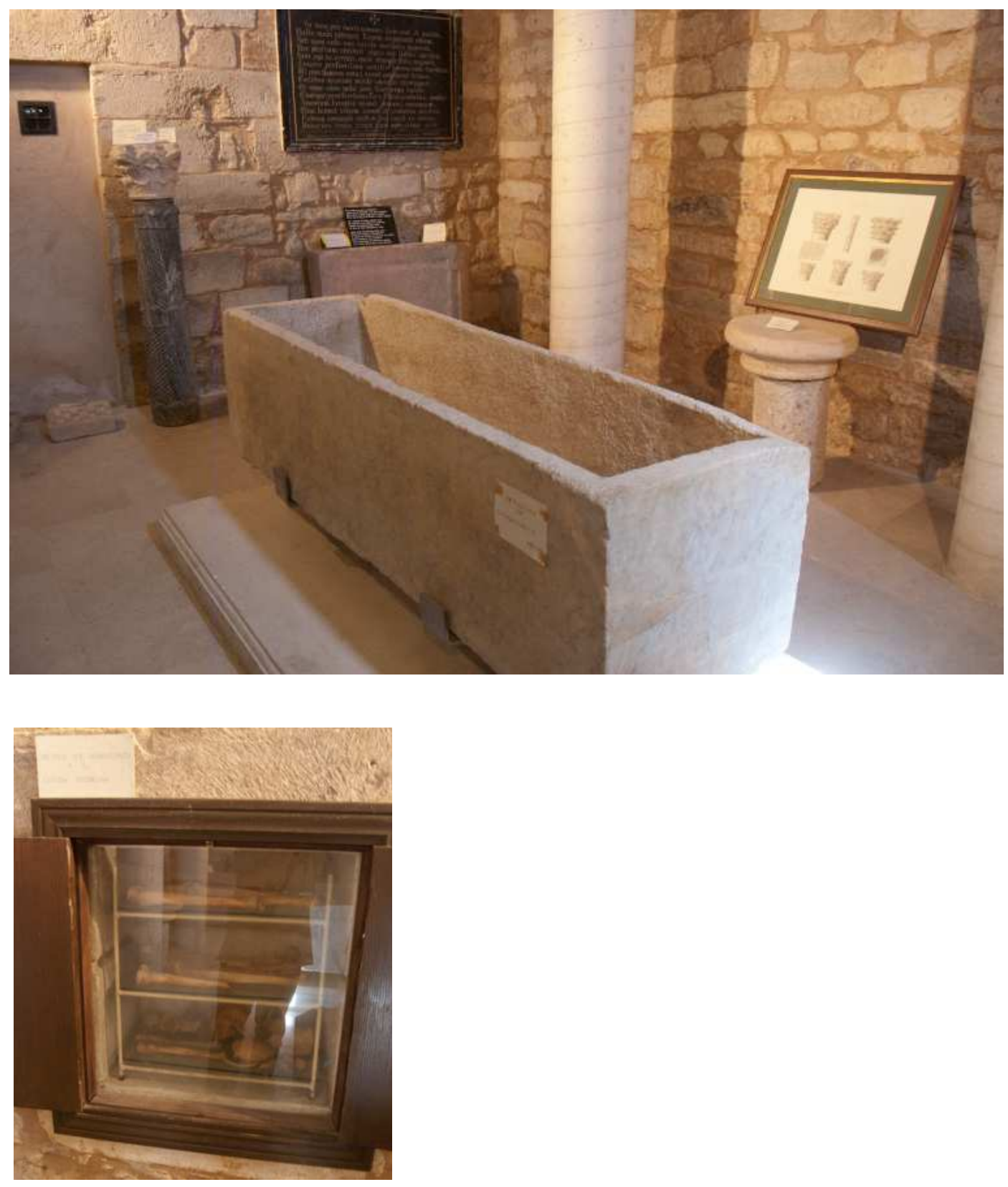

Figure 45: San Román de Hornija. View of the room to the south of the present-day nave where fragments from the Roman and Visigothic eras, and the tenth century are kept. The prominent tomb is believed to have belonged to King Chindaswinth. The remains that it purportedly once contained - that of Chindaswinth and Queen Recciberga, are today housed in a wall niche. Photo: author. 

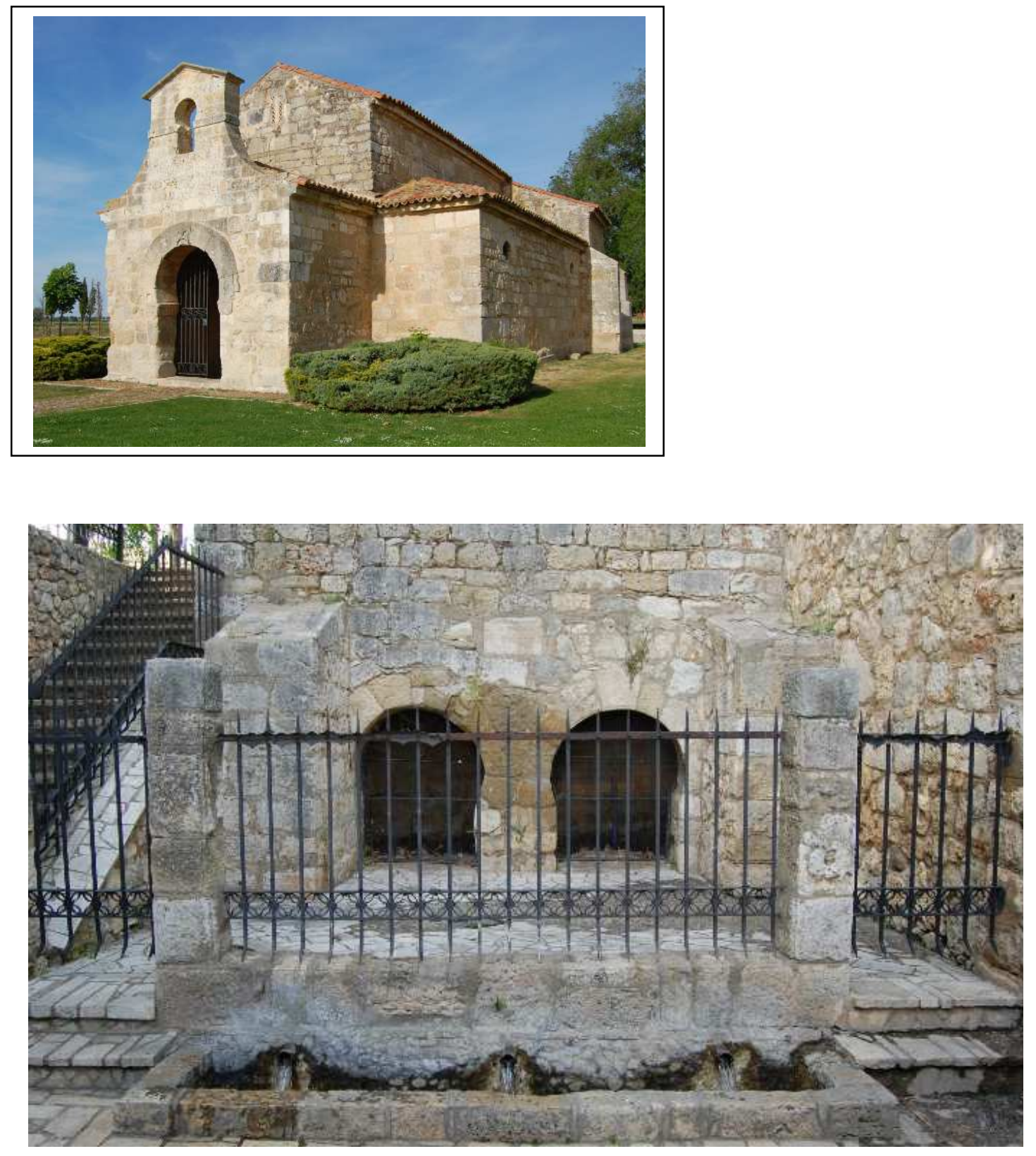

Figure 46: San Juan de Baños (Palencia), exterior view of the church. Less than a hundred meters away to the south of the church is the robust spring. Two stone horseshoe arches frame the subterranean water source. Photo: author. 


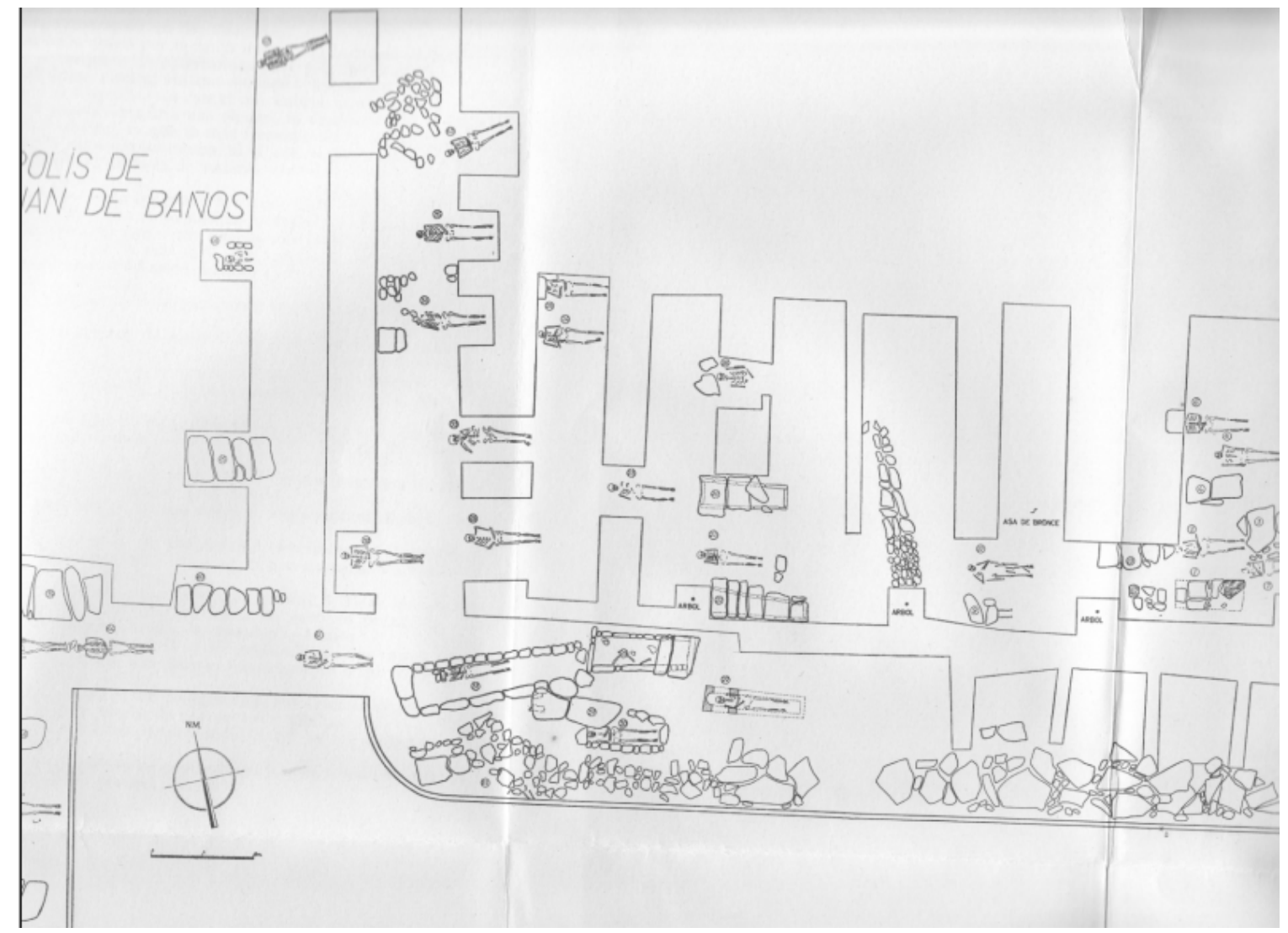

Figure 47: San Juan de Baños. After P. de Palol, Excavaciones en la necropolis de San Juan De Baños (Palencia) (Madrid, 1963), a diagram that depicts the location of a portion of the excavated remains, 1011.

To the right are photographs from the same archaeological campaign, showing graves beneath walls believed to date to the tenth century, plate $\mathrm{V}$.
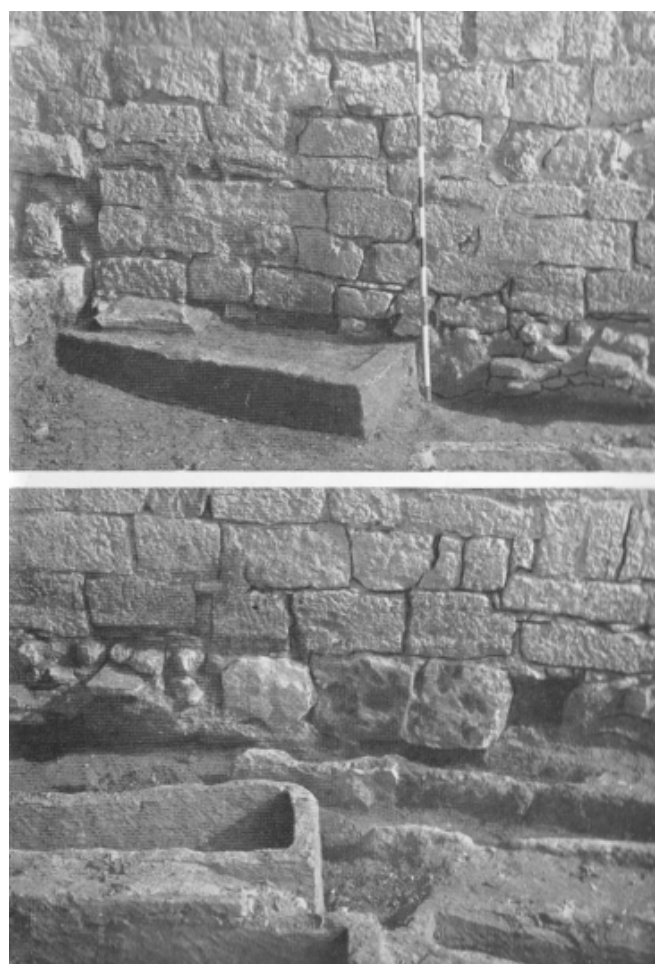


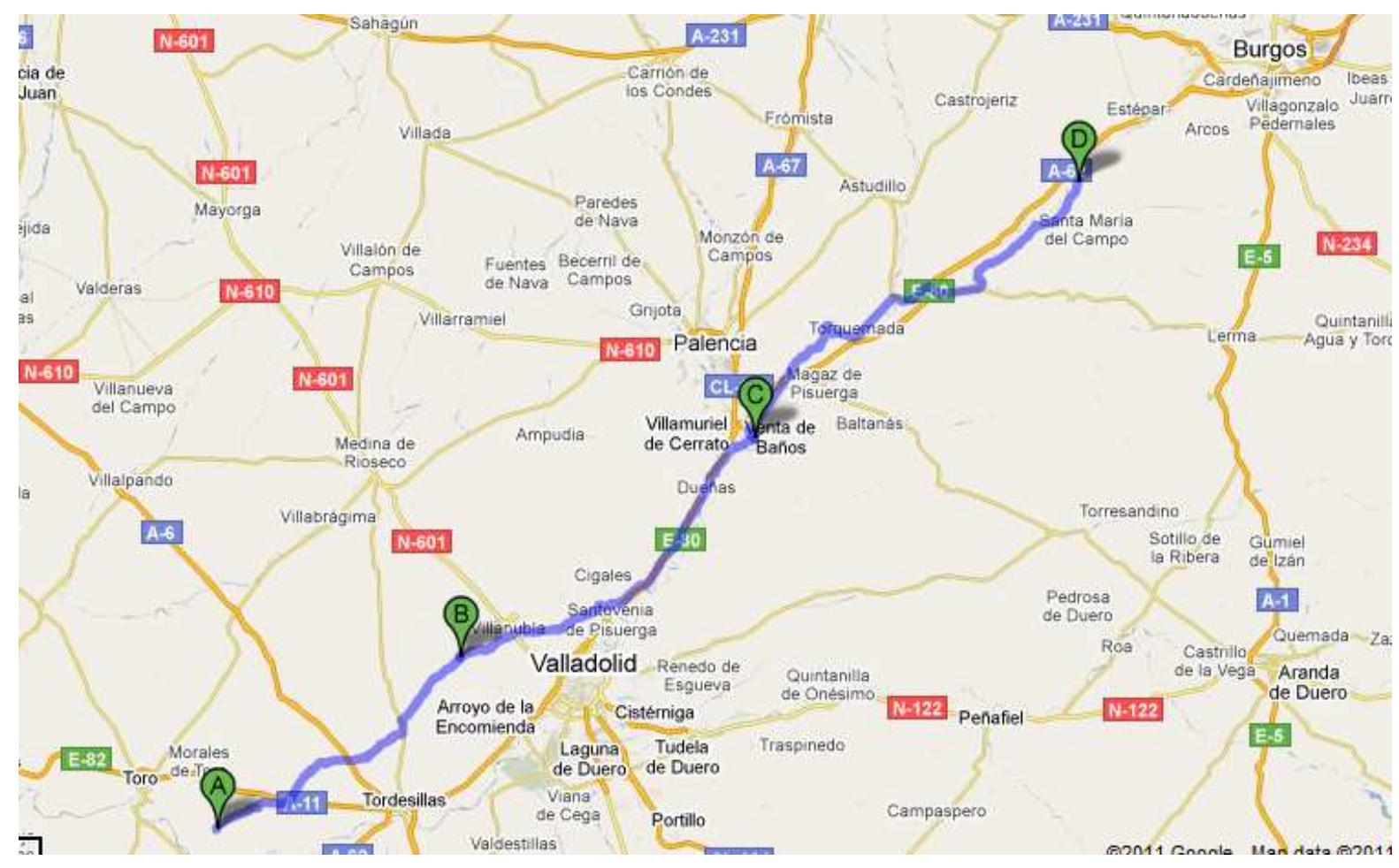

Figure 48: Map of the approximate locations of San Román de Hornija (A), Santa María de Wamba (B), San Juan de Baños (C), and the monastery of Pampliega (E). This screenshot is from Google Maps. 


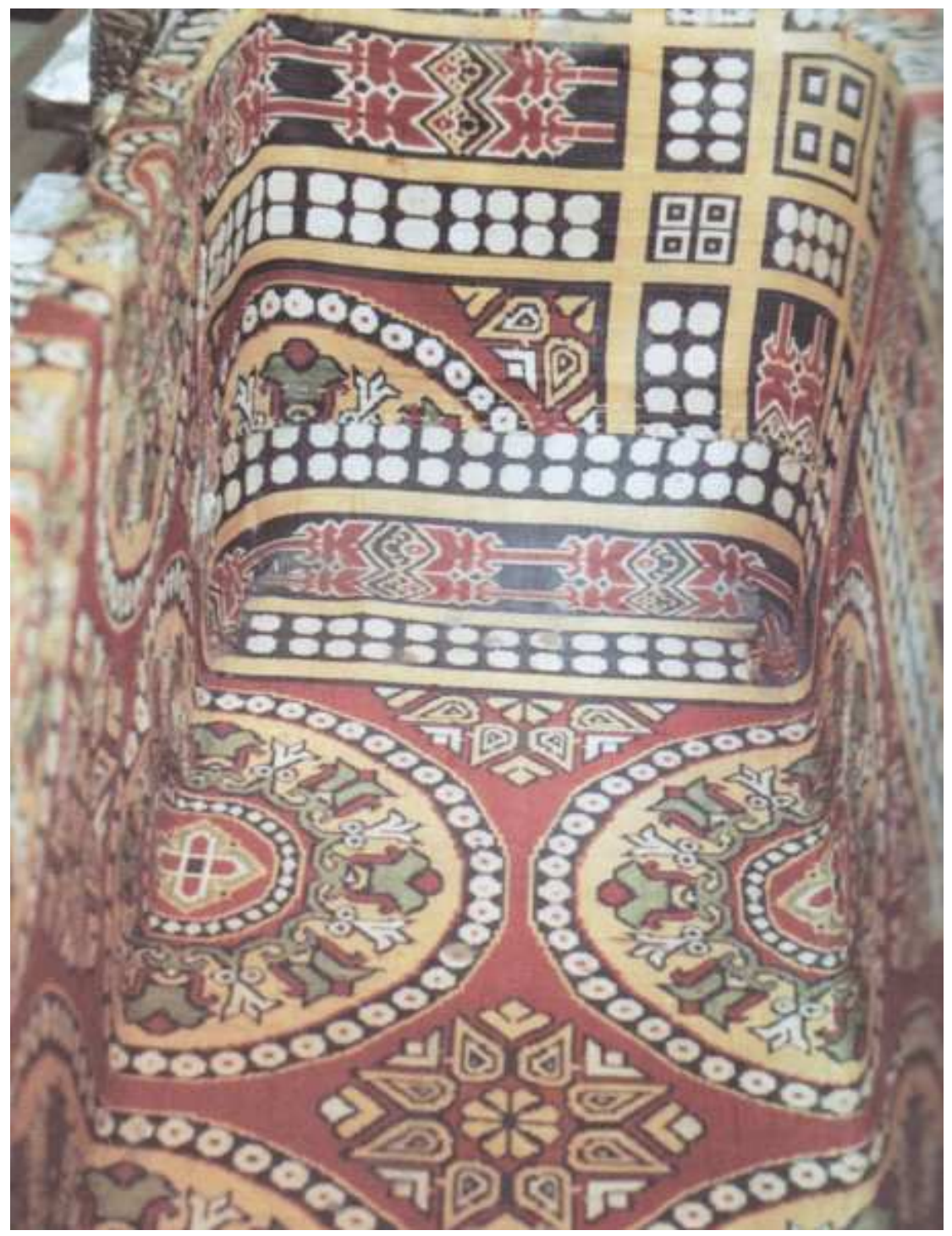

Figure 49: The interior of the circa 1063 Reliquary of Saint Isidore, in León. The interior is lined with two silk fabrics. The one pictured above is closely related to Umayyad textiles from north Africa. After The Art of Medieval Spain, A.D. 500-1200, New York: The Metropolitan Museum of Art, 1993, catalog entry 110, 244. 


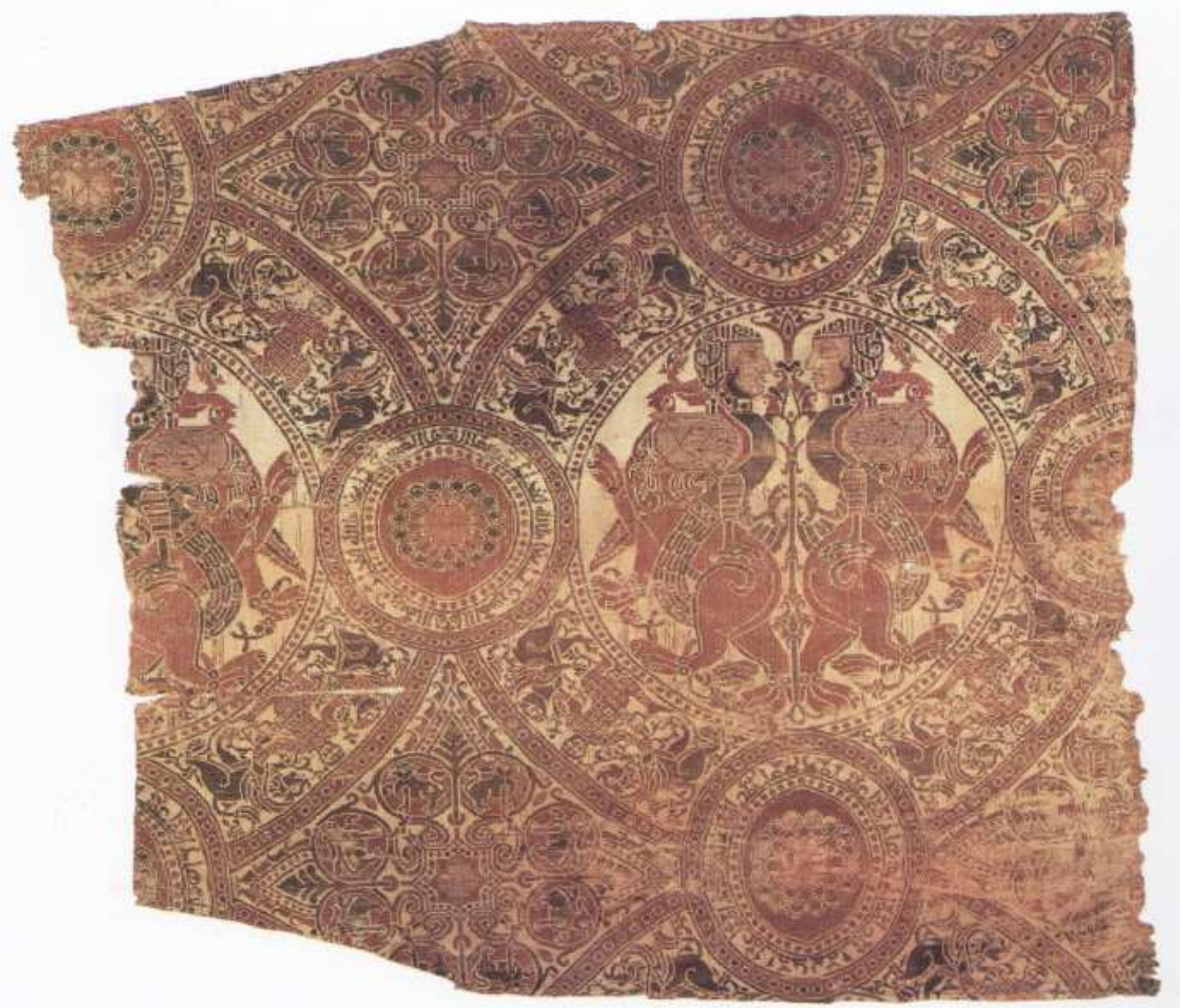

Figure 50: Circa 1100 silk fragment from the tomb of Pedro de Osma, bishop of Burgo de Osma. After The Art of Medieval Spain, A.D. 500-1200, New York: The Metropolitan Museum of Art, 1993, catalog entry 60, 108-109. 


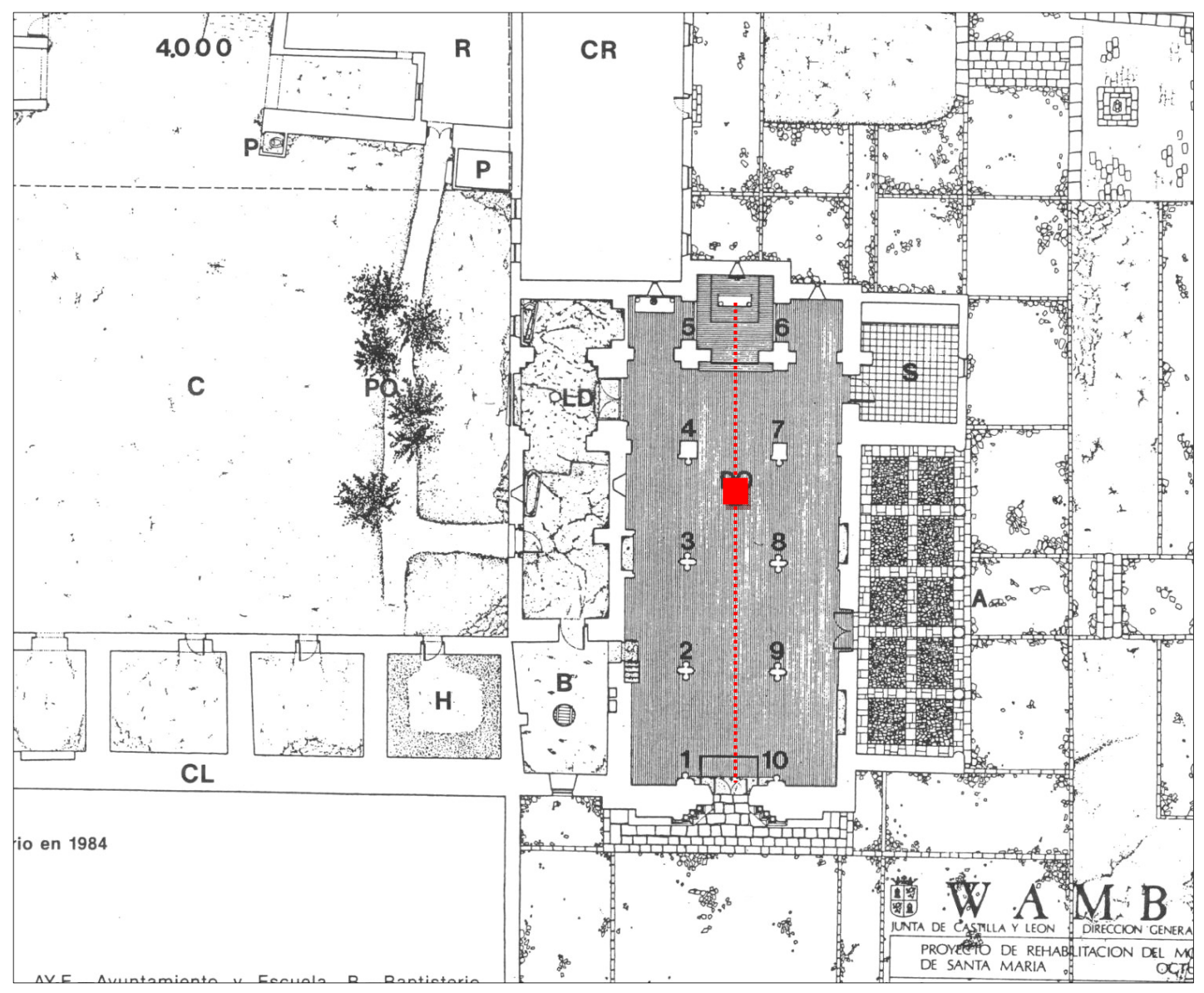

Figure 51: The position of the interior well along the east-west axis of the church. After J. L. de la Quintana Gordon and J. R. Boned Colera, "Santa María de Wamba, entre su pasado y el future (Valladolid)," figure 1. 


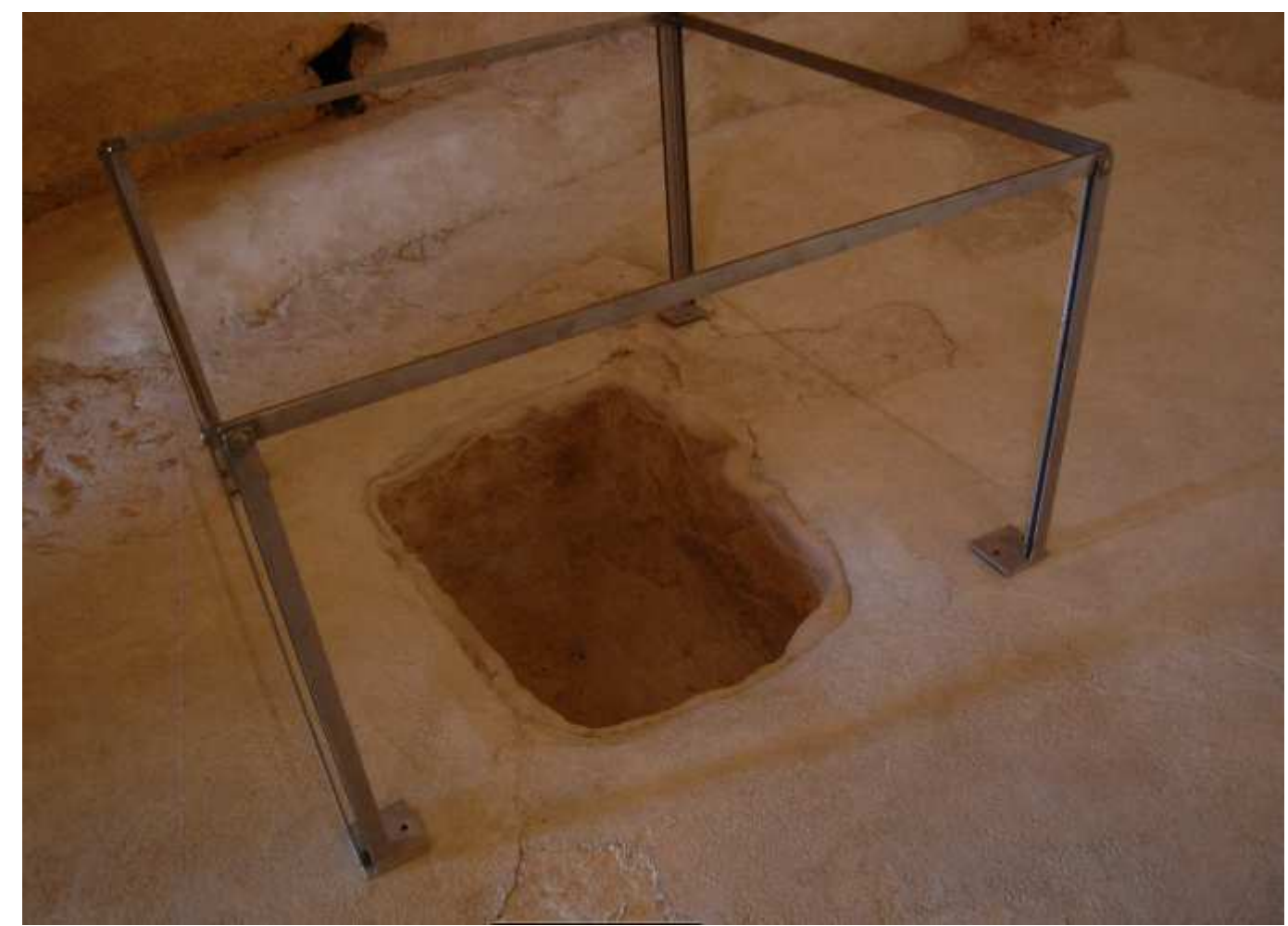

Figure 52: San Miguel de Gormaz (Soria), view of the baptistery excavated from the bedrock. Photo: author. 


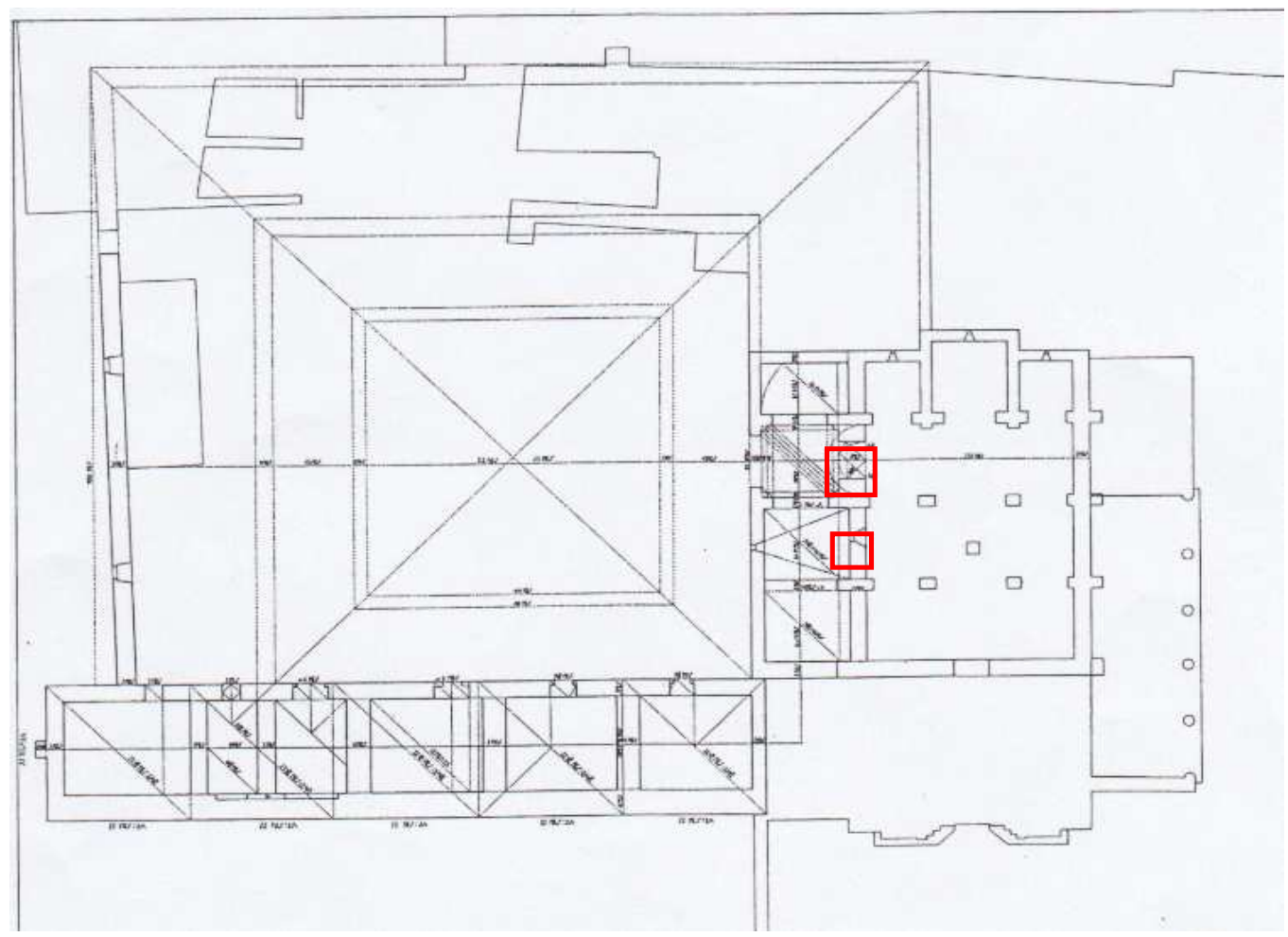

Figure 53: Santa Maria de Wamba, view of the plan for the twelfth-century phases. The red boxes highlight the position of the possibly coexisting portals. After J. L. de la Quintana Gordon and J. R. Boned Colera, "Santa María de Wamba, entre su pasado y el future (Valladolid), " figure $2 b$.

To the right is the architects' drawing of the present-day portal and the outline of the previous horseshoe-arched portal in the north wall. After J. L. de la Quintana Gordon and J. R. Boned Colera, "Santa María de Wamba, entre su pasado y el future (Valladolid)," figure 9a.

See figure 42 above for a photograph of the north wall.
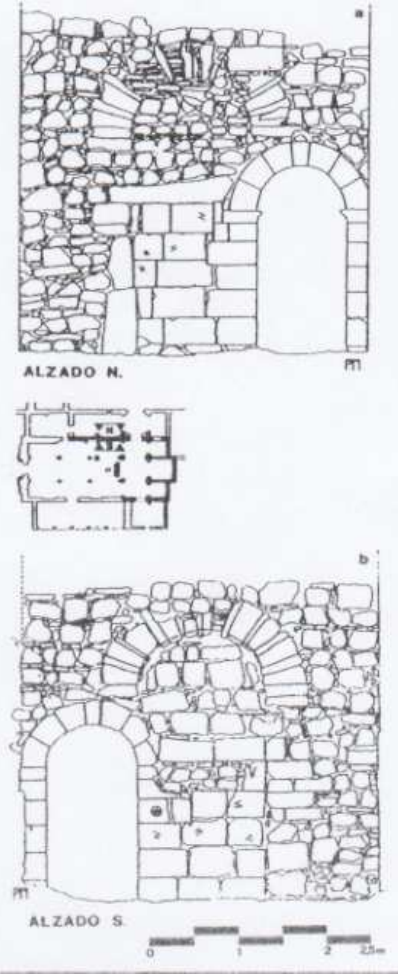


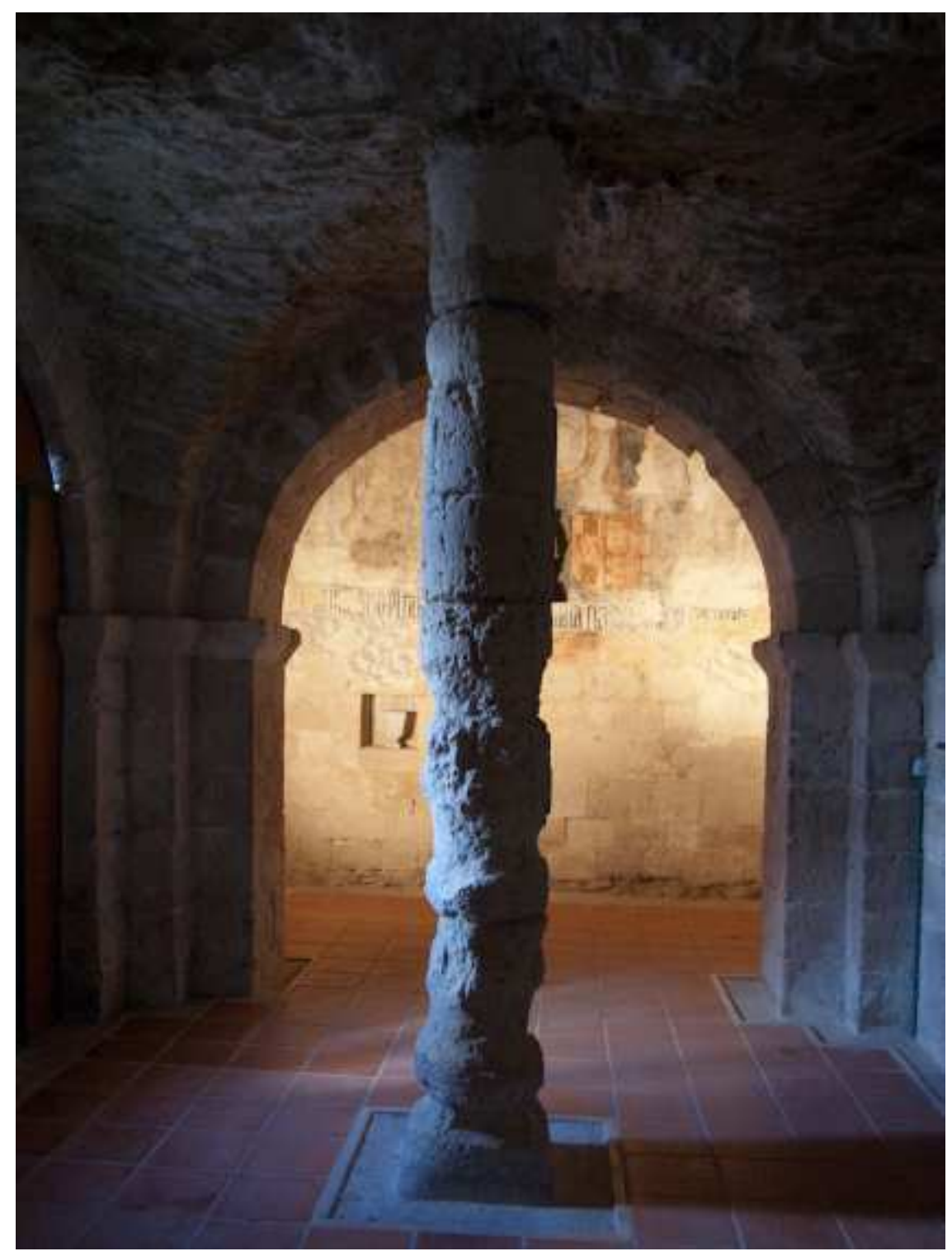

Figure 54: Santa María de Wamba, view of the column supporting the vaulted chamber located north of the tripartite choir. Photo: author. 


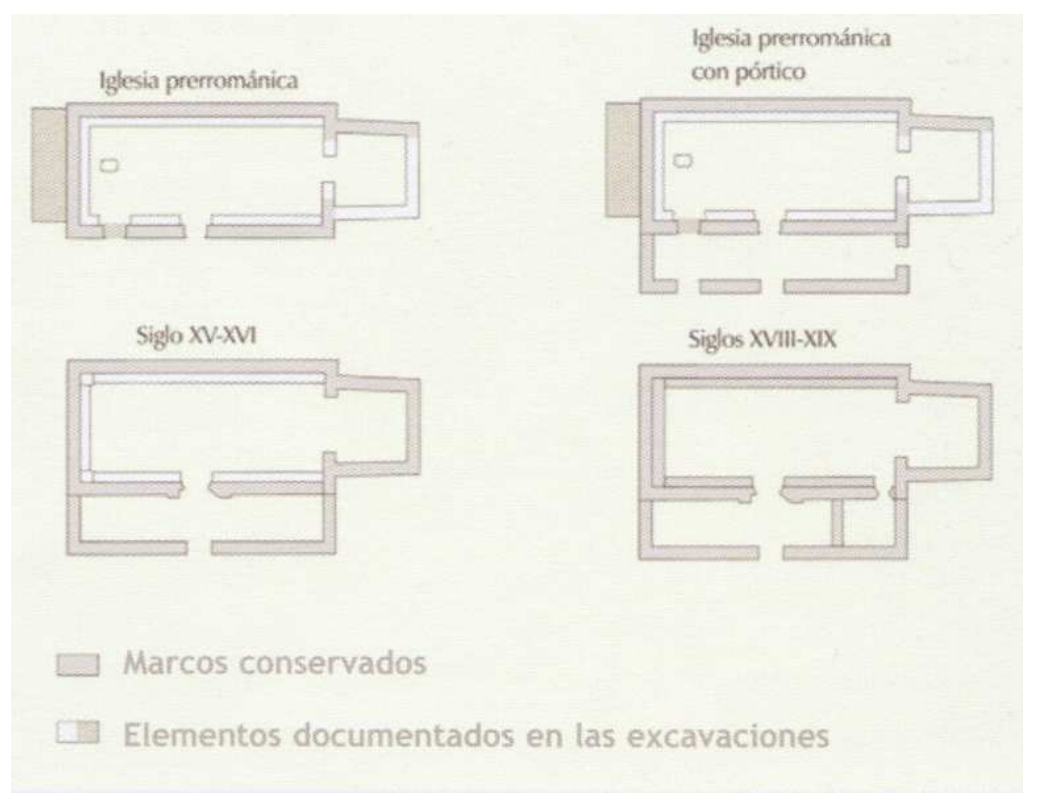

Figure 55: San Miguel de Gormaz, view of the reconstructed plans of the two portals dated to the eleventh-century structure. After C. Escribano Velasco and E. Heras Fernández, "La arqueología en San Miguel de Gormaz." Arevacon: Revista cultural, Asociación de Amigos del Museo Numantino 29 (2009): 4-11, figure 11.

To the right is the view of the baptistery from the southern portico, through the horseshoe-arched portal. Photo: author.

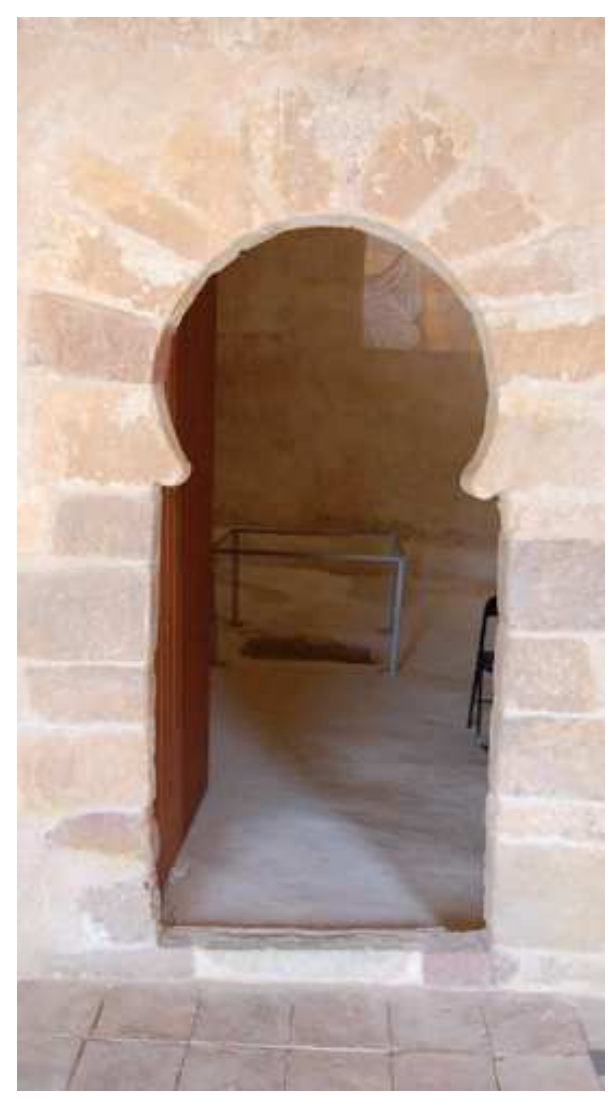




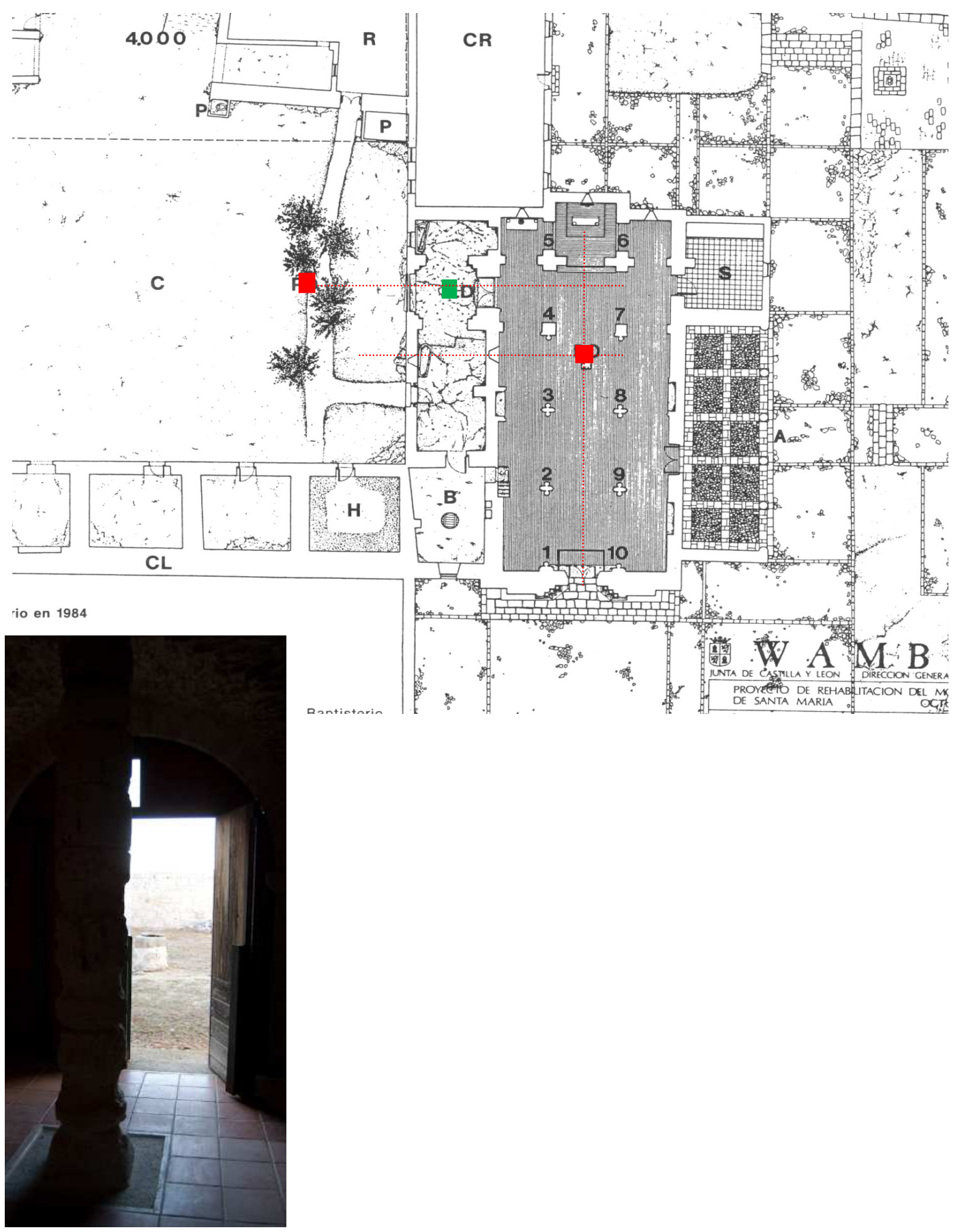

Figure 56: Santa María de Wamba, view of the alignment created between the cloister well (red), the Tree of Life (green) and the choir and the alignment of the horseshoe-arched portal and the interior well (red). The plan is after J. L. de la Quintana Gordon and J. R. Boned Colera, "Santa María de Wamba, entre su pasado y el future (Valladolid)," figure 1. The photograph provides a view of the Tree of life and the cloister well from the vantage point of the central choir. Photo: author. 


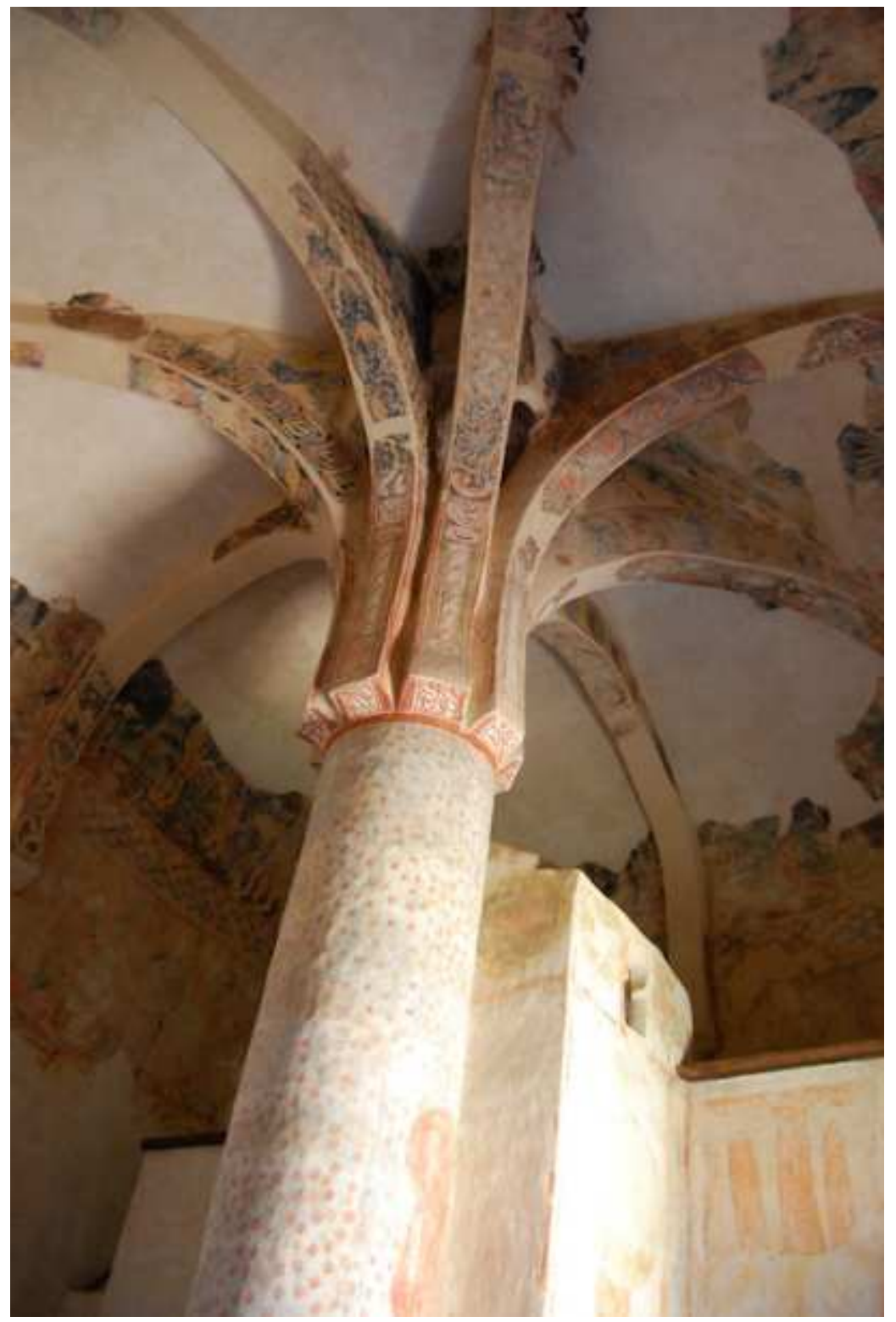

Figure 57: San Baudelio de Berlanga, view of the central column and chamber, the vault, and southwestern tribune. Photo: author. 


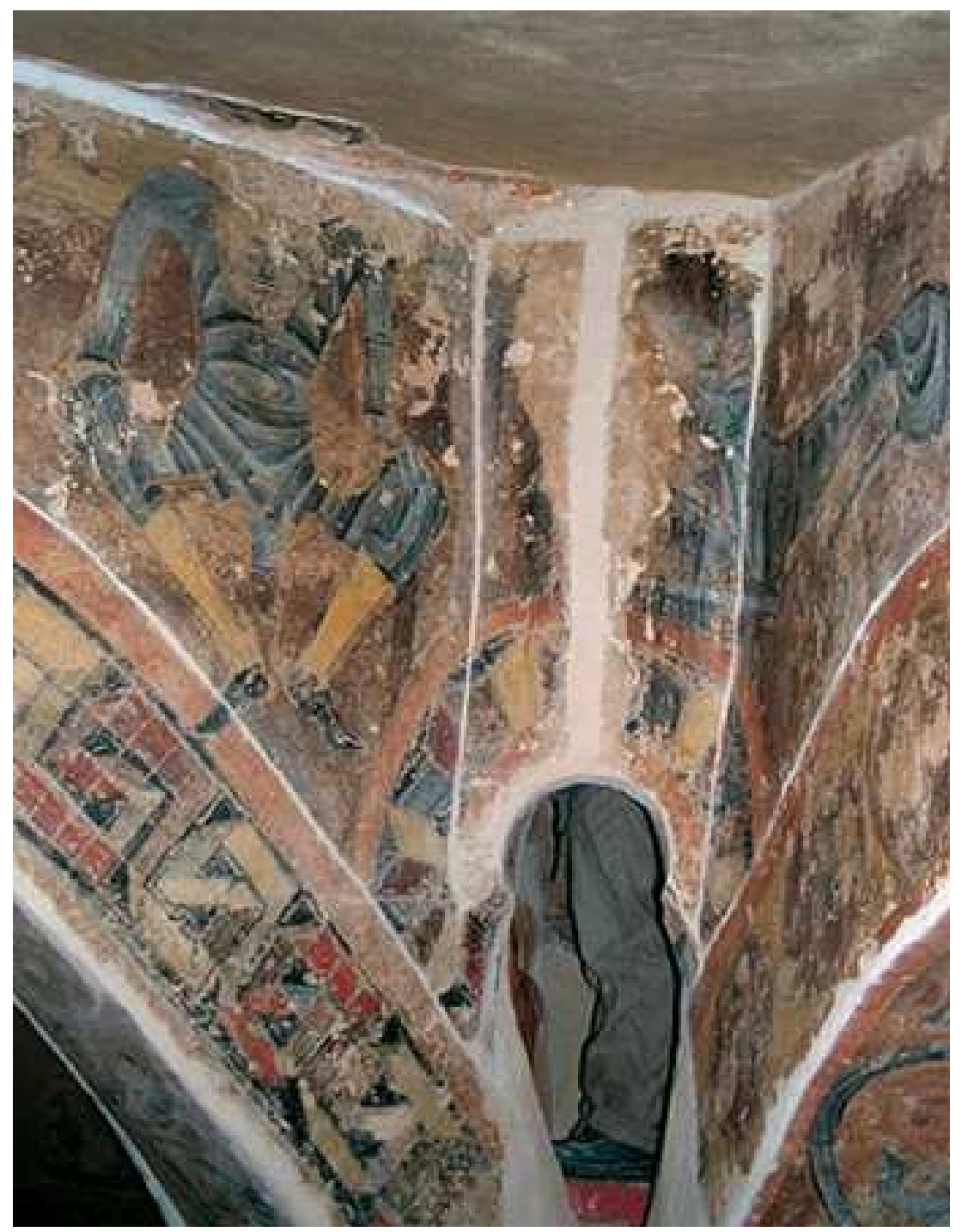

Figure 58: San Baudelio de Berlanga, view of one of the vault conservators standing in the upper chamber, after M. González Pascual, "San Baudelio de Berlanga (Soria): La reposición de las pinturas murales de la 'Palmera'," Bienes Culturales: revista del Instituto del Patrimonio Histórico Español 6 (2006): 77-97, figure 17.

To the right: the interior appearance of the crossribbed vault of the column chamber, after Escolano Benito, Guía, 2003, 59.

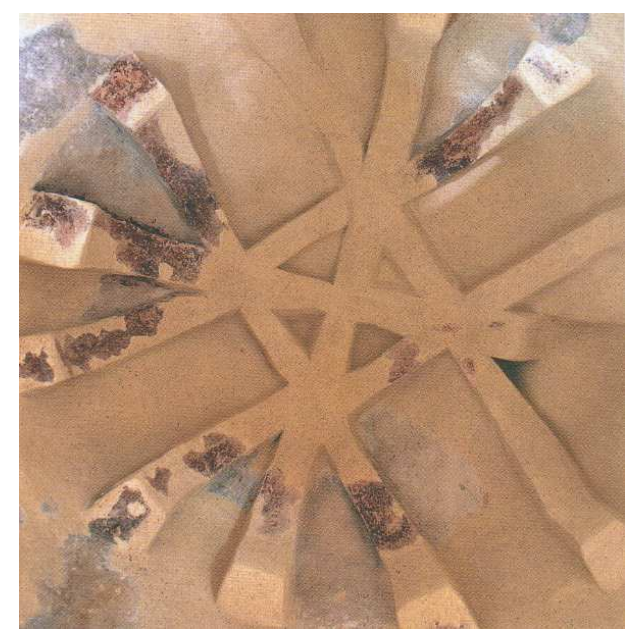




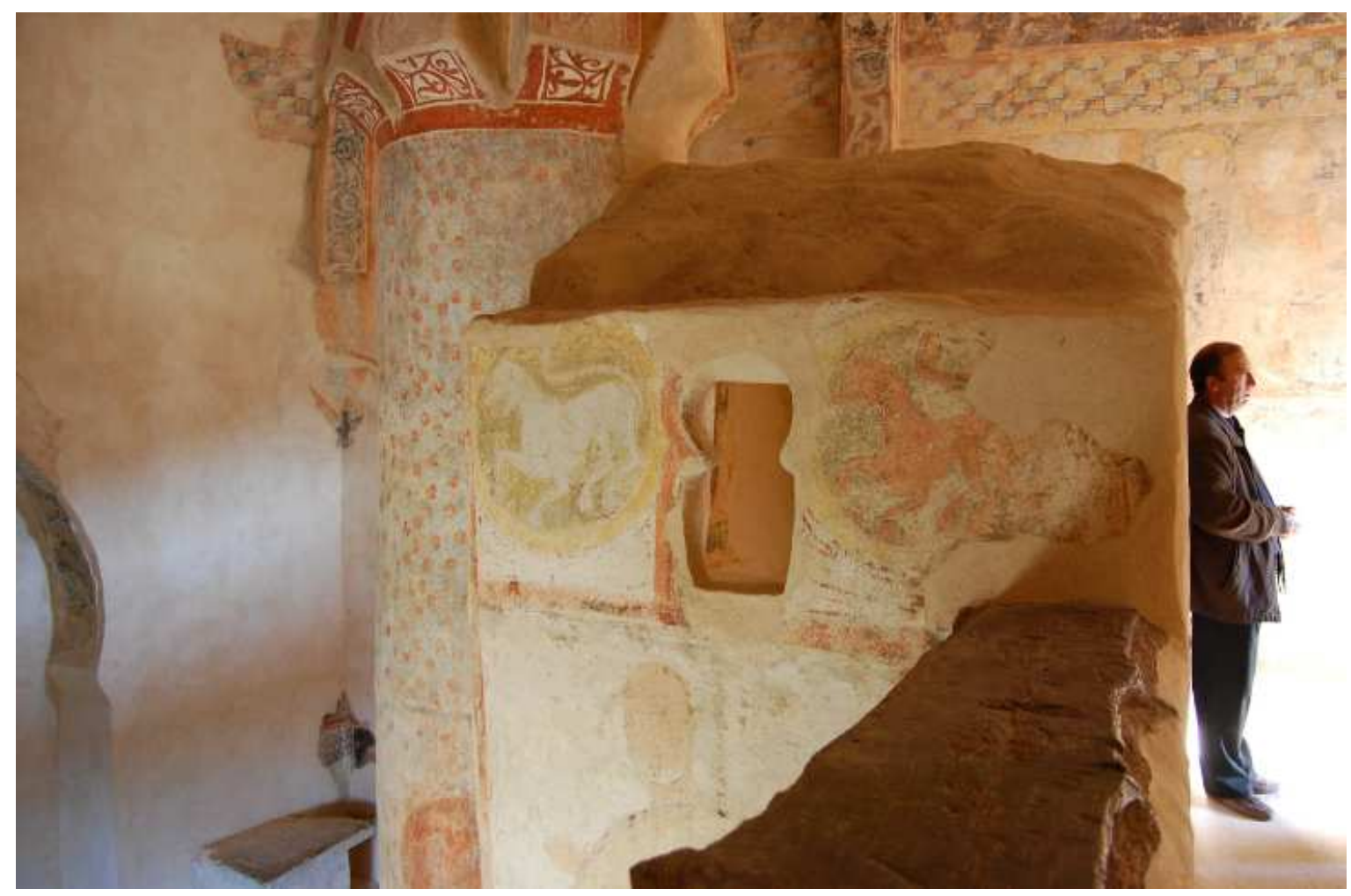

Figure 59: San Baudelio de Berlanga, view of the coro and the central column from the tribune. Photo: author. 


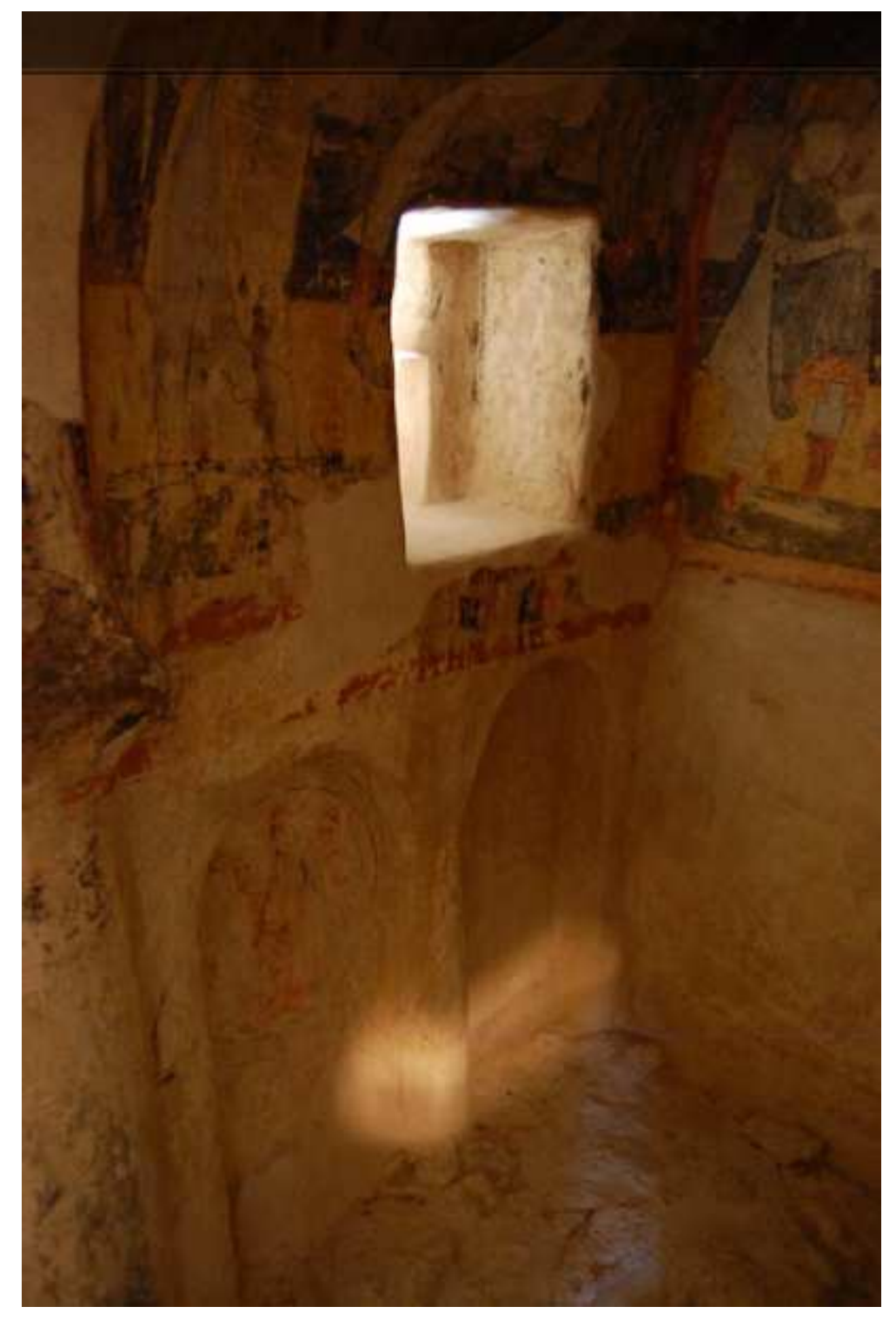

Figure 60: San Baudelio de Berlanga, view of the interior of the tribune coro. Photo: author. 


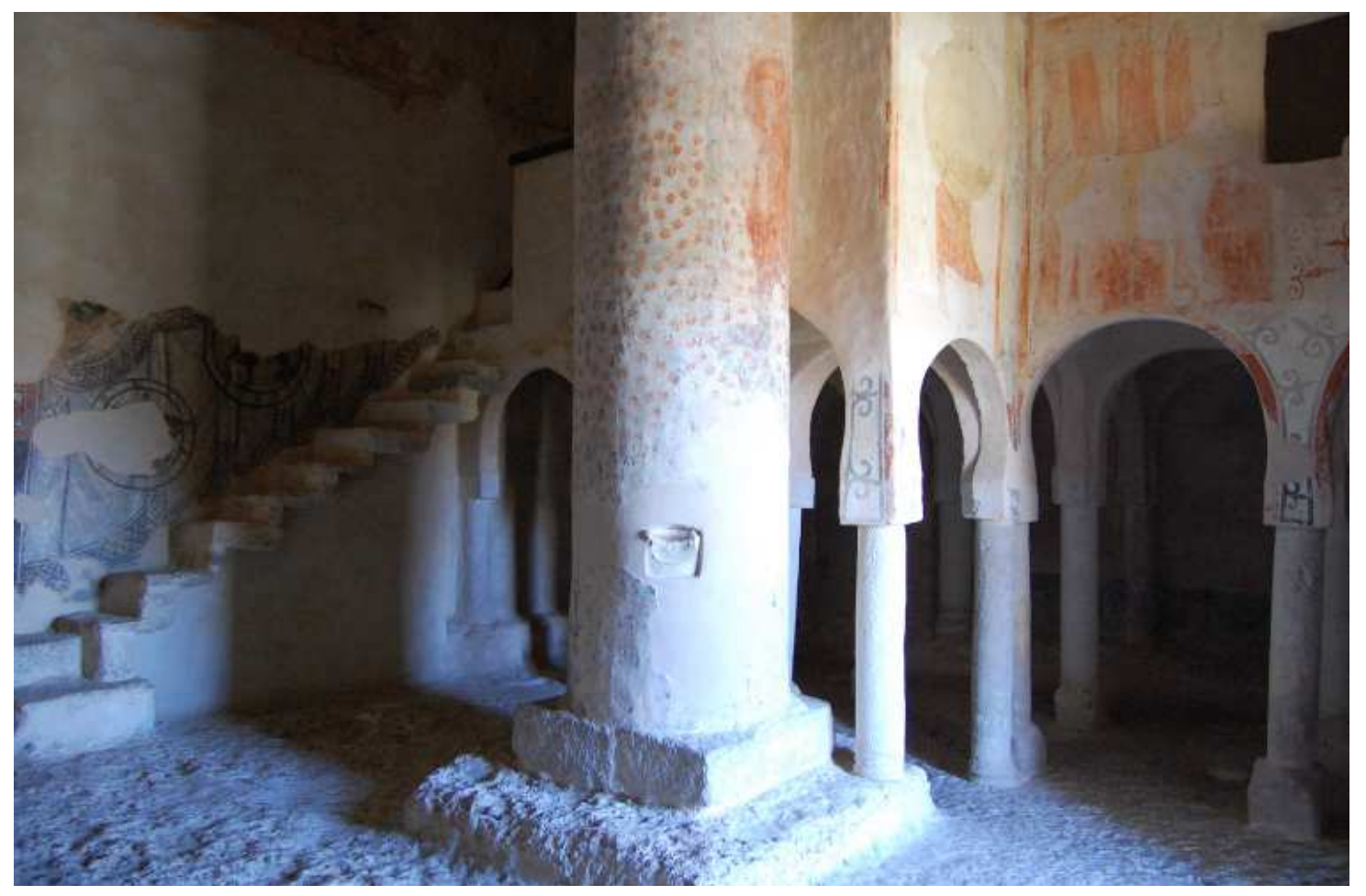

Figure 61: San Baudelio de Berlanga, view of the column-filled space beneath the southwestern tribune. Photo, author. 


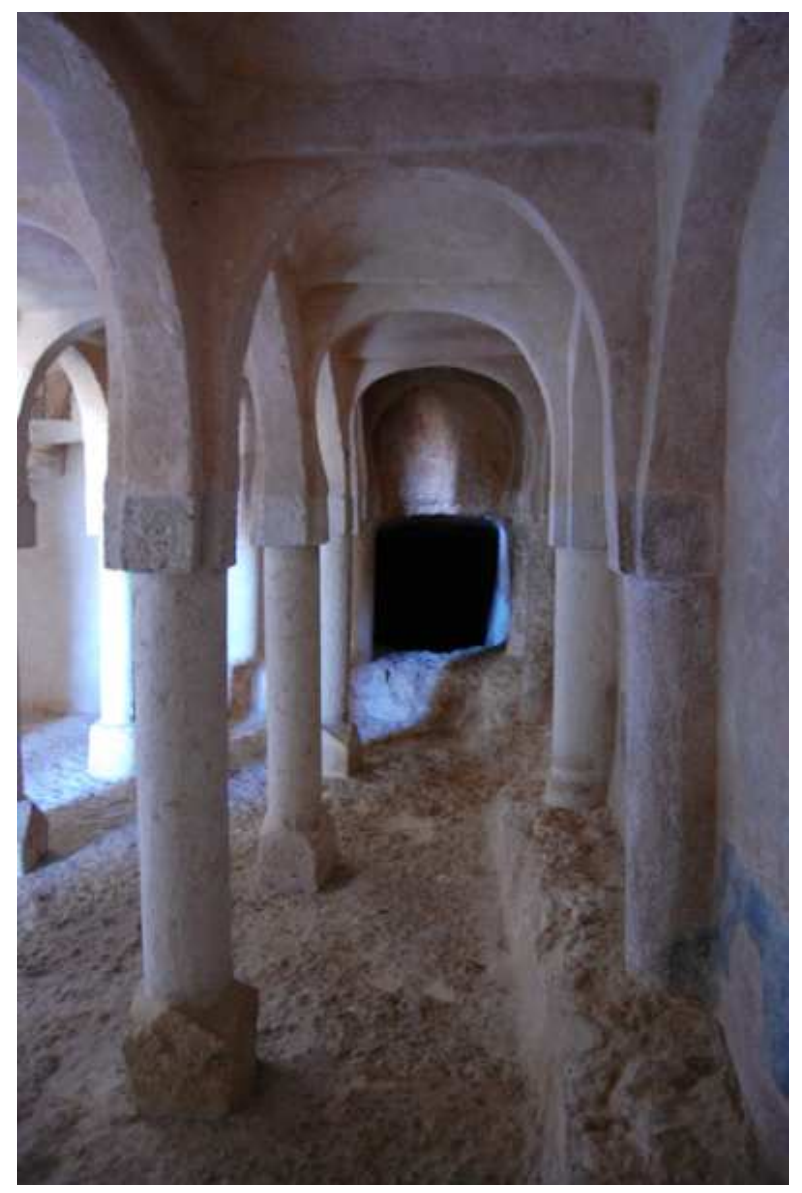

Figure 62: San Baudelio de Berlanga, view of the entrance to the cave beneath the tribune. Photo: author. 


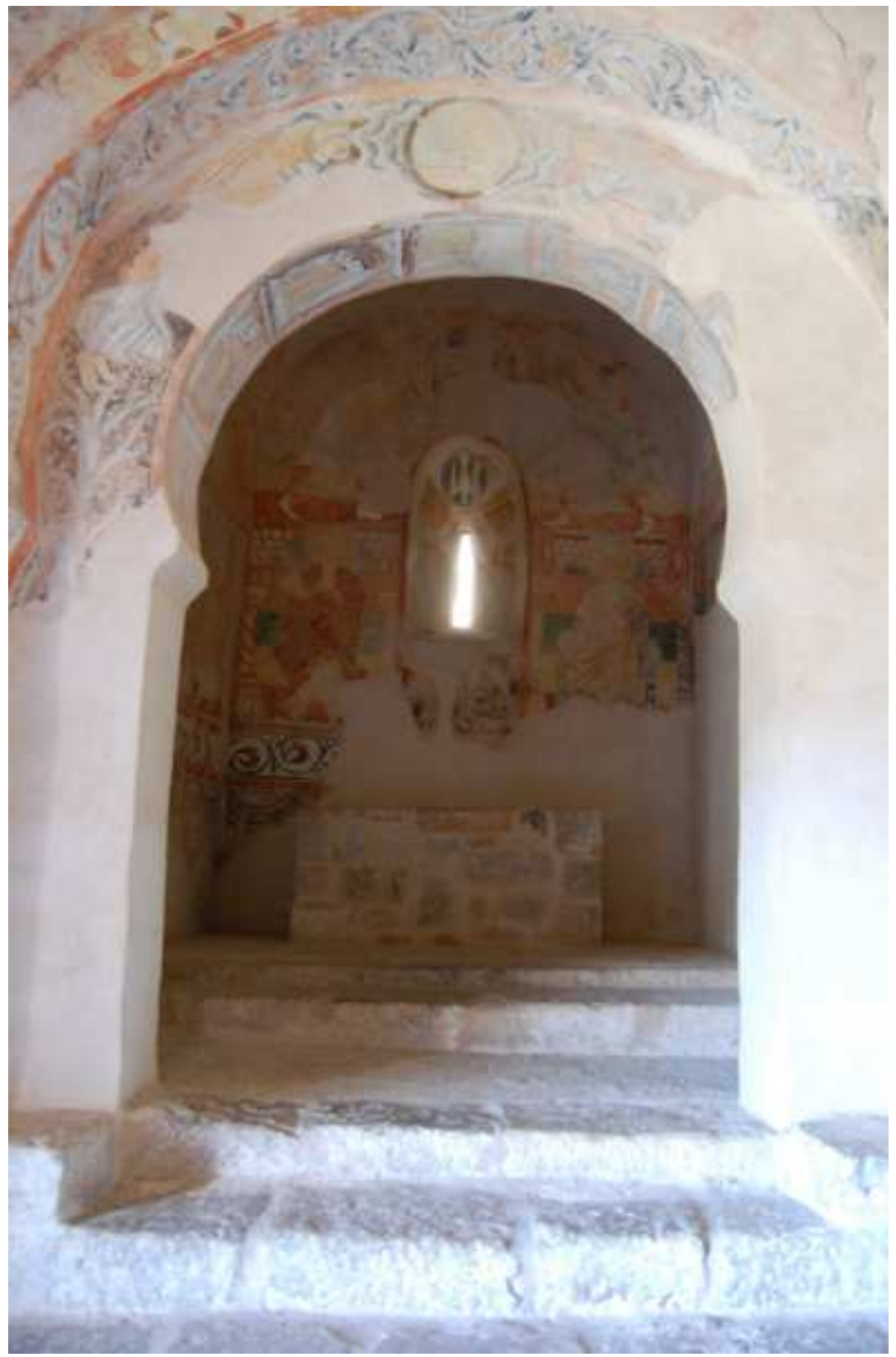

Figure 63: San Baudelio de Berlanga, view of the triumphal arch and apse entrance, looking toward the northeast. Photo: author. 


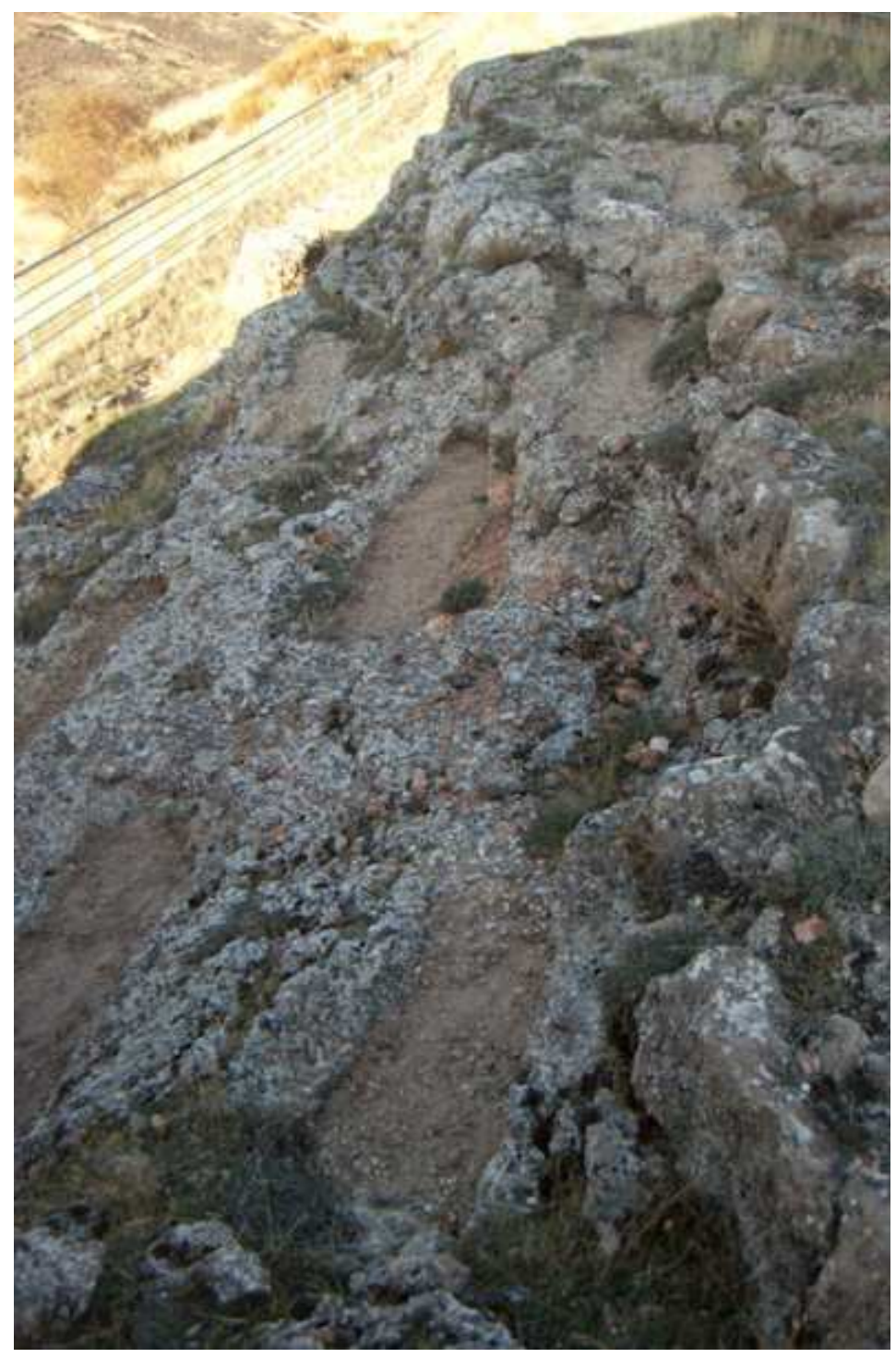

Figure 64: San Baudelio de Berlanga, view of the necropolis excavated from the rock to the northeast of the church apse. Photo: author. 


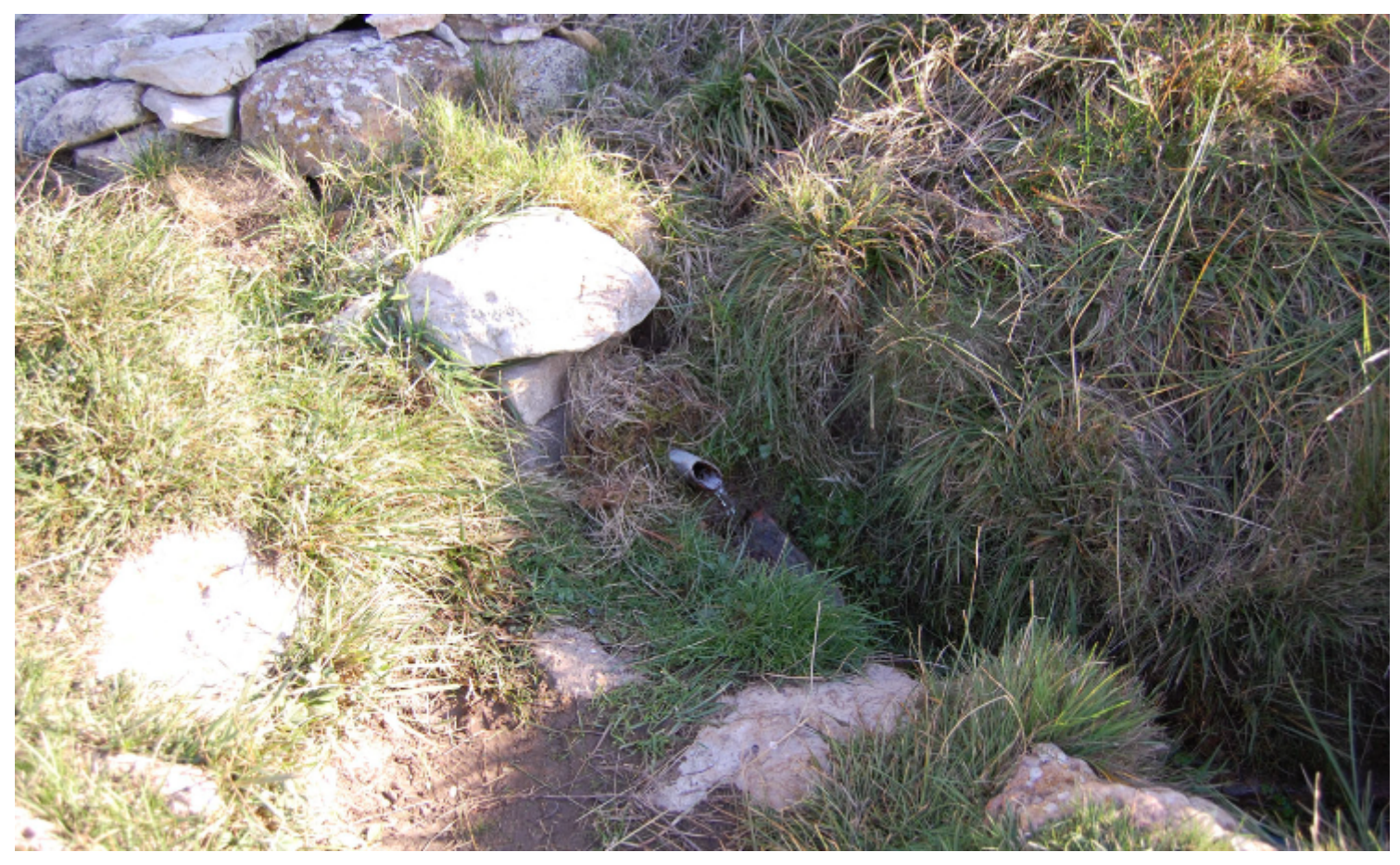

Figure 65: San Baudelio de Berlanga, view of the natural spring located at the west corner of the church. Photo: author. 


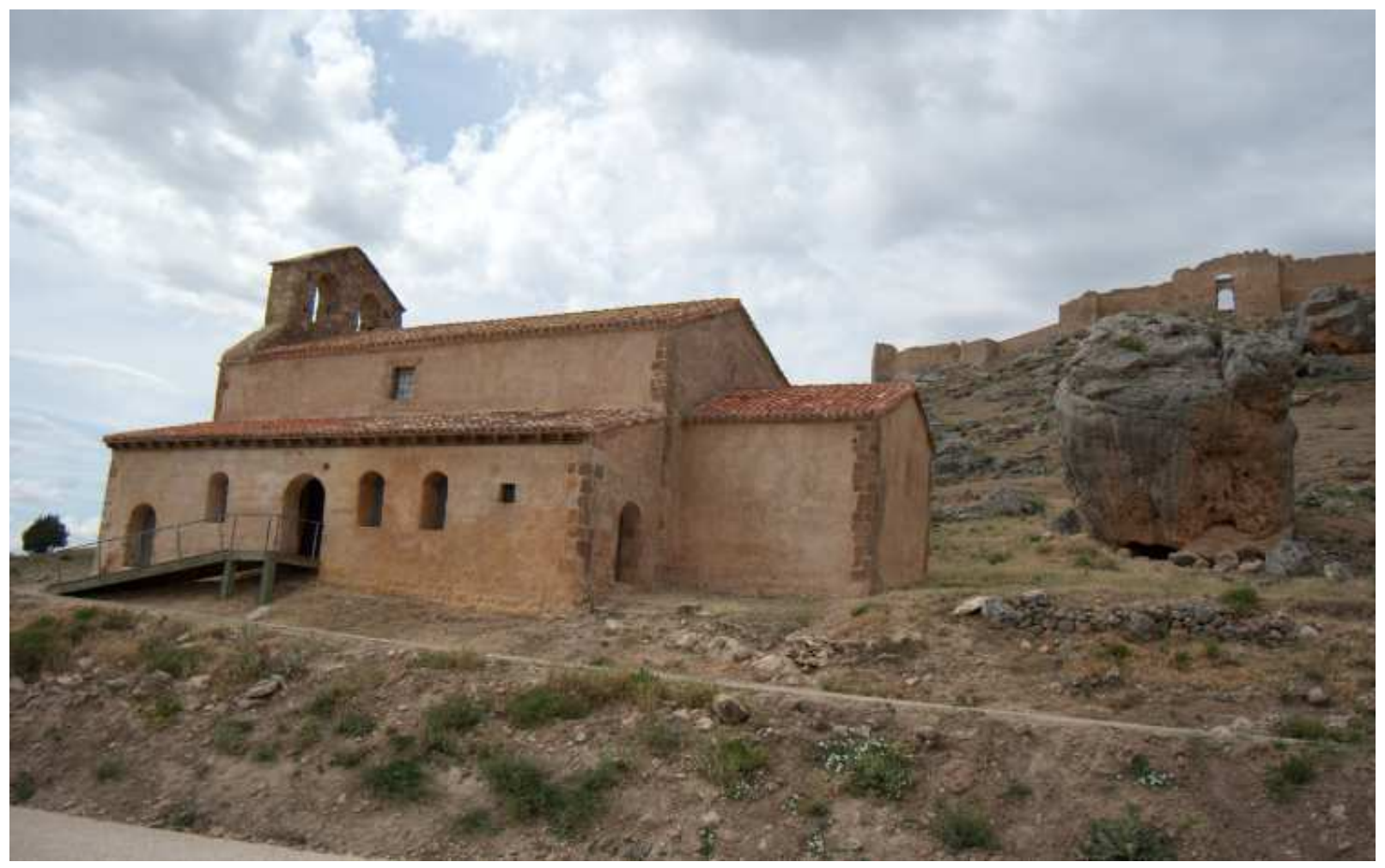

Figure 66: San Miguel de Gormaz, view of the church beneath the fortress. The rock lies a few meters to the northeast of the apse. Photo: author. 


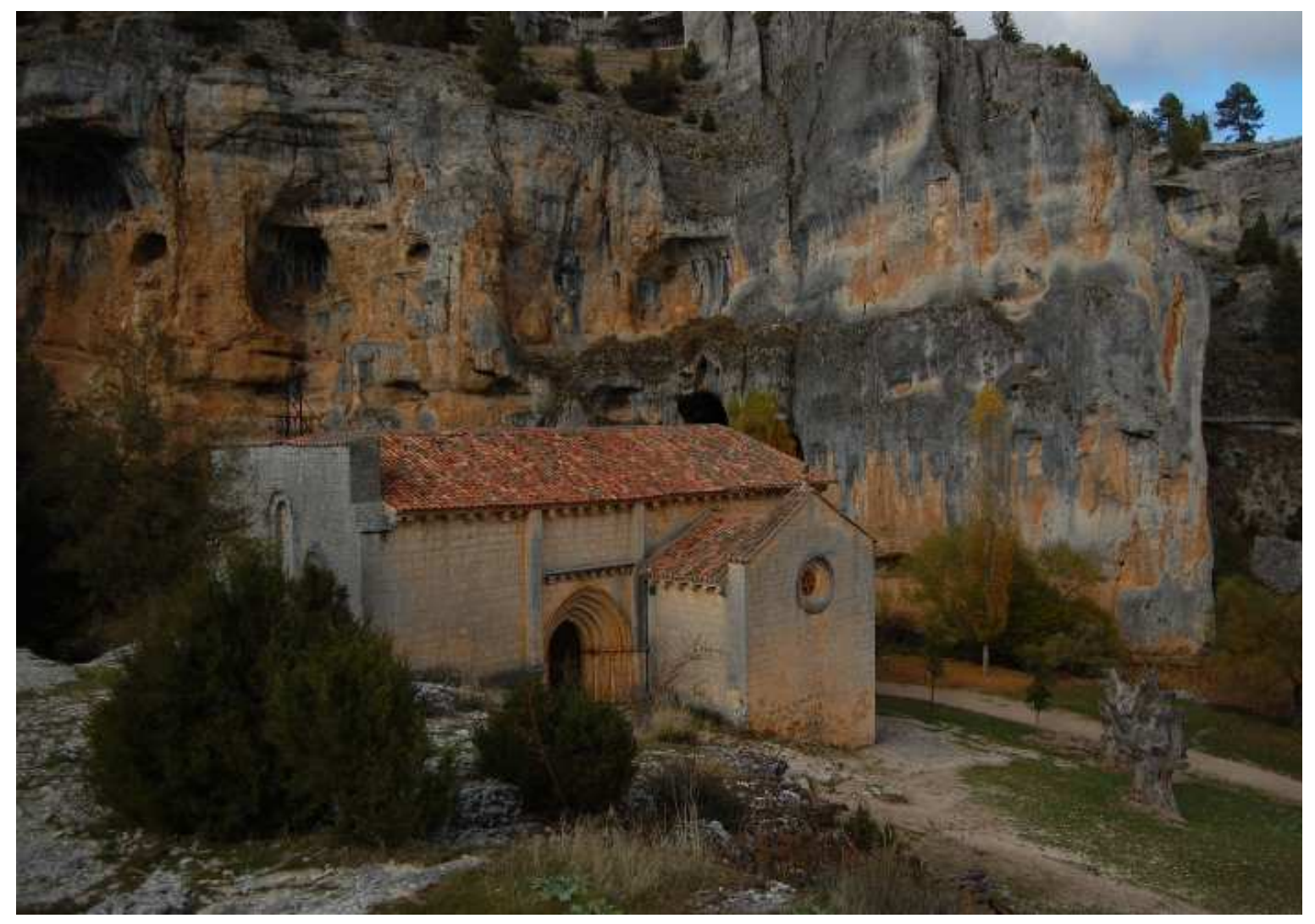

Figure 67: The ermita of San Bartolomé at the end of the cañón del río Lobos. Cave openings are visible behind the church, toward the northeast, while preserved trees stand to the southeast of the church. Photo: author. 


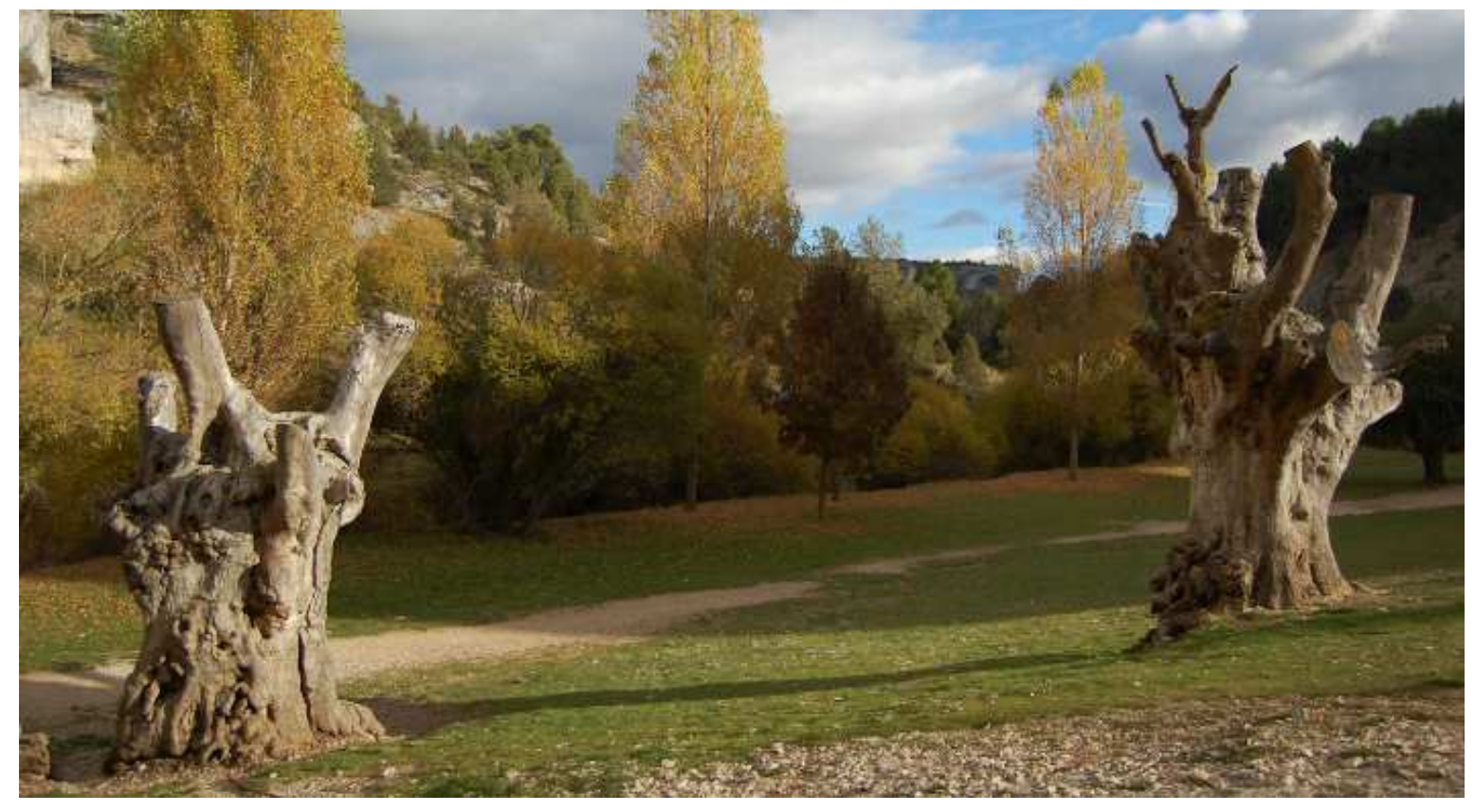

Figure 68: The ermita of San Bartolomé at the end of the cañón del río Lobos. Two of the standing trees preserved at the site of the ermita church. Photo: author. 


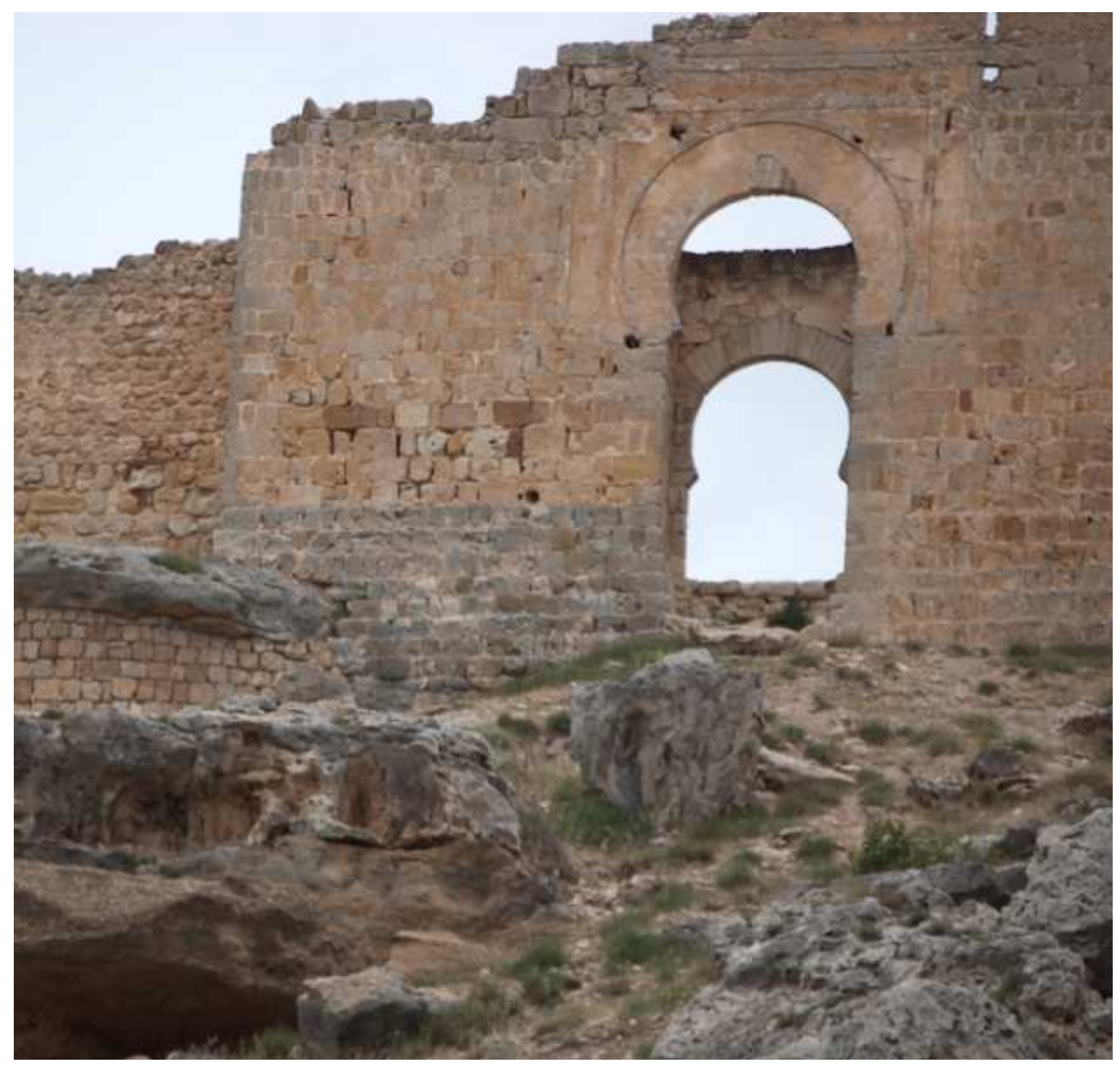

Figure 69: View of the so-called Caliphal Gate of the fortress of Gormaz, looking toward the north. Photo: author. 


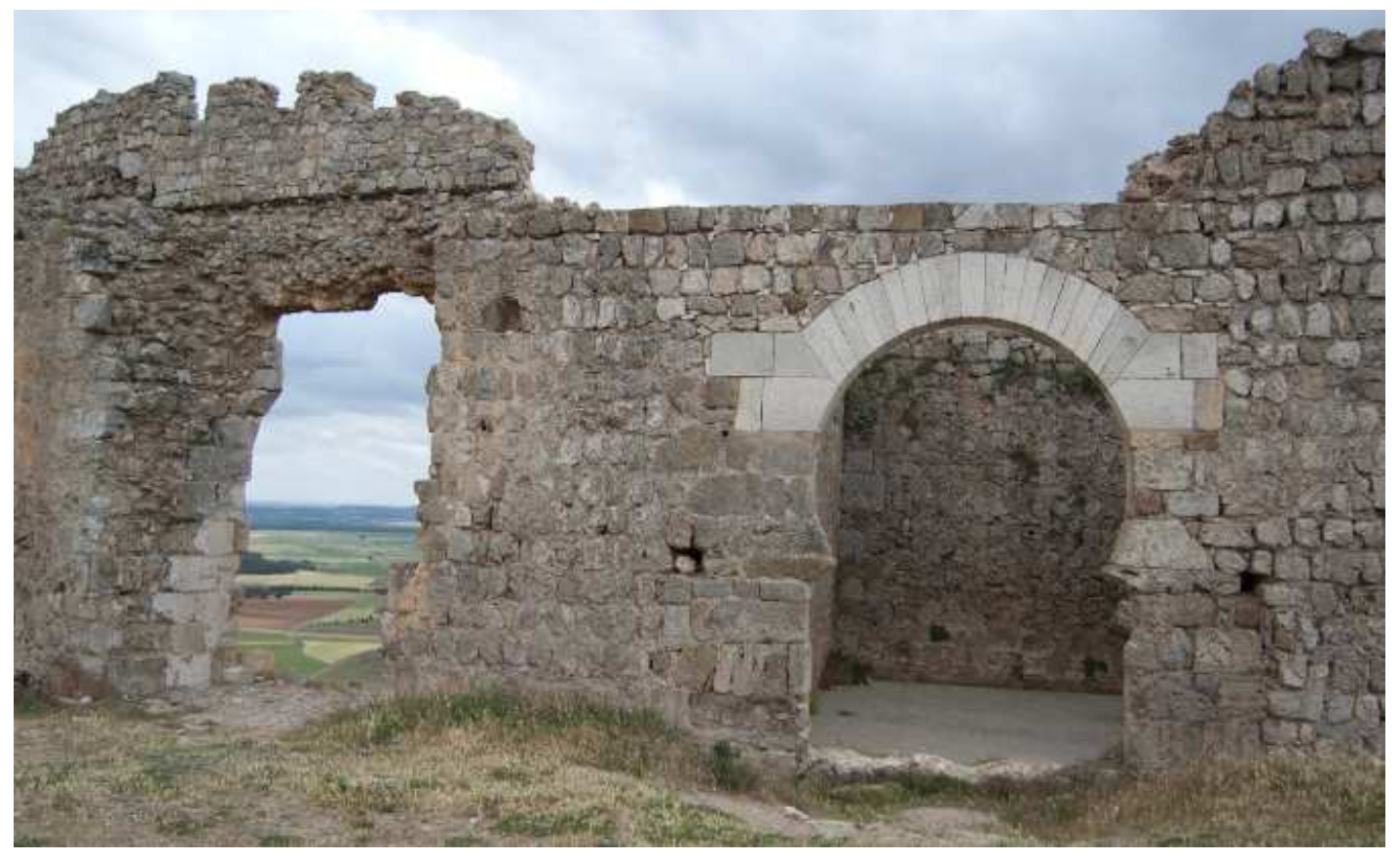

Figure 70: Fortress of Gormaz, view of the possible musalla space, located to the west of the main entry gate. Photo: author. 


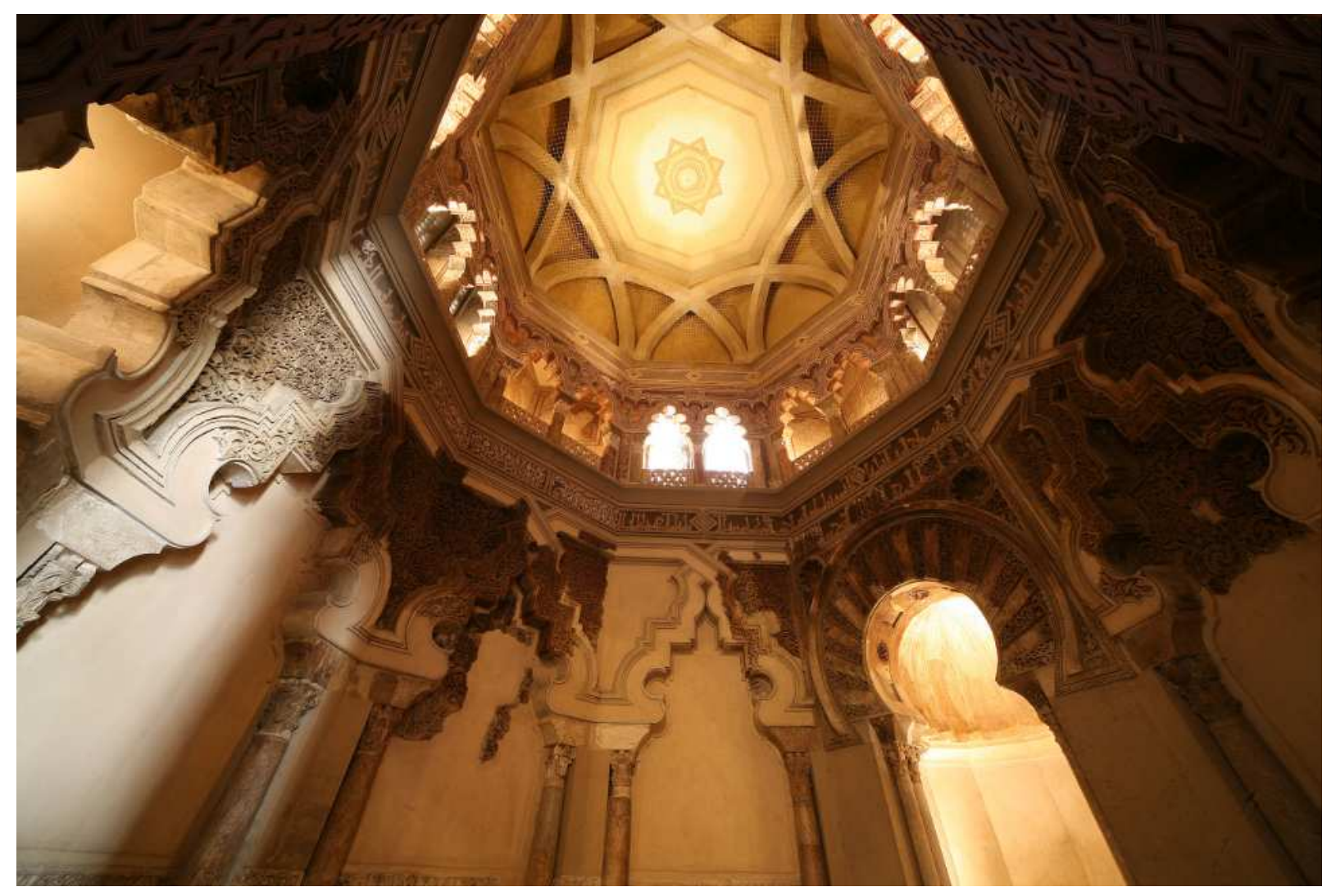

Figure 71: Above, a view of the audience hall of the Aljafería palace complex, Zaragoza. Image taken from http://www.lifeofanarchitect.com/reign-in-spain-zaragosa/ 


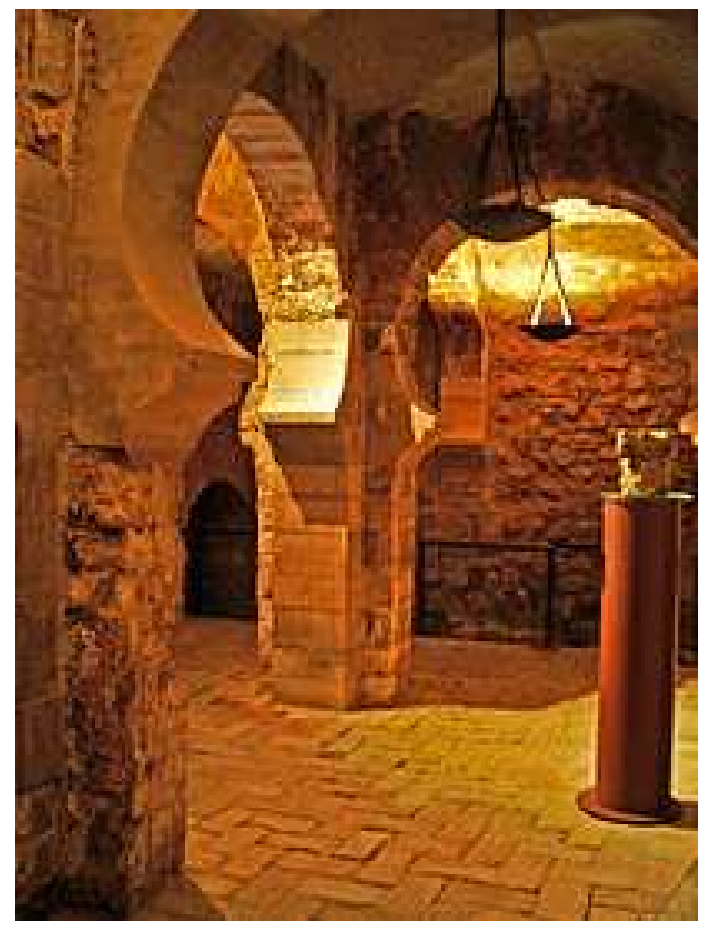

Figure 72: Above, a view of the so-called Troubadour Tower in the Aljafería palace complex, Zaragoza. Image taken from http://en.wikipedia.org/wiki/Aljafer\%C3\%ADa 


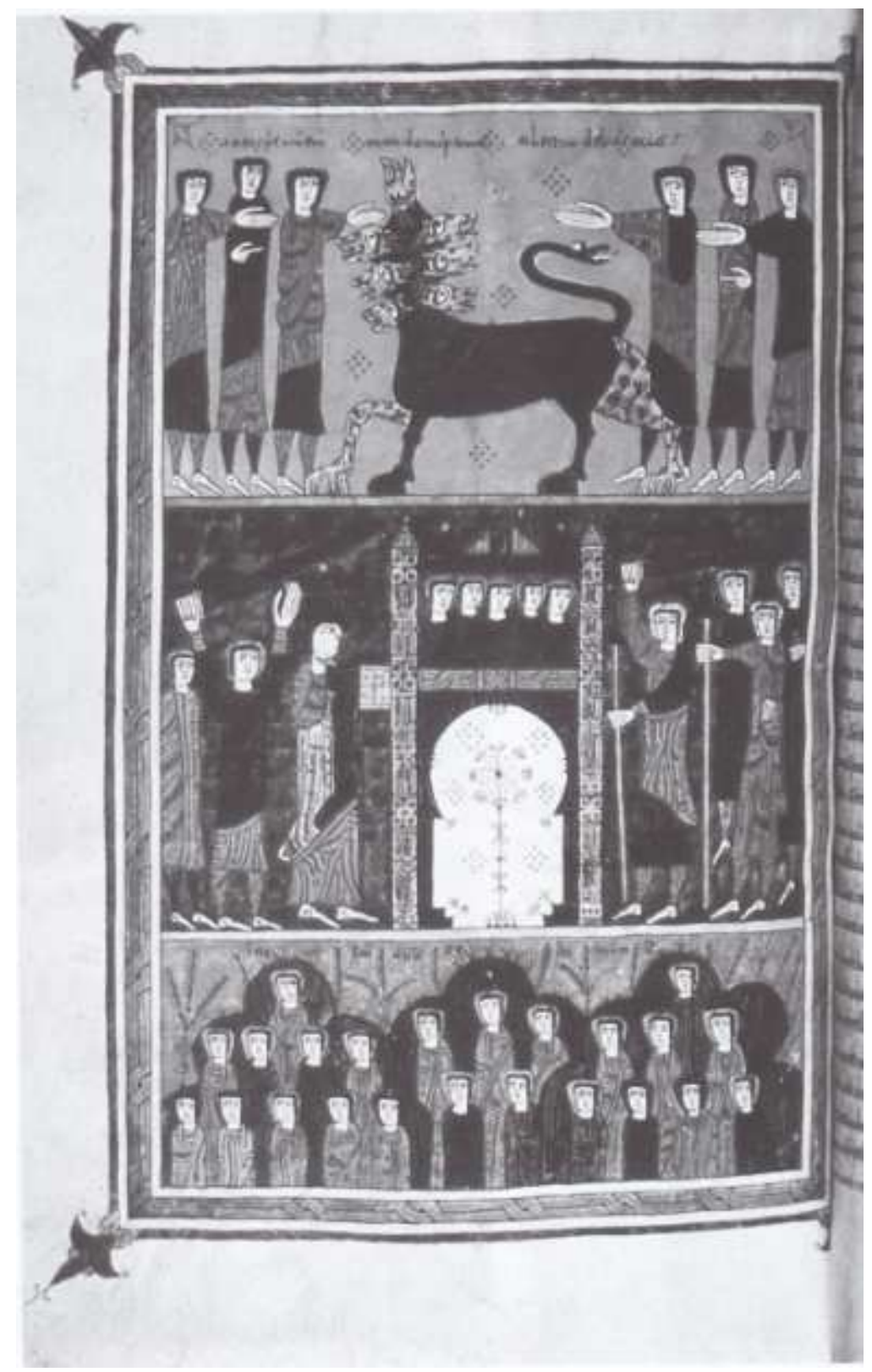

Figure 73: The decorated page depicting the "City of God" from the Silos Beatus, folio 202r, circa 1109. After The Art of Medieval Spain, A.D. 500-1200, New York: The Metropolitan Museum of Art, 1993, 130 


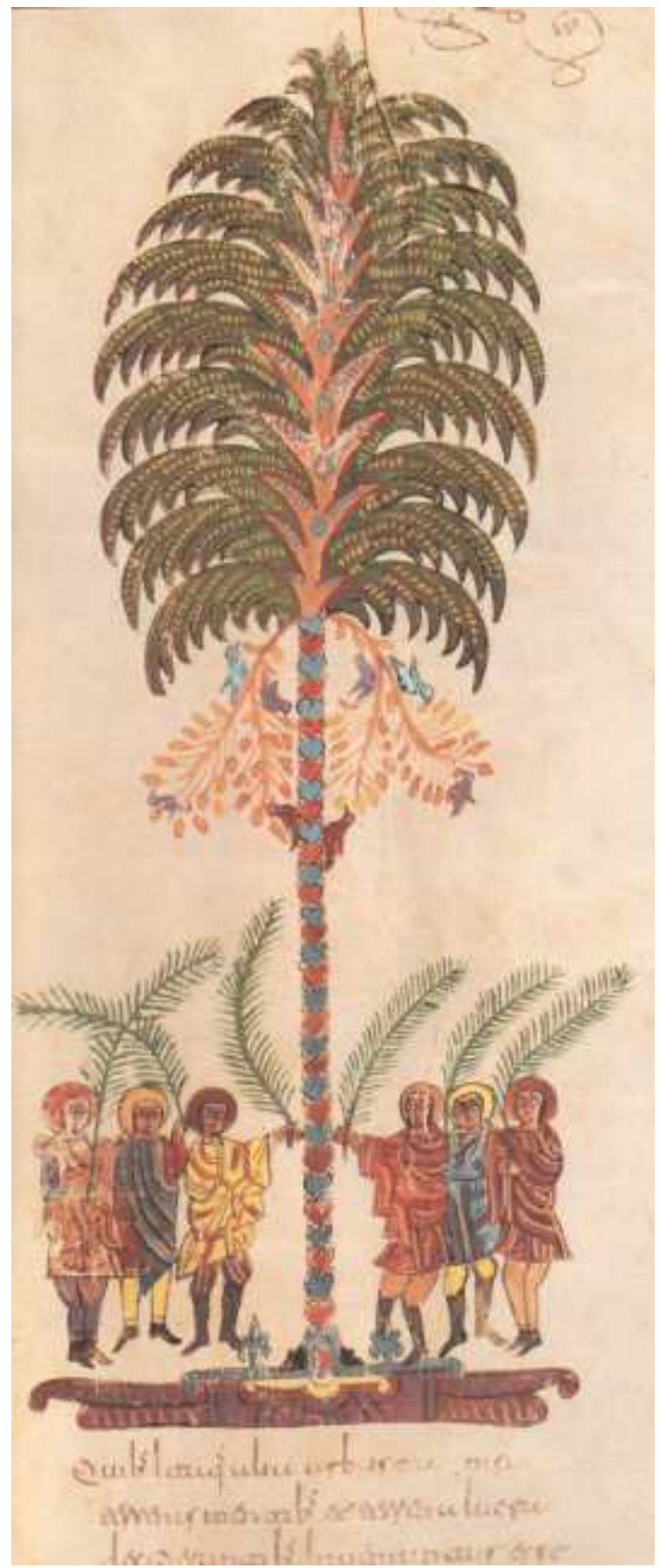

Figure 74: The Tree of Life as a palm tree, illustrated on folio 131 of the Morgan Beatus Commentary, circa 940. After J. Williams, A Spanish Apocalypse; the Morgan Beatus Manuscript, New York: George Braziller, inc., 1991, f. 131. 

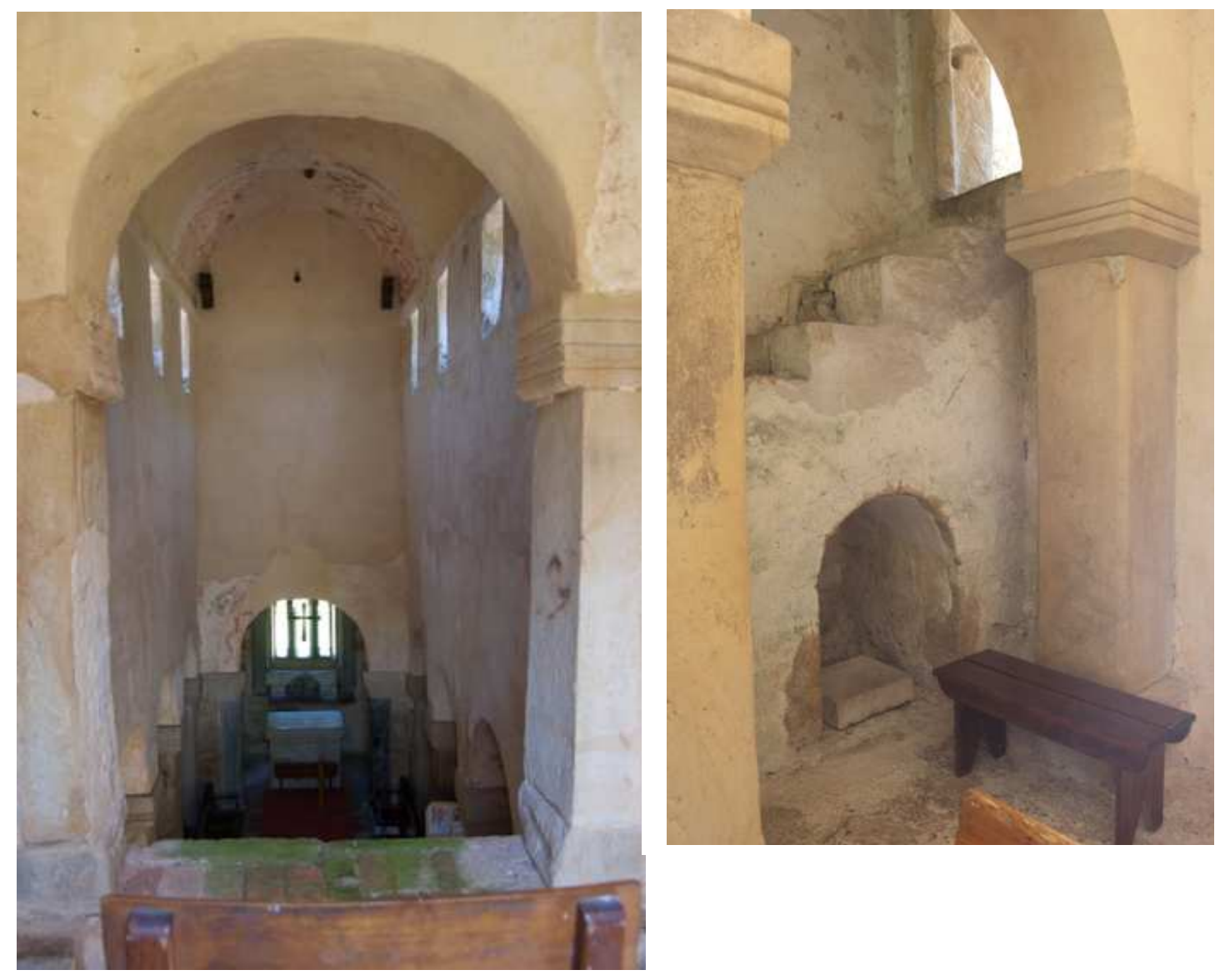

Figure 75: San Salvador de Valdediós, Asturias, view from the tribune into the nave, looking towards the east. Photo: author.

The photograph on the right shows the stair access to the tribune on the south wall. Photo: author. 


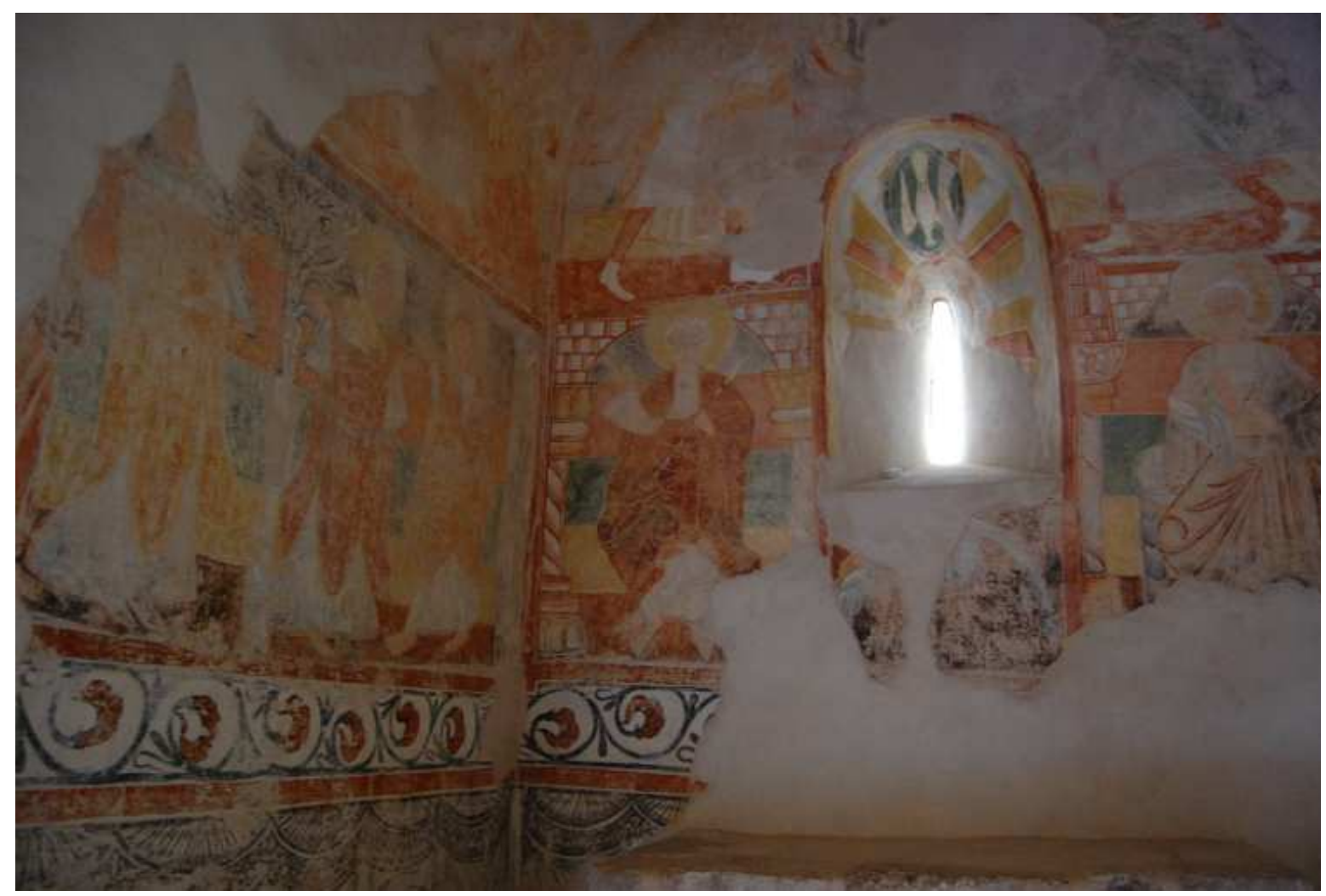

Figure 76: San Baudelio de Berlanga, view of the fragments of in situ images of the Lamb of God, Cain, Abel, Melchizedek, San Baudelio and trompe-l'oeil textiles. Image taken from lafronteradelduero.com 

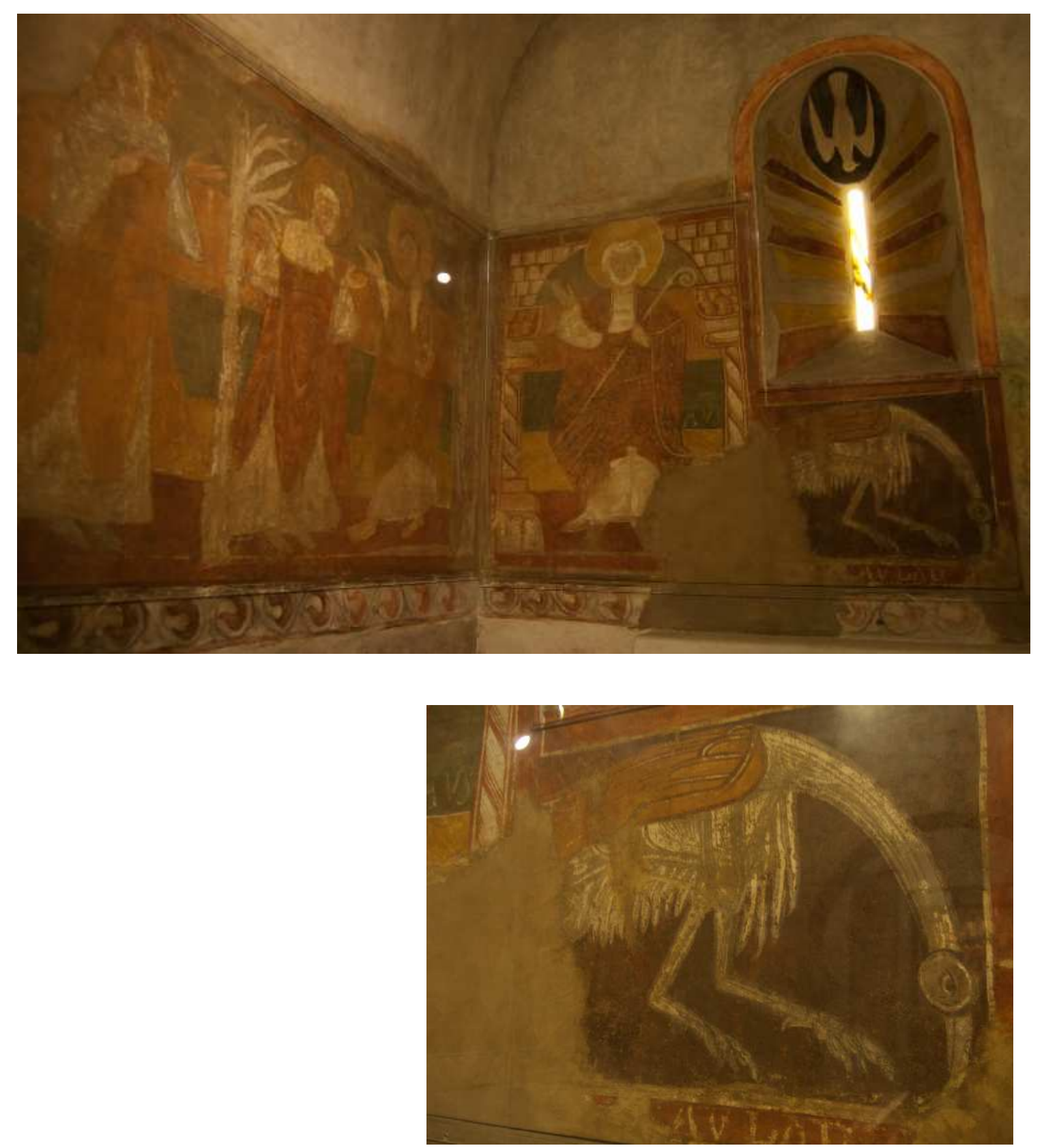

Figure 77: The Cincinnati Art Museum, view of the expoliated frescoes from San Baudelio de Berlanga. These paintings were originally located in the apse and depict from left to right: the Noli me Tangere, Saint Augustine, and an ibis. Detail of the ibis. Photo: author. 


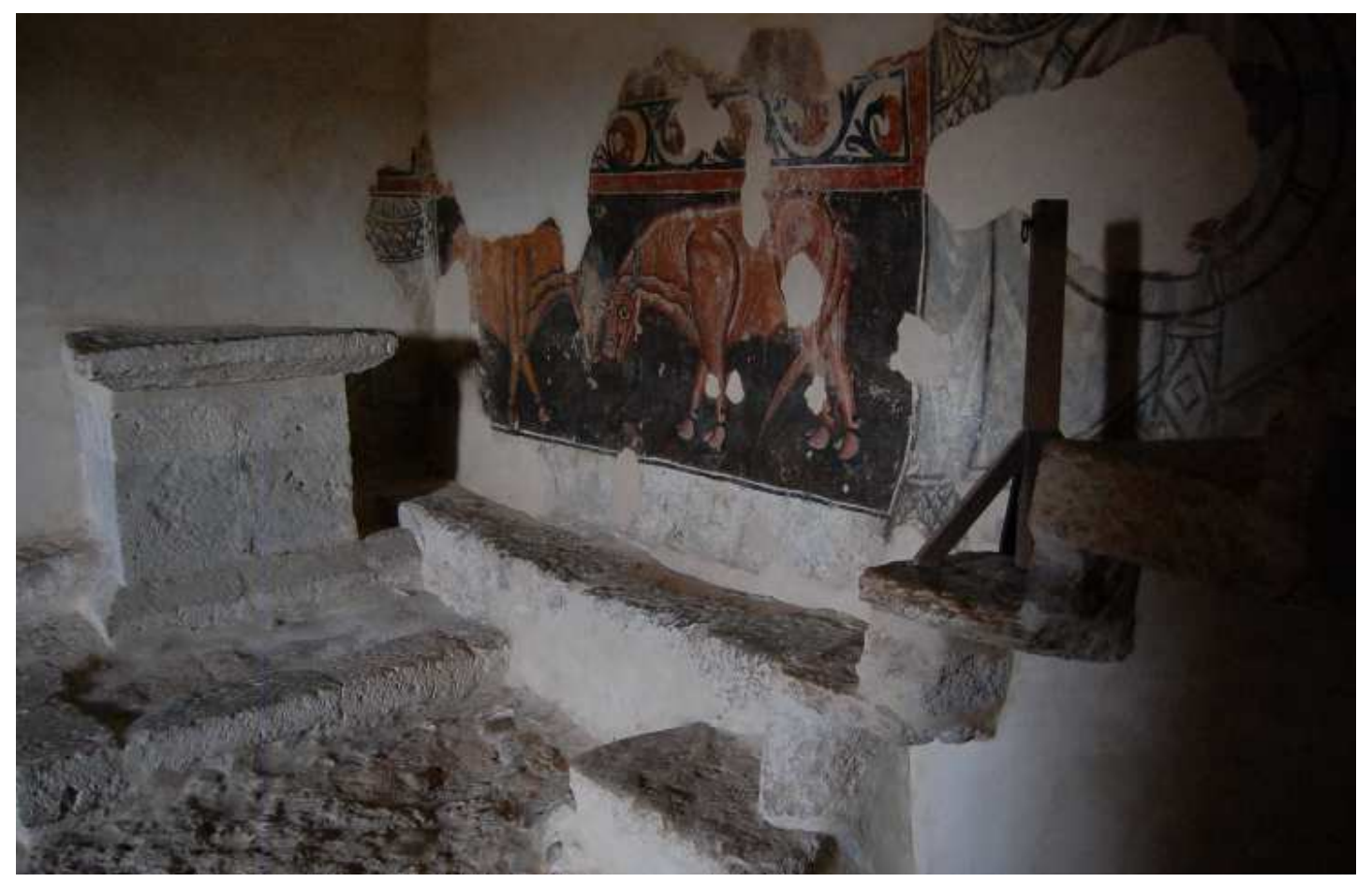

Figure 78: San Baudelio de Berlanga, view of the southeast wall and staircase with painted bulls and trompe l'oeil curtains. Photo: author. 


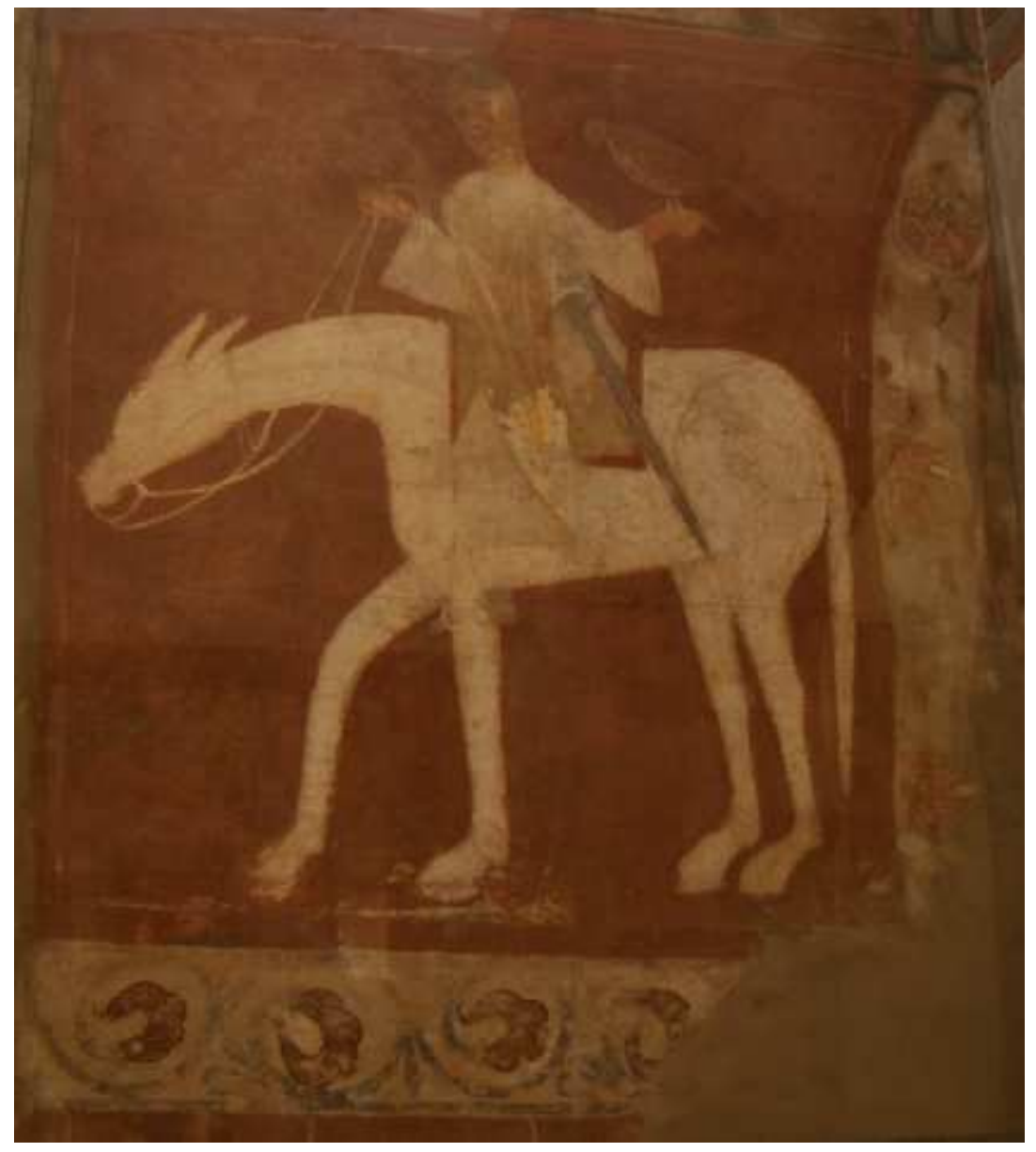

Figure 79: The Cincinnati Museum, view of the expoliated painting from San Baudelio de Berlanga of the falconer. Photo: author. 

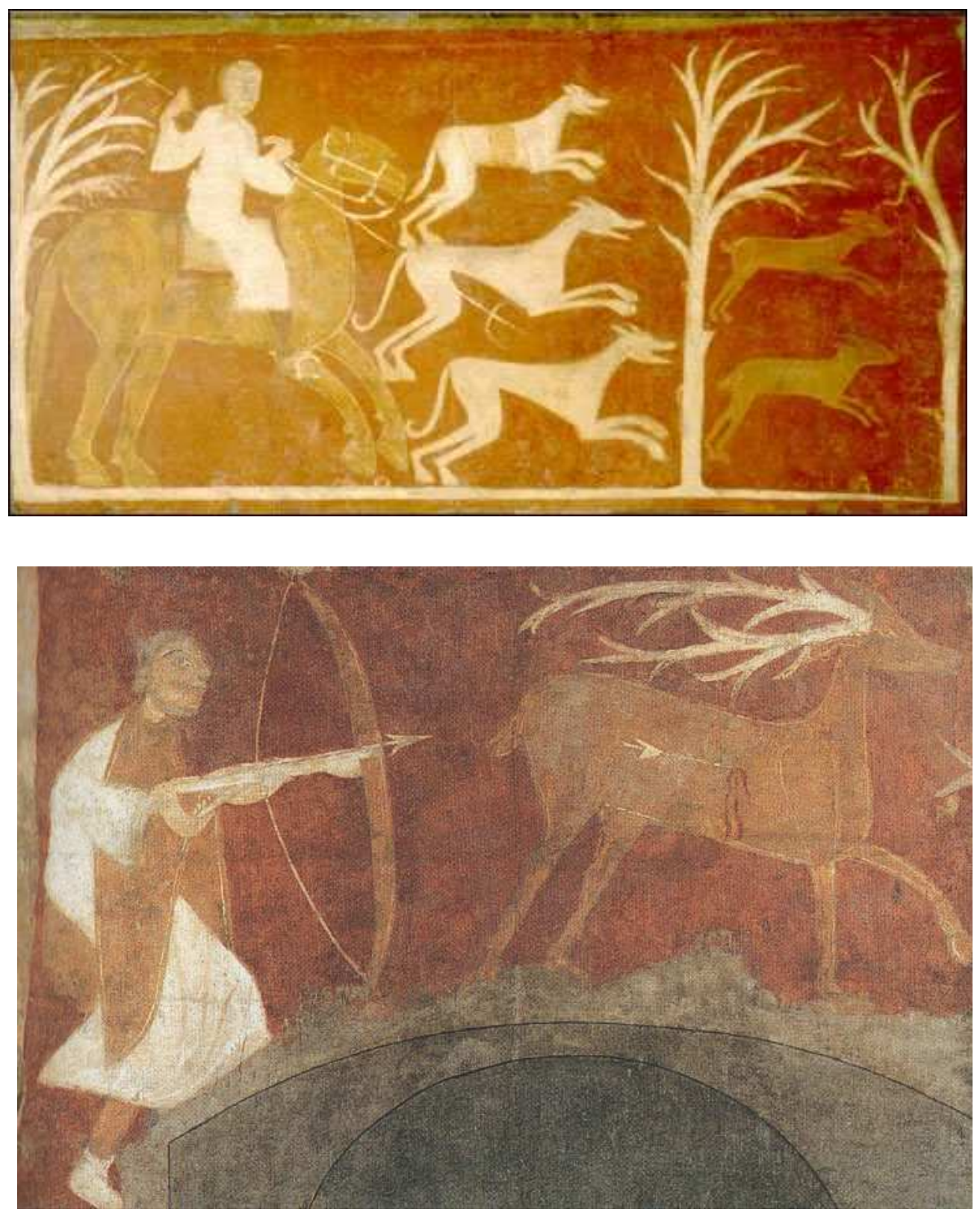

Figure 80: The Prado Museum, view of expoliated paintings from San Baudelio de Berlanga. The upper image is the rabbit hunt and the lower image is the stag hunt, both frescoes were pulled from the northwest wall. Images taken from the museo nacional del Prado website. 

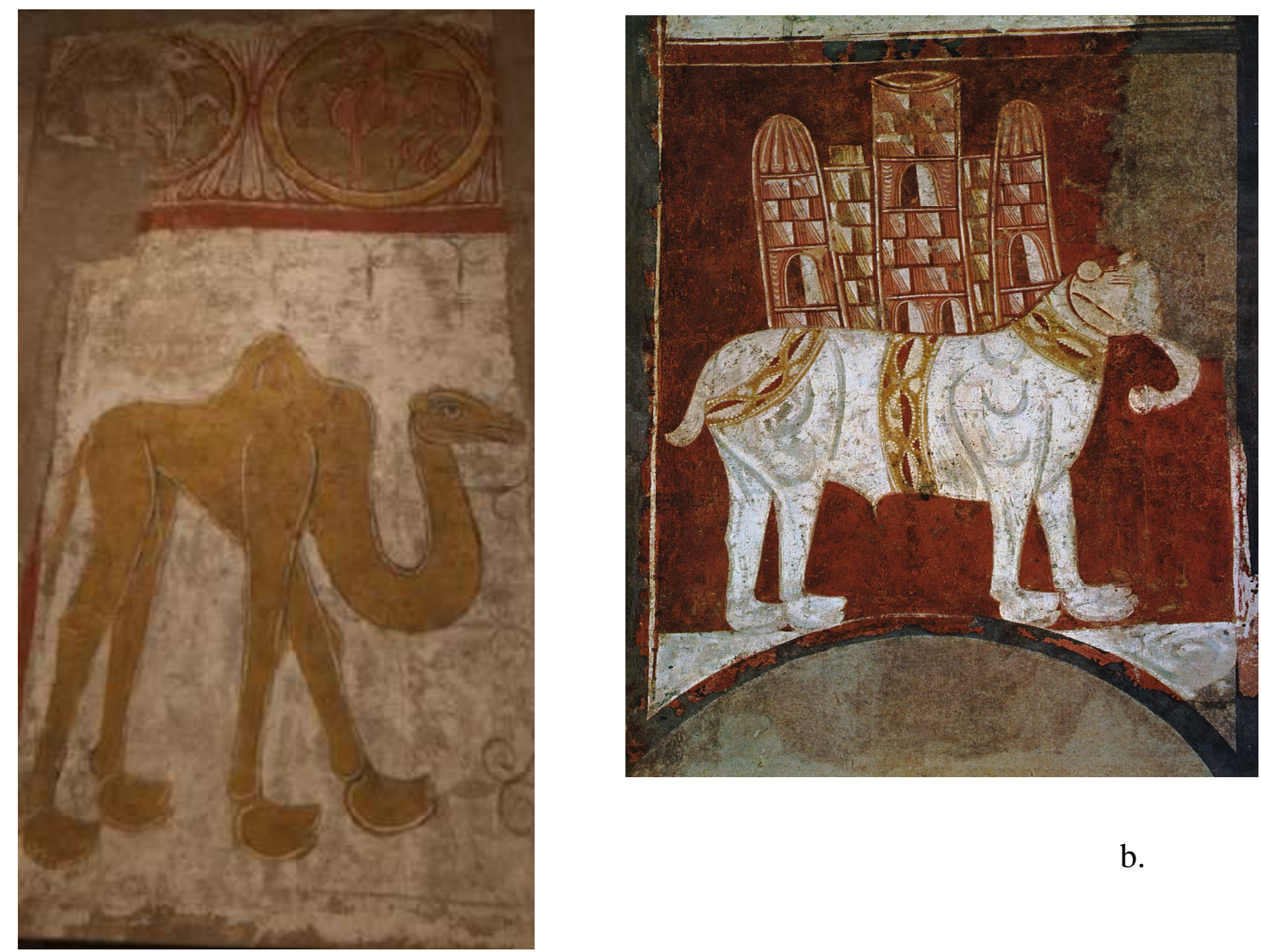

b.

a

Figure 81a: The Metropolitan Museum of Art, the Cloisters, view of the expoliated fresco of the camel. Photo: author.

Figure 81b: The Prado Museum, view of the expoliated fresco of the elephant with the castle on its back. Image taken from the museo nacional del Prado website. 


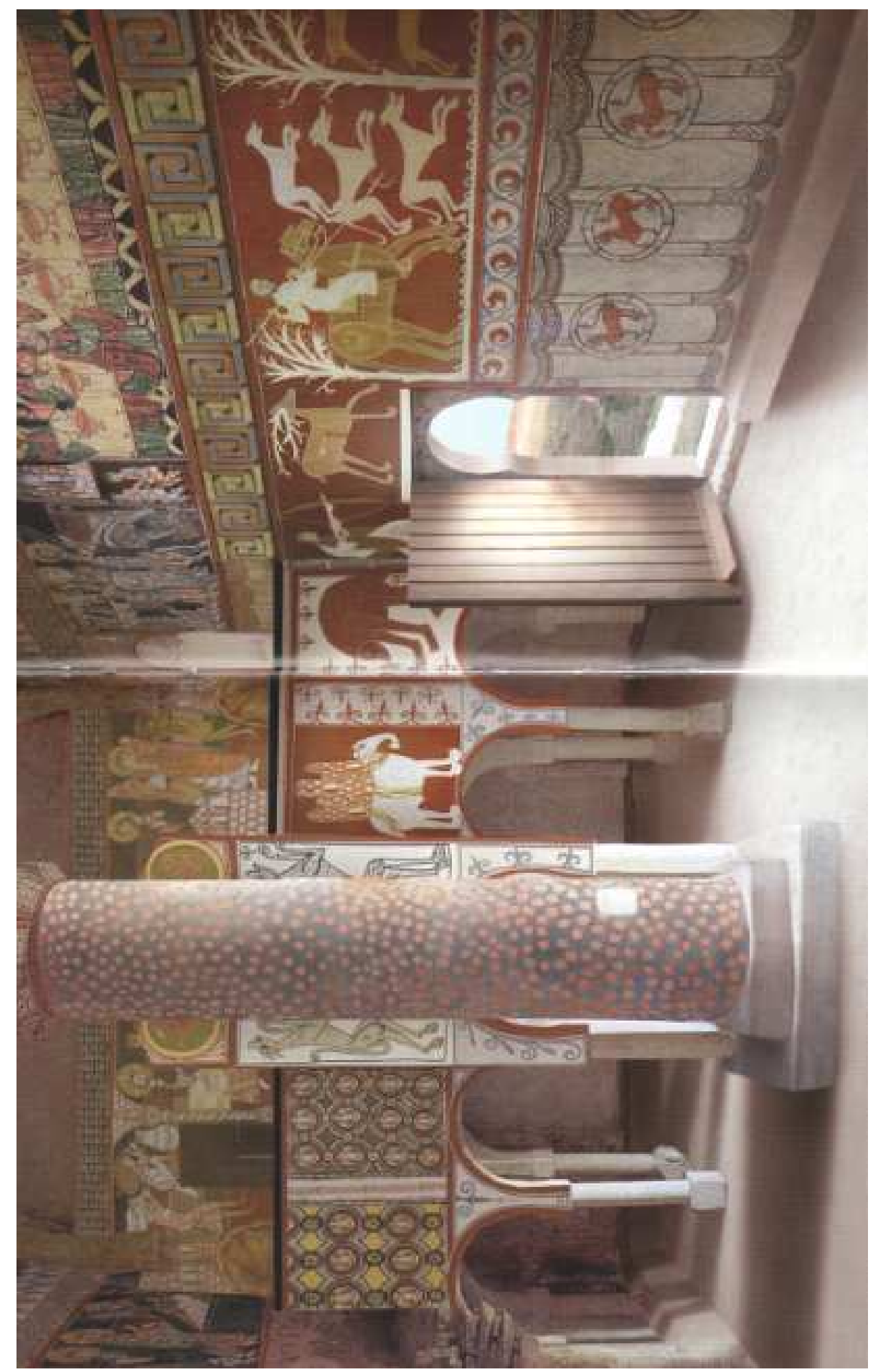

Figure 82: Reconstruction of the original appearance of the painted decoration of San Baudelio de Berlanga. After E. Terés Navarro, El expolio de las pinturas murales de la ermita mozárabe San Baudelio (Casillas de Berlanga, Soria): Ochoa Editores, 2008, 82-83. 


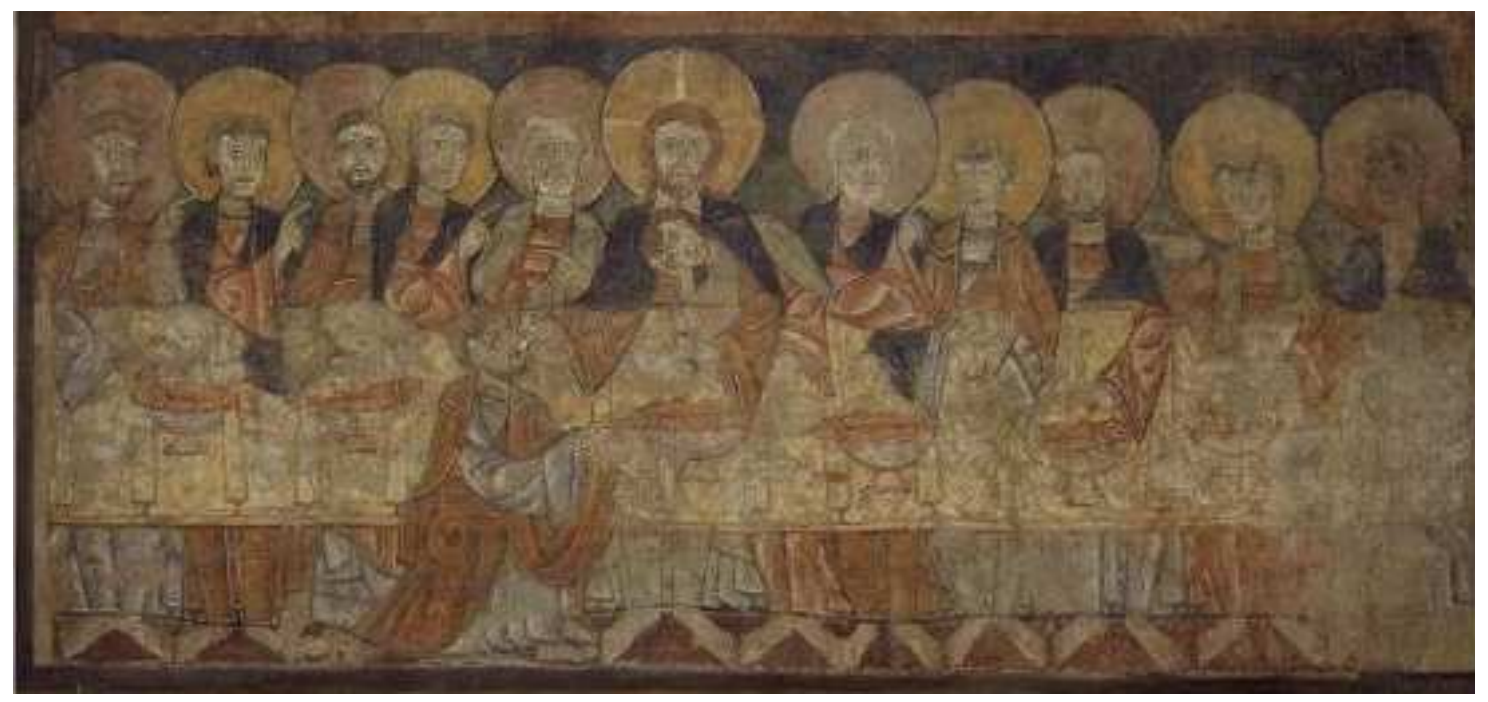

Figure 83: Above, the expoliated fresco of the Last Supper. The image was taken from the website of the Boston Museum of Fine Arts. Below, the expoliated fresco of the Entry into Jerusalem. The image was taken from the website of the Indianapolis Museum of Art.

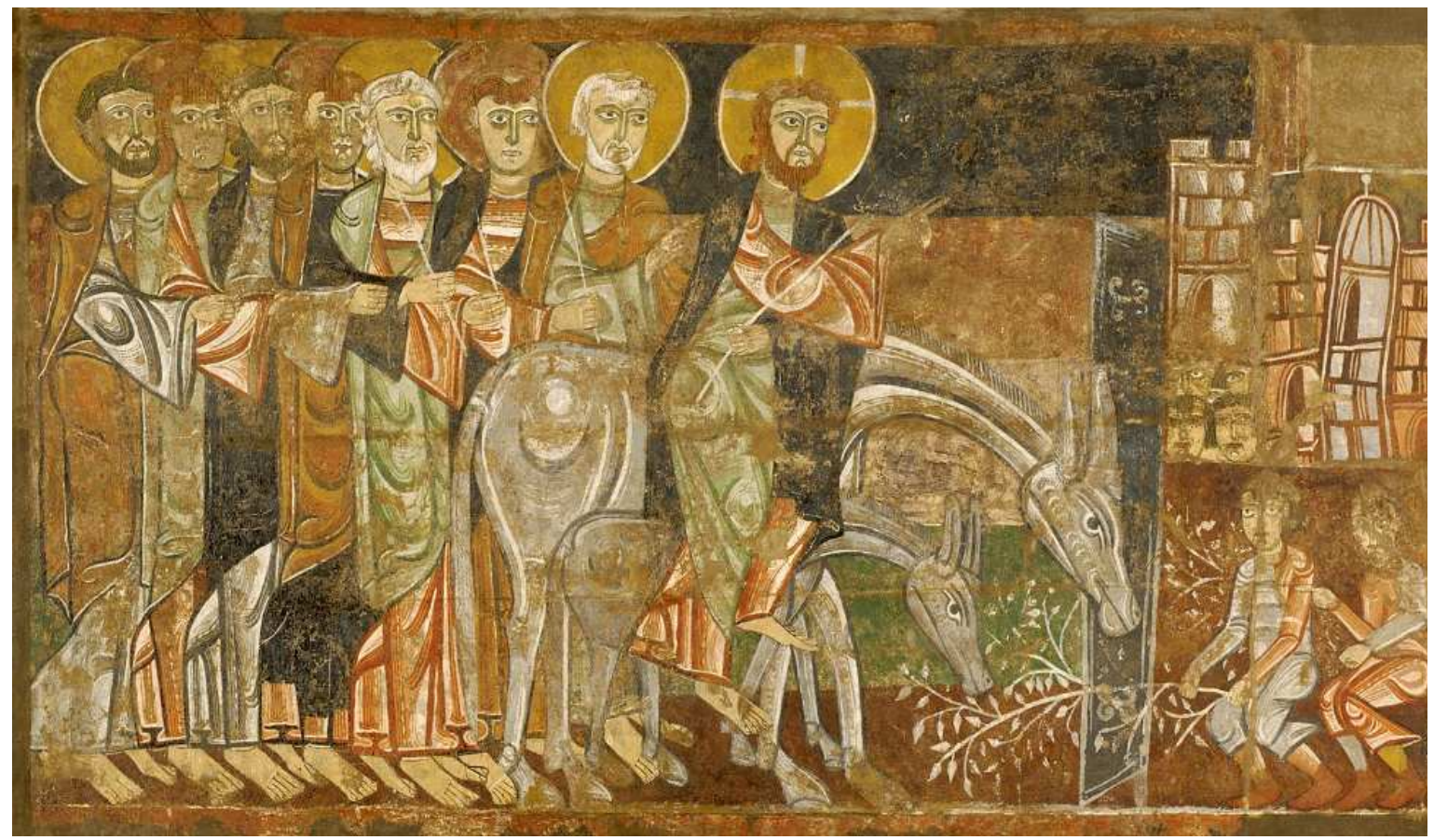




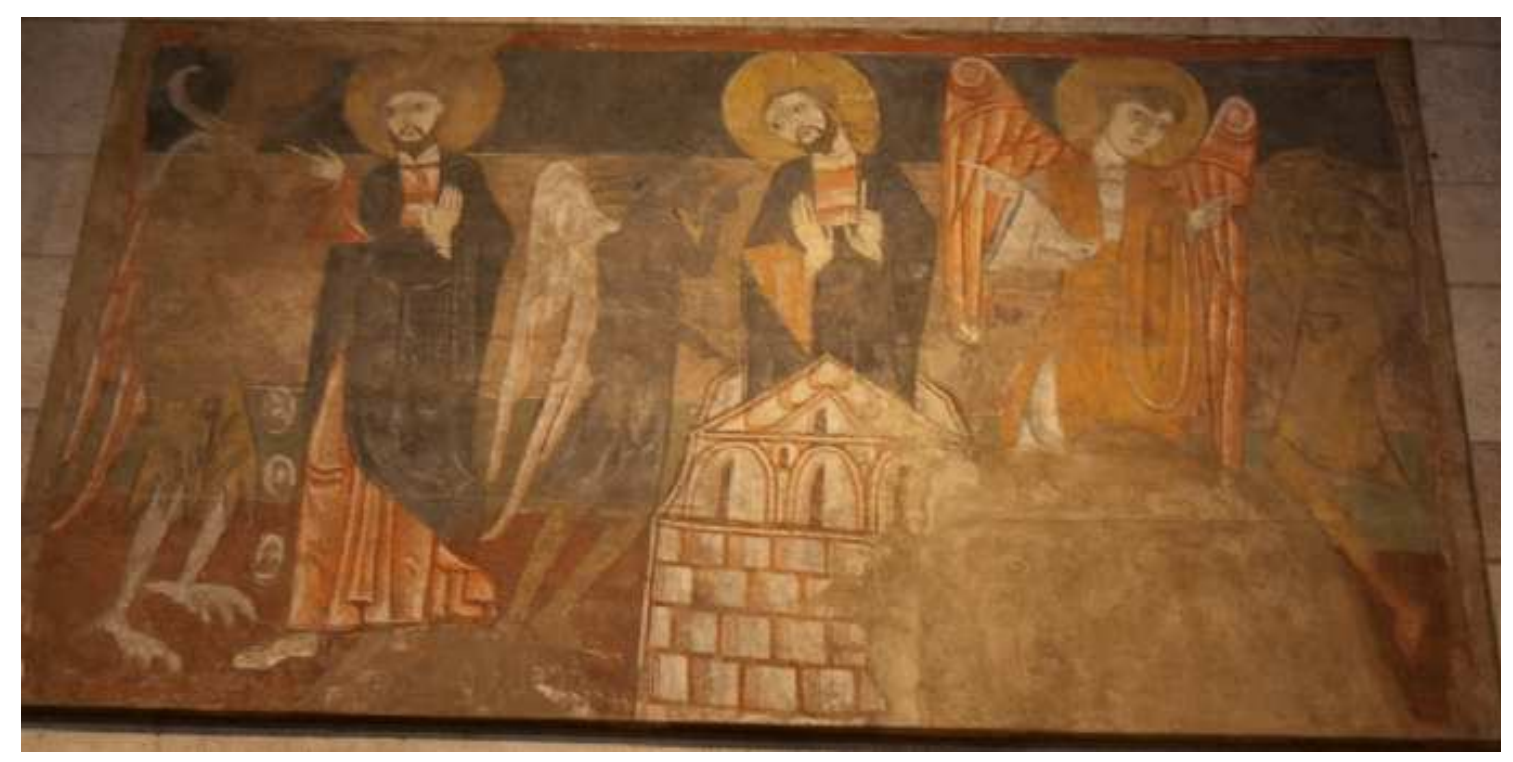

Figure 84: Above, the Cloisters, view of the expoliated fresco of the Temptation of Christ. Photo: author. Below, the expoliated fresco of the Wedding Supper at Cana, the image of which was taken from the Indianapolis Museum of Art's website.

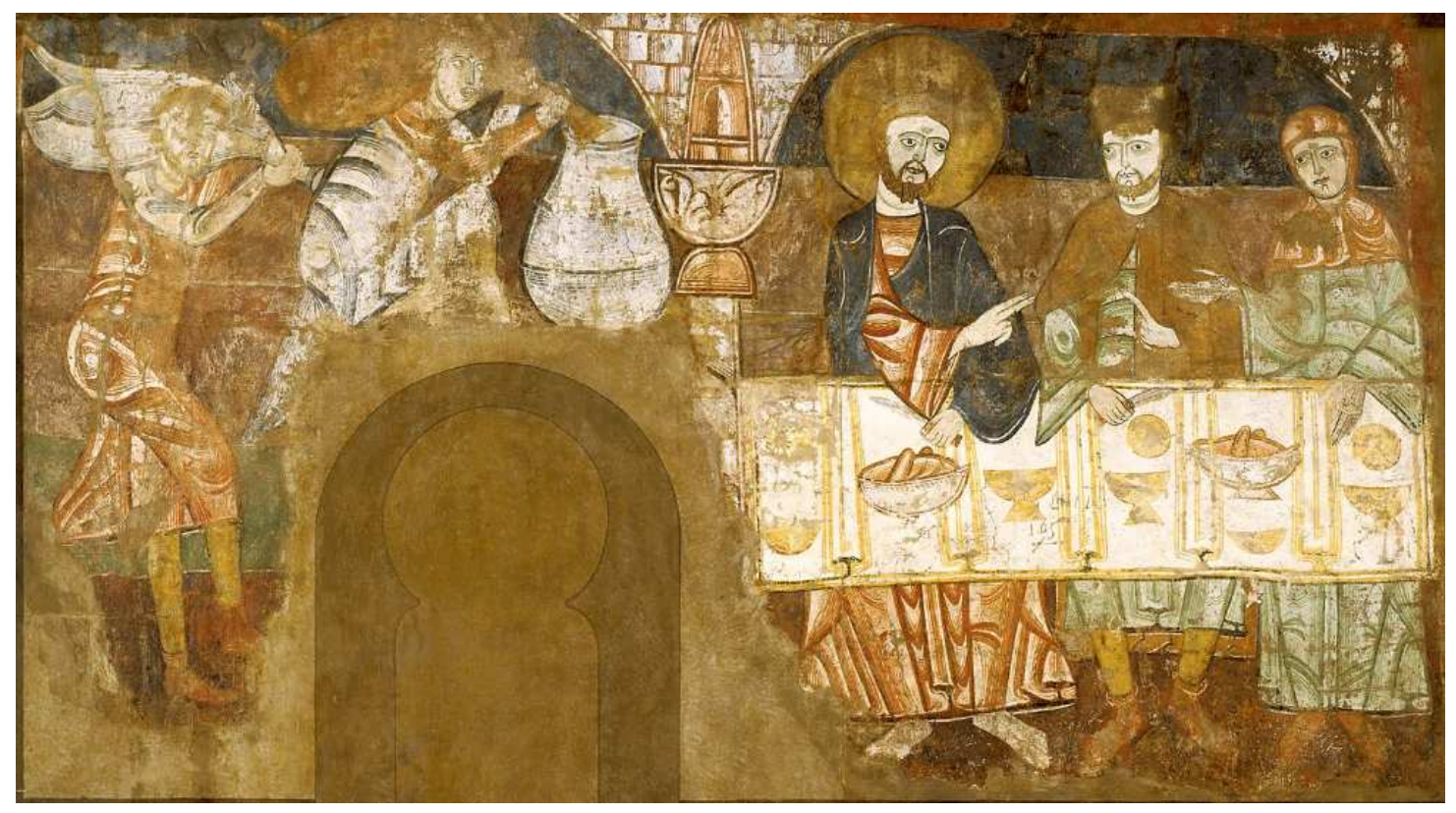




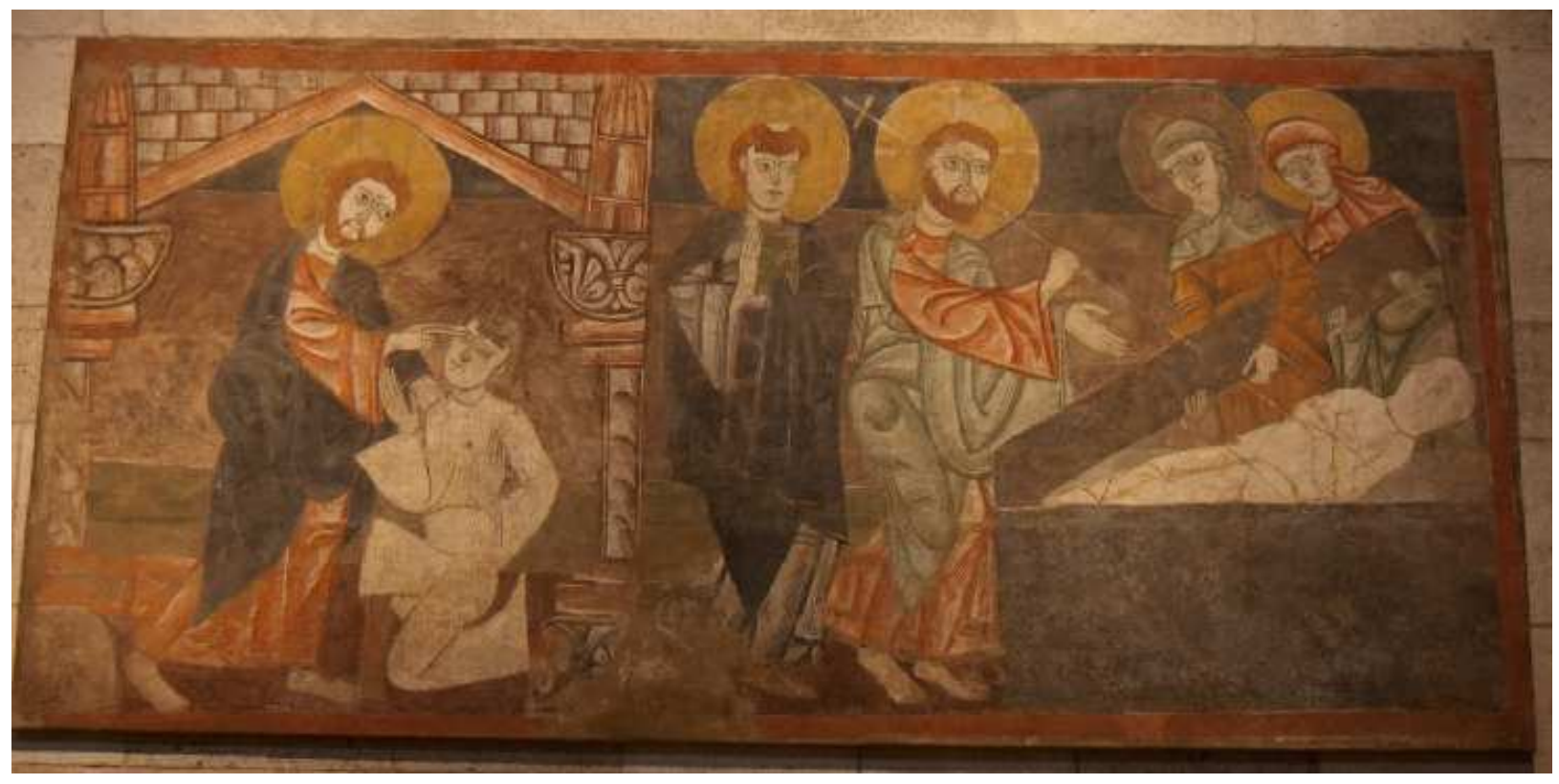

Figure 85: Above, the Cloisters, view of the expoliated fresco of the Resurrection of Lazarus and the Healing of the Blind. Photo: author. Below, expoliated fresco of the Three Marys at the Tomb, the image of which is taken from the website of the Boston Museum of Fine Arts.

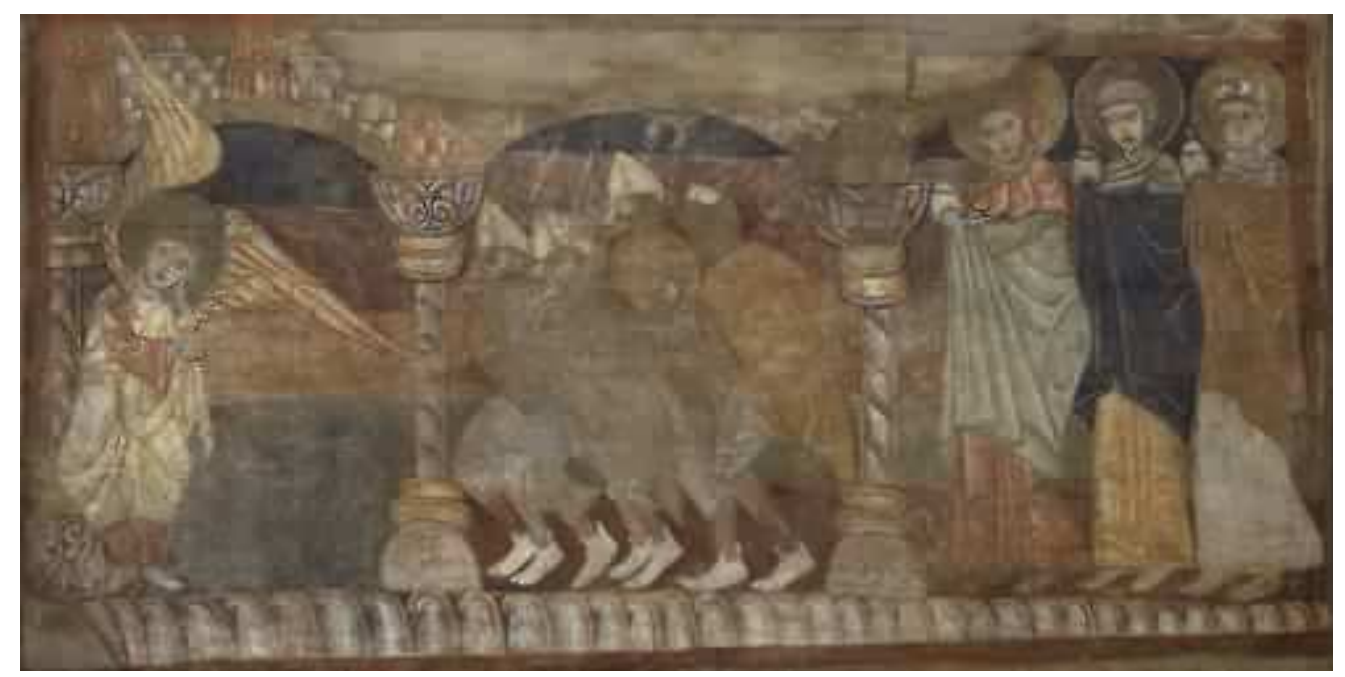




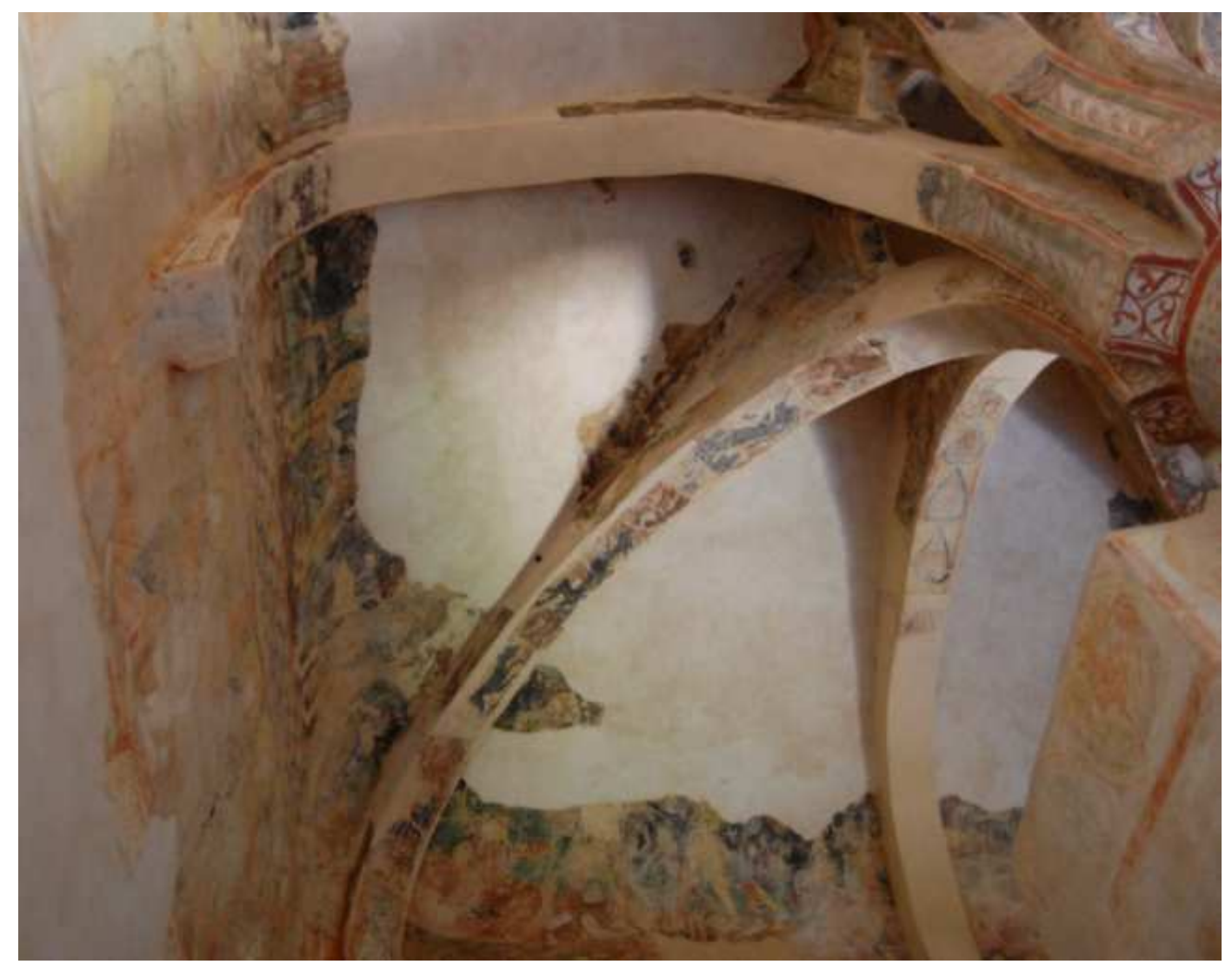

Figure 86: San Baudelio de Berlanga, fragments of the vault painting cycle in situ. Photo: author.

To the right is a diagram of the organization of the vault painting cycle. After Escolano Benito, Guía, 64.

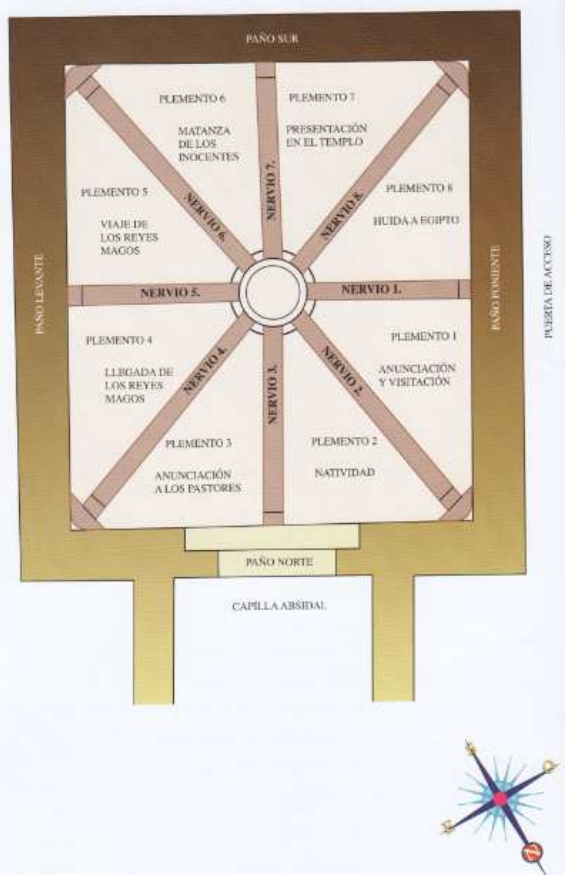



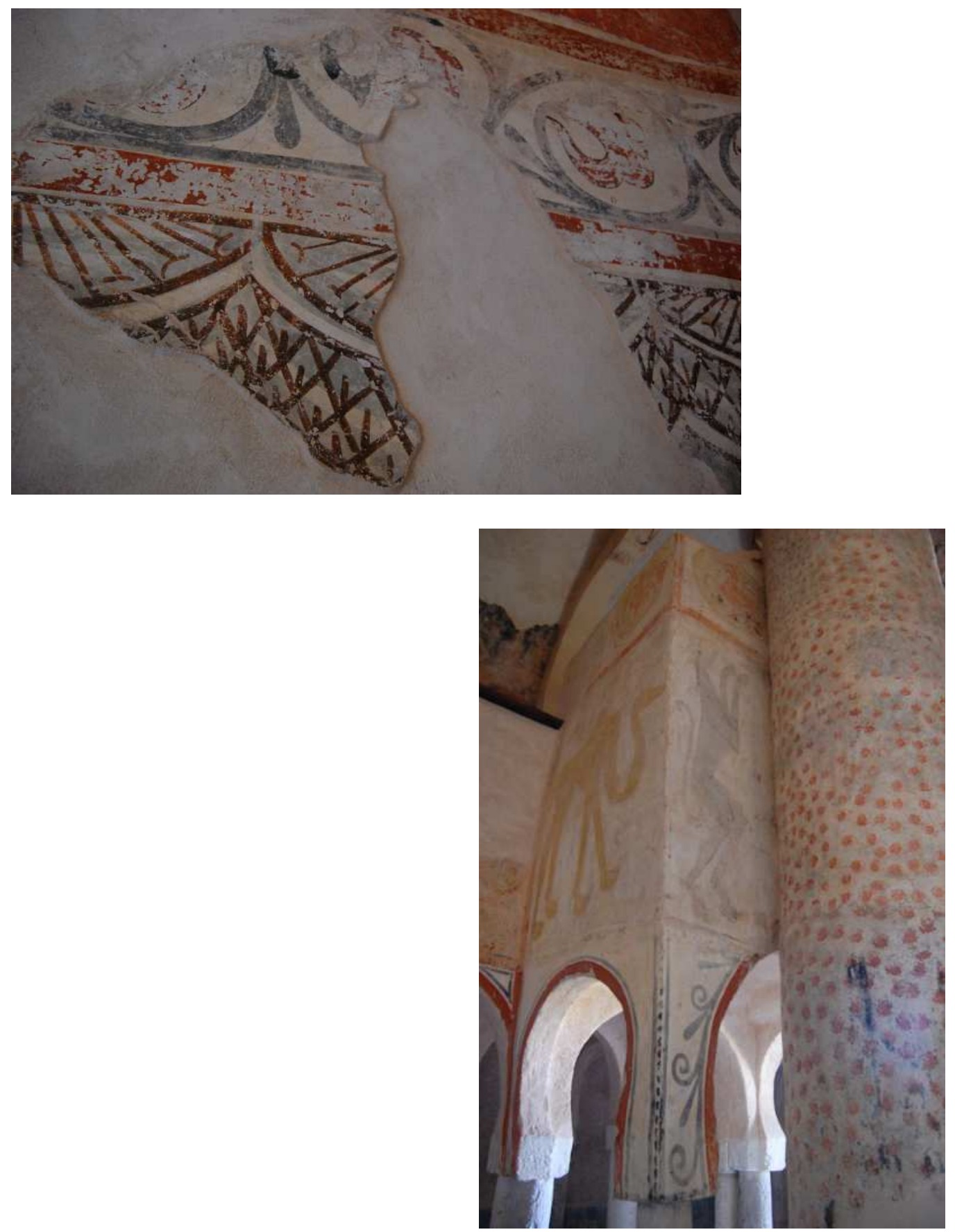

Figure 87: San Baudelio de Berlanga, details of the trompe l'oeil painted fabrics and the painted column in situ. Photo: author. 

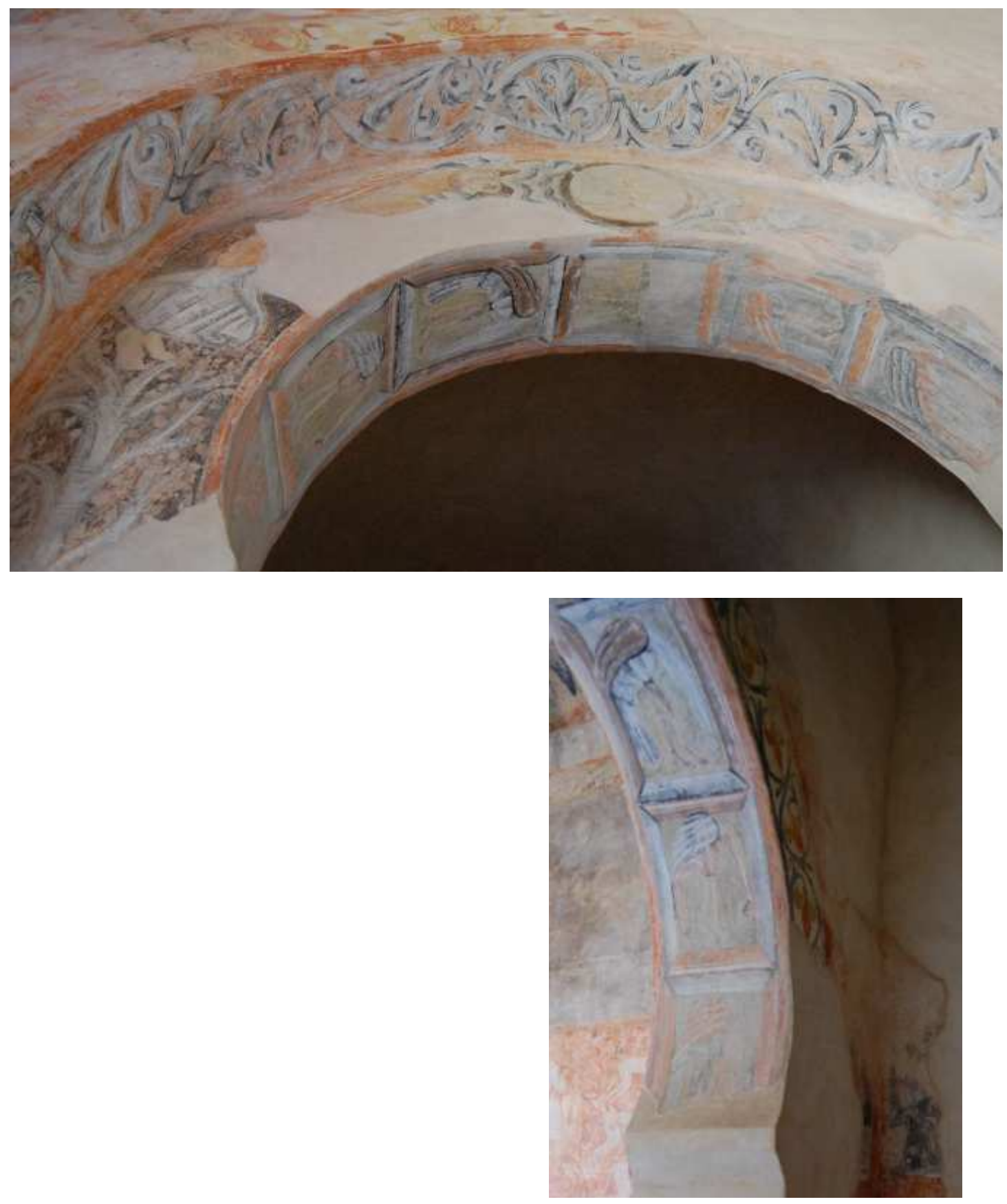

Figure 88: San Baudelio de Berlanga, in situ decoration for the intrados and voissoirs of the triumphal arch between the nave and the apse.

Photo: author. 


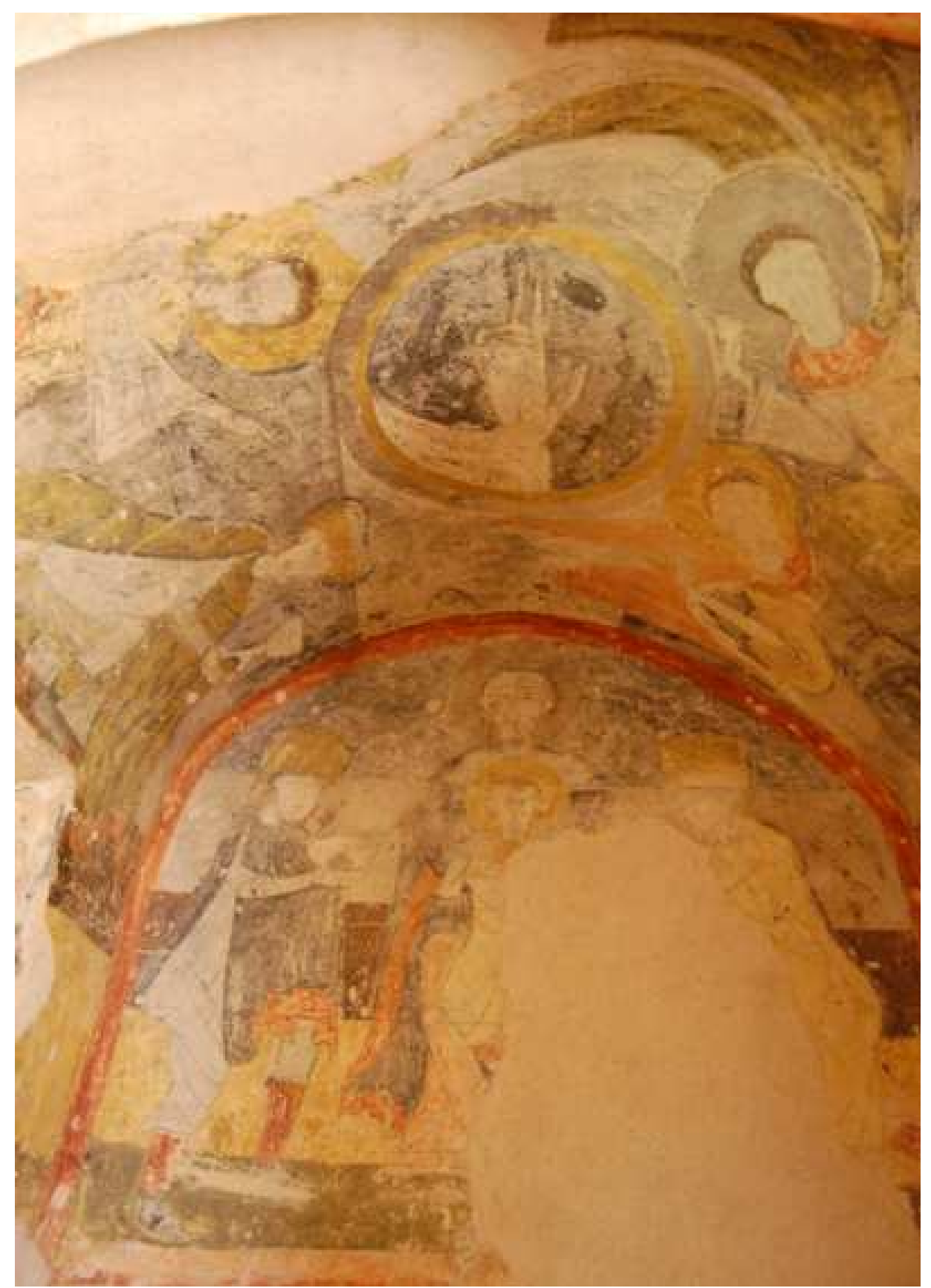

Figure 89: San Baudelio de Berlanga, tribune coro, painted decoration of the Virgin with Christ, and the adoration of the Magi. Photo: author. 

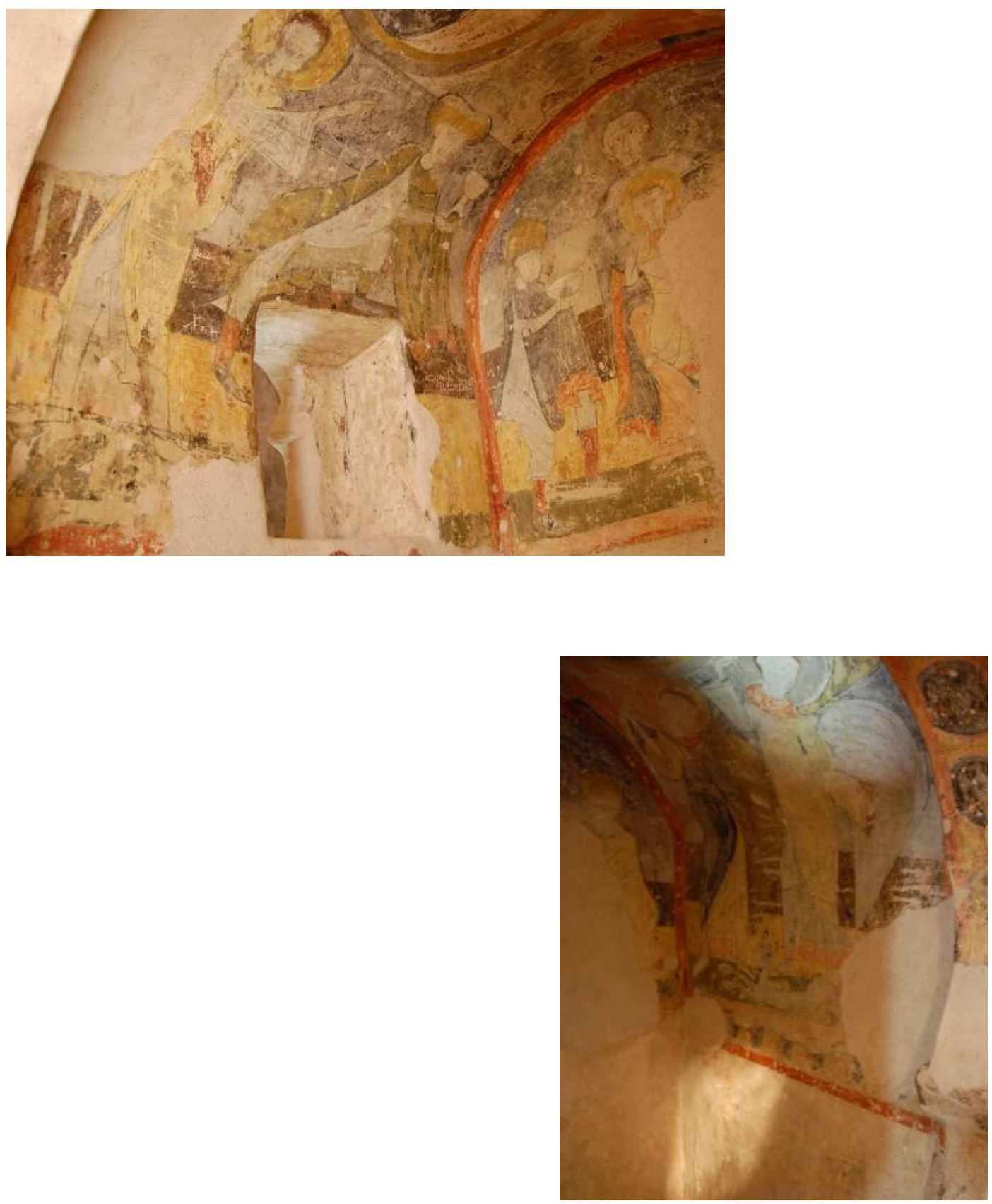

Figure 90: San Baudelio de Berlanga, tribune coro, painted details of the Magi and the angels. Photo: author. 


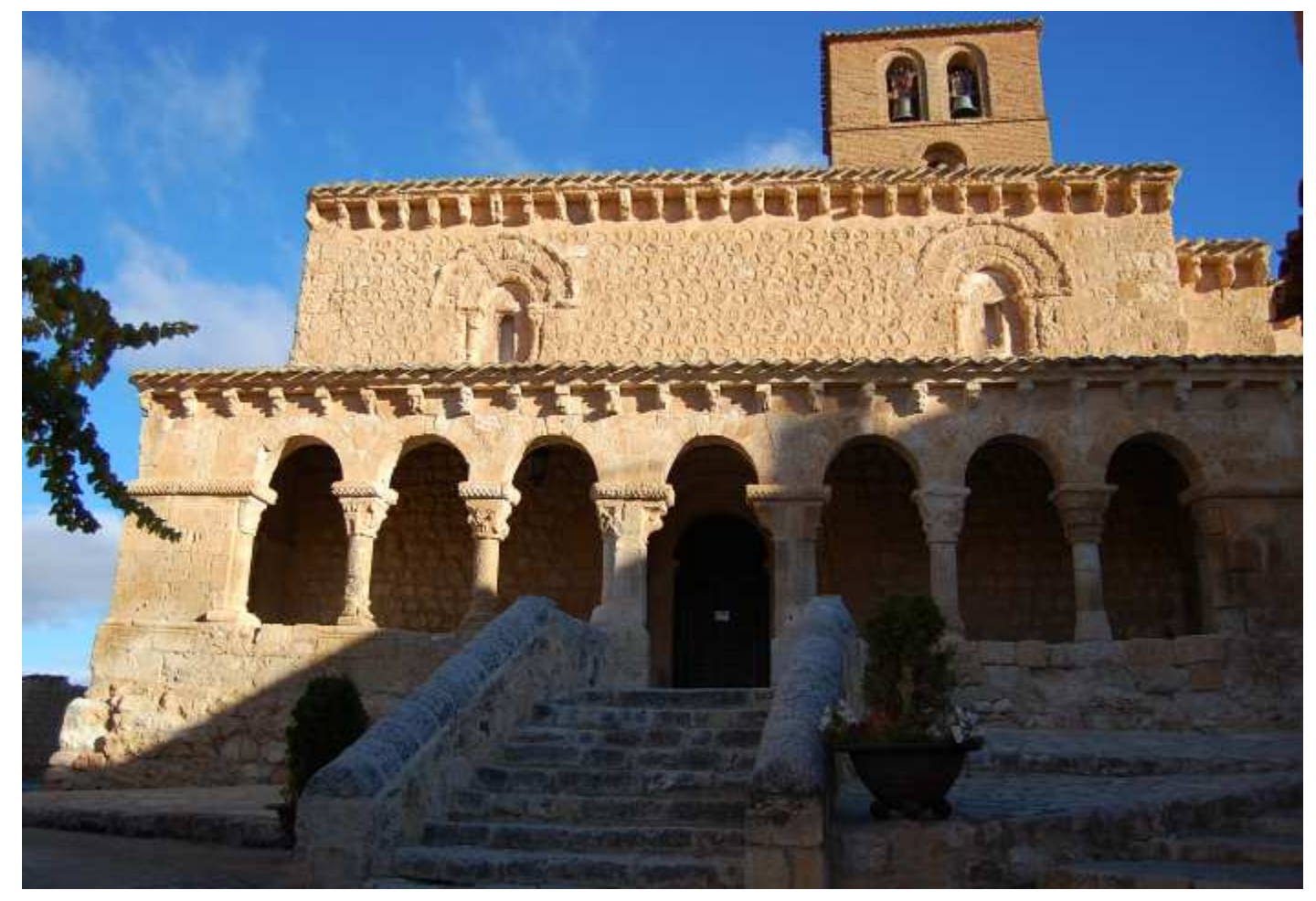

Figure 91: San Miguel de San Esteban de Gormaz (Soria). Photo: author. 


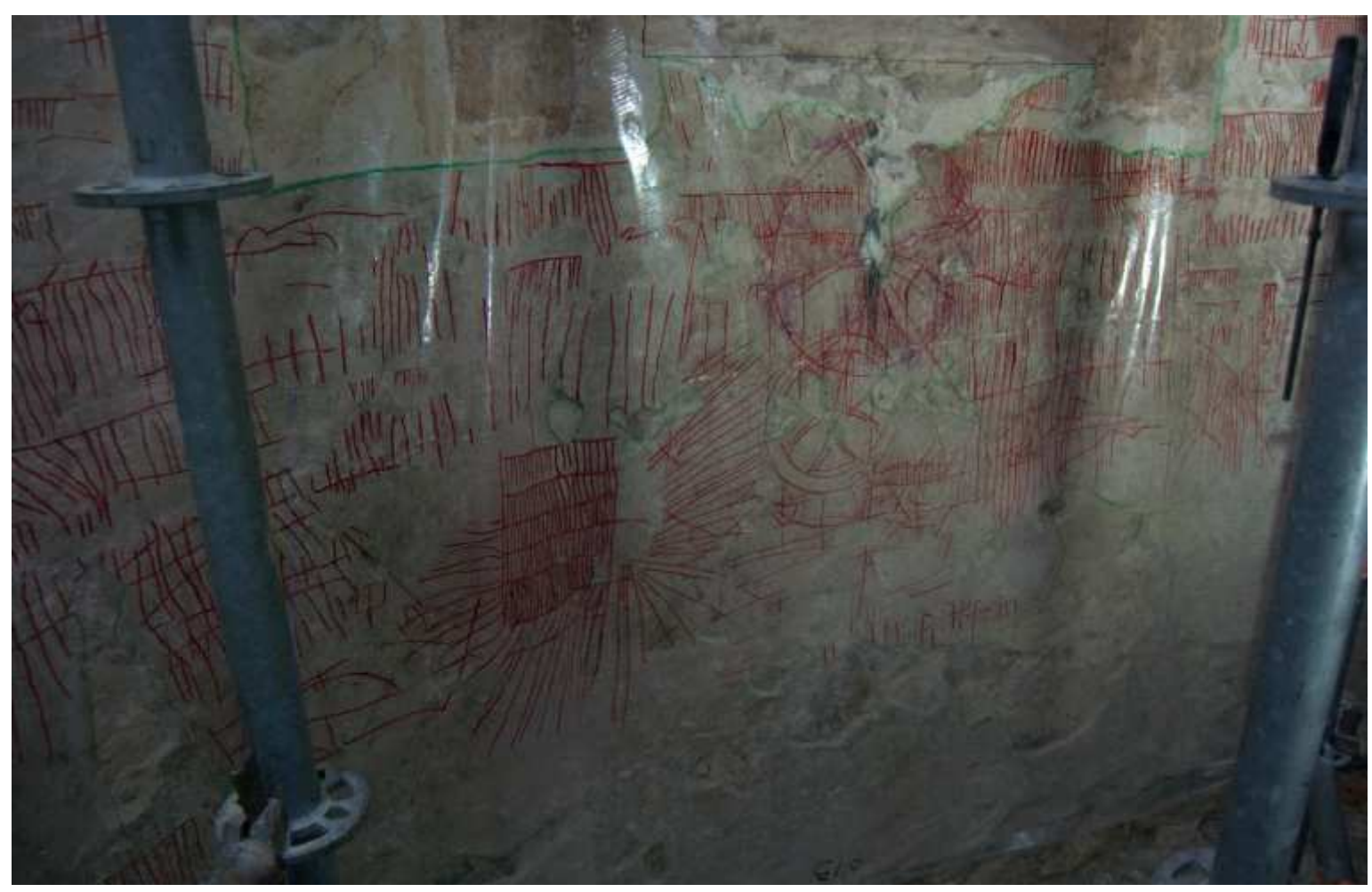

Figure 92: San Miguel de San Esteban de Gormaz. Above, examples of the numerous groups of "counting marks"; below left, the recovery of the outline of a warrior, below right, traces of a falconer.
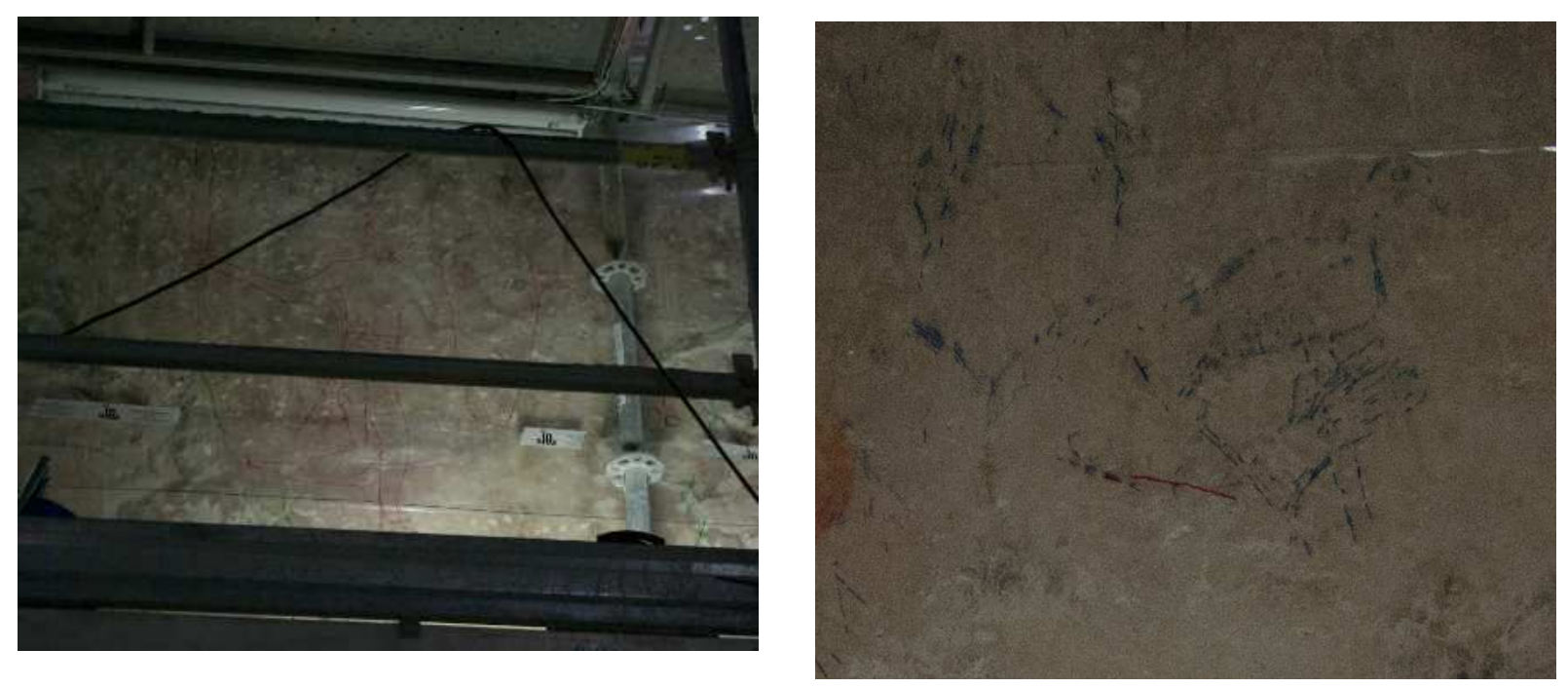


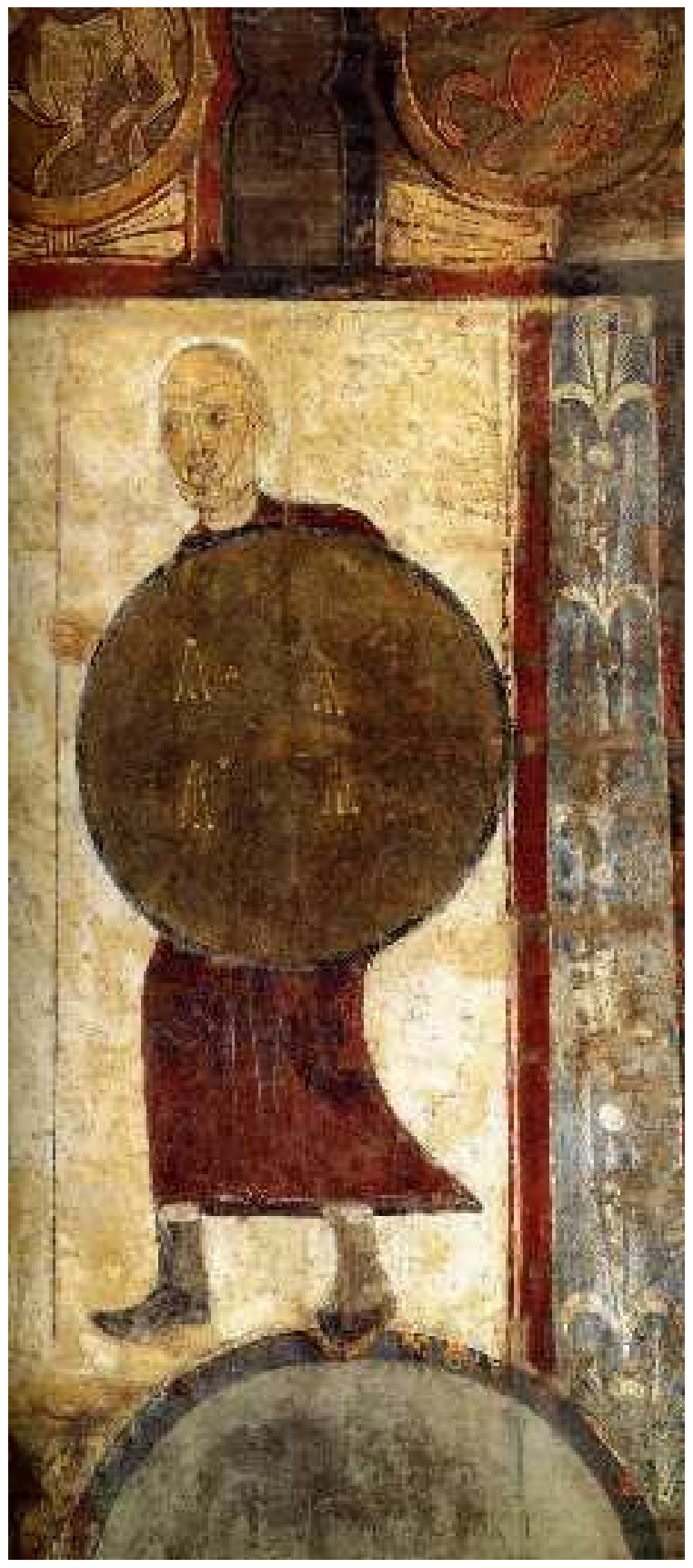

Figure 93: Museo nacional del Prado, expoliated fresco of the soldier, originally located on the tribune at San Baudelio de Berlanga. The image is from the museum's website 

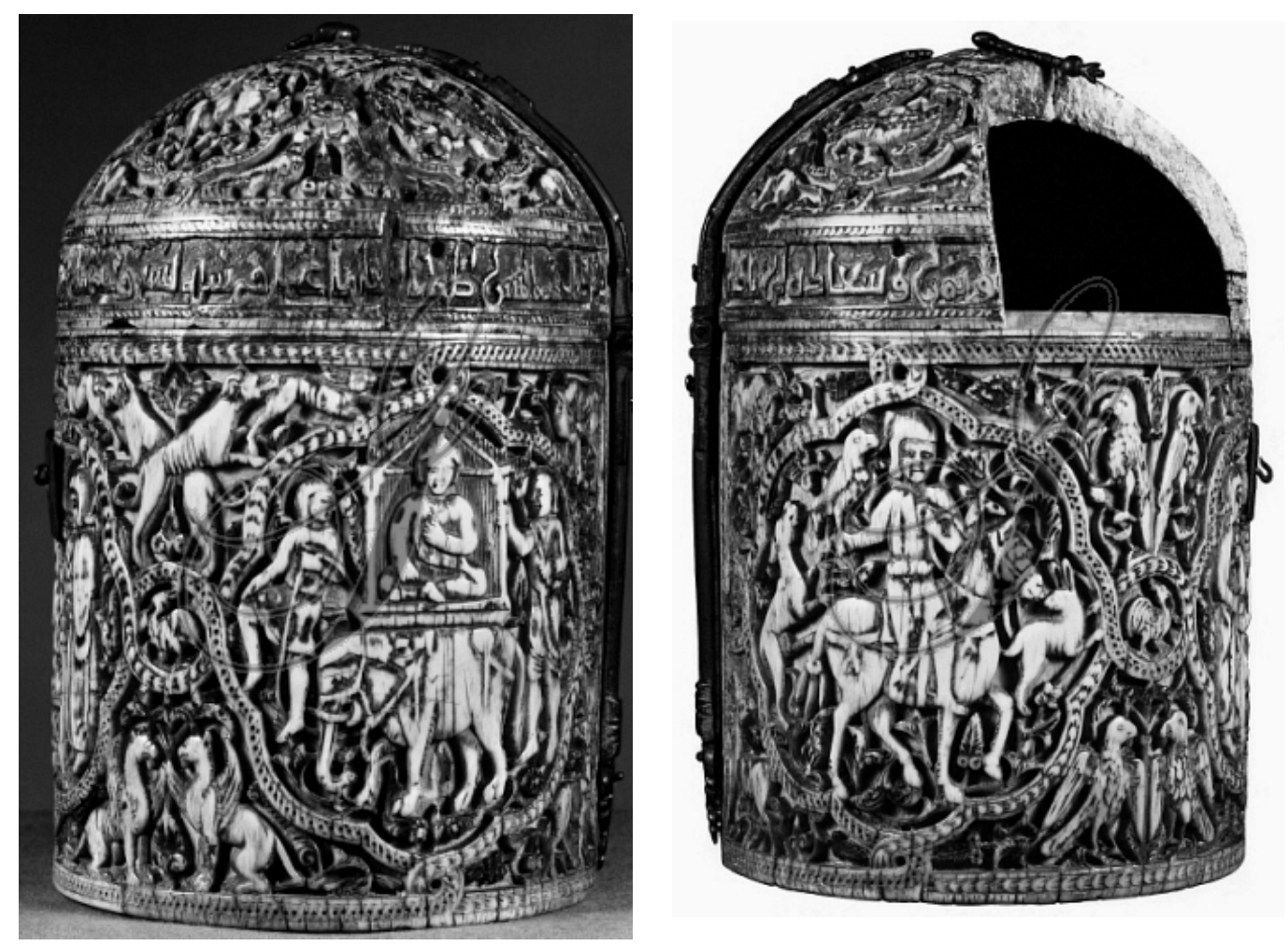

Figure 94: A tenth-century ivory vessel made for a Muslim judge (qadi), with elephant and falconer motifs similar to those found at San Baudelio de Berlanga. After, the Granger Collection, see

http://www.granger.com/searchresults.asp?txtkeys1=Ivory 


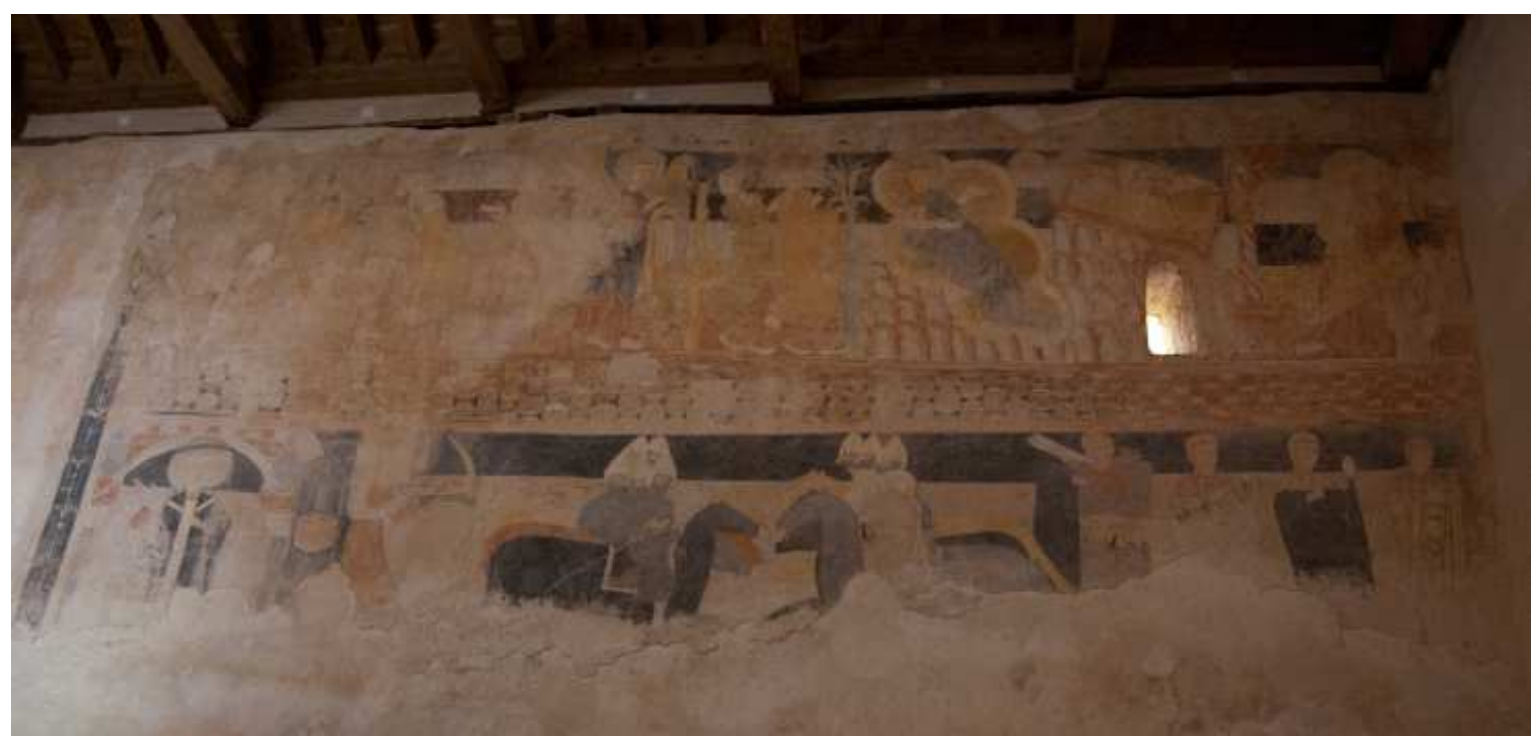

Figure 95: San Miguel de Gormaz, the fresco paintings of the north wall of the nave. 


\section{REFERENCES}

“Cartulario de San Millán de la Cogolla.” (Madrid: L. Serrano, 1930).

"Chronica Adefonsi Imperatoris." In The World of El Cid: Chronicles of the Spanish Reconquest, edited by Simon Barton and Richard Fletcher, 162-263. Manchester; New York: Manchester University Press, 2000.

“Chronicle of Alfonso III." In Conquerors and Chroniclers of Early Medieval Spain, edited by Kenneth Baxter Wolf, 161-78. Liverpool: Liverpool University Press, 1999.

The Chronicle of San Juan De La Peña; a Fourteenth-Century Official History of the Crown of Aragon. Translated by Lynn H. Nelson. Philadelphia: University of Pennsylvania Press, 1991.

Conquerors and Chroniclers of Early Medieval Spain. Translated by Kenneth Baxter Wolf. $2^{\text {nd }}$ ed. Liverpool: Liverpool University Press, 1999.

“Historia Silense.” In The World of El Cid: Chronicles of the Spanish Reconquest, edited by Simon Barton and Richard Fletcher, 24-64. Manchester: New York: Manchester University Press, 2000.

The Poem of the Cid, Translated by Rita Hamilton and Janet Perry. London: Penguin Books, 1975. 
Crónica de Alfonso III. Translated by Antonio Ubieto Arteta. Valencia: Universidad de Valencia, 1971.

Abel, Mickey. "Strategic Domain: Reconquest Romanesque along the Duero in Soria, Spain.” Peregrinations, International Society for the Study of Pilgrimage Art 2, no. 2 (2007): 1-57.

Abulafia, David. "Introduction: Seven Types of Ambiguity, c. 1100-c.1500.” In Medieval Frontiers: Concepts and Practices, edited by David Abulafia and Nora Berend. Aldershot, England; Burlington, VT: Ashgate, 2002.

Abulafia, David, and Nora Berend, eds. Medieval Frontiers: Concepts and Practices. Aldershot, England; Burlington, Vermont: Ashgate, 2002.

Adams, Philip R. "Mural Paintings from the Hermitage of San Baudelio de Berlanga, Province of Soria, Spain.” The Cincinnati Art Museum Bulletin 7, no. 2 (1963): 211.

Agudo, María de los Ángeles Utrero. "Late-Antique and Early Medieval Hispanic Churches and the Archaeology of Architecture: Revisions and Reinterpretation of Constructions, Chronologies and Contexts." Medieval Archaeology 54, no. 1 (2010): 1-33.

Alfonso, Isabel. "Judicial Rhetoric and Political Legitimation in Medieval León-Castile." In Building Legitimacy; Political Discourses and Forms of Legitimacy in Medieval Societies, edited by Isabel Alfonso, Hugh Kennedy and Julio Escalona, 51-87. Leiden; Boston: Brill, 2004.

Almagro, Antonio. "La puerta califal del castillo de Gormaz.” Arqueología de la Arquitectura 5 (enero-diciembre, 2008): 55-77. 
Alonso Álvarez, Raquel. "El monasterio de San Salvador de cornellana y el patrocinio nobilario: de la iglesia propia a la dependencia de Cluny.” In Imágenes y promotores en el arte medieval. miscelánea en homenaje a Joaquín Yarza Luaces, 45-57. Bellaterra: Universitat Autónoma de Barcelona Servei de Publicacions, 2001.

_ _ "Hornija, Bamba, Pampliega: las elecciones funerarias de los reyes hispanovisigodos.” Territorio, Sociedad, y Poder 3 (2008): 13-27.

__ "Los enterramientos de los reyes de León y Castilla hasta Sancho IV." e-Spania 3 (2007):13-27.

Alonso Matthias, Fernán, Luis Caballero Zoreda, and Eduardo Rodríguez Trobajo. "Cronología constructiva de la iglesia mozárabe de S. Baudelio de Berlanga (Soria): Primeros resultados de dendrocronología y carbono-14.” Boletín de arqueología medieval 11 (1997): 249-64.

Altschul, Nadia R. "The Future of Postcolonial Approaches to Medieval Iberian Studies.” Journal of Medieval Iberian Studies 1, no. 1 (2009): 5-17.

Álvarez Martínez, M. $\square$ Soledad. “Consideraciones en torno al templo prerrománico de San Salvador de Valdediós." LIÑO; Revista Anual de Historia del Arte 12 (2006): $9-29$.

Alvarez Villar, J. "Precisiones sobre San Baudel de Berlanga (Soria)." España entre el Mediterráneo y el Atlántico (1975): 275-79.

Andrio Gonzalo, J., E. Martín Rivas, and Philippe du Souich. "La necrópolis medieval de San Millán de la Cogolla de Suso (La Rioja).” Berceo 130 (1996): 49-106.

Anibal Alvarez, Manuel, and José Ramón Mélida. "Un momument desconocido. La 
ermita de San Baudelio en término de Casillas de Berlanga.” Boletín de la Sociedad Española de Excursiones (1907).

Araguas, Philippe. "Mozarabes et Lombards: les chateaux du premier art Roman en Aragon et Catalogne." In Actas del I Congresso de Castellología Ibérica; 14 a 17 de Septiembre de 1994, edited by Philippe Araguas, 15-32. Palencia: Diputación Provincial de Palencia, 1998.

Arbeiter, Achim. "Chapas decoradas de un posible relicario altomedieval Riojano." In Arte medieval en la Rioja: prerrománico y románico. VIII Jornadas de arte y patrimonio regional. edited by Ignacio Gil-Díez Usandizaga, 95-108. Logroño: Instituto Estudios Riojanos, 2004.

Arias Paramo, Lorenzo. “Geometría y proporción en la arquitectura prerrománica Asturiana.” In Actas del III Congresso de Arqueología Medieval Español. Oviedo: Universidad de Oviedo, 1992.

Arnáiz Alonso, Benito. "En clave románica: Las pinturas murales de San Miguel del Gormaz (Soria).” Arevacon: Revista Cultural, Asociación de Amigos del Museo Numantino 29 (2009): 28-48.

Arriaza, Armand. "The Castilian bourgeoisie and the caballeros villanos in the concejo before 1300: A revisionist view." The Hispanic American Historical Review 63, no. 3 (1983): 517-36

Aurell, Jaume. "A Secret Realm: Current Trends in Spanish Medieval Studies.” Journal of English and Germanic Philology 105, no. 1 (2006): 61-86.

Azuar Ruiz, Rafael. "Las técnicas constructivas en al-Andalus. El origen de la sillería y 
del hormigón de tapial." In $V$ Semana de Estudios Medievales, Nájera, 1 al 5 de Agosto de 1994, 125-42. Logroño, Instituto de Estudios Riojanos, 1995.

Bango Torviso, Isidoro. "El espacio para enterramientos privilegiados en la arquitectura medieval Española." Anuario del Departamento de Historia y Teoría del Arte IV (1992): 93-132.

—. "El neovisigotismo artístico de los siglos IX y X; la restauración de ciudades y templos." Revista de Ideas Estéticas 148 (1979): 319-38.

Bango Torviso, Isidro Gonzalo. “Arquitectura de la decima centuria: Repoblación o mozarabe?" Goya: Revista de Arte 122 (1974): 68-75.

Banks, P. and J. Zozaya. "Excavaciones en San Baudelio de Casillas de Berlanga (Soria)." Noticiario Arqueológico Hispánico 16 (1983): 383-440.

Banks, P. J., and J. Zozoya. "Excavations in the Caliphal Fortress of Gormaz (Soria), 1979-1981: A Summary.” In Papers in Iberian Archaeology, edited by T. F. C. Blagg, R. F. J. Jones, and S. J. Keay, 674-703. Oxford, 1984.

Barber, Richard W. Holy Grail: Imagination and Belief. Cambridge, MA: Harvard University Press, 2004.

Bartlett, Robert. The Making of Europe: Conquest, Colonization and Cultural Change 950-1350. Princeton, NJ: Princeton University Press, 1993.

Barton, Simon. The Aristocracy in Twelfth-Century León and Castile. Cambridge: Cambridge University Press, 1997.

Barton, Thomas W. "Constructing a Diocese in a Post-Conquest Landscape: A Comparative Approach to the Lay Possession of Tithes." Journal of Medieval History 35, no. 1 (2009): 1-33. 
Bédier, J. Les legends épiques; formation des chansons de geste. 4 vols. Paris, 1908 $-1913$.

Bishko, Charles Julian. "The Castilian as Plainsman: The Medieval Ranching Frontier in La Mancha and Extremadura.” In The New World Looks at Its History: Proceedings of the Second International Congress of Historians of the United States and Mexico, 47-69. Austin: University of Texas Press, 1963.

_ . "Salvus of Albelda and Frontier Monasticism in Tenth-Century Navarre." Speculum 23, no. 4 (1948): 559-90.

—. Studies in Medieval Spanish Frontier History. London: Variorum Reprints, 1980.

Bonnassie, Pierre. From Slavery to Feudalism in South-Western Europe. Cambridge: Cambridge University Press, 1991.

Boone, James L., and Nancy L. Benco. "Islamic Settlement in North Africa and the Iberian Peninsula.” Annual Review of Anthropology 28 (1999): 51-71.

Boto Varela, Gerardo. “Topografía de los monasterios de la marca de Hispania (ca. 800ca. 1030)." In Monjes y monasterios hispanos en la Alta Edad Media, edited by José Ángel García de Cortázar and Ramón Teja, 147-204. Aguilar de Campoo, 2006.

Bowes, Kimberly Diane. "'Christianization' and the Rural Home.” Journal of Early Christian Studies 15, no. 2 (2007): 143-70.

—_." 'Une coterie espagnole pieuse': Christian Archaeology and Christian 
Communities in Fourth-and-Fifth-Century Hispania.” In Hispania in Late Antiquity: Current Approaches, edited by Kimberly Diane Bowes and Michael Kulikowski. Leiden: Brill, 2005.

Bowman, Jeffrey A. Shifting Landmarks; Property, Proof, and Dispute in Catalonia around the Year 1000. Ithaca; London: Cornell University Press, 2004.

Bruter, Michael. "Winning Hearts and Minds for Europe: The Impact of News and Symbols on Civic and Cultural European Identity." Comparative Political Studies 36, no. 10 (2003): 1148-79.

Bulliet, Richard. Conversion to Islam in the Medieval Period. Cambridge: Harvard University Press, 1979.

Burman, Thomas E. Religious Polemic and the Intellectual History of the Mozarabs, $c$. 1050-1200. Leiden, NY: Brill, 1994.

Burns, Robert. "The Significance of the Frontier in the Middle Ages." In Medieval Frontier Societies, edited by Robert and MacKay Bartlett, Angus, 307-30. Oxford: Oxford University Press, 1989.

Caballero, Luis, Fernando Arce, and M.a de los Ángeles Utrero. "São Gião de Nazaré (Portugal). Un tipo original de iglesia.” Arqueología de la Arquitectura 2 (2003): $75-79$.

Caballero Zoreda, Luis. “La iglesia de San Millán de la Cogolla de Suso: Lectura de paramentos," In Arte medieval en La Rioja: prerrománico Y románico: VIII Jornadas de Arte y Patrimonio Regional, edited by Ignacio Gil-Díez Usandizaga, 13-94. Logroño: Instituto de Estudios Riojanos, 2004.

. "Observations on Historiography and Change from the Sixth to Tenth Centuries 
in the North and West of the Iberian Peninsula." In The Archaeology of Iberia; the Dynamics of Change, edited by Margarita Díaz-Andreu and Simon Keay, 23564. London; New York: Routledge, 1997.

Cabañero Subiza, Bernabé. “La Aljafería de Zaragoza.” Artigrama 22 (2007): 103-29.

Canning, Joseph. A History of Medieval Political Thought. London; New York: Routledge, 1996.

Cantarino, Vicente. Entre monjes y musulmanes, el conflicto que fue España. Madrid: Alhambra, 1978.

Carr, Karen Eva. Vandals to Visigoths: Rural Settlement Patterns in Early Medieval Spain. Ann Arbor, MI: University of Michigan Press, 2002.

Carrero Santamaría, Eduardo. "Centro y periferia en la ordenación de espacios litúrgicos: las estructuras corales." Hortus Artium Medievalium 14 (2008): 15978.

Carter, David G. "Two Romanesque Frescoes from San Baudelio de Berlanga.” BulletinJohn Herron Art Institute, Indianapolis 46, no. 1 (1959): 3-18.

Castellanos, Santiago and Martín Viso, Iñaki. “The Local Articulation of Central Power in the North of the Iberian Peninsula (500-1000)." Early Medieval Europe 13, no. I (2005): 1-42.

Castro, Américo. España en su historia: Cristianos, Moros y Judíos. Buenos Aires: Editorial Espasa, 1948.

Catlos, Brian A. The Victors and the Vanquished, Christians and Muslims of Catalonia and Aragon, 1050-1300, edited by D.E. Luscombe. Cambridge: Cambridge University Press, 2004. 
Chalmeta, Pedro. Invasión e Islamización; la sumisión de Hispania y la formación de al Andalus. Madrid: Editorial Mapfre, 1994.

Christie, Neil. "Landscapes of Change in Late Antiquity and the Early Middle Ages: Themes, Directions and Problems." In Landscapes of Change: Rural Evolutions in Late Antiquity and the Early Middle Ages, edited by Neil Christie. London: Ashgate Publishing, 2004.

Middle Ages. London: Ashgate Publishing, Ltd., 2004.

Cohen, Jeffrey Jerome, ed. The Postcolonial Middle Ages. New York: Palgrave, 2000.

Collins, Roger. The Arab Conquest of Spain, 710-797. Oxford, UK Cambridge, USA: Blackwell Publishers, Ltd., 1989.

—_. Spain, an Oxford Archaeological Guide. Oxford University Press, 1998.

Cook, Walter. “Romanesque Painting.” Art Bulletin 11, no. 4 (1930): 327-56.

__. "Romanesque Spanish Mural Painting (II) San Baudelio de Berlanga." Art Bulletin 12 (1930): 20-42.

Corral Lafuente, José Luis. "El proceso de centralización de los monasterios Aragoneses entre los siglos IX y XI.” In Homenaje a Don Antonio Durán Gudiol, 229-42. Huesca: Instituto de Estudios Altoaragoneses, Diputación de Huesca, 1995.

Cosmen Alonso, C., María Victoria Herráez Ortega, and Manuel Valdés Fernández. “Alfonso VI y el monasterio de Sahagún: Nuevos testimonios sobre la construcción del templo monástico.” De Arte: Revista de Historia del Arte 5 (2006): 29-41.

Cressier, Patrice. “Agua, fortificaciones y poblamiento: el aporte de la arqueología a los 
studios sobre el sureste peninsular.” Aragón en la Edad Media 9 (1991): 403-27.

Cressier, Patrice, Pierre Guichard, and André Bazzana, eds. Les châteaux ruraux d'al Andalus: Histoire et archeologie des husun du sud-est de l'Espagne. Madrid: Casa de Valásquez, 1988.

Curchin, Leonard. "Place-names of the Ebro Valley: Their Linguistic Origins." Palaeohispanica 8 (2008): 13-33.

- The Romanization of Central Spain; Complexity, Diversity and Change in a Provincial Hinterland. London; New York: Routledge, 2004.

Davies, Wendy. Acts of Giving: Individual, Community, and Church in Tenth-Century Christian Spain. Oxford: Oxford University Press, 2007.

—_ "Lordship and Community: Northern Spain on the Eve of the Year 1000." Past and Present Supplement 2 (2007): 18-33.

Davies, Wendy, Guy Halsall, and Andrew Reynolds, eds. People and Space in the Middle Ages, 300-1300. Turnhout, Belgium: Brepols, 2006.

de Avila Juárez, Antonio. "San Baudelio de Berlanga: Fuente sellada del paraíso en el desierto del Duero." Cuadernos de Arte e Iconografía 13, no. 26 (2004): 333-96. de Ayala Martínez, Carlos. "Las fortalezas castellanas de la Orden de Calatrava en el siglo XII.” En la España Medieval 16 (1993): 9-35.

—. Sacerdocio y reino en la España altomedieval; Iglesia y poder político en el occidente peninsular, siglos VII-XII. Madrid: Sílex, 2008.

de Berceo, Gonzalo. Berceo's Vida de Santa Oria: Text, Translation, and Commentary. Translated and edited by Anthony Lappin. Oxford: Legenda, 2000. Obras Completas. edited by Carlos Clavería Laguarda, García 
López, Jorge. Madrid: Fundación José Antonio de Castro, 2003.

de Cortázar, García, and José Angel Ruiz de Aguirre. El dominio del monasterio de San Millán de la Cogolla (siglos X a XIII) introducción a la historia rural de Castilla altomedieval. Salamanca: Universidad de Salamanca, 1979.

de Epalza, Míkel. "La espiritualidad militarista del Islam medieval. El ribat, los ribates, las rabitas y los almonastires de al-Andalus." Medievalismo 3 (1993): 5-18. de la Quintana Gordon, José Luis, and José Ricardo Boned Colera. “Santa María de Wamba, entre su pasado y el futuro (Valladolid)." Informes de la Construcción 43, no. 418 (1992): 35-52.

de Palol, Pedro. Excavaciones en la necropolis de San Juan de Baños (Palencia), excavaciones arqueologicas en España. Madrid, 1963.

de Wijk, Rob. “The Role of Military Power." In The Battle for Hearts and Minds: Using Soft Power to Undermine Terrorist Networks, edited by Alexander T. J. Lennon, 3-28. Cambridge, MA: The MIT Press, 2003.

Delahunty, J. L. "Religion, War, and Changing Landscapes: An Historical and Ecological Account of the Yew Tree (Tacus Baccata L.) in Ireland.” PhD, University of Florida, 2002.

Diaz, Pablo C., and M. R. Valverde. "The Theoretical Strength and Practical Weakness of the Visigothic Monarchy of Toledo.” In Rituals of Power: From Late Antiquity to the Early Middle Ages, edited by Frans Theuws and Janet Nelson, 59-94.

Leiden; Boston; Köln: Brill, 2000. 
Díaz, y Díaz, M. Libros y librerías en La Rioja altomedieval. Logroño, 1979.

Díaz-Andreu, Margarita. "Conflict and Innovation, the Development of Archaeological Traditions in Iberia." In The Archaeology of Iberia, the Dynamics of Change, edited by Margarita Díaz-Andreu and Simon Keay, 6-33. London; New York: Routledge, 1997.

Díez Herrera, Carmen. "Sociedad de frontera y monasterios familiares en la meseta del Duero en el siglo X.” In Monjes y monesterios hispanos, 35-57. Aguilar de Campo, Palencia: Fundación Santa María la Real, Centro Estudios del Románico, 2006.

Dodds, Jerrilynn. Architecture and Ideology in Early Medieval Spain. Philadelphia, PA: Pennsylvania State University Press 1990.

— . "Catalog Entry for Wall Paintings, the Hermitage of San Baudelio de Berlanga (Soria)." In The Art of Medieval Spain A.D. 500-1200, 223-28. New York: The Metropolitan Museum of Art, 1993.

__. "Hunting for Identity." In Imágenes y promotores en el arte medieval:

Miscelánea en homenaje a Joaquín Yarza Luaces, edited by $\mathrm{M}^{\mathrm{a}}$ Luisa Melero Moneo, et al., 89-100. Bellaterra (Barcelona): Universitat Autònoma de Barcelona, Servei de Publicacions, 2001.

—. "Rodrigo, Reconquest, and San Roman: Some Preliminary Thoughts.” In Spanish Medieval Art: Recent Studies, edited by Colum Hourihane. Tempe, AZ; Princeton, NJ: Arizona Center for Medieval and Renaissance Studies; Index of Christian Art, 2007.

Durán Gudiol, Antonio. "El traslado de las reliquias de San Indalecio a San Juan de la 
Peña." Revista de Ciencias Sociales del Instituto de Estudios Altoaragoneses 109 (1995): 13-24.

_ـ. "Inscripciones medievales de la provincia de Huesca." Estudios de Edad Media de la corona de Aragón 8 (1967): 45-155.

Ecker, Heather. "How to Administer a Conquered City in Al-Andalus: Mosques, Parish Churches and Parishes." In Under the Influence: Questioning the Comparative in Medieval Castile, edited by Cynthia Robinson and Leyla Rouhi, 45-65. Leiden; Boston: Brill, 2005.

Edwards, H. G. M., F. Rull, P. Vandenabeele, E. M. Newton, L. Moens, J. Medina, and C. García. "Mediaeval Pigments in the Monastery of San Baudelio, Spain: A Raman Spectroscopic Analysis.” Applied Spectroscopy 55 (2001): 71-76.

Effros, Bonnie. "Usuard's Journey to Spain and Its Influence on the Dissemination of the Cult of the Cordovan Martyrs." Comitatus: A Journal of Medieval and Renaissance Studies 21, no. 1 (1990): 21-37.

Elsner, Jas'. “Style.” In Critical Terms for Art History, edited by Robert S. Nelson and Richard Shiff, 98-109. Chicago: University of Chicago Press, 2003.

Escalona, Julio. "Mapping Scale Change: Hierarchization and Fission in Castilian Rural Communities During the Tenth and Eleventh Centuries." In People and Space in the Middle Ages, 300-1300, edited by Wendy Davies, Guy Halsall and Andrew Reynolds, 143-66. Turnhout, Belgium: Brepols, 2006.

Escalona, Romualdo. Historia del real monasterio de Sahagún: Sacada de la que dexó escrita el padre maestro fr. Ioseph Perez. Madrid: D. Joachín de Ibarra, 1782.

Esco Sampériz, J.C., and J. I. Lorenzo Lizalde. "Il campaña de excavaciones 
arqueológicos en el monasterio de San Juan de la Peña (Botaya-Jaca, Huesca).” Arqueología aragonés (1985): 141-44.

Escolano Benito, A. San Baudelio de Berlanga: Guía y complementarios. Salamanca, 2003.

Escribano Velasco, Consuelo, and Elena Heras Fernández. "La arqueología en San Miguel de Gormaz.” Arevacon: Revista Cultural, Asociación de Amigos del Museo Numantino 29 (2009): 4-11.

Estepa Díez, Carlos. Estructura social de la ciudad de León (siglos XI-XIII). León: Centro de Estudios e Investigación San Isidoro, 1977.

— . "Organización territorial, poder regio y tributaciones militares en la Castilla plenomedieval." Cuadernos de Investigación Histórica 20 (1996): 135-76.

Faber, Sebastiaan. "Economies of Prestige: The Place of Iberian Studies in the American University." Hispanic Research Journal 9, no. 1 (2008): 7-32.

Farcasiu, Simina M. "The Exegesis and Iconography of Vision in Gonzalo de Berceo's Vida de Santa Oria.” Speculum 61, no. 2 (1986): 305-29.

Feliciano, María Judith. "Muslim Shrouds for Christian Kings? A Reassessment of Andalusi Textiles in Thirteenth-Century Castilian Life and Ritual." In Under the Influence: Questioning the Comparative in Medieval Castile, edited by Cynthia Robinson and Leyla Rouhi, 101-31. Leiden Boston: Brill, 2005.

Feliciano, María Judith , and Leyla Rouhi. "Introduction: Interrogating Iberian Frontiers." Medieval Encounters 12,3 (2006): 317-28.

Fernández Arenas, José. Mozarabic Architecture. Barcelona: Ediciones Polígrafa, 1972. Fernández Ochoa, Carmen, and Ángel Morillo Cerdán. "Romanización y asimilación 
cultural en el norte peninsular. Algunas reflexiones sobre un topos historiográfico desde una perspecitva arqueológica." In Los poblados fortificados del noroeste de la península y desarrollo de la cultura castreña: Coloquios de arqueología en la cuenca del Navia, edited by Miguel Ángel de Blas Cortina and Ángel Villa Valdés, 261-78. Navia, 2002.

Filotas, Bernadette. Pagan Survivals, Superstitions and Popular Cultures in Early Medieval Pastoral Literature. Toronto: Pontifical Institute of Mediaeval Studies, 2005.

Fletcher, Madeline. "Al-Andalus and North Africa in the Almohad Ideology." In The Legacy of Muslim Spain, edited by Salma Khadra Jayyusi, 235-58. Leiden; New York: Köln, Brill, 1994.

Fletcher, R. A. The Barbarian Conversion: From Paganism to Christianity. New York: H. Holt and Co., 1998.

- The Episcopate in the Kingdom of León in the Twelfth Century. Oxford: Oxford University Press, 1978.

- Moorish Spain. $2^{\text {nd }}$ ed. Berkeley, CA: University of California Press, 1992.

—. The Quest for El Cid. New York: Alfred A. Knopf, Inc., 1990.

France, John and Zajac, William G., ed. The Crusades and Their Sources: Essays

Presented to Bernard Hamilton. Aldershot, Hampshire, Great Britain; Brookfield, Vermont: Ashgate, 1998.

Frinta, Mojmir S. “The Frescoes from San Baudelio De Berlanga.” Gesta 1 (1964): 9-13. Fromherz, Allen. "The Almohad Mecca. Locating Igli and the Cave of Ibn Tumart." Al Qantara 26, no. 1 (2005): 175-90. 
Fuguet Sans, Joan. "La historiografía sobre arquitectura templaria en la peninsula ibérica." Anuario de Estudios Medievales 37, no. 1 (2007): 367-86.

Ganim, John M. Medievalism and Orientalism: Three Essays on Literature, Architecture, and Cultural Identity. New York: Palgrave Macmillan, 2005.

García de Cortazar, José Angel. “Sociedad rural y organizacion del espacio en la Castilla del año mil." Campagnes médiévales: l'Homme et son espace; études offertes á Robert Fossier 31 (1995): 613-25.

García de Cortázar, J. A. “La implantación monastic en el camino de Santiago: ¿Monasterios del camino o monasterios en el camino?” In Monasterios y peregrinaciones en la España medieval, 72-99. Aguilar de Campoo: Fundación Santa María la Real, 2004.

García de Cortázar, J. A., and Ruiz de Aguirre. El dominio del monasterio de San Millán de la Cogolla (siglos X a XIII) introducción a la historia rural de Castilla altomedieval. Salamanca: Universidad de Salamanca, 1969.

García de Cortázar, José Angel, and Ramón Teja, eds. Monasterios y peregrinaciones en la España medieval. Palencia: Aguilar de Campo, 2004.

— de Campoo, 2006.

García de la Borbolla, Ángeles. "El papel de los monasterios en las peregrinaciones medievales: Cultos locales y tráfico de reliquias.” In Monasterios y peregrinaciones en la España medieval, edited by J. A. García de Cortázar and Ramón Teja, 50-71. Aguilar de Campoo: Fundación Santa María la Real, 2004. García González, J. J., and I. Fernández de Mata. “Antropología, arqueología e historia. 
La desestructuración de la cuenca del Duero en la transición de la antigüedad a la Edad Media.” In Estudios sobre la transición al feudalismo en Cantabria y la cuenca del Duero. Burgos, 1999.

García Guinea, M. A., J. González Echegaray, and J. L. Madariaga de la Campa. "Memoria de las excavaciones arqueológicas efectuadas en el Castellar, municipio de Villajimena (Palencia).” Publicaciones de la Institución Tello Téllez de Meneses 23 (1963): 129-58.

García Turza, Javier. "El monasterio de San Millán de la Cogolla en la alta Edad Media: Aproximación histórica.” Berceo 133 (1997): 9-25.

Garen, Sally. "Santa Maria de Melque and church construction under Muslim rule." The Journal of the Society of Architectural Historians 51, no. 3 (1992): 288-305.

Garnelo, José. "Descripcion de las pinturas murales que decoran la ermita de San Baudelio en Casillas de Berlanga (Soria).” Boletin de la Sociedad Espanola de Excursiones 32 (1924): 96-109.

Gaus, Gerald F., Kukathas, Chandran, ed. Handbook of Political Theory. London: SAGE Publications Ltd., 2004.

Gilbert, Creighton. "A Statement of the Aesthetic Attitude around 1230." Hebrew University Studies in Literature and the Arts 13, no. 2 (1985): 125-52.

Gilchrist, Roberta. "Magic for the Dead? The Archaeology of Magic in Later Medieval Burials.” Medieval Archaeology 52, no. 1 (2008): 119-59.

Glick, Thomas F. “Convivencia: An Introductory Note.” In Convivencia: Jews, Muslims, and Christians in Medieval Spain, edited by Vivian B. Mann, Thomas F. Glick and Jerrilynn D. Dodds, 1-9. New York: G. Braziller, 1992. 
- From Muslim Fortress to Christian Castle: Social and Cultural Change in Medieval Spain. Manchester: Manchester University Press, 1995.

- Islamic and Christian Spain in the Early Middle Ages. $2^{\text {nd }}$ rev. ed. Leiden; Boston: Brill, 2005.

_. Islamic and Christian Spain in the Early Middle Ages. Princeton: Princeton University Press, 1979.

__. "Tribal Landscapes of Islamic Spain: History and Archaeology." In Inventing Medieval Landscapes: Senses of Place in Western Europe, edited by John Howe and Michael Wolf, 113-35. Gainesville, FL: University Press of Florida, 2002. Golombek, Lisa. “The Draped Universe of Islam.” In Late Antique and Medieval Art of the Mediterranean World, edited by Eva R. F. Hoffman, 97-114. Malden, MA; Oxford, UK: Blackwell Publishing, 2007.

Gómez-Moreno, Manuel. "El arte Árabe español hasta los Almohades. Arte mozárabe." Ars Hispaniae 3 (1951): 355-409.

—. Iglesias mozárabes: Arte español de los siglos IX a XI. Madrid, 1919.

—_. "Las primeras crónica de la Reconquista: El ciclo de Alfonso III.” Boletín de la Real Academia de la Historia (1932): 526-628.

González Jiménez, Manuel. "Frontier and Settlement in the Kingdom of Castile (1085 1350).” In Medieval Frontier Societies, edited by R. Bartlett and A. MacKay, 4974. Oxford University Press, 1989.

—_ “ ¿Re-conquista? Un estado de la cuestión.” In Tópicos y realidades de la Edad Media, edited by Eloy Benito Ruano, 155-78. Madrid: Real Academia de la Historia, 2000. 
González Pascual, Margarita. "San Baudelio de Berlanga (Soria): La reposición de las pinturas murales de la 'Palmera'." Bienes Culturales: revista del Instituto del Patrimonio Histórico Español 6 (2006): 77-97.

González-Ruibal, Alfredo. “Artistic Expression and Material Culture in Celtic Gallaecia.” E-Keltoi: Journal of Interdisciplinary Celtic Studies 6 (2004): 113-66.

Gonzálvez, Ramón. "The Persistance of the Mozarabic Liturgy in Toledo after A.D. 1080.” In Santiago, St. Denis and St. Peter, the Reception of the Roman Liturgy in León-Castille in 1080, edited by Bernard F. Reilly, 157-85. New York: Fordham University Press, 1985.

Goodrich Remensnyder, Amy. Remembering Kings Past: Monastic Foundation Legends in Medieval Southern France. Ithaca: Cornell University Press, 1995.

Grabar, Oleg. "The Shared Culture of Objects." In Byzantine Court Culture from 829 to 1204, edited by H. Maguire, 115-30. Cambridge, MA: Harvard University Press, 1997.

Grau Lobo, Luís A. Pintura Románica En Castilla Y León. Junta de Castilla y León, Consejería de Educación y Cultura, 1996.

Guardia, Milagros. "Relire les espaces liturgiques à travers la peinture murale: Le programme iconographique de San Baudelio de Berlanga (Sòria).” Les Cahiers de Saint-Michel de Cuxa 34 (2003): 79-97.

Guichard, Pierre. Al-Andalus frente a la conquista cristiana: los musulmanes de Valencia, siglos XI-XIII. Madrid, España: Editorial Biblioteca Nueva, 2001. . Al-Andalus: Estructural antropológia de una sociedad Islámica en Occidente. Barcelona: Barral, 1976. 
Gutiérrez González, J. A. Fortificaciones y feudalismo en el origen y formación del reino leonés (siglos IX-XIII). Valladolid, 1995.

Guzmán, Roberto Marín. “Jihad vs. cruzada en al-Andalus: La reconquista española como ideología a partir del siglo XI y sus proyecciones en la colonización de América." Revista de Historia de América July-December, no. 131 (2002): 9-65.

Haas, Christopher. "Mountain Constantines: The Christianization of Aksum and Iberia." Journal of Late Antiquity 1, no. 1 (2008): 101-26.

Hamerow, Helena. Early Medieval Settlements, the Archaeology of Rural Communities in North-West Europe 400-900. Oxford: Oxford University Press, 2002.

Harris, Julie Ann. “The Arca of San Millán de la Cogolla and Its Ivories.” Ph.D. Dissertation, University of Pittsburgh, 1989.

—. "Mosque to Church Conversions in the Spanish Reconquest." Medieval Encounters, Jewish, Christian, and Muslim Culture in Confluence and Dialogue 3, no. 2 (1997): 158-72.

Hassig, Debra. "He Will Make Alive Your Mortal Bodies: Cluniac Spirituality and the Tomb of Alfonso Ansúrez." Gesta 30, no. 2 (1991): 140-53.

Herr, Richard. "Review of España, un enigma histórico by Claudio Sánchez-Albornoz." The Hispanic American Historical Review 38, no. 4 (1958): 553-54.

Hillgarth, J. N. "Popular Religion in Visigothic Spain.” In Visigothic Spain, Byzantium and the Irish, 3-60. London: Variorum Reprints, 1985.

Hilsdale, Cecily. "Towards a Social History of Art: Defining 'Mozarabic'." Medieval Encounters 5, no. 3 (1999): 272-88.

Hitchcock, Richard. Mozarabs in Medieval and Early Modern Spain, Identities and 
Influences. Aldershot, England: Ashgate, 2008.

Hodder, Ian. Theory and Practice in Archaeology. New York: Routledge, 1995.

Hoffman, Eva R. "Pathways of Portability: Islamic and Christian Interchange from the Tenth to the Twelfth Century." Art History 24, no. 1 (2001): 17-50.

Holsinger, Bruce W. "Medieval Studies, Postcolonial Studies, and the Geneaologies of Critique." Speculum 77, no. 4 (2002): 1195-227.

Ibáñez Rodríguez, Miguel. "La constitución del primer cenobio en San Millán." In VII Semana de estudios medievales: Nájera, 29 de Julio al 2 de Agosto de 1996, edited by José Ignacio de la Iglesia Duarte, 385-96. Logroño: Instituto de Estudios Riojanos, 1997.

Jaquin, P.A., C.E. Augarde, and C.M. Gerrard. "Analysis of Tapial Structures for Modern Use and Conservation." In Structural Analysis of Historical Constructions; Possibilities of Numerical and Experimental Techniques, edited by Claudio Modena, Paulo B. Lourenço and P. Roca, 1315-21. London: Taylor \& Francis, 2004.

Johnson, Mark. "The Episcopal and Royal Views at Cefalú.” Gesta 33, no. 2 (1994): 11831.

Keay, S. J. "Recent Archaeological Work in Roman Iberia (1990-2002).” The Journal of Roman Studies 93 (2003): 146-211.

Kennedy, Hugh. Muslim Spain and Portugal, a Political History of al-Andalus. Harlow, England: Pearson Education Ltd., 1996.

_. "Muslim Spain and Portugal: Al-Andalus and Its Neighbours." In The New 
Cambridge Medieval History, edited by D. E. Luscombe and Jonathan RileySmith, 599-622. Cambridge: Cambridge University Press, 2003.

Khoury, Nuha N. N. "The Mihrab Image: Commemorative Themes in Medieval Islamic Architecture.” Muqarnas 9 (1992): 11-28.

King, Georgiana Goddard. "The Problem of the Duero.” Art Studies 3 (1925): 3-11. Kingsley, Karen. "Visigothic Architecture in Spain and Portugal, a Study in Masonry, Documents, and Form.” PhD diss., University of California, Berkeley, 1980. Kinoshita, Sharon. Medieval Boundaries, Rethinking Difference in Old French Literature. Philadelphia: University of Pennsylvania Press, 2006.

Koder, Johannes. "Land Use and Settlement: Theoretical Approaches." In General Issues in the Study of Medieval Logistics, Sources, Problems and Methodologies, edited by John F. Haldon, 159-84. Leiden, Boston: Brill, 2006.

Kohl, Philip L., and Clare Fawcett, eds. Nationalism, Politics, and the Practice of Archaeology. Cambridge: Cambridge University Press, 1995.

Kosto, Adam J. Making Agreements in Medieval Catalonia; Power, Order, and the Written Word, 1000-1200. Cambridge: Cambridge University Press, 2001.

Kraus, Franz Xaver, and Joseph Sauer. Geschichte Der Christlichen Kunst. Vol. 2. Freiburg: Herder'sche Verlagshandlung, 1896.

Krüger, Kristina. “Architecture and Liturgical Practice: The Cluniac Galilaea.” In The White Mantle of Churches: Architecture, Liturgy, and Art around the Millennium, edited by Nigel Hiscock, 139-60. Turnhout: Brepols, 2003.

Kuehn, Evan F. "Melchizedek as Exemplar for Kingship in Twelfth-Century Political Thought." History of Political Thought 31, no. 4 (2010): 557-75. 
Kulikowski, Michael. Late Roman Spain and Its Cities. Baltimore, MD: John Hopkins University Press, 2004.

Kulp, April. "San Baudelio De Berlanga: New Considerations." MA thesis, University of Washington, 1984.

Laliena Corbera, Carlos. "La memoria real de San Juan de la Peña: Poder, carisma y legitimidad en Aragón en el siglo XI.” Aragón en la Edad Media 19 (2006): 30924.

Lapeña Paul, Ana Isabel. “Aspectos materiales y espirituales en la vida aragonesa medieval." In Arte y vida cotidiana en época medieval, edited by María del Carmen Lacarra Ducay, 223-66. Institución Fernando el Católico, 2008.

—. El monasterio de San Juan de la Peña en la Edad Media; Desde sus origenes hasta 1410. Zaragoza: Caja de Ahorros de la Inmaculada de Aragón, 1989.

—. San Juan De La Peña; Guía histórico-artística. Diputación General de Aragón, 1986.

Lapiedra Gutiérrez, Eva. Como los musulmanes llamaban a los Cristianos hispánicos. Alicante: Instituto de Cultura Juan Gil-Albert, 1997.

Lazure, Guy. "Possessing the Sacred: Monarchy and Identity in Philip II's Relic Collection at the Escorial." Renaissance Quarterly 60, no. 1 (2007): 58-93. León Portillo, Miguel. Bernardino de Sahagún, first anthropologist. Translated by Mauricio J. Mixco: University of Oklahoma Press, 2002.

Linaje Conde, Antonio. "Frontera y desierto en la España medieval." In Actas del 
Congresso la frontera oriental nazarí como sujeto histórico (s. XII-XVI): LorcaVera, 22 a 24 de Noviembre de 1994, edited by Pedro Segura Artero, 359-62. Almeria, 1997.

Linehan, Peter. "At the Spanish Frontier." In The Medieval World, edited by Peter Linehan and Janet Nelson, 37-59, 2003.

- History and the Historians of Medieval Spain. New York: Clarendon Press, Oxford University Press Inc., 1993.

Lomax, Derek W. The Reconquest of Spain. London; New York: Longman, 1978. Loperráez Corvalán, Juan. Descripción histórica del obispado del Osma. Madrid, 1788. Lorrio, A. J., T. Moneo, F. Moya, S. Pernas, and Ma. D. Sánchez de Prado. "La Cueva Santa del Cabriel (Mira, Cuenca): Lugar de culto antiguo y ermita Cristiana.” Complutum 17 (2006): 45-80.

Lourie, Elena. “A Society Organized for War: Medieval Spain.” Past and Present 35 (1966): 54-76.

MacKay, Angus. Spain in the Middle Ages: From Frontier to Empire, 1000-1500. London: Palgrave, 1977.

Magagna, Victor V. Communities of Grain: Rural Rebellion in Comparative Perspective. Ithaca: Cornell University Press, 1991.

Mañanes Pérez, Tomás. Arqueología del área central de la cuenca del Río Duero: de Simancas a Coco. Valladolid: Disputación Provincial de Valladolid, 2002.

Mann, Janice. "A New Architecture for a New Order: The Building Projects of Sancho El Mayor, 1004-1035.” In The White Mantle of Churches: Architecture, Liturgy, and 
Art around the Millennium, edited by Nigel Hiscock, 233-48. Turnhout, Belgium: Brepols, 2003.

- Romanesque Architecture and Its Sculptural Decoration in Christian Spain, 1000-1120; Exploring Frontiers and Defining Identities. Toronto: University of Toronto Press, 2009.

_ . "Romantic Identity, Nationalism, and the Understanding of the Advent of Romanesque Art in Christian Spain.” Gesta 36, no. 2 (1997): 156-64.

Manzano Moreno, Eduardo. "Christian-Muslim Frontier in al-Andalus; Idea and Reality." In The Arab Influence in Medieval Europe, edited by Dionisius A. Agius and Richard Hitchcock, 83-99. Reading, 1994.

Marco Simón, Francisco. "Religion and Religious Practices of the Ancient Celts of the Iberian Peninsula." e-Keltoi: Journal of Interdisciplinary Celtic Studies 6 (2005): $1-59$.

Martín Escorza, Carlos. Geología y arqueología en torno a el Burgo de Osma (Soria). Madrid: Senderos Geoarqueológicos, 2007.

Martín Gonzalez, J. J. "Pintura mural del iglesia de Santa María de Wamba (Valladolid)." Boletín del Seminario de Estudios de Arte y Arqueología 32 (1966): 435-36.

Martín Viso, Iñaki. Fragmentos del Leviatán: La articulación política del espacio Zamorano En La Alta Edad Media, Cuadernos De Investigación. Zamora: Instituto de Estudios Zamoranos Florián de Ocampo, 2002.

Martínez Pizarro, Joaquín, ed. The Story of Wamba: Julian of Toledo's 'Historia Wambae Regis'. Washington D.C.: Catholic University of America Press, 2005.

Martínez Sopena, P. La Tierra de Campos Occidental. Poblamiento, poder y comunidad 
del siglo X al XIII. Valladolid, 1985.

Martínez Tejera, Artemio M. "La realidad material de los monasterios y cenobios rupestres hispanos (siglos V-X).” In Monjes y monasterios hispanos en la alta Edad Media, edited by J. A. García de Cortázar and Ramón Teja, 61-97. Aguilar de Campoo, 2006.

McKiernan González, Eileen P. "The Persistence of the Romanesque in the Kingdom of Aragón.” In Church, State, Vellum, and Stone; Essays on Medieval Spain in Honor of John Williams, edited by Therese Martin and Julie A. Harris. Leiden; Boston: Brill, 2005.

Menéndez Pidal, R. Orígenes del español. $5^{\text {th }}$ ed. Madrid, 1964.

—_ . "Repoblación y tradicion en la cuenca del Duero; Despoblación y repoblación en el primitivo reino de Asturias. La Crónica de Alfonso III.” Enciclopedia Linguísta Hispánica 1 (1960): xxix-lvii.

Meri, Josef W., ed. Medieval Islamic Civilization, an Encyclopedia. Vol. 1. New York: Routledge, 2006.

Miguel, Marina, and Margarida Sala, eds. Tiempo de monasterios. Los monasterios de Cataluña en torno al año 1000. Barcelona: Pòrtic, 2000.

Minguella y Arnedo, T. Historia de la diócesis de Sigüenza y de sus obispos. Desde los comienzos de la Diócesis hasta fines del siglo XIII. Madrid, 1910.

Mínguez Fernández, José María. El dominio del monasterio de Sahagún en el siglo X, paisajes agrarios, producción y expasnión económica. Ediciones Universidad de Salamanca, 1980.

—. "Pervivencia y transformación de la concepción y práctica del poder en el Reino 
de León (siglos X y XI).”Studia Historica. Historia Medieval 25 (2007): 15-65.

Mogollón Cano-Cortés, M. Pilar. "Manifestations of Power and Visual Culture: Some Examples in Extremaduran Mudejar Architecture.” Medieval Encounters 12, no. 3 (2006): 341-59.

Monreal Jimeno, Luis Alberto. “Arquitectura religiosa de oquedades en los siglos anteriores al Románico.” In VII Semana de Estudios Medievales: Nájera, 29 de Julio al 2 de Agosto de 1996, edited by José Ignacio de la Iglesia Duarte, 235-64. Nájera, 1997.

Muñoz Jiménez, J. M. "El Tapiz de Bayeux y las pinturas de San Baudelio de Berlanga: La posible inspiración nórdica del ciclo profano.” Goya 253-254 (1996): 12-17. Muñoz Ramos, Eugenio. "El agua que bebió Recesvinto.” Boletín de la Sociedad Castellana de Excursiones (1904-1905): 164-65.

Nelson, Lynn H. “The Foundation of Jaca (1076): Urban Growth in Early Aragon.” Speculum 53, no. 4 (1978): 688-708.

Nieto-Gallo, Gratiniano. "Nuevos datos sobre la iglesia de San Baudelio de Berlanga (Soria)." In Espana entre el Mediterraneo y el Atlantico, Tomoii, Actas del 23 Congreso Internacional de historia del arte. Granada, 1973.

Nirenberg, David. "The Visigothic Conversion to Catholicism, the Third Council of Toledo." In Medieval Iberia; Readings from Christian, Muslim, and Jewish Sources, edited by Olivia Remie Constable, 12-20. Philadelphia: University of Pennsylvania Press, 1997.

Nolan, M. L., and S. Nolan. Christian Pilgrimage in Modern Western Europe. Chapel Hill: University of North Carolina Press, 1992. 
O'Callaghan, Joseph. A History of Medieval Spain. Ithaca, New York: Cornell University Press, 1983.

—. Reconquest and Crusade in Medieval Spain. Philadelphia: University of Pennsylvania Press, 2003.

O'Keefe, Tadhg. Archaeology and the Pan-European Romaneque, edited by Richard Hodges. London: Gerald Duckworth Co. Ltd., 2007.

Olarte, Juan B. Monasterio de San Millán de la Cogolla: Suso y Yuso. León: Edilesa, 1995.

Ortego Frías, Teógenes. La ermita mozarabe de San Baudelio en Casillas de Berlanga (Caltojar). Almazán, 1987.

Orten, Clive, Paul Tyers, and A. G. Vince. Pottery in Archaeology. Cambridge: Cambridge University Press, 1993.

Parcero Oubiña, César, Felipe Criado Boado, and Manuel Santos Estévez. "Rewriting Landscape: Incorporating Sacred Landscapes into Cultural Traditions.” World Archaeology 30, no. 1 (1998): 159-76.

Pascua, Esther. "South of the Pyrenees: Kings, Magnates and Political Bargaining in Twelfth-Century Spain.” Journal of Medieval History 27, no. 2 (2001): 101-20.

Pastor Díaz de Garayo, Ernesto. Castilla en el tránsito de la antiguedad al feudalismo: Poblamiento, poder político y estructura social: del Arlanza al Duero (siglos VII-XI). Junta de Castilla y León, 1996.

Pastor, Reyna, C. Estepa, J. A. García de Cortázar, J. L. Albellán, and J. L. Martín. Sánchez Albornoz a debate. Homenaje de la Universidad de Valladolid con motivo de su centenario. Valladolid, 1993. 
Patton, Pamela. "The Cloister of San Juan De La Peña and Monumental Sculpture in Aragon and Navarre.” PhD diss., Boston University, 1994.

_. Pictorial Narrative in the Romanesque Cloister: Cloister Imagery and Religious Life in Medieval Spain. New York: Peter Lang, 2004.

Payne, Stanley G. A History of Spain and Portugal, Vol. 1. Madison: University of Wisconsin Press, 1973.

Périn, Patrick. "The Origin of the Village in Early Medieval Gaul." In Landscapes of Change; Rural Evolutions in Late Antiquity and the Early Middle Ages, Ashgate, 2004, edited by Neil Christie, 255-78. Aldershot; Burlington VT: Ashgate, 2004. Pesqué Lecina, José Miguel. "Una singular caja de reliquias de San Juan de la Peña.” Bolskan: Revista de arqueología del Instituto de Estudios Altoaragoneses 10 (1993): 223-28.

Pick, Lucy. Conflict and Coexistence, Archbishop Rodrigo and the Muslims and Jews of Medieval Spain. Ann Arbor: University of Michigan Press, 2004.

_ . "Dominissima, Prudentissima: Elvira, First Queen-Regent of León.” In Religion, Text, and Society in Medieval Spain and Northern Europe: Essays in Honor of J.N. Hillgarth, edited by Thomas E. Burman, Mark D. Meyerson and Leah Shopkow, 38-69. Toronto: Pontifical Institute of Mediaeval Studies, 2002. Pijoan, Jose. "The Mozarabic Churches of the Ninth and Tenth Centuries in Spain.” The Burlington Magazine for Conoisseurs 40, no. 230 (1922): 214-15, 17-19, 22-24. Porter, Arthur Kingsley. The Romanesque Sculpture of the Pilgrimage Roads. 3 vols. Boston: M. Jones, 1923.

Potts, Alex. Flesh and the Ideal: Winckelmann and the Origins of Art History. New 
Haven, CT: Yale University Press, 1994.

Powers, James F. A Society Organized for War, the Iberian Municipal Militias in the Central Middle Ages, 1000-1284. University of California Press, 1988.

Puig i Cadafalch, J. L'art Wisigothique et ses Survivences. Paris, 1961.

Quevedo-Chigas, Elena. "Early Medieval Iberian Architecture and the Hispanic Liturgy: A Study of the Development of Church Planning from the First to the Tenth Centuries.” PhD diss., New York University, Institute of Fine Arts, 1996.

Reilly, Bernard F. The Contest of Christian and Muslim Spain: 1031-1157, A History of Spain. Cambridge, MA: Blackwell, 1992.

—. "Count Raimundo of Burgundy and French Influence in León-Castilla (1087 1107)." In Church, State, Vellum, and Stone; Essays on Medieval Spain in Honor of John Williams, edited by Therese Martin and Julie A. Harris, 85-109. Leiden Boston: Brill, 2005.

—. The Kingdom of León-Castilla under King Alfonso VI, 1065-1109. Princeton University Press, 1988.

- The Kingdom of León-Castilla under King Alfonso VII, 1126-1157. Philadelphia: University of Pennsylvania Press, 1998.

—. The Kingdom of León-Castilla under Queen Urraca, 1109-1126. Princeton, New Jersey: Princeton University Press, 1982.

—. The Medieval Spains. Cambridge: Cambridge University Press, 1993.

— - ed. Santiago, Saint-Denis, and Saint Peter: The Reception of the Roman Liturgy in León-Castile in 1080. New York: Fordham University Press, 1985.

Retuerce Velasco, Manuel. “Arqueología y poblamiento en la meseta andalusí. El 
referente cerámico." In V Semana de Estudios Medievales, 87-124. Logroño:

Ediciones Instituto de Estudios Riojanos, 1995.

Reyes Téllez, F., and M. L. Menéndez Robles. “Apectos ideológicos en la despoblación del valle del Duero." In Historiografía de la arqueología y de la historia antigua en España (siglos XVIII-XX), 203-07. Madrid, 1991.

Reyes Téllez, F., and Menéndez Robles. "Excavaciones en la ermita de San Nicolás. La sequera de Haza (Burgos).” NAHisp 26 (1985): 163-213.

Rico Camps, Daniel. "El claustro de San Pedro el Viejo de Huesca: Pascua, Bautismo y Reconquista." Locus amoenus 7 (2004): 73-97.

Robinson, Cynthia, and Leyla Rouhi. "Editor's Introduction to under the Influence." In Under the Influence: Questioning the Comparative in Medieval Castile, edited by Cynthia Robinson and Leyla Rouhi, 1-18. Leiden: Boston, 2005.

Rosenwein, Barbara. A Short History of the Middle Ages. Toronto: University of Toronto Press, 2009.

Ruiz, Teofilo F. From Heaven to Earth; the Reordering of Castilian Society, 1150-1350. Princeton; Oxford: Princeton University Press, 2004.

Russel, Josiah Cox. Medieval Regions and Their Cities. Bloomington, IN, 1972.

Saénz Preciado, M. P. “Arqueología en San Millán de la Cogolla: Situación actual y propuestas de intervención.” Berceo 133 (1997): 141-62.

Sáenz Rodríguez, Minerva. "El cenotafio de San Millán de la Cogolla el monasterio de Suso.” Berceo 133 (1997): 51-84.

Sage, Carleton M. "Paul Allbar of Cordoba: Studies on His Life and Writings." PhD diss., The Catholic University of America, 1943. 
Said, Edward. Orientalism. Toronto: Random House, 1978.

Sánchez-Albornoz, Claudio. Despoblación y repoblación del Valle Duero. Buenos Aires: Instituto de Historia de España, 1966.

—. España, un Enigma Histórico. 2 vols. Buenos Aires: Editorial Sucamericana, 1956.

Sastre de Diego, Isaac. "Iconographic Influences of Roman Aras in Early Christian Altars: Prevalence of Formal and Conceptual Elements in 'Hispania'.' In The Reception of Antiquity in Performing and Visual Arts, edited by María Josefa Castillo Pascual, 425-44. Logroño: Universidad de La Rioja, 2008.

Scales, Peter. "The Handing over of the Duero Fortresses; 1009-1011 (399-401 A.H.)." Al-Qantara 5, no. 1-2 (1984): 109-22.

Scales, Peter C. The Fall of the Caliphate of Córdoba: Berbers and Andalusis in Conflict. Leiden; New York: E.J. Brill, 1994.

Schapiro, Meyer. "From Mozarabic to Romanesque in Silos.” Art Bulletin 21, no. December (1939): 312-74.

Schlunk, Helmut. "La iglesia de S. Gião, cerca de Nazaré. Contribución al estudio de la influencia de la liturgia en la arquitectura de las iglesias prerrománicas de la península ibérica." Il Congreso Nacional de Arqueología 2 (1971): 509-28.

Senra, José Luis. “Aproximación a los espacios liturgico-funerarios en Castilla y León: Porticos y galileas." Gesta 36, no. 2 (1997): 122-43.

—. "Los programas constuctivos de los monasterios benedictinos en el

Camino de Santiago: Arquitectura y ornamentación.” In Monasterios y peregrinaciones en la España medieval, edited by José Ángel García de 
Cortázar and Ramón Teja, 100-27. Aguilar de Campoo: Fundación Santa María la Real, 2004.

. "Santo Domingo de Silos: New Interpretive Suggestions for the Medieval Church (1041-1143).” In Church, State, Vellum, and Stone; Essays on Medieval Spain in Honor of John Williams, edited by Therese Martin and Julie A. Harris, 329-72. Leiden: Brill, 2005.

Shalem, Avinoam. "Jewels and Journeys: The Case of the Medieval Gemstone Called Al Yatima.” Muqarnas 14 (1997): 42-56.

Silva y Verástegui, Soledad. "El monasterio de San Millán de la Cogolla: Tres hitos importantes en su actividad artistica." Berceo 133 (1997): 27-50.

Smith, Gregory D. and Clark, Robin J.H. "Note on Lead(II) Oxide in Mediaeval Frescoes from the Monastery of San Baudelio, Spain.” Applied Spectroscopy 56 (2002): 804-06.

Soyer, Francois. "Muslim Freedmen in León, Castile and Portugal (1100-1300)." Al Masaq: Islam \& the Medieval Mediterranean 18, no. 2 (2006): 129-43.

Stocking, Rachel L. "Review Article: Continuity, Culture and the State in Late Antique and Early Medieval Iberia.” Early Medieval Europe 15, no. 3 (2007): 335-48.

Tejedor Barrios, Carlos. "Restauración de las pinturas murales de la iglesia de San Miguel en Gormaz.” Arevacon: Revista Cultural, Asociación de Amigos del Museo Numantino 29 (2009): 22-27.

Terés Navarro, Elías. El expolio de las pinturas murales de la ermita mozárabe San Baudelio (Casillas de Berlanga, Soria). Logroño, Ochoa Editores, 2008.

Teresio Rivoira, Giovanni. Moslem Architecture, Its Origin and Development. Translated 
by Gordon McNeil Rushforth. Oxford: Oxford University Press, 1918.

Thompson, E. A. The Goths in Spain. Oxford: Oxford University Press, 1965.

Tomás González, A., ed. Colleción de cédulas, cartas-patentes, provisiones, reales

órdenes y otros documentos concernientes á las provincias vascongadas. Madrid, $1829-1833$.

Toubert, Pierre. Les structures du Latium médiéval: Le Latium méridional et la Sabine du IXe siècle à la fin du XIIe siècle. Rome: Bibilothèque des Écoles Françaises d'Athènes et de Rome, 1973.

Ubieto Arteta, Antonio. “Los Primeros Años Del Monasterio De San Millán.” Príncipe de Viana 34 (1973): 181-200.

Valdés Fernández, Fernando. "Precisiones cronológicas sobre los relieves profilácticos de la fortaleza de Gormaz (Soria)" Cuadernos de prehistoria y arqueología de la Universidad Autónoma de Madrid 5-6 (1978-1979): 177-85.

Viguera Molins, M. J. "The Muslim Settlement of Spania/al-Andalus.” In The Formation of Al-Andalus, 15-38. Aldershot, 1998.

Walker, Rose. "The Wall Paintings in the Panteón de los Reyes at León: A Cycle of Intercession." Art Bulletin 2, no. June (2000): 200-25.

Wasserstein, David. The Caliphate in the West. Oxford: Oxford University Press, 1993.

—. The Rise and Fall of the Party-Kings, Politics and Society in Islamic Spain (1002-1086). Princeton, NJ: Princeton University Press, 1985.

Werckmeister, O. K. "Cluny III and the Pilgrimage to Santiago de Compostela." Gesta 27, no. $1 / 2$ (1988): 103-12.

Whitehill, Walter Muir. Spanish Romanesque Architecture of the Eleventh Century. 
London: Oxford University Press, 1968.

Williams, John. "Meyer Schapiro in Silos: Pursuing an Iconography of Style.” Art Bulletin 85, no. 3 (2003): 442-68.

—_. "San Isidoro in León: Evidence for a New History.” The Art Bulletin 55, no. 2 (1973): 171-84.

—_. A Spanish Apocalypse; the Morgan Beatus Manuscript. New York: George Braziller, Inc., 1991.

Wolf, Kenneth Baxter. Christian Martyrs in Muslim Spain. Cambridge: Cambridge University Press, 1988.

Zadora-Rio, Elisabeth. "Le village des historiens et le village des archeologues." In Campagnes médiévales: L'homme et son espace. Études offertes à Robert Fossier, edited by Elizabeth Mornet and Robert Fossier, 145-53. Paris: Publications de la Sorbonne, 1995.

Zamora, Juan Gil de. De preconiis hispaniae. Edited by M. de Castro y Castro. Madrid, 1955.

Zozaya, J. “¿Fortificaciones tempranas?” In Actas del I Congresso de Castellogía Ibérica; 14 a 17 de septiembre de 1994, edited by Philippe Araguas, 71-146. Palencia: Diputación Provincial de Palencia, 1998. 


\section{CURRICULUM VITAE}

\section{Kelly L. Watt}

19394 Fox Chase Drive

Noblesville, IN

Phone: $317.773 .7267 / 513.435 .4876$

kelly.watt@louisville.edu

\section{EDUCATION}

2003 to present

Ph.D. Candidate, University of Louisville

Department of Fine Arts; Art History

Major concentration: Medieval Art; minor: Ancient Art

Advanced to candidacy, December, 2006

Dissertation Title: "Medieval Churches on the Spanish Frontier:

How Elite Emulation in Architecture Contributed to the

Transformation of a Territorial Expansion into Reconquista"

Director: Christopher Fulton 
College of Design, Architecture, Art and Planning; Art History Area of concentration: Medieval Art

Thesis: “The Illustrator's Hand: An Investigation Using Marginalia and Capitals of the Book of Kells to Illuminate Questions of Artistic Attribution"

1995

\section{B.A., magna cum laude, Olivet Nazarene University}

(Kankakee, Illinois)

Dual major: Fine Arts and History

\section{FELLOWSHIPS AND AWARDS}

University of Louisville, Department of Fine Arts

University of Louisville, Department of Fine Arts 
Lewis and Clark Fund for Exploration and Field Research, American Philosophical Society

Graduate Student Travel Grant

University of Louisville, Department of Fine Arts

R. W. Van Nostrand Memorial Scholarship, Beargrass Christian Church, Louisville, KY

2007-2008

Don Payton Graduate Award in Art History, University of Louisville

Gulnar Bosch Travel Assistance Award, Southeastern College Art Conference (SECAC)

Graduate Student Travel Grant

University of Louisville, Department of Fine Arts

2006-2007

Don Payton Graduate Award in Art History, University of Louisville

Education Abroad/International Conference Scholarship, International Center at the University of Louisville Society and Learning, University of Louisville 
University of Louisville, Department of Fine Arts

2003-2006

Full Graduate Teaching Assistantship, University of

Louisville

2004-present

Eta Sigma Phi, Zeta Lambda Chapter (National Honorary Classical Society)

1995-present

Phi Delta Lambda, Gamma Chapter (National

Academic Honor Society)

$1995-2002$

Full University Graduate Scholarship, University of

Cincinnati

1994-1995

Phi Alpha Theta (Historical Honor Society)

1993,1994

Spring Art Show Scholarship, Olivet Nazarene University

1992-1995

Academic Scholarship, Partial Tuition Remission, Olivet Nazarene University

Portfolio Scholarship, Olivet Nazarene University

University 


\section{PROFESSIONAL ORGANIZATIONS AND MEMBERSHIPS}

College Art Association

American Society of Hispanic Art Historical Studies

Society of Architectural Historians

Southeastern College Art Conference

Midwest Art History Society

The Medieval Academy

Aegis (Department of Fine Arts Graduate Student Association) University of Louisville: Co-President, 2009; Executive Symposium Committee Member, 2006/7, 2008/9

Golden Key International Honor Society

\section{PUBLICATIONS}

2005

"Norman Kingship in Sicily," Parnassus (Graduate Art Journal of the University of Louisville) Spring 2006, 38-45.

1997

Co-Author of Exhibition Review: "Mistress of the House, Mistress of Heaven: Women in Ancient Egypt," Art Words, Vol. 3, 1997.

\section{CONFERENCE PRESENTATIONS}

2009

"Finding Solid Ground: Site Appropriation as Legitimacy along the Medieval Iberian Frontier," College Art Association, Los Angeles, California

"Architecture as Propaganda on the Spanish Frontier: Capitalizing on the Inevitable," Southeast College Art Conference, Charleston, West Virginia "San Baudelio in the Light of the Reconquista," Midwest Art History Society, Dallas, Texas 


\section{BOOKS AND SYMPOSIA}

2009

Presenter: 'Food for Thought' Brown Bag Lunch Research

Series

University of Louisville, Department of Fine Arts

Topic: Santa María de Wamba, Wamba, Spain

Symposium Executive Committee

University of Louisville, Department of Fine Arts

“Imaging Desire," Aegis' $2^{\text {nd }}$ Biennial Graduate Symposium and Exhibition

Reviewer for forthcoming textbook Art Matters by Pamela Gordon

McGraw Hill Publishers

2008

Co-developer of Online Curricula

Elizabethtown Community and Technical College,

Elizabethtown, KY

Introduction to Art (ART 100)

Session Leader, Symposium Executive Committee

University of Louisville, Department of Fine Arts

“Cross-Cultural Encounters," Aegis' $1^{\text {st }}$ Biennial Graduate

Symposium on Art History and Visual Culture

Presenter: 'Food for Thought' Brown Bag Lunch Research Series

University of Louisville, Department of Fine Arts

Topic: Legitimation through Elite Burial in Medieval Iberia 
2001

Faculty Participant

Effective teaching methods seminar, Miami University,

Middletown

1997

Assistant Editor of Art Words (University of Cincinnati Art

History Graduate Journal) 